\author{
UNIVERSIDADE DE SÃO PAULO \\ FACULDADE DE FILOSOFIA, LETRAS E CIÊNCIAS HUMANAS \\ DEPARTAMENTO DE HISTÓRIA \\ PROGRAMA DE PÓS-GRADUAÇÃO EM HISTÓRIA SOCIAL
}

\title{
Uma "tão pesada cruz": o governo da Angola portuguesa nos séculos XVI e XVII na perspectiva de Fernão de Sousa (1624-1630)
}

Alec Ichiro Ito

Dissertação apresentada ao Programa de PósGraduação em História Social do Departamento de História da Faculdade de Filosofia, Letras e Ciências Humanas da Universidade de São Paulo, para obtenção do título de Mestre em História.

Versão corrigida

Orientadora: Profa. Dra. Marina de Mello e Souza

São Paulo

2016 


\section{AUTORIZO A REPRODUÇÃO E DIVULGAÇÃO TOTAL OU PARCIAL DESTE TRABALHO, POR QUALQUER MEIO CONVENCIONAL OU ELETRÔNICO, PARA FINS DE ESTUDO E PESQUISA, DESDE QUE CITADA A FONTE.}

Catalogação na Publicação Serviço de Biblioteca e Documentação

Faculdade de Filosofia, Letras e Ciências Humanas da Universidade de São Paulo

Ito, Alec Ichiro
Uma "tão pesada cruz": o governo da Angola
portuguesa nos séculos XVI e XVII na perspectiva de
Fernão de Sousa (1624-1630) / Alec Ichiro Ito ;
orientadora Marina de Mello e Souza. - São Paulo,
2016. 408 .
Dissertação (Mestrado) - Faculdade de Filosofia,
Letras e Ciências Humanas da Universidade de São
Paulo. Departamento de História. Área de concentração:
História Social.
1. História de Angola. 2. Expansão ultramarina
portuguesa. 3. Estudos sobre os contatos luso-
africanos. 4. Tráfico atlântico de escravos (séculos
XVI e XVII). 5. História Moderna. I. Souza, Marina de
Mello e, orient. II. Título.




\title{
FOLHA DE APROVAÇÃO
}

\author{
Alec Ichiro Ito \\ Uma "tão pesada cruz": o governo da Angola portuguesa nos séculos XVI e XVII \\ na perspectiva de Fernão de Sousa (1624-1630)
}

Dissertação apresentada à Faculdade de Filosofia, Letras e Ciências Humanas da Universidade de São Paulo, para obtenção do título de Mestre em História.

Aprovado em: 26/08/2016

Banca Examinadora

Profa. Dra. Marina de Mello e Souza - Universidade de São Paulo

Prof. Dr. Carlos Alberto de Moura Ribeiro Zeron - Universidade de São Paulo

Profa. Dra. Silvia Hunold Lara - Universidade Estadual de Campinas 


\section{AGRADECIMENTOS}

Destino meus singelos agradecimentos

Aos meus pais, Nair Massako Katayama Ito e William Kenji Ito, que não pouparam esforços e recursos financeiros para que eu dispusesse de paz e tempo necessários para a execução desta pesquisa. De forma alguma este trabalho seria possível sem a paciência e a confiança que eles depositaram em mim.

A Marina de Mello e Souza, orientadora desta pesquisa, que há cerca de seis anos me tutela em meio aos caminhos sinuosos da investigação na área da história de Angola. Meus profundos agradecimentos às correções, às sugestões e às críticas destinadas por ela. A Carlos Alberto de Moura Ribeiro Zeron, cujos ensinamentos modificaram minha forma de encarar as ciências humanas, formação acadêmica, reflexão e a escrita na área de história. Foi uma honra ser aluno do autor de Linha de Fé, obra que considero leitura obrigatória. Também agradeço aos alunos e aos orientandos desse professor, principalmente a Gustavo Velloso, que imbuídos de boa-vontade e espírito crítico me sugeriram mudanças e apontaram alguns equívocos que pretendo sanar ao longo da minha formação acadêmica. A Silvia Hunold Lara, autora de Campos da Violência, Fragmentos setecentistas e tantos outros textos inspiradores e instigantes, professora com rara atenção, disposição, senso crítico e didatismo, que bondosamente me enviou livros, artigos e sugeriu mudanças que espero ter incorporado nesta dissertação.

A Natália Vieira, companheira e amiga, que me auxiliou nas correções e revisões textuais, acudiu-me nos momentos de desalento e com doçura e afeto esteve sempre ao meu lado. Aos amigos do "Pico della Mirandola F. C.", ou só "picolinos", pelos ricos debates e discussões sobre praticamente tudo, além é claro dos copos de cerveja sempre cheios. Devem ser mencionados os tradicionais almoços patrocinados por Rodrigo Candido, onde se desfruta da boa gastronomia mexicana e se reafirma as velhas a caras amizades, sem as quais a vida perde um pouco da graça. No que tange à pesquisa, agradeço principalmente a Victor Abdala, Marcos Medeiros e Rodolpho Rabello da Rocha pelas indicações de dicionários e textos. Aos amigos do "intercâmbio" em Portugal, sobretudo às amáveis e inseparáveis Mariel Deak e Ana Paula Sella, dispostas sempre a conversar e a me resgatar do "claustro" que é a imersão nos textos seiscentistas, livros e bibliotecas. A Bruno Pastre 
Maximo, amigo recente que, com raríssima bondade, enviou-me fontes de época e textos de valor inestimável. Sem o auxílio e o altruísmo dessas pessoas, a presente pesquisa ficaria muito aquém do que aqui está apresentado.

Quase nada seria desenvolvido sem as dependências e as obras contidas nas bibliotecas do Museu de Arqueologia e Etnologia (MAE), da Faculdade de Economia e Administração (FEA), Florestan Fernandes (FFLCH) e Brasiliana Guita e José Mindlin, todas instaladas dentro do campus Butantã da Universidade de São Paulo (USP). Também foi de suma importância a existência do "Sistema Integrado de Bibliotecas da USP" (SIBi), viabilizado por essa universidade, que em grande medida facilitou e poupou tempo no garimpo de obras e artigos de referência. Portanto, direta e indiretamente, um grande grupo de professores e funcionários está por trás da concretização desta dissertação, e a todos esses "anônimos" devo meus sinceros agradecimentos. Também fico grato aos pareceristas da Agência de Amparo à Pesquisa do Estado de São Paulo (FAPESP) pelas sugestões e indicações feitas, além é claro do financiamento cedido por essa agência. ${ }^{1}$ Agradeço por fim à Associação Internacional de Lusitanistas (AIL) pela bolsa de mérito, agraciada em 2014.

${ }^{1}$ Modalidade de mestrado nacional entre 2013-2015, número de processo 2013/18238-3. 


\section{RESUMO}

Exercitando um escopo de análise histórico e eclético, a presente dissertação versará sobre o funcionamento de um sistema administrativo misto, arquitetado no formato de nodos interconectados, ou apenas "rede", em prol da manutenção de um espaço jurisdicional ultramarino. Nessa empreitada, seremos guiados por duas traves-mestras: a

primeira é o interesse nos fenômenos advindos dos contatos intersociais, a segunda é a análise perscrutada da documentação inserida nas Fontes para a história de Angola do século XVII, organizadas por Beatrix Heintze. Problematizando algumas das situações coetâneas pelas quais passavam a expansão portuguesa na África Centro-Ocidental, bem como nos debruçando sobre algumas das indagações levantadas por uma historiografia recente, defenderemos que havia uma série de movimentos ambivalentes e ambíguos no que tangia ao governo do domínio ultramarino da Angola portuguesa. Sucintamente, chamaremos atenção para a importância dos procedimentos e resoluções políticoadministrativas adotados naquele domínio, analisando as maneiras de arregimentação e condução de uma máquina de guerra portuguesa, destacando a importância da participação política de atores e sujeitos centro-africanos nos rumos políticos das chamadas "conquistas" e abordando as relações institucionais e econômicas entre Luanda e os entrepostos portugueses instalados no interior. Por excelência, as hierarquias internas e os contatos sociais e políticos luso-africanos foram gestados em um ambiente conflituoso, entrecortado por tensões sociais, atritos institucionais e embates políticos. Em ultima instância, concluiremos que ocorriam justaposições e aglutinações entre as formas de dominação e intermediação que faziam parte do funcionamento político e institucional da Angola portuguesa, contanto que duas precondições fossem atendidas: o engrandecimento da exploração economia através do tráfico transatlântico e a penetração institucional e política do continente.

Palavras-chave: História de Angola; Expansão ultramarina portuguesa; Estudos sobre os contatos luso-africanos; Tráfico atlântico de escravos (séculos XVI e XVII); História Moderna. 


\begin{abstract}
Considering an eclectic and historical scope of analysis, this dissertation will argue about the execution of a mixed administrative system, based on institutional nodes interconnected in a form of network system, operated on the behalf of an overseas jurisdictional space. Our efforts will be engaged with two mainstreams: the first is our interest in the phenomena related with some inter-social contacts, the second is the analytical research of the Fontes para a história de Angola do século XVII's documentation, organized by Beatrix Heintze. Casting some questions related to the different situations concerned with the Portuguese Expansion in the West Central Africa, as well as reflecting some inquiries posed by the recent historiography, here we stand for a settle of ambivalent and ambiguous series of movements emerged from the Portuguese Angola's overseas domain, calling up for the importance of some political and institutional forms of proceedings. They were all managed in order to resolve some issues related with the Portuguese Angola, paying attention to the recruitment and mobilizations of the Portuguese war machine, elucidating how the local political actors interacted with the conquistas and how was carried out the institutional and economical relations between Luanda and the interior entrepôts. All the internal hierarchies and luso-african contacts was settled down in a conflictive environment, crossed through social tensions, institutional frictions and political shocks. Finally, we conclude that some forms of domination and intermediation in the Portuguese Angola were sustained by a correlation between juxtapositions and agglutinations, but only if two demands were attended: the enlargement of the economical exploitation through the transatlantic slave trade and the institutional and political penetration of the African continent.
\end{abstract}

Keywords: History of Angola; Early Modern Portuguese Expansions; Luso-African Contacts Studies; Atlantic Slave Trade in the Sixteenth and Seventeenth Centuries, Modern History. 
Eu fico com esta cruz às costas, mas muito confiado que se haverá Sua Majestade por servido de ma mandar tirar, e pôr ao sucessor que vier. A Vossa Senhoria peço com todo o encarecimento para ir servir Vossa Senhoria nesse Reino [de Portugal] pois não prestei para o fazer neste [de Angola]. ${ }^{2}$ Fernão de Sousa

\footnotetext{
${ }^{2}$ Fernão de Sousa. Carta de Fernão de Sousa a D. Diogo de Castro. 5 de novembro de 1628. BAL, cód. 51IX-20, f. 380. IN: HEINTZE, Beatrix (coord.). Documento 122. FHA, vol. II, 1988, p. 219. Ver também: HEINTZE, Beatrix. Sobre a biografia de Fernão de Sousa, FHA, vol. I, 1985, p. 41.
} 


\section{SUMÁRIO}

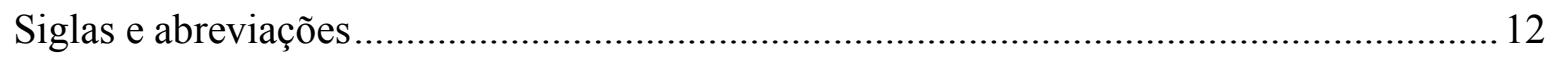

Esclarecimento sobre os nomes, topônimos e demais termos utilizados ............................... 13

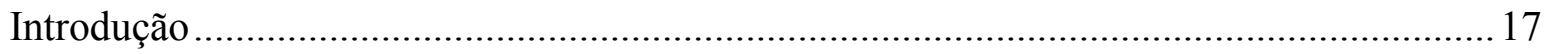

Alguns estudos sobre os contatos, intermediações e dominações ..................................... 18

Apresentação da Coletânea Documental de Fernão de Sousa............................................. 30

Apresentação às Fontes para a História de Angola do Século XVII ................................... 45

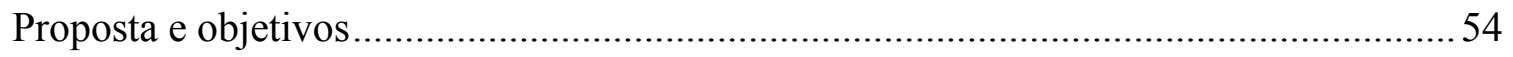

1 Histórias, contatos e a fundação da Angola portuguesa..................................................62

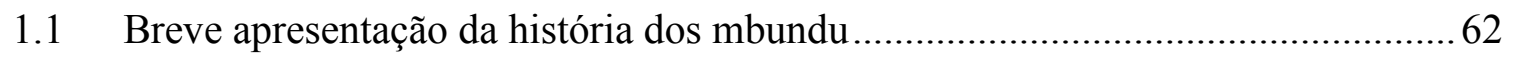

1.2 Os fundamentos do reino do Ndongo entre os séculos XVI e XVII.......................75

1.3 O período formativo da Angola portuguesa (1520-1590) ……………………..... 87

1.4 A consolidação de um sistema administrativo ultramarino (1607-1617) ............... 99

1.5 Por uma história das expansões e contatos luso-africanos ................................... 104

2 Imersão no passado político e institucional a partir de alguns escritos de Fernão de

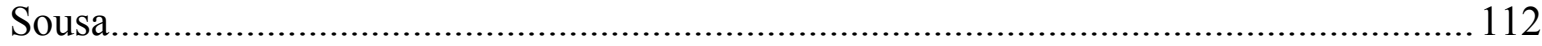

2.1 Anunciação do caos e das crises na Angola portuguesa (1617-1624) .................. 113

2.2 O paradigma do antigo comércio conjugado ao refortalecimento do Ndongo

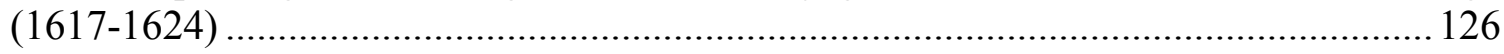

2.3 Os princípios da "conquista do Ndongo" em 1625 ............................................. 142

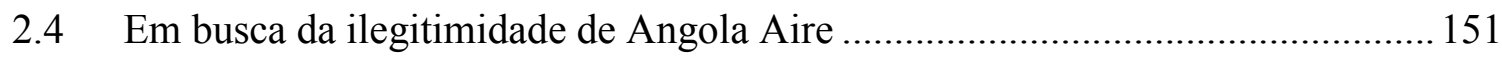

2.5 Do específico ao geral: a produção de autos de vassalagem, lembranças e relações 160

3 O funcionamento de um espaço administrativo e jurisdicional na Angola portuguesa 173

3.1 Penetração institucional rumo a Pungo Andongo (1624-1627)............................. 174

3.2 Agentes, presídios e mecanismos de vigilância e fiscalização .............................. 186

3.3 Da sindicância ao contragolpe de Angola Aire (1629-1630) ..............................2. 200

3.4 Justiça e as elites em Massangano e Muxima........................................................214

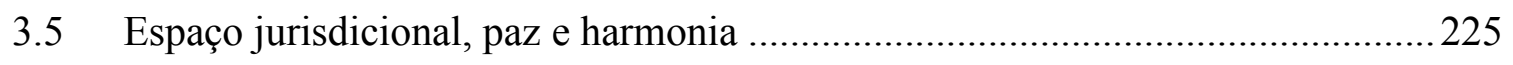

4 Política ultramarina e um estado de guerra econômica...............................................231

4.1 A partida da primeira jornada contra Ginga Ambande (1626-1627) ...................231

4.2 O regresso da segunda jornada contra Ginga Ambande (1628-1629) .................248 
4.3 Os conflitos ligados ao impasse de Boila (1626-1629) ......................................259

4.4 Institucionalização, populações e uma arte de governo da paz ............................279

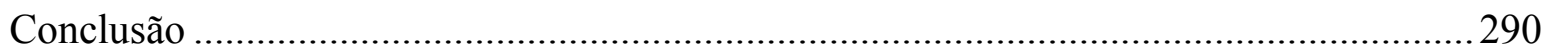

Escopos de análise, esferas de investigação e crítica das fontes .....................................291

Uma composição institucional mista e em rede da Angola portuguesa (início do século

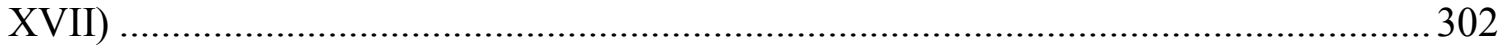

Nada mais... porém muito além do que o tráfico de escravos ..........................................306

Dinâmicas e complexidades na administração da governadoria ultramarina no início do século XVII

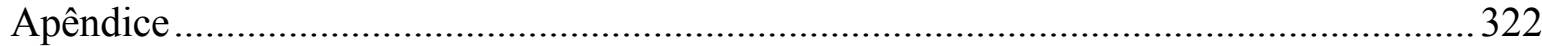

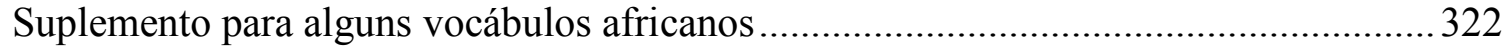

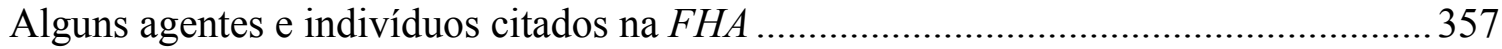

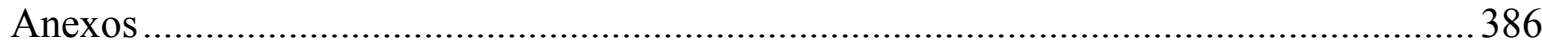

Alguns títulos ou posições de soberania no Ndongo......................................................386

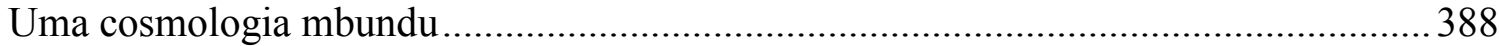

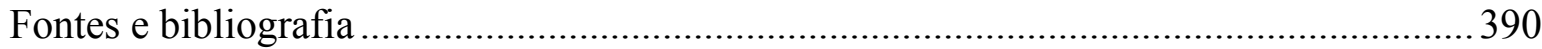

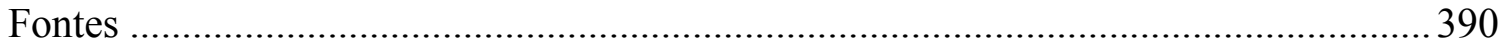

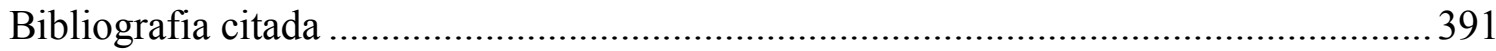

\section{ÍNDICE DE IMAGENS}

Imagem 1: Mapeamento da influência e do prestígio da família de Fernão de Sousa (séculos XVII e XVIII) ....................................................................................................... 41

Imagem 2: Genealogia parcial da família Sousa (séculos XVII e XVIII)............................... 44

Imagem 3: África Centro-Ocidental (século XVII)...........................................................58

Imagem 4: Ndongo, suas províncias e regiões circunvizinhas (séculos XVI e XVII) .......... 84

Imagem 5: A Angola portuguesa durante o governo de Fernão e Sousa (1624-1630) .......112

Imagem 6: O reino do Ndongo no século XVII ............................................................. 119

Imagem 7: Os presídios, vias fluviais e as principais regiões circunvizinhas da Angola

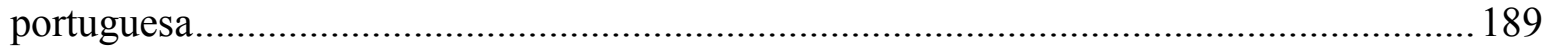

Imagem 8: Algumas feiras que abasteciam o comércio atlântico (1624-1627) .................. 192 Imagem 9: Algumas localidades citadas no caso das contravenções cometidas por Henrique

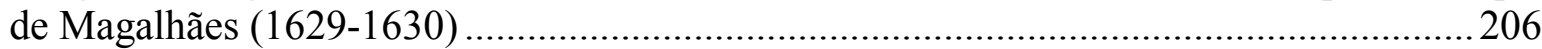

Imagem 10: O "reino de Matamba" (século XVII) ..........................................................223

Imagem 11: A incursão do quilombo português e alguns pontos de referência...................251

Imagem 12: O palco político centro-africano (década de 1620) ..........................................264 


\section{ÍNDICE DE TABELAS}

Tabela 1: Alguns africanos em contato com os portugueses (década de 1620)

Tabela 2: Alguns funcionários e auxiliares que serviam no interior (década de 1620).......372

Tabela 3: Genealogia dos reis do Ndongo de acordo com uma tradição pende...................386

Tabela 4: Genealogia dos reis do Ndongo segundo Francesco Maria Gioia........................386

Tabela 5: Genealogia dos reis do Ndongo segundo João António Cavazzi de Montecúccolo 387

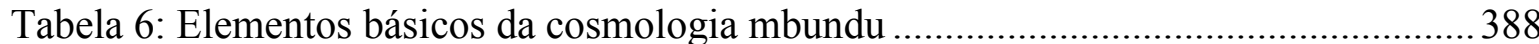

Tabela 7: Esboço geral sobre as concepções de kákùlù e kábàsà .......................................389 


\section{SIGLAS E ABREVIAÇÕES}

- AAOI: Angola. Apontamentos sobre a ocupação e início de estabelecimento dos portugueses no Congo, Angola e Benguela, de Alfredo Albuquerque de Felner, publicado em 1933.

- AHU: Arquivo Histórico Ultramarino de Lisboa.

- BAL: Biblioteca da Ajuda de Lisboa.

- CDFS: Coleção Documental de Fernão de Sousa.

- FHA: Fontes para a História de Angola do século XVII, editadas por Beatrix Heintze e publicadas em 1985 e 1988 (2 vols).

- HGGA: História Geral das Guerras Angolanas, escrita por António de Oliveira Cadornega. Edições de José Matias Delgado (vols. I e II) e Manuel Alves da Cunha (vol. III), publicadas entre 1940-1942.

- MMA: Monumenta Missionaria Africana, coligida e anotada pelo padre António Brásio. Publicadas entre 1952-1988, 15 vols., série 1.

- Ord. Fil.: Ordenações Filipinas.

- PMC: Portvgaliae Monvmenta Cartographica, organizada por Armando Cortesão e Avelino Teixeira da Mota. Publicada em 1960.

- Voc. Port:: Vocabulario portuguez, e latino, aulico, anatomico, architectonico, bellico, botanico... autorizado com exemplos dos melhores escritores portuguezes e latinos e offerecido a El rey de Portugal D. João V, escrito por Raphael Bluteau e publicado entre 1712-1728, 10 vols. 


\section{ESCLARECIMENTO SOBRE OS NOMES, TOPÔNIMOS E DEMAIS TERMOS UTILIZADOS}

A presente dissertação contém vocábulos estranhos ao leitor não especialista. Por isso, a nível terminológico e conceitual, aqui cabe fazer uma breve justificativa sobre certos termos e palavras empregados nela. Alguns deles evocam conceitos típicos do pensamento político e jurídico do Antigo Regime - por exemplo, noções como as de "guerra justa", "direito das gentes", "exames e títulos de escravidão" -, outros advêm da mentalidade política e jurídica da Idade Média - conceitos como os de "homenagem", "investidura", "feudo", por exemplo - e por fim ainda há terminologias típicas das sociedades bakongo e mbundu, como "mucano", "unda", "malafo", entre muitos outros. Quando necessário, forneceremos algumas explicações sobre os conceitos e o vocabulário de época, para que o leitor não se perca nas vicissitudes e nos falsos cognatos que uma leitura anacrônica possa induzir sobre as fontes coevas.

No sentido de facilitar a leitura desta dissertação, também optamos por modernizar a escrita de todas as citações de época e uniformizar a grafia de nomes portugueses. Assim, por exemplo, "Manoel" e "Manuel" ficaram apenas "Manuel". Os antropônimos africanos foram mantidos na sua forma "original", ou seja, conforme prescreveram os registros aportuguesados contidos na $F H A$ e que, por vezes, foram utilizados pelas próprias autoridades africanas. Assim, "Angola Aire" e "Ginga Ambande" não foram mudados para "Ngola Hare" e "Nzinga Mbande", como é o costume entre uma historiográfica angloamericana contemporânea. Em contrapartida, devido às variadas grafias dos etnônimos atualmente existente, preservamos aqui um padrão de escrita mais recorrente nos trabalhos acadêmicos dos últimos quarenta anos, em grande parte composta em inglês. Dessa forma, por exemplo, a forma aportuguesa contida de $F H A$ para se referir às contemporâneas etnias múndòngò, kámùndòngò ou mbûndu é "ambundo", 3 mas aqui utilizaremos uma forma científica universalizada e tributária da escrita acadêmica, "mbundu".

\footnotetext{
${ }^{3}$ As três primeiras grafias são comuns entre uma historiografia angolana. Para as duas primeiras, verificar esclarecimentos em: COELHO, Virgílio. Em busca de Kábàsà: Uma tentativa de explicação da estrutura político-administrativa do "Reino de Ndongo". Actas do Seminário Encontros de povos e culturas em Angola. Luanda: Comissão Nacional para as Comemorações dos Descobrimentos Portugueses, 1995, nota 3, p. 445.
} 
Ora, há ainda uma gama considerável de palavras africanas incorporada ao léxico moderno português. Os pormenores a respeito dos sentidos e dos significados desse léxico podem ser conferidos no Suplemento para alguns vocábulos africanos, presente nesta dissertação. Aqui nos limitaremos às explicações sobre as opções de grafia adotadas nesta dissertação. À luz das muitas variações do registro escrito existentes na documentação de época, como também das múltiplas tendências de escrita acadêmica e científica existente entre os especialistas contemporâneos, utilizamos nas páginas que se seguem três critérios lexicais diferentes, condizentes a três classes terminológicas igualmente distintas. $\mathrm{Na}$ primeira estão contidos os nomes de pessoas africanas, sobre os quais optamos por preservar a grafia dos documentos inseridos na $F H A$, por motivos já elucidados no parágrafo acima. Na segunda classe inserimos os topônimos geopolíticos que, grossamente, estão subdivididos entre os nomes dos "reinos", "províncias", "cidades", "capitais" e algumas "referências geopolíticas" fornecidas pelos cronistas e observadores de época. Quando forem consensuais, aqui adotaremos as grafias empregadas pelos autores das obras de referência que norteiam esta dissertação. Assim, a "cidade de Loanda" registrada nos documentos de época ficou "Luanda". Quando não tiverem uma grafia consensual, adotaremos aquela que for utilizada pelos especialistas mais influentes de hoje. ${ }^{4}$ Cabe notar que na maioria das vezes optamos por uma forma de escrita "modernizada", a fim de esquivarmos de possíveis mal-entendidos que as reproduções terminológicas homófonas podem acarretar. Por exemplo, grafaremos "Kongo" para que não haja confusão entre esse antigo reino e dois estados nacionais contemporâneos, a República do Congo (RC) e a República Democrática do Congo (RDC).

A terceira classe terminológica diz respeito à ampla gama de noções e conceitos em kimbundu e kikongo aos quais fazemos referência nesta dissertação. Aqui eles serão

COELHO, Virgílio, Os Túmúndòngò, os "génios" da natureza e o kílàmbà: Estudos sobre a sociedade e a cultura kímbùndù. Luanda: Kilombelombe, 2010, pp. 55 e 105, entre muitas outras passagens. Idem, "Em busca de Kábàsà!..." Estudos e reflexões sobre o "Reino" do Ndòngò: Contribuições para a História de Angola. Luanda: Kilombelombe, 2010, pp. 203-204, nota 2, entre mais passagens. Para a terceira: BATSÎKAMA, Patrício. O poder político entre os Mbûndu. Sankofa: Revista de História da África e de Estudos da Diáspora Africana. São Paulo: Universidade de São Paulo (USP), vol. 9, n. ${ }^{\circ}$ 16, janeiro de 2016. A opção aqui adotada segue a convenção utilizada por Joseph C. Miller desde a década de 70, mantida na tradução mais recente de uma das suas principais obras: MILLER, Joseph C. Poder político e parentesco: Os antigos estados Mbundu em Angola. [1976]. Luanda: Arquivo Histórico Nacional, 1995.

${ }^{4}$ São eles em nosso levantamento Jan Vansina, Beatrix Heintze, Joseph C. Miller e, bem mais recentemente, Catarina Madeira Santos. 
subdivididos em dois tipos. O primeiro diz respeito a algumas noções intraduzíveis registradas $F H A$, enraizadas das sociedades mbundu, bakongo e ndembu e que foram incorporadas ao léxico administrativo e institucional português. Nesse caso, há uma grande variedade de formas de escrita de termos que significam a mesma coisa, algo explicado pelo fato de que na época não havia acordos ortográficos amplamente formalizados, ou gramáticas normativas que fossem empregadas pelo funcionalismo régio de maneira generalizada. Independentemente de regionalismos, escrevia-se como se falava e ponto final. Para esse tipo de léxico, adotaremos nesta dissertação uma das opções de registro fornecida nos documentos inseridos na FHA. Assim, por exemplo, as grafias "mucano" e "mocano" serão uniformizadas somente em "mucano". A pluralização dessas palavras seguirá o padrão português, cuja marca maior é utilização de um "s" no final da palavra (ex: uma "murinda", duas "murindas"). Pelo fato de a utilização de vocabulário estrangeiro indicar uma incorporação de elementos africanos por parte dos cronistas e observadores régios, optamos por escrevê-las entre aspas, dissociando-as de outra subdivisão lexical, mediante a qual subclassificaremos os conceitos mbundu não necessariamente registrados nos documentos de época, mas que integram a lógica social mbundu, contemporânea e de antigamente. Esses termos e conceitos foram extraídos da experiência empírica de análise histórica, após a execução de uma "leitura a contrapelo" e "suspeição dos véus" que recobrem a realidade observada e registrada nas fontes escritas. A fim de demarcar com nitidez diferença entre os dois grupos terminológicos, essa segunda subclassificação será registrada em itálico uma única vez no corpo de texto e será flexionada apenas no singular. As formas plurais serão indicadas no Suplemento para alguns vocábulos africanos e por meio de notas de rodapé. Tais opções foram feitas por receio de que a utilização das formas singular e plural acarretasse em confusões de interpretação por parte de leitores não familiarizados com o modo de fixação da pluralidade no kimbundu e kikongo, ou mesmo para que o excesso de termos exógenos não atravancasse a leitura. Em muitas das línguas centro-africanas pertencentes à grande família bantu, o elemento de pluralidade frequentemente advém de modificações prefixais, não sufixais, como frequentemente ocorre nas línguas neolatinas ou mesmo no inglês. Por exemplo, ngundu é o singular de jingundu. 
Finalmente, cabe explicar que a grafia dos topônimos de rios, lagoas e oceanos seguiu os padrões internacionais estipulados para a língua portuguesa do início do século XXI, válidos na República de Angola. Assim, o antigo rio "Coanza” e a forma normatizada entre os acadêmicos, "Kwanza", foram substituídos por "Cuanza". 


\section{INTRODUÇÃO}

As chamadas "grandes navegações" e os "descobrimentos" portugueses suscitam inflamados debates entre os acadêmicos. São elencados muitos motivos para explicar por que a monarquia portuguesa e alguns investidores privados financiaram o desbravamento do Oceano Atlântico, bem como são variadas as considerações a respeito do que foram as "conquistas" e as "colonizações" no "Novo Mundo". Alguns levantam hipóteses sobre como a pobreza peninsular municiou a Coroa na busca por riquezas e lucros comerciais, alavancando o desenvolvimento de um comércio mercantilista; ${ }^{5}$ outros aventam que a posição geográfica de Portugal privilegiou as navegações e empreitada ultramarina a partir das chamadas "colunas de Hércules". ${ }^{6}$ Há ainda os pesquisadores que destacam a importância dos assuntos políticos e militares, afirmando que a ignição da expansão ultramarina foram as guerras de reconquista contra o "mouro infiel", ${ }^{7}$ ou que tudo não passava de um "pré-jogo" dos impérios europeus, na longa duração de um história de avanços e retrocessos. ${ }^{8}$

Por mais que a discussão levante pontos divergentes, há um chão-comum: as navegações fizeram com que os e desbravadores e navegadores europeus, sobretudo portugueses e italianos, encontrassem um "novo outro", tendo como consequência o surgimento de questões como a definição do "nosso mundo", o "mundo deles" e o estabelecimento de relações entre "mundos diferentes". ${ }^{9}$ Nasce desse interesse o mote desta pesquisa: investigar os desafios e os desdobramentos decorrentes de um ambiente conflituoso, inaugurado após os primeiros encontros modernos. Dito de outra forma, esta é

\footnotetext{
${ }^{5}$ BIRMINGHAM, David. Trade and empire in the Atlantic, 1400-1600. Londres e Nova Iorque: Routledge, 2000, pp. 2-3. Idem, Portugal and Africa. Athens: Ohio University Press, 1999, pp. 1, 33. Em específico sobre a importância do mercantilismo, consultar a obra de: NOVAIS, Fernando A. Portugal e Brasil na Crise do Antigo Sistema Colonial (1777-1808). [1979]. São Paulo: Editora Hucitec, 1995.

${ }^{6}$ SANTOS, Catarina Madeira. Portugal and the World Shipping Routes. Lisboa: Comissão Nacional para as Comemorações dos Descobrimentos Portugueses, 1997, p. 15.

${ }^{7}$ SANTOS, João Marinho dos. A Expansão pela espada e pela cruz. IN: NOVAES, Adauto (org.). $A$ descoberta do homem e do mundo. Rio de Janeiro: Minc-FUNARTE: Companhia das Letras, São Paulo, 1998, pp. 147-148.

${ }^{8}$ GODINHO, Vitorino Magalhães. O que significa descobrir?. IN: Ibidem, p. 55. ALENCASTRO, Luiz Felipe de. A economia política dos descobrimentos. IN: Ibidem, 1998, p. 193.

${ }^{9}$ Sobre as duas primeiras: BORNHEIN, Gerd. A descoberta do homem e do mundo. IN: Ibidem, pp. 17-18, 32-33. Sobre a última inquietação: GODINHO, Vitorino Magalhães. O que significa descobrir?. IN: Ibidem, pp. 71-72. BIRMINGHAM, David. Portugal and Africa. Athens: Ohio University Press, 1999, pp. 12-13.
} 
uma dissertação que tem como temática o contato prolongado entre sociedades distintas. Assim, repetindo as instigantes palavras de Vitorino Magalhães Godinho, estudar os contatos é inventar "a unidade do gênero humano na pluralidade". 10

\section{Alguns estudos sobre os contatos, intermediações e dominações}

Nosso ponto de partida advém de um dos desdobramentos propostos no seminal texto do intelectual Fernando Ortiz, intitulado Contrapunteo cubano del tabaco y el azúcar, publicado pela primeira vez em 1940. Ao analisar as vicissitudes formativas da sociedade cubana, através dos processos históricos enraizados em dois modos de produção opostos e dialéticos, ${ }^{11}$ um ligado à exportação do açúcar e outro à do tabaco, Fernando Ortiz levantou a importância de muitos "fenômenos econômico-sociais" que acompanhariam a história desse país. Um foi atribuído à escravidão de africanos na América, o outro à "transculturação do tabaco havanês" pelo mundo. ${ }^{12}$ Sem perder de vista a importância do fenômeno da escravidão, seja como negócio comercial e financeiro, seja nas profundas divisões de trabalho e produção engendradas pelo sistema escravista, Ortiz ressaltou como elemento constituidor do passado cubano um fenômeno sociocultural: a transculturação.

Uma das principais mercadorias exportáveis via Atlântico, o tabaco não era apenas uma erva tragável e cada vez mais apreciada no mercado global. Ele era um produto fruto do trabalho escravo e da empresa colonial, mediante os quais ocorriam "transmigrações" de pessoas em fluxos diversos e "transplantações" de órgãos e aparatos administrativos para a América. Foi desse tenso encontro entre um "novo mundo" para os europeus, ressalta Ortiz, ao mesmo tempo "novíssimo mundo" para os ameríndios, que surgiu uma "classe de novos dominadores e dominados". Da situação de dominação colonial é que germinaria uma

\footnotetext{
${ }^{10}$ GODINHO, Vitorino Magalhães. O que significa descobrir?. IN: NOVAES, Adauto (Org.). A descoberta do homem e do mundo. Rio de Janeiro: Minc-FUNARTE: Companhia das Letras, São Paulo, 1998, pp. 77, 80, 82.

${ }^{11}$ Paradoxalmente unidos e dessemelhantes em quatro pontos de desenvolvimento: uso da terra, emprego de máquinas, trabalho para fins de produção e dinheiro. Verificar resumo em: ORTIZ, Fernando. Contrapunteo cubano del tabaco y el azúcar. Habana: Editorial de Ciencias Sociales, 1983, p. 3. A versão do texto que aqui utilizamos está contida em uma coletânea póstuma à morte de Fernando Ortiz, editada pela primeira vez em 1983, intitulada igualmente como Contrapunteo cubano del tabaco y el azúcar.

${ }^{12}$ Ibidem, capítulo 1, especificamente a p. 3, onde são anunciados os interesses e objetivos sumários do autor. Sobre os chamados "complementos" e "adições", verificar a p. 83.
} 
"cultura nova", ${ }^{13}$ dando margem à releitura do conceito de "transculturação" mediante a ótica historicizante. ${ }^{14}$

Visando ultrapassar os limites conceituais das noções de aculturação - anulação e aquisição de uma nova cultura - e desculturação - perda ou degradação de uma cultural ,$^{15}$ a transculturação prevê uma difusão de objetos e aportes culturais - o consumo e o plantio do tabaco é exemplo disso - por meio de convergências de usos sociais e divergências entre culturas desniveladas entre si. ${ }^{16}$ Articulando coexistência e conflito entre matrizes culturais distintas, uma opressora e outra oprimida, a primeira impositiva e a segunda coibida, há uma luta constante entre as linhas de força que engendram a criação de uma nova cultura. Fernando Ortiz não pensa em termos de isolamento cultural ou resistência, mas em um ambiente totalmente fluido e adaptável às adversidades. Dessa forma, a relação entre o passado e o presente está expressa "em diferentes fases do processo transitivo de uma cultura a outra", mediante as quais a neoculturação - o surgimento de uma nova cultura, por excelência - descreve uma parábola determinada por três variantes principais: aquisição de elementos, apagamento parcial e recriação de culturas.

Influenciada pelas ideias de Fernando Ortiz, em 1992 a pesquisadora Mary Louise Pratt publicou a obra Os olhos do Império, ${ }^{17}$ cujo objetivo principal era o de investigar como a literatura de viagem exercitava "temáticas domésticas" - narrativas, crônicas, descrições, entre outras - sobre os povos ultramarinos que habitavam a Ásia e África, genericamente chamados de "os outros", durante a segunda metade do século XVIII e ao longo do XIX. O material produzido circulava por diversos públicos de leitores, da Europa e de outros continentes, contanto que também estivesse engajado às finalidades

\footnotetext{
${ }^{13}$ ORTIZ, Fernando. Contrapunteo cubano [...]. Habana: Editorial de Ciencias Sociales, 1983, pp. 87-88.

${ }^{14}$ Cabe aqui ressaltar que Ortiz reavaliou e repensou alguns pontos sobre o conceito de "transculturação", anteriormente suscitada pelo antropólogo Bronisław Malinowski.

${ }^{15}$ ORTIZ, Fernando. Contrapunteo cubano [...]. Habana: Editorial de Ciencias Sociales, 1983, p. 89. Sobre uma fórmula padrão de aculturação, ou "sistema intercultural", dividida em duas manifestações, sendo a primeira de "incorporação" (espontânea) e a segunda de "integração" (de cima para baixo), resultando na chamada "fossilização" das culturas autóctones, conferir: RESENDE, Maria Leônia Chaves de. Visões da conquista: verso e reverso (As missões jesuiticas nos séculos XVI/XVII). Dissertação de mestrado, Universidade de Campinas, 1993, pp. 17-18.

${ }^{16}$ ORTIZ, Fernando. Contrapunteo cubano [...]. Habana: Editorial de Ciencias Sociales, 1983, pp. 218-219, 222-223. Ortiz ainda oferece o exemplo bem interessante sobre a globalização de quatro alcaloides, cujos padrões de transculturação são parecidos entre si: café, tabaco, chocolate e chá. Verificar, especificamente a p. 240 dessa obra.

${ }^{17}$ PRATT, Mary Louise. Os olhos do Império: os relatos de viagem e transculturação. [1992]. Bauru, São Paulo: EDUSC, 1999.
} 
exploratórias e expansionistas dos Impérios. ${ }^{18}$ Tais fontes escritas foram encaradas pela pesquisadora como registros discursivos, muitas vezes ideológicos, que os viajantes produziam a partir de suas observações. Apesar de frequentemente condicionadas pelo momento histórico, ou distorcidas por traduções simplistas ou equivocadas, essas produções textuais continham informações importantes sobre como as relações sociais se desdobravam nas margens dos Impérios. Nesse sentido, há dois eixos centrais que conduziram as analises de Mary Louise Pratt. O primeiro deles é a transculturação, fenômeno que ocorre quando "grupos subordinados e marginais selecionam e inventam a partir de materiais a eles transmitidos por uma cultura dominante metropolitana", de modo que esses grupos sejam capazes de determinar, em graus variados, o que será absorvido e como a material exógeno será utilizado. ${ }^{19}$ A transculturação ocorre nas chamadas zonas de contato, sendo este um segundo eixo de importância das considerações de Pratt. Zonas de contato são "espaços de encontros culturais", dentro dos quais "pessoas geográfica e historicamente separadas encontram em contato umas com as outras e estabelecem relações contínuas, geralmente associadas a circunstâncias de coerção, desigualdade radical e obstinada". ${ }^{20}$ Nas zonas de contato, as relações entre colonizadores e colonizados são mediadas por interações mútuas e práticas interligadas, diferenciando-se assim de uma “fronteira colonial”, normalmente circunscrita à perspectiva europeia de expansão. Seja como for, em ambos os casos, a convivência entre estrangeiros e locais é mediada por "relações radicalmente assimétricas de poder", ${ }^{21}$ perceptíveis por meio de uma análise crítica da literatura de viagem imperialista, capaz de desbaratar as feições de superioridade e assimetrias que por vezes marcam o choque entre sociedades distintas, caso recordemos dos esforços acadêmicos de outra pesquisadora, Manuela Ribeiro Sanches. ${ }^{22}$

\footnotetext{
${ }^{18}$ PRATT, Mary Louise. Os olhos do Império [...]. Bauru, São Paulo: EDUSC, 1999, p. 28.

${ }^{19}$ Ibidem, 1999, pp. 30-31. A influência direita de Fernando Ortiz aqui é clara. Conferir a nota 4, p. 30, dessa mesma obra.

${ }^{20}$ Ibidem, 1999, pp. 31-32.

${ }^{21}$ PRATT, Mary Louise. Os olhos do Império [...]. [1992]. Bauru, São Paulo: EDUSC, 1999, pp. 31-32. Sobre as zonas de contato, as principais considerações feitas por Pratt dizem respeito à Nova Crônica e Bom Governo e Justiça, de Guaman Poma De Ayala, na p. 27. Sobre uma interpretação diferente desse mesmo documento, levantando argumentos voltados aos resultados práticos e redinamizações visados por Guaman Poma De Ayala, verificar: ZERON, Carlos Alberto de Moura Ribeiro. A ocidente do ocidente: linhas e perspectivas em confronto. Revista de História (USP). São Paulo: Universidade de São Paulo, n. ${ }^{\circ}$ 170, janeiro/junho, 2014, pp. 98-99.

${ }_{22}$ SANCHES, Manuela Ribeiro (org.). Malhas que os impérios tecem. Textos anticoloniais, contextos póscoloniais. Lisboa: Edição 70, 2011, p. 33. CANDIDO, Mariana P. Os agentes não europeus na comunidade
} 
Pouco tempo depois, em 1994, Homi K. Bhabha publicou uma das mais influentes obras sobre os contatos intersociais e os estudos culturais, The Location of Culture. Propondo uma análise historicizante a respeito da articulação cultural entre intersubjetividades e experiências coletivas múltiplas, Bhabha pondera que existem na "emergência dos interstícios", ou nestes "espaços intermédios" onde vigoram a "sobreposição e deslocamento dos domínios da diferença", 23 os potenciais gerativos de reformação das estratégias de individualidade. Nesses campos de inovação, a mudança cultural subexiste na estreia de novos signos de identidade, criados a partir da colaboração ou da contestação de pessoas não necessariamente unidas em prol de uma causa comum, além do próprio esforço de definição e redefinição da ideia de sociedade única e coeva. ${ }^{24}$ Assim, são a partir dos estremecimentos do engajamento cultural e da emergência da articulação sociocultural da diferença, em um esforço de constante negociação entre as partes sociais de um todo, que ocorre a "busca pela autorização de hibridismos culturais nos momentos de transformação histórica". ${ }^{25}$ Na perspectiva de Homi K. Bhabha, são estes "hibridismos culturais", menos como formas de miscigenação e mais como mecanismos criadores de "autorizações" e "alteridades" inovadas, os grandes viabilizadores das ambivalências que emergem dos interstícios das situações de contato. Assim sendo, trata-se de uma proposta que procura reinscrever os embates e convívios inter e intra sociais, forjados nos chamados "momentos monádicos" ensaiados por Walter Benjamin, na agenda acadêmica dos investigadores combativos. ${ }^{26} \mathrm{~A}$ mudança histórica é assim realocada ou reinscrita de modo a instaurar, ou simplesmente destacar, a posição de grupos marginalizados ou perseguidos, mas que não se rendem à integração forçada, imposta pelas

mercantil de Benguela, c. 1760-1820. Sceculum: Revista De História. João Pessoa: Universidade Federal da Paraíba (UFPB), n. ${ }^{\circ}$ 29, julho/dezembro de 2013, p. 98.

${ }^{23}$ No original "[...] the overlap and dislacement of domains of difference [...]".

${ }^{24}$ BHABHA, Homi K. The Location of Culture. Londres e Nova Iorque: Routledge, 1994, pp. 1-2.

${ }^{25}$ Ibidem, p. 2. "The social articulation of difference, from the minority perspective, in a complex, on-going negotiation that seeks to authorize cultural hybridities that emerge in moments of historical transformation".

${ }^{26}$ Ficamos aqui com a breve apresentação dessa noção, conforme as palavras do próprio Benjamin, sobre a busca da "totalidade do processo histórico" necessária ao ofício do historiador materialista: "Quando o pensamento para, bruscamente, numa constelação saturada de tensões, ele lhe comunica um choque, através do qual ela se cristaliza numa mônada. O materialista histórico aproxima-se de um objeto histórico somente quando ele o confronta enquanto mônada. Nessa estrutura, ele reconhece o sinal de uma imobilização messiânica dos acontecimentos, ou, dito de outro modo, de uma oportunidade revolucionária na luta pelo passado oprimido. [...] O fruto nutritivo do que historicamente contém, em seu interior, o tempo, como uma semente preciosa, mas insípida". BENJAMIN, Walter. Sobre o conceito da História. [1940]. IN: Magia e técnica, arte e política: ensaios sobre literatura e história da cultura. [1985]. São Paulo: Editora Brasiliense, vol. I, 2012, p. 251. 
camadas dominantes ou elitistas. Furtando-se da premissa de uma história teleológica da conquista dos derrotados, a conhecida "história dos vencidos", ${ }^{27}$ Bhabha situa as formas de autorização, imaginação e ambivalências no foco da análise.

A partir das propostas analíticas de Fernando Ortiz, Mary Louise Pratt e Homi K. Bhabha, os debates sobre os estudos dos contatos prosseguiram no século XXI. Dessa forma, em 2014, Cécile Fromont propos outros desdobramentos. Talvez uma das poucas a voltar as atenções para a África abaixo da linha do Equador, Fromont elegeu como objetos de estudos algumas narrativas, obras de arte e performances, analisados à guisa de "espaços de correlação", onde "pensamentos estrangeiros e locais podem evoluir em uma única e renovada perspectiva de mundo, novas noções podem transformar velhos conceitos, e atributos do outro podem transfigurar definições e representações de si". ${ }^{28}$ Focando no caso da formação da elite cristã do Kongo entre os séculos XVI-XVIII, Cécile Fromont afirmou que os fenômenos caracterizados pela transversalidade cultural são resultados de processos de matizes plurais, variando do sincretismo até a apropriação e inovação, podendo no final das contas acarretar no surgimento de algo que poderíamos chamar de "nova cultura" ou "nova religião". Sendo bastante sucinto, a pesquisadora estabelece que, no Kongo, a “imposição do cristianismo como religião de estado" acabou implantada por uma "elite do reino", capaz de interagir livremente com os estrangeiros, a partir de termos próprios ou emprestados, "de modo independente e considerando as ideias e formas introduzidas". 29

Cécile Fromont retoma duas temáticas que perpassaram os últimos anos de debates acadêmicos: se os pesquisadores aqui citados se interessaram pelos potenciais criadores, advindos da reiteração de contatos e do fluxo e refluxo de ideias e conceitos entre sociedades distintas, eles igualmente tiveram que lidar, em maior ou menor grau, com a chamada "situação colonial" e o fenômeno da dominação, conforme estabeleceu Georges

\footnotetext{
${ }^{27}$ BHABHA, Homi K. The Location of Culture. Londres e Nova Iorque: Routledge, 1994, pp. 4-6.

${ }^{28}$ FROMONT, Cécile. The Art of Conversion: Christian Visual Culture in the Kingdom of Kongo. Chapel Hill: The University of North Carolina Press, 2014, p. 15, tradução nossa ("[...] local and foreign thought can evolve into a single, novel worldview, new notions can transform old concepts, and attributes of the other can transfigure definitions and representations of the self').

${ }^{29}$ FROMONT, Cécile. The Art of Conversion [...]. Chapel Hill: The University of North Carolina Press, 2014, pp. 15-16, ("the imposition of Christianity as a state religion was an internal matter spearheaded by the kingdom's own elites who conversed freely and on their own terms with foreigners and independently considered the ideas and forms they introduced"). De maneira sucinta, sobre a cristandade do Kongo, verificar as pp. $1-2$.
} 
Balandier em um texto formador, datado de $1955 .^{30}$ Basta ressaltar que diversas experiências chocaram-se, ou entraram em contato, após as grandes navegações, gerando influência e impacto em graus dessemelhantes. No entanto, houve também trocas, negociações e diálogo. ${ }^{31}$ Implicadas em reverberações diferentes de graus distintos, tais experiências compartilhadas não estavam totalmente apartadas uma das outras: o Kongo se comunicava com Roma e a monarquia portuguesa mantinha planos complementares entre a colonização da América e o tráfico atlântico em Angola. Do particular para o geral, ou vice-versa, os sentidos de comunicação eram variados, como também eram variadas as formas de dominação e intermediação. Fato é que o continente africano não estava isolado ${ }^{32}$ e, da abertura da África Subsaariana para o Atlântico, surgiram novas demandas e anseios, mas também conflitos e negociações, como advertem os trabalhos de Catarina Madeira Santos, Rodrigo Faustinoni Bonciani, Luiz Felipe de Alencastro e do próprio Georges Balandier. $^{33}$

\footnotetext{
${ }^{30}$ Basta lembrar da seguinte assertiva, que consideramos ser cara ao intelectual e inspiradora para o presente trabalho: "qualquer estudo concreto das sociedades afetadas pela colonização que procure uma apreensão completa só pode realizar-se, no entanto, através da referência a este complexo qualificado de situação colonial”. BALANDIER, Georges. A Noção de Situação Colonial. [1955]. Cadernos de Campo. São Paulo: Universidade de São Paulo (USP), n. ${ }^{\circ}$ 3, 1993, p. 108. O tal "complexo qualificado" diz respeito às "maneiras de dominar", que são diversas e variavam de contexto para contexto. Para os interesses que convergem com esta dissertação, conferir especificamente os itens 1 e subitem 1.2, respectivamente nas pp. 113-115, sobre a administração ultramarina e a dominação, e 120-124, sobre alguns estudos fundadores sobre os contatos. A respeito do momento e das condições de escrita na época de Balandier, conferir: MONTERO, Paula. Introdução: A Questão Colonial Revisitada. Cadernos de Campo. São Paulo: Universidade de São Paulo (USP), nº3, 1993.

${ }^{31}$ Nesse sentido, Fromont frisou a importância de uma "arte da conversão" que figurava como um núcleo dos encontros transversais, capaz de assegurar uma "encenação do poder e legitimidade", em detrimento de operações de lutas, conflitos e desigualdades. Verificar: FROMONT, Cécile. The Art of Conversion [...]. Chapel Hill: The University of North Carolina Press, 2014, p. 16. (no original: "[...] The art of conversion did not emerge from a situation devoid of power struggles, conflict, and inequality; it was in many regards intricately linked to the to securing and enacting power and legitimacy [...]".)

${ }^{32}$ Quiçá como nunca esteve, conforme sustentam Philip D. Curtin e Jan Vansina, para quem a África sempre teve grandes movimentos ou ondas migratórias, de tal forma seus habitantes nunca estiveram "estagnados" em suas respectivas "tribos", advogando assim a favor de uma África "em movimento" e "destribalizada", portanto histórica. Conferir: CURTIN, Philip D. Why People Move. Waco: Baylor University Press, 1995, p. 5. Sobre o entendimento de "tribo" como uma comunidade populacional ahistórica, além da necessidade de ultrapassar esse conceito, verificar: VANSINA, Jan. Kingdoms of the Savanna. Madison: University of Wisconsin Press, 1966, pp. 14-15.

${ }^{33}$ Ao longo da dissertação, o leitor perceberá como tais pesquisadores nos influenciam. De antemão, são obrigatórias as seguintes obras: SANTOS, Catarina Madeira. Um governo "polido" para Angola: Reconfigurar dispositivos de domínio. (1750-c.1800). Tese de doutorado, Universidade Nova de Lisboa, 2005. BONCIANI, Rodrigo Faustinoni. O dominium sobre os indigenas e africanos e a especificidade da soberania régia no Atlântico: Da colonização das ilhas à política ultramarina de Felipe III (1493-1615). Tese de doutorado, Universidade de São Paulo, 2010. ALENCASTRO, Luiz Felipe de. O trato dos viventes: A formação do Brasil no Atlântico Sul. São Paulo: Companhia das Letras, 2000.
} 
Algumas inquietações são caras para essa bibliografia. Como medir ou qualificar o impacto estrangeiro? Como o "novo" se impunha ao "velho"? Como analisar o potencial inovador, quiçá criador, dos contatos? Igualmente se aproximando dessas inquietações, em 2007 foi publicada a obra Central Africans, Atlantic Creoles. Levantando a importância das transformações socioculturais ocorridas ao longo dos contatos quinhentistas e seiscentistas na África Centro-Ocidental, ${ }^{34}$ Linda Marinda Heywood e John Kelly Thornton propuseram que as "práticas políticas e culturais", decorrentes da evangelização e disseminação do cristianismo entre as populações mbundu e bakonga, ${ }^{35}$ foram capazes de sintetizar uma cultura inovadora, chamada de "crioula atlântica". ${ }^{36}$ Tal ideia gira em torno da difusão de duas variantes regionais de crioulos atlânticos que formavam, de forma amorfa, uma cultura “atlântica”, gestada a partir de núcleos de difusão cultural. O primeiro deles surgiria no Kongo durante um período estipulado, mas não necessariamente circunscrito ou fechado, entre 1485 a 1607, a partir da adoção do cristianismo e de hábitos portugueses pela elite local, levando a cabo "um dos mais ambiciosos programas bilaterais e culturais no período da expansão europeia", na medida em que os invasores abdicaram da "conquista ou conversão forçada". ${ }^{37}$ Seguido a ele viria o núcleo cultural da "Angola portuguesa", surgido novamente de maneira ideal entre 1575 a 1607, como fruto de três tendências mais ou

\footnotetext{
${ }^{34}$ Entendemos que a África Centro-Ocidental compreende a atual República de Angola, somada aos territórios nacionais da República Democrática do Congo (RDC), República do Congo (RC) e República Gabonesa, ao norte, até a fronteira geopolítica de Angola com a República da Namíbia, no sul. Em termos históricos, a macrorregião diz respeito ao "reino do Kongo", "reino do Ndongo", Loango, Tio, Kasanje, Matamba, Benguela e diversos outros povos que ocupavam as florestas tropicais costeiras, além das regiões entre os rios Cuango, Cassai e a Kissama, entre os rios Cuanza e Longa. Sobre o traçado regional, com base em divisões territoriais nacionais e contemporâneas, verificar: CANDIDO, Mariana P. Los lazos que unen Centroamérica a un puerto africano del Atlántico Sur. Benguela y la Trata de esclavos, 1617-1800. Boletín AFEHC. Toulouse: Asociación para el Fomento de los Estudios Históricos en Centroamérica, n. ${ }^{\circ} 55,4$ de dezembro de 2012, p. 2. Para a descrição histórica da África Centro-Ocidental, conferir: VASINA, Jan. Kongo, Angola, and Western Forests, History of (1500 to 1880). IN: MIDDLETON, John/ MILLER, Joseph C (Ed.). New Encyclopedia of Africa. [2007]. Detroit: Charles Scribner's Sons, vol. 3, 2008, pp. 161-165. Sobre a importância histórica dos povos que atualmente habitam Angola, verificar principalmente a nota $1 \mathrm{e}$ as primeiras considerações em: VANSINA, Jan. Communications between Angola and East Central Africa Before c. 1700. IN: HEINTZE, Beatrix; OPPEN, Achim von (Ed.). Angola on the Move: Transport Routes, Communications and History. Frankfurt am Main: Verlag Otto Lembeck, 2008. Sucintamente, sobre os traços técnico-culturais comuns a toda essa macrorregião, ligados à cerâmica, horticultura e pastoreio, ver em especial: VANSINA, Jan. How Societies Are Born: Governance in West Central Africa before 1600. Charlottesville: University of Virginia Press, 2004, pp. 67-68.

${ }^{35}$ Essas populações são atualmente encaradas como "etnias". Pormenorizaremos o caso mbundu no capítulo 1 desta dissertação.

${ }^{36}$ THORNTON, John K.; HEYWOOD, Linda M. Central Africans, Atlantic Creoles, and the Foundation of the Americas, 1585-1660. Cambridge: Cambridge University Press, 2007, p. 49 e nota 1.

${ }^{37}$ Ibidem, p. 61. Para mais informações, verificar em especial as pp. 60-62, 67, 96, 98-99.
} 
menos entrelaçadas: difusão cultural-religiosa vindo do Kongo, interiorização institucional proveniente de Luanda e reiteração de formas diversas de intermediação. ${ }^{38} \mathrm{Em}$ suma, a partir da articulação entre os polos "Kongo-Angola", as duas variantes da cultura atlânticocrioula acabariam transmitidas, retransmitidas e disseminadas pelo interior, porventura acarretando em transformações socioculturais no seio de alguns povos continentais não especificados. $^{39}$

Apesar de ser uma obra inspiradora e bem elaborada, Central Africans, Atlantic Creoles não faz profundas menções aos processos de expansão institucional da conquista portuguesa, ou analisa o dano causado pelo tráfico atlântico no seio das sociedades mbundu e bakonga, relegando para segundo plano aspectos importantes como a formação de um domínio ultramarino e o impacto europeu sobre os manis e sobas. Ficamos também com a sensação de que, ao privilegiar a análise de fatos como o bilinguismo e a interação cultural, o surgimento de uma cultura crioula e atlântica tenha sido encarado como algo de "fácil resolução", sem dar conta dos traumas de guerra ou da insensatez desumana, decorrentes do embarque de pessoas, à revelia delas, para o outro lado do Atlântico. Há ainda uma forte tendência de exaltar o potencial transformador do cristianismo, no final das contas relacionando-o, sem prévia justificativa e de maneira pouco convincente, a um movimento de remarcada "europeização" das populações mbundu e bakonga, como se a troca das culturas locais pelo crioulo atlântico, sobretudo sintetizado "à portuguesa", fosse uma opção adotada passivamente pelos locais. Não é menos relevante destacar que o escopo de análise e os processos históricos destacados por Linda M. Heywood e John K. Thornton envolvem uma miscelânea de processos diacrônicos e operações sincrônicas misturados entre si, acarretando em explicações pouco precisas e demasiadas generalizações. Por exemplo, os autores afirmam que a cultura atlântico-crioula seria detectável nos modos de agir, costumes, hábitos e no estilo de vida que, aos poucos, passariam a ser "crioulos" e "atlânticos". Tais hibridismos seriam perceptíveis na utilização de sobrenomes locais intercalados a nomes portugueses, uso de roupas europeias e no canto de músicas estrangeiras. Não há, todavia, uma exposição profunda, ou explicações detalhadas, sobre como esses hábitos e traços culturais se conectariam para formar uma "cultura crioula",

\footnotetext{
${ }^{38}$ THORNTON, John K.; HEYWOOD, Linda M. Central Africans, Atlantic Creoles, and the Foundation of the Americas, 1585-1660. Cambridge: Cambridge University Press, 2007, pp. 98-99, 101-104.

${ }^{39}$ Ibidem, p. 170.
} 
nem como a mudança cultural transformaria internamente o Kongo, Ndongo ou até a Angola portuguesa. Posteriormente, John K. Thornton ainda acrescentaria que a criação de uma nova cultura caminharia junto de uma "mistura racial", capacitando os indivíduos adeptos da cultura crioulo-atlântica a "viver nos dois mundos da África Central". ${ }^{40}$ Mas esses vestígios de variações de línguas, costumes e nomes portugueses advogam para a criação de uma nova cultura na África? Por que os movimentos de incorporação e integração abarcavam vastas populações já no século XVII? ${ }^{41}$ Apesar de instigante, o trabalho de Heywood e Thornton é vago quanto a esses pontos.

No caso da História de Angola entre os séculos XVI e XVII, abordar as criações advindas com os contatos implica também em manter atenção redobrada quanto a um fator crucial: a abertura para o Atlântico. A existência de Luanda, de comunidades e presídios portugueses e o crescimento de um comércio voltado para o tráfico de escravos acarretaram em transformações locais e regionais. Se por um lado as formas de intermediação eram fruto do convívio mútuo ou da busca por interesses pessoais ou comunitários, por outro lado o ambiente recriado na Angola portuguesa era conflituoso, marcado por tensões sociais, atritos institucionais e embates políticos. Havia uma íntima relação entre as intermediações e as chamadas "formas de dominação"

\footnotetext{
${ }^{40}$ Sobre os fluxos de influência cultural, com destaque ao cristianismo, verificar em especial: THORNTON, John K.; HEYWOOD, Linda M. Central Africans, Atlantic Creoles [...]. Cambridge: Cambridge University Press, 2007, pp. 62-63, 169-170. Sobre a "mistura racial", verificar: THORNTON, John K. A Cultural History of the Atlantic World, 1250-1820. Cambridge: Cambridge University Press, 2012, pp. 253-254.

${ }^{41}$ Aqui estamos nos baseando nas críticas que Gerhard Seibert endereçou a Linda M. Heywood e John K. Thornton, principalmente no que diz respeito às definições pouco criteriosas de fenômenos como a "crioulização" (creolization) e a "crioulidade" (creoleness) e, muitas vezes, sem diferenciar misturas culturas de outros tipos de misturas, como a sanguínea (ex: "mistura racial"). Vale lembrar que os fenômenos de "miscigenação" e "mestiçagem" são dessemelhantes, como ressaltou Rafael de Bivar Marquese a partir de Luiz Felipe de Alencastro, e, portanto, não devem ser confundidos. Por fim, apesar de não usar os termos "incorporação" e "integração", fortemente ligados à ideia de "aculturação", as considerações finais de Heywood e Thornton pressupõe o abandono da cultura mbundu pelas populações que estiveram em contato com a Angola portuguesa. Sobre as primeiras críticas, verificar o resumo em: SEIBERT, Gerhard. Creolization and Creole Communities in the Portuguese Atlantic: São Tomé, Cape Verde, the Rivers Guinea and Central Africa in Comparison. IN: GREEN, Tobias (ed.). Brokers of Change: Atlantic Commerce and Cultures in Precolonial Western Africa. Oxford: The British Academy/ Oxford University Press, 2012, pp. 29-31. Sobre as segundas: ALENCASTRO, Luiz Felipe de. O trato dos viventes: A formação do Brasil no Atlântico Sul. São Paulo: Companhia das Letras, 2000, p. 353. MARQUESE, Rafael de Bivar. A dinâmica da escravidão no Brasil: resistência, tráfico negreiro e alforrias, séculos XVII a XIX. Novos estudos. São Paulo: CEBRAP, n. ${ }^{\circ} 74,2006$, p. 118.

42 Trata-se de um empréstimo que fizemos de Rodrigo Faustinoni Bonciani, para quem a dominação se apresenta de maneira dialética em relação aos "níveis de domínio", revelados em discursos ou práticas, mais próximos do monarca ou perto dos agentes coloniais, de modo que "[...] as hierarquias de poder passam a ser definidas pelos níveis de apropriação do domínio sobre as populações não cristãs, reforçando a organização
} 
"clave" que muitas vezes regerá as nossas considerações. Assim sendo, veremos que paulatinamente alguns indivíduos e grupos de africanos prestaram serviço como agentes do funcionalismo régio português, adotando nomes e sobrenomes estrangeiros e se vestindo "à portuguesa", como notaram Heywood e Thornton. Em contrapartida, destoando por consequência da perspectiva desses pesquisadores, nosso esforço será o de não negligenciar que tais serviços muitas vezes orbitavam ao redor dos interesses de Luanda e estavam atrelados ao comércio atlântico. Em última instância - e como o leitor notará logo mais -, aqui a clave que rege as conexões e desconexões entre as formas de intermediação e dominação não figurará como um "pêndulo", apontando ora para cá, ora para lá, de acordo com os polos da discussão acadêmica, como diagnosticou Maria Leônia Chaves de Resende em um contexto diferente do nosso. ${ }^{43}$ Sob nossa clave reside uma pedra basilar, que deve ser esquadrinhada, descrita e analisada com cuidado e minúcia. Tal suporte nada mais é do que a chamada "documentação" dos historiadores de ofício.

Por mais que tais escritos sobre o passado sejam encarados atualmente como "documentos históricos", ou como uma pequena parte que conservamos sobre um passado remoto, isso não quer dizer que esses registros sejam uma "realidade tangível", depurada de imperfeições e livre de deturpações promovidas pelos cronistas, oficias e funcionários a serviço da monarquia. Sobretudo inspirados por Mary Louise Pratt e Catarina Madeira Santos, mas também por Edward W. Said e Valentin-Ives Mudimbe, nosso diagnóstico é o de que os documentos escritos são comumente "instrumentos intelectuais de poder" e, como tal, figuram como vestígios das relações assimétricas entre os povos em contato, como retoma Said a partir de Walter Benjamin, ao afirmar que "o documento de civilização é também um documento de barbárie". ${ }^{44}$ Assim, cremos que as reminiscências contidas nas

hierárquica daquela sociedade [ultramarina]". BONCIANI, Rodrigo Faustinoni. O dominium sobre os indígenas e africanos e a especificidade da soberania régia no Atlântico [...]. Universidade de São Paulo, 2010, p. 269. Conferir também a p. 177 sobre a disposição geral dos "níveis de domínios".

43 A metáfora do "pêndulo" e o impulso de superação para essa tendência foram impressos, para o caso ameríndio, em: RESENDE, Maria Leônia Chaves de. Visões da conquista [...]. Universidade de Campinas, 1993, pp. 31-32 e 38-39. Mesmo assim, apesar de propormos outro viés analítico, o leitor mais cuidadoso notará que a ideia de Resende continuará a nos influenciar.

${ }^{44}$ Para a noção de "instrumento intelectual de poder, verificar: SANTOS, Catarina Madeira. Écrire le pouvoir en Angola: Les archives ndembu (XVIIe-XXe siècles), Annales. Histoire, Sciences Sociales. Paris: Éditions de l'EHESS, n. ${ }^{\circ}$ 64, 2009/4, p. 777. A frase de Said pode ser conferida em: SAID, Edward W. Humanismo e crítica democrática. [2004]. São Paulo: Companhia das Letras, 2007, pp. 68-69. A citação original de Benjamin é a seguinte: "Nunca ouve um documento da cultura que não fosse simultaneamente um documento da barbárie". BENJAMIN, Walter. Sobre o conceito da História. [1940]. IN: Magia e técnica, arte e política: 
fontes escritas não devem ser lidas como um registro neutro do que aconteceu no momento da concepção textual, nem devem ser tratadas como "comprovações" úteis para validar ou desvalidar certas ideias que circulam na academia. O ponto nevrálgico é entender que há uma lógica de composição das fontes escritas, muitas vezes guiadas por ideias preconcebidas, ideologias e discursos montados pelo autor-compositor de escritos de época. Atento às escaramuças e às artimanhas das fontes coevas, cabe ao historiador não ser "capturado" ou enganado pelas desventuras e caminhos sinuosos que permeiam a lógica de composição textual.

Em um esforço de superação dos entraves e percalços já assinalados, nossa posição investigativa será a de nos valermos das fontes escritas como transcrições e composições textuais, ${ }^{45}$ capazes de refletir uma realidade observada "ao seu modo". Dessa forma, em um primeiro momento é necessário “desbaratar", ou simplesmente “desmontar”, a lógica de composição textual, para que em um segundo momento possamos extrair da documentação os eventos que nos auxiliarão na compreensão e explicação do processo histórico. ${ }^{46}$ Atentos, portanto, à importância de “espremer” a documentação ao máximo possível,

ensaios sobre literatura e história da cultura. [1985]. São Paulo: Editora Brasiliense, 2012, tese 7, pp. 244245. Em consonância com o pensamento de Edward W. Said, só que abordando a África, consultar: MUDIMBE, Valentin-Ives. The Invention of Africa: Gnosis, Philosophy, and the Order of Knowledge. Bloomington: Indiana University Press, 1988. Idem, The Idea of Africa. Bloomington e Indianapolis: Indiana University Press, 1994.

45 A "transcrição", ou também a "tradução", são atividades de articulação baseadas na utilização de "equivalências e homologias" necessárias para a convivência e comunicação entre sociedades distintas. Catarina Madeira Santos resume o ponto central da seguinte forma: "apesar da violência, da guerra, e do tráfico de escravos, a longa coabitação dos ambundo com os presídios, a instituição da vassalagem, e os interesses negreiros pelos caminhos e nas feiras, possibilitaram a abertura de canais de comunicação". Verificar: SANTOS, Catarina Madeira. Um governo "polido" para Angola [...]. Tese de doutorado, Universidade Nova de Lisboa, 2005, p. 12. Como produto de um tempo, os escritos oficiais contém o "interno pulsar documental", condizentes com as tipologias e utilizações de determinadas épocas, ou seja, os escritos seguem "formas de composição" inseridas no processo histórico. Verificar: HORTA, José da Silva. A "Guiné do Cabo Verde": produção textual e representações (1578-1648). [2002]. Tese de doutorado, Universidade de Lisboa, 2010, p. 279.

${ }^{46}$ Como lembra Eric Hobsbawn ao defender a primazia da evidência histórica, em claro desacordo com os exagerados relativismos do método desconstrutivista, "se o acusado em um processo por assassinato é ou não culpado, depende da avaliação da velha evidência positivista, desde que disponha de tal evidência. Qualquer leitor inocente que se encontrar no banco dos réus fará bem em recorrer a ela. São os advogados dos culpados que recorrem a linhas pós-modernas de defesa". O historiador ainda afirma, em outro momento: "Quando uma pessoa inocente é julgada por assassinato, e deseja provar a inocência, aquilo que se necessita não são as técnicas do teórico 'pós-moderno', mas as do antiquado historiador". Os trechos foram extraídos respectivamente de: HOBSBAWN, Eric. Sobre história. São Paulo: Companhia das Letras, 2001, pp. 8-9 e 287. Palavras importantes também foram legadas por Marc Bloch, para quem "existem duas maneiras de ser imparcial: a do cientista e a do juiz. Elas têm uma raiz comum, que é a honesta submissão à verdade". Verificar: BLOCH, Marc Leopold Benjamin. Apologia da história, ou, O Oficio de historiador. [1949]. Rio de Janeiro: Zahar, 2001, pp. 125-126. 
submeteremos à análise empírica algumas fontes secundárias, mas principalmente primárias, de autoria do governador português Fernão de Sousa, todas elas existentes na Coletânea Documental de Fernão de Sousa e que, há pouco tempo, foram premiadas com a edição organizada por Beatrix Heintze, intitulada Fontes para a História de Angola do Século XVII. ${ }^{47}$ Inspiradas pelo olhar e avaliação críticos de Heintze, ${ }^{48}$ o leitor perceberá que nossas considerações muitas vezes girarão em torno de preocupações sobre a confiabilidade de informações registradas, a partir dos termos "intrínsecos" à realidade de registro documental, quer dizer, voltados não necessariamente para uma “descrição fídedigna" e palpável da realidade - "isso aqui é real e portanto é passível de ser usada em minha narrativa sobre o passado" -, mas aos fenômenos de transcrição de realidades observadas “por que isso foi registrado? Isso é confiável?" -, imerso dentro de processos históricos e passíveis de serem reapreendidos pelos escopos de análise do historiador, como alertam as pesquisas de José da Silva Horta e Catarina Madeira Santos, no caso da África portuguesa, ${ }^{49}$ ou mesmo Silvia Hunold Lara, no caso da América portuguesa. ${ }^{50}$ Dessa

\footnotetext{
${ }^{47}$ HEINTZE, Beatrix (coord.). Fontes para a história de Angola do século XVII: I. Cartas e documentos oficiais da coletânea de Fernão de Sousa (1622-1635). Stuttgart: Frans Steiner Verlag Wiesbaden GMBH, 1985. II. Cartas e documentos oficiais da coletânea de Fernão de Sousa (1624-1635). Stuttgart: Frans Steiner Verlag Wiesbaden GMBH, 1988.

${ }^{48}$ Para exemplos da postura crítica de Heintze, sempre explorando as possibilidades dos arquivos históricos e defendendo uma investigação séria e comprometida com a análise documental, verificar: HEINTZE, Beatrix. Resenha sem título. Journal of the International African Institute. Cambridge: Cambridge University Press/ International African Institute, vol. 48, no. 1, 1978, pp. 83 e 85. Idem, References in the Humanities: Strategies of Being Open, Being Obscure and Being Misleading. History in Africa. Nova Jersey: African Studies Association, vol. 27, 2000, pp. 437-442. Heintze tem um minucioso trato com a documentação que nos inspira. Ela, por exemplo, ao diagnosticar que os africanistas enfrentam "mosaicos de informação" díspares entre si, criou uma forma de catalogar alguns "itens de informações", que passam assim a ser dispostos em uma linha cronológica confiável, capaz de auxiliar na investigação histórica voltada à leitura de documentos escritos. Sobre isso, ver especificamente: Written Sources and African History: A Plea for the Primary Source. The Angola Manuscript Collection of Fernão de Sousa. History in Africa. Nova Jersey: African Studies Association, vol. 9, 1982, pp. 77, 85-86 e 90-92.

${ }^{49} \mathrm{O}$ cerne da questão é rastrear o caminho ou sentido de proveniência da informação registrada em papel. Nesse sentido, poderíamos abordar as formas de "tradução ou transcrição" de diferentes "matrizes sociais", como fez Santos, ou advogar pela ideia de intercomunicação entre povos em contato, como fonte criadora de "coprodução de corpos textuais" na "expressão duma identidade e duma cultura luso-africanas", como propôs Horta. Apesar de dialogar com as duas posições, o leitor notará que concordamos mais com a primeira do que com a segunda. Verificar: SANTOS, Catarina Madeira. Um governo "polido" para Angola [...]. Tese de doutorado, Universidade Nova de Lisboa, 2005, pp. pp. 11-12. HORTA, José da Silva. A "Guiné do Cabo Verde" [...]. [2002]. Tese de doutorado, Universidade de Lisboa, 2010, pp. 41-42, 66 e 175.

${ }^{50}$ Estamos nos referindo a uma das preciosas assertivas feitas por essa pesquisadora, mais especificamente sobre o estudo da "escravidão atlântica", mas que vale também para o contexto de produção da nossa documentação: "O que é dito, escrito, desenhado está diretamente relacionado ao modo como, em determinada sociedade, as coisas podem ser ditas, escritas, faladas: os nexos que conformam um período histórico estão presentes também no movimento que dá origem às próprias fontes de história". Verificar:
} 
forma, o dito, não-dito e redito dos documentos são encarados como valiosos mananciais para a reconstrução do processo histórico, salvaguardado-nos de alguns dos anacronismos advindos do olhar contemporâneo. No mais, não desbravamos essa trilha solitariamente. No atual contexto acadêmico do Brasil, por exemplo, passos decisivos têm sido ensaiados por Lara, principalmente no que diz respeito a uma compreensão mais profunda de como "sintaxes e gramáticas políticas" diferentes, regionais ou locais, digladiavam nas mais diversas "arenas" de enfrentamento em voga no Atlântico moderno: jurídico, político, administrativo e social, para ficarmos apenas em algumas delas. ${ }^{51}$

\section{Apresentação da Coletânea Documental de Fernão de Sousa}

Atualmente a Coletânea Documental de Fernão de Sousa ${ }^{52}$ permanece conservada na Biblioteca da Ajuda de Lisboa (BAL), em Portugal. Contida nela estão dois códices encadernados em pergaminho e, na lombada de cada um deles, está escrito "Governo de Angolla do Senhor Fernando de Souza”. Os volumes de documentos recebem as cotas 51IX-20 e 51-IX-21, ${ }^{53}$ respectivamente. Em conjunto, eles somam cerca de 850 documentos de vários tipos, sobretudo abrangendo o período entre 1624 a 1635, totalizando aproximadamente 1700 páginas de texto manuscrito. ${ }^{54}$ Uma vez alojada na BAL, pressupomos que a $C D F S$ seguiu o princípio arquivístico de respeito aos fundos, assim preservando o âmago da proveniência documental. Quer dizer, as fontes escritas não foram destituídas de seus agrupamentos originais e, dessa forma, continuam a refletir as relações

LARA, Silvia Hunold. Fragmentos setecentistas: escravidão, cultura e poder na América portuguesa. São Paulo: Companhia das Letras, 2007, pp. 24-25, itálicos da autora.

${ }^{51}$ Sobre as tais "gramáticas e sintaxes políticas", tributárias dos estudos voltados à cultura política, verificar: Idem, Palmares \& Cucaú: o aprendizado da dominação. Tese para concurso de Professor Titular, Universidade Estadual de Campinas, 2008, pp. 120-121 e 169-170. Sobre a constatação da existência das chamadas "arenas", com enfoque nos choques de cunho político-jurídico, mas que extrapolavam as simples palavras de "lei e ordem", como marcas da América portuguesa e que pensamos também valer para o caso centro-africano, verificar: Idem, Senhores da régia jurisdição: o particular e o público na vila de São Salvador dos Campos dos Goitacases na segunda metade do século XVIII. IN: LARA, Silvia Hunold; MENDONÇA, Joseli Maria Nunes. Direitos e justiças no Brasil: ensaios de história social. Campinas: Editora da UNICAMP, 2006, p. 81.

${ }_{52}^{52}$ Doravante apenas $C D F S$.

${ }^{53}$ Conforme Heintze, as cotas antigas eram 51-VIII -30 e 51-VIII-31.

${ }^{54}$ De acordo com Heintze, são 510 e 350 folhas de papel para cada códice, respectivamente. A maioria das páginas está totalmente escrita. Verificar: HEINTZE, Beatrix (coord.). A Colectânea Documental de Fernão de Sousa, FHA, vol. I, 1985, p. 47. Idem, Written Sources and African History [...]. History in Africa. Nova Jersey: African Studies Association, vol. 9, 1982, p. 78. 
de produção tecidas com suas entidades geradoras. ${ }^{55}$ Para nós, historiadores, ${ }^{56}$ conhecer essa "organicidade" dos documentos é de grande auxílio, ${ }^{57}$ pois nos priva de assunções equivocadas e nos resguarda de falsas interpretações. Assim sendo, circunscritas às tipologias, às condições de produção e à circulação de documentos, as alongadas apresentações às fontes escritas feitas a seguir figuram como uma tentativa de nos furtar de armadilhas que volta e meia atravancam a investigação histórica, "enrascadas" necessariamente desviáveis para a apreensão de uma "história africana", a partir de documentos concebidos por europeus, conforme o diagnóstico de Adriano Parreira. ${ }^{58}$ Tal é o caso tanto na CDFS quanto na Fontes para a História de Angola do Século XVII. ${ }^{59}$

Começamos então pelo agrupamento do conteúdo inserido na $C D F S$, conforme as considerações feitas por Beatrix Heintze. ${ }^{60} \mathrm{O}$ primeiro volume do conjunto documental é

\footnotetext{
${ }^{55}$ Segundo Heintze, ainda são imprecisas as condições pelas quais a $C D F S$ passou até chegar em BAL. Sobre isso, verificar especialmente: HEINTZE, Beatrix (coord.). A Colectânea Documental de Fernão de Sousa, $F H A$, vol. I, 1985, p. 49. Sobre o princípio arquivístico dos fundos, verificar: MAESIMA, Cacilda. Noções de Arquivística e Organizações de Arquivos Históricos. IN: HAHN, Fábio André; MEZZOMO, Frank Antonio (orgs.). Nas Malhas do Poder: história, cultura e espaço social. Campo Mourão: Editora Fecilcam, 2011, pp. 166, 168-170.

${ }^{56}$ Fazemos de nossas palavras os ensinamentos de Marc Bloch, propriamente a respeito da "apologia da história", ou "ofício do historiador", como um estudo "regressivo" e, conforme a fórmula do próprio Bloch, "a ciência do homem no tempo". Dotado de um olhar contemporâneo, o historiador é um especialista capaz de "projetar" sua visão analítica ao passado, reconstruindo de "trás para frente" uma narrativa que, ao término do trabalho do historiador, será apresentada ao público de maneira cronológica, não deixando de ser também uma construção de seu próprio tempo. Verificar: BLOCH, Marc Leopold Benjamin. Apologia da história, ou, O oficio de historiador. [1949]. Rio de Janeiro: Zahar, 2001, pp. 66-67, 54-55. Conforme a edição brasileira utilizada, que conta com um prefácio de Jacques Le Goff e uma apresentação de Lilia Moritz Schwarcz, considerar também as explicações desta, nas pp. 7 e 9, e daquele, nas pp. 24-25 e 29-30. Ao lembrar do pouco apelo que o pensamento dos Annales teve entre os africanistas dos anos cinquenta e sessenta, Peter Burke não deixou de excetuar a figura de Jan Vansina, que fez uso da "distinção temporal braudeliana, curta, média e longa duração, como alicerce de seu estudo sobre a tribo Kuba, da África Central". A influência francesa também reverberou na geração seguinte, entre Joseph C. Miller e John K. Thornton. Verificar: BURKE, Peter. A Escola dos Annales (1929-1989): a Revolução Francesa da historiografia. [1990]. São Paulo: Fundação Editora da UNESP, 1997, pp. 114 e nota 11.

${ }^{57}$ Sobre a organicidade, verificar: MAESIMA, Cacilda. Noções de Arquivística [...]. IN: HAHN, Fábio André; MEZZOMO, Frank Antonio (orgs.). Nas Malhas do Poder [...]. Campo Mourão: Editora Fecilcam, 2011, pp. 168 e 170, especialmente a nota 24.

${ }^{58}$ PARREIRA, Adriano. Economia e sociedade em Angola na época da Rainha Jinga (século XVII). Lisboa: Editora Estampa, 1997, p. 20.

${ }^{59}$ Doravante apenas FHA. Para mais detalhes sobre as diferenças entre cópias, originais, rascunhos e vias, conferir os comentários em: HEINTZE, Beatrix (coord.). Selecção dos documentos e princípios de edição, FHA, vol. II, 1988, pp. 33-34.

${ }^{60}$ Estamos nos referindo às informações introdutórias sobre a $C D F S$ inseridas na $F H A$. Faremos uso também de um artigo de Heintze que, a despeito "infelizmente das numerosas erratas", conforme a própria pesquisadora, ainda nos parece útil para entender alguns aspectos da documentação. Quando necessário, indicaremos ao leitor o momento no qual as informações aqui fornecidas devem ser comparadas entre esses dois textos. Conferir: HEINTZE, Beatrix. Written Sources and African History [...]. History in Africa. Nova
} 
composto por várias "seções temáticas", perceptíveis através de entradas, ou notas manuscritas, inseridas no original. Tais seções não seguem à risca, todavia, temas e assuntos muito rígidos e meticulosamente separados, assim abarcando conteúdos variados, nas mais diferentes formas de documentos - portarias, bandos, regimentos, cartas, entre outros. Seja como for, a primeira das seções tem início com alguns documentos relacionados à nomeação de Fernão de Sousa ao governo de Angola, portanto oficialmente diretivos e legitimadores, seguidos por dois mapas e um quadro, no qual estão descritos as "fortalezas, soldados e provisões de armas e munições na região". ${ }^{61}$ Sabe-se que pelo menos um desses mapas foi publicado na Portvgaliae Monvmenta Cartographica de Armando Cortesão e Avelino Teixeira da Mota. ${ }^{62}$ A segunda seção contém cartas régias, alvarás e algumas provisões, além de um relatório de um autor anônimo e um parecer sobre a fortificação de Luanda. Doze desses documentos foram publicados por António Brásio no sétimo volume da Monumenta Missionaria Africana. ${ }^{63}$ Também há aqui cinco documentos deslocados, três de autoria do neto de Fernão de Sousa, que carregava o mesmo nome do avô, e duas de autoria do "nosso" Fernão de Sousa. ${ }^{64}$ Vem em seguida a terceira seção deste códice, considerada a mais importante de todas por Beatrix Heintze. Inicia com uma descrição, feita pela pena de Fernão de Sousa, da viagem de um homem chamado João Nunes de Andrade à África Ocidental. Segue-se então uma descrição da "Angola portuguesa e das regiões circunvizinhas", divididas em seis capítulos. ${ }^{65}$ No meio dessa seção está inserido "o documento de maior significado da Coletânea", o extenso relatório de Fernão de Sousa, que compreende desde o período de sua nomeação, em 5 de outubro de

Jersey: African Studies Association, vol. 9, 1982, pp. 80-84. Idem, A Colectânea Documental de Fernão de Sousa, FHA, vol. I, 1985, pp. 50-55 e nota 16.

${ }^{61}$ HEINTZE, Beatrix. A Colectânea Documental de Fernão de Sousa, FHA, vol. I, 1985, p. 50. Comparar com: Idem. Written Sources and African History [...]. History in Africa. Nova Jersey: African Studies Association, vol. 9, 1982, p. 80.

${ }^{62}$ Daqui para frente apenas $P M C$. Trata-se do mapa inserido no f. 2 da $C D F S$. Conforme Heintze, para a plenitude dos mapas verificar na $P M C$ o volume V, estampas 605 D, 606 A, B e C. Mais informações podem ser conferidas em: HEINTZE, Beatrix. Written Sources and African History [...]. History in Africa. Nova Jersey: African Studies Association, vol. 9, 1982, p. 55, nota 36.

${ }^{63}$ Doravante apenas $M M A$.

${ }^{64}$ Conferir especificamente: HEINTZE, Beatrix. A Colectânea Documental de Fernão de Sousa, $F H A$, vol. I, 1985, pp. 50-51. Comparar com: Idem. Written Sources and African History [...]. History in Africa. Nova Jersey: African Studies Association, vol. 9, 1982, p. 80.

${ }^{65}$ Conferir pormenores em: HEINTZE, Beatrix. A Colectânea Documental de Fernão de Sousa, FHA, vol. I, 1985, pp. 51-52. Comparar com: Idem. Written Sources and African History [...]. History in Africa. Nova Jersey: African Studies Association, vol. 9, 1982, p. 80. 
1623, até o término da vigência do mesmo, em 1630. No momento adequado apresentaremos mais considerações a respeito dele.

A terceira seção termina com uma lembrança sobre como os pagamentos eram procedidos na Angola portuguesa, vindo em seguida uma nova seção, composta por 130 cópias de cartas e relatórios de Fernão de Sousa, todas dirigidas às diversões instituições reinóis - Mesa da Consciência, Conselho da Fazenda Mesa do Paço, para ficar apenas nas mais importantes. Cerca de um quinto desses documentos foi publicado no sétimo volume da $M M A$ de Brásio. ${ }^{66}$ Anexas a esta seção estão inseridas mais 65 "cartas de Fernão de Sousa às altas individualidades", conforme explica Heintze, e que no original recebe a nota de "Lembranças do que se me encarregou do Reino e de que ei de dar razão nele". ${ }^{67} \mathrm{~A}$ quinta e última seção temática deste códice contém 97 cópias de escrituras, a respeito de concessões de terras nos rios Bengo, Dande, Quilunda e Cuanza e regiões do Sequele e lagoa de Quilunda. ${ }^{68} \mathrm{Na}$ obra Angola. Apontamentos sobre a ocupação e início de estabelecimento dos portugueses no Congo, Angola e Benguela, ${ }^{69}$ organizada por Alfredo Albuquerque de Felner, há uma lista com 96 dessas concessões, com o nome de beneficiados, dimensão e localização das terras concedidas. ${ }^{70} \mathrm{O}$ restante dos documentos não apresenta organização homogênea, havendo grande discrepância entre os escritos. ${ }^{71}$

O segundo volume da CDFS é sensivelmente menos organizado que o primeiro. Abrem-no dois mapas da baía de Luanda e uma planta de sua fortificação costeira, vindo em seguida uma primeira seção textual, com a entrada no original de "Cópias de informações de várias matérias que dei de Angola por particulares ordens que para isso

\footnotetext{
${ }^{66}$ Verificar pormenores em: Idem. Written Sources and African History [...]. History in Africa. Nova Jersey: African Studies Association, vol. 9, 1982, nota 16, p. 96.

${ }^{67}$ HEINTZE, Beatrix. A Colectânea Documental de Fernão de Sousa, FHA, vol. I, 1985, p. 53. Comparar com: Idem. Written Sources and African History [...]. History in Africa. Nova Jersey: African Studies Association, vol. 9, 1982, p. 82.

${ }^{68}$ HEINTZE, Beatrix. Written Sources and African History [...]. History in Africa. Nova Jersey: African Studies Association, vol. 9, 1982, p. 82. Idem. A Colectânea Documental de Fernão de Sousa, FHA, vol. I, 1985, p. 53.

${ }^{69}$ Doravante apenas AAOI.

${ }^{70}$ HEINTZE, Beatrix. Written Sources and African History [...]. History in Africa. Nova Jersey: African Studies Association, vol. 9, 1982, p. 96, nota 18. Conforme Heintze, consultar especificamente as pp. 524-28 da $A A O I$.

${ }^{71}$ Verificar os exemplos fornecidos pela pesquisadora em: Ibidem, pp. 82-83. HEINTZE, Beatrix. A Colectânea Documental de Fernão de Sousa, FHA, vol. I, 1985, pp. 53-54.
} 
recebi". Tanto a planta de fortificação quanto os mapas estão reproduzidos $P M C .^{72}$ Igualmente estão contidas nessa seção vinte memorandos e pareceres de Fernão de Sousa, todos escritos após o regresso do administrador a Portugal. Deles, os onze principais foram publicados no oitavo volume da $M M A .^{73}$ A segunda seção desse códice, com a entrada "treslado de algumas cartas e de outras cousas necessárias para os governos de quaisquer estado", contém modelos de cartas e documentos de diversos tipos. Nas palavras de Heintze, trata-se de "um caderno de modelos para formular corretamente os escritos oficiais de qualquer espécie". ${ }^{74} \mathrm{O}$ restante dessa seção é preenchido por cópias de cartas enviadas à Coroa e nomeações consideradas importantes, além de provisões, regimentos e bandos. Fora escassos aditamentos, todo o conteúdo dessas cópias bate com as vias inseridas no primeiro volume. As cópias inseridas nessa seção foram escritas pelo punho do secretário pessoal de Fernão de Sousa em Angola, Luís Correa Coelho, e de seu substituto, António Leitão, que assumiu o cargo após a morte do primeiro, em 1629. O segundo volume termina com uma miscelânea de documentos, com destaque a onze concessões de terras, complementares às existentes no primeiro volume. Na lista da $A A O I$, há informações sobre dez dessas concessões. ${ }^{75}$

Uma vez apresentada a forma com que os documentos da CDFS foram agrupados, cabe fazer algumas considerações a respeito das condições de produção do conjunto documental. Com a exceção de alguns documentos, a maioria dos escritos inseridos nos dois códices é de autoria de Fernão de Sousa, ou foram escritos por um de seus secretários, Luís Correa Coelho ou António Leitão, a pedido do governador. Naturalmente, o grosso dos documentos compreende o período entre 1624 a 1635, época em que Fernão de Sousa serviu no ultramar africano. Após o regresso a Portugal, ele acabaria investigado pelo Conselho da Fazenda e seria alvo dos relatórios do Desembargo do Paço, até pelo menos um período bem perto do ano de seu falecimento, em 1635. Assim, nos últimos cinco anos

\footnotetext{
${ }^{72}$ Conferir informação em: HEINTZE, Beatrix. A Colectânea Documental de Fernão de Sousa, $F H A$, vol. I, 1985 , p. 55, nota 36.

${ }^{73}$ HEINTZE, Beatrix. A Colectânea Documental de Fernão de Sousa, FHA, vol. I, 1985, p. 54. Comparar com: Idem, Written Sources and African History [...]. History in Africa. Nova Jersey: African Studies Association, vol. 9, 1982, p. 83.

${ }^{74}$ HEINTZE, Beatrix. A Colectânea Documental de Fernão de Sousa, FHA, vol. I, 1985, p. 54. Comparar com: Idem, Written Sources and African History [...]. History in Africa. Nova Jersey: African Studies Association, vol. 9, 1982, p. 83.

${ }^{75}$ Verificar: Idem, Written Sources and African History [...]. History in Africa. Nova Jersey: African Studies Association, vol. 9, 1982, p. 96, nota 18.
} 
de vida, Fernão de Sousa foi interrogado e sabatinado pelos órgãos reinóis, estando na mira de contestações a respeito das medidas que tomara durante o exercício de suas funções e sendo cobrado por explicações sobre a situação nada animadora na qual o espaço ultramarino foi encontrado pelo seu sucessor, Dom Manuel Pereira Coutinho. ${ }^{76}$ Portanto, não surpreende o fato de que boa parte dos documentos escritos entre 1631 e 1635, ao evocar algumas das experiências vividas em terras africanas, esteja imbuída de justificativas a repeito das decisões tomadas em ultramar.

A maioria dos problemas constatados pelo Conselho da Fazenda girava em torno do atribulado estado de guerra pelo qual passou a Angola portuguesa entre 1626 a 1629, além da ausência de comércio e tributação após 1630, divergindo das ordens e mercês régias conferidas a Fernão de Sousa a partir de $1623,{ }^{77}$ com destaque àquelas inseridas no chamado "regimento de do governador de Angola", datado de 20 de março de 1624. Aliás,

${ }^{76}$ HEINTZE, Beatrix. A Colectânea Documental de Fernão de Sousa, FHA, vol. I, 1985, p. 393.

${ }^{77}$ O relevante aqui é compreender que a "mercê" era uma "doação", ou uma "concessão", feita em nome da Coroa portuguesa, entendida como sendo um "árbitro" ou "juiz" que geria uma economia distributiva de cargos, honrarias, ofícios, títulos, comendas e graças, inegavelmente firmada nos princípios de fidelidade e lealdade recíprocas à monarquia. Resumidamente, existia uma economia redistributiva fundada na lógica de retribuição real, intimamente ligada ao funcionamento do "corpo místico" da monarquia, como indicam António Manuel Hespanha e outros pesquisadores. Posto dessa forma, valemo-nos de algumas explicações propostas por Fernanda Olival e Mafalda Soares da Cunha, a respeito da dádiva real das mercês: $i$ ) A "liberalidade" do rei estava baseada na reciprocidade aristotélica, também evocada nas Sagradas Escrituras cristãs; ii) Mercês poderiam ser concedidas por "via da graça", sem remuneração, e por via da "justiça", com remuneração e valor judiciário nos tribunais, como aconteceu com Fernão de Sousa; ii) No século XVIII, Dom João III proclamou ser da prerrogativa real "fazer mercê e perdoar"; iii) Nos termos de Olival, os serviços prestados ao rei eram uma espécie de "investimento, ou seja, um capital susceptível de ser convertido em doações da Coroa, num tempo posterior"; IV) Segundo Cunha, a "outorga de mercês" por parte do rei, como também acontecia nas ilustres "casas" do reino de Portugal, "recaia no domínio (quase) puro do arbítrio". Verificar: OLIVAL, Fernanda. As Ordens Militares e o Estado Moderno: Honra, Mercê e Venalidade em Portugal (1641-1789). Lisboa: Editora Estar, 2001, pp. 16, 18-20 e 24. CUNHA, Mafalda Soares da. A Casa de Bragança 1560-1640: Práticas senhoriais e redes clientelares. Lisboa: Editorial Estampa, 2000, p. 74. Para fins práticos, quando falarmos de "mercês", estamos nos referindo ao ato real de "fazer mercê", como foi exemplificado repetidas vezes em: BLUTEAU, Raphael. Vocabulario portuguez, e latino, aulico, anatomico, architectonico, bellico, botanico... autorizado com exemplos dos melhores escritores portuguezes e latinos e offerecido a El rey de Portugal D. João V. [1716] Hildesheim: Georg Olms Verlag, 2002, vol. V, pp. 430-432. Verificar também a obra já citada de Fernanda Olival, p. 22. Sobre a noção de "corpo místico", identificado por Hespanha através do conceito de "polissinodia", verificar a mesma obra de Olival, pp. 20-21. ZERON, Carlos Alberto de Moura Ribeiro. A construção de uma ordem colonial nas margens americanas do Império português: discussões sobre o "bem comum" na disputa de moradores e jesuitas pela administração dos índios (XVI-XVII). Tese de livre-docência, Universidade de São Paulo, 2009, p. 27. HESPANHA, António Manuel. As vésperas do Leviathan: instituições e poder político. Portugal, século XVII. Coimbra: Editora Almedina, 1994, p. 300. Idem, História das Instituições: época medieval e moderna. Coimbra: Livraria Almedina, 1982, pp. 201, 207 e nota 182. MARQUESE, Rafael de Bivar. Feitores do corpo, missionários da mente: Senhores, letrados e o controle dos escravos nas Américas, 16601860. São Paulo: Companhia das Letras, pp. 496. Idem, Ideologia imperial, poder patriarcal e o governo dos escravos nas Américas, c. 1660-1720. Afro-Ásia. Salvador: Universidade Federal da Bahia (UFBA), n. ${ }^{\circ}$ 31, 2004, p. 60 e nota 42. 
por mais importante que esse documento seja, à guisa de um "guia" seiscentista sobre a correta governança das periferias ultramarinas e esclarecedor quanto aos modos de governar da época, não alimentamos falsas expectativas quanto às encomendas e às prescrições nele inscritas. Tal regimento não era o reflexo das experiências vividas e nem o produto de uma ação tomada no ultramar e, por isso, é necessário ter cautela: uma coisa era o desejo e as encomendas reinóis registradas no regimento, outra coisa bem diferente foi o que aconteceu "em campo". 78

Também é interessante destacar que havia uma sensibilidade régia quanto à condição do domínio ultramarino centro-africano, tributário de outras notícias e investigações decorrentes do período posterior a 1630, mas que destoava de parte das notícias reportadas por Fernão de Sousa entre 1624 a 1630. Há uma discrepância entre o que era dito, ou o que "precisava ser dito" às instituições ibéricas e reinóis, e o que virava prática na costa e interior africanos. Isso nos remete a um segundo aspecto da composição documental: os escritos contidos na CDFS atestam para os "sucessos" e as dificuldades enfrentadas por Fernão de Sousa durante o tempo em que lá permaneceu. O intuito dos textos aqui utilizados não era simplesmente informar, como se a pena de Fernão de Sousa fosse guiada pelo intuito de "registrar uma realidade" tal como ela era apresentada, mas também justificar algumas das decisões tomadas durante o serviço ultramarino, apontando os serviços prestados e destacando as glórias e sucessos alcançados, sempre em nome da

\footnotetext{
${ }^{78}$ Dom Diogo de Castro [feito por António Correa e escrito por Cristovão Soares]. Regimento do governador de Angola. 20 de março de 1624. BAL, cód. 51-IX-20, ff. 7-11. IN: HEINTZE, Beatrix (coord.). Documento 4, FHA, vol. I, 1985, pp. 140-153. Disso também é possível depreender que havia uma relação dicotômica entre as expectativas do "centro político" - Lisboa, mais especificamente despachadas das instituições monárquicas ali sediadas - e as várias "realidade periféricas" no reino e ultramar, mesmo que a ordenação entre "centro e periferias" estivesse distribuída entre camadas e subcamadas, todas elas inter-relacionadas e compósitas de um todo orgânico e dialético. Para o contexto seiscentista de Portugal, com especial atenção ao desenvolvimento de redes clientelares, matrimoniais e familiares que poderiam ser reproduzidas em diferentes âmbitos, verificar: CUNHA, Mafalda Soares da; MONTEIRO, Nuno G. Aristocracia, poder e família em Portugal, séculos XV-XVIII. IN: CUNHA, Mafalda Soares da; FRANCO, Juan Hernández (orgs.). Sociedade, família e poder na Península Ibérica: Elementos para uma História Comparativa. Lisboa: Edições Colibri/ CIDEHUS - Universidade de Évora/ Universidad de Murcia, 2010, p. 74. Sobre os paradoxos e contrapontos que essa reprodução, ou recriação, atingiu no contexto ultramarino, conferir especificamente: BICALHO, Maria Fernanda Baptista. As fronteiras da negociação: as câmaras municipais na América Portuguesa e o poder central. História: Fronteiras - Anais do XX Simpósio Nacional de História. São Paulo: Associação Nacional de História (ANPUH), 1999, pp. 469 e 471-472. Para uma análise acerca dos regimentos, com especial atenção às formas de abordar as muitas discrepâncias entre norma e realidade, intenção anunciada e prática terrena, que estão imersas nas cláusulas permanentes inseridas no regimentos do século XVII, verificar: HEINTZE, Beatrix. Angola nos séculos XVI e XVII: estudos sobre fontes, métodos e história. Luanda: Kilombelombe, 2007, capítulo 3, especificamente as pp. 96-98.
} 
Coroa unificada dos Filipes. Poder-se-ia dizer também "autojustificar" as ações tomadas, como propôs Heintze, "especialmente quando estavam em jogo conflitos pessoais ou de carácter geral". ${ }^{79}$ Em suma, a necessidade de informar era importante desde que ela estivesse acoplada às justificativas de cunho legitimador dos serviços prestados. Podemos dizer que esse foi um primeiro crivo para a confecção do material escrito.

Como salienta Beatrix Heintze, as condições de produção da CDFS também seguiram outros aspectos importantes. A seriação e encadernação dos dois volumes contaram com a participação de Tomé de Sousa, filho de Fernão de Sousa, uma vez que, na nota inicial da seção mais importante do primeiro volume, está escrito: "Relação sumária de tudo o que sucedeu a meu pai e senhor no tempo em que foi governador de Angola...". 80 Foi contudo graças ao filho de Tomé de Sousa, outrossim chamado de Fernão de Sousa, que os dois compêndios de fato ganharam corpo, pois como bem nota Heintze, "disto podese deduzir indirectamente da inclusão de três cartas do rei do ano de 1653, dirigidas precisamente a este neto". ${ }^{81}$ A coprodução da CDFS evidentemente envolveu experiências pessoais díspares, contanto que os envolvidos na manufaturação do produto final partilhassem de um mesmo "fio condutor". Como materiais escritos, agrupados, encadernados e depois preservados em bibliotecas e arquivos, na verdade qualquer lugar que seja um "lugar de memória", 82 os dois códices da CDFS, e que hoje estão acondicionados na BAL, são produtos de seu tempo e, por consequência, são dotados de historicidade, de uma "história de composição", para simplificar. Esse foi o segundo crivo que competiu para a concepção da $C D F S$.

A produção da $C D F S$ foi condicionada não apenas pela busca ferrenha por legitimação e autoexplicações voltadas ao "correto" cumprimento dos serviços ultramarinos durante o Antigo Regime, mas está imersa também dentro de circunstâncias históricas e experiências de vida compartilhadas pelos coautores do conjunto documental. Faz-se necessário, portanto, pelo menos em um momento inicial e de maneira um pouco rasa,

\footnotetext{
${ }^{79}$ HEINTZE, Beatrix. A Colectânea Documental de Fernão de Sousa, FHA, vol. I, 1985, p. 41.

${ }^{80}$ Conforme ibidem, p. 47, nota 1 , trecho retirado de BAL, 20, f. 216.

${ }^{81}$ Conferir BAL, 20, ff. 202-06. Verificar ainda ibidem, p.47.

82 Dito de outra forma, lugares onde as memórias coletiva, nacional ou individual devem ser retidas e preservadas. Trata-se de "resgatar" as memórias: "como a criança que caiu no poço e não consegue subir à superfície sem o auxílio providencial dos bombeiros", as diferentes memórias devem "salvas" e alojadas em lugares de resguardo. MENESES, Ulpiano T. Bezerra de. A História, Cativa da Memória? Para um Mapeamento da Memória no Campo das Ciências Sociais. Revista do Instituto de Estudos Brasileiros. São Paulo: Universidade de São Paulo, n. ${ }^{\circ}$ 34, dez. 1992, p. 10.
} 
adentrarmos na privacidade e na história familiar dos parentes mais próximos e "célebres" de Fernão de Sousa, para então propormos desdobramentos condizentes com os nossos interesses de pesquisa. Assim, entrelaçando aspectos estruturais e factuais da história política de Portugal, notaremos ao longo deste caminho que as ações e interesses dos familiares dos Sousa convergiam diretamente com o desenvolvimento político da monarquia portuguesa, sobretudo na prestação de serviços à Casa de Bragança, sendo exatamente como agentes inseridos nos quadros do Antigo Regime, que as três gerações dos Sousa elaboraram e arregimentaram os dois códices que integram a CDFS e que agora temos em mãos como fontes históricas privilegiadas para remontar o passado de Angola.

Filho de Martin Afonso de Sousa e Joana Tavor, Fernão de Sousa, o governador de Angola entre 1624-1630, nasceu em 19 de abril de 1563, provavelmente em Vila Viçosa, ${ }^{83}$ vindo a falecer em 3 de outubro de 1635. Descendente da "grande e prestigiosa família dos Sousas", as evidências históricas pertinentes à biografia oficial de Fernão de Sousa e seus parentes mais próximos derivam da reconstituição genealógica, elitista e costumeira, existente entre as nobres famílias do Antigo Regime. ${ }^{84}$ Sobretudo preocupadas com a comprovação da filiação aristocrática ligado ao parentesco sanguíneo, o afamado "sangue azul", além do destaque aos "bons" serviços prestados às altas casas portuguesas, portanto ávidas pelo acúmulo de mais prestígio social e político, as árvores genealógicas e as memórias oficiais eram encomendadas aos linhagistas, a fim de restituir as carreiras de antepassados "ilustres" e rememorar os serviços prestados pelos "digníssimos" parentes, geralmente concatenando esses personagens a momentos-chave da história política de Portugal. Não era menos importante a tentativa de elevação de um passado nobiliárquico, que deveria ser marcado por glórias, além do persistente intuito em restituir as origens dos títulos nobiliárquicos, já que com isso se comprovava a fidalguia da família. À luz dessa prática memorialista, por estar entrelaçada com o funcionamento do Antigo Regime, a memória oficial da família dos Sousa assinala que o primeiro membro dessa estirpe a

\footnotetext{
${ }^{83}$ HEINTZE, Beatrix. Sobre a biografia de Fernão de Sousa, FHA, vol. I, 1985, pp. 11-12. Idem, Mais alguns dados sobre a biografia de Fernão de Sousa, FHA, vol. II, 1988, p. 11. Cabe ressaltar que Vila Viçosa era a "sede da administração senhorial" da Casa de Bragança, onde por exemplo ocorria a distribuição de cargos palatinos e administrativos. Verificar: CUNHA, Mafalda Soares da. A Casa de Bragança 1560-1640 [...]. Lisboa: Editorial Estampa, 2000, pp. 61-62 e 215.

${ }^{84}$ Genealogias essas que, como veremos, estavam empenhadas em relembrar o passado de determinada fidalguia ou nobreza em nome do presente, como destacado em: CUNHA, Mafalda Soares da. A Casa de Bragança 1560-1640 [...]. Lisboa: Editorial Estampa, 2000, p. 59.
} 
receber a titulação de Redondo fora o neto do "nosso" Fernão de Sousa. Trineto deste, outro ilustre membro da família, Francisco Inocêncio de Sousa Coutinho, viraria um importante governador de Angola entre 1764 e $1772 .{ }^{85}$ Salta aos olhos outra curiosidade. Coube a Francisco Inocêncio de Sousa Coutinho, mais de dois séculos após o "nosso" Fernão de Sousa ter falecido, a produção de um "material de fontes históricas de volume e riqueza semelhantes" ao que presenciamos na $C D F S$, como indicou Beatrix Heintze, sendo por meio dele que Sousa Coutinho acabaria lembrado pelos "sublimes" e "ilustríssimos" serviços prestados ao monarca português. ${ }^{86}$

O Fernão de Sousa da passagem do século XVI para o XVII era um fidalgo abastado, com diversas propriedades e detentor de rendas nobiliárquicas, provenientes de arrendamentos e impostos. ${ }^{87}$ Fora casado duas vezes, a primeira com Antónia de Lacerda e a segunda com Maria de Castro, aumentando a quantidade de propriedades e bens herdados dos pais. À parte dos matrimônios e das inúmeras alienações de terras que operou durante a vida, ${ }^{88}$ não foram menos importantes os cargos e serviços políticos, administrativos e burocráticos que o português exerceu, em notável ascensão social dentro dos quadros políticos-institucionais que integravam a monarquia. ${ }^{89}$ No começo da carreira, Fernão de Sousa serviu ao cardeal D. Henrique como "moço fidalgo", depois virou "vedor e mordomo-mor" da Casa dos Duques de Bragança, posto régio que ocupou por vinte e cinco

\footnotetext{
${ }^{85}$ Peculiar também é o fato de outro Fernão de Sousa da família, quinto-avô do "nosso" Fernão de Sousa, ter adquirido o senhorio de Gouveia em 1473, como pormenorizaremos mais para frente. Verificar: HEINTZE, Beatrix. Sobre a biografia de Fernão de Sousa, FHA, vol. I, 1985, pp. 11e 45.

${ }^{86}$ Idem, Mais alguns dados sobre a biografia de Fernão de Sousa, FHA, vol. II, 1988, pp. 33-34. Sobre o período de Francisco Inocêncio de Sousa Coutinho, ficamos com as palavras de Catarina Madeira Santos, para quem: "equiparada ao Marquês de Pombal, a figura do governador foi 'mitificada' por uma historiografia muito ligada à ideologia do Estado Novo e, embora esta já se quisesse científica, não deixou de produzir heróis nacionais, capazes de encarnar a ordem e a autoridade governamental". Verificar: SANTOS, Catarina Madeira. Um governo "polido" para Angola [...]. Tese de doutorado, Universidade Nova de Lisboa, 2005, p. 7. Outrossim verificar: CORRÊA, Elias Alexandre da Silva. História de Angola. [1792-1799]. Lisboa: Editorial Ática, vol. II, 1937. pp. 29-44. Cronista e militar, essa figura histórica era proveniente da América portuguesa e prestou serviço do outro lado do Atlântico, entre 1782 a 1789 , ou seja, pouco depois da "experiência centro-africana" publicaria sua História de Angola, possivelmente separada em dois volumes, apesar das informações desencontradas que foram adquiridas após um breve levantamento. Verificar: CARVALHO, Flávia Maria de. Os homens do rei em Angola: sobas, governadores e capitães-mores, séculos XVII e XVIII. Tese de doutorado, Universidade Federal Fluminense, 2013, pp. 17-18.

${ }^{87}$ HEINTZE, Beatrix. Sobre a biografia de Fernão de Sousa, FHA, vol. I, 1985, pp. 37-38.

${ }^{88}$ Ibidem, pp. 34-37. Conferir ainda, principalmente as figuras: Idem, Mais alguns dados sobre a biografia de Fernão de Sousa, FHA, vol. II, 1988, pp. 14-15 de Heintze 1988.

${ }^{89}$ Seguindo assim um padrão bastante difundido no Antigo Regime, capaz de formar uma multiplicidade de redes de solidariedade e de interesses coexistentes, como elucidado em: CUNHA, Mafalda Soares da. A Casa de Bragança 1560-1640 [...]. Lisboa: Editorial Estampa, 2000, pp. 42-43.
} 
anos. Enquanto servia diretamente à casa dos Bragança, habitou em Vila Viçosa, depois foi parar em Évora, onde teve breve passagem, ${ }^{90}$ até se instalar em Lisboa, ${ }^{91}$ momento no qual receberia a nomeação para o posto de governador de Angola. De todo modo, apesar de tocar a vida no sul de Portugal, Fernão de Sousa nunca se desvencilhou da herança nortista que herdara dos pais, onde era "senhor do concelho ${ }^{92}$ de Gouveia de Riba Tâmega"93 e recebia a tença anual de 80.000 réis, em Guimarães. ${ }^{94}$ Suas visitas à região eram constantes, nomeadamente a Amarante e Gouveia, onde seus parentes continuavam a habitar. Não é menos importante de lembrar que Fernão de Sousa semeava planos de reformar duas ilustres residências da família, uma em Lisboa e outra em Amarante. ${ }^{95}$ O percurso de vida desse membro dos Sousa seguia um nítido padrão de ascensão social reinol, baseado na concentração de interesses econômicos no sul e norte do reino de Portugal, onde Fernão de Sousa ocupava cargos de prestígio e detinha títulos nobiliárquicos, além de negociar propriedades e acumular cabedal, a maioria proveniente de arrendamentos e impostos, originários predominantemente de dois tipos de terras, "bens da Coroa" e morgados. ${ }^{96}$

\footnotetext{
${ }^{90}$ De acordo com Heintze, Fernão de Sousa estava em Évora em 1622, porém, no momento de sua nomeação formal para o ofício de governador de Angola, em 21 de outubro de 1623, já se encontrava em Lisboa. HEINTZE, Beatrix. Sobre a biografia de Fernão de Sousa, FHA, vol. I, 1985, p. 24. Mais alguns dados sobre a biografia de Fernão de Sousa podem ser conferidos em: Idem, FHA, vol. II, 1988, p. 22-23.

${ }^{91}$ Sobre a moradia de Fernão de Sousa em Lisboa, conferir: HEINTZE, Beatrix. Mais alguns dados sobre a biografia de Fernão de Sousa, FHA, vol. II, 1988, pp. 28-32.

${ }^{92}$ Segundo Rapahel Bluteau, "conselho, ou concelho, chamam em Portugal algumas terras, ou aldeias juntas, que se governam por uns mesmos estilos, e debaixo das mesmas justiças, e senhorios". Verificar: BLUTEAU, Raphael. Voc. Port. [1712]. Hildesheim: Georg Olms Verlag, vol. II, 2002, p. 432. Na definição do dicionário especializado de Joel Serrão, "concelho" seria então uma "comunidade vicinal", cujos moradores poderiam ser identificados como "vizinhos do concelho". SERRÃO, Joel (dir.). Dicionário de História de Portugal. [1963-1971]. Porto: Figueirinhas, vol. II, 2002, p. 137.

${ }^{93} \mathrm{O}$ senhorio de Gouveia de Riba Tâmega foi confirmado pelo rei em 4 de fevereiro de 1626, "como reconhecimento dos seus serviços prestados, embora o prazo prescrito já tivesse sido há muito ultrapassado", mas palavras de Heintze. A posse da terra advinha de 16 de agosto de 1473, quando um Fernão de Sousa mais antigo, quinto-avô do "nosso" Fernão de Sousa, comprou-a de Fernão Gonçalves de Miranda, virando o "primeiro senhor de Gouveia" por parte dos Sousa. A hereditariedade da posse seria confirmada por Dom Afonso V, através de uma carta de 18 de agosto de 1473. Verificar: HEINTZE, Beatrix. Sobre a biografia de Fernão de Sousa, FHA, vol. I, 1985, pp. 14-15 e 35.

${ }^{94}$ Ibidem, p. 28.

${ }^{95}$ Sobre Amarante, verificar ibidem, pp. 29, 37-38. HEINTZE, Beatrix. Mais alguns dados sobre a biografia de Fernão de Sousa, FHA, vol. II, 1988, pp. 3-5; sobre Lisboa, pp. 28-32.

${ }^{96}$ Idem, Sobre a biografia de Fernão de Sousa, FHA, vol. I, 1985, pp. 34-38. Segundo o intelectual Raphael Bluteau, "morgados" ou "bens de morgados" são inalienáveis, indivisíveis e que "o sucessor justamente o possua na mesma forma, e ordem, que o instituidor tem declarado". Verificar: BLUTEAU, Raphael. Voc. Port. [1712]. Hildesheim: Georg Olms Verlag, vol. V, 2002, p. 580. O entendimento histórico contemporâneo é consensual ao estabelecer que os morgados foram uma "forma institucional e jurídica destinada a defender a base econômica territorial da nobreza". SERRÃO, Joel (dir.). Dicionário de História de Portugal. [19631971]. Porto: Figueirinhas, vol. IV, 2002, p. 345. Heintze nesse sentido afirma que "o morgado é o vinculo de
} 


\section{Imagem 1: Mapeamento da influência e do prestígio da família de Fernão de Sousa (séculos XVII e XVIII) $^{97}$}

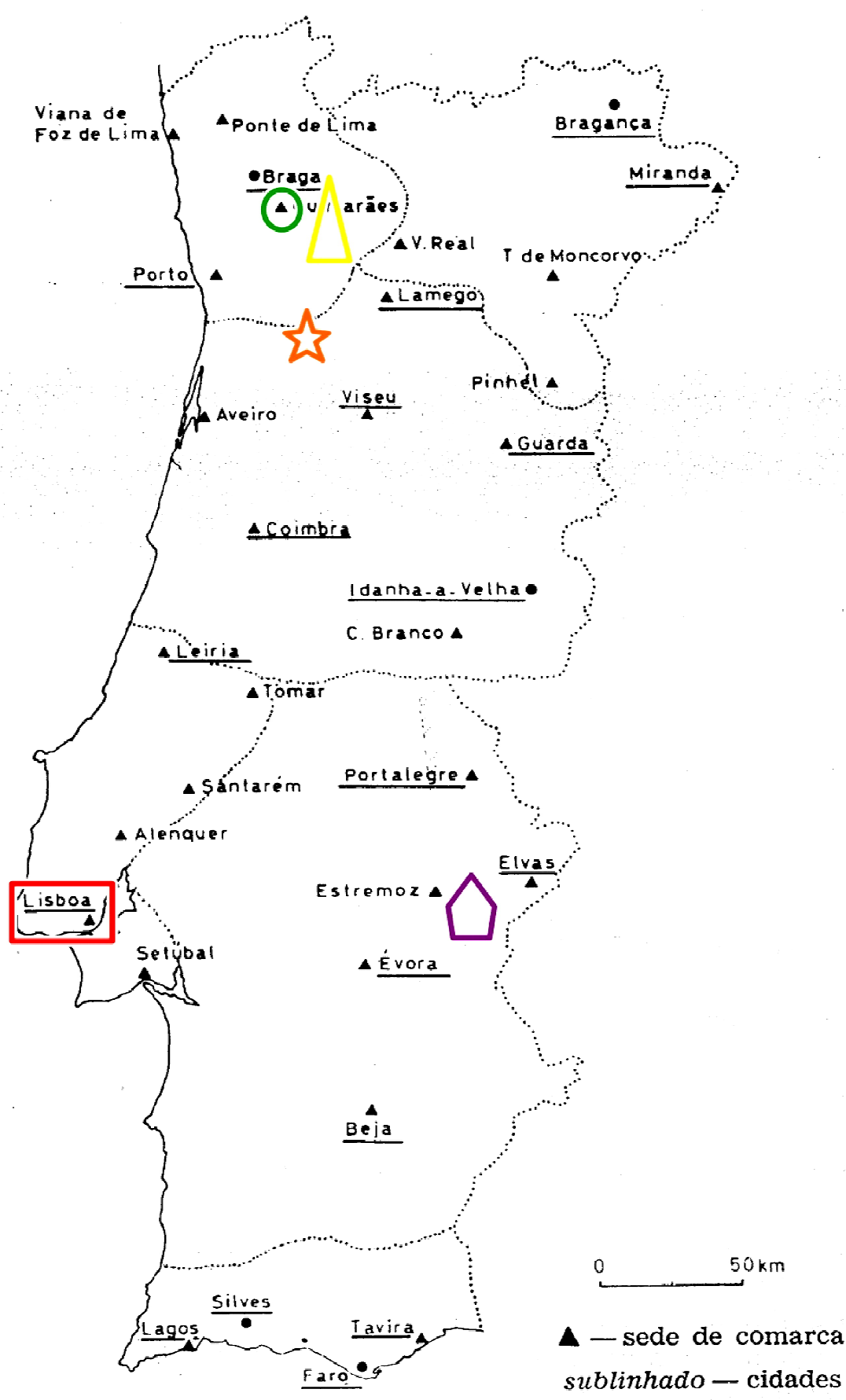

bens laicos a uma família nobre", à guiza de uma propriedade "transmitida em linha masculina através do primogénito, com exclusão dos irmãos". Sobre isso, verificar o primeiro texto de Heintze, nota 9, p. 34.

${ }^{97}$ Imagem retrabalhada a partir de: MARQUES, A. H. de Oliveira. História de Portugal: desde os tempos mais antigos até ao governo do Sr. Pinheiro de Azevedo. [1972]. Lisboa: Palas Editores, 1980, p. 401. 
Legenda: i) O triângulo em dourado representa a região conjunta de Amarante e Gouveia de Riba Tâmega, onde a família Sousa tinha propriedades, títulos e mantinha matrimônios; ii) $O$ círculo em verde assinala Guimarães, de onde os Sousa recebiam uma tença; iii) A estrela em laranja indica a localização aproximada do convento de Arouca, para onde algumas mulheres solteiras da família eram enviadas; $i v$ ) $O$ retângulo em vermelho assinala Lisboa, onde Fernão de Sousa tinha propriedade e assumiu cargos e postos administrativos; v) $O$ pentágono em violeta representa a região que abarca Vila Viçosa e Redondo, onde a família tinha propriedades, foi encarregada de postos, concentrou casamentos e assumiu o título de "Conde de Redondo" a partir de 1707.

Sem dúvida, tal padrão de ascensão social e enriquecimento era baseado em uma intrincada rede de casamentos e amizades, na qual as relações entre as casas e famílias da nobreza reinol eram entrelaçadas a um esquema de angariação de mercês e serviços institucionais e pessoais. Tal padrão pode ser resumido em dois traços. O primeiro era o de que os membros homens de uma família normalmente assumiam carreiras de ordem política, administrativa, militar ou intelectual, cada qual orbitando em torno da corte reinol, ao passo que as mulheres eram engajadas em matrimônios guiados por interesses sociais ou seguiam uma vida de serviços eclesiásticos. Assim, os vínculos políticos e as relações sociais, perpetuados por membros masculinos e femininos, jogavam a favor do acúmulo de prestígio e honrarias pela estirpe sanguínea, representado pelo "nome de família". O segundo traço importante da ascensão social de caráter reinol dizia respeito ao princípio da herança de méritos conquistados pelos antepassados de cada linhagem, ${ }^{98}$ ou seja, títulos, glórias e honras passavam de geração para geração. Um dos desdobramentos práticos desse padrão era o de que, na alta camada social portuguesa, os filhos herdeiros, normalmente primogênitos e legítimos, eram cobrados por fazer jus ao nome da família e dos antepassados, zelar pela harmonia da casa, manter ou intensificar as relações com outras famílias e, se possível, participar da vida na corte. Em troca, recebiam o grosso dos títulos e os bens do falecido pai. Os filhos não herdeiros viravam cavaleiros, estudavam ou serviam à Igreja; as filhas ocupavam lugares na corte, serviam em conventos ou se casavam "conforme a sua categoria". 99

Esse mesmo padrão de ascensão e enriquecimento foi reiterado por outros membros da família dos Sousa. Como assinala Beatrix Heintze, não por acaso as irmãs de Fernão de Sousa tomaram véu em "dois centros onde a família vivia: no norte, no conselho de Gouveia de Riba Tâmega (e especialmente em Amarante), no sul, em Vila Viçosa (na corte

\footnotetext{
${ }^{98}$ HEINTZE, Beatrix. Sobre a biografia de Fernão de Sousa, $F H A$, vol. I, 1985, pp. 34-38, p. 11.

${ }^{99}$ Ibidem, p. 20.
} 
dos Braganças)". ${ }^{100}$ Os irmãos de Fernão de Sousa mais lembrados nas genealogias, Gonçalo e João Rodrigues, foram cavaleiros da Ordem de Malta e acompanharam Dom Sebastião ao norte da África, onde um tombou em Alcácer Quibir, em 1578, e outro foi capturado, vindo a morrer no cativeiro. Nas palavras de Heintze, "as duas mortes foram acrescentadas aos méritos da família, que Fernão de Sousa e o seus descendentes poderiam invocar para obter mercês reais". O irmão mais novo de Fernão de Sousa, Martin Afonso, era abade de Taboado e morreu em 1627. Quiçá seja pouco citado nas fontes por ter gerado uma filha ilegítima e que se casaria com um barbeiro, algo que não era de grande valia à estirpe dos Sousa. ${ }^{101} \mathrm{Em}$ compensação, uma de suas irmãs, Branca de Castro, virou abadessa do convento cisterciense de Arouca, situado no norte de Portugal. Nesse mesmo convento residiram três filhas de Fernão de Sousa, sob "proteção familiar". ${ }^{102}$ Da geração seguinte, cabe ressaltar o papel do quinto e único filho sobrevivente na época em que Fernão de Sousa faleceu, Tomé de Sousa. Ele herdou todos os títulos e bens do pai. Prestou serviço ao Duque de Bragança após a restauração de 1640, vindo a desempenhar as funções de "trinchante, mestre sala e vedor da casa" dos Bragança, além de financiar a defesa do território contra o ataque espanhol. Faleceu em 13 de novembro de 1649, combatendo em Elvas, legando todos os bens e títulos ao seu filho, Fernão de Sousa. Esse Sousa, neto do "nosso" Fernão de Sousa, era filho de Francisca de Meneses, neta de Dom João Coutinho, o quinto conde de Redondo, cujo título seria transferido de maneira perpétua aos descendentes da linhagem dos Sousa, em 2 de março de 1707, já que Coutinho morrera solteiro e sem filhos. Assim acabou a trajetória de "glórias e honras" que os biógrafos destacaram sobre essas três gerações que participaram da composição da CDFS, compreendida entre a segunda metade do final de século XVI e início do século XVIII. ${ }^{103}$ Assim sendo, decerto o trabalho de biógrafos e genealogistas resultou na produção de explicações sobre como os Sousas obtiveram o senhorio de Gouveia, nas rememorações sobre os vários serviços prestados à casa de Bragança e na formalização em escrito de como a linhagem foi agraciada com o título de conde de Redondo.

\footnotetext{
${ }^{100}$ HEINTZE, Beatrix. Sobre a biografia de Fernão de Sousa, FHA, vol. I, 1985, pp. 20.

${ }^{101}$ Idem. Sobre a biografia de Fernão de Sousa, FHA, vol. I, 1985, pp. 18.

${ }^{102}$ Idem. Mais alguns dados sobre a biografia de Fernão de Sousa, FHA, vol. II, 1988, p. 9.

${ }^{103}$ Idem. Sobre a biografia de Fernão de Sousa, FHA, vol. I, 1985, p. 45.
} 


\section{Imagem 2: Genealogia parcial da família Sousa (séculos XVII e XVIII)}

Legenda: O "nosso" Fernão de Sousa está indicado em um retângulo verde. Seu neto foi o primeiro dos Sousa a ser nomeado Conde de Redondo. Seu trineto foi Dom Francisco Inocêncio de Sousa Coutinho, outro importante governador de Angola. ${ }^{104}$

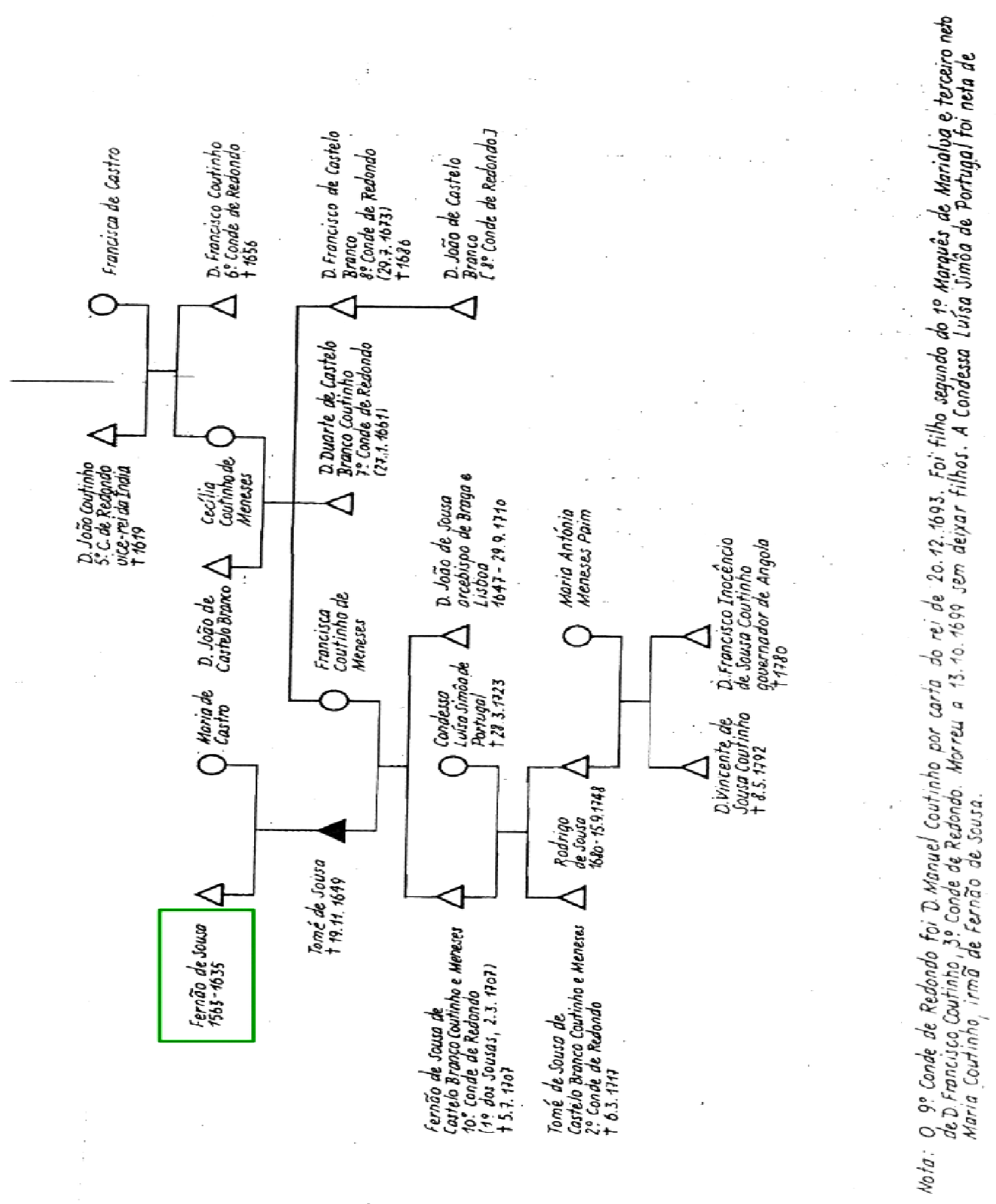

${ }^{104}$ Imagem modificada a partir de: HEINTZE, Beatrix. Fig. 7: Descendência de Tomé de Sousa, filho herdeiro de Fernão de Sousa e as suas relações com os Condes de Redondo no século XVII, FHA, vol. I, p. 43. 
Ao retroagirmos e avançarmos no tempo, fica claro que, a despeito de todas as experiências individuais mescladas ao longo processo histórico de cerca de três séculos da história de Portugal, a tendência perpassada ao longo do núcleo parental dos Sousa foi a de promoção da genealogia familiar, baseada não apenas na origem dos títulos políticos acumulados ao longo do tempo e da fíliação sanguínea nobiliárquica dos Sousa, mas também dos serviços prestados à monarquia e à casa do Bragança. Concluímos então que a confecção da $C D F S$ se justifica em grande medida pela necessidade de comprovação do "bom" exercício administrativo de Fernão de Sousa, atendendo com isso às demandas estipuladas nas atribuições reinóis, a serviço da vontade geral da monarquia e em respeito aos demais aspectos estruturantes das elites no Antigo Regime. Tratava-se de um padrão de ascensão e enriquecimento típico da fidalguia do reino de Portugal, refletido na disposição orgânica dos códices conservados na BAL, ${ }^{105}$ conforme introduzido no início deste item.

\section{Apresentação às Fontes para a História de Angola do Século XVII}

Nem tudo que acabou registrado na $C D F S$ advinha, porém, de uma ferrenha procura por explicações e legitimações formalizadas em papel. ${ }^{106}$ Se por um lado a documentação é reflexo da vida desse português e de sua personalidade única, por outro lado não foi menos impactante a experiência vivenciada no ultramar, adquirida nos anos de serviço como administrador da Angola portuguesa. Dito de outra forma, é preciso considerar a trajetória de vida de Fernão de Sousa como um todo, dado que seria improfícuo interpretar os registros documentais apenas à luz dos reflexos proveniente de Portugal, certamente porque a condução de sua pena ocorreu ao longo da "experiência de campo" na África. Portanto, ao inverso daquilo que seria apenas a "marca de uma época", de uma composição textual ou documental como fruto do desenvolvimento administrativo e burocrático das instituições régias, neste item serão levantados os "pontos fora da curva", as mudanças e estranhezas, que acreditamos refletir uma guinada importante na vida de Fernão de Sousa e, por

\footnotetext{
105 Poderíamos complementar, seguindo as considerações de Mafalda Soares da Cunha, que a partir da organicidade dos arquivos é possível depreender algumas "atividades administrativas" e as "competências dos oficiais administrativos" das instituições de época. Verificar: CUNHA, Mafalda Soares da. A Casa de Bragança 1560-1640 [...]. Lisboa: Editorial Estampa, 2000, p. 217.

${ }^{106}$ Nesse sentido, verificar: HEINTZE, Beatrix. Angola nos séculos XVI e XVII [...]. Luanda: Kilombelombe, 2007, p. 325.
} 
consequência, no que dizia respeito às condições de produção e circulação da documentação: trata-se da "atlanticidade" que passava a influenciar o agente reinol. Por "atlanticidade", entendemos ser um modo de vida movido e alavancado pela economia transatlântica moderna. Na prática, isso quer dizer que uma economia de mercado, as manifestações do comércio - as rotas marítimas e caravanas terrestres de longa, média e curta distância - e a reiteração da vida material eram estimulados cada vez mais por atividades econômicas e produtivas voltadas ao tráfico de escravos, à mercantilização das relações de comutação e permutação, à divisão do trabalho e à distribuição os bens materiais e imateriais produzidos socialmente.

Pois bem, nosso ponto de partida passa a ser um Fernão de Sousa desenraizado, mesmo que momentaneamente, de Gouveia e Vila Viçosa, que partiu de Lisboa e pisou pela primeira vez na ilha de Luanda em 22 de julho de $1624 .{ }^{107}$ Homem nobre, politicamente ativo e experiente na administração, Fernão de Sousa tinha 61 anos quando partiu de Lisboa para Luanda, sendo considerado um indivíduo bastante vivido para os padrões da época. ${ }^{108}$ Em sua conduta administrativa e moral, o reinol sexagenário era legalista e estritamente pragmático, fazendo parte de seu léxico alguns termos-chave como "rigor", "açoite”, “castigo", "pôr em presídio" e "guerra". Sua perspectiva frente aos africanos pode ser resumida através seguinte apreciação, destacada por Beatrix Heintze: "o tempo, e a experiência deste gentio tem mostrado que obedece aos arcabuzes, e não a recados, como parece aos padres, e que convém castigá-lo quando merece". ${ }^{109}$ Outro traço relevante da personalidade de Fernão de Sousa era o desprazer que remoia contra os cristãos-novos, judeus, crioulos e mulatos. Avesso às misturas em geral, Fernão de Sousa entregava seus preconceitos em muitas avaliações, como quando se dirigiu a Dionísio de Faria Barreto, padre africano por vezes a serviço de Luanda, como um "filho da terra, mas exemplar, e de boas partes", deixando a pequena partícula opositiva "mas" o claro "carácter de excepção deste depoimento", conforme explica Heintze. ${ }^{110}$ Em suma, Fernão de Sousa não "traía a sua gente”, suas raízes, sendo dessa forma um típico nobre do Antigo Regime.

\footnotetext{
${ }^{107}$ Fernão de Sousa. Carta de Fernão de Sousa ao governo. 15 de agosto de 1624. BAL, cód. 51-IX-21, ff. 146-46v. IN: HEINTZE, Beatrix (coord.). Documento 36, FHA, vol. II, 1988, p. 81.

${ }^{108}$ HEINTZE, Beatrix. Sobre a biografia de Fernão de Sousa, FHA, vol. I, 1985, pp. 40-41.

${ }^{109}$ Ibidem, p. 40.

${ }^{110}$ Ibidem, pp. 38-39. Sobre o trecho no original, conferir BAL 51-IX-20, f. 375v.
} 
Mas aquilo que nos estarrece neste item deriva da experiência ultramarina e africana de Fernão de Sousa, ou seja, da forma como ele lidou institucionalmente e foi influenciado pela "tão pesada cruz", maneira pela qual o reinol caracterizava repetidamente o governo ultramarino. ${ }^{111}$ Embora fosse reinol, Fernão de Sousa desviou da postura e das expectativas inicialmente projetadas no momento de sua escolha, algo que chama atenção por alguns motivos. Primeiro porque, através da pena e papel, remoia o "grandíssimo desgosto" pela delongada espera por um substituto, que a princípio deveria chegar após três anos de serviços no além-mar, como era o costume, mas que na prática só foi enviado após o dobro de tempo usual. ${ }^{12}$ Em segundo lugar, apesar da valorizada imagem retratada de seu governo durante o século XVII, por exemplo através dos juízos repassados por Manuel Severim de Faria e António de Oliveira de Cadornega, ${ }^{113}$ Fernão de Sousa não contava com apoio institucional ilimitado, tanto que em 19 de outubro de 1641 o Conselho Ultramarino repudiou suas atitudes beligerantes contra Ginga Ambande, admitindo que ela era a verdadeira herdeira do trono do Ndongo. ${ }^{114}$ Certamente o português era de uma "extraordinária personalidade" e detentor das "melhores intenções", como advogou a seu favor Beatrix Heintze, mas também há de se notar que nas entrâncias e rachaduras desses julgamentos e avaliações residem particularidades e estranhezas. Fato é que a época de Fernão de Sousa não foi marcada apenas por acertos e pelo apoio incondicional do Conselho da Fazenda, mas também por erros cometidos ao longo da administração e certas desconfianças levantadas por superiores e órgãos reinóis, a respeito de possíveis desvios de conduta e que, possivelmente, influenciaram nas reprovações lançadas pelo Conselho Ultramarino na década de 1640 .

Além disso, algumas aguçadas sugestões deixadas por Beatrix Heintze merecem atenção. Não foi por menos que o árduo trabalho da pesquisadora foi justificado através do seguinte argumento, outrossim aproveitado como "mote" de nossa pesquisa: “[...] ficará reservado para posterior interpretação as informações disponíveis, para as quais esta

\footnotetext{
111 Tal observação foi feita por Beatrix Heintze. Como exemplos da "tão pesada cruz", conferir BAL 51-IX20 , ff. 374, 377, 380 e 391v.

${ }^{112}$ HEINTZE, Beatrix. Sobre a biografia de Fernão de Sousa, FHA, vol. I, 1985, p. 41.

${ }^{113}$ Ibidem, notas 152 e 153, p. 46. De acordo com Heintze, consultar ainda: CADORNEGA, António de Oliveira de. História Geral das Guerras Angolanas, vol. I, pp. 171, 174 e 214. BRÁSIO, António (col. e anot.). MMA, Série 1, vol. VII, 1956, p. 81 [1622-1623]. Na CDFS, ver BAL, cota 51-IX-20, f. 210.

${ }^{114}$ HEINTZE, Beatrix. Sobre a biografia de Fernão de Sousa, FHA, vol. I, 1985, pp. 45-46. Idem, Angola nos séculos XVI e XVII [...]. Luanda: Kilombelombe, 2007, pp. pp. 379-380.
} 
publicação $[F H A]$ pretende contribuir", não deixando de salientar, brevemente em uma nota, que "[...] os seus esforços [de Fernão de Sousa] para uma melhor administração em Angola ainda não foram objectivo de investigação crítica profunda". ${ }^{115}$ Apesar de desmanchar a organicidade da $C D F S$, perdendo-se a disposição original dos fundos arquivísticos, os novos rearranjos e agrupamentos propostos na $F H A$ indicam caminhos e pistas propícios para a execução de novas investigações históricas.

Destarte, como documentação reorganizada por outrem e em uma época diferente da do período de concepção e armazenamento, cabe apresentarmos e descrevermos objeto de nossa investigação, a $F H A$. A elaboração do conjunto documental foi subsidiada pela Deutsche Forschungsgemeinschaft, contando com a colaboração de Maria Adélia de Carvalho Mendes, Lotte Pflüger e João Sampaio e Castro nas transcrições, anotações e revisões do material publicado. O primeiro tomo, com o subtítulo de Memórias, relações e outros manuscritos da Colectânea Documental de Fernão de Sousa (1622-1635), foi publicado em 1985 e conta com dez capítulos, separados em duas partes. A primeira delas tem como foco a introdução temática e documental ao leitor, além de breves explicações e justificativas sobre os critérios de editoração e inserção do conteúdo divulgado. A segunda parte, destinada aos documentos transcritos, destarte chama a atenção pela seriedade na separação. Mesmo que a divisão de capítulos não seja demasiadamente rígida, cada um deles diz respeito a um tema de interesse eleito por Heintze, mediante ao crivo de "valor histórico", sobre o qual nada mais é dito. As transcrições das fontes estão dispostas mais ou menos em ordem cronológica, de forma que o leitor tenha a noção geral do que aconteceu dentro desse período histórico. ${ }^{116}$ Em vista dos nossos interesses de pesquisa, destacaremos especialmente dois desses capítulos, cujos documentos, como o leitor perspicaz notará, volta e meia serão citados nesta dissertação.

O oitavo capítulo, intitulado Sobre a história de Angola portuguesa e do Ndongo, contém sete documentos, entre eles relações, regimentos e correspondências a respeito dos acontecimentos que marcaram o tempo de Luís Mendes de Vasconcelos até o início do

\footnotetext{
${ }^{115}$ HEINTZE, Beatrix. Sobre a biografia de Fernão de Sousa, FHA, vol. I, 1985, pp. 45-46 e nota 156.

${ }^{116}$ Os princípios e justificativas completos de seleção podem ser conferidos em: HEINTZE, Beatrix. A Colectânea Documental de Fernão de Sousa, FHA, vol. I, 1985, pp. 55-57.
} 
governo do substituto de Fernão de Sousa, Dom Manuel Pereira Coutinho. ${ }^{117}$ Quatro deles são narrativas histórico-explicativas compostas entre 1624 a 1631, de autoria comprovada de Fernão de Sousa, sendo que três delas receberam os títulos de "História das relações entre a Angola portuguesa e o Ndongo" e a outra de "A ilegitimidade do novo rei do Ndongo, Angola Aire". A despeito da titulação artificial, escolhida sugestivamente por Beatrix Heintze, a rigor esses documentos não podem ser enquadrados como "partes" de uma grande e única narrativa, como intuiu Mariana Bracks Fonseca, já que são distintos uns dos outros, produzidos em datas e circunstâncias diferentes. ${ }^{118}$ Afinal de contas, não foi vão que Beatrix Heintze preservou a unicidade de cada uma dessas composições ao término da indexação da $F H A$, com isso perpetuando as reminiscências da divisão orgânica dos fólios. Posto desta forma, por mais que compartilhem correspondências, cada uma dessas narrativas tem as suas particularidades originais, de modo que o nosso esforço será a de priorizar a organicidade quando possível, para depois atingirmos a inter-relação entre o todo, como propôs Heintze.

Prosseguindo com a descrição das fontes, o nono capítulo é quiçá o de maior significado da $F H A$. Avaliado como sendo o "núcleo" do primeiro tomo, ele contém apenas o documento intitulado por Heintze de "O extenso relatório do governador a seus filhos" e que, nas palavras de Fernão de Sousa, havia sido destinado "a meu filho Gonçalo de Sousa e seus irmãos", ${ }^{119}$ mas que de forma alguma significava ser um documento de teor ou cunho "privado" ou pessoal. De acordo com as estimativas da própria pesquisadora, o extenso relatório possivelmente foi composto continuadamente entre 1625 a 1630 , com a significativa ressalva de que o conteúdo descrito mantinha "certa distância de tempo em relação aos acontecimentos referidos, o que, conforme se deduz do seu modo de relatar, poderá abranger vários meses.” O conteúdo em si é registrado de forma cronológica, mas

\footnotetext{
117 Verificar a relação de governadores disponível em: HEINTZE, Beatrix. Apêndice: governadores de Angola, 1575-1639, FHA, vol. I, 1985, p. 393.

118 Basta verificar a opção escolhida por Fonseca na seguinte constatação: “Os três documentos reunidos por Heintze sob o título 'História das relações entre a Angola portuguesa e o Ndongo' evidenciam a mudança da atitude de Fernão de Sousa ao longo de seu mandato e mostra como o governador tentou manipular os fatos para macular a imagem de Nzinga Mbandi. Na última parte desta 'História', escrita em Agosto de 1631, após entregar o governo, Fernão de Sousa fez uma síntese dos principais fatos que justificavam o fracasso do comércio de escravos em Angola.”. Verificar: FONSECA, M.B. Nzinga Mbandi e as guerras de resistência em Angola: século XVII. Dissertação de mestrado, Universidade de São Paulo (USP), 2012, p. 130.

${ }^{119}$ Fernão de Sousa. O extenso relatório do governador aos seus filhos. S.d., 1625-1630. BAL, cód. 51-IX20, ff. 220-74v. IN: HEINTZE, Beatrix (coord.). Documento 30, FHA, vol. I, 1985, p. 217.
} 
não necessariamente datada, sendo circunscrito aos acontecimentos "julgados relevantes" pelo autor, entre o dia da nomeação de Fernão de Sousa como governador, em 5 de outubro de 1623 , até o término oficial do serviço ultramarino, formalizado em 28 de setembro de 1630, por meio de um inquérito realizado pelo "desembargador" do monarca, como era de costume na época. Sucintamente, as descrições e narrativas propostas por Fernão de Sousa estavam ligadas a uma "série de acontecimentos", que podiam condizer às invasões holandesas, às campanhas de guerra contra Ginga Ambande, à procura de metais preciosos ou a outros acontecimentos políticos de relevância, dentre eles insurgências, provas de lealdade e às situações materiais e políticas nas quais se encontravam o presídio e povoado de Benguela, as redondezas do Dembo ou a vasta região da Kissama. Tais séries podiam ser interrompidas, sugerindo interstícios na escrita da pena do português, ou estar entremeadas por trechos ou anexos de outros documentos, como cartas, relações, informações gerais, entre outros, trazendo à tona não apenas informações, mas também a "oficiosidade" e a legitimidade necessárias para o fortalecimento da capacidade de apelo e comprovação do conteúdo registrado. $^{120}$

Publicado em 1988, o segundo tomo da FHA recebe o subtítulo de Cartas e documentos oficiais da Colectânea Documental de Fernão de Sousa e, como o primeiro, está separado em duas partes. Na primeira há informações complementares sobre a bibliografia pessoal de Fernão de Sousa, além de breves explicações sobre as normas de transcrição, seleção e princípios de edição seguidas por Beatrix Heintze e sua equipe, em conformidade com o que descrevemos acima. De maior relevância para os nossos intuitos é a segunda parte do tomo, composta por seis capítulos, nos quais estão inseridos vários documentos a respeito das atividades políticas, administrativas e burocráticas de Fernão de Sousa. Instigantes, mas também inusitados, são os critérios de divisão capitular empregados por Beatrix Heintze. Um primeiro bloco documental, agrupados nos três últimos capítulos da segunda parte do tomo, é composto por tipos diferentes de fontes escritas - cartas, certidões, incumbências, entre outros - suplementares ou complementares ao governo de Fernão de Sousa. Apesar de a maioria ser escrita pelo governador, há documentos de outras

\footnotetext{
${ }^{120}$ HEINTZE, Beatrix. Sobre a biografia de Fernão de Sousa, FHA, vol. I, 1985, pp. 51-52. Ver também: Idem. Angola nos séculos XVI e XVII [...]. Luanda: Kilombelombe, 2007, p. 325. Para a questão do "início tardio" da composição desse documento, estipulado para 1625, conferir: Fernão de Sousa. O extenso relatório do governador aos seus filhos. S.d., 1625-1630. BAL, cód. 51-IX-20, ff. 220-74v. IN: HEINTZE, Beatrix (coord.). Documento 30, FHA, vol. I, 1985, nota 1, p. 217.
} 
autorias e fundos, como a inserção de uma carta escrita por Bento Banha Cardoso, atualmente conservada no Arquivo Histórico Ultramarino de Lisboa (AHU), quebrando com o padrão seguido no primeiro tomo. Mais revelador é o outro bloco de documentos, formado pelos três primeiros capítulos da segunda parte do tomo, sobre o qual nos deteremos com mais vagar. Para montar esse bloco, Heintze obedeceu ao critério de circulação da documentação, propriamente voltado ao sentido de emissão e recebimento de documentos, em âmbito interno ou externo. No geral, os escritos que compõe esse bloco documental aceitam três possibilidades de autoria: ou foram escritos por Fernão de Sousa, ou por um de seus secretários, ou foram encomendados por alguma instituição reinol ou ultramarina. Outro aspecto importante é que todos esses documentos foram compostos entre 1624 e 1630, constam na BAL e estão intimamente relacionados às atividades políticas, administrativas e burocráticas de Fernão de Sousa no governo da Angola portuguesa. Como fontes primárias de alta confiabilidade, em conjunto eles fornecem meios de confrontação com os assuntos narrados e descritos no tomo primeiro da $F H A$, sendo assim muito úteis para a averiguação científica mais densa e profunda. ${ }^{121}$

Lançando mão dos critérios formais apresentados como motivadores para a confecção da $F H A$, ou pelo menos aqueles que foram divulgados por Beatrix Heintze, chegamos a alguns desdobramentos relevantes. Primeiramente, o fulcro dos relatos de Fernão de Sousa está contido no primeiro tomo do material reordenado, a saber nos "relatórios e memórias da Colectânea, que constituem a essência do seu valor histórico, e cuja publicação nos parece ser a mais imediata", conforme justificado por Heintze. ${ }^{122}$ Acontece que os meandros dessas fontes escritas estão marcados por autojustificativas, autoexplicações, imprecisões, calúnias, inverdades e falácias, sendo todos esses aspectos compreensíveis em razão da disposição orgânica e devido às condições de produção da documentação que, como vimos, muitas vezes são o reflexo da "busca por legitimidade", fundada no anseio pela ascensão social típica do Antigo Regime, a convencionada “economia política de privilégios”, como logo veremos. Isso, inclusive, é a marca dos

\footnotetext{
${ }^{121}$ Nesse sentido, com base em um "catálogo de cem itens cronologicamente arranjados" e inventariados a partir da avaliação comparada entre diversas fontes primárias e secundárias de época, Beatrix Heintze chegou à conclusão de que os escritos de Fernão de Sousa são "muito superiores" às demais fontes analisadas. Verificar: HEINTZE, Beatrix. Written Sources and African History [...]. The Angola Manuscript Collection of Fernão de Sousa. History in Africa. Nova Jersey: African Studies Association, vol. 9, 1982, pp. 90-93.

${ }^{122}$ Idem, Sobre a biografia de Fernão de Sousa, FHA, vol. I, 1985, p. 55.
} 
documentos contidos na $F H A$, sem exceção. De todo modo - e abaixo esboçaremos núcleos de força importantes para a nossa análise -, a legitimidade não era o único aspecto que pautava o punho do funcionalismo régio. Fora a simples possibilidade de erro, ${ }^{123}$ que ora e vez inevitavelmente ocorria, as contradições e incongruências entre as informações também poderiam ser influenciadas por outro aspecto de relevância: era necessário dizer o que era preciso ser dito para certas pessoas e públicos, para outros não, e assim por diante. Assim, quando útil para análise, em segundo lugar prestaremos atenção nos problemas de interlocução, quer dizer locução e recepção, perceptíveis no nível de divulgação e restrição de certos documentos, além de atentarmos para a circulação da informação, problematizando o dito, redito ou não-dito das fontes escritas. Resumindo em um só termo, trata-se do fluxo de saberes e conhecimentos no espaço atlântico.

Havia de fato o movimento calculado e deliberado de escrita, mas não apenas isso. Por mais que a memória ou relatório se mostrem completos, frequentemente há lacunas, ou “espaços em branco". Há o desconhecido, ou melhor, o "não descoberto" ainda. Frente a esses empecilhos, cabe ao historiador penetrar, cruzar e comparar ao máximo os documentos, na tentativa de encontrar o maior número de vestígios que o auxiliem na reconstrução histórica. ${ }^{124}$ É confrontando e "espremendo" os diversos tipos de documentos que nos aproximamos de um conhecimento mais crítico e rigoroso sobre os denominados "momentos" apreendidos pelo historiador. ${ }^{125}$

Mesmo explorando os silêncios, ou quiçá os relatos que foram "silenciados" nas fontes escritas, nos escapará um quarto ponto notório da $F H A$. Em última instância, os documentos que temos em mãos foram fruto dos contatos, não apenas entre arcabouços e matrizes culturais endógenas e exógenas à África, mas também de interações políticas e sociais que culminaram no registro de elementos, sujeitos e autoridades africanos pelo

\footnotetext{
123 Tais "erros" poderiam derivar de uma informação incompleta, ou mal vertida em papel, decorrente da incapacidade do observador em compreender o que estava ocorrendo em campo, ou de uma deliberada criação de informação, dado, fato ou conhecimento. Verificar: COELHO, Virgílio. Em busca de Kábàsà: Uma tentativa de explicação da estrutura político-administrativa do "Reino de Ndongo". Actas do Seminário Encontros de povos e culturas em Angola. Luanda: Comissão Nacional para as Comemorações dos Descobrimentos Portugueses, 1995, p. 446.

${ }^{124}$ Sobre isso conferir o exemplo simples sobre a datação, fornecido por Heintze no caso do extenso relatório: HEINTZE, Beatrix. Sobre a biografia de Fernão de Sousa, FHA, vol. I, 1985, p. 52.

${ }^{125}$ Algo que Marc Bloch identificou como sendo o ponto de cristalização da "tomada de decisão" do "tempo da história". Verificar: BLOCH, Marc Leopold Benjamin. Apologia da história [...]. [1949]. Rio de Janeiro: Zahar, 2001, pp. 24-25.
} 
punho de Fernão de Sousa. Em parte, isso explica porque a $F H A$ está repleta de “impregnações" em kimbundu e kikongo, ${ }^{126}$ além é claro da referência a vários sobas, manis e reis africanos que mantinham algum vínculo político com a Angola portuguesa. Mas também, e de forma um tanto quanto implícita, o comércio e o trabalho de escravos eram as marcas das novas realidades conjugadas no além-mar, onde a violência e a assimetria eram aspectos fundamentais - atualmente renegados ou esquecidos por alguns pesquisadores - registrados de maneira formal e "naturalizados" pelo funcionalismo régio. Assim, a nova dimensão social e econômica advinda com o tráfico atlântico e moderno não pode ser esquecida e, fatalmente, acabou "inoculada" no nosso governador. ${ }^{127}$ Se havia contato e convívio, forçados ou não, havia igualmente o choque entre experiências reinóis, atlânticas e africanas, de pessoas inseridas em um ambiente conflituoso, marcado por tensões sociais, atritos institucionais e embates políticos de ordens local, regional e transcontinental, não estando nenhum desses componentes à margem das condições de produção das fontes.

Por último, não é demais lembrar que o serviço prestado no governo de Angola promovia "o alargamento do horizonte de poder e de experiência dos Portugueses para lá das fronteiras tradicionais", além de ter "influência imediata no destino de cada membro desta família nobre [dos Sousa], o que se acentuará ainda mais nas gerações seguintes...". ${ }^{28}$ Essas são algumas últimas pistas fornecidas por Beatrix Heintze, dentre as várias que indicamos até então. Seguindo o rastro deixado pela panóplia de vestígios, indícios e sinais encontrada na leitura perscrutada e esquadrinhada de nossas fontes escritas - e esse é o quinto e último ponto que suscitamos aqui -, velhas e novas veredas serão desbravadas. ${ }^{129}$

\footnotetext{
126 Essas línguas africanas são respectivamente faladas pelos povos mbundu e bakongo. Os primeiros habituam o atual território da República de Angola. Os segundos estão espalhados entre as atuais República do Congo (Congo-Brazzaville), República Democrática do Congo (Congo-Kinshasa) e República de Angola. Conferir a breve explicação para as "convenções de ortografia e datas citadas" em: VANSINA, Jan. How Societies Are Born [...]. Charlottesville: University of Virginia Press, 2004.

${ }^{127}$ Conforme a sugestão de Beatrix Heintze, assumimos que Fernão de Sousa enriqueceu, ou ficou mais rico, através do comércio de escravos atlântico, que não foi necessariamente declarado ao fisco régio. HEINTZE, Beatrix. Sobre a biografia de Fernão de Sousa, FHA, vol. I, 1985, pp. 37-38.

${ }^{128}$ HEINTZE, Beatrix. Sobre a biografia de Fernão de Sousa, FHA, vol. I, 1985, p. 20.

129 Somos assim influenciados pelo impulso instigante sinalizado por Beatrix Heintze: “A minha principal preocupação é a procura de indícios [...] os principais problemas que se colocam ao conhecimento não são lacunas, mas sim as diminutas indicações referidas de passagem, sobre as quais adoramos debruçarmo-nos, mas que muitas vezes podem não passar de declarações fortuitas, meras figuras de estilo, ou ornamentos". HEINTZE, Beatrix. Angola nos séculos XVI e XVII [...]. Luanda: Kilombelombe, 2007, p. 476. Poderíamos também lembrar dos ensinamentos e das lições expostas em: GINZBURG, Carlo. Mitos, emblemas, sinais.
} 
São também a deixa para, enfim, explicarmos os anseios e expectativas que medeiam os interesses desta pesquisa.

\section{Proposta e objetivos}

Destarte, retomaremos o fio da meada que deixamos mais ou menos solto no final do primeiro item desta introdução, para que não reste dúvidas sobre o que nos pauta. Na tentativa de abordar as contradições, incoerências, dissonâncias e incongruências registradas nas fontes escritas da $F H A$, propomos na presente dissertação uma "leitura a contrapelo" ${ }^{\prime 130}$ dos registros escritos sobre as situações de contato durante o tempo de Fernão de Sousa. Nosso foco repousa na formação da Angola portuguesa durante essa época, através de uma abordagem que consideramos plural, ou seja, que se esforce em ouvir as diferentes vozes registradas, ou mesmo omitidas, na documentação. Destarte, salientamos que essa pluralidade não quer dizer igualdade ou simetria de relacionamento entre os agentes e grupos envolvidos nos processos históricos, os chamados "sujeitos históricos”, que aparecerão nesta reelaboração sobre o passado de Angola. Retomando o que foi dito nos itens anteriores, queremos chamar a atenção para o fato de que o processo histórico de expansão portuguesa ultramarina foi marcado por vários tipos de contatos, gerando um ambiente conflituoso, no qual a participação de agentes e grupos diferentes era desigual: o conturbado convívio entre reinóis, portugueses experientes na terra, membros das elites africanas e escravos de todos os tipos era marcado por tensões sociais, atritos institucionais e embates políticos. ${ }^{131}$ Mediadas por choques entre as experiências reinóis, atlânticas e africanas, nossas fontes escritas foram gestadas em meio ao encontro entre

morfologia e história. [1986]. São Paulo: Companhia das Letras, 2012, capítulo 5, especialmente quando o intelectual escreve sobre o chamado "paradigma indiciário ou semiótico", afirmando que "se a realidade é opaca, existem zonas privilegiadas - sinais, indícios - que permitem decifrá-la” (p. 177).

${ }^{130}$ Trata-se de uma postura crítica e combativa, na qual o leitor-pesquisador não se deixa iludir pela narrativa fixada em papel, explorando as omissões, contradições e brechas deixadas pelos produtores da documentação. Por exemplo, a despeito da frequente ausência de "sujeitos históricos" e cosmogonias africanas nas fontes escritas portuguesas dos séculos XVI e XVII, ainda é possível extrair um viés africano, ou africanista, desses relatos. Faz-se necessário "apercebermo-nos das suas eventuais incongruências", comparar os discursos e extrair o "lugar-comum das coisas reais", para então apreender o passado de forma crítica. Sobre isso, verificar: PARREIRA, Adriano. Economia e sociedade em Angola [...]. Lisboa: Editora Estampa, 1997, p. 20.

${ }^{131}$ Nossa inspiração são as tais "clivagens", já levantadas por Silvia Hunold Lara, imersas em um ambiente conflituoso e capazes de guiar classificações e seleções feitas por aqueles responsáveis pelo registro documental, "cujo sentido se explicava no interior da rede hierarquizada de posições que conformava a sociedade colonial e dependia de jogo de forças da dominação que lhe dava sentido e consciência". LARA, Silvia Hunold. Fragmentos setecentistas [...]. São Paulo: Companhia das Letras, 2007, pp. 282-283. 
modelos distintos de ascensão social, historicamente separados entre si, $^{132}$ mas que ao longo da expansão ultramarina portuguesa convergiram em nome da formação de um domínio ultramarino. De modo esquemático, ao longo do processo histórico havia três formas de escalar as pirâmides sociais, não necessariamente isoladas ou excludentes entre si. Uma era baseada na redistribuição de cargo e títulos políticos, sendo atualmente reconhecida pelo nome de "economia política de privilégios" ou "economia do dom". ${ }^{133}$ Outra forma de ascensão social era baseada na exploração do trabalho escravo e no tráfico transatlântico, estando mais atada a uma elite terratenente ou ligada ao comércio. Uma terceira maneira de ascender socialmente girava em torno da participação nas organizações sociopolíticas endógenas, por exemplo do Kongo ou do Ndongo, fundadas nas concepções de parentesco perpétuo e em outros princípios mentais que estruturavam as sociedades centro-africanas, vinculadas a regimes institucionais arrojados e à existência de hierarquias sociopolíticas diversificadas, que variavam desde o trabalho na base produtiva até o engajamento nas funções de mestres-especialistas. ${ }^{134}$

Particularmente influenciada pela ânsia exploratória e escravista dos invasores, em consonância com a manutenção de Luanda, dos presídios do interior e da sustentação de um discurso legitimador, a formação de uma Angola portuguesa não foi unilateral e nem

\footnotetext{
${ }^{132}$ Conforme exposto a propósito de Mary Louise Pratt no início desta introdução. Apesar dos ceticismos e desconfianças que ainda pairam sobre a viabilidade de uma "história luso-africana" como maneira de superação das distâncias entre o passado e o presente dos povos inseridos em uma situação histórica de contato intersocial, fazemos nossas palavras as de José da Silva Horta, principalmente no que diz respeito ao impulso de escrita de "histórias conectadas" (connected histories) que visa, "pela reconstituição de laços e denominadores comuns entre histórias que decorrem em diferentes espaços, escolher uma escala de análise historiográfica, mais globalizante, que permita captar as relações entre povos, culturas, economias e poderes". Sucintamente, Horta se vale de uma síntese de Roger Chartier, mais especificamente sobre Sanjay Subrahmanyam e Serge Gruzinski, para empregar o conceito de "histórias conectadas". Segundo o historiador português, para o caso da África, tal conceito também encontra respaldo nas propostas de John K. Thornton e Patrick Manning. Verificar: HORTA, José da Silva. A "Guiné do Cabo Verde” [...]. [2002]. Tese de doutorado, Universidade de Lisboa, 2010, p. 10 e nota 28.

${ }^{133} \mathrm{O}$ primeiro nome foi convencionado por importantes pesquisadores da historiografia brasileira, enquanto que o segundo foi difundido por António Manuel Hespanha. Verificar: FRAGOSO, João; GOUVÊA, Maria de Fátima Silva; BICALHO, Maria Fernanda Baptista (org.). Uma leitura do Brasil Colonial: Bases da materialidade e da governabilidade no Império. Penélope: revista de história e ciências sociais. Lisboa: Cooperativa Penélope, Fazer e Desfazer a História, n. ${ }^{\circ} 23,2000$.

${ }^{134}$ Ressaltando que o presente trabalho frisa especificamente o caso mbundu, como explicitaremos mais para frente. Sucintamente, nosso arcabouço teórico-metodológico tem como base três obras essenciais: COELHO, Virgílio. "Em busca de Kábàsà!..." Estudos e reflexões sobre o "Reino" do Ndòngò: Contribuições para a História de Angola. Luanda: Kilombelombe, 2010. Idem, Os Túmúndòngò, os "génios" da natureza e o kílàmbà: Estudos sobre a sociedade e a cultura kímbùndù. Luanda: Kilombelombe, 2010. MILLER, Joseph C. Poder político e parentesco: Os antigos estados Mbundu em Angola. [1976]. Luanda: Arquivo Histórico Nacional, 1995.
} 
unívoca. Sem se isentar de "subjugação", "sujeição" e "submissão" - quer dizer, formas de dominação -, ela foi dependente da cooperação e do auxílio de autoridades e soberanias africanas, ou seja, da capacidade de negociação e de uma certa "plasticidade" - quer dizer, formas de intermediação - para fazer valer uma ordem e um mando ultramarinos, certamente não hegemônicos ${ }^{135}$ e que acreditamos implicar na conformação de um sistema administrativo misto e em rede, no final de contas criado para atender as necessidades de tráfico de escravos. A par desses eixos de interesse, prevemos incentivar um diálogo eclético entre bibliografias distintas, ${ }^{136}$ visando não somente posicionar nossa argumentação em meio à discussão acadêmica, feito uma bússola capaz de indicar direções e nortear a pesquisa, mas também como um direcionador, à guisa de um "mapa" com coordenadas pré-especificadas, para não nos perdermos nos vastos oceanos que são os documentos. Uma interlocução ampliada também visa auxiliar outros pesquisadores que, porventura, levantem inquietações e indagações parecidas com as nossas.

Partindo do pressuposto de que a Angola portuguesa concatenava experiências reinóis, atlânticas e africanas, nossa hipótese é a de que os contatos e intermediações forneceram "traves-mestras"137 para a vagarosa implementação de um sistema administrativo misto, dessemelhante do existente no reino de Portugal e estranho às formas políticas em voga na África Centro-Ocidental. Baseado em princípios legais e políticos importados de Portugal, esse sistema acabava adaptado às condições materiais e sociais encontradas em Luanda e nos entrepostos de apoio institucional espalhados pelo interior, tentando abarcar ao máximo os sobas dentro de noções ligadas à "justiça" e à "paz”, ao

135 Como ressaltado em: SANTOS, Catarina Madeira. Administrative knowledge in a colonial context: Angola in the eighteenth century. The British Journal for the History of Science (BJHS), vol. 43, dezembro de 2010, pp. 555-556.

${ }^{136}$ Conferir esforço análogo em: MILLER, Joseph C. Way of Death: Merchant Capitalism and the Angolan Slave Trade, 1730-1830. Madison: The University of Wisconsin Press, 1988, p. xvi.

${ }^{137}$ Recordamos da influência e importância fundadora dos trabalhos de Caio Prado Junior na década de 40, por exemplo, através da ideia de "sentido da colonização" como "trave-mestra", cujo cerne da abordagem foi retomado na década de 70 por Fernando Novaes, através do modelo de "antigo sistema colonial" e das várias associações entre as relações tecidas em torno da lógica mercantilista, metrópole-colônia, e do comércio triangular Europa-África-América, como trave-mestra do "pacto colonial". Consultar: PRADO JR., Caio. Formação do Brasil Contemporâneo. [1942]. São Paulo: Brasiliense, 2007, principalmente o capítulo 1. NOVAIS, Fernando A. Portugal e Brasil [...]. [1979]. São Paulo: Editora Hucitec, 1995, principalmente o capítulo 2. Sobre o pensamento desses dois intelectuais, conferir: PUNTONI, Pedro L. O Estado do Brasil: poder e política na Bahia colonial. São Paulo: Universidade de São Paulo (USP), 2010, pp. 13-14. 
mesmo tempo que tendia a uma finalidade-chave: o aumento do tráfico de escravos. ${ }^{138} \mathrm{~A}$ recriação social na Angola portuguesa dependia do trabalho e comércio de escravos, de tal forma que os enlaces e desenlaces históricos que exploraremos nesta dissertação são tributários, em grande medida, do comércio atlântico associado à penetração política e institucional do continente.

Nosso objeto de pesquisa é a $F H A$, conforme apresentamos anteriormente. Nosso escopo temporal, por consequência, é o período entre 1624-1630, mas como o leitor perceberá essa periodização pode ser expandida para trás, voltando ao tempo de Paulo Dias de Novais, ou para frente, alargando-se para o tempo do sucessor de Fernão de Sousa, Dom Manuel Pereira Coutinho. Às vezes também lançaremos mão de um tempo indeterminado, "em suspenso", principalmente quando abordarmos os processos históricos dos mbundu. Essa "longa periodização", de seis anos expansíveis, é justificável em respeito aos processos históricos vigentes em nosso recorte espacial. De notável multiplicidade de tempos, os processos aos quais nos referimos advêm do avanço da conquista portuguesa no Ndongo, que de fato apenas terá um desfecho em 1671, com a conquista efetiva de Pungo Andongo. ${ }^{139} \mathrm{O}$ escopo geopolítico que escolhemos privilegia os espaços de contato abertos nos presídios de Massangano, Muxima, Cambambe, Ambaca, feiras do interior e no Ndongo. Como pontos de apoio institucionais espalhados no interior, acreditamos que essas localidades conformavam núcleos administrativos de relativa independência, contanto que mantivessem uma interconexão burocrática e institucional com Luanda. Esta era a Angola portuguesa, marcada por um sistema administrativo misto.

\footnotetext{
${ }^{138}$ Lembramos que a transferência do aparato administrativo foi moldada pela vinda de "homens livres e pequenos fidalgos" portugueses que desembarcavam nos portos ultramarinos "na esperança não de reproduzir, mas de emular na peculiaridade que lhe era permitido, uma situação social na qual se estruturavam novas hierarquias - marcadas pela presença do escravismo". Tais modificações, ou "adaptações", também são caracterizadas como sendo "deslizes" e "contaminações", respectivamente por Guida Marques e Stuart Schwartz. Visíveis na América portuguesa, tais singularidades também surgem no caso africano. Para as primeiras citações, verificar: PUNTONI, Pedro Luis. O Estado do Brasil [...]. Tese de livre-docência, Universidade de São Paulo, 2010, pp. 163-164. Ver também: MARQUES, Guida. Do índio gentio ao gentio bárbaro: usos e deslizes da guerra justa na Bahia seiscentista. Revista de História (USP). São Paulo: Universidade de São Paulo, n. 171, p. 15-48, jul.-dez., 2014. SCHWARTZ, Stuart B. Burocracia e sociedade no Brasil Colonial: o Tribunal Superior da Bahia e seus desembargadores, 1609-1751. [1973]. São Paulo: Companhia das Letras, 2011.

${ }^{139}$ Verificar: ALENCASTRO, Luiz Felipe de. $O$ trato dos viventes [...]. São Paulo: Companhia das Letras, 2000, p. 302. HEINTZE, Beatrix. Angola nos séculos XVI e XVII [...]. Luanda: Kilombelombe, 2007, p. 235. LARA, Silvia Hunold. Palmares \& Cucaú [...]. Tese para concurso de Professor Titular, Universidade Estadual de Campinas, 2008, pp. 160-161 e 174.
} 
Imagem 3: África Centro-Ocidental (século XVII) ${ }^{140}$

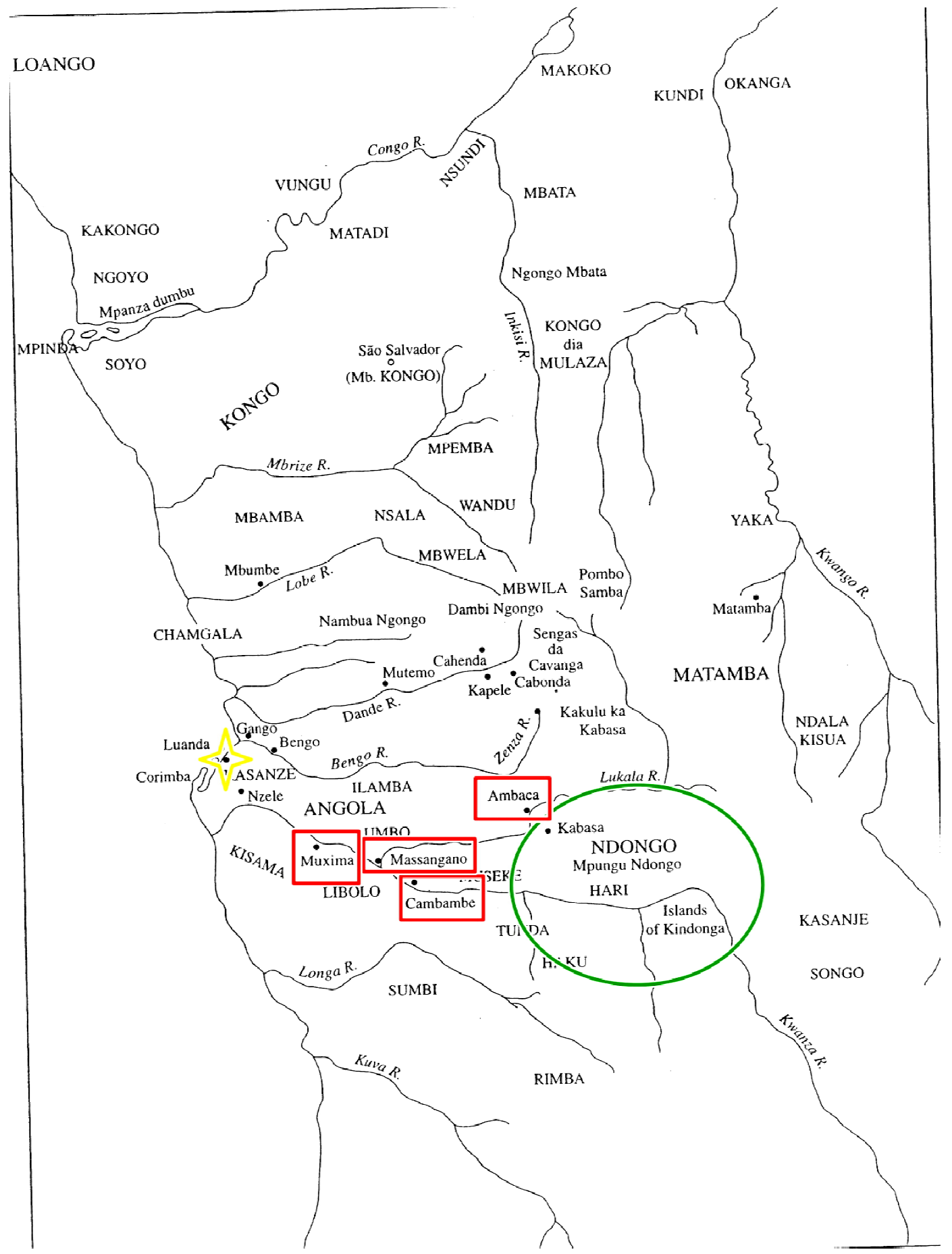

Legenda: i) A esfera verde representa o chamado "reino do Ndongo"; ii) Os quadrângulos vermelhos indicam os presídios portugueses do interior; iii) A estrela em amarelo indica a "cidade de São Paulo de Luanda".

${ }^{140}$ Imagem retrabalhada a partir da figura existente em: HEYWOOD, Linda M.; THORNTON, John K. Central Africans, Atlantic Creoles [...]. Cambridge: Cambridge University Press, 2007, p. 50. 
Residia aí um ponto-chave da transferência institucional para além-mar, que não seria somente "portuguesa", mas como já dissemos, "mista". Em parte influenciados pelas ideias de Mary Louise Pratt, cremos que esses pontos de apoio administrativos figuraram como importantes centros de encontro entre sociedades e ideias distintas. Simplificando o argumento, existiria de um lado um "mundo mbundu", de outro um "mundo português", originário da Península Ibérica, e entre eles uma situação de contato constante, onde eram gestados campos de intermediação. Diferentemente das “zonas de contato" de Pratt, onde o movimento determinante é pautado pela imposição metropolitana, acreditamos que nos campos de intermediação havia uma mescla de usos e costumes estrangeiros e locais, em "vias de mão-dupla" de influências portuguesa e africana, sucintamente reconhecidas na atualidade, de forma pouco criteriosa e problemática, como influências de tipo "lusoafricano", quer dizer, fenômenos socioculturais marcados por hibridismos, sincretismos, mulatizações e crioulizações de vários tipos, ${ }^{141}$ capazes de propulsar o surgimento de identidades singulares ou passageiras. Por entender que tais problemáticas e conceitos são empregados de forma generalizante e frequentemente pouco criteriosa no atual contexto de produção científica, porventura até sobrepostos um sobre os outros e indicando para caminhos sinuosos, defletiremos de tais veredas. Em contrapartida, nossa intenção será a de explorar as experiências de vida daquelas pessoas que integravam os campos de intermediação, algo que volta e meia causará um choque entre os modos de ascensão social reinol, atlântica e mbundu, sempre lembrando que os registros escritos que temos em mãos são reflexos da formação de um domínio ultramarino, a denominada "Angola portuguesa". ${ }^{142}$ As formas de intermediação, então, são reveladas através do incentivo a

\footnotetext{
141 Termo "mulatização" é mais utilizado entre os intelectuais e pesquisadores voltados às questões caboverdianos, referindo-se propriamente à mistura de cores ou, como alguns deles fazem menção, "raças". Verificar especificamente: CABRAL, Iva. Ribeira Grande: vida urbana, gente, mercancia, estagnação. IN: SANTOS, Maria Emília Madeira (coord.). História Geral de Cabo Verde. Lisboa: Instituto de Investigação Científica Tropical, vol. II, 1995, p. 245. Desse mesmo manual, verificar: SILVA, António Leão Correia e. A sociedade agrária, gentes das águas: senhores, escravos e forros, p. 353. Para uma abordagem conceitual mais genérica, na qual a "mulatização tornou-se uma realidade, tanto a nível político, como econômico, social e cultural”, verificar: TEIXEIRA, André. Povoamento: um processo que se prolonga no tempo IN: SERRÃO, Joel; MARQUES, A. H. Oliveira (dir.). Nova História da Expansão Portuguesa: A Colonização Atlântica. Lisboa: Editorial Estampa, vol. III, tomo 2, 2005, p. 19, além do capítulo 4, onde é descrita a "mulatização de uma elite insular", especialmente nas pp. 185-186.

${ }^{142}$ Nossas principais influências aqui são: CUNHA, Mafalda Soares da. A Casa de Bragança 1560-1640 [...]. Lisboa: Editorial Estampa, 2000. CUNHA, Mafalda Soares da; MONTEIRO, Nuno G. Aristocracia, poder e família em Portugal [...]. IN: CUNHA, Mafalda Soares da; FRANCO, Juan Hernández (orgs.). Sociedade,
} 
duas operações específicas, a incorporação de elementos locais e a absorção de agentes, sedimentadas no estabelecimento de um espaço jurisdicional português, onde valiam os mecanismos de vigilância e fiscalização promovidos por Luanda. Será no seio desse ambiente conflituoso, mas ao mesmo tempo criador, onde havia tráfico atlântico e se desdobrava o domínio português, que estão situados os nossos "luso-africanos", ou quiçá luso-africanidades, como identidades múltiplas acionáveis mediante a procura de inserção social de indivíduos deslocados e que estavam em situação de contato. ${ }^{143}$

Finalmente, e nesse terceiro ponto retornamos com mais afinco a um assunto para o qual chamamos a atenção várias vezes até aqui, a montagem do aparato ultramarino no interior da África atendia aos interesses do tráfico atlântico. Durante a época de Fernão de Sousa, a penetração do continente para a busca de escravos, ou algo que poderíamos chamar de expansão da fronteira escravista para o interior, nos termos revisitados por Joseph C. Miller, apenas confirmou a grande importância que o tráfico atlântico detinha para o enriquecimento não somente dos cofres régios, mas também dos bolsos de governadores e capitães que lá faziam a vida. ${ }^{144} \mathrm{O}$ recuo demográfico que atingira a região entre o Ndongo e a costa atlântica, traduzido em um decréscimo populacional mbundu, era sensível e a guerra iminente, salvo raras exceções. Como "efeito colateral" do incentivo aos negócios escravistas, as aspirações para a ascensão socioeconômica voltada ao Atlântico ganharam preponderância, de tal forma que os agentes institucionais e grupos sociopolíticos passaram a divergir não mais por mercês reais, mas por escravos. Além disso, por mais que

família e poder na Península Ibérica [...]. Lisboa: Edições Colibri/ CIDEHUS - Universidade de Évora/ Universidad de Murcia, 2010.

${ }^{143}$ Ao longo desta dissertação tentaremos abarcar e pormenorizar todos esses pontos ressaltados.

${ }^{144}$ Nesse sentido, tanto Joseph C. Miller como Paul E. Lovejoy concordam que havia uma espécie de linha geograficamente indeterminada, talvez até "imaginária", de onde a maior parte dos escravos "exportáveis" para o comércio atlântico poderia ser drenada. Tal seria a "fronteira da escravidão", irrevogavelmente acompanhada de guerras, razias, "disseminação na anarquia" e "da escravização como uma punição para criminosos condenados", nas palavras de Lovejoy. A conclusão de Miller é outra, afirmando que a expansão da fronteira da escravidão seria promovida pelo aumento da importância do tráfico transatlântico nas economias africanas continentais, de modo que os "reis africanos" permaneceram "fiéis aos bens importados, como o motor condutor do mecanismo político, então comprometido irrevocavelmente à economia do Atlântico". Verificar: LOVEJOY, Paul E. A escravidão na Africa: uma história de suas transformações. [1983]. Rio de Janeiro: Civilização Brasileira, 2002, pp. 141-142. MILLER, Joseph C. Way of Death [...]. Madison: The University of Wisconsin Press, 1988, pp. 666 e 676, de onde foi extraída a citação com tradução nossa (no original: "Production rested on the coerced labor of slaves rather than on relatives and wives' cooperating to work and land. The kings used people to get more goods, not goods to obtain further claims on people. Though they remained solidly within the African political economy, their reliance on goods as the motor now driving the political mechanism had also committed then irrevocably to the economy of the Atlantic"). 
de chofre o tráfico atlântico não causasse drásticas mudanças no miolo da África Central, aos poucos a consolidação e ampliação de um "domínio ultramarino", de uma Angola portuguesa voltada ao tráfico de escravos, impactou o palco político regional. ${ }^{145}$ Fato é que, já no tempo de Fernão de Sousa, os escravos costeiros de proveniência mbundu e que eram aceitos legitimamente como "peças", por sobas locais e pelo próprio funcionalismo régio, rarearam. ${ }^{146}$ Como tentaremos mostrar ao longo desta dissertação, embora este não fosse um movimento hegemônico ou unidirecional, entre 1575 a 1671 o avanço da conquista política e da guerra portuguesa rumo ao Ndongo estava relacionado à prosperidade do negócio escravista, não podendo tal aspecto ficar à margem da análise histórica. Doravante, de maneira sucinta, o governo de Fernão de Sousa é um marco-chave, constituinte da história das expansões e dos contatos luso-africanos entre Luanda e o Ndongo nos séculos XVI e XVII.

A presente dissertação está separada nos seguintes temas. No primeiro capítulo, ensaiaremos uma conexão entre historiografias distintas, uma delas voltada à compreensão do passado político e institucional dos mbundu, outra enraizada no processo de expansão e ocupação oficial de um pequeno território contido na África Centro-Ocidental. No segundo capítulo, analisaremos os acontecimentos históricos pertinentes ao período que vai de 1617 a 1630, mediante o qual transcorreram cinco governos ultramarinos portugueses. No terceiro capítulo, tentaremos esmiuçar a gestão jurisdicional, política e econômica de um espaço reivindicado por Luanda entre 1624 e 1630, preservado em regime de justaposição e coexistência junto de outras legislações e unidades sociopolíticas africanas. No quarto capítulo, verificaremos como foram gestadas e organizadas as guerras contra Ginga Ambande, entre 1626 e 1629. A título de conclusão, no término deste trabalho encaminharemos algumas últimas considerações e deduções, sobre tudo o que foi desenvolvido nesta empreitada científico-acadêmica.

\footnotetext{
${ }^{145}$ Seguindo as considerações específicas presentes em: HEINTZE, Beatrix. Angola nos séculos XVI e XVII [...]. Luanda: Kilombelombe, 2007, pp. 380-381. Também consultar as análises e alguns dos argumentos levantados nos seguintes trabalhos: CURTO, José C. Resistência à escravidão na áfrica: o caso dos escravos fugitivos recapturados em Angola, 1846-1876. Afro-Ásia. Salvador: Universidade Federal da Bahia (UFBA), n. ${ }^{\circ}$ 33, 2005. Idem, The Anatomy of a Demographic Explosion: Luanda, 1844-1850. The International Journal of African Historical Studies. Boston: Boston University African Studies, vol. 32, n. . 2/3, 1999.

${ }^{146}$ Assumimos dois jargões, ou ditames do senso comum, válidos para época. Um era o de que existiam "africanos escravizáveis", outros não. Outro que "nunca se escravizava o vizinho", mas sobretudo as pessoas "desconhecidas", os indivíduos "diferentes".
} 


\section{HISTÓRIAS, CONTATOS E A FUNDAÇÃo DA ANGOLA PORTUGUESA}

\section{Apresentação}

O presente capítulo está separado basicamente em dois blocos temáticos. No primeiro deles, composto pelos dois itens de assunto que seguem abaixo, introduziremos algumas informações sobre o funcionamento das organizações sociais, divisões políticas e os princípios estruturais que fizeram parte da história dos mbundu e do desenvolvimento institucional do Ndongo. No segundo bloco, igualmente composto por dois itens, apresentaremos algumas fases e subfases que integraram uma história de expansões e contatos que teve, como um de seus vários e possíveis desdobramentos, o avanço de Portugal em direção ao Ndongo. Por fim, no último item deste capítulo, serão apresentadas algumas considerações finais sobre os assuntos e matérias aqui discorridos.

\subsection{Breve apresentação da história dos mbundu}

Os "mbundu" são atualmente considerados um macrogrupo étnico - Joseph C. Miller, quiçá um dos mais renomados e influentes africanistas contemporâneos, identificouos como um povo "pan-mbundu" - internamente composto por subgrupos, denominados comumente "populações", elencados pelos estudos antropológicos através de subidentidades autodeclaradas pelas próprias populações endógenas. São elas os lenge, ndongo, songo, mbondo, pende, hungu e os libolo. ${ }^{147}$ Até o século XIX, os limites etnolinguísticos ${ }^{148}$ que separavam o macrogrupo mbundu de seus vizinhos - os bakongo,

\footnotetext{
${ }^{147}$ De acordo com os historiadores tradicionais imbangala e informantes de Joseph C. Miller, é possível que no século XVII os libolo fossem divididos entre os "Libolo propriamente ditos (a oeste do rio Luhinga) e os Hako (a leste do Luhinga)". Informações extraídas de: MILLER, Joseph C. Poder político e parentesco: Os antigos estados Mbundu em Angola. [1976]. Luanda: Arquivo Histórico Nacional, 1995, p. 40. Conforme explica Virgílio Coelho, o termo "populações" pode também ser utilizado para separar os diferentes aglomerados populacionais falantes de kimbundu, não necessariamente mbundu, entre si. Verificar: COELHO, Virgílio. Em busca de Kábàsà: Uma tentativa de explicação da estrutura político-administrativa do "Reino de Ndongo". Actas do Seminário Encontros de povos e culturas em Angola. Luanda: Comissão Nacional para as Comemorações dos Descobrimentos Portugueses, 1995, p. 445.

${ }^{148}$ Lembrando que qualquer demarcação estritamente rígida de ocupação populacional e separação linguística do território deve ser relativizada. Para além das considerações que faremos ao longo deste capítulo e dos demais que compõe esta dissertação, cabe ressaltar dois aspectos que até o presente momento foram abordadas de maneira pouco crítica e um tanto quanto mecânica por alguns pesquisadores. O primeiro diz
} 
ndembu, cokwe-lwena e ovimbundu foram os mais conhecidos deles - seguiam o curso dos rios e montanhas. Ao norte, eram as zonas montanhosas, junto às nascentes dos rios Bengo e Dande, que cindiam os espaços ocupados pelos mbundu dos reivindicados pelos bakongo e ndembu. Nos séculos XVI e XVII, a centralidade política que mais bem representava os bakongo era o chamado "reino do Kongo", enquanto que os ndembu estavam espalhados pela montanhosa região identificada nos registros escritos pelo topônimo "Dembos". 149 Imediatamente ao sul do Cuanza, residiam povos como os kisama e sumbe, mais próximos das populações ovimbundu do planalto de Benguela, região que no século XVII era genericamente reconhecida como o "reino de Benguela". Subindo o Cuanza em sentido nordeste, os limites etnolinguísticas se diluíam e os mbundu se misturavam gradualmente com os povos cokwe, lwena, ngangela e lunda, abarcando a Baixa de Cassanje até aproximadamente as margens do Cuango. ${ }^{150}$ De modo geral, o povo mbundu tendia a habitar os planaltos ao redor do Cuanza e, diferentemente do que o senso comum atualmente prega, eles não povoavam as regiões litorâneas perto de Luanda. Se é que essa e outras regiões foram alvo de aumentos demográficos significativos, provenientes de

respeito às "padronizações" e às "classificações" de natureza étnico-social, propostas pelos observadores europeus dos séculos XVI e XVII, muitas vezes falhas ou homogeneizantes, perceptíveis por exemplo nas divisões simplistas e imprecisas propostas entre os "mbundu" e os "ovimbundu" nas fontes escritas de época. $\mathrm{O}$ segundo se refere à possibilidade de empréstimos lexicais e vocabulares existente entre sociedades centroafricanas, explicando por que termos em kikongo às vezes são utilizados para descrever realidades mbundu, ou vice-versa - por exemplo, o registro de mbanza e bakula para realidades diferentes são indícios disso. Sobre esses termos, consultar o "suplemento para alguns vocábulos africanos" desta dissertação. Aconselhamos também a consulta do termo "bambe". Verificar igualmente: HEYWOOD, Linda M.; THORNTON, John K. Central Africans, Atlantic Creoles, and the Foundation of the Americas, 1585-1660. Cambridge: Cambridge University Press, 2007, pp. 203.

${ }^{149}$ MILLER, Joseph C. Poder político e parentesco [...]. [1976]. Luanda: Arquivo Histórico Nacional, 1995, p. 32. Poderia também ser apenas "Dembo".

${ }^{150}$ Ibidem, p. 34. Os cokwe são grupos lembrados pela participação no comércio transcontinental de caravanas, particularmente intensa durante a segunda metade do século XIX, além do crescimento político, militar e econômico que eles obtiveram ao longo desse século. Talvez o ápice da sociedade cokwe tenha sido alcançado no final do XIX, quando derrotou o "Império Lunda do Muatiânvua" em confrontos bélicos. Apesar de os registros escritos sobre os cokwe terem início a partir do último quartel do século XVIII, resultando na frequente depreensão equivocada de que esse grupo centro-africano "passou a existir" a partir de então, são mais sábios os comentários de Jill Dias, para quem os registros escritos setecentistas e novecentistas refletem "não a sua [dos cokwe] eventual ausência física ou linguística [para um período anterior ao século XVIII], mas a falta de conhecimento geográfico ou etnográfico do europeu acerca das regiões a leste dos rios Kwango e Kwanza". Assim, é possível sustentar que os cokwe já existiam como unidade grupal no século XVII, como faz Miller. Verificar: DIAS, Jill. Caçadores, Artesãos, Comerciantes, Guerreiros: os Cokwe em perspectiva histórica. IN: SILVA, Armando Coelho Ferreira da; GONÇALVES, António Custódio (org.). A Antropologia dos Tshokwe e povos aparentados. Porto: Faculdade de Letras da Universidade do Porto, 2003, pp. 17, 20 e em especial a 22. Sobre as demais informações: SANTOS, Maria Emília Madeira. Nos caminhos de África: serventia e posse (Angola - Século XIX). Lisboa: Instituto de Investigação Científica Tropical, 1998, pp. 266 e 459-460. 
deslocamentos populacionais mbundu, tais transformações demográficas e sociais foram propulsadas provavelmente por influências externas, impactando diretamente na vida e no cotidiano das comunidades locais. Embora impactos e transformações fizessem parte da dinâmica dos povos africanos, nada antes visto na região se comparou ao estardalhaço que a fundação da Angola portuguesa e seus desdobramentos causaram entre os séculos XVI e XVII.

De 1570 a 1630, a variante populacional mbundu que mais interagiu com os funcionários régios, oficiais e agentes representantes de Luanda foi a ndongo. ${ }^{151}$ Foi a partir das influências e impactos desses contatos, em voga desde a década de 1620 e que perdurariam até o século XIX, que as populações mbundu sofreriam pelo menos três grandes transformações populacionais e linguísticas, historicamente explicadas da seguinte forma por Joseph C. Miller. Parte dos lenge e ndongo "caíram sob administração directa dos Portugueses durante a década de 1620, começando assim o processo de homogeneização e assimilação que culminou com a emergência dos Ambaquistas" do século XIX, enquanto que uma outra parte substancial dos ndongo atingiu "um certo grau de unidade política centrado no estado que sucedera ao reino da Matamba", liderado ao longo do século XVII pela "famosa Rainha Nzinga". Ainda nos termos de Miller, postumamente à morte da líder africana, parte dos seguidores dela passaria a ser chamada de "jingas" pelo funcionalismo régio do século XIX. ${ }^{152}$ Por fim, diversos subgrupos mbundu foram brutalmente encaminhados a Luanda e às suas vizinhanças, onde acabariam despachados em tumbeiros ou serviriam como mão-de-obra compulsória nas propriedades

\footnotetext{
${ }^{151}$ Estudos recentes indicam a possibilidade de o etnônimo "ndongo" ser uma invenção moderna, uma vez que tradicionalmente os mbundu "sobretudo nas províncias de Malanje, Kwanza-Norte e Luanda, se considerarem como sendo Múndongo ou Kámùndòngò, isto é, alguém que é originário do país Ndongo (Ákwàndongo, marca do plural, significa 'os cidadãos do país Ndòngò'; Múkwàndòngò)". Verificar: COELHO, Virgílio. Em busca de Kábàsà [...]. Actas do Seminário Encontros de povos e culturas em Angola. Luanda: Comissão Nacional para as Comemorações dos Descobrimentos Portugueses, 1995, nota 3, p. 445. Aqui optaremos pela utilização do termo "mbundu" para nos referirmos a uma realidade geral, pertinente à sociedade pan-mbundu, e "ndongo" ou "are" em situações bastante contextualizadas, como ficará ao longo desta dissertação.

${ }^{152}$ MILLER, Joseph C. Poder político e parentesco [...]. [1976]. Luanda: Arquivo Histórico Nacional, 1995, pp. 41-42. Ressaltando que, para esse pesquisador, as posições de "reis jingas" eram "títulos portugueses" concedidos aos soberanos centro-africanos. Verificar as pp. 76-77 dessa mesma obra. O chamado "reino Njinga" parece ter surgido antes do século XIX, havendo vestígios de sua existência no início do terceiro quartel do século XVIII. Verificar especificamente: VANSINA, Jan. The Ambaca Society and the Slave Trade c. 1760-1845. The Journal of African History. Cambridge: Cambridge University Press, vol. 46, n. ${ }^{\circ}$, 2005, p. 8. Para mais informações sobre o chamado "reino independente de Njinga", bem como a sua política externa autônoma, verificar as pp. 14-16 do artigo de Jan Vansina.
} 
da Companhia de Jesus e nas sesmarias e lavouras de senhores portugueses, estabelecidas em continente africano. Inicialmente deformados e desenraizados, os ndongo e as demais populações centro-africanas relocadas em Luanda e nas propriedades portuguesas criaram novos falares e dispositivos de integração social, resultando no aparecimento de um novo subgrupo, hoje conhecido como "ambundu" ou "luanda". 153

A existência histórica desses três subgrupos africanos - ambaquista, jinga e luanda está correlacionada ao impacto derivado das novas relações escravistas tecidas a partir do litoral atlântico. Isso, contudo, não nos permite estipular que a economia atlântica causou profundas transformações no âmago de todas as populações mbundu, mas apenas deduzir, ainda que de maneira imprecisa, que o gradativo peso econômico e demográfico do comércio atlântico gerou contínuas mudanças ao longo dos séculos, sobretudo de cunho cultural e linguístico. ${ }^{154}$ Mas qual seria o peso desses impactos e transformações? De acordo com o atual consenso acadêmico, promulgado por especialistas como Joseph C. Miller e Virgílio Coelho, eles eram pequenos, pois o sentimento de pertencimento e de autoidentidade mbundu, formado por distintos subgrupos pan-mbundu, continuou a ser preservado pelo menos até o final do século $\mathrm{XX}^{155}$ A resistência desses traços sociopolíticos, estruturantes da sociedade em questão, também permite inferir que uma "visão de mundo", impressa e traduzida como elementar e comum por todos os subgrupos

\footnotetext{
${ }^{153}$ MILLER, Joseph C. Poder político e parentesco [...]. [1976]. Luanda: Arquivo Histórico Nacional, 1995, pp. 41-42. Ressaltando que para esse pesquisador as posições de "reis jingas" eram "títulos portugueses" concedidos aos soberanos centro-africanos. Verificar as pp. 76-77 dessa mesma obra.

${ }^{154}$ Basta notar na diferenciação dialetal entre os "luanda" e "ambaquistas", como também na organização de comunidades independentes que preservavam o sentimento de pertencimento mbundu, ao passo que também autoafirmavam serem populações "apartadas" e independentes, pelo menos entre a segunda metade do século XVIII e início do XIX. Verificar: MILLER, Joseph C. Poder político e parentesco [...]. [1976]. Luanda: Arquivo Histórico Nacional, 1995, pp. 39-40. VANSINA, Jan. The Ambaca Society and the Slave Trade c. 1760-1845. The Journal of African History. Cambridge: Cambridge University Press, vol. 46, n. ${ }^{\circ}$ 1, 2005, pp. 24-25. Sobre o surgimento dos ambaquistas como um dos reflexos causados pelo tráfico de escravos, verificar o mesmo artigo de Jan Vansina, p. 27.

${ }^{155}$ Pelo menos é isso que podemos depreender da pesquisa de campo feita por Virgílio Coelho, nas atuais províncias de Lunda, Bengo, Kwango-Norte, Kwanza-Sul e Malange (1984-1992), e Joseph C. Miller, no contemporâneo distrito de Malanje (cinco meses), em dois trabalhos distintos e de grande valor científico. $\mathrm{O}$ interesse em Malanje é explicado devido à construção de uma hidroelétrica na região, fato que motivou a implementação de diversas missões científicas para lá, como as antropológicas e arqueológicas. Verificar: COELHO, Virgílio. Em busca de Kábàsà [...]. Actas do Seminário Encontros de povos e culturas em Angola. Luanda: Comissão Nacional para as Comemorações dos Descobrimentos Portugueses, 1995, nota 1, p. 443. MILLER, Joseph C. Poder político e parentesco [...]. [1976]. Luanda: Arquivo Histórico Nacional, 1995, p. xii. FERREIRA, Autora Fonseca; TAVARES, Ana Paula Ribeiro. A problemática da pesquisa sobre História de Angola. Africa: Revista do Centro de Estudos Africanos da USP. São Paulo: Universidade de São Paulo, n. ${ }^{\circ} 9,1986$, p. 86 .
} 
pan-mbundu, também vigorou como um traço essencial de pertencimento identitário desde o século XVI. ${ }^{156}$ Mesmo assim - e o tom de nossas hipóteses e argumentações envereda para isto - é inegável que a formação da Angola portuguesa acarretou em alguns tipos de modificação e influência na vida dos mbundu, alguns deles sutis, outros de maior peso. É explorando a tensão entre mudança e continuidade que, neste e no próximo item, abordaremos a relação dialética entre a estrutura organizacional-sociopolítica endógena e os princípios essenciais da cosmogonia da sociedade mbundu. Sustentando que tal dialética é bastante útil para a investigação científica de cunho histórico, pretendemos doravante recalibrar algumas especificidades dos mbundu face à "matriz africana" ou ao "mundo bantu", conforme determinam as macroanálises de Catarina Madeira Santos e Jan Vansina, além de propor algumas claves de análise úteis para a interpretação e a argumentação gerais desenvolvidas nesta dissertação. ${ }^{157}$

Nosso ponto de partida é que a estrutura organizacional dos mbundu está dividida quer dizer, estava já montada no século XVII e manteve-se inalterada em seu âmago até o século XX - em unidades sociopolíticas, atreladas usualmente a uma espécie de escala de centralização política. A base dessa sociedade mbundu é a "aldeia", ou libata em kimbundu, ${ }^{158}$ centrada em torno de um grupo de filiação, ou $n g u n d u,{ }^{159}$ encabeçado por homens adultos, comumente os cabeças mais velhos ou anciões de prósperas famílias, que são parentes entre si. A descendência entre os mbundu é matrilinear, ${ }^{160}$ quer dizer, passada apenas pelas mães. Todas as vezes que um casamento entre um homem e uma mulher é

${ }^{156}$ Sobre tal resistência e capacidade de perpetuar ao longo do tempo, verificar: VANSINA, Jan. Paths in the Rainforests: Toward a History of Political Tradition in Equatorial Africa. Madison-Wisconsin: University of Wisconsin Press, 1990, p. 236.

${ }^{157} \mathrm{O}$ conceito de "matriz" foi inicialmente proposto por Catarina Madeira Santos, mas depois derrogado por outro conceito, o de "saberes". Problematizando a questão, é possível afirmar que há matrizes que figuram como vetores de saberes, ao passo que, imbuídos de conhecimentos e informações sobre o outrem, os próprios saberes figuram como promulgadores de clichês, estereótipos e estigmas projetados aos povos contatados. Verificar: SANTOS, Catarina Madeira. Um governo "polido" para Angola: Reconfigurar dispositivos de domínio. (1750-c.1800). Tese de doutorado em História, Universidade Nova de Lisboa, 2005, pp. 11-12. Sobre a noção de "mundo bantu", verificar: VANSINA, Jan. Paths in the Rainforests [...]. MadisonWisconsin: University of Wisconsin Press, 1990, pp. 72 e 95 e How Societies Are Born: Governance in West Central Africa before 1600. Charlottesville: University of Virginia Press, 2004, pp. 2, 103 e 201.

${ }^{158}$ Conferir o "suplemento para alguns vocábulos africanos", inserido nesta dissertação.

${ }^{159}$ No plural, jingundu.

${ }^{160}$ Assim, ao discorrer sobre a sucessão política de sobas nas aldeias mbundu, Fernão de Sousa afirmou que o sucessor de algum soba falecido, ou expulso de seu local de origem, era comumente um "sobrinho do morto, filho de sua irmã, porque este tem por legítimo senhor". Verificar: Fernão de Sousa. O extenso relatório do governador aos seus filhos. S.d., 1625-1630. BAL, cód. 51-IX-20, ff. 220-74v. IN: HEINTZE, Beatrix (coord.). Documento 30, FHA, vol. I, 1985, pp. 280-281. 
firmado, é a esposa que se transfere para a aldeia do marido, assim respeitando a regra de virilocalidade. ${ }^{161}$ Esses casamentos são normalmente efetuados entre linhagens de aldeias próximas uma das outras, o que permite a existência de uma inter-relação entre os vários ndungu sem que, com isso, a "solidariedade do grupo de filiação" que chefia cada aldeia seja desacatada. ${ }^{162}$ Esse tipo de relação de parentesco matinha íntima associação com uma perspectiva mbundu de politização das comunidades locais, ligada a algo que Joseph C. Miller chamou de "parentesco perpétuo", que nada mais é do que a metaforização das chamadas "posições titulares", impressas em nomes de chefias que encabeçam cada ngundu, ${ }^{163}$ através da "linguagem de parentesco", quer dizer, de relações entre pais e filhos, tios e sobrinhos, avós e netos, entre outras. Isso se traduzia frequentemente no amálgama entre nomes biológicos, posições titulares e sucessões políticas, vislumbrados de maneira metafórica e emparelhados a encadeamentos metonímicos. ${ }^{164} \mathrm{Na}$ prática, então, uma posição titular perpétua poderia ser sucedida por vários indivíduos ao longo do tempo, "exercendo os direitos e deveres que competem a tal posição". ${ }^{165}$ Quando, por exemplo, na

${ }^{161}$ Atentando então para o fato de que a poligamia era aceita apenas para os homens. Outro relevante aspecto é que, em caso de divórcio, os indivíduos femininos retornavam para os seus respectivos ngundu.

${ }^{162}$ MILLER, Joseph C. Poder político e parentesco [...]. [1976]. Luanda: Arquivo Histórico Nacional, 1995, pp. 42-43. Mais informações sobre o principio da "solidariedade" como necessário à manutenção do equilíbrio social local ou mesmo infralocal, verificar: VANSINA, Jan. Paths in the Rainforests [...]. MadisonWisconsin: University of Wisconsin Press, 1990, pp. 99-100 e Kingdoms of the Savanna. Madison: University of Wisconsin Press, 1966, p. 25. Em sentido parecido com a desses pesquisadores, verificar: FERREIRA, Roquinaldo. Cross-Cultural Exchange in the Atlantic World: Angola and Brazil During the Era of the Slave Trade. Cambridge: Cambridge University Press, 2012, pp. 55-56.

${ }^{163}$ Era através das posições titulares que os sobas se apresentavam aos estrangeiros, ou mesmo clamavam sua importância internamente contra qualquer desafiador ou elemento subversivo, o que permite depreender que essas posições mantinham a congruência das relações inter e extrapolíticas de uma aldeia. $\mathrm{O}$ mesmo mecanismo de parentesco e política também foi ressaltado em: VANSINA, Jan. Kingdoms of the Savanna. Madison: University of Wisconsin Press, 1966, p. 27.

${ }^{164}$ Tal conceito foi extraído a partir das tradições orais imbangala. Sucintamente, há dois tipos de narrativas orais de cunho histórico para esse povo: os "episódios narrativos chamados malunda (singular lunda)" e as "genealogias históricas, ou musendo", nas quais ocorre uma extensa listagem de nomes. A primeira funciona através de metáforas sincrônicas, a segunda através de metonímias diacrônicas. O importante é entender que, nos musendo, a relação parental "pai-filho" exprime a lógica política "títulação-subordinação". Assim, um "pai" é sempre um título político "sênior", ao passo que um "filho" simboliza um título político "júnior". MILLER, Joseph C. Poder político e parentesco [...]. [1976]. Luanda: Arquivo Histórico Nacional, 1995, pp. 16-17.

${ }^{165}$ Ibidem, p. 45. Em termos empíricos de investigação histórica, um grande desafio é detectar quando e como ocorrem as interpolações entre a "titularidade" de algumas nomenclaturas africanas registradas nos textos de época, equivalentes a "títulos políticos" propriamente ditos, e a "personificação" dessas mesmas nomenclaturas, que assim seriam "pessoas políticas". Para mais explicações de como isso ocorre, verificar: HEINTZE, Beatrix. Angola nos séculos XVI e XVII: estudos sobre fontes, métodos e história. Luanda: Kilombelombe, 2007, pp. 180-181. Corroborando com as interpretações propostas por Miller e sobre a linguagem do parentesco político, verificar as considerações feitas em: COELHO, Virgílio. "Em busca de Kábàsà!..." Estudos e reflexões sobre o "Reino" do Ndòngò: Contribuições para a História de Angola. 
década de 1620 as autoridades africanas declaravam ser "filhas do capitão", quer dizer, “filhas de Fernão Sousa", nada mais faziam do que interpretar a relação política mantida com o administrador régio, através do crivo do parentesco político perpétuo, comum à sociedade mbundu. ${ }^{166}$

As posições de maior destaque no seio da ngundu são lembradas pelos mbundu como "tios da linhagem", ou lemba em kimbundu, ${ }^{167}$ sendo que a posição de chefia, ou liderança, do grupo de filiação recebia o título de lemba dya ngundu. Acreditamos que tal posição de comando e direção das linhagens condizia com aquilo que os cronistas, eclesiásticos e funcionários régios dos séculos XVI e XVII identificaram, de modo genérico e homogeneizante, como sendo os tais "sobas" e que, como notaremos ao longo desta dissertação, equivalia a dizer "chefe". ${ }^{168}$ Sabe-se com certeza que nos séculos XVI e XVII o termo "soba" estava largamente disseminado e em franca utilização, o que possivelmente indica não apenas uma reapropriação terminológica por parte do funcionalismo régio, mas também uma vulgarização lexical desse vocábulo por parte dos mbundu. Seja como for, havia matizes e gradações entre esses "chefes" locais, condizentes com os papéis e as hierarquias existentes nas diferentes esferas da vida política e social. É de responsabilidade desses líderes linhageiros, ou simplesmente "sobas", a execução de ritos que assegurem a boa colheita, a precipitação de copiosas chuvas, a fartura na caça e a fertilidade das mulheres que integravam o grupo de filiação. Cabe ao soba também exercer a "dimensão espiritual" do ngundu que, na prática, traduz-se na execução da intermediação entre o mundo dos vivos e o dos mortos, como também na mediação entre os membros do "ngundu

Luanda: Kilombelombe, 2010, p. 227-228. VANSINA, Jan. L'homme, les forêts et le passé en Afrique. Annales. Économies, Sociétés, Civilisations. Paris: Éditions de l'EHESS, ano 40º n. ${ }^{\circ} 6,1985$, p. 1323.

166 Segundo Fernão de Sousa, comumente os sobas vassalos e as autoridades africanas fiéis a Luanda declaravam "ser filha" ou "ser filho" do governador português. Na prática, eles se apresentavam em Luanda, ou enviavam um representante oficial para lá, a fim de jurar ser "filho do capitão", sendo "capitão" a forma como denominavam o governador em Luanda. Na ótica institucional ultramarina, o juramento era uma das solenidades prestadas pelos "sobas vassalos do rei de Portugal". Fernão de Sousa. O extenso relatório do governador aos seus filhos. S.d., 1625-1630. BAL, cód. 51-IX-20, ff. 220-74v. IN: HEINTZE, Beatrix (coord.). Documento 30, FHA, vol. I, 1985, pp. 230-231. A expressão também recorre em outros trechos, como na p. 298, "pela vontade que tem em ser filha do capitão"; p. 345, "porque entre pai [Fernão de Sousa], e filho [os soba Boila] não podia haver descontentamento que tirasse a comunicação"; p. 343, "[em relação ao soba Gunza Ambambe] vassalo de Sua Majestade e filho meu"; p. 296, "peça e filha minha [em relação a Ginga e a tentativa de acordo entre as partes]".

${ }^{167}$ Lemba é o singular; no plural, malemba.

${ }^{168}$ Essa é a simplificação semântica normalmente adotada pelos funcionários e oficiais régios. Apesar de a posição sustentada aqui não ser consensual, fato é que o termo "soba" aceita acepções e níveis de entendimento variados. Para mais informações, conferir o "suplemento para alguns vocábulos africanos", inserido nesta dissertação. 
e os espíritos das terras e das águas que eles possuíam". Eles não chefiam as aldeias sozinhos. Em torno dos sobas jazem conselheiros e juízes, também conhecidos como os "macotas", ${ }^{169}$ o que em kimbundu quer dizer literalmente "mais velhos". ${ }^{170}$ Os sobas zelavam pela utilização e distribuição de símbolos tradicionais e ritualísticos altamente valorizados pelas populações mbundu, motivo pelo qual tais práticas eram difundidas por toda a savana meridional. Alguns simbolismos importantes estavam contidos na utilização dos pós pemba ${ }^{171}$ e takula, o primeiro de coloração branca e o outro vermelha, ambos empregados em rituais de fertilidade. Nesses cultos ministrados por sobas, as mulheres recebiam a pemba, enquanto que os homens eram pintados com takula. Outro símbolo reivindicado pelos mbundu eram as árvores mulemba, que eram as mais tradicionais insígnias políticas capazes de representar a autoridade dos sobas e das linhagens de cada aldeia, onde essas grandes figueiras eram plantadas e serviam como um espaço de "deliberações" entre os titulares políticos locais. ${ }^{172}$ Cabe salientar que, para um indivíduo autoproclamado "mbundu", o sentimento de pertencimento a um ngundu era de suma importância, sem o qual o mesmo não encontraria lugar dentro da comunidade ou corporação existente, sendo destituído de segurança e do bem-estar proporcionado pela solidariedade local. Assim, em teoria, a exclusão de um ngundu bloqueava qualquer "pessoa dos direito de apelar ao apoio dos seus parentes, impedia-a de casar ou de cultivar alimentos, negava-lhe conforto espiritual" ${ }^{173}$ algo que relegava ou induzia os excluídos, ou marginalizados sociais, à possibilidade de subordinação a outrem, que poderia ser ou não mbundu. Durante a era do tráfico de escravos moderno, tal funcionamento das relações sociais mbundu foi traduzido como sendo uma espécie de "regime de escravidão" africano, interpretado através de simples aproximações e equivalências. Assim, o não-pertencimento

\footnotetext{
${ }^{169}$ No plural em kimbundu, grafado como makota. No singular, kota ou dikota.

${ }^{170}$ MILLER, Joseph C. Poder político e parentesco [...]. [1976]. Luanda: Arquivo Histórico Nacional, 1995, pp. 46-47. Os macotas também eram responsáveis pelas eleições de novos sobas. Verificar: HEINTZE, Beatrix. Angola nos séculos XVI e XVII [...]. Luanda: Kilombelombe, 2007, pp. 221-222.

${ }^{171}$ Conferir o "suplemento para alguns vocábulos africanos", inserido nesta dissertação.

${ }^{172}$ MILLER, Joseph C. Poder politico e parentesco [...]. [1976]. Luanda: Arquivo Histórico Nacional, 1995, pp. 47-48. Nas palavras de Virgílio Coelho, a mulemba é uma "árvore do poder dos chefes locais", atualmente valorizada como um "lugar de culto". Mulemba seria o singular, mílèmbà. Verificar: COELHO, Virgílio. Em busca de Kábàsà [...]. Actas do Seminário Encontros de povos e culturas em Angola. Luanda: Comissão Nacional para as Comemorações dos Descobrimentos Portugueses, 1995, nota 23, p. 460. Consultar ainda o capítulo 4 desta dissertação.

${ }^{173}$ MILLER, Joseph C. Poder político e parentesco [...]. [1976]. Luanda: Arquivo Histórico Nacional, 1995, p. 48.
} 
e a falta de solidariedade entre membros que não estivessem à mercê de algum grupo de filiação abria alas à possibilidade de venda como escravos, ou seja, quanto mais um indivíduo mbundu mantivesse relações sociais frouxas com um soba e seu ngundu, maior era a possibilidade dele ser vendido como "peça" para os negociantes e representantes comerciais de Luanda. ${ }^{174}$ A ambivalência entre os binômios destacados - solidariedadepertencimento e marginalização-exclusão - são os princípios essenciais da visão de mundo compartilhada por todos os subgrupos pan-mbundu e que, de modo dialético, estão respaldados na forma como se estruturam essas sociedades até hoje, o que permitiu Joseph C. Miller considerar que "por todas estas razões, os Mbundu davam às suas linhagens grande importância e é evidente que conseguiram preservar a sua estrutura básica sem grandes mudanças através de vários séculos". ${ }^{175}$

Havia um macrocosmo que reiterava a vida dos mbundu, vigente na história de fundação e preponderante no desenvolvimento político do chamado "reino do Ndongo", a primeira soberania mbundu a entrar em contato com os portugueses no século XVI. ${ }^{176}$ Assim, e parafraseando Jan Vansina, para acessar a historicidade desse reino, é preciso primeiro compreender as origens e os fundamentos dos governos africanos, apropriando-se das regras e normas que regeram as mudanças e persistências ao longo do tempo. ${ }^{177} \mathrm{O}$ elementar aqui é compreender que alguns processos de convergência e divergência, sempre no sentido regional para o local, estiveram na África Centro-Ocidental associados à adoção de novas técnicas ou tecnologias. A fluidez desses aspetos culturais e técnicos é perceptível

\footnotetext{
${ }^{174}$ A explicação de Miller é nesse sentido mais completa: "os Mbundu apenas aceitavam como seres humanos seus semelhantes as pessoas que tinham alguma posição no seu sistema de linhagens, quer como detentores de um dos nomes dos ngundu, quer como dependentes formalmente de algum grupo de filiação ("escravos", "penhores" etc.)". MILLER, Joseph C. Poder político e parentesco [...]. [1976]. Luanda: Arquivo Histórico Nacional, 1995, p. 48.

${ }^{175}$ MILLER, Joseph C. Poder político e parentesco [...]. [1976]. Luanda: Arquivo Histórico Nacional, 1995, p. 48. Tais binômios podem também ser "traços perenes" de uma "cultura política" não apenas circunscrita aos mbundu, mas quiçá existente em outras sociedades africanas implicadas no tráfico de escravos. Igualmente nesse sentido verificar: LARA, Silvia Hunold. Palmares \& Cucaú: o aprendizado da dominação. Tese para concurso de Professor Titular, Universidade Estadual de Campinas, 2008, p. 96.

176 Em consonância com Virgílio Coelho, para quem o chamado "rei do Ndongo" pode também ser identificado como um "soberano" mbundu. Verificar: COELHO, Virgílio. Em busca de Kábàsà [...]. Actas do Seminário Encontros de povos e culturas em Angola. Luanda: Comissão Nacional para as Comemorações dos Descobrimentos Portugueses, 1995, pp. 446-447.

${ }^{177}$ Como veremos a seguir, trata-se de um tipo de estudo focado no surgimento e no funcionamento dos chamados "estados africanos" pré-coloniais. Para além dos diversos textos de Jan Vansina referenciados neste capítulo, imbuídos dessa tendência de análise e crítica, consultar os apelos e as indicações feitos em: VANSINA, Jan. Ethnohistory in Africa. Ethnohistory. Durham: Duke University Press, vol. 9, n. ${ }^{\circ}$ 2, primavera de 1962 .
} 
através de difusões culturais e linguísticas, podendo gerar inovações sociopolíticas e "evoluções" ${ }^{178}$ Fazendo uso de uma metáfora largamente empregada por Jan Vansina, é a inovação que move as engrenagens do "motor da história". ${ }^{179}$ Simbolizam essas "engrenagens" possíveis linhas de desenvolvimento histórico, potencialmente ativas, não necessariamente vindouras, pontilhadas por "unidades sociopolíticas" - linhagem, casa/aldeia, comunidades/distritos, chefaturas, principados/províncias e reinos -, de tal forma que a "historicidade" dessas comunidades estivesse contida em uma "escada de mudança institucional", na qual cada uma dessas unidades representasse um estágio distinto de desenvolvimento, rumando sempre em direção a uma maior centralização política e provedora de uma "territorialização" do espaço geofísico. ${ }^{180}$ Assim sendo, para cumprir com o cronograma de desenvolvimento e superação histórica, galgando ou "subindo" os estágios de desenvolvimento, é necessário que ocorram séries de "impulsos" técnicoculturais, geralmente disparados por fatores externos e que são capazes de promover sucessivas inovações no interior dos aglomerados populacionais. O percurso esperado é frequentemente progressivo, iniciado em um plano de sobrevivência elementar e assente nos primórdios de vivência e socialização de indivíduos caçadores-coletor, desaguando ou não em um estágio mais avançado de estatização e governança, onde estariam situados os chamados "reinos africanos", como o Kongo e o Ndongo dos séculos XVI e XVII. ${ }^{181}$

\footnotetext{
${ }^{178}$ Na perspectiva de Jan Vansina e Joseph C. Miller, são varias as potenciais linhas de desenvolvimento entrelaçadas entre si, sendo que apenas a minoria delas, quiçá as "exceções", capazes de vingar e gerar mudanças efetivas dentro de alguma sociedade. Trata-se de uma releitura das teorias de desenvolvimento e evolução humanas, de modo algum "vulgar" ou "fatalista", apesar de ainda estar ancorada na noção de progresso humano e não repudiar uma perspectiva teleológica de escrita da história. Verificar: VANSINA, Jan. Paths in the Rainforests [...]. Madison-Wisconsin: University of Wisconsin Press, 1990, pp. 254-255. MILLER, Joseph C. Poder político e parentesco [...]. [1976]. Luanda: Arquivo Histórico Nacional, 1995, pp. 58-59.

${ }_{179}$ CURTIN, Philip D. Why People Move. Waco: Baylor University Press, 1995, pp. 6-8. VANSINA, Jan. How Societies Are Born [...]. Charlottesville: University of Virginia Press, 2004, p. 14.

${ }^{180}$ Joseph C. Miller destaca que, entre os mbundu, a tendência era a de "agregar" sem anular instituições políticas convergentes, perpetrando com isso uma "coexistência" institucional ao longo do tempo e em diferentes espaços. Verificar: MILLER, Joseph C. Poder político e parentesco [...]. [1976]. Luanda: Arquivo Histórico Nacional, 1995, pp. 57-58 e 68. O resumo dessa ideia foi esboçada na seguinte obra, hoje considerada um clássico: VANSINA, Jan. Kingdoms of the Savanna. Madison: University of Wisconsin Press, 1966, pp. 28 e 30.

${ }^{181}$ No pensamento de Vansina, a ideia de "mudança" está atada à ocorrência de "contatos milenares" entre o leste e o oeste da África Central. A explicação completa fornecida pelo etno-historiador é a de que, pelo menos até o primeiro milênio após a morte de Cristo, o teor dessa mudança estava relacionado às "inovações" despertadas no seio das comunidades locais, incentivadas pelos fluxos migratórios, trocas comerciais e ondas difusoras. Para Vansina, a difusão seria mais importante do que as outras modalidades de transmissão e de comunicação, principalmente por espalhar, com certa autonomia e facilidade, técnicas e tecnologias ligadas à
} 
Assim sendo, a busca pelas origens e fundamentos dos governos africanos está intimamente influenciada, para não dizer atada, aos interesses de pesquisa relacionados ao desenvolvimento estatal e à centralização política. Talvez mais interessante seja o fato de que esse tipo de investigação possibilitar meios sólidos para a reconstrução de um passado pré-atlântico e ágrafo, quer dizer, anterior aos encontros modernos e destituído de fontes primárias escritas pelos autóctones. Engajado a essa seara de pesquisa, Joseph C. Miller propôs na década de 1970 a escrita de uma história institucional e regressiva, baseada nas chamadas "tradições fundadoras", ${ }^{182}$ sem datas precisas ou cronologia detalhada, capaz de

agricultura, à cerâmica, à metalurgia e ao pastoreio. A "difusão tecnocultural", normalmente no sentido oriente-ocidente, fluiria através dos chamados "canais de comunicação", também conhecidos como "canais de difusão". Sobre isso, alguns pontos são destacados pelo pesquisador: i) $\mathrm{O}$ pressuposto é o de que as comunidades almejariam uma "melhora de vida" material; $i$ i) Os "fluxos de comunicação são sempre fluxos de inspiração social", ou seja, a difusão obteria êxito penas se as inovações fossem "acatadas" e "repetidas" pelas comunidades locais; iii) Havia uma miríade de "histórias de sociedades de pequena escala", no "nível local da vida cotidiana", sobreposta a "padrões de larga escala"; iv) Em grande medida, o que estava em jogo era a "história das atividades de produção de alimentos nas aldeias" e, por isso, a difusão tecnocultural - a introdução de "novos animais domésticos e plantas, novas práticas agrícolas, novas divisão de trabalho" - e o acesso à mão-de-obra seriam decisivas para a "mudança nos padrões de nutrição e demografia", finalmente causando "mudanças nos padrões da organização social"; v) No pensamento de Vansina, a cadeia "contatotransmissão-comunicação-mudança" mantinha íntima associação com a dupla "agricultura e estratificação social", já ressaltada por Marshall Sahlins; vi) Por volta de 1700, a combinação entre a "expansão Lunda" e o aumento do tráfico atlântico fez com que "a frequência e intensidade da comunicação" entre leste e oeste aumentasse, de forma que a grande "barreira" que dificultava a comunicação entre os extremos do continente, o deserto do Kalahari, fosse ultrapassado. Verificar: VANSINA, Jan. Finding Food and the History of Precolonial Equatorial Africa: A Plea. African Economic History. Madison: University of WisconsinMadison/ African Studies Program, n. ${ }^{\circ}$ 7, primavera de 1979, pp. 14-15. Idem, Communications between Angola and East Central Africa Before c. 1700. IN: HEINTZE, Beatrix; OPPEN, Achim von (ed.). Angola on the Move: Transport Routes, Communications and History. Frankfurt am Main: Verlag Otto Lembeck, pp. 130, 140-142. VANSINA, Jan. Kingdoms of the Savanna. Madison: University of Wisconsin Press, 1966, pp. 16-17. Para as passagens mais fundamentais a respeito da trajetória política centro-africana, com destaque à liderança local dos chamados "sobas": Idem, How Societies Are Born [...]. Charlottesville: University of Virginia Press, 2004, pp. 143, 160, 162-163 e 165. A respeito da matrilianeidade e a expansão de virilocalidades em direção a uma ordenação infrarregional, verificar a última obra de Jan Vansina, pp. 143, 145-146, 169-170, 176-177 e 202-203. Sobre o surgimento de uma "constelação de pequenos reinos", dos quais no norte os mais importantes eram os de Kongo, Loango e Tio, e na região dos mbundu o Ndongo e Matamba, verificar as pp. 188-189. Sobre isso, ver também: Idem, Paths in the Rainforests [...]. MadisonWisconsin: University of Wisconsin Press, 1990, pp. 155-156.

${ }^{182}$ A análise crítica de Miller pressupõe que as tradições fundadoras, ou "originais", não podem ser interpretadas como um registro de "fatos históricos" sobre o passado, mas como dispositivos de legitimação de uma dada ordem sociopolítica, reencenadas e recontadas nos rituais e cerimônias autóctones. Assim, na prática, por envolver uma "performance" dos tradicionalistas, a recitação das tradições fundadoras era influenciada por estímulos do meio. Por exemplo, em uma cerimônia comunitária repleta de ouvintes, certa tradição poderia ser modificada para atender as reivindicações de proeminência ancestral de membros que almejassem conquistar uma posição de liderança na comunidade, ou simplesmente para atender ao gosto da plateia presente. Fundamental menos pelo conteúdo narrado e mais por ser um fenômeno social e simbólico, a performance oral é um aspecto cultural, hereditário, perpétuo e estruturante das visões de mundo e ideologias que fornecem coesão ao corpo social centro-africano como um todo. VANSINA, Jan. Paths in the Rainforests [...]. Madison-Wisconsin: University of Wisconsin Press, 1990, pp. 5-6, 8-9, 31 e 33. Idem, How Societies Are 
explicar o "passo a passo" da evolução do Ndongo. A proposta de Miller está associada diretamente ao surgimento de "insígnias políticas", sendo a mais elementar e recorrente nos registros seiscentistas e coloniais a imponente árvore mulemba, representante da chefia de um soba. ${ }^{183}$ Menos antiga que a mulemba e outrora uma das mais respeitadas insígnias políticas dos mbundu, apareceu entre as linhagens que habitam a parte média e norte do rio Lui uma nova insígnia, a lunga ${ }^{184}$. Como uma "relíquia sagrada", a lunga tem "a forma de uma figurinha humana talhada em madeira", proveniente, explicam os anciões, da "kalunga", a "grande água" não geofisicamente determinada, dado que fez com que os observadores europeus e cronistas novecentistas a identificassem à imagem do "oceano Atlântico", ou dos "grandes lagos da África". Não é por menos que, até hoje, a lunga ainda é associada à chuva e à água em geral, "habitando" nos rios e conectada ao "sucesso da agricultura e, portanto, com a própria vida, na visão do mundo do camponês". ${ }^{185}$

O diferencial da lunga foi o de conseguir "atravessar" as relações de parentesco que limitavam as relações entre aldeias. Assim, alguns grupos de filiação mbundu conseguiram agregar diferentes linhagens em torno de uma unidade sociopolítica supralocal, portanto capaz de ultrapassar os limites das localidades. Como prefere Joseph C. Miller, igual a tantas outras insígnias políticas que depois surgiriam, a lunga era uma "instituição transversal" ${ }^{\$ 186}$ pioneira entre os mbundu, capaz de proporcionar uma maior centralidade e maturação à ordem e ao mando dos mbundu. ${ }^{187}$ De todo modo, anos mais tarde a lunga acabaria superada por outra insígnia política, através da qual seria consagrada uma unidade institucional relativamente mais forte e centrípeta, representada pelo salto em direção à fundação do chamado "reino do Ndongo". Essa insígnia era o ngola, termo analogamente

Born [...]. Charlottesville: University of Virginia Press, 2004, p. 2. Apesar de inovadora, a proposta de análise de Joseph C. Miller não foi de modo algum pioneira, uma vez que David Birmingham já havia proposto muito antes uma leitura interessante sobre as tradições. Verificar, em especial: BIRMINGHAM, David. Trade and conflict in Angola: the Mbundu and their neighbours under the influence of the Portuguese 1483-1790. Londres: Clarendon Press/ Oxford University Press, 1966, pp. 18-20. Sobre tal perspectiva de análise, verificar também a primeira obra supracitada de Jan Vansina, p. 237, além de: VANSINA, Jan. Kingdoms of the Savanna. Madison: University of Wisconsin Press, 1966, p. 9-10. Voltaremos a tocar na questão das tradições fundadoras no capítulo 4 desta dissertação.

${ }^{183}$ Voltaremos à importância dessas grandiosas árvores no capítulo 4 desta dissertação.

${ }^{184}$ No singular. No plural, malunga.

${ }^{185}$ MILLER, Joseph C. Poder político e parentesco [...]. [1976]. Luanda: Arquivo Histórico Nacional, 1995, pp. 59-60.

${ }^{186}$ Sobre isso, verificar: MILLER, Joseph C. Poder político e parentesco [...]. [1976]. Luanda: Arquivo Histórico Nacional, 1995, pp. 42, 49 e 53, entre outras.

${ }^{187}$ Ibidem, pp. 61-63, 67-68 e 70 . 
empregado para identificar os chamados "reis do Ndongo", também conhecidos nos registros portugueses dos séculos XVI e XVII como os "reis Angola". Tal insígnia era um objeto de ferro que, originalmente, podia ser "um martelo, um sino, uma enxada e uma faca", mas que hoje em dia declinou, podendo ser representado por "praticamente qualquer deformado ou ferrugem pedaço de metal". ${ }^{188}$ Aquele que portasse o ngola reforçava a sua capacidade de mediar a comunicação entre o mundo dos vivos e o dos mortos, situando-se no topo da hierarquia espiritual e política dos mbundu.

Junto com a adoção do ngola veio uma nova estrutura política, identificada pelos primeiros observadores quinhentistas como um "reino", na imagem de algo que podemos chamar atualmente de "soberania". No posto mais alto de direção dessa unidade política viria o "rei", ou "soberano", uma espécie de líder supremo dedicado à governança institucional, ${ }^{189}$ identificado pelos mbundu pela posição titular de "ngola", nome análogo ao da insígnia que ele sustentava. O soberano estava cercado por chefes de linhagem lemba dya ngola, os "tios do ngola", ${ }^{190}$ que passavam a formar uma cúpula de ordem judiciária e mando político, ou "corte real", na forma de "efetivos chefes da linhagem e dignatários políticos dominantes do grupo". Abaixo deles vinham os antigos lemba dya ngundu, os "tios da linhagem", mais circunscritos às suas respectivas aldeias e sem grande respaldo político na corte real. ${ }^{191}$ São escassas as informações sobre quando teria sido consolidada a formação de um "estado mbundu", à guisa daquilo descrito pelos observadores portugueses como sendo o "reino do Ndongo". De todo modo, aqui seguimos a opinião de Jan Vansina, o núcleo central do Ndongo teria surgido no final do século XV. ${ }^{192}$ Assim, como uma instituição transversal forte, portátil e provedora de centralização política, o ngola intensificou a multiplicação dos vínculos que cortavam os laços de parentesco, redimensionando as relações vigentes entre as linhagens dos séculos XVI e XVII. ${ }^{193}$ A

${ }^{188}$ MILLER, Joseph C. Poder político e parentesco [...]. [1976]. Luanda: Arquivo Histórico Nacional, 1995, p. 63 .

189 Menos centralizada, porém, do que o Kongo. Verificar, por exemplo, as considerações feitas por: HEYWOOD, Linda M.; THORNTON, John K. Central Africans, Atlantic Creoles [...]. Cambridge: Cambridge University Press, 2007, pp. 72-73.

${ }^{190}$ No singular. No plural malemba dya ngola.

${ }^{191}$ MILLER, Joseph C. Poder político e parentesco [...]. [1976]. Luanda: Arquivo Histórico Nacional, 1995, pp. 63-64.

${ }_{192}$ VANSINA, Jan. How Societies Are Born [...]. Charlottesville: University of Virginia Press, 2004, pp. 188189.

${ }^{193}$ MILLER, Joseph C. Poder político e parentesco [...]. [1976]. Luanda: Arquivo Histórico Nacional, 1995, pp. 64-65. 
partir de então, o olhar e a pena dos observadores estrangeiros não ficariam isentos de anotar as mudanças ocorridas. Na documentação inserida na $F H A$, mesmo que mal demarcada e muitas vezes implícita, há uma gradual dissociação entre os "sobas mais fortes" - na ótica mbundu, os lemba dya ngola - e os "sobetas", 194 ou "sobas menos importantes" - possivelmente os lemba dya ngundu. Assim sendo, em meados do último quartel do século XVI, já é possível falar de uma soberania no Ndongo estatizada, quer dizer, com intrincadas hierarquias e camadas sociais, ordenadas em um espaço com divisões políticas, as chamadas "províncias" registradas nos fontes escritas, como veremos no próximo item. ${ }^{195}$

\subsection{Os fundamentos do reino do Ndongo entre os séculos XVI e XVII}

Uma vez apresentada uma concisa reconstituição da história política do Ndongo, podemos neste item abordar um pouco sobre o funcionamento da soberania mbundu no momento em que Paulo Dias de Novais, o representante da monarquia portuguesa encarregado da "colonização e conquista" ultramarina, a encontrou. Retomando alguns dos conceitos destacados no item anterior, por volta da década de 1570 já existia no Ndongo uma estrutura organizacional-sociopolítica bem estabelecida, em linhas gerais dividida entre uma "camada de elite", possuidora de posições titulares e insígnias políticas, e outra "popular", responsável pelo trabalho nas plantações, confecção têxtil, artesanato, pecuária e outras tarefas braçais. O diferencial da elite mbundu jazia no respeito e no respaldo político que os membros de cada ngundu tinham em relação às posições titulares de chefia local, além é claro do ngola, a maior entidade e autoridade respeitada entre os mbundu. No âmago da divisão social e do surgimento de lideranças políticas no Ndongo residia um princípio básico e essencial, regedor da cosmogonia mbundu do alto escalão: a busca por prestígio, representado pela aquisição de posições e insígnias, propiciador de uma matização interelites e diferenciação hierárquica dos membros da sociedade africana.

Havia ainda uma estrutura de governo montada em torno do ngola, aparentemente oficial e centralizada em uma cúpula de comando, ao qual chamaremos doravante de "corte

\footnotetext{
194 Sobre isso consultar a entrada para "soba" no "suplemento para alguns vocábulos africanos", disponível nesta dissertação.

${ }^{195}$ Devido à complexidade do tema, mais considerações sobre o ngola e as relações que ele mantinha com organização do "reino do Ndongo" serão retomadas no segundo capítulo desta dissertação.
} 
real" ${ }^{196}$ Segundo os eclesiásticos, funcionários e oficiais régios dos séculos XVI e XVII que serviam em Luanda e regiões vizinhas, a corte do reino do Ndongo funcionava da seguinte forma. Havia um núcleo centrípeto de ordem e mando representado pelo "ngola", cercado e assistido por macotas e sobas mais importantes, provavelmente os lemba dya ngola. Essa cúpula participava de "deliberações" políticas, além de ser responsável pela eleição de novos ngola. Quiçá emparelhado a essas autoridades, ou talvez um pouco inferiores a elas, estava o "tendala" da corte, "uma espécie de primeiro-ministro, documentado pela primeira vez em 1588", como explica Beatrix Heintze, ${ }^{197}$ ao qual eram atribuídas incumbências judiciais, entre outros afazeres não documentados em escrito. Outra importante posição era a de "quiambole", ${ }^{198}$ ao qual eram delegados os assuntos militares e territoriais do reino do Ndongo. ${ }^{199} \mathrm{O}$ interessante aqui é notar que o cronista António de Oliveira de Cadornega foi o primeiro a registrar por escrito que o tendala era de proveniência "escrava", ou seja, totalmente à parte das linhagens mbundu, algo que igualmente parecia valer para o quiambole da corte. Havia motivos práticos para que isso ocorresse, ligados ao equilíbrio sociopolítico interno. Alguns escravos, ou como logo veremos "quizicos", eram escolhidos para esses importantes cargos a fim de tolher uma competição acirrada em torno de postos de proximidade e confiança junto ao ngola. $\mathrm{O}$ medo era o de que a alta disputa política acarretasse na contestação direta à autoridade do soberano, viabilizando com isso golpes políticos levados a cabo por linhagens mbundu descontentes e ávidas por prestígio. ${ }^{200}$ Isso nos leva a uma segunda consideração. Embora

${ }^{196}$ Composta pelas pessoas identificadas como os "habitantes do interior da paliçada real" ou os de "dentro de dentro" do sistema e da cúpula política do Ndongo. Conferir: COELHO, Virgílio. "Em busca de Kábàsà!..." [...]. Luanda: Kilombelombe, 2010, pp. 160-169. Idem, Os Túmúndòngò, os "génios" da natureza e o kílàmbà: Estudos sobre a sociedade e a cultura kímbùndù. Luanda: Kilombelombe, 2010, pp. 161-162. Para uma explanação geral sobre alguns termos-chave da cosmologia mbundu, importantes para entender o funcionamento dos centros políticos do Ndongo, consultar as tabelas inseridas na seção "uma cosmologia mbundu", contida nos anexos desta dissertação.

${ }^{197}$ Algumas lendas mbundu também identificam esse tendala como um "vice-rei". Tal é a interpretação seguida, por exemplo, em: VANSINA, Jan. Paths in the Rainforests [...]. Madison-Wisconsin: University of Wisconsin Press, 1990, p. 195.

${ }^{198}$ Também grafado como ngolambole.

${ }^{199}$ VANSINA, Jan. Paths in the Rainforests [...]. Madison-Wisconsin: University of Wisconsin Press, 1990, pp. 195-196. HEINTZE, Beatrix. Angola nos séculos XVI e XVII [...]. Luanda: Kilombelombe, 2007, pp. 222224. De acordo com Beatrix Heintze, parece que no século XIX as antigas responsabilidades do tendala da corte foram delegadas ao ngolambole. Verificar essa mesma obra da pesquisadora, nota 290, pp. 221-222.

${ }^{200}$ HEINTZE, Beatrix. Angola nos séculos XVI e XVII [...]. Luanda: Kilombelombe, 2007, pp. 221-222. Segundo Heintze, consultar: CADORNEGA, António de Oliveira de. $H G G A$, vol. III, 1940-42, p. 253. Verificar também: HEYWOOD, Linda M.; THORNTON, John K. Central Africans, Atlantic Creoles [...]. Cambridge: Cambridge University Press, 2007, pp. 75-76. Sobre os macotas do ngola, Beatrix Heinte resume 
esteja atrelada ao regime de uso da terra e à produção de bens e serviços na economia mbundu, aquilo identificado pelos observadores e cronistas de época como sendo a "escravidão africana" não pode ser interpretada apenas através de crivos simplistas, tributários das noções de cativeiro e de trabalho compulsório. Entre os mbundu, a "escravidão" estava também fundada no desempenho de papéis sociais e na formação política do Ndongo, devendo ser interpretada também como uma instituição sociopolítica que evocava três pontos fundamentais: parentesco político, binômio pertencimentosolidariedade e a possibilidade real de ascensão de pouquíssimos indivíduos como quadros políticos no reino africano. ${ }^{201}$

$\mathrm{Na}$ corte do Ndongo existiam ainda outros cargos que poucas vezes são registrados nas fontes escritas, entre eles o de mopolo, responsável por cuidar das questões dos escravos "quizicos" - logo mais veremos o que eram eles - e os vários "mani qualquer coisa" - basicamente ndongo, lumbo, kudya e misete - nas palavras de Virgílio Coelho, autoridades palacianas que zelavam pelos aposentos do ngola, sua alimentação e que cuidavam também dos assuntos espirituais e sobrenaturais junto ao soberano. ${ }^{202}$

Abaixo dessa elite havia os demais indivíduos que habitavam em terras mbundu, posicionados em uma camada mais baixa da sociedade. Nas fontes escritas de época, inclusive na $F H A$, há alguns vestígios sobre esses indivíduos, classificados e agrupados por meio de critérios subsumidos às noções de liberdade e escravidão. Um primeiro grupo registrado eram as "murindas" 203 que, segundo a explicação de Beatrix Heintze, estavam organizadas mediante as "linhagens matrilineares em chefados encabeçados por um soba".

com precisão, na primeira obra referenciada: "Os makota (“o mais-velho de uma linhagem”, "homem velho e influente"; ministro, conselheiro e funcionário) constituíam o conselho dos mais velhos que aconselhava o ngola em todas as ocasiões importantes" (pp. 205-206).

${ }^{201}$ HEINTZE, Beatrix. Angola nos séculos XVI e XVII [...]. Luanda: Kilombelombe, 2007, pp. 232-233, 481482.

${ }^{202}$ Sobre o cargo de mopolo, verificar: HEINTZE, Beatrix. Angola nos séculos XVI e XVII [...]. Luanda: Kilombelombe, 2007, pp. 485-486. Sobre o cargo de "mani ndongo", verificar: VANSINA, Jan. How Societies Are Born: Governance in West Central Africa before 1600. Charlottesville: University of Virginia Press, 2004, p. 195. Sobre os demais cargos, HEYWOOD, Linda M.; THORNTON, John K. Central Africans, Atlantic Creoles [...]. Cambridge: Cambridge University Press, 2007, pp. 75-76. Sobre os "manis" como títulos artificiais entre as populações localizadas a sul do rio Congo, Virgílio Coelho sustenta a seguinte posição: "Tendo conhecido e vivido no Reino do Congo e na Mbanza real, a tendência geral dos Portugueses foi a de tudo ver em função desse país, como se a descontinuidade territorial e até de línguas e culturas idênticas se tratassem". Os registros escritos então criariam os vários "mani qualquer coisa", na égide de "um título que é e era desconhecido das populações que habitam ao sul do Congo". Verificar: COELHO, Virgílio. Em busca de Kábàsà [...]. Actas do Seminário Encontros de povos e culturas em Angola. Luanda: Comissão Nacional para as Comemorações dos Descobrimentos Portugueses, p. 451.

${ }^{203}$ No singular em kimbundu, murinda. No plural, arinda. 
A murinda era tida como uma população livre, obediente e fiel, à autoridade de um soba e ao ngola. Outro grupo constantemente referenciado eram os chamados "quizicos", 204 rotulados nas fontes escritas como uma população escrava, habitante de aldeias apartadas das murindas e "segundo parece, também em aglomerações maiores, que se encontravam fora do sistema de linhagem dos Mbundu e que constituíam em larga medida os domínios dinásticos do rei e de sobas poderosos.",205

Os ana murinda, "filhos da murinda", podiam ser tributados por seus sobas e pelo ngola, gozando em contrapartida da possibilidade de apelo judicial e de proximidade linhageira e política com alguma dessas autoridades. Na ótica institucional portuguesa, o termo murinda também poderia ser empregado com o sentido de "morador", ou "vassalo que não podia ser vendido". Já os quizicos eram de fato uma "classe trabalhadora", responsável pelos serviços braçais e identificados pelos observadores portugueses como "servos e escravos da murinda", segundo John K. Thornton e Linda M. Heywood. ${ }^{206}$ Um dado que deve ser retido é que eles não eram originários dos ngundu, ou seja, os quizicos não mantinham parentesco político com os grupos de parentesco mbundu, sendo na verdade "anexados como patrimônio dos senhores de murinda". Era de amplo conhecimento também que o ngola detinha várias "libatas", ou aldeias, repletas deles. Tal base trabalhadora, fundamental para a produção agrícola e para a sustentação geral de uma elite política desobrigada socialmente do trabalho braçal, não poderia ser vendida e, curiosamente para um observador do século XXI, poderia exercer cargos e postos de respeito junto ao ngola, como os de tendala e quiambole, ${ }^{207}$ como já mencionado. Isso pelo

\footnotetext{
${ }^{204}$ No singular em kimbundu, kijiku. No plural, ijiku.

${ }^{205}$ HEINTZE, Beatrix. Angola nos séculos XVI e XVII [...]. Luanda: Kilombelombe, 2007, p. 278.

${ }^{206}$ HEYWOOD, Linda M.; THORNTON, John K. Central Africans, Atlantic Creoles [...]. Cambridge: Cambridge University Press, 2007, pp. 77-78.

207 HEYWOOD, Linda M.; THORNTON, John K. John K. Central Africans, Atlantic Creoles [...]. Cambridge: Cambridge University Press, 2007, pp. 77-78. HEINTZE, Beatrix. Angola nos séculos XVI e XVII [...]. Luanda: Kilombelombe, 2007, p. 482. Nessa obra, Heintze chama especial atenção à relevância e à particularidade dos escravos no Ndongo, comentando: "A importância que no Ndongo se dava ao papel dos ijiku na vida política pode ser deduzida do facto de os seus chefes pertencerem, juntamente com os verdadeiros eleitores e os sobas, ao círculo dos que em 1626 elegeram o novo rei do Ndongo", Angola Aire. Além disso, como bem nota Heintze, não era desprezível a margem de manobra que essa gente trabalhadora detinha, uma vez que "alguns deles chegavam até a recusar durante anos a obediência ao novo rei [Angola Aire] e apoiar abertamente a sua opositora Njinga" (pp. 485-486).
} 
menos em teoria, pois as contingências da época e pressões externas, exercidas principalmente após a fundação de Luanda, podem ter modificado essa regra. ${ }^{208}$

Há por fim um terceiro grupo que, até onde sabemos, é apenas descrito por Pierre de Iarric, em 1610, e Olfert Dapper, em 1668. ${ }^{209}$ Igualmente subsumido ao epíteto da escravidão, os indivíduos que compunham esse grupo eram denominados "mubicas", 210 sendo diferenciados dos quizicos pelo fato de poderem ser vendidos licitamente. ${ }^{211}$ Apesar de as informações sobre eles serem diminutas, é possível afirmar que o grupo social dos mubicas era o mais marginalizado e excluído de todos, sendo totalmente desconectados das linhagens locais e com pouquíssima margem de manobra, quiçá sendo até desprezados pelo restante dos mbundu. Também é possível sugerir que tanto quizicos quanto mubicas eram "dependentes" das linhagens mbundu, ${ }^{212}$ embora a contrapartida não fosse válida para o caso dos mubicas, uma vez que estes eram dispensáveis para os grupos linhageiros locais. De todo modo, ao que tudo indica, um dos elementos compartilhado e invariável entre todos esses agentes e grupos - ngola, macotas, sobas, tendala, quiambole, mopolo, murindas, quizicos e mubicas - era o sentimento de pertencimento ao macrogrupo mbundu, independentemente do papel ou da camada social ao qual pertencessem.

\footnotetext{
${ }^{208}$ Fato é que muitos dos quizicos acabavam vendidos com o passar do tempo, excetuando os "descendentes de escravos" que há gerações conviviam no seio de alguma comunidade local. Mesmo assim, vale a ressalva feita por Beatrix Heintze: "no entanto, os portugueses tinham a impressão de que o rei podia dispor deles bastante mais livremente do que eles próprios teriam ousado, caso dominassem a região". HEINTZE, Beatrix. Angola nos séculos XVI e XVII [...]. Luanda: Kilombelombe, 2007, p. 278.

${ }^{209}$ Informações retiradas de: HEINTZE, Beatrix. Angola nos séculos XVI e XVII [...]. Luanda: Kilombelombe, 2007, pp. 205-206, nota 18, p. 484. Conforme indica a pesquisadora, as informações foram retiradas de: DAPPER, Olfert. Umbständliche und eigentliche Beschreibung von Afrika, Anno 1668. Amsterdam: Steingrüben, 1670 , p. 559. IARRIC, Pierre du. Histoires des choses plus memorables advenves tant ez Indes Orientales, que autres païs de la decounerte des Portugais. Bordeaux, 1610, pp. 79-80.

${ }^{210}$ Em kimbundu, no singular, mubika. No plural, abika.

${ }^{211}$ Todas essas informações estão contidas em: HEINTZE, Beatrix. Angola nos séculos XVI e XVII [...]. Luanda: Kilombelombe, 2007, pp. 205-206 e 484-485. VANSINA, Jan. How Societies Are Born [...]. Charlottesville: University of Virginia Press, 2004, p. 196. Na primeira obra, Beatrix Heintze aventa a possibilidade de existência de outro grupo mbundu, afirmando que já na primeira metade do século XVII os "escravos domésticos" poderiam ser "denominados mukama (kimbundu: sing. akama)" (p. 484). Nesse sentido, é de suma importância assinalar que muitos cronistas coevos confundiam algumas esposas "escravas domésticas", identificadas pelo termo mukama pelos mbundu, com triviais "concubinas", quando na verdade elas pareciam ser parceiras legítimas das autoridades locais (nota 269, p. 218). Vale lembrar que essa sociedade mbundu era poligâmica, ou seja, o fato de um marido ter várias esposas era encarado com normalidade.

${ }^{212}$ HEINTZE, Beatrix. Angola nos séculos XVI e XVII [...]. Luanda: Kilombelombe, 2007, pp. 232-233. Reparando que essas divisões, conforme registradas nas fontes escritas quinhentistas e seiscentistas, estão necessariamente atadas a uma cisão bipolar, havendo de um lado o polo da "escravidão" e de outro o da "liberdade". Verificar: SANTOS, Catarina Madeira. Esclavage africain et traite atlantique confrontés : transactions langagières et juridiques (à propos du tribunal de mucanos dans l'Angola des XVIIe et XVIIIe siècles). Brésil(s). Paris: Éditions de la Maison des Sciences de l'Homme, n. ${ }^{\circ} 1,2012$, pp. 127-134.
} 
Assim, replicamos as palavras de Beatrix Heintze, para quem o Ndongo apresentava uma "estratificação social relativamente diferenciada", rígida mas não imóvel, na qual estavam contidas camadas sociais altas e baixas, com disposições e agrupamentos bastante distintos entre si. $^{213}$ Também é perceptível que, para que a estrutura organizacionalsociopolítica do reino do Ndongo não ruísse, era necessário alguns princípios essenciais da cosmogonia mbundu fossem respeitados, principalmente aqueles respaldados nos binômios solidariedade-pertencimento e marginalização-exclusão. De todo modo, e apesar de o ngundu continuar a ser a unidade sociopolítica mais elementar da sociedade mbundu, entre o final do século XV e início do XVII prosperou no Ndongo uma governança regional que ultrapassou os limites locais dos grupos de parentesco. Concomitantemente à fundação de um governo político centrado na imagem do ngola, novos princípios cosmogônicos foram acoplados aos antigos, sinalizando para uma renovação da sociedade mbundu. Um deles ocorreu através do fomento ao prestígio advindo de algumas insígnias políticas de peso, correspondendo à criação de posições titulares escorados na força dos mulemba, lunga e ngola. Outra foi o incentivo ao princípio da reciprocidade transversal, entre a sede do governo do Ndongo, uma "capital do reino" onde permaneciam a corte e o séquito do ngola, e as sub-regiões que compunham o tal reino do Ndongo, algo que os observadores e cronistas de época denominaram "províncias".

Apesar de a localização e a representatividade das então "capitais" do Ndongo suscitarem importantes discussões e questionamentos hoje em dia, ${ }^{214}$ fato é que havia uma sede do governo e uma corte, independentemente do nome ou da localização da mesma, na dita região do Ndongo. Segundo John K. Thornton e Linda M. Heywood, orbitava ao redor dessa capital uma série de províncias, ${ }^{215}$ sendo que nas aldeias ainda valia a autoridade dos ngundu. O centro político de cada província era uma ou mais "banzas", um tipo de aglomerado populacional que poderia ser equiparado a uma "cidade" e que figurava como um canal de ligação entre a capital do Ndongo e as demais sub-regiões. Uma das províncias

\footnotetext{
${ }^{213}$ Somos aqui inspirados em algumas considerações feitas em: HEINTZE, Beatrix. Angola nos séculos XVI e XVII [...]. Luanda: Kilombelombe, 2007, pp. 232-233.

${ }^{214}$ Voltaremos a essa matéria no próximo capítulo desta dissertação.

${ }^{215}$ HEYWOOD, Linda M.; THORNTON, John K. Central Africans, Atlantic Creoles [...]. Cambridge: Cambridge University Press, 2007, p. 73. Os autores ainda mencionam a existência de kanda, uma organização sociopolítica situada em um patamar superior à autoridade de apenas um soba, mas inferior à proeminência das províncias. Consultar o termo "canda", inserido no "suplemento para alguns vocábulos africanos", para mais informações.
} 
identificadas no século XVI foi a Quituchela, ${ }^{216}$ situada a nordeste da capital do Ndongo, para além do Lucala. Era farta em palmeiras e outrora teria sediado a "capital dos reis do Ndongo", havendo em seu território uma rota comercial que conectava Matamba à costa atlântica. $^{217}$ Junto ao Cuanza estava a província de Aire, ${ }^{218}$ famosa por nela existir a importante posição de Pungo Andongo, "conhecida fortaleza natural rochosa e última cidade residencial dos reis do Ndongo". ${ }^{219}$ A oeste de Aire estava a província de Musseque, possivelmente entre os rios Cuanza e Muzoco, abrangendo "os chefados de Cambambe, Angola Calunga e Quilonga Quiabongo". O caso de Musseque é especialmente interessante, pois o termo análogo a esse topônimo em kimbundu, museke, significa "local arenoso", o que talvez indique, conforme a sugestão de Beatrix Heintze, o "carácter predominantemente geográfico" dessas províncias dos mbundu, "cujas fronteiras ainda não estavam estabelecidas de forma rígida e inequívoca" antes da fundação de Luanda. ${ }^{220}$ Ao norte do Cuanza situava-se a Ilamba, ${ }^{221}$ também denominada "Ilamba nossa" nos escritos portugueses, pelo fato de ter sido a "primeira província conquistada". ${ }^{222}$ A oeste da Ilamba e junto à lagoa de Quilunda encontrava-se a afamada “ensaca de Casanze", foco de luta e insurgência contra os planos de Portugal desde o século XVI e que viria a ser combatida pelo governador João Correia de Sousa, em 1622. ${ }^{223}$ Localizava-se entre os rios Luinha, Dande e Zenza a província de Lumbo, ou "Ilamba Alta", que provavelmente correspondia também à província de Zenza dos finais do século XVI. Ao que tudo indica, somente em parte o Lumbo pertencia ao "reino do ngola". ${ }^{224}$ A sul do Cuanza até o rio Longa jazia a insubordinada Quissama, cobiçada pelo sal das minas de Demba e cujos principais sobas

\footnotetext{
${ }^{216}$ Também conhecida como "Quituxila".

${ }^{217}$ HEINTZE, Beatrix. Angola nos séculos XVI e XVII [...]. Luanda: Kilombelombe, 2007, p. 191.

${ }^{218}$ Grafada também como Are, Haire ou Hare. Como veremos ao longo desta dissertação, "Aire" também faz referência a uma linhagem e título político mbundu.

${ }^{219}$ HEINTZE, Beatrix. Angola nos séculos XVI e XVII [...]. Luanda: Kilombelombe, 2007, pp. 191-192.

${ }^{220}$ HEINTZE, Beatrix. Angola nos séculos XVI e XVII [...]. Luanda: Kilombelombe, 2007, p. 192.

221 Também conhecida como "Ilamba Baixa".

${ }^{222}$ HEINTZE, Beatrix. Angola nos séculos XVI e XVII [...]. Luanda: Kilombelombe, 2007, pp. 192-193.

${ }^{223}$ Sem autoria [encomendado por João Correia de Sousa]. Mapa das regiões circunvizinhas de Luanda com uma minuciosa descrição. S.d., 1622. BAL, cód. 51-IX-20, f. 2. IN: HEINTZE, Beatrix (coord.). Documento 8, FHA, vol. I, 1985, pp. 158-162. Pouco ainda é conhecido pela chamada "ensaca de Casanze", ou "ensaka de Kasanje", cuja ligação com importante figura registrada nas fontes escritas portuguesas, o "jaga Dom João Casanze”, ainda não foi bem explicada, se é que havia alguma. Sobre a primeira, conferir: BIRMINGHAM, David. Trade and conflict in Angola [...]. Londres: Clarendon Press/ Oxford University Press, 1966, pp. 8990. Tocaremos no caso do "jaga Dom João Casanze" no próximo capítulo.

${ }^{224}$ HEINTZE, Beatrix. Angola nos séculos XVI e XVII [...]. Luanda: Kilombelombe, 2007, p. 193.
} 
eram "Muxima, Quimone Quiasonga e Cafuche Cambare". ${ }^{225}$ Mais a oriente achava-se a Tunda, província que, graças às repetidas informações apresentadas por António de Oliveira de Cadornega, sabemos que teve o nome mudado para "Lubolo" e depois "transformado pelos portugueses em Libolo". ${ }^{226}$ Existem ainda duas províncias que suscitam controvérsia entre os historiadores, pois não se sabe se fizeram ou não parte do chamado "reino do Ndongo". Uma era Haco, ${ }^{227}$ a princípio pertencente ao "Grande Libolo", cuja autoridade maior era Gunza Ambambe, lembrado como um respeitado soba nas fontes escritas. Outra era Ungo, sobre a qual dispomos de pouquíssimas informações, salvo apenas o fato de que nela havia minas de cobre. ${ }^{228}$

As províncias eram por sua vez subdivididas em numerosos "chefados", também conhecidos como "sobados". Tais unidades sociopolíticas eram lideradas por sobas, normalmente fiéis seguidores do ngola, aconselhados por macotas. ${ }^{229}$ Pouco mais sabemos sobre como os chefados eram governados, exceto pela alta independência que detinham. Abaixo deles vinham as aldeias, ou "libatas", chefiadas por sobas mais modestos, sobre as quais já discorremos no item anterior. Jazia na autonomia dos membros políticos e jurisdicionais do Ndongo uma característica marcante dessa soberania, diferenciando-a de Portugal, Kongo e quiçá Matamba. Certamente ele não era altamente centralizado, tampouco fragmentado e caótico, pelo menos não como foram descritas as províncias de Ilamba, Quissama e o Dembo. ${ }^{230}$ O Ndongo seria um meio-termo, algo que talvez o

\footnotetext{
${ }^{225}$ HEINTZE, Beatrix. Angola nos séculos XVI e XVII [...]. Luanda: Kilombelombe, 2007, pp. 193-194.

${ }^{226}$ Ibidem, p. 195. Conforme indicações da pesquisadora, consultar: CADORNEGA, António de Oliveira de. $H G G A$, vol. I, 1940-42, pp. 52, 63, 344, 551, 552; vol. II, p. 393; vol. III, pp. 168, 152-153, 232, nota de rodapé 27 e 249.

${ }^{227}$ Grafada também como "Acco" ou "Oacco".

${ }^{228}$ HEINTZE, Beatrix. Angola nos séculos XVI e XVII [...]. Luanda: Kilombelombe, 2007, pp. 195-196. No geral, para uma opinião distinta da de Heintze sobre a organização das províncias do Ndongo, ou "Angola", conferir especialmente: VANSINA, Jan. How Societies Are Born [...]. Charlottesville: University of Virginia Press, 2004, pp. 189-190. Para um arrolamento das províncias do Ndongo, muito menos detalhado do que a relação oferecida por Heintze, verificar: COELHO, Virgílio. "Em busca de Kábàsà!..." [...]. Luanda: Kilombelombe, 2010, p. 232. Idem, Os Túmúndòngò, os "génios" da natureza e o kílàmbà [...]. Luanda: Kilombelombe, 2010, p. 182.

${ }^{229}$ HEINTZE, Beatrix. Angola nos séculos XVI e XVII [...]. Luanda: Kilombelombe, 2007, pp. 205-206 e 278.

${ }^{230}$ Beatrix Heintze destaca que, contrariamente ao que existia no Kongo, onde havia "governadores de província", no Ndongo elas estavam divididas internamente "em numerosos chefados (sobados), na maioria autónomos, dos quais dois ou três eram particularmente poderosos." Aliás, fazemos das palavras da pesquisadora as nossas, certamente porque "há que ter isto em conta, quando ao longo deste texto, se fala de províncias". Verificar: Ibidem, p. 190. De todo modo, parece claro que havia uma divisão geopolítica baseada em "províncias" e que elas eram habitadas por vários "sobas", contrastando com a organização política fragmentada e atomizada dos grupos "jagas". Verificar: NETO, Maria da Conceição. In Town and Out of Town: A Social History of Huambo (Angola), 1902-1961. Tese de doutorado, Universidade de Londres, 2012,
} 
aproximasse de uma confederação, muito mais do que de uma monarquia. Um "reino", portanto, com características particulares, para não dizer peculiares, algo que suscita indagações e questionamentos sobre os próprios conceitos de "estado" e "modernidade" ocidentais, encarados habitualmente às vistas de um corolário universalista imerso em preceitos e saberes eurocêntricos. Fato é que, na visão dos funcionários e oficiais régios quinhentistas e seiscentistas, todas as diferenciações e matizes que aqui detalhamos foram simplificadas e rearranjadas da seguinte maneira: de um lado havia os chamados "reinos", cujos representantes para os assuntos internos e externos eram os "reis" e "rainhas", e do outro lado havia as "províncias" e os vários chefados, cujos representantes eram os "sobas". 231

p. 38. Para outra perspectiva, conferir especificamente: HEYWOOD, Linda M.; THORNTON, John K. Central Africans, Atlantic Creoles [...]. Cambridge: Cambridge University Press, 2007, p. 76.

${ }^{231}$ Há de se considerar também o interesse velado de governadores e capitães que, muitas vezes, "designavam por Angola, tanto o Ndongo, como a capitania de Paulo Dias de Novais (a partir de 1571)", forçosamente acarretando em "confusões e imprecisões na indicação das fronteiras". Verificar: HEINTZE, Beatrix. Angola nos séculos XVI e XVII [...]. Luanda: Kilombelombe, 2007, pp. 182-183. 


\section{Imagem 4: Ndongo, suas províncias e regiões circunvizinhas} (séculos XVI e XVII)

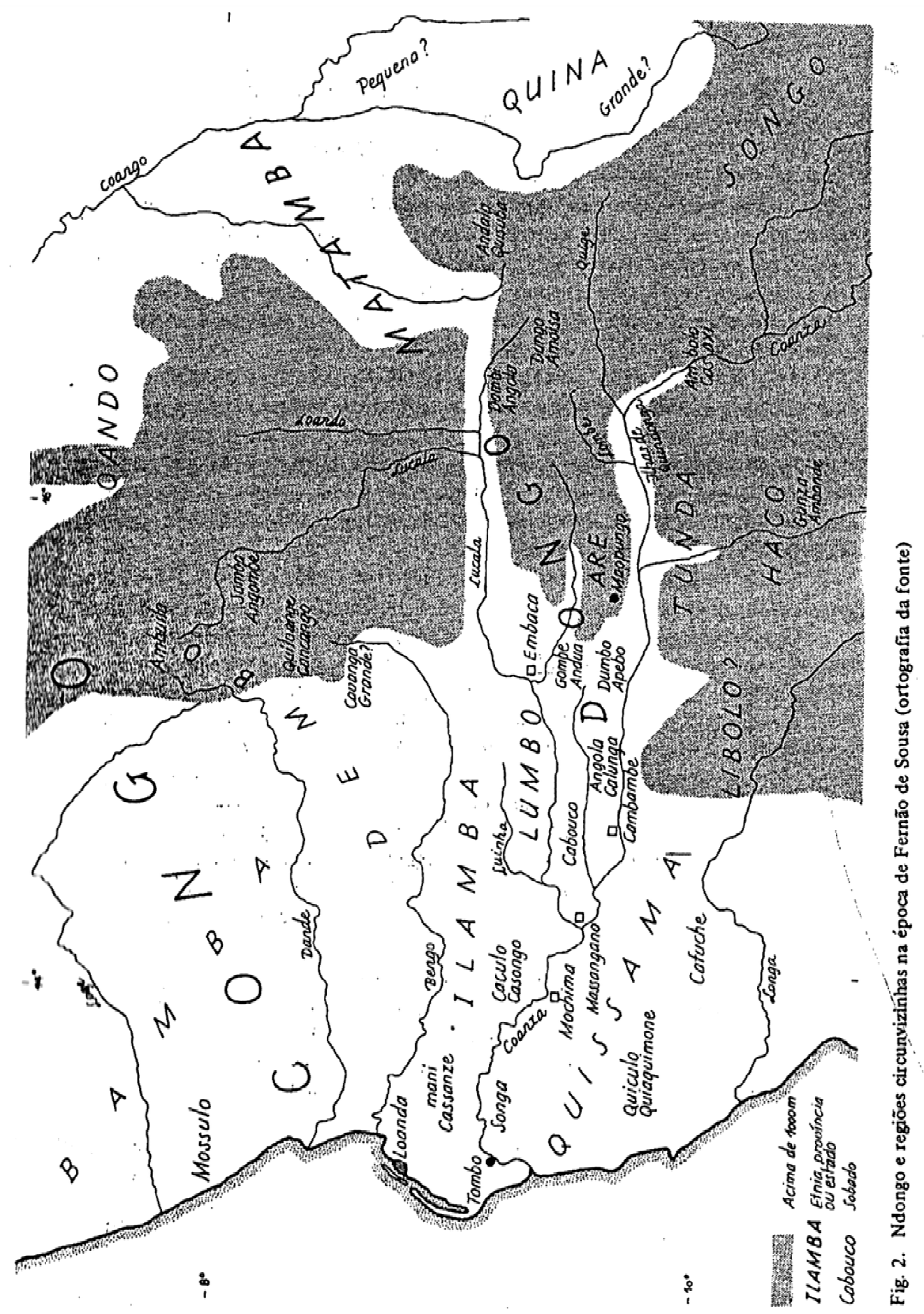

Extraída de: HEINTZE, Beatrix (coord.). Fig. 2: Ndongo e regiões circunvizinhas na época de Fernão de Sousa (ortografia da fonte), FHA, vol. I, 1985, p. 6. 
Assim, entre os séculos XVI e XVII, a estrutura organizacional-sociopolítica do Ndongo estava dividida em unidades sociopolíticas internamente coerentes, atuantes em diversos níveis - reino, província, sobado e libata - interligados coesamente entre si. A título de consideração final, é possível afirmar que toda essa estrutura legislativa e política mbundu era sustentada pela manutenção de um mando e uma ordem centrípetos, capaz de interconectar as partes ao todo e sustentar, com isso, um comando político que viabilizasse a governabilidade interna e a representatividade externa do Ndongo, sempre em nome dos mbundu. A unidade do todo era garantida e três eram os critérios que jogavam a favor de uma "estruturação estatal" nesse reino africano. O primeiro era a grande quantidade de pessoas que juravam fidelidade, ou algum tipo de laço parental-político simbólico ao ngola, mimetizado através de relações metafóricas emparelhadas a encadeamentos metonímicos, como ainda é típico nessa e em outras sociedades africanas. Sobre isso, não poderiam ser mais felizes as palavras de Beatrix Heintze:

"Tal como para o Kongo, também para os Mbundu o Estado não assentava prioritariamente num território rigorosamente delimitado, mas sim nas pessoas. $\mathrm{O}$ fundamental não era o domínio de uma determinada área geográfica, mas sim a autoridade sobre os homens e a existência de um centro de poder eficaz." 232

O segundo critério dizia respeito à extensão e à configuração de natureza geopolítica desse domínio africano. A despeito da ausência de burocracia central e subregional, da inexistência de funcionários administrativos responsáveis pela gestão da "coisa pública" e de um exército profissional qualificado e pago pelo ngola, os sobas do Ndongo e os provinciais mbundu "juravam fidelidade" - ato representado pelo termo em kimbundu unda e seu posterior aportuguesamento, o "undamento" -, depois "pagavam homenagem" ao ngola - ato representado pelo termo em kimbundu bakula, posteriormente assimilado por Luanda, na forma da tributação denominada "baculamento" - e enfim traziam um tributo à banza do soberano, que consistia basicamente em produtos da terra. Em troca dele, os sobas esperavam receber algum presente à altura do que fora ofertado e, caso necessário, alguns "macunzes" 233 poderiam ser despachados da capital às banzas das províncias, ou vice-versa, levando presentes e agrados. Quando o Ndongo passava por turbulências

\footnotetext{
${ }^{232}$ HEINTZE, Beatrix. Angola nos séculos XVI e XVII [...]. Luanda: Kilombelombe, 2007, pp. 182-183.

233 Em kimbundu, makunji. Para mais informações, consultar o "suplemento para alguns vocábulos africanos", inserido nesta dissertação.
} 
políticas e o decreto de guerra era a única saída encontrada, o tendala e o quiambole da corte arregimentavam o exército por meio de uma convocação geral, atendida pelos sobas fiéis ao ngola e que, em contrapartida, esperavam receber proteção e amparo do soberano quando necessário. $^{234}$

Seja na forma de um "reino", como registrado nas fontes escritas modernas e perpetuado no imaginário político e nas tradições fundadoras, seja como um "estado", conforme preconizado por David Birmingham, Jan Vansina e Beatrix Heintze, ${ }^{235}$ o que garantia a unidade sociopolítica regional dos mbundu era o respeito e o cumprimento do princípio essencial de reciprocidade, na forma da troca de presentes e auxílio militar mútuo, ${ }^{236}$ entre o soberano e os líderes locais, ou entre a sede política do Ndongo e as banzas provinciais. Assim sendo, se em grande medida a riqueza e imponência da banza real advinha da arrecadação de "impostos" - ou seja, "presentes" e "serviços" prestados -, em contrapartida essa riqueza teria que ser partilhada entre os grupos de filiação mbundu mais próximos do ngola. Por fim, este é então o terceiro critério que perpassava a estrutura organizacional-sociopolítica do Ndongo, garantindo a sustentação de algo que dissemos ser um "estado africano": o binômio prestígio-reciprocidade estava intimamente relacionado à coerência interpessoal de convívio mbundu e à coesão intrarregional do regime político,

${ }^{234}$ VANSINA, Jan. How Societies Are Born [...]. Charlottesville: University of Virginia Press, 2004, pp. 194195. HEINTZE, Beatrix. Angola nos séculos XVI e XVII [...]. Luanda: Kilombelombe, 2007, p. 207. Na nota 202 dessa obra, Heintze destaca o fato de o sistema de convocação militar surtir efeito, já que impressionantemente o ngola conseguia "reunir constantemente novos exércitos de proporções consideráveis, entre os portugueses, em relativamente pouco tempo".

${ }^{235}$ Verificar os exemplos especificamente em: BIRMINGHAM, David. Trade and conflict in Angola [...]. Londres: Clarendon Press/ Oxford University Press, 1966, p. 33. HEINTZE, Beatrix. Angola nos séculos XVI e XVII [...]. Luanda: Kilombelombe, 2007, p. 196. VANSINA, Jan. How Societies Are Born [...]. Charlottesville: University of Virginia Press, 2004, pp. 188-189. A polêmica a respeito do conceito de "estado" ainda vigora nos dias de hoje, uma vez que, entre os antropólogos, o conceito mais utilizado é o de "chefatura". Aqui concordamos com John K. Thornton, para quem não apenas existiam "estados africanos" desde antes do século XV, mas também que o processo histórico de estatização pode ser divido em pelo menos duas vertentes, mediante as quais poderiam surgir "estados grandes" e "miniestados". Verificar: THORNTON, John K. A Cultural History of the Atlantic World, 1250-1820. Cambridge: Cambridge University Press, 2012, pp. 74-75, nota 44, 75-76, 79 e 81. Em defesa de uma ordem estatal africana, em detrimento do conceito de "tribo" na imagem de "fóssil" humano ainda vivo e estático, sem história, verificar: VANSINA, Jan. Kingdoms of the Savanna. Madison: University of Wisconsin Press, 1966, pp. 5, 12 e 14-16. Virgílio Coelho prefere outro conceito, optando pelo termo "país ndòngo" ao se referir ao reino do Ndongo: COELHO, Virgílio. Em busca de Kábàsà [...]. Actas do Seminário Encontros de povos e culturas em Angola. Luanda: Comissão Nacional para as Comemorações dos Descobrimentos Portugueses, p. 460.

${ }^{236}$ De forma complementar, ficamos com algumas informações fornecidas por Silvia H. Lara: "A cada novo governador em Angola, renovavam-se os laços de vassalagem, por meio do envio de embaixada e troca de presentes". Verificar: LARA, Silvia Hunold. Palmares \& Cucaú [...]. Tese para concurso de Professor Titular, Universidade Estadual de Campinas, 2008, p. 167. 
necessárias para a estabilidade de mando e ordem dentro de uma unidade sociopolítica alargada, simbolizada pela governança centro-africana do Ndongo, capaz de unir politicamente as subidentidades pan-mbundu sob a égide de uma representatividade política soberana. $^{237}$

\subsection{O período formativo da Angola portuguesa (1520-1590)}

Um estudo histórico sobre os contatos deve procurar o entendimento e a crítica sobre os vários polos - "eurocentrismos", "etnocentrismos", "afrocentrismos" são alguns exemplos - e versões - "extravertidos" e "intravertidos" são as faces da mesma moeda relacionados a perspectivas discursivas existente nas documentações e bibliografias, de modo a conciliar os saberes e conhecimentos apreendidos em pesquisas e investigações históricas. Nesta dissertação, nossa tentativa será a de ultrapassar esses limites por meio da proposição e descrição de uma história das expansões e contatos luso-africanos. Para isso, evocamos uma linha narrativa, entre várias possíveis de serem suscitadas, que privilegiará uma elucidação sobre as fases formativas da dominação e intermediação, ou doravante “expansão e contato", que envolveram e impulsionaram as forças institucionais e bélicas portuguesas em direção ao Ndongo.

O primeiro vestígio escrito sobre o soberano do Ndongo data de 1520, durante o reinado de Manuel I de Portugal. Até onde sabemos, trata-se de um regimento composto na cidade de Évora, no qual o monarca português ordenou aos seus representantes que visitassem o "rei de Angola", cristianizassem-no e depois levantassem o máximo de informações sobre o domínio africano. ${ }^{238}$ Tinha com isso o início de uma protofase de expansão e contato do reino de Portugal no Ndongo (1520-1575), marcada pelas idas e vindas diplomáticas e averiguações sobre quem de fato era o "angola", ou como apresentamos desde o início deste capítulo, o "ngola". ${ }^{239}$ Sobretudo, essa fase preliminar de

\footnotetext{
${ }^{237}$ Ao leitor é importante que retenha as informações até aqui introduzidas, uma vez que elas serão de suma importância para compreender a lógica de pensamento e organização social dos mbundu, por vezes evocada ao longo desta dissertação.

${ }^{238}$ BIRMINGHAM, David. Trade and conflict in Angola [...]. Londres: Clarendon Press/ Oxford University Press, 1966, pp. 28-30. HEINTZE, Beatrix. Angola nos séculos XVI e XVII [...]. Luanda: Kilombelombe, 2007, p. 169.

${ }^{239}$ Tal associação é explicada especificamente em: HEINTZE, Beatrix. Angola nos séculos XVI e XVII [...]. Luanda: Kilombelombe, 2007, nota 1 da p. 278 e p. 169. Para outra acepção, na qual "Angola" seria vagamente, na perspectiva portuguesa, uma região "no interior ao sul do reino do Kongo", verificar: BIRMINGHAM, David. Trade and conflict in Angola [...]. Londres: Clarendon Press/ Oxford University
} 
reconhecimento é caracterizada como um período de investigação e "descoberta" do Ndongo, em grande medida tributária de informações coletadas a partir do Kongo e de relatos coletados de agentes comerciais portugueses que desbravavam a região, além de dados e informações registrados por missionários enviados pela Companhia de Jesus, sobretudo para Kongo. ${ }^{240}$ Tal impulso de busca por outro "reino africano" que não fosse esse advinha, entre outros fatores, do afinco em procurar centralidades políticas fortes que, porventura, viessem a cooperar e a virar parceiras de Portugal na África. Por consequência, não deixava de ser evidente também que a percepção régia na época foi a de que o Ndongo era grande o bastante para receber uma missão diplomática e religiosa, o que de modo algum estava errado porque, como explicam David Birmingham e Beatrix Heintze, parecia clarividente para qualquer observador coevo que essa soberania mbundu estava em franca expansão, quiçá rumo a oeste. ${ }^{241}$

Até pelo menos a década de 1570, não houve interferência régia direta nas terras dos mbundu. Quer dizer, o contato se limitava ao proselitismo diminuto e às trocas comerciais, principalmente de escravos, a partir de agentes comerciais "lançados" clandestinamente na região, residentes em pequenas comunidades respingadas em um território ainda pouco desbravado e a contragosto da monarquia portuguesa. Mesmo que o olhar régio observasse com desconfiança e revelia a pequena imigração que ocorria na região, como também desaprovava qualquer chance de florescimento de contrabando de armas e outros produtos vetados aos mercados ultramarinos, era de amplo conhecimento reinol que comunidades portuguesas prosperavam em São Salvador, sede de governo do rei do Kongo, reconhecida pelos bakongo até hoje como Mbanza Kongo. O comércio com essas comunidades também era praticado em algumas províncias desse reino, como em Pinda, na província de "Sonho",

Press, 1966, nota 2, p. 26. A íntima ligação entre o "título" com a "soberania" ficará mais clara no próximo capítulo desta dissertação. A periodização aqui sustentada foi baseada em considerações feitas por Beatrix Heintze, com a única diferença de que o nosso marco final é a fundação de Luanda, ao passo que Heinte determina como marco final o início da grande guerra entre Luanda e Ndongo, entre 1579 e 1580. Verificar a primeira obra citada nesta nota, p. 169.

${ }_{240}^{24}$ Lembrando que o primeiro período missionário dos jesuítas na região aconteceu entre 1540 e 1555 . Verificar: THORNTON, John K. The Portuguese in Africa. IN: BETHENCOURT, Francisco; CURTO, Diogo Ramada. Portuguese Oceanic Expansion [...]. Cambridge: Cambridge University Press, 2007, p. 150.

${ }^{241}$ BIRMINGHAM, David. Trade and conflict in Angola [...]. Londres: Clarendon Press/ Oxford University Press, 1966, p. 30. HEINTZE, Beatrix. Angola nos séculos XVI e XVII [...]. Luanda: Kilombelombe, 2007, pp. 190-191. Para Virgílio Coelho, um "processo migratório". Verificar, em especial: COELHO, Virgílio. Em busca de Kábàsà [...]. Actas do Seminário Encontros de povos e culturas em Angola. Luanda: Comissão Nacional para as Comemorações dos Descobrimentos Portugueses, 1995, p. 460. 
também conhecida como Soyo. ${ }^{242}$ Uma reviravolta política aconteceu especialmente na década de 1550, quando os intuitos expansionistas do Ndongo fomentaram rivalidades contra o Kongo, principal ator político na costa centro-atlântica até então. Ao que parece, as disputas giravam em torno do controle das rotas do tráfico de escravos existentes norte da região, onde elas seguiam o traçado do rio Dande e vieram a formar uma linha de separação implícita entre os dois reinos africanos. Assim, e concordando com a explicação fornecida por David Birmingham, a querela entre o Kongo e o Ndongo foi motivada pela obtenção do

${ }^{242}$ Segundo David Birmingham, é difícil saber qual foi a real presença de comerciantes portugueses na banza do ngola, uma vez que a atuação comercial direta com o soberano africano era tida como uma "contravenção" por parte da Coroa portuguesa. Fato é que ela acontecia extraoficialmente. Verificar: BIRMINGHAM, David. Trade and conflict in Angola [...]. Londres: Clarendon Press/ Oxford University Press, 1966, pp. 26 e 31. "Lançado" é um termo a propriamente empregado na África Ocidental, mas que se encaixa bem com o modo de vida dessas primeiras comunidades de portugueses no espaço ultramarino, caracterizadas por Linda M. Heywood e John K. Thornton como "luso-africanas". Segundo eles, tais comunidades detinham escravos, eram dependentes dos nativos para sobreviver e paulatinamente se tornaram "descendentes miscigenados" que galgaram postos administrativos e militares nos "estados africanos". Verificar: HEYWOOD, Linda M.; THORNTON, John K. Central Africans, Atlantic Creoles [...]. Cambridge: Cambridge University Press, 2007, pp. 70. Particularmente Thornton os caracteriza como "mercenários" e agentes comerciais, diretamente ligados à noção de "lançado". Verificar: THORNTON, John K. The Portuguese in Africa. IN: BETHENCOURT, Francisco; CURTO, Diogo Ramada. Portuguese Oceanic Expansion [...]. Cambridge: Cambridge University Press, 2007, pp. 147-149. Em obra posterior, Thornton sustentou um paralelo direto entre as "comunidades portuguesas no Kongo" e as demais comunidades portuguesas situadas na África Ocidental, funcionais "sob o sistema de feitorias". Em ambas, continua Thornton, foram geradas proles de miscigenados, bilíngues e biculturais, que no caso da experiência no Kongo se assemelhavam em demasia com a "elite local". THORNTON, John K. A Cultural History of the Atlantic World [...]. Cambridge: Cambridge University Press, 2012, p. 253. De todo modo, ainda é incerto o papel que esses agentes marginalizados pelo físco régio, vivendo em comunidades "incrustadas" na África e dependentes do trabalho e comércio de escravos, tinham em cada contexto africano. Apenas para ter uma ideia, diversos são os entendimentos sobre o que foram os "lançados" e "tangomãos" (tangomaus ou tangomãos) nas várias localidades que compunham África Ocidental. O consenso é que esses portugueses viviam na costa da Guiné, “à margem da própria lei” portuguesa. SANTOS, Maria Emília Madeira (coord.). História Geral de Cabo Verde. Lisboa: Instituto de Investigação Científica Tropical, vol. II, 1995, pp. 24-26. Segundo José da Silva Horta, eles eram indivíduos que viviam na costa e que passavam por um processo de "miscigenação com algumas analogias com o de Santiago. Falar-se-á, por isso, para já, em geral de Luso-africanos". HORTA, José da Silva. A "Guiné do Cabo Verde": produção textual e representações (1578-1648). [2002]. Tese de doutorado, Universidade de Lisboa, 2010, pp. 56-57. Philip D. Curtin igualmente defendeu que os lançados eram luso-africanos, porém salientando que eles serviam como mediadores do comércio costeiro com Cabo Verde. CURTIN, Philip D. Economic Change in Precolonial Africa: Senegambia in the Era of the Slave Trade. Wisconsin: University of Wisconsin, 1975, vol. I, pp. 75-76. Walter Rodney destaca também a importante função de intermediação comercial feita pelos lançados, indicando que eles exerciam papeis similares aos dos "pombeiros" em Angola. Para Rodney, tanto os "lançados" quanto os "tangomaos" eram termos genéricos, utilizados para designar os comerciantes privados na costa, sendo que os primeiros seriam simplesmente brancos que residiam no continente, enquanto que os segundos seriam brancos que passassem a adotar a religião e costumes locais, além de cobrirem o corpo com tatuagens. RODNEY, Walter. A History of the Upper Guinea Coast, 1545 to 1800. [1970]. Nova Iorque: Monthly Review Press, 1989, pp. $74-75$ e 81. Tobias Green ressalta que os lançados eram europeus que viviam na costa e que normalmente eram identificados como cristãos-novos. GREEN, Tobias (ed). Masters of Difference: Creolization and the Jewish presence in Cabo Verde, 1497-1672. Tese de doutorado, Universidade de Birmingham, 2007, pp. 28-29, 101102. 
"monopólio do comércio externo e, se tal comércio era baseado no tráfico de escravos", era necessário que as soberanias controlassem igualmente as fontes que abasteciam o tráfico, cujos cativos normalmente vinham de guerras. Expandir significava também explorar o potencial econômico do tráfico atlântico, de modo que Birmingham intuiu, de uma forma um tanto quanto operacional, mas no geral correta, que "ao comercializar com os mbundu, portanto, os portugueses foram indiretamente responsáveis pela emergência de um estado poderoso e unitário em Angola". 243

Enquanto que as rivalidades entre o Kongo e o Ndongo cresciam, alavancadas pela prosperidade do negócio escravista e pela multiplicação de agentes que aportavam na região, atraídos pela possibilidade de enriquecimento ou por serem marginalizados e excluídos socialmente em Portugal, novos acontecimentos atingiram a África CentroOcidental. Em 1561 teve início um "boicote comercial” no Kongo e, pouco tempo depois, dois embates militares abalaram o reino africano. Em 1567 estourou uma guerra entre o Kongo e o chamado "reino de Tyo", representante do povo teke ou "anzico", como correntemente os falantes de kikongo os denominavam. ${ }^{244}$ Ao que parece, o confronto militar foi suscitado pelo controle da rota do tráfico de escravos, que partia do lago Malebo. ${ }^{245}$ No ano seguinte, o Kongo foi invadido por bandos militarizados, conhecidos pelos contemporâneos portugueses como "jagas". ${ }^{246}$ Foram quase dez anos de "ocupação" jaga, até que os invasores foram expulsos com o auxílio de seiscentos soldados portugueses, em 1576. A ajuda militar não foi obtida a troco de nada. Refugiado em uma das ilhas do rio Congo, ${ }^{247}$ o rei Álvaro I do Kongo enviou uma carta a Lisboa, solicitando o apoio militar da Coroa portuguesa, em troca de um estreitamento de laços políticos entre os

${ }^{243}$ BIRMINGHAM, David. Trade and conflict in Angola [...]. Londres: Clarendon Press/ Oxford University Press, 1966, p. 33, tradução nossa (no original: "In a Bantu state the king frequently held a monopoly of external trade, and if that trade was a slave trade he also controlled the supplies, since he was responsible for all wars. By trading with the Mbundu, therefore, the Portuguese were themselves indirectly responsible for the emergence of a powerful unitary state in Angola."). É óbvio que caracterização do Ndongo como um "estado poderoso e unitário" precisa ser relativizada e contextualizada, principalmente em razão do momento de escrita da obra de Birmingham, pioneira para a época. Voltaremos à depreensão de Birmingham no final deste capítulo e na conclusão desta dissertação.

${ }^{244}$ Consultar a entrada para "anzico" no "suplemento para alguns vocábulos africanos", inserido nesta dissertação.

${ }^{245}$ Antigo "lago Stanley", como era conhecido nos séculos XIX e XX.

${ }^{246}$ VANSINA, Jan. Paths in the Rainforests [...]. Madison-Wisconsin: University of Wisconsin Press, 1990, p. 201. BIRMINGHAM, David. Trade and conflict in Angola [...]. Londres: Clarendon Press/ Oxford University Press, 1966, pp. 42-43. Segundo o primeiro pesquisador, a invasão ocorreu em 1568, enquanto que o segundo afirmou que ela ocorreu em 1569.

${ }^{247}$ Antigo "rio Zaire". 
dois reinos, além de outros benefícios. ${ }^{248}$ Em suma, a protofase de expansão e contato em direção ao Ndongo foi marcada por encontros amenos, pelo empenho diplomático sincero e pela realização de uma política de "cooperação" entre as autoridades do Ndongo e os poucos portugueses, na maioria negociantes e comerciantes, residentes na região. ${ }^{249}$

Paralelamente ao desenrolar do palco político centro-africano, foi entre os anos sessenta e setenta do século XVI que começou a despontar uma figura conhecida na história da expansão ultramarina da segunda metade do século XVII. Seu nome era Paulo Dias de Novais, português que com afinco atuava na região desde meados de 1560, negociando escravos e empreendendo viagens de "exploração e descobrimento". ${ }^{250}$ Aos poucos ele se tornou conhecedor dos assuntos regionais e ficou prático nas trocas locais, participando ativamente do trato escravista que interligava as carreiras transatlânticas às rotas terrestres de comércio. Aconteceu então que, em 1561, Paulo Dias de Novais e o padre Francisco de Gouveia, este em missão no Ndongo de 1560 até o falecimento em $1575,{ }^{251}$ foram retidos na capital do ngola, em parte porque o africano desejava a qualquer custo receber um batismo, o que não implicava em uma total conversão ao catolicismo, em parte porque o "cativeiro forçado" servia para chamar a atenção régia quanto à importâncias das suas demandas políticas e espirituais. ${ }^{252}$ Finalmente, em 1565, Paulo Dias de Novais foi liberado para retornar a Portugal, ${ }^{253}$ acompanhado de um enviado do rei africano, trazendo consigo

\footnotetext{
${ }^{248}$ O principal deles foi a permissão de estabelecimento de um povoado português na costa atlântica, futuramente chamado de "São Paulo de Luanda". THORNTON, John K. A Cultural History of the Atlantic World [...]. Cambridge: Cambridge University Press, 2012, p. 183. Idem, Warfare in Atlantic Africa 15001800. [1999]. Londres e Nova Iorque: Routledge, 2003, p. 101. Na segunda obra, o pesquisador afirmara que eram "setecentos soldados mercenários", verificar a p. 108. Beatrix Heintze também indicou o número como sendo de seiscentos soldados. HEINTZE, Beatrix. Angola nos séculos XVI e XVII [...]. Luanda: Kilombelombe, 2007, p. 245.

${ }^{249}$ Há uma divergência em relação às datas, mas o consenso é o de que o início dos contatos foi baseado na diplomacia, na cooperação e no mútuo aprendizado. Conferir, em especial: BIRMINGHAM, David. Trade and conflict in Angola [...]. Londres: Clarendon Press/ Oxford University Press, 1966, pp. 38. HEINTZE, Beatrix. Angola nos séculos XVI e XVII [...]. Luanda: Kilombelombe, 2007, pp. 234-235.

${ }^{250}$ Segundo Virgílio Coelho, o português Paulo Dias de Novais "chegou à barra do Kwànzà em meio de 1560". COELHO, Virgílio. Em busca de Kábàsà [...]. Actas do Seminário Encontros de povos e culturas em Angola. Luanda: Comissão Nacional para as Comemorações dos Descobrimentos Portugueses, p. 460.

${ }^{251}$ BIRMINGHAM, David. Trade and conflict in Angola [...]. Londres: Clarendon Press/ Oxford University Press, 1966, nota 3, p. 42. COELHO, Virgílio. “Em busca de Kábàsà!...” [...]. Luanda: Kilombelombe, 2010, p. 120.

${ }^{252}$ Poderíamos também dizer que "Paulo Dias de Novais são feitos prisioneiros" do ngola, como proposto em: COELHO, Virgílio. “Em busca de Kábàsà!...” [...]. Luanda: Kilombelombe, 2010, pp. 118-119.

${ }^{253} \mathrm{O}$ tempo de cativeiro do aventureiro português é incerto, podendo ter iniciado em 1560 ou $1561 \mathrm{e}$ terminado em 1565 ou 1566. Verificar: Ibidem, p. 119.
} 
alguns presentes do ngola. ${ }^{254}$ De volta a Lisboa, o português começou a planejar e a procurar apoiadores para os seus intuitos no ultramar, ligados à conquista territorial e ao povoamento de porções de terra junto ao Atlântico. ${ }^{255}$ Cerca de cincos anos mais tarde, chegariam a Lisboa as novas de Álvaro I do Kongo a respeito da invasão jaga e, pouco tempo depois, no início de 1571, Paulo Dias de Novais seria agraciado com as permissões em escrito, oficiais e legítimas, para começar os preparativos do empreendimento ultramarino. ${ }^{256}$

Iniciava dessa forma a primeira fase de expansão e contato do reino de Portugal no Ndongo (1575-1590), marcada pela consolidação da então “cidade de São Paulo de Luanda" como um dos atores políticos regionais e um núcleo comercial de peso, voltado para o mercado atlântico. Tal fase também se confunde com o rememorado "tempo de Novais", às vezes evocado na $F H A$ e que muitas vezes acabou sendo personificado na figura e sob os auspícios do "capitão-donatário". ${ }^{257}$ Em sentido parelho a historiografia contemporânea difundiu que a criação de uma "capitania" portuguesa em território africano girou em torno das ambições pessoais de Paulo Dias de Novais, concatenada-a à vontade monárquica, assente em dois documentos avalizados por Dom Sebastião I de Portugal e seus conselheiros em 1571. Sobre essas duas fontes primárias, ficamos com as breves explicações de Beatrix Heintze. A primeira era a "carta de foral", na qual eram esclarecidos os "estatutos, de acordo com os quais os colonos deveriam ser governados, os seus direitos,

\footnotetext{
${ }^{254}$ Segundo Birmingham, cinquenta anéis de cobre, trinta e cinco presas de marfim, quarenta "quicongos", uma tipo de madeira de onde se extraía uma valiosa tintura, e muitos escravos. BIRMINGHAM, David. Trade and conflict in Angola [...]. Londres: Clarendon Press/ Oxford University Press, 1966, p. 38.

${ }^{255}$ Nas palavras de Beatrix Heintze, o "plano para a submissão militar de Angola ficou concluído, o mais tardar, em finais de 1570", ou seja, o efetivo projeto de ocupação portuguesa já estava definido antes mesmo das solicitações de auxílio militar emitidas por Álvaro I e que, como veremos, foi um dos álibis fornecidos para iniciar as operações militares. Verificar: HEINTZE, Beatrix. Angola nos séculos XVI e XVII [...]. Luanda: Kilombelombe, 2007, p. 244.

${ }^{256}$ BIRMINGHAM, David. Trade and conflict in Angola [...]. Londres: Clarendon Press/ Oxford University Press, 1966, pp. 38 e 43. HEINTZE, Beatrix. Angola nos séculos XVI e XVII [...]. Luanda: Kilombelombe, 2007, pp. 245-246.

${ }^{257}$ A periodização aqui adotada é um meio-termo, fiel ao processo histórico vigente, das propostas de divisão feitas em: BIRMINGHAM, David. Trade and conflict in Angola [...]. Londres: Clarendon Press/ Oxford University Press, 1966, capítulo 3. HEINTZE, Beatrix. Angola nos séculos XVI e XVII [...]. Luanda: Kilombelombe, 2007, capítulo 7. À parte de periodizações muito gerais, como propõe Jan Vansina, ainda é problemática e cheia de lacunas as interpretação histórica acerta do período que vai de 1575 a 1617 . Verificar: VANSINA, Jan. Paths in the Rainforests [...]. Madison-Wisconsin: University of Wisconsin Press, 1990, capítulo 7 e principalmente a p. 198.
} 
deveres mas, principalmente, os seus impostos". ${ }^{258}$ O segundo documento, talvez o mais fundamental, era a "carta de doação" entregue a Paulo Dias de Novais, datada de 19 de setembro de 1571, na qual estavam registrados "os direitos e os deveres do donatário que, dada a sua dupla função militar e de direito civil, usava os títulos de capitão e governador". ${ }^{259}$ Baseado na experiência portuguesa sul-americana, conforme contida na carta de doação cedida ao aventuroso português, o modelo de capitania-donataria projetava uma demarcação administrativo-utilitária, de limites geográficos pouco precisos, mas de aplicação descomplicada e que dividia o solo centro-africano até então conhecido em duas partes. A primeira dizia respeito a um espaço, sem limites definidos, a sul do Cuanza e alhures dele, que deveria ser gerido através de quatro ditames prescritos a Paulo Dias de Novais: lá o desbravamento expansionista do território era "hereditário, inalienável, indivisível e (sob certas condições que Dias tinha de cumprir) irrevogável”. A segunda parte estava situada entre o Cuanza e o Dande, território onde se incentivaria a ocupação populacional portuguesa e a instalação de órgãos ultramarinos representes da monarquia. ${ }^{260}$ Paulo Dias de Novais poderia usufruir e beneficiar tal região enquanto estivesse vivo e, após a sua morte, ela seria entregue à administração régia. ${ }^{261}$

Havia três graduações do regime de domínio territorial previstas no protoestabelecimento da Angola portuguesa. ${ }^{262}$ A primeira era meramente modelar, ou seja, baseada nas regras ligadas à ordenação geral de capitanias e donatarias ultramarinas. Tratava-se de normas ou regras regimentais, adotadas em escala ultramarina. A segunda era administrativo-utilitária, separando o território conforme o modo de uso e transmissão do mesmo. Aqui é possível falar de uma padronização comparada, que poderia ter sido

\footnotetext{
${ }^{258}$ HEINTZE, Beatrix. Angola nos séculos XVI e XVII [...]. Luanda: Kilombelombe, 2007, p. 246. Itálicos da autora.

${ }^{259}$ Seguindo aqui as indicações e Beatrix Heintze, sobretudo. Consultar: Paulo Dias de Novais. 19 de setembro de 1571. IN: BRÁSIO, António (col. e anot.). MMA. Série 1, vol. IV, 1954, pp. 276-277. A datação desse documento é controversa. David Birmingham lembra que Alfredo Albuquerque de Felner transcreveu o primeiro dígito da data de sua composição como "seis", enquanto que António Brásio o interpretou como sendo um "dezenove". BIRMINGHAM, David. Trade and conflict in Angola [...]. Londres: Clarendon Press/ Oxford University Press, 1966, nota 1, p. 46. De acordo com ele, consultar: FELNER, Alfredo Albuquerque de. AAOI, 1933, 127-129.

${ }^{260}$ Esmiuçaremos o funcionamento desse espaço reivindicado por Luanda no capítulo 3 desta dissertação.

${ }^{261}$ HEINTZE, Beatrix. Angola nos séculos XVI e XVII [...]. Luanda: Kilombelombe, 2007, p. 246, p. 246.

${ }^{262}$ Nos detemos em uma análise sobre os conceitos inseridos na carta de doação a Paulo Dias de Novais para reforçar um tipo de leitura e análise da documentação, em descompasso com o de outros pesquisadores. Verificar, por exemplo: HEYWOOD, Linda M.; THORNTON, John K. Central Africans, Atlantic Creoles [...]. Cambridge: Cambridge University Press, 2007, pp. 82-83.
} 
mimetizada ou emulada de outras regiões, guardadas as especificidades de cada domínio ultramarino. A terceira graduação estava ligada ao direito de usufruto do terreno, baseado na concessão territorial mediante o regime de sesmarias que, tão logo, resultará em uma peculiaridade institucional na consolidação do domínio ultramarino centro-africano. Por um instante nos deteremos nesta última gradação, devido à sua importância no processo histórico de contato, expansão e invenção da Angola portuguesa. Destarte, o regime de doação e concessão de terras centro-africanas estava aglutinado ao de vinculação política, uma vez que as porções de terras cedidas aos "beneficiados" portugueses não estavam desabitadas, sendo portanto ocupadas por "donos africanos". Para dispor de fazendas e pessoas que viabilizassem a ocupação territorial efetiva, antes de tudo os sobas, ou as autoridades africanas que clamassem pertencimento ao solo, deveriam ser "avassalados" à Coroa portuguesa, oficializando com isso as doações. Depois disso, mediante o prisma régio, a tutela e a administração dos territórios e seus habitantes acabavam cedidos a entidades independentes e de natureza variada - normalmente identificadas como "senhores portugueses", "pessoas importantes e capitães" ou a "Companhia de Jesus" -, à guisa de amos ou "protetores". O resultado empírico dessa fórmula era sempre o mesmo. Apesar de no discurso oficial as sesmarias serem "doações de terras", na prática "só se falasse da doação ou repartição dos sobas." O importante era possuir pessoas, não terreno. Dessa forma, aquele que recebesse a tutela dos sobas, ou seja, dispusesse de "sobas vassalos", ${ }^{263}$ seria reconhecido como "amo dos seus sobas - uma designação introduzida pelos jesuítas pelo que esta modalidade especial de doação de pessoas na antiga Angola ficou também conhecida pela instituição dos amos". ${ }^{264}$

A dimensão imbricada e dual que envolveu a instituição dos amos - em teoria, uma “concessão de terras" que, na prática, resultava na tutela de chefes africanos, com base na

\footnotetext{
${ }^{263}$ É de suma importância ressaltar que, desde o início, o entendimento régio era o de que os sobas sob a instituição dos amos eram "vassalos do rei de Portugal", sendo apenas tutelados, em nome da monarquia portuguesa, pelos senhores privados e jesuítas. HEINTZE, Beatrix. Angola nos séculos XVI e XVII [...]. Luanda: Kilombelombe, 2007, pp. 255-258.

${ }^{264}$ Ibidem, pp. 253-255. Itálicos da autora. HEYWOOD, Linda M.; THORNTON, John K. Central Africans, Atlantic Creoles [...]. Cambridge: Cambridge University Press, 2007, pp. 101-102. Em obra posterior, Thornton afirma que um "africano cristão", normalmente "recrutado" no Kongo, auxiliava os amos na administração dos "sobas conquistados". THORNTON, John K. A Cultural History of the Atlantic World [...]. Cambridge: Cambridge University Press, 2012, p. 210. Ver também: BONCIANI, Rodrigo Faustinoni. $O$ dominium sobre os indígenas e africanos e a especificidade da soberania régia no Atlântico: Da colonização das ilhas à política ultramarina de Felipe III (1493-1615). Tese de doutorado, Universidade de São Paulo (USP), 2010, p. 257.
} 
imposição de vassalagem à Coroa portuguesa - implicou em uma série de conflitos na época, além de acarretar em explicações deturpadas, até hoje aceitas como verdadeiras, mas que podem ser questionadas. ${ }^{265}$ Fato é que, ao instituir o regime de amos, Paulo Dias de Novais abdicou da possibilidade de explorar economicamente os sobas vassalos, cedendo-a corporações e entidades privadas, que passaram a receber tributos e taxas deles. Ao capitãodonatário restaria a incumbência maior de avassalar, estabelecer benfeitorias ${ }^{266}$ e esticar os limites geopolíticos reivindicados pela monarquia portuguesa até onde fosse possível, já que na carta de setembro de 1571 eles estavam totalmente "em aberto". ${ }^{267}$

Fundada em $1575,{ }^{268}$ a "cidade de São Paulo de Luanda" assinalava para uma possível, mas improvável, efetivação da conquista territorial e povoamento de porções consideráveis de território africano, dentro dos moldes imaginados por Paulo Dias de Novais na década de 1560. Como há de se notar, contudo, isso nunca chegou a ser realizado. A exploração agrícola da terra, com base em mão-de-obra escrava e análoga às vastas plantações da América portuguesa, não foi concretizada, limitando-se a pequenas glebas de terra, os chamados "arimos", ${ }^{269}$ que pouco forneciam os víveres de subsistência para os residentes. ${ }^{270}$ Aliás, como ressaltam David Birmingham e Luiz Felipe de

${ }^{265}$ Uma diz respeito às contendas e aos litígios abertos entre jesuítas e os senhores portugueses, em torno da exploração e maus-tratos destinados aos sobas vassalos. Outra está ligada à impressão, ainda bastante disseminada, de que a instituição dos amos estava somente baseada em uma forma de intermediação política de natureza africana. Em face desses problemas, algumas explicações e posicionamentos interessantes são fornecidos em: HEINTZE, Beatrix. Angola nos séculos XVI e XVII [...]. Luanda: Kilombelombe, 2007, pp. 262-263.

${ }^{266}$ Entre elas, poderíamos considerar, por exemplo, igrejas e instituições administrativas básicas. Verificar: BIRMINGHAM, David. Trade and conflict in Angola [...]. Londres: Clarendon Press/ Oxford University Press, 1966, p. 47.

${ }^{267}$ Ibidem, p. 46. HEINTZE, Beatrix. Angola nos séculos XVI e XVII [...]. Luanda: Kilombelombe, 2007, p. 260.

${ }^{268}$ Pouco tempo depois da chamada "expulsão jaga" do Kongo que, como dissemos, havia sido viabilizada graças ao apoio militar fornecido pelo Dom Sebastião I de Portugal. As tropas portuguesas desocuparam a região em 1574. Verificar: VANSINA, Jan. Paths in the Rainforests [...]. Madison-Wisconsin: University of Wisconsin Press, 1990, p. 201. THORNTON, John K. A Cultural History of the Atlantic World [...]. Cambridge: Cambridge University Press, 2012, pp. 183-185. CURTIN, Philip D. et. al. African History: From Earliest Times to Independence. [1978]. Edimburgo: Longman Pearson Education, 1995, pp. 229-230.

269 "Arimo" quer dizer, tanto para os povos centro-africanos quanto para os portugueses que lá habitavam, "campo lavrado, plantação". Verificar: HEINTZE, Beatrix (coord.). Esclarecimentos sobre vocábulos africanos, FHA, vol. I, 1985, p. 114.

${ }^{270}$ David Birmigham afirma também que o baixo e inconstante índice pluvial e a carência de abastecimento de água potável dificultavam ainda mais o plantio da terra e a sobrevivência em geral. BIRMINGHAM, David. Trade and conflict in Angola [...]. Londres: Clarendon Press/ Oxford University Press, 1966, p. 47. Thornton é hesitante em suas especulações, afirmando que a colonização, nos moldes iniciais imaginados por Paulo Dias de Novais, logrou êxito, mas de uma forma peculiar, pois os "[...] arimos renderam colheitas de exportação, porém normalmente não para serem vendidas fora da África, mas para sustentar as centenas de 
Alencastro, a inclinação natural de Luanda, voltada ao abastecimento de tumbeiros que cruzavam as águas atlânticas a caminho da América portuguesa, era antagônica à manutenção de latifúndios escravistas em terras centro-africanas. ${ }^{271}$ Desde sempre Luanda esteve propensa a virar um núcleo de convergência e distribuição do comércio regional, ${ }^{272}$ atraindo as rotas de escravos que partiam do lago Malebo e de Ocanga. ${ }^{273}$ Assim, e em concomitância à prosperidade do tráfico de escravos e do desbravamento territorial, Paulo Dias de Novais intensificou a política de cooperação com o Ndongo, brevemente paralisada durante o período em que fora detido pelo ngola. ${ }^{274} \mathrm{Na}$ perspectiva de um tempo estrutural, a princípio de longa duração e que extrapola os limites dos séculos XVI e XVII, vigorava desde 1520 um período de cooperação e parceria luso-africanas, tanto para o Ndongo quanto para Luanda, cheia de vicissitudes e, por assim dizer, mal-estares entre ambos os lados, alavancado pelas rivalidades políticas e econômicas entre o Kongo e Ndongo, cada vez mais interessados em tirar proveito do comércio atlântico. ${ }^{275}$

A primeira fase de expansão e contanto encontraria um ponto de estremecimento entre 1579-1580, momento a partir do qual seria colocada em voga uma nova conjuntura histórica, sinalizando para o princípio da "dissolução e destruição" do reino do Ndongo,

escravos concentrados em Luanda e no seu interior imediato [...]”. THORNTON, John K. A Cultural History of the Atlantic World [...]. Cambridge: Cambridge University Press, 2012, p. 210, tradução nossa (no original: "the arimos in turn grew export crops, not usually for sale outside Africa, but to support the thousands of slaves who were concentrated in Luanda and its immediate hinterland awaiting transportation").

${ }^{271}$ BIRMINGHAM, David. Trade and conflict in Angola [...]. Londres: Clarendon Press/ Oxford University Press, 1966, p. 47. Luiz Felipe de Alencastro descreve as relações transatlânticas por meio de um silogismo de época, "sem Angola não há Brasil, sem Brasil não há Angola". Ele se refere evidentemente à necessidade de importação de escravaria, mão-de-obra principal nas plantações monocultoras extensivas da América portuguesa, principalmente trazidos de Angola. Verificar: ALENCASTRO, Luiz Felipe de. $O$ trato dos viventes: A formação do Brasil no Atlântico Sul. São Paulo: Companhia das Letras, 2000, pp. 222-223 e 226. No mais, como lembra Rodrigo Faustinoni Bonciani, havia uma relação institucional de complementaridade e coordenação projetada para os dois lados do atlântico, de modo que "lá [na Angola portuguesa], a Coroa precisava assegurar o controle comercial do tráfico; aqui [no Estado do Brasil], ela precisa fazer valer sua política indigenista. Mas, para essas medidas serem efetivas, elas precisavam ser coordenadas, porque esses espaços e relações de domínio eram complementares." Verificar: BONCIANI, Rodrigo Faustinoni. $O$ dominium sobre os indígenas e africanos [...]. Tese de doutorado, Universidade de São Paulo (USP), 2010, p. 269.

${ }^{272}$ Jan Vasina usa o termo em inglês $h u b$, no original.

${ }^{273}$ VANSINA, Jan. Paths in the Rainforests [...]. Madison-Wisconsin: University of Wisconsin Press, 1990, pp. 201-220.

${ }^{274}$ THORNTON, John K. Warfare in Atlantic Africa [...]. [1999]. Londres e Nova Iorque: Routledge, 2003, p. 101. THORNTON, John K. A Cultural History of the Atlantic World [...]. Cambridge: Cambridge University Press, 2012, pp. 183-185. HEINTZE, Beatrix. Angola nos séculos XVI e XVII [...]. Luanda: Kilombelombe, 2007, pp. 234-235. Heintze ainda salienta: "Nesse tempo, o rei do Ndongo recebia apoio militar do governador e, na sua capital, residia permanentemente um português, com o posto de capitão, incumbido de apaziguar os conflitos que aí surgissem entre os portugueses e os crioulos de S. Tomé”.

${ }^{275}$ Talvez, em alguma medida, também valendo para o Kongo. 
"que conduziu à perda da independência e culminou com a conquista do que restava do Estado pelos portugueses em 1671". ${ }^{276}$ Por mais que o período compreendido entre o inicio do século XVI e final do XVII fosse recoberto pela redoma de perene cooperação e parceria luso-africana, conforme argumentaremos ao longo desta dissertação, existiam conjunturas cíclicas que entrecortavam esse tempo estrutural, mediante as quais "guerras intestinas" e "angolanas" eram aguçadas por elementos externos, sendo nesse sentido preponderantes as motivações econômicas advindas no Atlântico e os concertos políticos regidos em âmbito regional. As fases do processo histórico sobrepunham uma multiplicidade de tempos estrutural, conjuntural e factual -, capaz de estimular a experiência dos homens envolvidos na construção da Angola portuguesa. Na prática de longa duração, todavia, o domínio ultramarino centro-africano continuaria a ser erigido através de contínuas reformas políticas, guiadas a partir de duas pedras angulares, constantemente redimensionadas até o século XIX: a ideia de vassalagem atrelada à de tutela. ${ }^{277}$

Possivelmente motivada pela transição política um pouco conturbada vivida no Ndongo, existente em torno dos embates entre linhagens que normalmente competiam pela insígnia política de ngola, ${ }^{278}$ como também visando demonstrar a força da linhagem que

276 HEINTZE, Beatrix. Angola nos séculos XVI e XVII [...]. Luanda: Kilombelombe, 2007, p. 235. Semelhantes são as considerações em: HEYWOOD, Linda M.; THORNTON, John K. Central Africans, Atlantic Creoles [...]. Cambridge: Cambridge University Press, 2007, pp. 84-85.

${ }^{277}$ Aos que persistirem na leitura desta dissertação, ficará claro que a concepção de "domínio indireto", ou "tutela", estava diretamente ligada à imposição de vassalagem e à sustentação do mando e da ordem reivindicados dentro de um espaço designado aqui como sendo a "Angola portuguesa". Aqui somos influenciados por duas linhas de investigação, expressas nas seguintes obras: HEINTZE, Beatrix. Angola nos séculos XVI e XVII [...]. Luanda: Kilombelombe, 2007. ZERON, Carlos Alberto de Moura Ribeiro. Linha de fé: a Companhia de Jesus e a Escravidão no Processo de Formação da Sociedade Colonial (Brasil, Séculos XVI e XVII). [1998]. São Paulo: Editora da Universidade de São Paulo, 2011. No que diz respeito à historicização do passado de Angola, poucos a fazem tão bem como: SANTOS, Catarina Madeira. Escrever o Poder: os Autos de Vassalagem e a Vulgarização da Escrita entre as Elites Africanas Ndembu. IN: HEINTZE, Beatrix; OPPEN, Achim von (ed.). Angola on the Move: Transport Routes, Communications and History. Frankfurt am Main: Verlag Otto Lembeck, 2008. SANTOS, Catarina Madeira. Écrire le pouvoir en Angola: Les archives Ndembu (XVIIe-XXe siècles). Annales. Histoire, Sciences Sociales. Paris: Éditions de l'EHESS, n. ${ }^{\circ}$ 64, 2009/4. HENRIQUES, Isabel Castro. A materialidade do simbólico: marcadores territoriais, marcadores identitários angolanos (1880-1950). Textos De História. Brasília: Universidade de Brasilia (UnB), vol. $12, \mathrm{n}^{\circ} 1 / 2,2004$. DIAS, Jill. Mudanças nos padrões de poder no «hinterland» de Luanda: o impacto da colonização sobre os Mbundu (c. 1845-1920). Penélope: revista de história e ciências sociais. Lisboa: Cooperativa Penélope, Fazer e Desfazer a História, n. ${ }^{\circ}$ 14, 1994. Nossos interesses ficarão mais claros ao longo da dissertação, sobretudo no capítulo 3 .

${ }^{278}$ As tradições descrevem uma crise política, da qual despontou a linhagem reivindicante de pertencimento à forte tradição do título fundador de Ngola Kiluanji kia Samba que, segundo Virgílio Coelho, "está ainda hoje muito presente e bem marcada na vida quotidiana e na memória das populações que vivem na região de Luanda." Também participaram da disputa, como coadjuvantes, alguns líderes da região de Are que, anos mais tarde, finalmente encabeçariam o trono do reino mbundu. Os pleiteadores principais giravam em torno 
porventura galgasse o posto mais alto do comando político mbundu, o novo ngola massacrou alguns portugueses que residiam em sua capital. ${ }^{279} \mathrm{Com}$ o álibi de vingar a morte e disciplinar o rei do Ndongo, além de estar muito desejoso em expandir os limites da donataria, o capitão-donatário deu início à primeira guerra direta entre Luanda e o Ndongo, em 1581. Paulo Dias de Novais aliciou alguns sobas dissidentes, inimigos ou descontentes com o ngola, como os de Musseque, ${ }^{280}$ e assim arregimentou seu exército. As longas operações militares e as idas e vindas da guerra propiciaram a construção do denominado "presídio de Massangano", estrategicamente erigido na confluência do Cuanza com o Lucala, que serviria como base de apoio para os avanços e defesas necessários. ${ }^{281} \mathrm{Na}$ verdade, Massangano foi a ponta de lança e o sinal mais contundente de que o alvo militar e a meta política de Luanda era o Ndongo, já que fora erguido na mesma região concebida na época como sendo a "porta de entrada" desse reino africano. ${ }^{282}$

Dois fatos marcaram o final da década de 1580. Em 9 de maio de 1589, Paulo Dias de Novais faleceu, entregando o comando do exército português a Luis Serrão. Essa foi a deixa para que, no ano seguinte, em 29 de dezembro de 1590, viesse a resposta do ngola e dos macotas, temerosos quanto à possibilidade real de invasão dos domínios africanos. Um grande exército, formado pelas forças aliadas do Ndongo com Matamba, derrotou as formas militares portuguesas, dando cabo não apenas ao estado de guerra generalizado existente

da posição titular de Njinga Ngola Kilombo kia Kasenda que, ao reivindicar parentesco político (ser "bisneto") daquele título fundador que mencionamos no início desta nota, colocou abaixo a posição de Ngola Kiluanji kya Ndambi, em vigor de 1562 a 1575. Seu precedente havia sido Ndambi a Ngola (1556-1562). Foi dessa forma que o a posição Njinga Ngola Kilombo kia Kasenda reinou entre 1575-1592. Verificar: COELHO, Virgílio. Em busca de Kábàsà [...]. Actas do Seminário Encontros de povos e culturas em Angola. Luanda: Comissão Nacional para as Comemorações dos Descobrimentos Portugueses, p. 460, especialmente a nota 23. HEYWOOD, Linda M.; THORNTON, John K. Central Africans, Atlantic Creoles [...]. Cambridge: Cambridge University Press, 2007, pp. 80-86. BIRMINGHAM, David. Trade and conflict in Angola [...]. Londres: Clarendon Press/ Oxford University Press, 1966, pp. 34-37 e 49. Para um arrolamento dos títulos políticos retirados de algumas tradições locais, consultar a série de tabelas inseridas na seção "alguns títulos ou posições de soberania no Ndongo", contida nos anexos desta dissertação.

279 Apesar de não ser consensual, ficamos com a posição firmada em: BIRMINGHAM, David. Trade and conflict in Angola [...]. Londres: Clarendon Press/ Oxford University Press, 1966, p. 52.

280 Poderíamos citar também sobas como "Muxima Kitangonge" e "Mocumbe", conforme os seguintes trabalhos: HEYWOOD, Linda M.; THORNTON, John K. Central Africans, Atlantic Creoles [...]. Cambridge: Cambridge University Press, 2007, pp. 87-88. THORNTON, John K. The Portuguese in Africa. IN: BETHENCOURT, Francisco; CURTO, Diogo Ramada. Portuguese Oceanic Expansion, 1400-1800. Cambridge: Cambridge University Press, 2007, pp. 151-152.

${ }^{281}$ HEYWOOD, Linda M.; THORNTON, John K. Central Africans, Atlantic Creoles [...]. Cambridge: Cambridge University Press, 2007, pp. 87-88.

${ }^{282}$ Não à toa, o presídio e a vila que cresceria nos arredores da construção de pedras, e que posteriormente viraria uma cidade, seriam denominados "Nossa Senhora da Vitória de Massangano". BIRMINGHAM, David. Trade and conflict in Angola [...]. Londres: Clarendon Press/ Oxford University Press, 1966, p. 54. 
desde 1580, mas também fornecendo uma trégua momentânea aos acirrados embates ocorridos na região. ${ }^{283}$

\subsection{A consolidação de um sistema administrativo ultramarino (1607-1617)}

A derrota de 1590 teve um impacto negativo em Lisboa e Madri. Unificadores das monarquias peninsulares, a casa de Habsburgo e os conselheiros reinóis decidiram revogar a capitania-donataria encomendada na carta de doação de 1571, amplamente respaldada na instituição dos amos. Foi estipulado em seu lugar o sistema de governadoria-geral, no qual um representante direto do rei, o "governador-geral", seria encarregado da direção e do governo político ultramarino. ${ }^{284}$ Decorreria a partir de então um breve período de gestação e transição político-administrativa, necessário para que fossem efetivadas as adaptações e modificações necessárias para a implementação de uma reforma governamental no domínio ultramarino, em um período histórico ainda pouco investigado, aqui classificado como uma subfase de transição, que vai de 1590 a $1607 .{ }^{285}$ De todo modo, a reorientação da política ultramarina portuguesa na África Centro-Ocidental, ou simplesmente o projeto administrativo e político ultramarino, ${ }^{286}$ estaria fundamentada já em 1605. Ela se resumia

${ }^{283}$ HEYWOOD, Linda M.; THORNTON, John K. Central Africans, Atlantic Creoles [...]. Cambridge: Cambridge University Press, 2007, pp. 89-90. THORNTON, John K. Warfare in Atlantic Africa 1500-1800. [1999]. Londres e Nova Iorque: Routledge, 2003, p. 101. David Birmingham fornece outra data para a derrota de Luís Serrão: 28 de dezembro de 1590. Um dos principais documentos que registra e descreve a guerra de 1590 é o "Sumário e Descrição do Reino de Angola", de autoria de Domingos de Abreu e Brito, no qual está escrito que o Ndongo tinha como aliados o "rei de Matamba" e os "reis Yaka", trazendo consigo algumas tropas do Kongo, "guindas" e "jagas". Birmingham, Heywood e Thornton são céticos quanto a veracidade de todas essas informações. Verificar: BIRMINGHAM, David. Trade and conflict in Angola [...]. Londres: Clarendon Press/ Oxford University Press, 1966, p. 55, principalmente a nota 4. Verificar outrossim a obra supracitada de Heywood e Thornton, pp. 89-90, principalmente a nota 180. Para uma opinião dissonante: VANSINA, Jan. How Societies Are Born [...]. Charlottesville: University of Virginia Press, 2004, pp. 196-197 e nota 106. Sobre o documento em questão, consultar: BRITO, Domingos de Abreu e. Um inquérito à vida administrativa e económica de Angola e do Brasil em fins do século XVI: segundo o manuscrito inédito existente na Biblioteca Nacional de Lisboa. Coimbra: Imprensa da Universidade, 1931, pp. 41-2. Esse mesmo trecho também está disponível em: BRÁSIO, António (col. e anot.). MMA. Série 1, vol. IV, 1954, pp. 533-5.

${ }^{284}$ HEYWOOD, Linda M.; THORNTON, John K. Central Africans, Atlantic Creoles [...]. Cambridge: Cambridge University Press, 2007, p. 90. BIRMINGHAM, David. Trade and conflict in Angola [...]. Londres: Clarendon Press/ Oxford University Press, 1966, pp. 55-56.

${ }^{285}$ Esse período é ainda pouco investigado. Algumas breves considerações podem ser verificadas em: HEYWOOD, Linda M.; THORNTON, John K. Central Africans, Atlantic Creoles [...]. Cambridge: Cambridge University Press, 2007, p. 91. BIRMINGHAM, David. Trade and conflict in Angola [...]. Londres: Clarendon Press/ Oxford University Press, 1966, pp. 58-59. O marco final aqui estipulado condiz com o proposto em: HEINTZE, Beatrix. Angola nos séculos XVI e XVII [...]. Luanda: Kilombelombe, 2007, capítulo 7.

${ }^{286}$ Trata-se de um "projeto" ou "programa" imperial composto por dois eixos, a abrangência intercontinental e a complementaridade entre os domínios ultramarinos. Verificar: SANTOS, Catarina Madeira. Um governo 
em um conjunto de diretrizes, renovado a cada mudança de governador-geral, contido nos chamados "regimentos". Tais documentos nada mais eram do que guias e instruções gerais ligados ao "bom governo" e que, em teoria, deveriam ser acatados pelos governadores enviados ao domínio ultramarino, o que não quer dizer que foram cumpridos à risca ou necessariamente obedecidos. Além disso, a tendência observada é a de que o conjunto de assuntos contidos nos regimentos, juntamente com algumas matérias repetidas na época, permanecessem inalterados por longos anos. O que normalmente mudava eram alguns tópicos, como a cronologia específica de cada época, as medidas circunstanciais adotadas em momentos específicos, a disposição de algumas informações, caligrafia, assinaturas, entre outros aspectos menos importantes. Em suma, o corpo unívoco de um projeto para a governadoria da Angola portuguesa era imutável, sendo guiado pelas seguintes diretrizes gerais.

Não mais se procurariam com tanto vigor as tão sonhadas minas de metais preciosos, como acontecia nos séculos XV e XVI e que nunca foram achadas na África, pelo menos não em quantidades generosas. A conquista territorial seria suspensa por tempo indeterminado. Deveria vigorar, tanto no território ocupado por portugueses, quanto nos arredores africanos, um "clima de paz e justiça" e de prevenção "contra inimigos internos e externos", livre de belicismos e revoltas políticas. Isso em teoria pois, na prática, as guerras voltarão a ocorrer e as insurgências serão frequentes. De todo modo - e isto será um traço terminológico, para não dizer conceitual, da documentação inserida na $F H A-$, mesmo que as palavras de ordem "paz e justiça" não fossem obedecidas plenamente, elas passavam a fazer parte do léxico e das necessidades institucionais inseridas nas fontes escritas primárias e secundárias, produzidas muitas vezes para finalidades pragmáticas e obrigatoriamente provedoras da legitimação de atos oficias. Dito de outra forma, tudo o que fosse feito pelos funcionários e oficiais régios deveria ser justificado à luz dos conceitos de "paz" e "justiça" portuguesas, o que não impedia que demais estados de guerra generalizados voltassem a ocorrer, como ao longo desta dissertação veremos que aconteceram, paradoxalmente em nome da própria "paz e justiça" entre os povos. Subjacente às explicações e justificativas de ordem político-legal, jazia uma governadoria necessariamente inclinada à economia

\footnotetext{
"polido" para Angola [...]. Tese de doutorado em História, Universidade Nova de Lisboa, 2005, p. 36-37. Tal
} noção ficará mais clara no próximo capítulo. 
escravista. Não à toa, como explica Beatrix Heintze, nos regimentos era incentivado o "antigo comércio, isto é, o comércio de escravos, para o benefício dos cofres do Estado e dos vassalos". 287

Como já dito, outro assunto bastante importante foi o da "anulação e abolição definitiva de todas as doações de sobados", sob a justificativa de que elas causavam muitos "incômodos" aos sobas e desrespeitavam o direito português e os costumes dos gentios. A vassalagem e a tutela dos sobas continuariam a prevalecer, porém os sobas vassalos não mais seriam "protegidos" ou "geridos" por particulares, mas unicamente pelos representantes diretos da monarquia portuguesa, que deveriam em nome da lei persuadi-los "por meios brandos, suaves, e sem rigor" a aceitar o avassalamento e a pagar os tributos acordados "voluntariamente". $\mathrm{Na}$ perspectiva histórica de formação institucional ultramarina e do fomento aos contatos luso-africanos, o que ocorreu foi um reencaixe do antigo princípio de vassalagem e tutela, existente desde a Idade Média europeia e que no ultramar subsistia na dita instituição dos amos, ao novo sistema de governadoria-geral proposto, igualmente funcional a partir da cooperação e parceria com as autoridades locais. A principal diferença é que, doravante, eram os funcionários e oficiais régios que supervisionavam e administravam o domínio indireto imposto aos sobas vassalos. ${ }^{288}$ Alguns deles o aceitavam de bom grado, em alguns casos chegando até a procurar a vassalagem portuguesa de livre e espontânea vontade, logicamente raciocinando a partir de seus próprios termos políticos e jurídicos, o que permite afirmar, como faz Catarina Madeira Santos, que na região vigorou um regime de coexistência entre os princípios do direito português - por exemplo, a noção de "vassalagem" e o próprio crivo legal-político dos "usos e costumes", interpretado através do conceito do "direito das gentes" imbricados a princípios africanos de governo e do "direito africano" - como o binômio prestígio-reciprocidade entre os mbundu, generalizado para uma categoria mais ampla, a "africana". ${ }^{289}$ Voltaremos a tocar nessas matérias ao longo da dissertação.

\footnotetext{
${ }^{287}$ HEINTZE, Beatrix. Angola nos séculos XVI e XVII [...]. Luanda: Kilombelombe, 2007, p. 268.

${ }^{288}$ HEINTZE, Beatrix. Angola nos séculos XVI e XVII [...]. Luanda: Kilombelombe, 2007, p. 268.

${ }^{289}$ Nossas considerações foram feitas a partir do arcabouço teórico já abordado por Catarina Madeira Santos. Verificar sobre as coexistências, imbricações e rearranjos, verificar especificamente: SANTOS, Catarina Madeira. Entre deux droits: les Lumières en Angola (1750-v. 1800). Annales. Histoire, Sciences Sociales. Paris: Éditions de l'EHESS, n. ${ }^{\circ}$ 60, 2005/4, p. 817-848. 2005, p. 826. Idem, Escrever o Poder [...]. IN: HEINTZE, Beatrix; OPPEN, Achim von (Ed.). Angola on the Move [...]. Frankfurt am Main: Verlag Otto Lembeck, 2008, p. 174. SANTOS, Catarina Madeira. Administrative knowledge in a colonial context: Angola
} 
Na prática, a imposição de vassalagem continuava atrelada às maneiras de submeter, subjugar e dominar alguns sobas que repudiassem, ou que não abaixassem a cabeça, às normas estabelecidas pelos oficiais e funcionários régios. A princípio, o sustento econômico e a sobrevivência material de Luanda, Massangano e das pequeníssimas comunidades mistas, ainda espalhadas pelo sertão e que não foram mapeadas nas fontes escritas, continuavam ancoradas em uma economia um tanto quanto limitada, circunscrita à troca local de gêneros de subsistência e ao comércio de longa distância, ambos contando com a participação de escravos, tanto como agentes comerciais nas rotas do tráfico interiorano, quanto como objeto de comutação, a chamada "peça". ${ }^{290}$ Uma terceira forma de obtenção de renda e fazendas derivava do cultivo e do aproveitamento agrícola da terra, fundados na concessão de terras por meio do regime de sesmarias, só que agora "aparentemente de terras desabilitadas ou abandonadas pela população de forma mais ou menos voluntária, cujos limites, mais reduzidos, eram medidos na maioria das vezes em braças e talvez ocasionalmente também em léguas". As glebas cultivadas normalmente estavam anexadas aos rios Bengo, Luanda e aos presídios portugueses, sendo trabalhadas por escravos. Qualquer uma dessas modalidades econômicas de criação ou aquisição de riquezas implicava na exploração de mão-de-obra escrava, de modo que na prática o “comércio de escravos continuou a ser o único motor e medida de todos os investimentos e de toda a política de Angola". 291

Gestada desde 1590 e ensaiada plenamente pela primeira vez em 1607, durante o brevíssimo governo de Dom Manuel Pereira Forjaz, ${ }^{292}$ a segunda fase de expansão e contato do reino de Portugal no Ndongo (1607-1617) foi marcada pelo relativo sucesso do

in the eighteenth century. The British Journal for the History of Science (BJHS), vol. 43, dezembro de 2010, pp. 554-555. Para uma breve explicação histórica a respeito do vocabulário ligado ao mundo da escravidão, subsumido e pensado a partir do que comumente foi evocado a partir do conceito genérico de "usos e costumes", verificar: SANTOS, Catarina Madeira. Esclavage africain et traite atlantique confrontés [...]. Brésil(s). Paris: Éditions de la Maison des Sciences de l'Homme, n. ${ }^{\circ}$ 1, 2012, p. 127.

${ }^{290}$ Consultar o capítulo 3 desta dissertação.

${ }^{291}$ HEINTZE, Beatrix. Angola nos séculos XVI e XVII [...]. Luanda: Kilombelombe, 2007, pp. 268-269 e 271.

${ }^{292}$ HEINTZE, Beatrix (coord.). Apêndice: governadores de Angola, 1575 - 1639, FHA, vol. I, 1985, p. 393. Em consonância com o que até então foi desenvolvido neste item, conferir especificamente: BIRMINGHAM, David. Trade and conflict in Angola [...]. Londres: Clarendon Press/ Oxford University Press, 1966, pp. 8182. Segundo Rodrigo Faustinoni Bonciani, uma espécie de tripé sustentava as instruções emitidas a Dom Manuel Pereira Forjaz, do qual faziam parte: $i$ ) A fundação de um "sistema de vassalagem", em detrimento do de "amos"; ii) Justaposição desse sistema a outro, o de "embaixadas"; iii) A garantia do "domínio de Angola contra os inimigos internos e externos". Verificar: BONCIANI, Rodrigo Faustinoni. O dominium sobre os indigenas e africanos [...]. Tese de doutorado, Universidade de São Paulo (USP), 2010, p. 245. 
sistema de governadoria-geral. Doravante, podemos falar na consolidação de uma "Angola portuguesa", proposta e funcional a partir de dois eixos elementares entrelaçados entre si. O primeiro estava ligado à imposição de um domínio indireto e tutelar, ${ }^{293}$ na imagem de um impulso régio de pacificação e avassalamento de sobas. O segundo suscitava a formação de uma sociedade escravista, dentro da qual ocorreria o surgimento de elites locais que prosperariam através da participação no tráfico de escravos. $\mathrm{O}$ mercado atlântico e a economia escravista foram fundamentais para a reiteração da vida material em Luanda, onde as relações de trabalho e produção seriam mediadas pelas tensões entre liberdade e escravidão, entre outros fatores que abordaremos nesta dissertação, incentivando a criação de mecanismos de fiscalização e vigilância de espaços e pessoas. Em poucas palavras, essa era uma sociedade violenta e monitorada, na qual vigorava um sistema administrativo interconectado e misto. ${ }^{294}$ Herdadas do tempo de Paulo Dias de Novais, o novo sistema não se desvencilharia de antigas situações e contextos existentes a níveis local e regional, sendo dois deles de especial atenção para a presente pesquisa. Um era a "plasticidade" poderíamos até dizer, em termos anacrônicos, "multiétnica" ou mesmo "multicultural" derivada da situação de contato aberta desde o final do século XVI e que, evidentemente, propiciou a integração de diferentes povos, como os mbundu, bakongo, ndembu e portugueses, para ficarmos nos mais citados. Outro adveio das repetidas tentativas em “conquistar" o Ndongo, a despeito de qual fossem as ordens e instruções despachadas por Lisboa, desde que o tráfico de escravos não fosse prejudicado. Entremeando o geral com o específico, reajustando o antigo no novo e vice-versa, a segunda fase da história das expansões e dos contatos luso-africanos foi muito mais uma continuação de um longo

${ }^{293}$ HEINTZE, Beatrix. Angola nos séculos XVI e XVII [...]. Luanda: Kilombelombe, 2007, p. 280. Para explicar melhor, ficamos com as palavras da pesquisadora, nessa mesma página. "A política de conquista deveria ser abandonada a partir de então e a soberania portuguesa imposta apenas por meios pacíficos. O objectivo era um domínio indirecto sobre os territórios conquistados, que seria posto em prática através dos contratos de vassalagem com os sobas". Aproveitamos aqui para evocar umas chaves interpretativas utilizadas por Carlos Alberto de Moura Ribeiro Zeron, para quem uma política de descimentos, reduções, aldeamentos e missões fazia parte da implementação de um "projeto de tutela de toda a sociedade colonial", por parte da Companhia de Jesus na América portuguesa. Sustentando a prerrogativa de um "poder indireto" sobre a sociedade colonial, os jesuítas foram responsáveis, em partes da América portuguesa, por instituir uma "política indigenista" impressa no sistema de aldeamento missionário, em vigor após uma concessão estipulada por Filipe I de Portugal. Verificar: ZERON, Carlos Alberto de Moura Ribeiro. Interpretações das relações entre cura animarum e potestas indirecta no mundo luso-americano. Clio: Revista de Pesquisa Histórica. Recife: Universidade Federal de Pernambuco (UFPE), n. ${ }^{\circ}$ 27-1, 2009, p. 154. Idem, Linha de fé [...]. [1998]. São Paulo: Editora da Universidade de São Paulo, 2011, p. 40.

${ }^{294}$ Para mais informações, consultar o capítulo 3. 
processo histórico do que uma interrupção ou total modificação do rumo histórico dos contatos luso-africanos.

\subsection{Por uma história das expansões e contatos luso-africanos}

Retomando alguns pontos levantados no início deste capítulo, podemos esboçar algumas considerações preliminares. Na primeira parte deste capítulo, deixamos claro que há um macrocosmo mbundu que permeia a formação histórica do reino do Ndongo, impulsionada por uma relação dialética entre a estrutura organizacional-sociopolítica e os princípios essenciais de cosmogonia mbundu. Reconstituir um passado de contatos consiste em afirmar que havia formas de dominação e intermediação centro-africanas, ligadas à história específica dos mbundu e ao desenvolvimento do reino do Ndongo, ressaltando que a partir do século XVI novas dinâmicas de permanência e mudança serão trazidas pelas grandes navegações europeias e pela expansão ultramarina portuguesa. Nesse momento de “encontro de histórias", de dois processos diferentes mas intimamente relacionados entre si, o Ndongo emergiu como uma unidade sociopolítica que despertou a atenção de Paulo Dias de Novais e a da unificada Coroa de Madri e Lisboa. Em virtude desse novo interesse regional, a tradicional procura por um cooperador ou parceiro político centro-africano deixou de ser concentrada no Kongo, para abarcar também o Ndongo. O macrocosmo mbundu passou a figurar como uma nova "pedra de toque" utilizável na construção de um imaginário extravertido sobre a África, sem contudo excluir os corolários e crenças acumulados sobre os bakongo e demais povos africanos. Na segunda metade deste capítulo fizemos então um breve levantamento de como tal deslocamento de foco sucedeu, destacando a importância da expansão ultramarina rumo ao Ndongo, em um processo histórico que vai de 1520 a 1617.

À luz do que foi dito, é possível afirmar que as descrições e os traços de uma pretensa "africanidade" centro-africana, esboçados nas fontes escritas modernas e registrados através do crivo dos "usos e costumes" locais, advieram principalmente da interpolarização entre o que foi descoberto e observado no Kongo e Ndongo. Foram essas as distintas realidades que acabaram homogeneizadas em discursos e visões genéricas sobre o que seriam os "centro-africanos". Apesar de haver deformidades, deturpações e distorções presentes nos registros de época, resultando alguns falseamentos e mal- 
entendidos por parte dos leitores desavisados, ${ }^{295}$ os estereótipos e estigmas que a documentação reflete sobre o "gentio" centro-africano não eram totalmente apartados de um firmamento sólido, ou seja, de uma realidade observada. Os binômios solidariedadepertencimento, marginalização-exclusão e prestígio-reciprocidade são marcas constituidoras das normas de socialização e da visão de mundo não apenas circunscritas aos mbundu, mas também presentes entre os bakongo e ndembu, autodeclaradas por esses povos e recorrentes em fontes escritas administrativas e etnográficas. Por consequência, se no segundo item deste capítulo fizemos uma reconstituição geral sobre disposição geopolítica e o funcionamento geral do chamado "reino do Ndongo", aqui fica mais do que evidente que o conceito de "estado", atualmente utilizado para caracterizar essa e outras soberanias centro-africanas, precisa ser relativizado. Não que ele deva ser descartado, mas é preciso ter em mente que alguns "reinos africanos", como o Ndongo, não detinham um sistema tributário e taxativo desenvolvido nem eram tão organizados supralocalmente como os reinos de Portugal ou do Kongo, com funcionários representantes do governo central distribuídos pelas províncias. Também não parece ter havido suntuosas rotas comerciais que atravessavam o continente e abasteciam as praças comerciais mbundu, apesar de o comércio de sal e escravos ser bastante relevante ali. As epistemologias ocidentais não fornecem sozinhas os subsídios necessários para explicar o funcionamento do Ndongo como um "estado territorial", assemelhado muito mais a uma confederação de províncias mbundu, organizadas em torno do prestígio e da reciprocidade de filiação político-parental de um soberano, o ngola. Na banza dele, figurava o núcleo representativo de ordem regional, capaz de concentrar as forças centrípetas e unificadoras do sentimento de pertencimento mbundu, além de ser um espaço de devoção e respeito, "considerado o centro ideológico do Estado, a quem, em última análise, tudo que reportava e a quem atribuía uma vasta influência sobre o bem-estar do país" ${ }^{296}$ Assim, em última instância, os

\footnotetext{
${ }^{295}$ Nas ótimas palavras de Catarina Madeira Santos, há no registro escrito tensões entre três âmbitos: $i$ ) A produção repetida de imagens e estereótipos; ii) A ordem epistemológica de escrita e discurso; iii) A realidade e alteridade dos africanos. SANTOS, Catarina Madeira. Un Monde Excessivement Nouveau - savoirs africains et savoirs missionnaires: fragments, appropriations et porosités dans l'œuvre de cavazzi di montecúccolo. IN: CASTELNAU-L'ESTOILE, Charlotte De et. al. (ed.). Missions d'évangélisation et circulation des savoirs (XVIe-XVIIIe siècle). Madri: Casa de Velázquez, 2011, p. 301.

${ }^{296}$ HEINTZE, Beatrix. Angola nos séculos XVI e XVII [...]. Luanda: Kilombelombe, 2007, pp. 233-234. Nesse mesmo sentido: COELHO, Virgílio. Em busca de Kábàsà [...]”. Actas do Seminário Encontros de povos e culturas em Angola. Luanda: Comissão Nacional para as Comemorações dos Descobrimentos Portugueses, 1995, p. 467. Por mais que Virgílio Coelho desconfie da existência geográfica de "Kabasa", é inegável que os
} 
observadores e cronistas portugueses dos séculos XVI e XVII foram incapazes de desafiar os ditames do olhar eurocêntrico, aludindo precipitadamente à "província do Ndongo", uma supralocalidade geopolítica onde habitava e governava um dos subgrupos mbundu de maior respeito regional, o "ndongo", a um "reino do Ndongo" na imagem de um estado territorial, "à europeia". 297

Reaproveitando uma das claves analíticas ensaiadas por John K. Thornton, ${ }^{298}$ temos aqui riquíssimos elementos para conjecturar sobre as razões pelas quais alguns africanos participaram diretamente, sem serem totalmente compelidos ou coagidos para tal, de um negócio tão desumano e extremamente danoso ao continente africano ao longo do tempo: o tráfico de escravos transatlântico. A possibilidade de cooperação e parceria, em prol do infame comércio de gente, vigorava entre as soberanias africanas porque nelas estava enraizado um "regime de escravidão africano", no qual os escravos eram interpretados legalmente como um tipo de "propriedade" rentável e produtora de bens e serviços para uma elite local que, ao desfrutar da exploração da energia produtiva de outrem, poderia abdicar do trabalho manual. ${ }^{299}$ Sendo a base produtora de riqueza africana movida pela propriedade forçada do trabalho, as instituições políticas locais acabariam erigidas a partir da aquisição e concentração de mão-de-obra escrava, nas mãos de algumas linhagens soberanas e que dispunham de vastos territórios férteis e desocupados, que pudessem ser produzidas sem grandes percalços. ${ }^{300}$ Bastava ter gente para trabalhar. Independentemente

topônimos mais citados nas fontes escritas - Ambaca, Kabasa, Vunga e Pungo Andongo - eram espaços ocupados por pessoas. Por exemplo, Kabasa era uma "banza" ou cidade, que contava com benfeitorias e residências. Verificar as descrições fornecidas em: BIRMINGHAM, David. Trade and conflict in Angola [...]. Londres: Clarendon Press/ Oxford University Press, 1966, p. 36. Ainda conforme Birmingham, há um quinto topônimo frequentemente citado nos escritos de época, "Ngoleme". Verificar a mesma obra, pp. 39-40. Para uma sucinta explanação sobre o pensamento e as normas políticas mbundu, às vezes refletidos nos topônimos e antropônimos registrados nos escritos antigos, consultar as tabelas inseridas na seção "uma cosmologia mbundu", contida nos anexos desta dissertação.

${ }^{297}$ Em sentido análogo ao estipulado em: COELHO, Virgílio. Em busca de Kábàsà [...]". Actas do Seminário Encontros de povos e culturas em Angola. Luanda: Comissão Nacional para as Comemorações dos Descobrimentos Portugueses, 1995, p. 467.

${ }^{298}$ Até onde sabemos. De todo modo, os primeiros trabalhos de vulto que levantam tais perspectivas, ainda de forma pioneira e bastante ensaística, são ambos da década de 1960: BIRMINGHAM, David. Trade and conflict in Angola [...]. Londres: Clarendon Press/ Oxford University Press, 1966. VANSINA, Jan. Kingdoms of the Savanna. Madison: University of Wisconsin Press, 1966.

${ }^{299}$ THORNTON, John K. Africa and Africans in the Making of the Atlantic World, 1400-1800. [1992]. Cambridge: Cambridge University Press, 1998, pp. 74-76. A passagem-chave fornecida por Thornton, no original, é a seguinte: "Slavery was widespread in Atlantic Africa because slaves were the only form of private, revenue-producing property recognized in African law" (p. 74).

${ }^{300}$ Ibidem, pp. 85-88. 
das assunções de Thornton sobre a noção de "propriedade" serem vagamente problematizadas, como também a noção de escravidão um tanto simplista e mecânica, o crucial é ter em mente que, no Ndongo e o Kongo dos séculos XVI e XVII, ${ }^{301}$ o trabalho escravo e a aquisição desse tipo de gente, através de guerras e do comércio, eram componentes basilares dos fundamentos de um governo político e da produção de excedentes, necessários para a sobrevivência de uma elite política e administrativa

Nesse sentido, a exportação de pessoas para o mercado atlântico foi paradoxal, pois desarticulou o modo de produção voltado para o aproveitamento da terra. Em contrapartida, após estarem consolidados, os ditos "estados centro-africanos" apenas cooperariam com os estrangeiros, como membros atuantes do comércio atlântico, pois em troca almejavam o prestígio advindo dos produtos importados da Europa - roupas, papel, carimbos, penas, entre outras "regalias atendidas e presentes ofertados" - e calculavam politicamente que a aliança com os estrangeiros lhes favoreceria, uma vez que o acionamento ao princípio de reciprocidade proporcionaria ajuda militar como forma de aplacar os iminentes ou possíveis abalos internos e invasões externas - os casos de teke, jagas-imbangala, entre outros abordados nesta dissertação e são prova disso. ${ }^{302}$ Assim, não se pode perder de vista que "a disposição social [africana] preexistente [à chegada dos portugueses] foi tão responsável, quanto qualquer força externa, para o desenvolvimento do tráfico de escravos atlântico". 303

Pelo menos entre os séculos XVI e XVII, três foram os elementos do regime de governança política que permaneceram imodificáveis no Ndongo: estrutura sociopolítica, princípios cosmológicos e regimes de trabalho e comércio. Sobrepostos uns aos outros, tais elementos também explicam por que houve cooperação, parceria política e participação no tráfico de escravos. Essa situação perdurou desde meados de 1550 até cerca de 1607, quando surgiram os primeiros indícios claros de que o jogo de forças político-econômico estava mudando. Uma vez consolidada a Angola portuguesa, na imagem de uma

\footnotetext{
${ }^{301}$ THORNTON, John K. Africa and Africans [...]. [1992]. Cambridge: Cambridge University Press, 1998, pp. 93-94.

${ }^{302}$ Nesse sentido, verificar também: BIRMINGHAM, David. Trade and conflict in Angola [...]. Londres: Clarendon Press/ Oxford University Press, 1966, p. 40.

${ }^{303}$ THORNTON, John K. Africa and Africans [...]. [1992]. Cambridge: Cambridge University Press, 1998, p. 97 (tradução nossa. No original: "The institution of slavery was widespread in African and accepted in all the exporting regions, and the capture, purchase transport, and sale of slaves was a regular feature of African society. This preexisting social arrangement was thus as much responsible as any external force for the development of the Atlantic slave trade"). O autor reafirma essas ideias em: THORNTON, John K. A Cultural History of the Atlantic World [...]. Cambridge: Cambridge University Press, 2012, pp. 79 e 81.
} 
governadoria-geral amadurecida, o primeiro impacto direto da economia atlântica na vida dos grupos sociopolíticos locais foi o crescente aumento da busca por riqueza, material e imaterial, de tipo africano ou português, cada vez mais pendente para uma forma de ascensão social inclinada ao comércio de pessoas abarrotadas em tumbeiros imundos, o chamado tráfico de escravos transatlântico. Os sobas do Ndondo e proximidades não estariam à margem disso porque, como lembra Beatrix Heintze, o "comércio de escravos organizado sistematicamente e em grande estilo só foi introduzido pelos portugueses, tendo atingido tal proporção, mesmo antes do início da conquista, que não pode ter deixado de influenciar a sociedade local." ${ }^{304}$ A partir de então, impactos, influências e transformações significativos ocorrerão no âmago dos contatos luso-africano. À luz do processo histórico vigente, será na terceira fase de expansão e contato do reino de Portugal no Ndongo, iniciada em 1617 e em pleno vapor na época de Fernão de Sousa, que assistiremos algumas mudanças engendradas nas relações diplomáticas e interpessoais levadas a cabo a partir das tensões, atritos e embates em âmbito regional. ${ }^{305}$ Dessa forma, ao longo desta dissertação, vislumbraremos os diferentes aspectos e dimensões que envolveram a história das expansões e contatos luso-africanos. Para finalizar, aqui nos limitaremos à apresentação preliminar de um dos aspectos essenciais desta pesquisa, ligado à construção e à manutenção de presídios, meio pelo qual ocorreu a transferência de órgãos institucionais ultramarinos ao sertão centro-africano.

Os presídios eram mais do que postos avançados ou estruturas feitas de pedra e madeira. Como produções humanas, eles são marcos da passagem e da ocupação do meio

\footnotetext{
${ }^{304}$ HEINTZE, Beatrix. Angola nos séculos XVI e XVII [...]. Luanda: Kilombelombe, 2007, pp. 205-206.

${ }^{305}$ Tal é a proposta em: HEINTZE, Beatrix. Angola nos séculos XVI e XVII [...]. Luanda: Kilombelombe, 2007, capítulo 8. Apesar das divergências no que diz respeito às datas e fatos históricos de maior peso, em linhas gerais a divisão temporal aqui proposta condiz com as fases históricas presentes em: BONCIANI, Rodrigo Faustinoni. O dominium sobre os indigenas e africanos [...]. Tese de doutorado, Universidade de São Paulo (USP), 2010, capítulos 2, 3 e 4. No final das contas concordamos com a perspectiva geral, portanto, de Jan Vansina, Beatrix Heintze e David Birmingham, com apenas algumas contraposições. No que diz respeito à periodização proposta por Jan Vansina, que separa o processo formativo do "sistema atlântico" em duas fases, uma que vai de 1500 a 1660, marcada pela detecção de potenciais parceiros locais que viabilizassem o tráfico atlântico e a construção de "mecanismos" capazes de unificar economias distintas, e outra que vai de 1660 a 1830, no qual os participantes africanos do sistema atlântico sofreriam impactos demográficos, econômicos e sociais relevantes, consideramos tais separações temporais válidas, conquanto sejam muito amplas. Verificar: VANSINA, Jan. Paths in the Rainforests [...]. Madison-Wisconsin: University of Wisconsin Press, 1990, 198. Sobre e relevância do desenvolvimento do mercado atlântico, verificar: VANSINA, Jan. How Societies Are Born [...]. Charlottesville: University of Virginia Press, 2004, pp. 99. BIRMINGHAM, David. Trade and conflict in Angola [...]. Londres: Clarendon Press/ Oxford University Press, 1966, pp. 27-28.
} 
geofísico, detendo funções espaciais delineadas pelos seus construtores e que, ao longo do tempo e espaço, são passíveis de serem reinventados. Dito de outra forma, tais construções não eram apenas "lugares", "ruínas" ou "escombros" do passado, mas vestígios que poderiam ser reapropriados pelas memórias dos diferentes indivíduos que viessem a reocupá-los ao longo do tempo. Além disso, a construção de presídio sinalizava para a ocupação efetiva de um território que, não necessariamente, era desocupado, sem utilidade ou "selvagem". Nosso ponto é que o processo histórico de ocupação e modificação do espaço físico não indica para a apropriação de uma "natureza primitiva" e "sem dona", mas sinaliza para a transplantação de novas formas de interação material e imaterial com o meio natural e social que compunha parte da África Centro-Ocidental, algo que por consequência interferia na vida dos habitantes locais. Esses sabiam detectar e avaliar o peso que os estrangeiros de além-mar traziam de fora, fazendo dessa maneira uso das novidades estrangeiras ao seu modo e desejo, embora também fossem influenciados pelas pressões exercidas pela economia atlântica. ${ }^{306}$

Os presídios portugueses mais conhecidos - Massangano, Cambambe, Muxima e Ambaca - contavam com uma população que habitava em terras extramuros, eram visitados por comerciantes e passavam por reformas e mudanças de guarnecimento. Havia uma vida em torno deles, chefiada ou organizada ao redor de uma autoridade local de grande importância até o século XIX, o capitão de presídio. ${ }^{307}$ Erguido no final da década de 1580, o presídio de Massangano estava situado às portas dos julgados limites do

\footnotetext{
${ }^{306}$ Sobre o controle da natureza pelo homem, conferir os questionamentos feitos por Jan Vansina a respeito do "mito da grande floresta": VANSINA, Jan. L'homme, les forêts [...]. Annales [...]. Paris: Éditions de l'EHESS, ano $40^{\circ}$, n. ${ }^{\circ} 6,1985$, pp. 1307 e 1314-1315. Sobre as demais considerações feitas acima, conferir o mesmo artigo de Vansina, pp. 1328-1329. SANTOS, Maria Emília Madeira. Nos caminhos de África [...]. Lisboa: Instituto de Investigação Científica Tropical, 1998, capítulo 4. Sobre a interação entre o Estado da Índia e as sociedades asiáticas, mediante a qual o protagonismo local também é visível, verificar: SUBRAHMANYAM, Sanjay. O Império Asiático Português 1500-1700: Uma História Política e Econômica. [1993]. Linda-avelha: Difel, 1995, pp. 9-10.

${ }^{307}$ Faremos mais considerações sobre a importância dos capitães de presídios, capitães-mores e simples capitães nos capítulos 3 e 4 . Por enquanto, basta saber que eles eram nomeados pelo governador de Luanda, detendo especial importância na administração geral dos presídios, algo que incluía uma grande liberdade no que tangia à tomada de decisão a respeito dos assuntos políticos e judiciais. Até o século XIX, a autonomia dos capitães de presídios era tamanha que eles eram acusados inúmeras vezes por ter cometidos abusos e deslealdades contra os sobas. Verificar: FERREIRA, Roquinaldo. Cross-Cultural Exchange in the Atlantic World [...]. Cambridge: Cambridge University Press, 2012, pp. 37-38, 42-43, 103, 113. SANTOS, Maria Emília Madeira. Nos caminhos de Africa [...]. Lisboa: Instituto de Investigação Científica Tropical, 1998, pp. 435-436. Catarina Madeira Santos destaca que, no século XVIII, vários capitães-mores eram "luso-africanos", ou mesmo africanos. Verificar: SANTOS, Catarina Madeira. Administrative knowledge in a colonial context [...]. The British Journal for the History of Science (BJHS), vol. 43, dezembro de 2010, pp. 546-547.
} 
Ndongo, sendo um posto militar estratégico e uma estrutura física capaz de deter, ou desmotivar, a expansão do Ndongo para o ocidente. Devido ao aumento populacional e à importância econômica que adquiriu rapidamente, Massangano foi no tempo de Fernão de Sousa elevado ao estatuto de vila. Hoje em dia, é uma das povoações que integram o município de Cambambe, um dos muitos que integram a República de Angola.

Sucedeu o erguimento de Massangano a construção do presídio de Muxima, no início do século XVII. ${ }^{308}$ O presídio surgia como uma tentativa de criar uma "linha de comunicação" entre os entrepostos institucionais portugueses e como uma forma de guardar uma posição estratégica de frente a Quissama. Logo em seguida foi erguido Cambambe, localizado nas "bordas" do Ndongo segundo as fontes coevas, indicando que o reino africano estava em visível regressão territorial. ${ }^{309} \mathrm{O}$ sentido de construção de presídios seguia uma tendência clara: adentrar a África subindo o Cuanza, exercendo pressão e empurrando para o interior as pretensas linhas fronteiriças do reino do Ndongo. Essa regra seria ultrapassada com a construção do Ambaca, presídio erguido dentro de território africano em 1618, na vizinhança das então especuladas "capitais" do reino do Ndongo. A mais nova construção apontava para uma coabitação conflituosa, quiçá indesejada desde os princípios de seu soerguimento, por parte das autoridades mbundu e a jurisprudência de Luanda, representantes de legislações diferentes. ${ }^{310}$

Se especulamos desde o princípio deste capítulo que um macrocosmo mbundu resistiu à passagem do tempo, aqui podemos incluir que subsistiu a esse aspecto de longa duração alguns aspectos de mudança de menor vulto, mas que de forma alguma podem ser desconsiderados. No século XVII, prosperaram novas comunidades anexadas aos presídios portugueses do interior, povoadas por pessoas negras ou pardas, versadas em

\footnotetext{
${ }^{308}$ Muxima foi erguido durante o governo de João Furtado de Mendonça, entre 1594 e 1601/1602. Sobre a duração do governo, verificar: HEINTZE, Beatrix (coord.). Apêndice: governadores de Angola, 1575 - 1639 , $F H A$, vol. I, 1985, p. 393. BIRMINGHAM, 1966, p. 60.

${ }^{309}$ Cambambe foi erigido durante o primeiro governo de Manuel Cerveira Pereira, entre 1603 e 1607. Para a duração dos governos de Manuel Cerveira Pereira, verificar: HEINTZE, Beatrix (coord.). Apêndice: governadores de Angola, 1575 - 1639, FHA, vol. I, 1985, p. 393. BIRMINGHAM, David. Trade and conflict in Angola [...]. Londres: Clarendon Press/ Oxford University Press, 1966, pp. 60-61 e 80.

${ }^{310}$ HEINTZE, Beatrix. Angola nos séculos XVI e XVII [...]. Luanda: Kilombelombe, 2007, pp. 183-184 e 190191. Mesmo que concordemos que houve uma política de cooperação luso-africana, sobreposta à coexistência de saberes e matrizes e mesmo uma coabitação voluntária entre indivíduos brancos e negros, é preciso problematizar ideias como a de "coadministração" de territórios e pessoas, ou as de reciprocidades e respeitos político-jurídicos trocados igualitariamente entre autoridades africanas e portuguesas. Para uma posição diferente dessa, mesmo que pontual, verificar: FERREIRA, Roquinaldo. Cross-Cultural Exchange in the Atlantic World [...]. Cambridge: Cambridge University Press, 2012, p. 39.
} 
conhecimentos e saberes técnicos - podiam saber ler e escrever, por exemplo - eram bilíngues - normalmente em kimbundu e português - e às vezes se vestiam "à portuguesa", entre outros modos atípicos às comunidades africanas. Todos eles parecem ter abdicado de alguns dos princípios locais, como o pertencimento a linhagens e o juramento de fidelidade ao ngola, para então se dedicar à aquisição de escravos e ao comércio. Assim, nessas comunidades interioranas florescia um inovado microcosmo de transformação, aparentemente circunscrito às formas de socialização infralocais de Ambaca, Massangano, Muxima e Cambambe, todavia certamente atado a um tipo de ascensão social particular, refletido nos moldes da economia atlântica. Em último caso, o sentido histórico e geográfico da fundação das estruturas administrativo-militares no interior, como também a contínua manutenção dessas posições geopolíticas, indicam para os caminhos de penetração expansionista e exploratória do continente africano, como se fossem segmentos espaciais que resistem até hoje como comprovativos do sentido do interesse político e econômico ao longo do tempo e do espaço. ${ }^{311}$

311 Concordando com algumas das posições sustentadas por Thornton, principalmente em relação à importância que o comércio atlântico passaria a ter em alguns espaços do interior. Verificar: THORNTON, John K. A Cultural History of the Atlantic World [...]. Cambridge: Cambridge University Press, 2012, p. 211. 


\section{IMERSÃO NO PASSADO POLÍTICO E INSTITUCIONAL A PARTIR DE ALGUNS ESCRITOS DE FERNÃO DE SOUSA}

\section{Apresentação}

O presente capítulo versará sobre alguns acontecimentos históricos pertinentes à terceira fase de expansão e contato do reino de Portugal no Ndongo (1617-1630), levantando como objeto de análise uma série de "lembranças" e "relações" produzidas durante o governo de Fernão de Sousa. Discorremos sobre algumas das maneiras de governar a Angola portuguesa, sobretudo chamando atenção para as vicissitudes de informações e dados contidos nas fontes secundárias analisadas, bem como a participação de vários atores, agentes e grupos sociopolíticos no processo histórico vigente. Por último, faremos algumas considerações a respeito da atual celeuma que repercute sobre a chamada "eleição e avassalamento de Angola Aire no Ndongo", desdobrando-a em dois pontos de tensão: o papel controverso desse líder centro-africano e a busca por legitimidade durante a composição textual.

Imagem 5: A Angola portuguesa durante o governo de Fernão e Sousa (1624-

$$
\text { 1630) } 312
$$

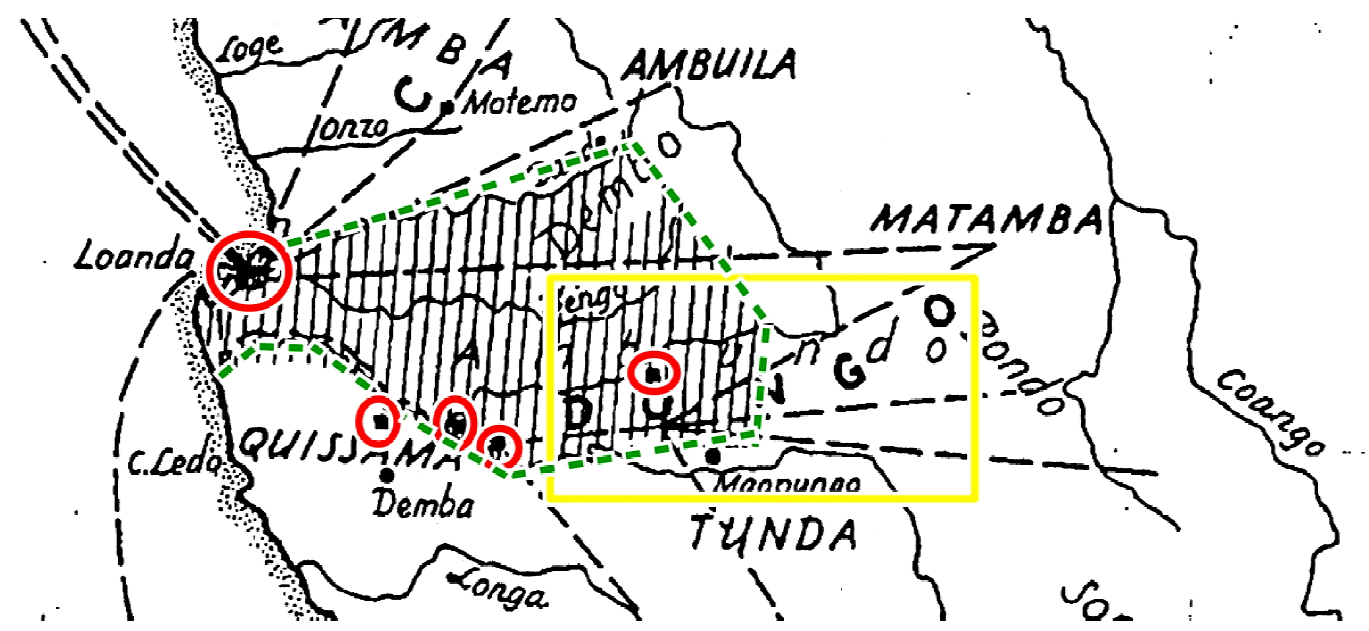

Legenda: $i) O$ traçado pontilhado em verde, cujo interior está riscado com linhas negras verticais, é o espaço reivindicado oficialmente como sendo a "Angola portuguesa"; ii) Os círculos em vermelho destacam os

\footnotetext{
${ }^{312}$ A imagem que segue abaixo foi retrabalhada a partir de: HEINTZE, Beatrix (coord.). Fig. 1: A África Central Ocidental na época de Fernão de Sousa (ortografia da fonte), FHA, vol. I, 1985, p. 4.
} 
principais centros populacionais e institucionais que compunham Angola portuguesa; iii) O quadrângulo em dourado assinala o espaço pertencente ao "Ndongo".

\subsection{Anunciação do caos e das crises na Angola portuguesa (1617-1624)}

Desde que chegou a Luanda até 1630, Fernão de Sousa escreveu uma série de três narrativas de cunho histórico, registradas comumente pela pena do administrador português como sendo as "lembranças" e "relações" "313 de um passado não muito distante, vivido por ele e seus correligionários. Tais registros se confundem com os principais acontecimentos que marcaram a terceira fase de expansão e contato do reino de Portugal no Ndongo (16171630) e, não à toa, na criteriosa indexação proposta por Beatrix Heintze para a $F H A$, dois desses três documentos ganharam o título de "história", sendo que o outro recebeu a designação sugestiva de "a ilegitimidade do novo rei do Ndongo", por motivos que abordaremos neste capítulo. Além disso, destarte é importante deixar claro que essas três lembranças e relações, poderíamos dizer também "rememorações", compartilham algumas características comuns. Primeiramente, elas são versões sobre o passado da Angola portuguesa, alicerçadas em acontecimentos históricos e interpretações pessoais e institucionais de Fernão de Sousa, promulgadas e abonadas para serem repassadas às gerações futuras como "narrativas oficiais" a respeito dos governos de Luís Mendes de Vasconcelos, João Correia de Sousa, Pedro de Sousa Coelho, Dom Frade Simão de Mascarenhas e do próprio Fernão de Sousa. Dito de outra forma, elas são "memórias institucionais" sobre o período compreendido entre 1617 a 1630. Em segundo plano, tais memórias ou narrativas são mediadas por discursos legitimadores e entrecortadas por

\footnotetext{
${ }^{313}$ Basta verificar a primeira linha dos seguintes escritos: Fernão de Sousa. História das relações entre a Angola portuguesa e o Ndongo 1617-1624. S.d., por volta do outono de 1624. BAL, cód. 51- IX-20, ff. 41414v. IN: HEINTZE, Beatrix (coord.). Documento 23, FHA, vol. I, 1985, pp. 195-197. Fernão de Sousa. História das relações entre a Angola portuguesa e o Ndongo 1617 - setembro de 1625.6 de setembro de 1625 . BAL, cód. 51-IX-20, ff. 326-27. IN: HEINTZE, Beatrix (coord.). Documento 24, FHA, vol. I, 1985, pp. 197201. Fernão de Sousa. A ilegitimidade do novo rei do Ndongo, Angola Aire. S.d., entre 20 de julho e 14 de setembro de 1629. BAL, cód. 51-IX-20, ff. 415-15v. IN: HEINTZE, Beatrix (coord.). Documento 28, FHA, vol. I, 1985, pp. 209-210. Oficialmente, o governo de Fernão de Sousa foi de 22 de junho de 1624 a 4 setembro de 1630. Na FHA, há ainda uma quarta narrativa de cunho histórico, escrita pelo punho de Fernão de Sousa, mas quando ele já se encontrava de volta em Lisboa. Esse documento foi composto em uma situação delicada, no momento de investigação e inquérito submetido pelo Conselho da Fazenda, como era a prática da época. Foi devido a essa condição de produção que decidimos não abordar esse documento. Para os interessados, consultar: Fernão de Sousa. História das relações entre a Angola portuguesa e o Ndongo 16171631. 6 de agosto de 1631. BAL, cód. 51-IX-20, ff. 362-63. IN: HEINTZE, Beatrix (coord.). Documento 25, $F H A$, vol. I, 1985, pp. 201-203. As datas de início e término do governo de Fernão de Sousa podem ser verificadas em: HEINTZE, Beatrix (coord.). Apêndice: governadores de Angola, 1575 - 1639, FHA, vol. I, 1985, p. 393.
} 
argumentos políticos, visando à construção de provas escritas, conforme as leis portuguesas e os costumes políticos do Antigo Regime, a respeito do "bom governo" de Fernão de Sousa, o autor comprovado de todos esses documentos. ${ }^{314}$

A esse último aspecto é possível adicionar que os escritos de Fernão de Sousa são influenciados pelos apelos e avaliações dos órgãos régios em geral, como também pelas expectativas e anseios tradicionalmente almejados pela monarquia, explícitos nas normas e diretrizes contidas nos chamados "regimentos". 315 Todo um esforço de idealização e definição de um "bom governo" se contrapunha também à imagem de "tempos pouco louváveis" ou "governos ineficientes", representados pelas experiências falhas de alguns predecessores de Fernão de Sousa, cujo governo foi rememorado como sendo mais "grandioso" e "elaborado" do que os demais. Na intersecção entre presente e passado, reside uma terceira característica fundamental. Ao retomar a história recente da Angola portuguesa, as lembranças e relações de Fernão de Sousa fornecem algumas explicações e razões que oficialmente impulsionaram uma política expansionista-exploratória rumo ao Ndongo, gestada em 1617 e que resultarão na conquista efetiva do Ndongo em 1671, ocorrida após a invasão de Pungo Andongo. ${ }^{316} \mathrm{O}$ que é importante ter em mente aqui é que, de 1617 a 1630, foi desenvolvida e aperfeiçoada uma das principais medidas institucionais que Fernão de Sousa vangloriará ter alcançado: a alegada "conquista do Ndongo".317

O primeiro dos documentos contemplados pela série de memórias foi escrito por volta do verão ou do outono de 1624, no mesmo ano em que Fernão de Sousa aportou em Luanda e, "para todos os efeitos, antes da dramática deterioração das relações com Nzinga na Primavera de 1625", nas palavras de Beatrix Heintze condutora da "resolução de entrar

\footnotetext{
${ }^{314}$ A comprovação de autoria foi feita por Beatrix Heintze. Verificar: Fernão de Sousa. História das relações entre a Angola portuguesa e o Ndongo 1617-1624. S.d., por volta do outono de 1624. BAL, cód. 51-IX-20, ff. 414-14v. IN: HEINTZE, Beatrix (coord.). Documento 23, FHA, vol. I, 1985, nota 1, p. 195. Fernão de Sousa. História das relações entre a Angola portuguesa e o Ndongo 1617 - setembro de 1625. 6 de setembro de 1625. BAL, cód. 51-IX-20, ff. 326-27. IN: HEINTZE, Beatrix (coord.). Documento 24, FHA, vol. I, 1985, nota 11, p. 197. Fernão de Sousa. A ilegitimidade do novo rei do Ndongo, Angola Aire. S.d., entre 20 de julho e 14 de setembro de 1629. BAL, cód. 51-IX-20, ff. 415-15v. IN: HEINTZE, Beatrix (coord.). Documento 28, FHA, vol. I, 1985, nota 71, p. 209.

${ }_{315}$ Conforme comentado na introdução e no primeiro capítulo desta dissertação.

${ }^{316}$ Aqui nos fiamos em algumas das considerações feitas por Beatrix Heintze, discordando parcialmente no que diz respeito à perda total da independência do Ndongo após 1630. Nesse sentido, comparar e confrontar nossa argumentação, desenvolvida neste e no capítulo 3 desta dissertação, com a da pesquisadora em: HEINTZE, Beatrix. Angola nos séculos XVI e XVII: estudos sobre fontes, métodos e história. Luanda: Kilombelombe, 2007, capítulo 8.

${ }^{317}$ Nesse sentido, ver também: THORNTON, John K. A Cultural History of the Atlantic World, 1250-1820. Cambridge: Cambridge University Press, 2012, p. 185.
} 
em guerra no Verão deste mesmo ano" de 1625 . $^{318}$ Para fundamentar a linha de raciocínio traçada no documento, Fernão de Sousa inicia-o afirmando que nele estava contida uma "lembrança do estado em que achei a El-rei de Angola", condizente ao tempo em que Luís Mendes de Vasconcelos foi governador de Angola, ou seja, de 1617 a $1621 .^{319}$ Em princípios desse período, o "soba Caita Cala Balanga, que era muito poderoso", levantarase contra Luanda por causa de motivos vagamente elucidados, salvo pelo breve comentário de Fernão de Sousa, segundo o qual "diziam por aí" que a revolta do soba fora causada por "sem razões que se lhe fez Francisco Antunes da Silva", que era o então capitão do presídio de Hango, 320 "com favor de Manuel Cerveira Pereira que era governador [de Benguela]". No documento também há a relevante informação de que Francisco Antunes da Silva contava com o "favor de parentesco" de Paio de Araújo de Azevedo, proeminente capitão da região e que era casado com a sua irmã, a portuguesa "Dona Ana da Silva".321 Sucintamente, tratava-se da existência de um círculo de interesse e sociabilidade encabeçado pelo governador Luís Mendes de Vasconcelos, cujos membros eram oficiais que haviam adquirido a afinidade e confiança do governador, como Francisco Antunes da Silva e Paio de Araújo de Azevedo, quiçá também Manuel Cerveira Pereira. ${ }^{322}$ Esse círculo sociopolítico estava inclinado para a guerra, por motivos que declaradamente eram

\footnotetext{
${ }^{318}$ Sobre isso, verificar: Fernão de Sousa. História das relações entre a Angola portuguesa e o Ndongo 16171624. S.d., por volta do outono de 1624. BAL, cód. 51-IX-20, ff. 414-14v. IN: HEINTZE, Beatrix (coord.). Documento 23, FHA, vol. I, 1985, nota 1, p. 195.

${ }^{319}$ Sobre esse período, verificar: HEINTZE, Beatrix (coord.). Apêndice: governadores de Angola, 1575 1639, FHA, vol. I, 1985, p. 393.

${ }^{320}$ Grafado na documentação como "Ango". Erguido nas terras do soba "Ango Aquicaito" durante o governo de Bento Banha Cardoso, o presídio de Hango estava localizado aos pés de Kabasa, também conhecida como "Cabaça", tida pelo funcionalismo régio da época como a então "capital" do Ndongo. Verificar: BIRMINGHAM, David. Trade and conflict in Angola: the Mbundu and their neighbours under the influence of the Portuguese 1483-1790. Londres: Clarendon Press/ Oxford University Press, 1966, pp. 82-83.

${ }^{321}$ Fernão de Sousa. História das relações entre a Angola portuguesa e o Ndongo 1617-1624. S.d., por volta do outono de 1624. BAL, cód. 51-IX-20, ff. 414-14v. IN: HEINTZE, Beatrix (coord.). Documento 23, FHA, vol. I, 1985, p. 195. Afora pequenos fragmentos textuais, apenas sabemos que Francisco Antunes da Silva foi capitão de barcos, durante o governo do bispo Dom Frei Simão Mascarenhas. Depois acabará capturado por holandeses no porto de Luanda. Em 22 de agosto de 1625, foi detido por Fernão de Sousa, acusado de ter participado no episódio conhecido como a "negligência dos portugueses", mediante o qual alguns navios portugueses foram capturados por holandeses, no verão de 1624. Acabou morrendo na prisão, em um momento ainda indeterminado, mas antes de 20 de março de 1628. HEINTZE, Beatrix (coord.). Breves biografias de alguns europeus em Angola (1620-1630). FHA, vol. I, 1985, p. 86 e principalmente as pp. 106107.

${ }^{322}$ Uma figura de peso na região e em Portugal. Manuel Cerveira Pereira foi por duas vezes nomeado governador de Angola, a primeira entre 1603 e 1607, a segunda vez entre 1615 e 1617. Foi também o primeiro administrador da governadoria geral de Benguela, fundada durante o início do século XVII. Verificar: HEINTZE, Beatrix (coord.). Apêndice: governadores de Angola, 1575 - 1639, FHA, vol. I, 1985, p. 393.
} 
políticos, mas que implicitamente também envolviam interesses econômicos, ligados à possibilidade de captura de escravos provenientes do saque a aldeias e do butim de guerra.

À revelia do "parecer e o conselho de todos", ou seja, dos membros da Câmara de Luanda e das autoridades eclesiásticas integrantes da Companhia de Jesus e do bispado de Congo e Angola, contrários a qualquer confronto militar com as populações locais, o governador Luís Mendes de Vasconcelos e seus apoiadores foram com o "intento de guerra" para cima do Ndongo, justificando a investida militar ao declarar que "El-rei [do Ndongo] fomentava a Caita [Cala Balanga]" e lhe fornecia "socorros", sendo assim conveniente começar a guerra pelo "mais poderoso", ou seja, pelo soberano mbundu Angola Ambande, pois com a sua derrota Cata Calla Balanga abaixaria as armas. ${ }^{323}$ Caso consideremos como verdadeira a informação de Fernão de Sousa, havia desde já pelo menos duas posturas que rivalizavam em Luanda, representadas por dois grupos sociopolíticos distintos. De um lado existiam os membros da Câmara de Luanda que eram contrários à guerra, possivelmente negociadores, representantes de contratadores, grandes comerciantes e proprietários de terras e escravos, todos eles totalmente dependentes do mercado de exportação e do tráfico de escravos. Sinônimo de paralisação do comércio nas feiras e capaz de gerar desestabilizações sociais que acarretassem na fuga de cativos, a guerra era malquista por eles. Tais interesses convergiam com os de um segundo grupo, formado por eclesiásticos, nessa altura contrários aos confrontos militares, por entender que eles rendiam apenas "peças" aos que faziam a guerra, em troca de pouco ou quase nenhum resultado no campo do proselitismo. Liderando a posição oposta ao dos eclesiásticos, o terceiro grupo sociopolítico era evidentemente militarizado e responsável pela condução da chamada "gente de guerra" e da administração dos presídios do interior. Filiado a essa seara e respaldada na importância local do oficialato, Luís Mendes de Vasconcelos desrespeitou as posições contrárias aos seus interesses, e autoritariamente, partiu para a "conquista do Ndongo". 324

\footnotetext{
${ }^{323}$ Fernão de Sousa. História das relações entre a Angola portuguesa e o Ndongo 1617-1624. S.d., por volta do outono de 1624. BAL, cód. 51-IX-20, ff. 414-14v. IN: HEINTZE, Beatrix (coord.). Documento 23, FHA, vol. I, 1985, p. 195.

324 A linha divisória entre "público" e "privado" era tênue. Portanto, nos âmbitos locais do além-mar, é impossível falar em "monopólio real" dos assuntos e ações econômicos e políticos, uma vez que grupos de particulares e investidores privados participavam ativamente do ambiente político de Luanda, sustentando opiniões e interesses próprios e que, às vezes, entravam em choque com os defendidos pelos representantes régios e entidades religiosas. Nesse sentido, verificar: THORNTON, John K. Africa and Africans in the
} 
A campanha de guerra aberta por Luís Mendes de Vasconcelos obteve êxito e desbaratou o então "El-rei Angola Ambande" que, após a invasão das tropas de Luís Mendes de Vasconcelos, fugiu para alguns "matos pela ba[nza] de Samba Aquisenzele", permitindo com que a "gente de guerra" saqueasse as banzas de Kabasa e Vunga. ${ }^{325}$ Reconhecidos como "residências dos reis do Ndongo" entre os séculos XVI e XVII, ou capitais mbundu onde existiriam as chamadas "cortes reais", esses topônimos são recorrentes no imaginário centro-africano e nas fontes escritas que hoje temos em mão. Citada pela primeira vez nos escritos portugueses em 1563, Kabasa foi transferida diversas vezes de lugar, vindo a aparecer "perto de Pungo Andongo e podia ser alcançada, a partir da fortaleza de Ambaca, num dia de marcha", na explicação geral de Beatrix Heintze. Por sua vez, a Vunga foi citada pela primeira vez nas fontes escritas em 1622, descrita então como uma "banza d'El-rei d'Angola" situada nas proximidades de Ambaca. Assim como Kabasa, "Vunga" é um topônimo cuja localização é imprecisa, ${ }^{326}$ apesar de ser possível determinar que os dois locais estavam situados nas redondezas de Pungo Andongo e Ambaca. O relevante é destacar aqui a existência de um quadrante que compreendia alguns dos nomes de lugares mais evocados nas fontes escritas da FHA - Ambaca, Kabasa, Vunga e o mais isolado deles, Pungo Andongo -, sendo esses lugares centros políticos mbundu renomados e que despertavam a atenção de funcionários e oficiais ultramarinos.

Making of the Atlantic World, 1400-1800. [1992]. Cambridge: Cambridge University Press, 1998, pp. 59-60. THORNTON, John K. A Cultural History of the Atlantic World [...]. Cambridge: Cambridge University Press, 2012, pp. 48-49. HEINTZE, Beatrix. Angola nos séculos XVI e XVII [...]. Luanda: Kilombelombe, 2007, pp. 280-281. Consultar também o último item do capítulo 4 desta dissertação.

${ }^{325}$ Fernão de Sousa. História das relações entre a Angola portuguesa e o Ndongo 1617-1624. S.d., por volta do outono de 1624. BAL, cód. 51-IX-20, ff. 414-14v. IN: HEINTZE, Beatrix (coord.). Documento 23, FHA, vol. I, 1985, p. 195. Em outro momento, Heintze adicionou que "as duas residências do rei do Ndongo, Vunga e Cabaça, foram realmente tomadas e destruídas pelos portugueses" durante a época de Luís Mendes de Vasconcelos. Verificar: HEINTZE, Beatrix. Angola nos séculos XVI e XVII [...]. Luanda: Kilombelombe, 2007, p. 296.

${ }^{326}$ Fernão de Sousa. História das relações entre a Angola portuguesa e o Ndongo 1617-1624. S.d., por volta do outono de 1624. BAL, cód. 51-IX-20, ff. 414-14v. IN: HEINTZE, Beatrix (coord.). Documento 23, FHA, vol. I, 1985, nota 3, p. 195. Seguindo as indicações de Beatrix Heintze, sobre a Vunga, consultar: Sem autoria [encomendado por João Correia de Sousa]. Mapa das regiões circunvizinhas de Luanda com uma minuciosa descrição. S.d., 1622. BAL, cód. 51-IX-20, f. 2. IN: HEINTZE, Beatrix (coord.). Documento 8, FHA, vol. I, 1985, pp. 158-165. Fernão de Sousa. O extenso relatório do governador aos seus filhos. S.d., 1625-1630. BAL, cód. 51-IX-20, ff. 220-74v. IN: HEINTZE, Beatrix (coord.). Documento 30, FHA, vol. I, 1985, pp. 217-362. Fernão de Sousa. A ilegitimidade do novo rei do Ndongo, Angola Aire. S.d., entre 20 de julho e 14 de setembro de 1629. BAL, cód. 51-IX-20, ff. 415-15v. IN: HEINTZE, Beatrix (coord.). Documento 28, FHA, vol. I, 1985, pp. 209-210. 2 de março de 1632. BRÁSIO, António (col. e anot.). MMA. Série 1, vol. VIII, 1960, p. 158. 
Fernão de Sousa prosseguiu a narrativa de 1624 afirmando que o governador Luís Mendes de Vasconcelos substituiu o "rei Angola Ambande", então fugido das residências reais e recolhido nas "ilhas da Cuanza na Quindonga", por um fantoche chamado pelas autoridades régias de "António Correia", cujo "nome da terra" era "Samba Antumba". A despeito de toda maquinação e execução dos planos de conquista, Luís Mendes de Vasconcelos e sua seara política não lograram êxito, uma vez que António Correia "não foi obedecido, assim por ser vivo Angola Ambande, como porque este gentio não obedece senão aos que são legitimamente filhos, ou descendentes do rei". ${ }^{327}$ Daí tirava-se uma importante lição: não era possível implantar uma pessoa totalmente estranha às linhagens que reinavam no Ndongo. Mais para frente notaremos que o aprendizado local será de grande valia, uma vez que a implantação de um "fantoche", um forasteiro intruso e desvinculado das relações linhageiras, era inaceitável, ou mesmo uma possibilidade irreal ou impensável, dentro do imaginário político dos mbundu. Tal erro não voltará a ser repetido por Fernão de Sousa.

\footnotetext{
${ }^{327}$ Fernão de Sousa. História das relações entre a Angola portuguesa e o Ndongo 1617-1624. S.d., por volta do outono de 1624. BAL, cód. 51-IX-20, ff. 414-14v. IN: HEINTZE, Beatrix (coord.). Documento 23, FHA, vol. I, 1985, pp. 195-196. Deposições e substituições de "reis" e "sultões", seguidas pelo avassalamento de uma elite tributária à monarquia portuguesa, foram frequentes nas regiões costeiras da África e Ásia desde 1486. Verificar: HEINTZE, Beatrix. Angola nos séculos XVI e XVII [...]. Luanda: Kilombelombe, 2007, p. 392.
} 


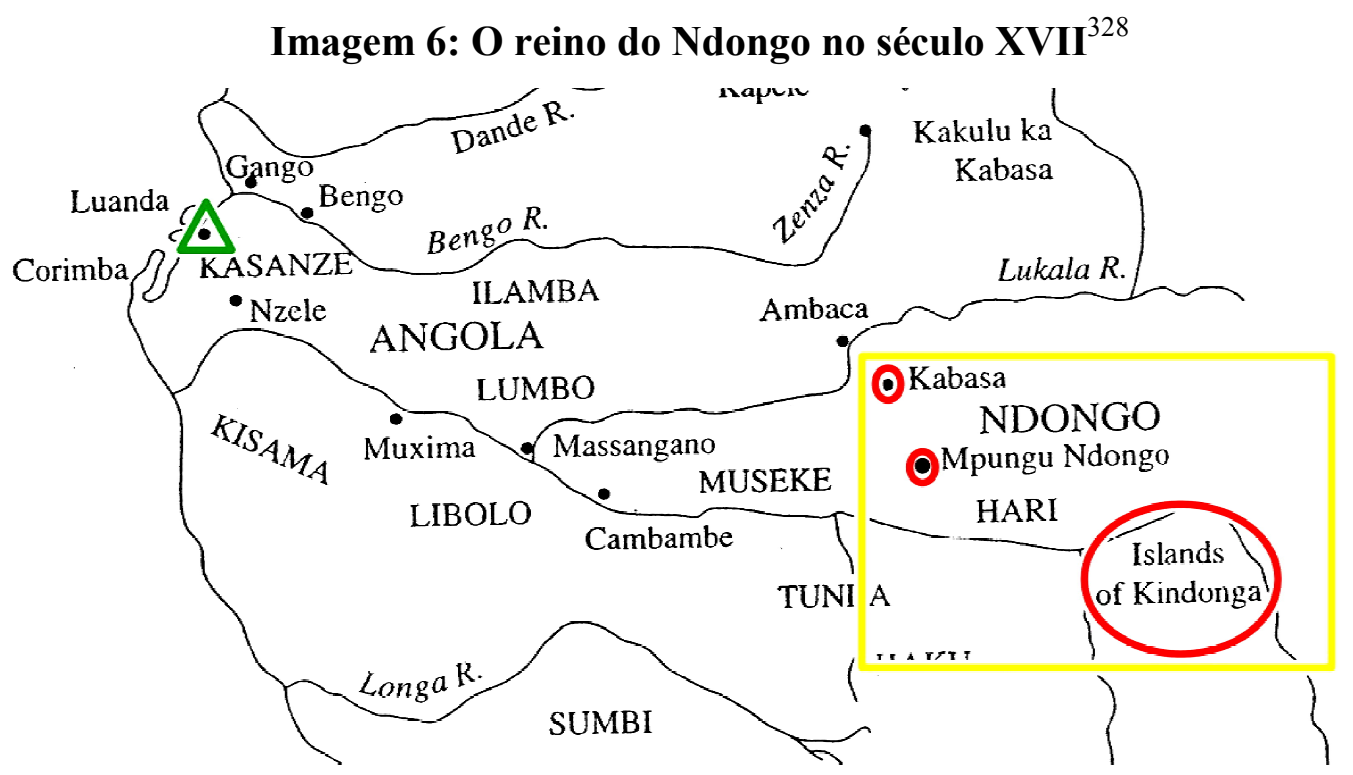

Legenda: $i)$ O retângulo dourado indica o espaço reivindicado como sendo o "reino do Ndongo"; ii) Os círculos vermelhos indicam os topônimos mbundu mais citados na $F H A$; iii) $\mathrm{O}$ triângulo em verde indica Luanda.

Sucintamente, o governo de Luís Mendes de Vasconcelos acabaria em 1621 com Luanda passando por agitações e desentendimentos sociopolíticos internos, além do evidente estremecimento das relações externas com o Ndongo. Tratava-se de um cenário caótico, agravado pelo fato de Angola Ambande estar nas ilhas de Quindonga "sem querer sair ou tungar em terra firme". ${ }^{329}$ Desalojado mas não aniquilado, o legítimo soberano mbundu e seus apoiadores sustentavam uma política avessa a Luanda, ${ }^{330}$ porém talvez inócua, uma vez que estava enfraquecido por um movimento de profunda desagregação entre os ngundu que apoiavam Angola Ambande. ${ }^{331}$ Outro agravante advindo do caos produzido por Luís Mendes de Vasconcelos decorreu da quantidade de cativos exportada

\footnotetext{
${ }^{328}$ Imagem retrabalhada a partir de: HEYWOOD, Linda M.; THORNTON, John K. Central Africans, Atlantic Creoles [...]. Cambridge: Cambridge University Press, 2007, p. 50.

${ }^{329}$ Fernão de Sousa. História das relações entre a Angola portuguesa e o Ndongo 1617-1624. S.d., por volta do outono de 1624. BAL, cód. 51-IX-20, ff. 414-14v. IN: HEINTZE, Beatrix (coord.). Documento 23, FHA, vol. I, 1985, p. 196. Nesse contexto, "tungar" quer dizer "morar". Para mais informações, conferir o "suplemento para alguns vocábulos africanos", inserido nesta dissertação.

${ }^{330}$ Nesse sentido, verificar o comentário em: HEINTZE, Beatrix. Angola nos séculos XVI e XVII [...]. Luanda: Kilombelombe, 2007, p. 296

${ }^{331}$ Ficamos também com sucinta conclusão de Beatrix Heintze: "A nível político, a guerra contra o Ndongo teve como consequência a expansão formal do domínio português, bem como a segmentação do Ndongo, mas não a submissão efectiva, e ainda menos, a sua destruição." Verificar: HEINTZE, Beatrix. Angola nos séculos XVI e XVII [...]. Luanda: Kilombelombe, 2007, p. 296.
} 
pelo porto de Luanda entre 1617 e 1621, girando por volta de 50.000, número que apesar de controverso "não parece, de forma alguma, irrealista", na opinião de Beatrix Heintze. ${ }^{332}$

O governador seguinte, João Correia de Sousa, ao aportar em Luanda, notou que "as coisas do Reino iam para a pior e que não havia feiras, nem comércio". Para amenizar a situação de recessão econômica, ${ }^{333}$ João Correia de Sousa decidiu enviar o padre Dionísio de Faria Barreto, acompanhado de um homem chamado Manoel Dias, ao "Ndongo e às ilhas" de Quindonga, a fim de cristianizar Angola Ambande e convencê-lo a deixar o ostracismo, "tungando em terra firme". Sem oferecer maiores detalhes, Fernão de Sousa afirmou que no encontro promovido nas ilhas de Quindonga "se trataram capitulações de amizade", de tal modo que Manoel Dias regressou a Luanda com as três "reféns" do ngola, enquanto que Dionísio de Faria Barreto foi retido em Quindonga. Na verdade, essas reféns eram as irmãs de Angola Ambande, sendo Ginga Ambande a mais velhas delas, seguida por Cambo e Quifunge. ${ }^{334}$ Juntos, o governador e as irmãs Ambande acertaram as condições de algo que seria chamado de "capitulações de amizade". Contentes com o acordo firmado, as líderes africanas voltaram às ilhas de Quindonga, na companhia do português Bento Rebelo Vilasboas, levando em mãos “as condições declaradas nos autos que tenho em meu poder”, ressaltou Fernão de Sousa. A diplomacia caminhava a passos largos até que um contratempo solapou o acordo de paz. Por motivos não declarados, em 1623 João Correia

\footnotetext{
${ }^{332}$ HEINTZE, Beatrix. Angola nos séculos XVI e XVII [...]. Luanda: Kilombelombe, 2007, pp. 294-296 e a nota 65 , onde a pesquisadora fornece algumas provas documentais importantes para sustentar a sua opinião, seguida por pesquisadores como Heywood e Thornton. Verificar: HEYWOOD, Linda M.; THORNTON, John K. Central Africans, Atlantic Creoles, and the Foundation of the Americas, 1585-1660. Cambridge: Cambridge University Press, 2007, p. 185. THORNTON, John K. A Cultural History of the Atlantic World [...]. Cambridge: Cambridge University Press, 2012, p. 185. Para uma cronologia detalhada sobre o governo de Luís Mendes de Vasconcelos que, no essencial, não diverge da narrativa acima exposta, verificar a obra sobrecitada de Beatrix Heintze, especificamente as pp. 284-286 e 288.

${ }^{333}$ Reforçando, portanto, a constatação de que as guerras em geral, por um lado, paralisavam o comércio e, por outro lado, proporcionavam um afluxo imenso de "peças" ao tráfico atlântico, legal e ilegal, circunscrito ao período de confronto bélico. É de consenso historiográfico que essa modalidade de aquisição de escravos, também chamada de "guerra econômica", estava atrelada aos saques e às pilhagens e não rendia quantidade de escravos de maneira constante, abastecendo tanto os mercados oficiais quanto os secundários.

${ }^{334}$ HEINTZE, Beatrix. Angola nos séculos XVI e XVII [...]. Luanda: Kilombelombe, 2007, p. 196. Em um texto anterior, Heintze ressaltou que há controvérsias a respeito da ordem de nascimento das três irmãs Ambande. Aqui seguimos a opinião da pesquisadora, para quem Ginga Ambande era a mais velha, seguida por Cambo e depois Quifunge. Verificar: HEINTZE, Beatrix. Translations as Sources for African History. History in Africa. Nova Jersey: African Studies Association, vol. 11, 1984, pp. 155 e 161, nota 30. O termo "refém" é em si problemático, pois como veremos mais para frente o mesmo não será mais empregado e nem rememorado por Fernão de Sousa. Nosso ponto é o de que há indícios suficientes para afirmar que a utilização terminológica variava de acordo com o interesse de momento dos autores-compositores das fontes escritas.
} 
de Sousa abandonou precocemente o posto de governador ultramarino e, ${ }^{335}$ dessa forma, "não tiveram efeito as ditas condições e capitulações" registradas nos autos. Talvez por prudência ou medo, Dionísio de Faria Barreto fugiu das ilhas do Cuanza, com a desculpa de que "vinha confessar-se a fortaleza de Ambaca". 336

Apesar de breves, as informações registradas por Fernão de Sousa fornecem pistas sobre a existência de alguns indivíduos importantes, atuantes especificamente nas visitas diplomáticas, reconhecidas também como "embaixadas". $\mathrm{Na}$ forma de agentes de intermediação, eles compactuavam com o funcionalismo régio e prestavam serviços de confiança e representatividade institucional-política. Um dos agentes referenciados na documentação é Manuel Dias, soldado português experiente na terra, descrito como “conquistador" e um dos "mais beneméritos do território", não sendo por menos que ficaria encarregado de uma visita diplomática tão delicada como a que fora despachada para o Ndongo. É inegável que Fernão de Sousa o tinha em conta, uma vez que o nomeou “auditor de campo" em 6 de setembro de 1624 e, apesar de ter sido posteriormente preso pela acusação de "negligência" durante o ataque holandês de 1624, ficou pouquíssimo tempo no cárcere. ${ }^{337}$ Sabe-se também que Manuel Dias detinha terras no Sequele e que era vereador na Câmara de Luanda. ${ }^{338}$ Surpreendentemente, a despeito de em 1630 ter sido acusado de transportar "clandestinamente escravos de Angola para o rio da Prata", no ano seguinte foi nomeado capitão-mor. ${ }^{339}$ Outro agente de intermediação citado recorrentemente na série documental investigada é Dionísio de Faria Barreto, um "clérigo originário de Matamba" tido em alta conta por Fernão de Sousa, que o caracterizou como um "teólogo de profissão,

\footnotetext{
${ }^{335}$ No documento consta apenas o seguinte trecho: “[...] e por se embarcar João Correia de Sousa e deixar o governo [...]". Sobre a data do abandono de Luanda por parte de João Correia de Sousa, verificar: HEINTZE, Beatrix (coord.). Apêndice: governadores de Angola, 1575 - 1639, FHA, vol. I, 1985, p. 393.

${ }^{336}$ Fernão de Sousa. História das relações entre a Angola portuguesa e o Ndongo 1617-1624. S.d., por volta do outono de 1624. BAL, cód. 51-IX-20, ff. 414-14v. IN: HEINTZE, Beatrix (coord.). Documento 23, FHA, vol. I, 1985, p. 196.

${ }^{337}$ O mesmo não aconteceria com Francisco Antunes da Silva, preso pelo mesmo motivo e que acabaria falecendo na prisão, como já dito.

${ }^{338}$ Eram "200 braças de terra craveira", recebidas em 20 de setembro e 1627 . O cargo de vereador estava vigente pelo menos desde 1629 .

339 Tal comércio ficou escancarado durante o tempo do então arrendador dos contratos de rendimento de Angola, António Fernandes d'Elvas. Verificar: HEINTZE, Beatrix. Angola nos séculos XVI e XVII [...]. Luanda: Kilombelombe, 2007, pp. 290-292. Para uma explanação geral sobre a atuação e as estratégias de negócio da família desse comerciante, consultar: HUTZ, Ana. Homem de Nação e de Negócio: redes comerciais no Mundo Ibérico (1580-1640). Tese de doutorado, Universidade de São Paulo (USP), 2014, parte 2. Sobre a atuação de Elvas em várias regiões da África, verificar o resumo em: GREEN, Tobias. Masters of Difference: Creolization and the Jewish presence in Cabo Verde, 1497-1672. Tese de doutorado, Universidade de Birmingham, 2007, pp. 185-186.
} 
filho da terra, mas exemplar, e de boas partes, e foi já provisor e vigário-geral, e governador do bispado sendo bispo Dom Frei Manoel Batista”. Eclesiástico nascido na terra, falante da língua kimbundu e conhecedor dos costumes mbundu, Dionísio de Faria Barreto era uma peça-chave na intermediação política, tanto como tradutor e interprete das informações trocadas, quanto pela mediação que porventura poderia exercer nas conversações junto à cúpula de comando do Ndongo. Apesar do respaldo institucional que tinha, por motivos que voltaremos a abordar ao longo deste capítulo, em 1625 Bento Rebelo Vilasboas prendeu o eclesiástico negro, que acabou embarcado para Portugal, à revelia de Fernão de Sousa. ${ }^{340} \mathrm{O}$ terceiro e último agente de intermediação bastante citado na $F H A$ é Bento Rebelo Vilasboas, português experiente na terra e dono de uma carreira políticaadministrativa de bons serviços prestados, sendo por isso estimado por Fernão de Sousa. Tinha alguma ambição, mas não acumulou riqueza ao longo da vida. Possivelmente entendia kimbundu e conhecia um pouco sobre os "usos e costumes" do gentio, só que muito menos do que padre Dionísio de Faria Barreto, contra quem remoia algum tipo de rivalidade pessoal ou mesmo institucional, o que talvez explique a prisão deste por aquele e o envio do africano a Portugal, além de outros eventos que apresentaremos mais para frente. $^{341}$

Mais do que simples enviados de Luanda, esses agentes de intermediação eram representantes diretos dos interesses que emanavam dos grupos sociopolíticos associados à Câmara de Luanda. Manuel Dias representava o interesse militar, Dionísio de Faria Barreto o eclesiástico e Bento Rebelo Vilasboas o administrativo. Juntos, eles formavam uma espécie de "junta diplomática", que nada mais era do que o reflexo, poderíamos também dizer a imagem de uma "encenação social", reprodutora dos interesses multifacetados e do equilíbrio que deveria reinar entre as elites influentes de Luanda. ${ }^{342}$ Residiam nos aspectos

\footnotetext{
${ }^{340}$ Sobre isso, verificar: Fernão de Sousa. História das relações entre a Angola portuguesa e o Ndongo 16171624. S.d., por volta do outono de 1624. BAL, cód. 51-IX-20, ff. 414-14v. IN: HEINTZE, Beatrix (coord.). Documento 23, FHA, vol. I, 1985, nota 4, p. 196.

${ }^{341}$ Informações gerais sobre Bento Rebelo Vilasboas podem ser consultadas em: HEINTZE, Beatrix. Breves biografias de alguns europeus em Angola (1620-1630). FHA, vol. I, 1985, pp. 112-113. Discorreremos mais sobre esse agente no próximo capítulo.

${ }^{342}$ Supondo também que as embaixadas carregavam consigo uma alta carga simbólica e ritualística ligada às normas de conduta política e "polida" da época, "induzindo um conjunto de disposições e motivações - um ethos - e definindo uma imagem da ordem cósmica - uma visão de mundo - por meio de um único conjunto de símbolos", dessa forma conotando um "modelo para e do modelo de aspectos [...] meras transposições de um e de outro". Verificar: GEERTZ, Clifford. A interpretação das Culturas. Rio de Janeiro: Editora
} 
da política interna ultramarina, ou seja, na deliberação política e na busca por consenso, duas tendências primordiais. A primeira dizia respeito à postura dos governadores de Angola. Um bom administrador régio não poderia ser intransigente, como fora Luís Mendes de Vasconcelos, senão despertaria o descontentamento de grupos rivais. Ao mesmo tempo, e esta é a segunda tendência, ele não poderia vacilar no momento de tomar partido de algumas causas, controlando as rédeas de um círculo de interesse e sociabilidade comum e, assim, "dar rumo" institucional a Luanda, meio pelo qual zelaria pela prosperidade econômica e pela bonança material dos moradores do ultramar. O desrespeito a essas tendências podia acarretar no surgimento de "crises" políticas e econômicas, culminando na ingovernabilidade total da Angola portuguesa, algo que pode ter sido o motivo da fuga abrupta de João Correia de Sousa, que durante a sua época pareceu ter negligenciado a importância do tráfico de escravos, interrompendo as guerras e não disponibilizando meios alternativos de angariar escravos. ${ }^{343}$

Após o malogro de João Correia de Sousa, a governadoria-geral foi sucedida por Pedro de Sousa Coelho, escolhido "por eleição" local em 1623. Comprometido com o prosseguimento das negociações em torno da paz, o soberano Ndongo enviou macunzes ao mais novo governador português, solicitando através deles o "cumprimento ao capitulado, de que se fizeram autos em aprovação dos de João Correia [de Sousa] que tenho em meu poder". Provavelmente a troca de missivas orais e escritas aconteceu entre maio e agosto de 1623, não tardando para que fossem interrompidas, pois aportou "o bispo Dom Frei Simão de Mascarenhas" em Luanda e, em agosto de 1623, acabou sendo o eclesiástico "eleito governador" de Angola, de tal modo que Pedro de Sousa Coelho foi destituído da governadoria e relegado à posição de capitão-mor. Ao tomar conhecimento da vinda e eleição de um novo governador, Angola Ambande prontamente enviou a Luanda um macunze, novamente solicitando à autoridade maior de Luanda para que "cumprisse o que estava assentado, e mandasse desoprimir o Reino [no Ndongo] do Jaga". Sabemos por informações posteriores que esse indivíduo era o chamado "Dom João Casanze", um temido chefe jaga-imbangala que rondava a região e que, no final da década de 1620 ,

Guanabara Koogan, 1989, p. 134, itálicos do autor. Para a simbolização de ordem política e as relações que ela mantém com o discurso diplomático, verificar especificamente a p. 156 dessa obra.

${ }^{343}$ Para mais informações sobre o governo de João Correia de Sousa, conferir: HEINTZE, Beatrix. Angola nos séculos XVI e XVII [...]. Luanda: Kilombelombe, 2007, pp. 297-301. 
estabeleceu residência na Baixa do Cassange, onde fundou o "reino de Kasanje".344 Acatando o desejo de Angola Ambande em expulsar o jaga, como também se mostrando inclinado à pacificação da região, Dom Frei Simão de Mascarenhas fez "outros autos que confirmou [sic] o que estava capitulado" e enviou Pedro de Sousa Coelho, nomeado às pressas capitão-mor, "acima para dar guerra ao jaga". A tentativa do bispo-governador era a de primeiro resolver a situação de caos político e social, para que com isso o comércio fosse retomado. Todavia, Pedro de Sousa Coelho não cumpriu as ordens de Dom Frei Simão de Mascarenhas, devido a "razões que não foram aprovadas, e paixões entre ele, e o bispo que procederam da eleição do governo". 345

Os acontecimentos acima destacados revelam que o período que vai de maio de 1623 até junho de 1624 foi marcado por inconstâncias internas e pelo aprofundamento de tendências desagregadoras, vale lembrar advindas da situação caótica na qual Luís Mendes de Vasconcelos deixara a região e que foi agravada após a deserção de João Correia de Sousa. Aliás, a alta rotatividade de governadores - na prática, Luanda teve três governadores em menos de três anos - nada mais era do que o reflexo de uma inexorável

\footnotetext{
${ }^{344} \mathrm{O}$ atual consenso em relação a isso foi defendido por Joseph C. Miller e depois reafirmado por Jan Vansina. Construído com base em tradições orais coletadas nos séculos XIX e XX, a história de fundação de Kasanje está respaldada nas chamadas "migrações lunda". Sucintamente, elas são caracterizadas pela partida de diversos grupos, identificados atualmente pelo etnônimo "lunda", do miolo da África Central e que após muitas andanças chegariam à costa atlântica no início do século XVII. Um dos grupos migrantes carregava consigo uma posição titular dissidente lunda, denominado kulaxingo. Ao longo da travessia continental, o grupo inicial liderado por kulaxingo sofreu diversas transformações sociopolíticas, até estabelecer moradia na baixa do Cassange, onde fundaria o afamado "Reino de Kasanje", no final da década de 1620. A partir da segunda metade do século XVII, os reinos de Kasanje e Matamba figurarão como os principais "estados intermediários" do tráfico de escravos, gerindo a interconexão entre o comércio continental e o mercado atlântico, ao mesmo tempo que exerciam o papel de "estados tampões", protegendo Luanda de qualquer invasão continental. Na explicação de Miller, era de Kasanje que partiria "a segunda principal rede de tráfico de escravos em Angola, ou seja, a oficial", enquanto que a rota secundária, "paralela e ilegal que vinha da Matamba até aos ndembu e seus aliados", divergiria do porto de Luanda, sobretudo abastecendo as naus holandesas. Também é relevante destacar que da série de migrações lunda surgiria as principais forças políticas na região após 1650, entre elas o "Kalandula, Kabuku ka Ndonga, Matamba, Holo, Kasanje, Mwa Ndonje, e outros". Verificar: MILLER, Joseph C. Poder politico e parentesco: Os antigos estados Mbundu em Angola. [1976]. Luanda: Arquivo Histórico Nacional, 1995, pp. 149, 189, 199 e 206. CURTIN, Philip D. et. al. African History: From Earliest Times to Independence. [1978]. Edimburgo: Longman Pearson Education, 1995, pp. 230-231. VANSINA, Jan. How Societies Are Born: Governance in West Central Africa before 1600. Charlottesville: University of Virginia Press, 2004, pp. 198-199.

${ }^{345}$ Fernão de Sousa. História das relações entre a Angola portuguesa e o Ndongo 1617-1624. S.d., por volta do outono de 1624. BAL, cód. 51-IX-20, ff. 414-14v. IN: HEINTZE, Beatrix (coord.). Documento 23, FHA, vol. I, 1985, p. 196. As datas aqui estipuladas foram retiradas de: HEINTZE, Beatrix (coord.). Apêndice: governadores de Angola, 1575 - 1639, FHA, vol. I, 1985, p. 393. Para uma boa cronologia sobre o governo de Simão Mascarenhas, conferir: HEINTZE, Beatrix. Angola nos séculos XVI e XVII [...]. Luanda: Kilombelombe, 2007, pp. 309-310.
} 
situação de "caos e crise" anunciada na lembrança de $1624 .{ }^{346}$ Além disso, a situação interna da Angola portuguesa e as relações externas de Luanda com o Ndongo se deteriorarão ainda mais durante a época do bispo-governador, devido a um episódio histórico que tão logo dará margem à controvérsia. Angola Ambande, aclamado como legítimo "rei" dos mbundu e soberano do "reino do Ndongo", descrente quanto às inconstâncias do diálogo em torno da paz e sofrendo com as "dilatações" do Ndongo, "julgou que eram de paixões, e morreu e dizem que de peçonha, que ele mesmo tomou de desesperado" na primavera de $1624 .{ }^{347}$ Com a morte do soberano africano, sua irmã mais velha e pretensamente cristianizada, "Dona Ana de Sousa Ginga Ambande", mais conhecida pela historiografia atual como "Nzinga a Mbande", 348 assumiu a liderança das linhagens e grupos de parentesco alojados em Quindonga. Após assumir a direção do Ndongo, a africana avisou a Dom Frei Simão de Mascarenhas sobre a morte do irmão e solicitou o "cumprimento dos autos" de paz, matéria sobre a qual Fernão de Sousa advertiu que o "Bispo não deu cumprimento logo". ${ }^{349}$ Perto do final da lembrança de 1624, parecia clara a situação calamitosa e desanimadora na qual Fernão de Sousa disse ter encontrado o domínio ultramarino às vésperas da tomada de posse da governadoria, ocorrida em junho de 1624. De forma sucinta, "caos e crise" generalizados emergiam de três esferas: intraelites dirigentes da Angola portuguesa, entre os representantes régios sediados em Luanda e enviados às ilhas de Quindonga e intralideranças do Ndongo.

\footnotetext{
${ }^{346}$ Esses governadores eram cronologicamente João Correia de Sousa (1621-1623), Pedro de Sousa Coelho (1623) e o frade e bispo Dom Frei Simão de Mascarenhas (1623-1624). Atentando para o fato de que o prazo normal para a função de governador de Angola era o de três anos. Tal padrão é perceptível, por exemplo, em: HEINTZE, Beatrix (coord.). Apêndice: governadores de Angola, 1575 - 1639, FHA, vol. I, 1985, p. 393.

${ }^{347}$ Fernão de Sousa. História das relações entre a Angola portuguesa e o Ndongo 1617-1624. S.d., por volta do outono de 1624. BAL, cód. 51-IX-20, ff. 414-14v. IN: HEINTZE, Beatrix (coord.). Documento 23, FHA, vol. I, 1985, nota 8, p. 196.

${ }^{348}$ Conforme Beatrix Heintze explica, Ginga Ambande havia sido batizada em Luanda em 1622, na companhia de suas duas irmãs, Cambo e Quifunge. Seu padrinho fora o então governador João Correia de Sousa, sendo a madrinha provavelmente Ana da Silva, irmã de Francisco Antunes da Silva e esposa de Paio de Araújo de Azevedo. Verificar: Ibidem, nota 9, p. 196. HEINTZE, Beatrix (coord.). Breves biografias de alguns europeus em Angola (1620-1630). FHA, vol. I, 1985, p. 107. Sobre as grafias completas nos nomes da africana, verificar: MILLER, Joseph C. Legitimacy and Political Power: Queen Njinga, 1624-1663. The Journal of African History. Cambridge: Cambridge University Press, vol. 32, n. ${ }^{\circ} 1$, 1991, nota 2, p. 25. Para uma perspectiva distinta da de Heintze, sobretudo tributária de uma leitura dos escritos de João António Cavazzi de Montecúccolo e António de Oliveira e Cadornega, consultar: FONSECA, M.B. Nzinga Mbandi e as guerras de resistência em Angola: século XVII. Dissertação de mestrado em História Social, Universidade de São Paulo (USP), 2012, especialmente os itens 3.2 e 3.3.

${ }^{349}$ Fernão de Sousa. História das relações entre a Angola portuguesa e o Ndongo 1617-1624. S.d., por volta do outono de 1624. BAL, cód. 51-IX-20, ff. 414-14v. IN: HEINTZE, Beatrix (coord.). Documento 23, FHA, vol. I, 1985, p. 196.
} 


\subsection{O paradigma do antigo comércio conjugado ao refortalecimento do}

\section{Ndongo (1617-1624)}

Tão logo ocupou a administração da Angola portuguesa, Fernão de Sousa recebeu das mãos de Bento Rebelo Vilasboas as "cartas de Dona Ana senhora de Angola”. Após lêlas, o novo governador constatou que era preciso ter cautela com o "trato" destinado à líder africana, para que o quadro geral das relações entre Luanda e Ndongo não se deteriorasse ainda mais. Está contida na lembrança de 1624 também uma "pista", relacionada diretamente aos aspectos que deram forma à composição geral da série de documentos aqui analisada. No último trecho da documentação de 1624, o recém-empossado governador Fernão de Sousa afirmou que os restantes dos "termos" e das "relações" sobre os acontecimentos decorrentes desde 1617 continuariam a ser tratados conforme "o que se verão do caderno das coisas deste Reino até o presente", 350 assim anunciando o porvir de mais escritos relacionados à memória institucional local. Fernão de Sousa estava propenso a continuar com a narrativa sobre os acontecimentos passados, tendo a convicção e o discernimento sobre a importância das "lembranças" e "relações" como conjuntos de fontes escritas capazes de advogar para o seu comprometimento com o serviço ultramarino. No mais, a simples decisão de compor a série de narrativas de cunho histórico já fazia parte das intenções legitimadoras de Fernão de Sousa, segundo as quais os "bons feitos" de seu governo deveriam ser exaltados, seus erros pessoais camuflados e os vacilos de seus predecessores indicados, na forma de um emaranhado de experiências históricas e opiniões institucionais amalgamadas entre si, resultando na composição escrita de uma série de memórias oficiais não destituída de julgamentos e avaliações pessoais suas e de seus informantes. Na busca por explicações e legitimações jurídico-políticas, fatos e argumentos do presente e do passado poderiam ser manejados e reorganizados em prol de uma retórica e de um discurso favoráveis ao governo de Fernão de Sousa (1624-1630). Assim sendo, muito do que sabemos sobre a terceira fase de expansão e contato de Portugal no Ndongo é tributário desse tipo de saber assentado em papel.

\footnotetext{
${ }^{350}$ Fernão de Sousa. História das relações entre a Angola portuguesa e o Ndongo 1617-1624. S.d., por volta do outono de 1624. BAL, cód. 51-IX-20, ff. 414-14v. IN: HEINTZE, Beatrix (coord.). Documento 23, FHA, vol. I, 1985, p. 197.
} 
Prosseguindo com a análise aqui proposta, em 6 de setembro de 1625 o governador compôs uma segunda memória oficial, esclarecendo, na primeira linha dela, que escrevia uma "relação de Ndongo". Não se tratava, porém, de um Ndongo qualquer, marcando uma diferença fulcral entre as narrativas de 1624 e a de 1625. Enquanto que a primeira propunha uma "lembrança" política dos fatos que marcaram a condução institucional e diplomática dos contatos entre 1617 e 1624, na relação de 1625 Fernão de Sousa levantou como mote a elucidação sobre a ligação do Ndongo com o "comércio de Angola". ${ }^{351}$ Em linhas gerais, continua o administrador português, o comércio de Angola consistia no envio de "escravos que vão de mar em fora a que chamam peças de que se pagam os direitos a Vossa Majestade", sendo que a totalidade das "peças", ou seja, de escravos exportáveis via Oceano Atlântico, ${ }^{352}$ era proveniente "deste reino [de Ndongo], porque no de Congo se resgata panaria que fica na terra[,] porque os escravos que dele vêm não serem para a armação por serem Anzicos e morrem muitos". ${ }^{353}$ Fernão de Sousa segue afirmando que a

${ }^{351}$ Viés analítico abordado com profundidade por Beatrix Heintze que, com perspicácia, salientou que a despeito de "preservar a sua independência em numerosas batalhas", as relações econômicas e políticas mantidas entre Luanda e o Ndongo estavam fundadas em uma "estreita associação com o comércio atlântico de escravos que estabelecera uma interdependência entre a classe dirigente africana e os portugueses no litoral". Principal fornecedor de escravos desde o último quartel do século XVI e nas primeiras décadas do XVII, provinha do Ndongo e de regiões "tão longínquas como Matamba" o grosso dos escravos que eram embarcados legalmente no porto de Luanda, chegando a atingir de 12.000 até 13.000 pessoas exportadas anualmente. HEINTZE, Beatrix. Angola nos séculos XVI e XVII [...]. Luanda: Kilombelombe, 2007, p. 279.

${ }^{352} \mathrm{Na}$ documentação que utilizamos, o vocábulo mais comum para designar os indivíduos escravizados e inseridos nas rotas comerciais não é "escravo", mas "peça", empregado às vezes também como sinônimo de "cativo". Quando uma "peça" tinha bom porte, plena saúde, era do sexo masculino e estava em boa idade de trabalho, ela levava o nome de "peça da Índia", atingindo altos valores nos leilões portuários e feiras interioranas de escravos. Era como se os centro-africanos, ao virarem "peças", passassem pelo processo de reificação e transformação em mercadoria, através da estipulação de um valor de mercado baseado, sobretudo, no potencial de trabalho. Para mais informações, conferir o termo "moleque", contido no "suplemento para alguns vocábulos africanos" inserido nesta dissertação.

${ }^{353}$ História das relações entre a Angola portuguesa e o Ndongo 1617 - setembro de 1625. 6 de setembro de 1625. BAL, cód. 51-IX-20, ff. 326-27. IN: HEINTZE, Beatrix (coord.). Documento 24, FHA, vol. I, 1985, p. 197. Sobre "anzico", consultar o capítulo anterior, além do "suplemento para alguns vocábulos africanos", fornecido nesta dissertação. Como ressalta David Birmingham, os escravos eram virtualmente $o$ bem exportável (commodity) via comércio atlântico. Verificar: BIRMINGHAM, David. Trade and conflict in Angola [...]. Londres: Clarendon Press/ Oxford University Press, 1966, pp. 25-26. A chamada "panaria" consistia em panos de ráfia, de variedades distintas e que eram produzidas sobretudo no Kongo e em Loango, onde uma espécie de "indústria têxtil" preexistia à chegada das naus portuguesas. Por toda a região, a panaria era utilizada como insígnias de prestígio, sendo trocada entre as elites locais e encarada entre os mbundu como um produto de comutação. Verificar: THORNTON, John K. Africa and Africans [...]. [1992]. Cambridge: Cambridge University Press, 1998, pp. 49-50 e 53. Ver também a obra supracitada de Birmingham, p. 79. Na Angola portuguesa, os panos acabariam adotados como uma moeda corrente dos negócios locais e regionais, sendo bastante utilizadas no comércio continental de escravos. HEYWOOD, Linda M.; THORNTON, John K. Central Africans, Atlantic Creoles [...]. Cambridge: Cambridge University Press, 2007, p. 79. Durante o tempo de Fernão de Sousa, por motivos que não discutiremos aqui, os panos 
maioria das peças exportadas pelo mercado atlântico, ou "escravos regatados", 354 era comercializada por "El-rei de Angola ${ }^{355}$ nas feiras que fazia com os portugueses por fazendas do Reino [de Portugal]", algo apenas possível porque esses escravos "estava[m] obedecido[s] de Ndongo" e podiam os seus soberanos, baseados na tradição e nos costumes centenários existentes na região, "vendê-los justamente por serem todos seus cativos". ${ }^{356} \mathrm{~A}$ título de justificativa legal e oficial, a relação de 1625 sustenta que as peças adquiridas nas feiras do Ndongo eram todas escravas de nascimento e sangue, ou seja, tratava-se de uma “escravidão inata" ou congênita. ${ }^{357}$ Se haviam sido adquiridas há muito tempo atrás por meio de comércio, ou escravizadas por meio de guerra, não sabemos. Fato é que, na lógica de quem compôs o documento de 1625, os títulos de escravidão dessas pessoas eram "justos" porque os agentes comerciais dessa forma os legitimaram - por exemplo,

acabariam empregados como moeda prioritária para o pagamento do soldo de funcionários e oficiais, vindo depois deles as peças. Consultar: Fernão de Sousa [escritos por António Leitão]. Provisão e regimento de Fernão de Sousa sobre os salários de Angola. 18 e 21 de maio de 1629. BAL, cód. 51-IX-21, ff. 274-77v. IN: HEINTZE, Beatrix (coord.). Documento 1988, FHA, vol. II, 1988, pp. 288-296.

${ }^{354}$ No mundo atlântico, os termos "resgate" e "escravo resgatado" aceitam múltiplas acepções e empregos, todas elas relacionadas à escravidão como um negócio atlântico e que, por consequência, deveria ser organizado por meio de leis e regras. No excerto acima, "escravos resgatados" diziam respeito às "peças" comercializadas de modo legítimo, obtidas por meio daquilo que Fernão de Sousa chama vulgarmente de "antigo comércio", encarado então como um "trato tradicional". Na teoria, isso equivalia a dizer que esses escravos haviam sido obtidos por meio do comércio com autoridades africanas, cujo estatuto da escravidão não suscitava discórdia e nem exame de obtenção de título de escravidão, devido à assunção de que, por estar enraizado nas sociedades provedoras e negociadoras de "peças", o estatuto de cativo era naturalmente legítimo. Verificar: BONCIANI, Rodrigo Faustinoni. $O$ dominium sobre os indigenas e africanos e a especificidade da soberania régia no Atlântico: Da colonização das ilhas à política ultramarina de Felipe III (1493-1615). Tese de doutorado, Universidade de São Paulo (USP), 2010, p. 163, principalmente a nota 445, e p. 175. Para uma posição diferente, na qual os "regates" foram interpretados como sendo "mercados", conferir: HEYWOOD, Linda M.; THORNTON, John K. Central Africans, Atlantic Creoles [...]. Cambridge: Cambridge University Press, 2007, pp. 95-96. Na América portuguesa havia o chamado resgate "dos presos de corda", que consistia na compra como escravos de "vítimas do sacrifício ritual canibal, amarrados à cintura por uma corda antes de serem golpeados com um tacape, ou ivirapema". Nesse contexto, a escravização poderia ser interpretada como uma espécie de "salvação" de indígenas à beira da morte. Verificar: ZERON, Carlos Alberto de Moura Ribeiro. Linha de fé: a Companhia de Jesus e a Escravidão no Processo de Formação da Sociedade Colonial (Brasil, Séculos XVI e XVII). [1998]. São Paulo: Editora da Universidade de São Paulo, 2011, pp. 109-110 e 170-171. Para mais informações, consultar o capítulo 4 desta dissertação.

${ }^{355}$ Quer dizer, de modo geral, os soberanos do Ndongo.

${ }^{356}$ História das relações entre a Angola portuguesa e o Ndongo 1617 - setembro de 1625. 6 de setembro de 1625. BAL, cód. 51-IX-20, ff. 326-27. IN: HEINTZE, Beatrix (coord.). Documento 24, FHA, vol. I, 1985, p. 197.

${ }^{357}$ Diga-se de passagem, tendência essa símile entre outros povos africanos, como por exemplo os que habitavam nas florestas tropicais, como ressaltado em: VANSINA, Jan. L'homme, les forêts et le passé en Afrique. Annales. Économies, Sociétés, Civilisations. Paris: Éditions de l'EHESS, ano 40 ${ }^{\circ}$, n. ${ }^{\circ}$ 6, 1985, pp. 1322-1323. Lembra Vansina que, por mais que a escravidão estivesse atada ao nascimento, nada impedia que um escravo ascendesse socialmente dentro de determinada comunidade da floresta, ou que a condição de "escravo" estivesse inserida dentro de um "jogo ideológico", respaldado nas lógicas de parentesco e nas relações linhageiras. 
sustentaram que a escravização era reconhecida pelas normas do ngola,$-{ }^{358}$ com a conivência ou não das autoridades mbundu.

Embora tal generalização esteja em grande medida atrelada à necessidade de legitimação do trato negreiro, em vista dos exames dos títulos de escravização e à luz do direito português, ${ }^{359}$ é inegável que a instituição da escravidão e a comutação de pessoas eram aceitas pelos mbundu. Não era tudo uma mera quimera ou manipulação de Fernão de Sousa. Assim, subjacente ao registro escrito, jazia uma perspectiva mbundu, mediante a qual os escravos "negociáveis" pelo soberano do Ndongo provavelmente pertenciam ao escalão mais baixo da hierarquia social mbundu, os chamados "mubicas" e "quizicos", indivíduos sem laços de pertencimento direto aos grupos de filiação e que governavam o reino africano, proporcionando a venda sem embaraços ou constrangimentos internos às autoridades africanas e aos negociantes estrangeiros. ${ }^{360}$ Dessa forma, e considerando algumas reflexões feitas por Isabel Castro Henriques, é possível reafirmar que a identificação da "escravidão africana" pelos observadores coevos repousava tanto na ambição, quanto na motivação econômica, ligadas às “operações comerciais organizadas pelos europeus". Concomitantemente aos interesses mercantis do tráfico negreiro do Atlântico, a identificação de escravidão legítima estava respaldada nos laços de dependência e exclusão existentes no âmago das sociedades centro-africanas participantes do comércio de pessoas. Entre senhores e subordinados africanos, existiam laços e filiações

\footnotetext{
${ }^{358}$ Havia uma grande importância dos agentes comerciais na comprovação da licitude de escravidão, porém ineficaz no bloqueio da comercialização de indivíduos "injustamente reduzidos à servidão", como ressaltado em: ZERON, Carlos Alberto de Moura Ribeiro. Pombeiros e tangomaus, intermediários do tráfico de escravos na Africa. IN: LOUREIRO, Rui Manuel; GRUZINSKI, Serge (coord.). Passar as Fronteiras: Actas do II Colóquio Internacional sobre Mediadores Culturais, Séculos XV a XVIII. Braga: Centro de estudos Gil Eanes, 1999, pp. 34-35.

${ }^{359}$ Tais títulos advinham de uma "tradição jurídica antiga e medieval", sendo na síntese legal e erudita de Luís de Molina basicamente quatro, contanto que as pessoas escravas fossem cristãs: "além do princípio partus sequitur ventrem [nascimento], estes estímulos incluíam a guerra justa, o da comutação de uma pena de condenação à morte, e enfim alienação voluntária de uma pessoa maior de idade, ou sua prole, em caso de necessidade extrema". Verificar: Ibidem, p. 32. Voltaremos a tocar na questão dos títulos de escravidão no capítulo 4 desta dissertação. A legitimação jurídico-política da escravidão estava intimamente ligada a um discurso ideológico que validava o regime de trabalho baseado na mão-de-obra escrava, conforme explicado por esse mesmo pesquisador em: ZERON, Carlos Alberto de Moura Ribeiro. Les Jésuites et le commerce d'esclaves entre le Brésil et l'Angola à la fin du XVIe siècle: contribution à un débat. Traverse: Zeitschrift für Geschichte. Zurique: Éditions Chronos, n. ${ }^{\circ}$ 1, 1996, p. 42. Sobre algumas fórmulas e cláusulas estereotipadas que serviam para legitimar a atuação da Coroa no comércio de escravos, verificar: HEINTZE, Beatrix. Angola nos séculos XVI e XVII [...]. Luanda: Kilombelombe, 2007, p. 112.

${ }^{360}$ Cabendo ressaltar que, na teoria, os quizicos não poderiam ser vendidos. Sobre esses agentes comerciais, consultar o próximo capítulo.
} 
sociopolíticas capazes de serem aproximadas ou equiparadas às relações entre senhores e escravos, à moda da escravidão atlântica dos séculos XVI e XVII. Em suma, nas palavras de Henriques, "é da dependência que os homens partem para escravatura, ou seja transformando a diferença em agente de exclusão e dominação". 361

Uma dissociação precisa ser logo assinalada. O Ndongo não era um mero ponto de passagem de "peças", mas uma unidade sociopolítica onde os "escravos" despachados via Atlântico eram drenados da própria estrutura e hierarquia mbundu. Assim, nesse reino africano a organização social endógena estava intimamente integrada ao trato escravista de exportação, em contraste com outras soberanias centro-africanas setecentistas, capazes de exercer a função de um "conjunto de estados traficantes", economicamente monopolizador do comércio de pessoas e paulatinamente mais dependente do Atlântico até o século XIX, como explicou Joseph C. Miller. ${ }^{362}$ Além disso, e isto é mais importante de reter em mente, ao acoplar economias e sociedades distintas, o comércio transatlântico era capaz de interconectar usos e valores diferentes sob um mesmo conceito, o da "escravidão", garantindo com isso a prosperidade material da Angola portuguesa. ${ }^{363}$ Tais eram as bases do chamado "antigo comércio" ou "trato tradicional", ameaçado desde 1617 por Luís Mendes de Vasconcelos, que invadira o "reino do Ndongo" e "lançou" dele Angola Ambande. $^{364}$ A consequência imediata disso foi o início de um o estado de guerra generalizado, que acarretou em muitas mortes e "se cativaram inumerável gente com que faltou a abundância dos escravos", 365 como já foi abordado no item anterior. Apesar de confuso, esse fragmento de texto deixa claro que a guerra acarretou no aprisionamento de muita gente mbundu. Dentre as pessoas acorrentadas e trazidas a Luanda, existiam vários quizicos - são eles que conformam o grosso da população local -, mas também uma

${ }^{361}$ HENRIQUES, Isabel Castro. Reflexões sobre o "escravo" africano. IN: O Pássaro do mel: Estudos de História Africana. Lisboa: Edições Colibri, 2003, pp. 60-61 e 67.

362 MILLER, Joseph C. Poder político e parentesco [...]. [1976]. Luanda: Arquivo Histórico Nacional, 1995, pp. 205-206 e 218. Para a ideia geral de Miller, consultar a seguinte obra desse mesmo autor: Way of Death: Merchant Capitalism and the Angolan Slave Trade, 1730-1830. Madison: The University of Wisconsin Press, 1988. Ver também: FERREIRA, Roquinaldo. Cross-Cultural Exchange in the Atlantic World: Angola and Brazil During the Era of the Slave Trade. Cambridge: Cambridge University Press, 2012, pp. 23-24.

${ }^{363}$ Em consonância com: HEINTZE, Beatrix. Angola nos séculos XVI e XVII [...]. Luanda: Kilombelombe, 2007, capítulo 11. Para mais considerações sobre o comércio de escravos, consultar o próximo capítulo.

${ }^{364}$ Para uma explicação esquemática sobre o funcionamento do "antigo comércio", mas que no essencial emula o breve comentário de Fernão de Sousa, verificar: Ibidem, pp. 488-489.

${ }^{365}$ História das relações entre a Angola portuguesa e o Ndongo 1617 - setembro de 1625. 6 de setembro de 1625. BAL, cód. 51-IX-20, ff. 326-27. IN: HEINTZE, Beatrix (coord.). Documento 24, FHA, vol. I, 1985, p. 197. 
quantidade considerável de populações mbundu que apoiavam Angola Ambande, socialmente encaradas como "livres" e solidárias com as causas dos Ambande.

As guerras de Luís Mendes de Vasconcelos resultaram na exportação ininterrupta de escravos em um primeiro momento e, por consequência, em um segundo momento acarretou no esgotamento dos recursos humanos do Ndongo. ${ }^{366}$ Luís Mendes de Vasconcelos promovera guerras para escravizar gente nas redondezas, inicialmente rendendo muitos escravos, mas depois que elas cessaram as peças minguaram e a economia voltou a enfraquecer. Assim, seguindo a mesma tendência do documento de 1624, na relação de 1625 o final do governo de Luís Mendes de Vasconcelos é relegado a uma imagem de decadência e descrédito, pintada por um ciclo vicioso que intercalava quatro matérias entre si - estado de guerra, abalo político, interrupção comercial e escravização de gente livre -, de modo que o comércio ficou inoperante e "a gente que escapou [da guerra] se espalhou por diversas partes por se passar El-rei [Angola Ambande] a umas ilhas de Cuanza", também conhecidas como as "ilhas de Quindonga". De lá, miserável e abatido, Angola Ambande não mais saiu. Retomando acontecimentos narrados havia um ano, porém dessa vez adicionando e modificando informações de relativa importância, Fernão de Sousa também afirmou que o "jaga Dom João Casanze”, inicialmente aliado do exército português e inimigo das forças de Angola Ambande, passou a enfrentar o soberano mbundu por contra própria, sem mais contar com o apoio de Luanda, acabando por "consumi-lo" e "impediu o comércio que El-rei pudera continuar se tornara [sic] para a terra firme". 367

Foi nessa situação que João Correia de Sousa encontrou a Angola portuguesa ao aportar em Luanda. Novato na terra e empenhado em "reduzir a El-rei [...] e o tirar das

\footnotetext{
${ }^{366}$ História das relações entre a Angola portuguesa e o Ndongo 1617 - setembro de 1625. 6 de setembro de 1625. BAL, cód. 51-IX-20, ff. 326-27. IN: HEINTZE, Beatrix (coord.). Documento 24, FHA, vol. I, 1985, p. 197. A despeito, portanto, das baixas demográficas que as intempéries do clima, as faltas de mantimentos e as epidemias causavam na região. Contudo, é importante lembrar que em termos quantitativos e na longa duração esses três aspectos juntos exerceram mais perdas populacionais do que o tráfico sozinho. Verificar: DIAS, Jill. Famine and Disease in the History of Angola c. 1830-1930. The Journal of African History. Cambridge: Cambridge University Press, vol. 22, n. ${ }^{\circ}$ 3, 1981, p. 352. Sobre as questões do clima, fome, doenças, tráfico de escravos e os impactos demográficos gerados por esses quatro fatores, recomendamos a leitura por completo desse artigo de Jill Dias, além do seguinte: MILLER, Joseph C. The Significance of Drought, Disease and Famine in the Agriculturally Marginal Zones of West-Central Africa. The Journal of African History. Cambridge: Cambridge University Press, vol. 23, n. ${ }^{\circ}$ 1, 1982.

${ }^{367}$ Fernão de Sousa. História das relações entre a Angola portuguesa e o Ndongo 1617 - setembro de 1625.6 de setembro de 1625. BAL, cód. 51-IX-20, ff. 326-27. IN: HEINTZE, Beatrix (coord.). Documento 24, $F H A$, vol. I, 1985, p. 197. As mesmas informações são disponibilizadas em: THORNTON, John K. $A$ Cultural History of the Atlantic World [...]. Cambridge: Cambridge University Press, 2012, p. 185.
} 
ilhas", cria que "vindo para a terra se lhe ajuntariam os seus e se continuariam as feiras". Assim, o governador enviou ao Ndongo o padre Dionísio de Faria Barreto, homem com a experiência de ter sido "vigário-geral e governador deste bispado", além de ser conhecedor da "língua da terra", junto de Manoel Dias, com uma "oferta de paz" ao rei africano. Sobre isso já discorremos no item anterior, cabendo aqui apenas salientar algumas dissonâncias e complementaridades existentes entre os escritos de 1624 e 1625. De acordo com o primeiro, os enviados de João Correia de Sousa levavam consigo as chamadas condições de “capitulações de amizade", termos omitidos no segundo documento. Complementando essa informação, Fernão de Sousa escreveu que, após analisá-las, o soberano Angola Ambande acrescentou à oferta de paz alguns pedidos, aos quais denominaremos "cláusulas". A primeira delas declarava que, para o líder do Ndongo deixar de maneira segura as ilhas, seria necessário "desalojar [...] da terra ao jaga inimigo que atualmente lhe fazia guerra", ou seja, o jaga Dom João Casanze. A segunda cláusula era a de que o rei de Portugal deveria "largar os sobas, e quizicos de sua obediência que o governador Luís Mendes [de Vasconcelos] com guerra lhe tinha tomado", uma vez que "não podia ser rei sem vassalos que lhe obedecessem e sem cativos que o servissem". Em terceiro lugar, o presídio de Ambaca deveria voltar ao seu lugar de origem, na então região de Hango, porque estando ele "dentro das terras de Ndongo" e a um dia de "caminho da sua banza e corte", seria impossível "conservar [o mando e ordem do africano no Ndongo] estando presídio sobre ele de que não resultava utilidade a Vossa Majestade, antes grande impedimento para o comércio pela cobiça dos brancos". ${ }^{368}$ As cláusulas reivindicadas por Angola Ambande, juntamente com a opinião expressa por Fernão de Sousa nas narrativas históricas de 1624 e 1625, confluíam para a argumentação de que a desestabilização da ordem judiciária e do mando político no Ndongo, promovida pela falta de uma autoridade forte reestabelecida em Kabasa ou Vunga - o importante era ter uma espécie de "capital mbundu" em terra firme -, causava o pauperismo das populações mbundu do Ndongo e desestimulava o comércio de escravos, acarretando na penúria material de Luanda e dos presídios. Outro efeito colateral gerado pelo desmonte da soberania mbundu possivelmente foi o de deixar os sobas à mercê

\footnotetext{
${ }^{368}$ Fernão de Sousa. História das relações entre a Angola portuguesa e o Ndongo 1617 - setembro de 1625.6 de setembro de 1625. BAL, cód. 51-IX-20, ff. 326-27. IN: HEINTZE, Beatrix (coord.). Documento 24, FHA, vol. I, 1985, p. 198.
} 
da "cobiça dos brancos" de Ambaca, que extorquiam e chantageavam os chefes mbundu em troca de escravos.

Uma vez sugeridas as adições, a "oferta de paz" ou "de capitulações" foi reconduzida a Luanda por Manoel Dias, enquanto que o padre Dionísio de Faria Barreto permaneceu na companhia de Angola Ambande. ${ }^{369}$ Temos aqui uma discrepância de suma importância: na narrativa de 1624, foi registrada a informação de que as irmãs Ambande foram trazidas como "reféns" de Manoel Dias para Luanda, todavia no documento de 1625 essa informação é retirada. Na verdade, como logo abordaremos, alguns conjuntos de informações são totalmente reformulados. Seja como for, prosseguindo com a relação de 1625, após João Correia de Sousa ter conhecimento sobre as cláusulas reivindicadas por Angola Ambande, ele apresentou-as à Câmara de Luanda e aos "capitães e mais pessoas". ${ }^{370}$ Vale lembrar que esse era um recinto "público" de debate e discussão, onde os planos e rumos políticos regionais eram traçados. Eram membros efetivos da Câmara de Luanda pessoas ilustres e influentes que habitavam na dita "cidade", ou que exerciam alguma função ou ofício de importância. Na prática, porém, frequentava as seções de discussões camarárias qualquer pessoa que fosse influente o bastante para acessar o recinto institucional, membro de qualquer uma das alas de representatividade que auxiliavam no governo de Luanda: administradores, senhores, militares, comerciantes e eclesiásticos. ${ }^{371}$

Após discussões acerca das cláusulas inseridas por Angola Ambande, os membros da Câmara "assentaram" que o mais correto seria conceder ao ngola o que ele pedia, "por ser de maior utilidade para a Fazenda Real em bem comum deste Reino [de Angola], que para Ndongo pela grande fertilidade que nele haverá se estiver povoado e pelo proveito que redundaria das feiras". Ficou então decidido que o presídio de Ambaca deveria ser movido para "Luinha", 372 já que era um "sítio mais a propósito a ser socorrido que o de Ango onde d'antes estava". As elites dirigentes entendiam que a sustentação de Ambaca, no lugar onde estava, dificultava o refortalecimento da banza do rei do Ndongo, impedindo com isso a

\footnotetext{
${ }^{369}$ Fernão de Sousa. História das relações entre a Angola portuguesa e o Ndongo 1617 - setembro de 1625.6 de setembro de 1625. BAL, cód. 51-IX-20, ff. 326-27. IN: HEINTZE, Beatrix (coord.). Documento 24, FHA, vol. I, 1985, p. 198.

${ }^{370}$ Ibidem, p. 198.

${ }^{371}$ Lembrando que tais tipificações devem ser relativizadas. Por exemplo, os jesuítas podiam ser também "senhores de terras" e comerciantes, ao passo que os administradores régios comumente atuavam no comércio de escravos.

${ }^{372}$ Normalmente grafado na CDFS como "Loynha".
} 
retomada do comércio nos moldes tradicionais. A mesma crença implicou no apoio institucional à guerra contra o jaga "Dom João Casanze", sendo que o entendimento era o de que o aniquilamento do principal inimigo do ngola poderia fazê-lo "politicamente dependente dos portugueses e obrigá-lo a uma cooperação político-comercial com eles", como sugere Beatrix Heintze. ${ }^{373}$ Fato é que a Câmara de Luanda chegou a um consenso, resultado na produção de alguns "autos" que acabaram assinados por todos os presentes nesse recinto. Por intermédio de Bento Rebelo Vilasboas, os autos foram enviados às ilhas de Quindonga, onde seriam lidos por Dionísio de Faria Barreto a Angola Ambande. Segundo Fernão de Sousa, Angola Ambande ficou muito satisfeito com o que fora decidido. $^{374}$

Retomando sucintamente alguns pontos já destacados, é possível fazer algumas considerações. Em primeiro lugar, na narrativa de 1624 a participação de autoridades africanas em torno das “condições de capitulação", sobretudo das irmãs Ambande, é muito maior do que no documento de 1625, no qual uma "oferta de paz" foi negociada através da troca de missivas, obtendo destaque as funções de intermediação e diplomacia exercidas por Manoel Dias, Dionísio de Faria Barreto e Bento Rebelo Vilasboas. Neste documento, a participação de Ginga Ambande entre 1621 e 1623 é totalmente eclipsada, por motivos que abordaremos ao longo deste capítulo. ${ }^{375}$ Em segundo lugar, no que dizia respeito à produção de documentos como forma de inscrição formal do passado recente da Angola portuguesa, o que ocorreu foram a reformulação e o rearranjo de informações históricas em prol de uma maior oficialização institucional das decisões políticas acordadas, formalizados por meio da confecção de documentos escritos durante um período de maturação de ideias ocorrido entre o meio de 1624 e setembro 1625. Por detrás de todo o emaranhado de

\footnotetext{
${ }^{373}$ HEINTZE, Beatrix. Angola nos séculos XVI e XVII [...]. Luanda: Kilombelombe, 2007, p. 304. Nessa mesma página, Heintze sugere que "o Cristianismo deveria servir de alavanca ideológica complementar, para conseguir a submissão ambicionada e garantir, para sempre, o domínio dos portugueses", aspecto que poderia ter feito com que os eclesiásticos, composto pelos jesuítas e o padroado régio, apoiassem a decisão firmada na Câmara de Luanda.

${ }^{374}$ Fernão de Sousa. História das relações entre a Angola portuguesa e o Ndongo 1617 - setembro de 1625.6 de setembro de 1625. BAL, cód. 51-IX-20, ff. 326-27. IN: HEINTZE, Beatrix (coord.). Documento 24, FHA, vol. I, 1985, p. 198.

375 Apenas para reforçar esse ponto, conforme o que está escrito na lembrança de 1624, Ginga Ambande teve papel fundamental nas rodadas de negociações efetuadas durante o tempo de João Correia de Sousa. Não apenas essa informação foi excluída posteriormente, na relação de 1625 , como já dissemos, mas neste também Ginga Ambande seria relegada ao mero papel de "porta-voz" das reivindicações do irmão Angola Ambande, durante o governo de João Correia de Sousa. Em contrapartida, no documento de 1624, o responsável por encaminhar a missiva havia sido apenas um macunze.
} 
legalismos e negociações engendrados, havia atritos e tensões na Câmara de Luanda, além de uma sutil tentativa de riscar da memória institucional possíveis clivagens internas. ${ }^{376}$

Venho então a breve passagem de Pedro de Sousa Coelho pelo governo de Angola, ${ }^{377}$ na qual ficou determinado que a gente de guerra "partiria para a conquista lançar o jaga [Dom João Casanze] de Ndongo", conforme assentado em conselho. Nada mais é dito e a relação de 1625 pula para o governo de Dom Frei Simão Mascarenhas. Assim que soube que o eclesiástico fora incumbido da administração régia, Angola Ambande lembroulhe sobre a promessa feita pelos governadores anteriores "e para o obrigar mais lhe mandou os autos do assento que estava feito". Segundo Fernão de Sousa, Dom Frei Simão Mascarenhas havia cruzado as informações contidas nos autos enviados por Angola Ambande com as registradas nos autos acondicionados nos arquivos de Luanda, que eram os mesmos que o nosso reinol tinha em mãos no momento da escrita da relação de 1625 , chegando à conclusão de que o melhor seria enviar Pedro de Sousa Coelho, nomeado às pressas para o posto de capitão-mor do exército português, para "dar guerra ao jaga" Dom João Casanze. Contudo, o avanço militar não chegou a ser concretizado por dois motivos declarados no documento. Em primeiro lugar, ao saber que Pedro de Sousa Coelho partia de Luanda com um exército, Angola Ambande enviou uma “ordem” para o recém-nomeado capitão-mor, solicitando que ele "marchasse ao longo do Lucala, e não pelo meio do Ndongo por não destruir alguns poucos que começaram a ajuntar naquele Reino", o que "Pedro de Sousa Coelho recusou a fazer" e tudo voltou mais uma vez à estaca zero. O ngola e seu povo não eram tolos: sabiam que, por onde passassem, o exército português promoveria saques e pilhagens, como a memória coletiva dos tempos de Paulo Dias de

\footnotetext{
${ }^{376}$ Sobre as deduções aqui feitas, conferir especificamente: Fernão de Sousa. História das relações entre a Angola portuguesa e o Ndongo 1617-1624. S.d., por volta do outono de 1624. BAL, cód. 51-IX-20, ff. 41414v. IN: HEINTZE, Beatrix (coord.). Documento 23, FHA, vol. I, 1985, p. 196. Fernão de Sousa. História das relações entre a Angola portuguesa e o Ndongo 1617 - setembro de 1625. 6 de setembro de 1625. BAL, cód. 51-IX-20, ff. 326-27. IN: HEINTZE, Beatrix (coord.). Documento 24, FHA, vol. I, 1985, p. 198. A questão de Ginga Ambande e a sucessão régia no Ndongo está intimamente ligada à eleição de Angola Aire, como veremos ao longo deste capítulo.

${ }^{377}$ Novamente, a relação de 1625 apresenta uma modificação em relação à lembrança de 1624 . Nesta, Fernão de Sousa havia afirmado que, ao tomar conhecimento da súbita troca de governador, Angola Ambande enviou alguns macunzes a Luanda, a fim de retomar as negociações acerca da paz. Naquela, Fernão de Sousa afirmou que, ao tomar conhecimento da mudança administrativa ocorrida em Luanda, de imediato Angola Ambande mandou sua irmã mais velha, "que pelo nome da terra se chama Ginga e pelo de cristã Ana de Sousa", ao encontro do governador, a fim de solicitar o "cumprimento do assento" da oferta de paz. Fernão de Sousa. História das relações entre a Angola portuguesa e o Ndongo 1617 - setembro de 1625. 6 de setembro de 1625 . BAL, cód. 51-IX-20, ff. 326-27. IN: HEINTZE, Beatrix (coord.). Documento 24, FHA, vol. I, 1985 , p. 198.
} 
Novais e Luís Mendes de Vasconcelos conservava muito bem. Por sua vez, Pedro de Sousa Coelho não abriria guerra, colocando sua vida e a de seus homens em risco, a troco de nada. Os pedidos do ngola eram simplesmente uma afronta aos interesses da guerra portuguesa, de modo que, por "paixões do Bispo, e do governo, se recolheu no presídio de Ambaca de que resultou dividir-se a gente de guerra". ${ }^{378}$ Ofendido com a preferência régia dada ao bispo recém-escolhido governador e consternado com o rumo político na região, uma vez que os representantes diretos da monarquia não lhe davam ouvidos e nem respeitaram a decisão tomada em âmbito local - afinal de contas, ele havia sido escolhido "em conselho" para exercer o cargo mais alto da administração ultramarina ${ }^{-}$, Pedro de Sousa Coelho desacatou as ordens de superiores e não guerreou contra o jaga Dom João Casanze. Ao invés de unir os grupos locais em torno de uma causa comum, a preferência régia causara o efeito contrário, despertando a inveja e o desentendimento entre as autoridades locais. ${ }^{379}$

Nas palavras de Fernão de Sousa, ainda no governo de Dom Frei Simão Mascarenhas, as suspeitas e desconfianças de Angola Ambande eram grandes, em vista da postura vacilante de Luanda e dos desencontros de ideias acerca das posturas adotadas por dois agentes de intermediação que serviam na banza do ngola, Bento Rebelo Vilasboas e Dionísio de Faria Barreto. Novamente, aqui é importante examinar minuciosa e comparativamente as informações contidas nas narrativas de 1624 e 1625 . O chão-comum entre elas é o de que os dois representantes de Luanda permaneceram juntos na companhia dos Ambande, com a missão de convencer e agilizar o acordo de paz, desde a época de João Correia de Sousa. Na lembrança de 1624, está registrado que, após a súbita partida de João Correia de Sousa de Luanda, o eclesiástico teria "fugido" das ilhas de Quindonga, deixando Bento Rebelo Vilasboas sozinho. No documento composto em setembro de 1625, esse mesmo evento está associado ao período de governo de Dom Frei Simão Mascarenhas, precisamente após o vacilo de Pedro de Sousa Coelho em atacar o jaga Dom João Casanze, agravando as "desconfianças" e "suspeitas" que causariam a piora do quadro emocional de

\footnotetext{
${ }^{378}$ Fernão de Sousa. História das relações entre a Angola portuguesa e o Ndongo 1617 - setembro de 1625.6 de setembro de 1625. BAL, cód. 51-IX-20, ff. 326-27. IN: HEINTZE, Beatrix (coord.). Documento 24, FHA, vol. I, 1985, p. 198.

${ }^{379}$ De todo modo, há outros motivos que poderiam explicar a hesitação do bispo-governador, entre eles uma possível preocupação em relação à sucessão política no Kongo. Verificar: HEINTZE, Beatrix. Angola nos séculos XVI e XVII [...]. Luanda: Kilombelombe, 2007, p. 317.
} 
Angola Ambande, que tão logo viria a óbito. ${ }^{380}$ Acreditamos que a mudança nos registros não aconteceu por mero acaso ou descuido no momento da escrita. Sabe-se que ambos os agentes de intermediação, Bento Rebelo Vilasboas e Dionísio de Faria Barreto, contavam com a simpatia dos governadores João Correia de Sousa e Fernão de Sousa, mas em graus distintos: aparentemente Dionísio de Faria Barreto estava mais próximo do primeiro e Bento Rebelo Vilasboas do segundo. Além disso, ambos representavam alas distintas dos grupos sociopolíticos que dirigiam Luanda, sendo o padre africano próximo aos eclesiásticos, e o português experiente na terra à ala administrativa. Outros importantes indícios estão presentes em eventos posteriores, ligados ao governo de Fernão de Sousa. Logo que o nosso reinol chegou a Luanda, Bento Rebelo Vilasboas foi ao encontro dele, a fim de lhe apresentar a tão citada “oferta de paz". No ano seguinte, em 1625, Dionísio de Faria Barreto foi preso por Bento Rebelo Vilasboas e depois enviado para Portugal, como já dito no item anterior. Desde a chegada de Fernão de Sousa até a quebra das relações diplomáticas com Ginga Ambande, em algum momento da segunda metade de 1624, Bento Rebelo Vilasboas atuaria como homem de confiança do governador para os assuntos externos, como se fosse um "diplomata", representante e porta-voz do monarca português e de Luanda, na banza do Ndongo. Pelo menos entre 1627 e 1630, esse mesmo homem passaria a representar quase que exclusivamente os interesses de Luanda no Ndongo, como uma espécie de autoridade maior estrangeira, ou "embaixador", atuante na nova "capital" do Ndongo, "Pungo Andongo". De novo, o que presenciamos é a reformulação de informações de cunho histórico, que agora foram remodeladas de modo a beneficiar Bento Rebelo Vilasboas em detrimento de Dionísio de Faria Barreto. Mais relevante é perceber, contudo, como as dissonâncias e discrepâncias entre as fontes secundárias podem ser apreendidas através de uma análise crítica, preservando a historicização e contextualização de comprovativos textuais que, de modo algum, devem ser encarados como vestígios neutros sobre os fatos do passado.

Outra matéria de extrema importância às duas narrativas de época está ligada à morte de Angola Ambande. Abatido, o líder africano "brevemente morreu pelo desgosto, e

\footnotetext{
${ }^{380}$ No original está escrito: "Com este sucesso [referindo-se às inconstâncias de Luanda] se desconfiou El-rei [Angola Ambande] de tal modo, e concebeu tais suspeitas que se veio Dionísio de Faria, e ficou com ele Bento Rebelo, e brevemente morreu deste desgosto [...]". Verificar: Fernão de Sousa. História das relações entre a Angola portuguesa e o Ndongo 1617 - setembro de 1625. 6 de setembro de 1625. BAL, cód. 51-IX20, ff. 326-27. IN: HEINTZE, Beatrix (coord.). Documento 24, FHA, vol. I, 1985, p. 198.
} 
publicou-se de peçonha que tomou para isso por se lhe não cumprir a palavra, e por se ver esbulhado do Reino, e metido nas ilhas do rio Cuanza". ${ }^{381}$ A mesma informação foi repetida na lembrança de 1624, só que em setembro de 1625 Fernão de Sousa adicionaria mais conteúdo a ela. ${ }^{382}$ Neste momento, explicou o governador, antes de cometer suicídio por "peçonha", Angola Ambande teria feito questão de deixar "o pouco que possuía" encomendado "a Dona Ana de Sousa sua irmã, e em poder do jaga Casa um só filho que tinha por lhe parecer que estava com ele mais seguro de nós", sendo que esse tal "jaga Casa” era também conhecido como “jaga Dom João Casa Cangola”, não devendo ser confundido com o "jaga Dom João Casanze". 383

Aqui nos deteremos em um aspecto estritamente documental, capaz de render indícios relevantes sobre as relações tecidas entre Ginga Ambande, o jaga Dom João Casa Cangola e Angola Ambande. Nesse sentido, é preciso reacessar com minúcia e cautela os vestígios do passado, apurando aspectos do registro escrito e eventos históricos, para que nada passe desapercebido. De acordo com Beatrix Heintze, duas versões da relação de 6 de setembro de 1625 se encontram em BAL, sendo a versão utilizada na transcrição existente na $F H A$ correspondente ao códice 51-IX-20. A outra versão do mesmo documento, não datada, é o códice 51-IX-21. Apesar de as duas apresentarem no geral "diferenças de

${ }^{381}$ Beatrix Heintze afirma que, devido ao pequeno "apoio dinástico" que na época detinha, Ginga Ambande "não tardou a dirigir-se ao bispo governador de Luanda, para lhe comunicar a notícia da morte do ngola e a sua sucessão, tentando ao mesmo tempo convencê-lo a cumprir os acordos". Verificar: HEINTZE, Beatrix. Angola nos séculos XVI e XVII [...]. Luanda: Kilombelombe, 2007, p. 317.

${ }^{382}$ Alguns pesquisadores ainda sustentaram que o ngola havia sido envenenado por Ginga Ambande, algo que não é relatado nos documentos aqui analisados. Sobre isso, verificar: VANSINA, Jan. Kingdoms of the Savanna. Madison: University of Wisconsin Press, 1966, p. 134.

${ }^{383}$ Fernão de Sousa. História das relações entre a Angola portuguesa e o Ndongo 1617 - setembro de 1625.6 de setembro de 1625. BAL, cód. 51-IX-20, ff. 326-27. IN: HEINTZE, Beatrix (coord.). Documento 24, p. 199. Sobre as diferenças entre esses dois jagas, ambos registrados nesse documento de setembro de 1625, mas que diziam respeito a pessoas e acontecimentos distintos, verificar as notas 16 e 22 de Beatrix Heintze, pp. 197 e 199 respectivamente. Segundo Joseph C. Miller, o "caza [ou kasa] era originalmente um título do Libolo aparentado com o hango, mas pouco depois tornou-se um íntimo associado dos títulos Lunda" que migravam do interior para a costa do continente africano, motivo pelo qual também é referido como kaza ka hango. Por sua vez, "Casanze" está associado especificamente à série de ondas migratórias lideradas por kulaxingo. Menos poderoso do que este, mas igualmente temido, o "casa" combateria ao lado das tropas portuguesas no início do século XVII, mas por motivos ainda desconhecidos acabaria expulso das redondezas do Ndongo em 1621, reaparecendo por lá em meados de 1624. Verificar: MILLER, Joseph C. Poder político e parentesco [...]. [1976]. Luanda: Arquivo Histórico Nacional, 1995, pp. 166, especificamente a nota 53 e 216. 
pouca monta", conforme as palavras de Heintze, ${ }^{384}$ especificamente após a narrativa sobre o assassinato do filho de Angola Ambande encontra-se, no códice 51-IX-21, logo no final do fólio 224, o título "sobre os escravos fugidos e guerras", retirado da versão datada. ${ }^{385}$ Talvez a obliteração dessa breve informação chamasse pouca atenção da administração régia, mas o leitor mais desassossegado perceberá que há nesse pequeno ato um indício valioso: tenta-se divergir o olhar do leitor de matérias tão delicadas e até então irresolutas a fuga de escravos, a consequente falta de ordem na região e as guerras que não cessam -, ao passo que o ato de apagamento do pequeno título adverte para a intenção deliberada de atenuar os problemas enfrentados em campo. Vale complementar que, paradoxalmente a essa intenção furtiva, Fernão de Sousa teve que fazer referência em escrito a todos os problemas que persistiram durante o seu governo, devido à relevância que eles tinham e às pressões exercidas por parte dos superiores reinóis. $O$ funcionário reinol tinha as suas artimanhas, mas não era omisso.

Figurando como parte do cotidiano Angola portuguesa, a fuga de escravos capturados em guerras era uma tônica de importância a partir da segunda metade de 1625, não podendo ser negligenciada em vista do processo histórico em voga desde 1617, marcada pelos vai-e-vens das campanhas militares e pela crise política vivida no Ndongo. Desde então, a sustentação de Angola Ambande no Ndongo estava abalada não apenas pela iminência de confronto bélico com os oficiais de Luanda e os jagas de Dom João Casanze, mas também pelos abalos e inconstâncias internos sofridos na cúpula de comando do Ndongo, fraturada após captura de parte considerável dos sobas e murindas que a apoiava no comando dos quizicos. Daí emana outro motivo que advoga para a importância de falar de "guerras" junto do tópico da "fuga de escravos", pois a população aprisionada no tempo de Luís Mendes de Vasconcelos, à espera de embarque nos tumbeiros ou que servia como mão-de-obra compulsória nos arimos portugueses, ainda clamava pertencimento e reciprocidade aos grupos de filiação encabeçados por Angola Ambande. Sendo mais preciso, regenerar e refortalecer a soberania do Ndongo daria motivo para os escravizados

\footnotetext{
${ }^{384}$ Fernão de Sousa. História das relações entre a Angola portuguesa e o Ndongo 1617 - setembro de 1625.6 de setembro de 1625. BAL, cód. 51-IX-20, ff. 326-27. IN: HEINTZE, Beatrix (coord.). Documento 24, FHA, vol. I, 1985, nota 11, p. 197.

${ }^{385}$ Fernão de Sousa. História das relações entre a Angola portuguesa e o Ndongo 1617 - setembro de 1625.6 de setembro de 1625. BAL, cód. 51-IX-20, ff. 326-27. IN: HEINTZE, Beatrix (coord.). Documento 24, FHA, vol. I, 1985, nota 23, p. 199.
} 
de guerra se juntarem novamente ao ngola, assim ocasionando a fuga em massa do litoral. $^{386}$

Mas por que retirar esse subtítulo "sobre os escravos fugidos e guerras" da versão que acabaria inserida na $F H A$ ? Insistimos nesse ponto por um último motivo. Por mais que a fuga de escravos fosse matéria de suma importância para uma parcela dos moradores portugueses, sobretudo para os senhores de escravos e proprietários de arimos, fato é que Fernão de Sousa optou pela omissão provavelmente para não suscitar embaraços à organização discursiva da composição textual. Assim, o importante era não fornecer brechas para enfraquecer a principal argumentação desenvolvida na relação de 1625, ligada à retomada do antigo comércio mediante as bases de cooperação e parceria com um Ndongo fortalecido. Apesar disso, e paradoxalmente ao desdobramento das ações tal como viria de fato a acontecer, a construção discursiva de Fernão de Sousa era uma fantasia. Dito de outra forma, tratava-se da adução incomprovada do paradigma de que a retomada do antigo comércio pressupunha o refortalecimento da soberania de Angola Ambande, ou de modelo de soberania símile ao dele, conquanto destituída e apartada de experiências factuais e coevas. Primeiramente, porque a fuga de escravos não seria mais tolerada por ninguém que dependesse da escravidão como meio de vida, ou seja, virtualmente todos os moradores da Angola portuguesa. Segundo, pois nada garantia que as feiras continuariam a funcionar como outrora. Em terceiro lugar, e isto é mais importante, cresciam no Ndongo as forças desagregadoras vindas "de dentro".

Ao notar a fragilidade pela qual passava o reinado de Angola Ambande, outras elites mbundu passaram a vislumbrar uma possibilidade real de tomar a insígnia e a posição

\footnotetext{
${ }^{386}$ Assim, segundo Beatrix Heintze, as elucubrações de Fernão de Sousa confirmam dois pontos muito importantes a respeito dessas fugas de escravos. O primeiro era o de que a maioria dos cativos que cultivava as propriedades portuguesas era composta de "prisioneiros de guerra do Ndongo, provenientes de territórios que agora estavam sob a autoridade portuguesa". O segundo é o de que, contido nas "entrelinhas" dos escritos de Fernão de Sousa, é possível perceber que "os escravos oriundos do Ndongo tinham sido maioritariamente capturados - como se pode depreender dos pareceres sobre a questão kijiku - numa guerra que no geral foi classificada de 'injusta', durante o mandato de Luís Mendes de Vasconcelos, o que lhes conferia um direito legal à libertação". Verificar: HEINTZE, Beatrix. Angola nos séculos XVI e XVII [...]. Luanda: Kilombelombe, 2007, pp. 333-334. Mais recentemente John K. Thornton lançou algumas especulações a respeito das fugas e deslocamentos populacionais, afirmando que elas não eram tão relevantes a ponto de modificar profundamente as populações que habitavam o planalto do Cuanza, divergindo da opinião de Joseph C. Miller. Verificar: HEYWOOD, Linda M.; THORNTON, John K. Central Africans, Atlantic Creoles [...]. Cambridge: Cambridge University Press, 2007, pp. 160-162. MILLER, Joseph C. Way of Death: Merchant Capitalism and the Angolan Slave Trade, 1730-1830. Madison: The University of Wisconsin Press, 1988, pp. 22, 37-38. De todo modo, a importância dessa matéria era tão grande que reaparece em outros documentos, como retomaremos no capítulo 4 desta dissertação.
} 
de ngola para si. Dentre as forças refratárias ao ngundu governante, despontavam os líderes da província de Are. Aliás, circulavam as notícias de que as forças de Dom João Casanze engrandeciam, passando o inimigo jaga a figurar como um perigo real, algo que despertava a apreensão de Angola Ambande. Se o jaga mancomunasse com Are um ataque às ilhas de Quindonga, as chances de Angola Ambande sucumbir eram grandes. Em vista da situação política delicada pela qual passava o Ndongo, a reaproximação política com Luanda parecia uma solução viável. Era necessário colocar qualquer ressentimento ou vaidade que ainda existia de lado, pois o que estava em jogo era a própria sobrevivência política de Angola Ambande, sua família e prole na corte real. É por isso que acreditamos que ele foi favorável à reaproximação diplomática de Luanda e conducente ao tráfico de escravos: o soberano mbundu buscava na cooperação e parceria luso-africanas mais prestígio para o seu grupo de filiação, além de auxílio militar que poderia ser fornecido contra Dom João Casanze. Assim, se à primeira vista o processo histórico parecia ser dúbio - Luanda foi a causa das mazelas do ngola e, mesmo assim, ele procurou uma reconciliação política com ela -, por outro lado tal ele é explicado à luz da manutenção política dos Ambande no Ndongo, intimamente respaldada na regeneração hierárquica e institucional do Ndongo e nos princípios essenciais da cosmogonia endógena. ${ }^{387}$

Na prática, o rumo histórico divergiu em muito das pretensões retórico-discursivas de Fernão de Sousa e do cálculo político inicialmente operado por Angola Ambande. Às vésperas de sua morte, o ngola considerou mais prudente entregar seu único menino, primeiro na linha de sucessão política do Ndongo, ao temido líder jaga Dom João Casa Cangola, para que ele o protegesse caso o Ndongo viesse a ruir. No trono real sentou Ginga Ambande, possivelmente de maneira interina e sem causar constrangimento ao ngundu, em algum momento impreciso de 1624. Depois disso, a relação de 1625 segue afirmando que, logo após "empossar o governo" do Ndongo, a líder africana solicitara ao jaga Dom João Casa Cangola seu sobrinho e, tendo-o em mãos, "o matou por se perpetuar o governo contra todo o direito", ou seja, o assassinato do menino Ambande, além de ser um crime contra a vida, estava ancorado no desrespeito à sequência de sucessão legítima no Ndongo. Criticando a conduta do "Bispo Governador", Fernão de Sousa afirmou que ele foi negligente ao não pedir ao jaga o filho de Angola Ambande, pois salvaguardando o garoto,

\footnotetext{
${ }^{387}$ Nesse sentido, lembrar principalmente dos itens 1 e 2 do capítulo anterior.
} 
o governador poderia "metê-lo no Reino [de Angola] em nome de Vossa Majestade[,] com que ficava tudo seguro". ${ }^{388}$ Por fim, exprimiu Fernão de Sousa por meio de uma glosa conclusiva, tal era o "estado calamitoso" no qual encontrara o "Reino [de Angola] e o de Ndongo, e o Bispo que corria com Dona Ana [Ginga Ambande], mas sem feiras, e resgate, que é mais miserável que possa ser", 389

\subsection{Os princípios da "conquista do Ndongo" em 1625}

Pela metade do corpo de texto da relação datada de setembro de 1625 , ocorre uma descrição de algo que podemos considerar como sendo um conteúdo "inédito" para época, pelo menos em termos históricos e em razão da comunicação régia mantida entre a governadoria de Luanda e a monarquia portuguesa. Logo que tomara posse do governo em Luanda, Fernão de Sousa deparou com uma situação econômica e política nada favorável na Angola portuguesa, descrita por jargões remetidos às "calamidades" e às “desestabilizações" advindas do ciclo vicioso criado pelo governo de Luís Mendes de Vasconcelos. Prezando pela retomada do comércio de escravo nas feiras do Ndongo e, com isso, apoiando-se no paradigma destrinchado no item anterior, ${ }^{390}$ assim que tomou as rédeas do governo, Fernão de Sousa salientou que faria de tudo para que Ginga Ambande "passasse para terra firme", facilitando concomitantemente a isso a "entrada aos padres da Companhia [de Jesus]" no Ndongo renovado. ${ }^{391}$ Além do mais, observou Fernão de Sousa, parecia consensual que a carência de peças estava ligada à "ausência de rei em Ndongo", necessário para barrar "o jaga virem $[$ sic $]$ às feiras com a guerra que faz", referindo-se ao

\footnotetext{
${ }^{388}$ Fernão de Sousa. História das relações entre a Angola portuguesa e o Ndongo 1617 - setembro de 1625.6 de setembro de 1625. BAL, cód. 51-IX-20, ff. 326-27. IN: HEINTZE, Beatrix (coord.). Documento 24, FHA, vol. I, 1985, p. 199.

${ }^{389}$ Ibidem, p. 199. Não deixando de notar que essa era uma informação exagerada de Fernão de Sousa, "uma legitimação posterior da sua política em relação a Njinga, que não reflectia, nem de longe, a verdadeira situação econômica, aquando da sua chegada a Angola", nos termos de Beatrix Heintze, para quem, por mais reduzido que estivesse, o comércio não havia cessado por completo. Verificar: HEINTZE, Beatrix. Angola nos séculos XVI e XVII [...]. Luanda: Kilombelombe, 2007, pp. 331-332 e 336.

${ }^{390}$ Em sentido análogo ao que Beatrix Heintze já ressaltou. Verificar: HEINTZE, Beatrix. Angola nos séculos XVI e XVII [...]. Luanda: Kilombelombe, 2007, pp. 337-338.

${ }^{391}$ Fernão de Sousa. História das relações entre a Angola portuguesa e o Ndongo 1617 - setembro de 1625.6 de setembro de 1625. BAL, cód. 51-IX-20, ff. 326-27. IN: HEINTZE, Beatrix (coord.). Documento 24, FHA, vol. I, 1985, p. 199. Nessa altura, aos olhos dos órgãos reinóis, João Correia de Sousa era um fugitivo porque, como explicou Fernão de Sousa, "ao tempo que parti do Reino [de Portugal], não era chegado a ele".
} 
jaga Dom João Casanze. ${ }^{392}$ A convicção do administrador é reforçada, agora com informações complementares, na versão existente no códice $51-\mathrm{IX}-21 .^{393}$ Nela, está registrada que a presença de um "rei em Ndongo" combateria a "guerra que atualmente está dando" o jaga Dom João Casanze, que na época "impedia os caminhos por onde [se] vem as feiras" e desestimulava o comércio. ${ }^{394}$

Foi então que em meados de $1625^{395}$ reverberaram alguns burburinhos em Luanda, espalhando que Ginga Ambande disseminava boatos e promessas entre os cativos de senhores portugueses, prometendo liberdade e amparo caso eles fugissem para as ilhas de Quindonga. Se os "escravos fugidos" eram em um primeiro momento ex-membros dos sobados fiéis ao grupo de filiação dos Ambande, é possível especular que em um segundo momento eles acabaram forçados à labuta nos arimos portugueses. ${ }^{396}$ Fato é que a mensagem de Ginga Ambande se alastrou entre 1624 e 1626, seduzindo a mão-de-obra dos senhores portugueses e maximando ainda mais a capacidade de atração de Quindonga, refletindo no aumento das queixas sobre o sumiço e a visível carência deles, sendo "todos de guerra com que ela se melhora, e este Reino [de Angola] enfraquece porque se não pode fazer sem gente preta que a faz à sombra dos arcabuzes". ${ }^{397}$ Sem escravos não haveria trabalho compulsório nos arimos e tráfico de escravos, e sem essas atividades econômicas

\footnotetext{
${ }^{392}$ Seguindo um comentário de Beatrix Heintze, cabe ressaltar que nada mais se conhece sobre os alvoroços causados por esse jaga, fora o que é dito na "resolução da junta" que será mencionada ainda neste documento que analisamos. De todo modo, ao que parece "ele manteve-se junto à fronteira leste no Ndongo, controlando assim os caminhos para o interior, mas não se deve ter aproximado muito dos territórios e dos presídios portugueses" HEINTZE, Beatrix. Angola nos séculos XVI e XVII [...]. Luanda: Kilombelombe, 2007, p. 336.

${ }^{393}$ Especificamente o fólio 225.

${ }^{394}$ Fernão de Sousa. História das relações entre a Angola portuguesa e o Ndongo 1617 - setembro de 1625.6 de setembro de 1625. BAL, cód. 51-IX-20, ff. 326-27. IN: HEINTZE, Beatrix (coord.). Documento 24, FHA, vol. I, 1985, notas 27 e 28 da p. 200.

${ }^{395}$ Esse período foi determinado a partir das datas de composição dos dois documentos que analisamos até então, conforme indicado por Beatrix Heintze.

${ }^{396}$ Nesse sentido, verificar: HEYWOOD, Linda M.; THORNTON, John K. Central Africans, Atlantic Creoles [...]. Cambridge: Cambridge University Press, 2007, p. 200. Para Beatrix Heintze, os cativos aceitos por Ginga Ambande podem ser caracterizados como "refugiados sem linhagem", não suscitando dessa forma contestação quanto ao estatuto de escravidão deles. Verificar: HEINTZE, Beatrix. Angola nos séculos XVI e XVII [...]. Luanda: Kilombelombe, 2007, p. 337.

${ }^{397}$ Fernão de Sousa. História das relações entre a Angola portuguesa e o Ndongo 1617 - setembro de 1625.6 de setembro de 1625. BAL, cód. 51-IX-20, ff. 326-27. IN: HEINTZE, Beatrix (coord.). Documento 24, $F H A$, vol. I, 1985, p. 199. Aqui há dois sutis acréscimos na versão existente em BAL, códice 51-IX-21. A primeira é a de que "arcabuzes" se tornam "nossos arcabuzes". A segunda é a de que, no último fólio dessa versão, é repetido o título "sobre os escravos fugidos e guerras", reiterando a importância do tema no momento da confecção do manuscrito. Verificar: Fernão de Sousa. História das relações entre a Angola portuguesa e o Ndongo 1617 - setembro de 1625. 6 de setembro de 1625. BAL, cód. 51-IX-20, ff. 326-27. IN: HEINTZE, Beatrix (coord.). Documento 24, FHA, vol. I, 1985, notas 23 e 26, p. 199.
} 
não haveria Angola portuguesa. ${ }^{398}$ Tal era o cerne do inventário histórico proposto por Fernão de Sousa a respeito dos "caos e crises", conforme mencionado no primeiro item deste capítulo. A par disso e pressionado por senhores de terras e comerciantes de escravos, o governador tomou uma decisão contundente, pedindo para que Ginga Ambande "entregasse os escravos pois corríamos em paz, e amizade porque a declarava inimiga; assim o fiz". Após muitos recados enviados e nenhuma resposta obtida, a africana quebrou o silêncio e solicitou, em troca da devolução dos fugitivos, o envio de padres da Companhia de Jesus. Fernão de Sousa atendeu ao pedido e enviou Jerônimo Vogado, "Reitor do Colégio da Companhia de Jesus de Luanda", ${ }^{399}$ e o padre Francisco Pacónio ao presídio de Ambaca, carregando juntos a "ordem que não passariam antes de Dona Ana [Ginga Ambande] entregar os escravos, porque não os dando o não faria depois de estarem os padres em Dongo[,] porque os queria para livrarem da guerra que merecia". Ginga Ambande, ao chegar ao presídio de Ambaca e ser notificada sobre o desejo do governador, sentiu-se ultrajada e não devolveu escravo algum. Por consequência, o acordo acabou desfeito e os padres retornaram a Luanda, acompanhados novamente de Bento Rebelo Vilasboas. $^{400}$

Se por um lado Ginga Ambande era uma estrategista política e líder nata, valente o bastante para desafiar Luanda e não aceitar desaforos e nem as singelas mitigações dos representantes régios, por outro lado a postura da africana despertou a ira de integrantes da cúpula política de Luanda, entre eles do próprio Fernão de Sousa. Como bem percebeu Beatrix Heintze, a partir do malogro ocorrido em Ambaca as acusações contra a líder africana passariam a ser registradas cada vez com mais gravidade nas fontes escritas, defendendo a eliminação por completo da africana, a fím de "cortar o mal pela raiz". Reforçando tal assunção, continua Heintze, "nas fontes documentais - compostas quase exclusivamente por relatos de Fernão de Sousa - verificam-se, a partir de então, constantes

\footnotetext{
${ }^{398}$ Sobre o papel preponderante do exército português no avanço militar e penetração do continente, associado à proteção e coerção interna dos habitantes da Angola portuguesa, consultar o capítulo 4 desta dissertação. Sobre o funcionamento dos mecanismos de vigilância e fiscalização e como eles beneficiavam a abertura de feiras e fluxo de mercadorias para Luanda, consultar o próximo capítulo.

${ }^{399}$ Extraído de: Fernão de Sousa. História das relações entre a Angola portuguesa e o Ndongo 1617-1631. 6 de agosto de 1631. BAL, cód. 51-IX-20, ff. 362-63. IN: HEINTZE, Beatrix (coord.). Documento 25, FHA, vol. I, 1985, p. 201.

${ }^{400}$ Fernão de Sousa. História das relações entre a Angola portuguesa e o Ndongo 1617 - setembro de 1625.6 de setembro de 1625. BAL, cód. 51-IX-20, ff. 326-27. IN: HEINTZE, Beatrix (coord.). Documento 24, FHA, vol. I, 1985, p. 199.
} 
equívocos entre causas e efeitos", ${ }^{401}$ sinalizando igualmente que a sondagem e a descrição sobre os problemas históricos estavam sendo mais influenciados pelos dilemas e pelo clima político carregado que havia no ano de 1625, abrindo brechas para deslizes. No mais, malsucedido e apenas atestando para o excessivo desgaste das relações políticas entre Ndongo e Luanda, o acontecimento em Ambaca causou um racha na Câmara de Luanda. Embora fosse suficientemente claro que todas as medidas tomadas desde 1621 foram inócuas, o ambiente político em 1625 era ainda de grande incerteza.

À época da composição textual do documento de 1625, cinco eram as principais alas representativas que integravam a Câmara de Luanda - a saber novamente, administradores, senhores, militares, comerciantes e eclesiásticos -, organizadas distintamente em blocos de interesse e opinião, emissores de três tipos de "pareceres". Apoiado em um grupo sociopolítico diretamente relacionado ao mercado de exportação e ao tráfico de escravos - negociadores, representantes de contratadores, comerciantes de todas as montas, proprietários de terras e escravos -, um desses pareceres defendia que a guerra contra Ginga Ambande deveria ser travada antes que a africana "acabasse de recolher todos os escravos". Aqui se primava por uma economia escravista, sobretudo voltada ao tráfico transatlântica de escravos e, em menor medida, ao trabalho cativo em lavouras de subsistência. Outro parecer, encabeçado por um bloco militarizado e responsável pela condução da chamada "gente de guerra" e da administração dos presídios do interior, foi movido por indivíduos que sustentavam as patentes de "capitão" e "capitãomor", sob a palavra de ordem de que "se acabe o nome de rei de Angola porque enquanto houver há de ser inimigo, e que se faça o Ndongo província como a Ilamba". 402 Esses indivíduos tinham o intuito de aniquilar a soberania mbundu, riscando-a do mapa através de uma guerra total. Havia também quem defendesse um terceiro parecer, mediante o qual a guerra deveria ser feita contra o jaga Dom João Casanze, “e desalojando do sítio em que está se concertará, e comporá, o Reino pondo nele rei que governe, que abra feiras, e comércio". Pelo fato de tal parecer atender aos encarecidos pedidos da monarquia, desejosa de "paz" e "comércio" no domínio ultramarino, é possível assumir que esse terceiro posicionamento representasse a opinião conjunta dos integrantes dos quadros

\footnotetext{
${ }^{401}$ HEINTZE, Beatrix. Angola nos séculos XVI e XVII [...]. Luanda: Kilombelombe, 2007, p. 337.

${ }^{402}$ Sobre a "província de Ilamba", consultar o capítulo anterior.
} 
administrativos e institucionais da Angola portuguesa, contando inclusive com o apoio do governador e simpatia da ala eclesiástica. Assim, com esses "pareceres" em sua mesa e ponderando sobre "o quanto convém o comércio pelo que resulta à Real Fazenda", Fernão de Sousa advogou para que "se lance fora ao jaga por parte de menor dano para o Ndongo e dos sobas amigos" e, após "desalojar" o jaga Dom João Casanze do Ndongo, fosse capturada "Dona Ana [Ginga Ambande] que tiranicamente está intrusa no Reino [de Angola]" juntamente com suas irmãs Cambo e Quifunge. ${ }^{403}$

Respaldada nas ponderações expostas acima, ganhava forma no ano de 1625 o "planejamento da conquista do Ndongo", uma espécie de "planificação" de ordem institucional e política, criado a partir de pareceres locais e na busca de um equilíbrio consensual, ajustando e articulando as demandas contidas no regimento ultramarino e os interesses e objetivos perseguidos pelos grupos sociopolíticos de além-mar. Assim, se no capítulo anterior introduzimos a noção de projeto, na figura de um programa político transcontinental capaz de manter a coesão e a coligação entre o centro político e os domínios ultramarinos, ${ }^{404}$ aqui frisamos a necessidade de haver nessas regiões de além-mar, ou "nas partes do império", como também é possível aludir, planejamentos de várias ordens, atrelados a e entrelaçando os grupos sociopolíticos mandatários da Angola portuguesa às adversidades vividas no ambiente muitas vezes inóspito do ultramar, sem negligenciar a necessidade de atender as expectativas e demandas promulgadas pela

\footnotetext{
${ }^{403}$ Fernão de Sousa. História das relações entre a Angola portuguesa e o Ndongo 1617 - setembro de 1625.6 de setembro de 1625. BAL, cód. 51-IX-20, ff. 326-27. IN: HEINTZE, Beatrix (coord.). Documento 24, FHA, vol. I, 1985, p. 200.

${ }^{404}$ Aqui somos influenciados pelas pesquisas de Carlos Alberto de Moura Ribeiro Zeron e Rodrigo Faustinoni Bonciani. De acordo com o primeiro, uma "política indigenista" e ultramarina estaria alicerçada nos consensos e debates capazes de configurar uma "síntese teológico-jurídica", legitimadora da escravidão e do dominium imposto aos povos ultramarinos, algo que aqui se confunde com as operações de absorção e incorporação de elementos e indivíduos locais e com as noções de domínio indireto e tutela, com os quais trabalhamos nesta dissertação. O segundo advoga para a construção ibérica de uma "política imperial atlântica", complementar e coordenada entre os dois lados do Atlântico, impressa nos regimentos entregues aos governadores e, a nível regional, viabilizadora da "incorporação das sociedades indígenas ao domínio político-jurídico da Coroa", ao mesmo tempo que "ampliava a dependência política dos agentes coloniais". Verificar: ZERON, Carlos Alberto de Moura Ribeiro. A construção de uma ordem colonial nas margens americanas do Império português: discussões sobre o "bem comum" na disputa de moradores e jesuitas pela administração dos índios (XVI-XVII). Tese de livre-docência, Universidade de São Paulo, 2009, pp. 27, 7374. Idem, Linha de fé: a Companhia de Jesus e a Escravidão no Processo de Formação da Sociedade Colonial (Brasil, Séculos XVI e XVII). [1998]. São Paulo: Editora da Universidade de São Paulo, 2011, p. 40. Idem, A ocidente do ocidente: linhas e perspectivas em confronto. Revista de História (USP). São Paulo: Universidade de São Paulo, n. ${ }^{\circ}$ 170, jan.-jun., 2014, pp. 81 e 89. BONCIANI, Rodrigo Faustinoni. $O$ dominium sobre os indigenas e africanos [...]. Tese de doutorado, Universidade de São Paulo, 2010, pp. 154, 170, 177, 254-255 e 263.
} 
monarquia ibérica. ${ }^{405}$ Abaixo desse patamar político subsistia a localidade política - no nosso caso, nomeadamente Luanda, Massangano, Cambambe, Muxima e Benguela -, composta por espaços infralocais de carizes "privado" e "público" - por exemplo, tavernas e a Câmara de Luanda -, ${ }^{406}$ onde é possível cogitar a existência de uma miríade de anseios, objetivos e desejos individuais, aos quais chamaremos simplesmente de planos. ${ }^{407}$

Na mente de Fernão de Sousa, a conquista do Ndongo seria arquitetada da seguinte maneira. Uma vez aberta a guerra e capturada Ginga Ambande, os funcionários régios interfeririam na eleição de um novo "rei natural a quem por direito pertencer avassalado a Vossa Majestade em cem peças cada ano, com a obrigação que darão [sic] entrada a nossa santa fé católica e liberdade para se batizar”. Aliás, há na versão do códice $51-\mathrm{IX}-21^{408}$ os relevantes acréscimos de que esse tributo imposto ao "rei avassalado" no Ndongo seria identificado pelo nome de "baculamento", além do relevante adendo de que os jesuítas receberiam a permissão de batizar quem bem entendessem na região, a partir de uma residência que poderia ser erguida nas terras do Ndongo. ${ }^{409}$ Era preciso atender aos interesses das elites ultramarinas e do fisco régio, sempre na busca de um objetivo final, certas vezes repetido na $F H A$ : abrir "feiras francas de peças, e de mantimentos como

\footnotetext{
${ }^{405}$ Ficamos então com a breve explicação de Pedro Luís Puntoni para a América portuguesa, para quem o domínio ultramarino consistia em "um sistema político centralizado (o governo-geral), definindo a priori uma jurisdição territorial (o Estado do Brasil) e, ao mesmo tempo, um projeto e colonização particular (definido no regimento)", mediante o qual o papel dos governadores era o de "instaurar um novo espaço jurisdicional, múltiplo, e, ao mesmo tempo, proceder à acomodação dos diversos outros poderes". Assim sendo, entre a esfera regional e o âmbito local, aquilo que garantia a governabilidade e a coerência entre o todo e as partes era a construção de "redes locais de exercício do poder", tecidas por intermédio de relações interpessoais e movidas pelas influências política e econômica, nos termos de Rafael Ivan Chambouleyron. Verificar: PUNTONI, Pedro Luis. O Estado do Brasil: poder e politica na Bahia colonial. Tese de livre-docência, Universidade de São Paulo, 2010, pp. 39-40, 68-69. CHAMBOULEYRON, Rafael; MELO, Vanice Siqueira de. Governadores e índios, guerras e terras entre o Maranhão e o Piauí (primeira metade do século XVIII). Revista de História (USP). São Paulo: Universidade de São Paulo, n. ${ }^{\circ}$ 168, janeiro/junho 2013, pp. 177, 180, 186 e 195-196.

${ }^{406}$ Pesquisas sobre o cotidiano, espaços de residência e a privacidade dos moradores de Luanda e dos presídios do interior são uma raridade. Sobre as tavernas, senzalas e cubatas, verificar: FERREIRA, Roquinaldo. Cross-Cultural Exchange in the Atlantic World [...]. Cambridge: Cambridge University Press, 2012, pp. 147, 150-151.

${ }^{407}$ Voltaremos às relações entre projeto (transcontinental), planejamentos (regional) e planos (local) no capítulo 4 desta dissertação.

${ }^{408}$ Verificar especificamente o fólio 225.

${ }^{409}$ Verificar: Fernão de Sousa. História das relações entre a Angola portuguesa e o Ndongo 1617 - setembro de 1625. 6 de setembro de 1625. BAL, cód. 51-IX-20, ff. 326-27. IN: HEINTZE, Beatrix (coord.). Documento 24, FHA, vol. I, 1985, notas 30 e 31, p. 200. Sobre o termo "baculamento", conferir o "suplemento para alguns vocábulos africanos", inserido nesta dissertação.
} 
d'antes se faziam". ${ }^{410}$ Também seria necessário debater e negociar com as autoridades africanas, uma vez que sem essas cautelas não surtiriam efeito o "baculamento de cem peças nem fazer feiras sem os sobas e quizicos”. Para que as maquinações obtivessem êxito, era necessário adquirir a confiança dos mbundu e acalmar o Ndongo. Por isso, o governador aconselhou o monarca português a proceder com a restituição dos indivíduos que haviam sido "apossados" durante as campanhas bélicas de Luís Mendes de Vasconcelos, como também transferir o presídio de Ambaca para Luinha, "por ser mais conveniente ao real serviço de Vossa Majestade que a extinguir o Reino e fazê-lo província porque não militam nele as razões da Ilamba porque é toda povoada de sobas". ${ }^{411}$ Do conjunto de informações expostas por Fernão de Sousa, é possível ressaltar duas considerações fundamentais. Em primeiro lugar, o governador nada mais fez do que atender a algumas antigas reivindicações de Angola Ambande, sempre em nome do pressuposto histórico de que o refortalecimento de alguma soberania mbundu impulsionaria a retomada do antigo comércio. Em segundo lugar, em 1625 a conquista do Ndongo não foi pensada dentro dos moldes de uma "guerra total", mas da planificação de um avanço político e econômico, capaz de concatenar operações militares, rodadas de negociações e acertos políticos entre os membros de Luanda e Quindonga. Aqui, o princípio era o da subjugação por meio da lógica tripontual tutela-vassalagem-domínio indireto, tópico não somente encomendado nos regimentos da governadoria centro-africana, mas também porque as experiências passadas - nomeadamente, durante as épocas de Paulo Dias de Novais e Luís Mendes de Vasconcelos - demonstraram ser uma "guerra de conquista total" inviável. Assim, como parte do processo histórico e espelhado nele, o planejamento da conquista do Ndongo envolvia aprendizagem histórica e estratégia política.

Subordinada frequentemente às formas de dominação baseadas na "submissão", “subjugação" e "sujeição" de entidades políticas africanas, tal fórmula de imposição de domínio direto estava intimamente ligada às formas de classificação e identificação de unidades sociopolíticas vislumbradas pelos funcionários e oficiais régios. Havia um esforço

\footnotetext{
${ }^{410}$ Fernão de Sousa. História das relações entre a Angola portuguesa e o Ndongo 1617 - setembro de 1625.6 de setembro de 1625. BAL, cód. 51-IX-20, ff. 326-27. IN: HEINTZE, Beatrix (coord.). Documento 24, FHA, vol. I, 1985, p. 200.

${ }^{411}$ Fernão de Sousa. História das relações entre a Angola portuguesa e o Ndongo 1617 - setembro de 1625.6 de setembro de 1625. BAL, cód. 51-IX-20, ff. 326-27. IN: HEINTZE, Beatrix (coord.). Documento 24, $F H A$, vol. I, 1985, p. 200. Sobre as ditas "cláusulas" reivindicadas por Angola Ambande, verificar esse mesmo documento, p. 198.
} 
de definição da realidade observada, baseado em um raciocínio simples de comparação e qualificação. Por exemplo, perpassa a FHA a noção implícita de que o "reino do Ndongo" era centralizado e soberano, em contraste à outra região citada na documentação, a "Ilamba". Diferentemente desta, onde cada "soba" era "senhor de sua morinda na terra em que vive, e se conserva", no Ndongo a pressuposta disposição política e social endógena promulgava a existência de uma larga base de "quizicos que é o mesmo que cativos de elrei". ${ }^{42}$ Mediante o prisma institucional seiscentista, as definições formais de espaços, através de termos como "província" e "reino", estavam subsumidas a uma espécie de escala de centralização política. No caso específico dos mbundu, o relevante é ressaltar que a incorporação terminológica de topônimos mbundu implicou em caracterizações e descrições enviesadas, guiadas por esforços de definição e qualificação de acordo com crivos régios. ${ }^{413}$ Tal esforço de incorporação de elementos africanos ao léxico português pode ser explicado da seguinte forma. A operação de registro institucional determinava que a Ilamba era uma "província" porque nela havia uma atomização de centralidades políticas, representadas pela autonomia e independência de vários sobas, ao passo que no "Ndongo" ocorria uma centralização das hierarquias sociais em torno de uma figura importante, um "rei africano", dono de muitos escravos. Trata-se de um procedimento de conduta oficial igualmente visível em outros casos, como no da "província da Quissama" e do "reino do Kongo". Dessa forma, em última instância, por mais que os nomes de lugares fossem mantidos - Ndongo, Kongo, Ilamba e Kissama, para citar apenas alguns -, os topônimos eram definidos e qualificados em vista do interesse político dos oficiais e funcionários régios, não passando ao largo da ideologia de conquista e dominação, que acabava perpetrada nas "memórias", "lembranças", "relações" e demais tipologias documentais inseridas na $F H A$.

Nem implacável, nem compassível: a conquista do Ndongo necessitava de engenho e maleabilidade. Primeiro porque era necessário atender às demandas encomendadas nos regimentos e cartas enviadas pelo monarca e seus representantes, pois Fernão de Sousa almejava regressar ao reino de Portugal após as temporadas no ultramar, onde esperava

\footnotetext{
${ }^{412}$ Fernão de Sousa. História das relações entre a Angola portuguesa e o Ndongo 1617 - setembro de 1625.6 de setembro de 1625. BAL, cód. 51-IX-20, ff. 326-27. IN: HEINTZE, Beatrix (coord.). Documento 24, $F H A$, vol. I, 1985, p. 200.

${ }^{413}$ Consultar o capítulo 1 desta dissertação.
} 
receber as mercês condizentes com a grandeza dos serviços prestados. Segundo, porque a submissão do Ndongo deveria ser feita aos poucos e sem intransigências. Não é por menos que, na relação de 1625, Fernão de Sousa explicou que não via grande vantagem em manter como cativos os quizicos tomados no Ndongo na época de Luís Mendes de Vasconcelos, "como de presente o não são por andarem fugidos e estar a terra desabitada", sendo mais vantajoso devolvê-los ao "novo rei [...] nomeado [...] avassalado", e assim "tornar-se-á a povoar [o Ndongo] porque é muito fértil, e cultivada tornará a dar o rendimento que d'antes dava". ${ }^{414}$ E mesmo que as maquinações de Fernão de Sousa não lograssem êxito e o novo entronado no Ndongo se rebelasse contra Luanda, não seria o caso de exasperações e "nem por isso se lhe deve dar guerra [novamente ao Ndongo] porque a feira que fazia montava mais para a Real Fazenda do que se pode montar o baculamento", posto que a cada negociação de escravos "somana [sic] se resgatavam nelas duzentas, e trezentas peças, e sendo mil cada mês saiam deste porto doze mil cada com que se provia o Estado do Brasil, e Índias, de que resulta grande rendimento a esta Coroa [de Portugal], e a de Castela". ${ }^{415}$ Assim, em tom apelativo e emergencial, Fernão de Sousa complementou que "tanta consideração para ambas as Coroas, porque se faltar a escravaria deste Reino acabar-se-á o comércio de que Vossa Majestade é senhor que é de mais estimação que sê-lo de Ndongo". 416

Prezando pela prosperidade do comércio atlântico, o administrador régio aproveitou para esclarecer que o interesse econômico no tráfico de escravos não poderia ser defendido a todo custo. Por um lado, advogando pela "paz e justiça" tanto encomendada pela monarquia, por outro lado atestando para o fato de a opinião que defendia não era unânime em Luanda, ele alertou que "quando os sobas merecem castigo" apenas se deveria fazer "danos que aos culpados", de modo que as operações militares fossem incentivadas unicamente "em defensão dos presídios, e destes presídios, e desta cidade, e porto, porque os mais dos levantamentos destes Reinos são fingidos, a fim de haver mais peças" ${ }^{417}$ Nesse pequeno trecho o administrador ultramarino deixava claro o abismo que existia entre as

\footnotetext{
${ }^{414}$ Fernão de Sousa. História das relações entre a Angola portuguesa e o Ndongo 1617 - setembro de 1625.6 de setembro de 1625. BAL, cód. 51-IX-20, ff. 326-27. IN: HEINTZE, Beatrix (coord.). Documento 24, FHA, vol. I, 1985, p. 200.

${ }^{415}$ Ibidem, p. 200.

${ }^{416}$ Ibidem, p. 200.

${ }^{417}$ Ibidem, pp. 200-201.
} 
diretrizes régias, refletidas em um projeto ultramarino de nível atlântico, daquilo que era praticado "em campo", no espaço ultramarino e longe das cortes ibéricas. O buraco era ainda mais profundo. Por mais que os governadores de Angola informassem e jurassem que as expedições punitivas e guerras de conquista - operações militares, poderíamos dizer em sentido lato - eram sempre suscitadas por motivos legítimos, quer dizer, estavam fundadas no conceito jurídico e político de "guerra justa", na realidade as operações militares eram movidas histórica e empiricamente pelos lucros advindos dos butins e pilhagens de guerra. O desafio de Fernão de Sousa era exatamente este: reverter o cenário de "caos e crises" sem perder a governabilidade da Angola portuguesa, através da implementação de um planejamento da conquista do Ndongo respaldado no consenso político alcançado em Luanda, respeitando as bases de uma política de cooperação e parceria fundada na "paz e justiça" ${ }^{418} \mathrm{e}$ visando à retomada do tráfico transatlântico de escravos.

\subsection{Em busca da ilegitimidade de Angola Aire}

Até então tentamos analisar os paradoxos e contrassensos que perpassam o conteúdo registrado em algumas das "lembranças" e "relações" inseridas na $F H A$, de modo que eles não fossem tratados como fatos históricos neutros, descontaminados de interpretações e forjamentos, mas como conteúdo histórico produzido em contextos e situações específicos. Não se pode perder de vista que, como produções escritas, esses registros estão imbuídos de inclinações oficiais e formais, detendo por consequência uma natureza muitas vezes discursiva e retórica, sobre os desafios governamentais que inquietavam a direção da Angola portuguesa. Havia duas formas de descrição colonial concorrentes, mesmo incompatíveis, executadas e alinhavadas por Fernão de Sousa: a legitimação e a ilegitimação. De olho nesses planos de importâncias, parte fulcral dos acontecimentos e informações descritos nos documentos inseridos na FHA é tributária do processo de maturação política e da vivência no ultramar daquele que os compuseram, Fernão de Sousa. Governar o domínio centro-africano foi um desafio com o qual o enviado reinol teve que

\footnotetext{
${ }^{418}$ Tais termos devem ser relativizados, como explicaremos nos próximos capítulos. Também é preciso reter algumas das considerações de Beatrix Heintze sobre o tempo de Fernão de Sousa, para quem: "a diferença em relação aos governos anteriores consistia no facto de que agora já não se tratava de campanhas e pilhagem de curto prazo, mas sim dos primeiros passos para concretização de um conceito de ordenamento e economia política de longo prazo". Verificar: HEINTZE, Beatrix. Angola nos séculos XVI e XVII [...]. Luanda: Kilombelombe, 2007, pp. 331-332.
} 
aprender a lidar, internalizando a experiência adquirida e refletindo-a em seus escritos. Assim sendo, como se fosse um autor-compositor, os resultados práticos desse aprendizado apareceriam nas descrições e narrativas sobre os acontecimentos posteriores a 1625, ligados ao início das campanhas ou jornadas de guerra contra Ginga Ambande. Como abordaremos no quarto capítulo desta dissertação, elas foram divididas em duas fases, a primeira ocorrida entre fevereiro de 1626 e julho de 1627 e a segunda de setembro de 1628 a novembro de $1629 .{ }^{419}$ Por enquanto, basta ressaltar alguns aspectos gerais dessas jornadas militares. Apesar de saírem do papel, elas não atenderam as expectativas e previsões inicialmente almejadas pelas autoridades portuguesas e africanas. Primeiro porque algumas medidas, como a expulsão do jaga Dom João Casanze e a mudança de lugar do presídio de Ambaca, não passaram de letra-morta. Em segundo lugar, como bem nota Beatrix Heintze "a guerra não tinha limite uma vez ateada", inevitavelmente colocando "fim a todo o comércio". ${ }^{420}$ Em terceiro lugar, porque não bastava apenas expulsar ou capturar Ginga Ambande e avassalar alguém em seu lugar, senão assegurar que o posto de liderança mbundu fosse sucedido por alguém da confiança de Luanda e que fosse subserviente ao governador português. Posto dessa forma, na ótica de Fernão de Sousa a conquista do Ndongo só obteria êxito caso fossem contornados os problemas de sucessão política no Ndongo. A canalização desses esforços institucionais rendeu alguns resultados práticos, inscritos na memória institucional coeva por meio da chamada "eleição e avassalamento de Angola Aire", ocorrida especificamente em 12 de outubro de $1626 .{ }^{421}$ A fim de destrincharmos com profusão e minúcia esse episódio histórico, analisaremos neste item um dos documentos-chave composto por Fernão de Sousa a respeito dele, um dos poucos ao qual temos acesso e que está disponível para consulta na $F H A$.

No que diz respeito à linha de argumentação aqui desenvolvida, a fonte à qual nos referimos acima é a terceira narrativa que integra a série histórica composta por Fernão de Sousa durante o seu governo (1624-1630). Antes de adentrarmos nas vicissitudes do conteúdo documentado, cabe ressaltar alguns aspectos mais técnicos sobre a composição

\footnotetext{
${ }^{419}$ Esses episódios serão analisados mais para frente, no capítulo 4 desta dissertação. Para as informações cronológicas citadas no corpo de texto, verificar: HEINTZE, Beatrix (coord.). Apêndice: Tabela Cronológica, 1618-1630. FHA, vol. I, 1985, pp. 395-396.

${ }^{420}$ HEINTZE, Beatrix. Angola nos séculos XVI e XVII [...]. Luanda: Kilombelombe, 2007, pp. 337-338.

${ }^{421}$ Data retirada de: Idem, Apêndice: Tabela Cronológica, 1618-1630. FHA, vol. I, 1985, p. 396. Sobre os demais acontecimentos aqui citados, verificar ainda a cronologia existente em: Idem, Angola nos séculos XVI e XVII [...]. Luanda: Kilombelombe, 2007, pp. 317-324.
} 
escrita. Primeiramente, há nela o autógrafo de Fernão de Sousa, o que a princípio comprova a autenticidade do documento. Curiosamente, o documento não conta com destinatário, o que não acontece com a maioria dos demais escritos inseridos na $F H A$. Além disso, é importante notar que na $F H A$ ele foi intitulado "A ilegitimidade do novo Rei do Ndongo, Angola Aire" por Beatrix Heintze, algo que como veremos não foi feito ao esmo. Conquanto não esteja datado, é possível sugerir, como faz Heintze, que o escrito fora composto entre 20 de julho e 14 de setembro de $1629 .{ }^{422}$ A primeira linha do documento anuncia o tema proposto: "lembrança das razões que há para Angola Aire não ser rei". Assim, destarte fica claro que o escrito versará sobre os "motivos" que levaram à indevida colocação de "Angola Aire" no trono do Ndongo, através da rememoração de um passado recente. A título de curiosidade, assim como as demais lembranças e relações aqui analisadas, o documento de meados de 1629 pode ser considerado como um elo entre o presente, o passado recente e a escrita de uma história oficiosa sobre a formação da Angola portuguesa. Como memória institucional com ares de oficialidade, essa narrativa é a prova escrita de um processo histórico, ao mesmo tempo que é resultante desse mesmo processo. $^{423}$

O mote da discussão, a questão da ilegitimidade sobre a eleição política de soberano no Ndongo, é outro assunto de particular interesse. Ele faz parte da construção de uma verdade legal sobre os intentos ultramarinos no Ndongo, além é claro de estar respaldada da série de documentos de caráter histórico que foi anexada à $C D F S$ e que temos em mãos sob a forma da $F H A$. A legitimação, ou a falta dela, não estava limitada às discussões jurídicas, ou seja, aos debates sobre "direitos" e "justiças", travada entre juristas e eclesiásticos peninsulares, ${ }^{424}$ mas à “justificação", perante as instituições monárquicas, portanto em

\footnotetext{
${ }^{422}$ Esse período foi deduzido a partir de informações e eventos citados no próprio documento. Segundo Beatrix Heintze, os acontecimentos mais tardios, e que mais auxiliam com bases sólidas na estipulação do período de composição do mesmo, foram a chegada das irmãs de Ginga Ambande em Luanda, em 20 de julho de 1629, e a escrita da "ordem de Fernão de Sousa para a dissolução do exército" português, comandado por Paio de Araújo de Azevedo, em 14 de setembro de 1629. De todo modo, o exame do conteúdo inserido no documento possibilita uma datação diferente, desde que parta de uma data igual ou posterior a 20 de julho de 1629. Verificar: Fernão de Sousa. A ilegitimidade do novo rei do Ndongo, Angola Aire. S.d., entre 20 de julho e 14 de setembro de 1629. BAL, cód. 51-IX-20, ff. 415-15v. IN: HEINTZE, Beatrix (coord.). Documento 28, FHA, vol. I, 1985, nota 71, p. 209.

${ }^{423}$ Ibidem, p. 209.

${ }^{424}$ Nos séculos XVI e XVII, as ideias portuguesas de "direito e justiça" se confundiam com os conceitos de "lei" e "costume". Os dois pares giravam em torno do debate entre teólogos como Francisco Suárez e Francisco de Vitoria, suscitando problemas e abordagens sobre como organizar uma ordem política e jurídica
} 
escala transcontinental, dos planejamentos expansionistas e exploratórios adotados em âmbito regional. Aliás, mesmo que em parte o documento fosse escrito com base em uma confissão formal, na medida em que Fernão de Sousa alertara para um equívoco cometido durante a eleição régia no Ndongo - afinal de contas, ele colocou uma pessoa ilegítima no trono africano, em um processo que deveria ter sido do começo ao fím "legítimo" -, a pretensa ilegitimidade de Angola Aire deve ser lida de maneira historicizada. Se nos séculos XVI e XVII a busca por legitimidade era uma prática institucionalizada, é lógico ensaiar que a alegação de uma "ilegitimidade" também estava imbuída de interesse e sagacidade. Assim sendo, o pressuposto é o de que a lembrança sobre a ilegitimidade de Angola Aire deve ser lida como uma produção documental decorrente do processo histórico de "busca por ilegitimidade", sendo assim analisada como um fragmento aglutinador e colmatador das brechas e lacunas que percorrem a série de narrativas históricas que compõe a FHA.

Pois bem, para além da questão da determinação de ilegitimidade, também é relevante notar que ocorreu no documento uma omissão de conteúdo relevante. $\mathrm{O}$ africano que contava com o apoio de Luanda no processo de sucessão régia no Ndongo, denominado “Angola Aire”, era meio-irmão de outro indivíduo, ou posição titular mbundu, de nome "Aire Aquiloange". Durante o início do século XVII, este havia sido um dos principais e mais fiéis "sobas vassalos" do monarca português, sendo também lembrado como um incontestável líder local da "província de Are". Mais informações sobre essa posição titular são vagas, mas sabe-se que na época de João Correia de Sousa a vassalagem de Aire Aquiloange acabaria doada a Angola Ambande, de modo a facilitar a reaproximação política e diplomática com o ngola. Após a expulsão de Ginga Ambande e estando vago o trono do Ndongo, entre 1625 e 1626, o soba de Aire foi o principal nome cotado para

global, capaz de "incorporar os costumes locais, tanto dos indígenas como dos moradores portugueses" que habitavam os diversos espaços ultramarinos, que necessariamente deveriam zelar pela "paz e bem comum". Lançando mão de algumas diretrizes apontadas por Carlos Alberto de Moura Ribeiro Zeron, discernimos aqui três pontos que inquietavam os funcionários régios da época e que, portanto, faziam parte da escrita dos documentos oficiais: $i$ ) A "incorporação de costumes locais" não estava atada a uma "genérica cultura indígena" ou "africana", mas a diferentes grupos autodeterminados de culturas, línguas e rituais imbricados entre si; ii) Havia tensões entre os moradores vindos de além-mar, "gente da terra" ou "colonos", em relação aos "agentes da colonização na metrópole" e aos funcionários enviados por períodos previamente estipulados; iii) Os conflitos e tensões geravam uma "estrutura social original". Verificar: ZERON, Carlos Alberto de Moura Ribeiro. Interpretações das relações entre cura animarum e potestas indirecta no mundo lusoamericano. Clio: Revista de Pesquisa Histórica. Recife: Universidade Federal de Pernambuco (UFPE), n. ${ }^{\circ} 27-$ 1, 2009, pp. 142-143. 
receber a investidura e o apoio institucional português. Contrariamente a todas as expectativas, Aire Aquiloange acabou acometido pelas tais "bexigas", doença atualmente identificada como sendo a varíola, o que fez com que Fernão de Sousa preenchesse às pressas o trono do Ndongo com um "plano b", o meio-irmão do falecido soba, Angola Aire. $^{425}$

Seguindo a proposta de escrita do documento, Fernão de Sousa descreve um homem que nem de longe tinha as qualidades e inclinações necessárias para ser rei. De acordo com o registro de meados da segunda metade de 1629, Angola Aire seria então "filho de escravo nascido em casa de el-rei Angola Ambande", com a especificidade de que era uma "peça de sua filha Dona Ana Graça Quifunge e que por nascer em casa se lhe não pusera marca", quiçá uma escarificação ou sinal feito à brasa. ${ }^{426}$ Sabemos, no entanto, que as "marcas de escravidão" são matéria controversa, uma vez que o próprio Fernão de Sousa tinha o costume de marcar as "peças" que eram exportadas do porto de Luanda para fins de fiscalização e taxação, clamando às vezes ter "instituído" a prática para melhorar a fiscalização e evitar contrabandos. ${ }^{427}$ Essas "marcas" eram uma inovação instituída pelo funcionalismo régio, ou constituíam uma prática corrente entre os mbundu? Ainda carecem investigações mais aprofundadas sobre isso. De todo modo, fato é que tal indagação também nos remete à problematização do próprio estatuto de escravidão identificado entre os mbundu, respaldado no binômio marginalização-exclusão. Talvez o não pertencimento de Angola Aire ao grupo de parentesco liderado pelos Ambande tenha sido a "deixa" para Fernão de Sousa forjar o estatuto de "peça" do soba de Aire, ato esse motivado em grande medida pela necessidade de construir uma argumentação plausível sobre a ilegitimidade dele. Assim, fundindo duas ideias bastante difundidas pelo funcionalismo régio entre os séculos XVI e XVII, a primeira a de que a soberania mbundu contava com uma vasta gama de subordinados políticos, a segunda a de que a escravidão estava altamente difundida e

\footnotetext{
${ }^{425}$ HEINTZE, Beatrix (coord.). Apêndice: Tabela Cronológica, 1618-1630. FHA, vol. I, 1985, p. 396.

${ }^{426}$ Fernão de Sousa. A ilegitimidade do novo rei do Ndongo, Angola Aire. S.d., entre 20 de julho e 14 de setembro de 1629. BAL, cód. 51-IX-20, ff. 415-15v. IN: HEINTZE, Beatrix (coord.). Documento 28, FHA, vol. I, 1985, p. 209.

427 Ficamos então com a breve explicação de Beatrix Heintze, pertinente ao problema: “Aos escravos comprados pelos portugueses, ou em seu nome, era feita uma marca de propriedade com um ferro com brasa no peito, um procedimento adoptado posteriormente pelos Mbundu (ou parte deles), os Mbangala e mais tarde também pela rainha Njinga em Matamba. A sua principal finalidade era impedir uma troca fraudulenta por escravos de menor valor". Verificar: HEINTZE, Beatrix. Angola nos séculos XVI e XVII [...]. Luanda: Kilombelombe, 2007, p. 495. Para mais informações são entre as páginas 451-452.
} 
introjetada na sociedade mbundu, parecia seguro e "cômodo" alegar que Angola Aire era peça da família Ambande. O amálgama de ideias estereotipadas e o estigma da escravidão africana, intimamente associado à concepção de uma África onde o sentimento de pertencimento à escravidão foi naturalizado, proporcionou o forjamento de uma falcatrua plausível para os olhos de reinóis, desconhecedores da realidade de além-mar.

Partindo da pretensa condição de escravo de Angola Aire, Fernão de Sousa afirmou que nenhum "soba dos da casa d'El-rei [Angola Ambande] lhe quer obedecer, nem o há de fazer" e, possivelmente motivada pela lealdade de algumas linhagens apoiadoras de Ginga Ambande, mesmo ostentado a posição de "el-rei", Angola Aire não "ousou exercitar atos de rei nem o há de fazer". O governador também repreendeu o caráter do africano, afirmando que lhe faltava coragem em "ir diante de Ginga nem de suas irmãs", além de fraquejar na hora de pegar em armas e partir com o exército de Paio de Araújo de Azevedo. Mesmo depois do término das campanhas militares, demonstrava vacilação e covardia, não se atrevendo a encarar as irmãs Maria Cambo e Gracia Quifunge Ambande de frente, aprisionadas em Luanda desde 20 de julho de $1629 .{ }^{428}$ Ao invés de se apresentar pessoalmente, ressaltou Fernão de Sousa, Angola Aire mandou um enviado a Luanda para dizer-lhes que "confessava ser peça sua [de Ginga Ambande], e que por isso as não via ver" e, para o espanto de Fernão de Sousa, ele trazia consigo "mimos e regalos" às africanas. As irmãs Ambande no entanto não os aceitaram e, por volta da segunda metade de $1629,{ }^{429}$ havia rumores de que "nenhum tempo ele [Angola Aire] poderá ser obedecido, sendo vivas [as irmãs de Angola Ambande], porque a elas direitamente pertencem o Reino". Assim, apenas confirmando a sua fraqueza, "não saiu nem sairá das Pedras [de Pungo Andongo]" e "nem foi nunca às imbilas dos reis". ${ }^{430}$

A imagem negativa criada de Angola Aire deve ser contrastada e perscrutada em relação a uma contraimagem, produzida a partir de alguns critérios de exercício da atividade política e do caráter pessoal que um legítimo soberano no Ndongo deveria ter aos olhos dos mbundu. Assim, de acordo com uma perspectiva autóctone, um "verdadeiro" rei

\footnotetext{
${ }^{428}$ HEINTZE, Beatrix (coord.). Apêndice: Tabela Cronológica, 1618-1630. FHA, vol. I, 1985, p. 396. Para mais informações sobre esses eventos, consultar o capítulo 4 desta dissertação.

${ }^{429}$ No original está escrito apenas "[...] e dizem que é nenhum tempo [...]."

${ }^{430}$ Fernão de Sousa. A ilegitimidade do novo rei do Ndongo, Angola Aire. S.d., entre 20 de julho e 14 de setembro de 1629. BAL, cód. 51-IX-20, ff. 415-15v. IN: HEINTZE, Beatrix (coord.). Documento 28, FHA, vol. I, 1985, p. 209.
} 
do Ndongo seria uma espécie de "deidade" na terra, capaz de influenciar nas condições atmosféricas, trazendo ou contendo as chuvas. A princípio, como eles mesmos clamavam responsabilidade, eram os ngola "senhores do sol e da chuva". A isso se somava uma segunda característica: a de ativa ingerência no plantio e na fertilidade da terra. A tradição mbundu prescrevia que o plantio de arimos fosse precedido pelos rituais da sementeira, ficando portanto a cargo do ngola o zelo pela "fertilidade da terra" e pelo "bem-estar da população". 431 O soberano mbundu clamava parentesco político e simbólico com os fundadores do ngundu, ou grupo de filiação, que encabeçava o Ndongo. Era ele igualmente uma das entidades responsáveis por preservar a tradição fundadora da soberania, tendo acesso à consulta dos membros já falecidos de sua linhagem, antigos detentores da posição titular em vigor, em um ritual que tanto dizia respeito ao íntimo do exercício da soberania, quanto era feito em vistas de um caráter mais público, para ser vislumbrado pelos mbundu fiéis ao Ndongo. Fazia também parte dos rituais sagrados visitar as "imbilas", termo que designava "especialmente o local das sepulturas dos reis do Ndongo (ou de um rei só)", como lembra Beatrix Heintze. ${ }^{432}$

Sendo uma figura prestigiada e de grande veneração, o ngola era muitas vezes uma autoridade imponente, mas não autoritária. ${ }^{433} \mathrm{O}$ respeito que os mbundu lhe conferiam não estava ligado apenas ao sobrenatural e ao místico, mas também à personalidade individual de cada ngola, valorizada na sociedade mbundu por ser justa, maleável e carismática no exercício do governo. Era em nome dele que a cúpula do Ndongo recebia tributos e presentes, redistribuindo-os entre as demais dignidades e autoridades, de acordo com as importâncias e qualidades delas. O círculo político do ngola também era encarregado pelos afazeres ligados à justiça, como o julgamento de mucanos e o zelo pela legislação do povo mbundu, de forma que o direito local garantisse a reparação de indivíduos que se considerassem lesados por outrem. ${ }^{434}$ Assim sendo, na prática de governança e ação política

\footnotetext{
${ }^{431}$ Verificar, sobre todos esses atributos: HEINTZE, Beatrix. Angola nos séculos XVI e XVII [...]. Luanda: Kilombelombe, 2007, pp. 211-213.

${ }^{432}$ HEINTZE, Beatrix (coord.). Esclarecimentos sobre vocábulos africanos, FHA, vol. I, 1985, p. 118. O leitor mais atento notará que é óbvia a razão pela qual Angola Aire não visitara as ditas "imbilas", pelo menos na perspectiva mbundu: tratava-se do lugar de sepultamento dos membros da linhagem Ambande. $O$ novo soberano não pertencia a essa linhagem e, portanto, não teria nexo visitá-las.

${ }^{433}$ Verificar, sobre todos esses atributos: HEINTZE, Beatrix. Angola nos séculos XVI e XVII [...]. Luanda: Kilombelombe, 2007, pp. 211-213.

${ }^{434}$ Conferir a entrada para "mucanos" existente no "suplemento para alguns vocábulos africanos" e, para além disso, consultar o capítulo 3 desta dissertação.
} 
efetiva, o ngola era responsável pela redistribuição de bens e serviços entre os seus fiéis e leais subordinados, ao passo que encabeçava um núcleo judiciário responsável pela reparação de injustiças que, porventura, abalassem o equilíbrio interno na sociedade mbundu. Assim sendo, devido à múltipla importância que detinha, não é à toa que o ngola era a maior autoridade representativa dos mbundu para assuntos externos. Clamado como a maior entidade representativa dos diferentes subgrupos pan-mbundu, o ngola era a clara imagem da unidade política registrada na FHA como sendo o "reino do Ndongo".

Após expor algumas "razões" que justificavam e ilegitimidade de Angola Aire, Fernão de Sousa forneceu certas informações que desdiziam a linha argumentativa traçada até então. O governador afirmou que, desde o momento em que ele subira no trono do Ndongo até a época em que a dita "lembrança" fora elaborada, "[Angola Aire] procurou por todo este tempo esfruitar [sic] o Reino" e, recolhido nas "Pedras de Pungo Andongo", juntava "peças, fazendas, e mantimentos por si" através de seu "tendala e mani lumbo", a princípio "com tenção de se ir para o Lembo", para onde as pessoas afirmavam que ele concentrava um número considerável de "peças", a despeito de não "pagar o baculamento à Sua Majestade, nem dar cousa de consideração", sob o falseamento de que era pobre. ${ }^{435}$ Embora fosse descrito como um covarde e ilegítimo soberano do Ndongo, o simples fato de ele conseguir vários tipos de riquezas e enviá-las ao Lembo é um forte vestígio de que Angola Aire não era tão incapaz como a máscara que lhe fora relegada por Fernão de Sousa mostrava. Contando com grande respaldo em Are e no Lembo, e negando propositalmente o pagamento de baculamentos a Luanda, o africano tramava algo. Por isso, desconfiado com os rumos das coisas, Paio de Araújo de Azevedo fora ordenado pelo governador a averiguar, por todas as "vias" necessárias, se "Angola Aire ficaria obedecido rei" caso "recolhida a [nos]sa guerra", ou se "rebelariam os sobas como se presumia deles". 436

Retomando a linha argumentativa do texto, o administrador indicou que em Luanda ocorreram algumas conversas entre Maria Cambo, Gracia Quifunge e os padres da

\footnotetext{
${ }^{435}$ Fernão de Sousa. A ilegitimidade do novo rei do Ndongo, Angola Aire. S.d., entre 20 de julho e 14 de setembro de 1629. BAL, cód. 51-IX-20, ff. 415-15v. IN: HEINTZE, Beatrix (coord.). Documento 28, FHA, vol. I, 1985, p. 209.

${ }^{436} \mathrm{O}$ envio dessa ordem e a possível troca de vias entre Fernão de Sousa e Paio de Araújo de Azevedo ocorreu em um período de cerca de dois meses, entre o final de julho e a primeira metade de setembro de 1629. Tal assunção foi feita com base em dois marcos históricos. O primeiro foi a chegada das irmãs de Ginga Ambande como prisioneira em Luanda, em 20 de julho de 1629, o segundo foi a composição da ordem de dissolução do exército português, em 14 de setembro de 1629. Verificar: HEINTZE, Beatrix (coord.). Apêndice: Tabela Cronológica, 1618-1630. FHA, vol. I, 1985, p. 396.
} 
Companhia de Jesus. De acordo com Fernão de Sousa, juntas essas autoridades chegaram ao consenso de que os sobas do Ndongo não obedeciam a Angola Aire por desdenhá-lo "mais que o rato com medo de arcabuz", conforme a metáfora empregada no texto. Informação complementar foi recolhida por Paio de Araújo de Azevedo que, ao indagar aos sobas sobre as razões para não quererem "ir para" Angola Aire, recebeu a resposta de que "antes perderiam as vidas porque era peça [Angola Aire], e eles queriam antes sê-lo minha [de Fernão de Sousa] que sua [de Angola Aire]", 437 o que é claramente um exagero ou uma mentira descarada, já que recentemente muitos escravos haviam fugido da Angola portuguesa e nenhum deles parecia propenso a retornar às propriedades portuguesas, ou ser exportado via atlântico. À luz dessas "desinformações", algumas considerações ficam evidenciadas. A primeira é a de que, embora o planejamento da conquista do Ndongo tenha saído do papel, pouco ou quase nada do que inicialmente fora previsto acabou ocorrendo de fato. O Ndongo ainda estava fragilizado, o comércio estava na mesma, os sobas estavam descontentes, uma clima de desconfiança sobre a "pacificação portuguesa" pairava no ar e a família Ambande continuava a deter a mesma importância de antes. A segunda é a de que Angola Aire não era o "fantoche" que as autoridades portuguesas esperavam que ele fosse. Tão logo percebeu isso, Fernão de Sousa ordenou Paio de Araújo de Azevedo a obrigá-lo, através de ameaças ou do próprio derramamento de sangue, a "pagar o baculamento que devia" e a deixar as "Pedras de Pungo Andongo", a fim de "tungar na Kabasa e na Vunga e nas demais partes" e abrir feiras de escravos. Assim, às vésperas da retornada em definitivo do exército liderado por Paio de Araújo de Azevedo a Luanda, ocorrida em 8 de novembro de 1629, Fernão de Sousa fez de tudo para corrigir e "maquiar" todas as imperfeições e deslizes cometidos de 1625 a 1629, mesmo que isso acarretasse na destruição por completo da unidade política do Ndongo, pois "depois de consumido o Reino o houver de o largar, que será melhor logo". 438

Essa foi a "deixa” para que ele expusesse uma última consideração acerca da busca pela comprovação da ilegitimidade de Angola Aire. Em tom de conselho, ${ }^{439}$ o administrador aventou a possibilidade de retomar o diálogo com Ginga Ambande, caso ela

\footnotetext{
${ }^{437}$ Fernão de Sousa. A ilegitimidade do novo rei do Ndongo, Angola Aire. S.d., entre 20 de julho e 14 de setembro de 1629. BAL, cód. 51-IX-20, ff. 415-15v. IN: HEINTZE, Beatrix (coord.). Documento 28, FHA, vol. I, 1985, pp. 209-210.

${ }^{438}$ Ibidem, p. 210.

${ }^{439}$ Nas palavras registradas no original, "Seria bom saber $[\ldots]$ ".
} 
aparecesse em Luanda, "por razão de suas irmãs para se tratar da composição entre todos para maior aumento do Reino". Apesar de todos os desentendimentos revezes históricos, na perspectiva de Fernão de Sousa a retomada das negociações era necessária pelos seguintes motivos. O primeiro era o de que o "Senhor Bispo", Dom Francisco do Soveral, duvidava acertadamente dos procedimentos adotados acerca da "eleição deste rei Angola Aire", além de estar cético quanto à possibilidade "de se lhe poder dar Reino e tirá-lo a elas". 440 Responsável pela condução do bispado de Congo e Angola, Dom Francisco Soveral era uma importante autoridade eclesiástica regional e, como veremos no quarto capítulo desta dissertação, integrava o círculo de influência e sociabilidade institucionalmente encabeçada por Fernão de Sousa. O segundo motivo era o de que, segundo o que sustentava "Dona Maria Cambo Ambande", o escolhido por Angola Aire "será are, mas angola não será nunca", ou seja, podia ser uma liderança e posição titular importante na "província de Are", mas nunca contaria com a aprovação necessária, por parte dos grupos linhageiros que compunham o Ndongo, para se firmar como um soberano legítimo. No entanto, o futuro mostrará ser tal dedução precipitada, pois a linhagem e posição renovada de Angola Aire dirigiu o Ndongo até 1671. Em terceiro lugar, segundo o que afirmava Maria Cambo Ambande, a autoridade da irmã mais velha Ginga Ambande jamais seria contestada, porque "antes a deixariam passar livremente e lhe dariam o necessário porque é angola que ninguém ousa pegar", ${ }^{441}$ o que o tempo demonstrou ser verdade.

\subsection{Do específico ao geral: a produção de autos de vassalagem, lembranças e}

\section{relações}

Cabe fazer algumas considerações finais neste item. Algo que não poderia passar ao largo da análise aqui empreendida diz respeito à eleição de Angola Aire e ao seu investimento como vassalo do rei de Portugal. A historiografia até hoje deu relativa atenção à ilegitimidade de escolha desse africano, interpretando os argumentos lançados

\footnotetext{
${ }^{440}$ Dom Francisco Soveral era um "monge agostinho" vindo da diocese de Lisboa. Era doutor em teologia por Coimbra. Exerceu cargos junto ao santo ofício e foi eleito bispo de São Tomé, porém não chegou a exercer o cargo. Foi apenas após a eleição para "bispo do Congo e de Angola", concretizada em 8 de fevereiro de 1627, que finalmente desembarcara em terras africanas, em 7 de agosto de 1628. Morreu em 4 de janeiro de 1642, em Massangano. Verificar: HEINTZE, Beatrix (coord.). Breves biografias de alguns europeus em Angola (1620-1630). FHA, vol. I, 1985, p. 109.

${ }^{441}$ Fernão de Sousa. A ilegitimidade do novo rei do Ndongo, Angola Aire. S.d., entre 20 de julho e 14 de setembro de 1629. BAL, cód. 51-IX-20, ff. 415-15v. IN: HEINTZE, Beatrix (coord.). Documento 28, FHA, vol. I, 1985, p. 210.
} 
por Fernão de Sousa e de outros observadores portugueses, como António de Oliveira de Cadornega. No debate são normalmente abordados alguns tópicos recorrentes na $F H A$, como a "peçonha" e a morte de Angola Ambande, a "usurpação e tirania" de Ginga Ambande e a eleição e avassalamento de Angola Aire. Parte fulcral das discussões acabou condensada nos trabalhos de Joseph C. Miller e Adriano Parreira, sobretudo através de análises e críticas sobre os denominados "direitos africanos". ${ }^{442}$ Dos vários desdobramentos resultantes dessas pesquisas, um chama particular atenção. Há o consenso contemporâneo de que os litígios e pleito jurídicos e políticos, movidos historicamente em torno da insígnia e do título de soberania governamental do ngola, muitas vezes eram propulsados por rivalidades linhageiras e tensões existentes entre grupos sociopolíticos da sociedade mbundu. Por exemplo, no caso da eleição e avassalamento de Angola Aire, de um lado havia as linhagens da província de Are e de outro os Ambande. Fernão de Sousa apoiou um ngundu principal que liderava essa província - lembrando, mais uma vez, que esse grupo foi representado por Aire Aquiloange e depois por Angola Aire -, ao passo que derrogou os Ambande do Ndongo. Dessa forma, mesmo que a maioria do mbundu desejasse a permanência de Ginga Ambande no posto de ngola, de modo interino ou não, é mais do que claro que Angola Aire era no mínimo elegível e contava com apoio local para se sustentar no poder. A eleição e o avassalamento de Angola Aire não indicou a colocação de um completo "fantoche" no trono do Ndongo, totalmente desconhecido das linhagens locais,

\footnotetext{
${ }^{442}$ Explorando as possibilidades abertas pelos estudos ligados à cultura política e jurídica mbundu, na década de 1970 Joseph C. Miller propôs a existência de um "quadro" legalista de sucessão política no Ndongo, à guisa de uma "constituição" mbundu, que descredenciaria Ginga Ambande da sucessão real. Resumidamente, a subida ao trono da líder mbundu era incompatível com as seguintes condições: sexo do proponente, genealogia imprópria, alienação das linhagens, regionalismos políticos, usurpação do poder, injustiça legal e ostracismo da tradição oral. Adriano Parreira discordou do fato de que o sexo feminino de Ginga Ambande ser um empecilho à ocupação do trono mbundu, afirmando que ela era a natural sucessora do falecido soberano mbundu. Após as críticas de Parreira, Miller esclareceu que a questão da ilegitimidade de sucessão régia estava intimamente ligada às normas constitutivas e legais em vigor na sociedade mbundu, sendo igualmente influenciadas pelos precedentes históricos e dinásticos que até então ditavam a escolha real. $\mathrm{O}$ leitor notará que aqui salientamos a importância das rivalidades internas no Ndongo, sem menosprezar a importância do direito nos processos históricos locais, conforme as conclusões mais bem acabadas de Miller. Verificar: MILLER, Joseph C. Nzinga of Matamba in a New Perspective. The Journal of African History. Cambridge: Cambridge University Press, vol. 16, n. ${ }^{\circ}$ 2, 1975. Idem, Legitimacy and Political Power [...]. The Journal of African History. Cambridge: Cambridge University Press, vol. 32, n. ${ }^{\circ} 1,1991$, pp. e 35, 37 e 40. Idem, Poder político e parentesco [...]. [1976]. Luanda: Arquivo Histórico Nacional, 1995, pp. 83-84. PARREIRA, Adriano. Economia e sociedade em Angola na época da Rainha Jinga (século XVII). Lisboa: Editora Estampa, 1997, pp. 178-181. Sobre os critérios de sucessão régia e alguns exemplos interessantes, verificar: HEINTZE, Beatrix. Angola nos séculos XVI e XVII [...]. Luanda: Kilombelombe, 2007, pp. 218221.
} 
como fizera Luís Mendes de Vasconcelos, mas o firmamento de apoio político a um candidato que dificilmente teria chance de concorrer ao trono mbundu sem ajuda externa. Diferença sutil, mas essencial para o contexto seiscentista. Fantoche era António Correia, enquanto que Angola Aire estava mais para um sujeito que galgou o posto mais elevado de liderança política no Ndongo, graças ao apoio de Luada. O primeiro era um mero comandado, já o segundo tinha vida e vontade próprias. ${ }^{443}$

Muito também tem-se discutido sobre os chamados "contratos" ou "tratados" de vassalagem, chamados comumente de "autos de vassalagem" nos documentos inseridos na FHA. Expoentes dessa discussão, Beatrix Heintze e Catarina Madeira Santos suscitaram importantes considerações acerca da evocação de terminologias distintas, através do emprego de vocábulos e conceitos em kimbundu - undamento, baculamento, luanda e gingo são algumas utilizações recorrentes -, ou que derivam de uma tradição política anterior à do Antigo Regime, ligada à Idade Média e aos contratos feudo-vassalos juramento de fidelidade, prestação de homenagem, vassalagem e outras noções normalmente evocadas. ${ }^{444}$ Sobre o arcabouço vocabular e conceitual empregado, não resta dúvida quanto a dois traços estruturais e ambivalentes que engendraram a confecção desses autos durante a longa história dos contatos luso-africanos em Angola. O primeiro é a subjugação, veladamente impressa na cerimônia solene de vinculação política, o "avassalamento" propriamente dito. Na ótica institucional portuguesa, o avassalamento era um pacto político acertado de maneira "consensual e acordada", mediante o qual ficavam estabelecidas algumas condições ou cláusulas, também chamadas de "direitos e deveres", que ambas as partes deveriam respeitar de maneira isonômica e recíproca. Retórica discursiva, poderíamos complementar. $\mathrm{Na}$ prática, os autos de vassalagem eram oficializações e formalizações do estreitamento de vínculos políticos, enlaçando os

\footnotetext{
${ }^{443}$ Um dos diferenciais de Fernão de Sousa foi realmente o de ter associado aprendizado histórico ao fazer político, de modo que não caíra na "falácia em que também já caíra Luís Mendes de Vasconcelos", mediante a qual supunha-se "que bastava fazer 'eleger' um novo rei 'legítimo' [...], escolhido pelos portugueses, para que tudo desse certo", como lembra Heintze. Verificar: HEINTZE, Beatrix. Angola nos séculos XVI e XVII [...]. Luanda: Kilombelombe, 2007, pp. 337-338. Assim, "fantoche" estaria mais para os chamados "chefes de palha" descritos por Georges Balandier, fruto de um "arranjo de poderes" capaz de criar "novos chefes ou chefes investidos". Verificar: BALANDIER, Georges. A Noção de Situação Colonial. [1955]. Tradução de Nicolás Nyimi Campanário, revisão de Paula Monteiro. Cadernos de Campo. São Paulo: Universidade de São Paulo (USP), n. ${ }^{\circ}$ 3, 1993, p. 114.

${ }^{444}$ Salientando então que esse "fundo de medievalismo", representado pela utilização de um léxico feudovassalo, era encaixado a uma aplicação moderna, intimamente ligada ao meio ultramarino e atípica à Idade Média europeia.
} 
sujeitados à tutela régia, de acordo com a qual o agora "soba vassalo" se comprometia a prestar fidelidade e respeito à Coroa portuguesa, a troco de quase nada. ${ }^{445} \mathrm{O}$ segundo traço é o da "bricolagem ideológico-cultural", perpetuadora de uma relação multilógica de coexistência por imbricação e rearranjo, mediante a qual os indivíduos provenientes de matrizes culturais diversas, classificadas genericamente de "portuguesa" e "africana", comunicavam-se através de termos políticos aproximados, sem deixar de interpretá-los através de conceitos endógenos e visões de mundo próprias. ${ }^{446}$ Concomitantemente à transcrição da realidade observada em papel, os elementos constitutivos de sociedades distintas acabavam inscritos nas gramáticas políticas em contato. ${ }^{447}$ A perpetração desses dois traços entre os séculos XVI e XX, de maneira quase que imodificável, permite a constatação de que os autos de vassalagem são produções escritas entremeadas de "transcodificações" estruturais, capazes de promover articulações de e integrações entre modelos políticos distintos, principalmente entre os do Antigo Regime com os das estruturas organizacionais africanas, traduzindo-se em uma forma de dominação menos

${ }^{445}$ Basta, por exemplo, notar a discrepância que havia entre os direitos e deveres que deveriam cumprir o "senhor suserano" em relação aos "sobas vassalos". Estes deveriam cumprir seis pontos de fundamentação, a saber: $i$ ) "Respeito e acatamento às leis do governo"; ii) Pagamento de taxas, entre elas o "dízimo"; iii) Assistência militar durante guerras; iv) O livre trânsito de mercadorias; v) O recebimento dos "oficiais do governo e missionários"; vi) A extradição de foras da lei e a convivência pacífica com os demais povos na região. O "senhor", ou a monarquia portuguesa, deveria em troca apenas ceder auxílio militar e proteção contra os inimigos comuns. Verificar: SANTOS, Catarina Madeira. Entre deux droits : les Lumières en Angola (1750-v. 1800). Annales. Histoire, Sciences Sociales. Paris: Éditions de l'EHESS, n. ${ }^{\circ}$ 60, 2005/4, p. 825 .

${ }^{446}$ Nesse sentido, são apropriadas três considerações feitas por António Manuel Hespanha. A primeira era a de que havia incertezas sobre como a "população colonial ou natural" iria ser sujeitada à justiça portuguesa (ius commune). Inevitavelmente, os "sobas amigos mas não vassalos" estariam relegados ao direito das gentes (iura propria), fazendo do "tratado de vassalagem" um instrumento de integração de alguns sobas avassalados à ordem política e jurídica portuguesa. Esse segundo ponto é desdobrado um terceiro, muito importante para interpretar a documentação de época. Devido à "heterogeneidade do estatuto político dos vassalos" e à "pluralidade dos tipos de laços políticos" que poderiam ser firmados pelas autoridades representantes do monarca, não havia muito rigor e controle quanto aos argumentos jurídicos lançados para impor o avassalamento a certos sobas, ou mesmo para fazer decreto sobre a justiça de guerra no caso de confronto militar contra algum "inimigo" da Coroa. Na prática, muitos argumentos e motivações sustentados eram forjados e formulados de "maneira verossímil", apenas para legitimar alguns atos políticos. Verificar: HESPANHA, António Manuel. A constituição do Império português. Revisão de alguns enviesamentos correntes. IN: FRAGOSO, João; BICALHO, Maria Fernanda Baptista; GOUVÊA, Maria de Fátima Silva (org.). O Antigo Regime nos trópicos: a dinâmica imperial portuguesa (séculos XVI-XVIII). Rio de Janeiro: Civilização Brasileira, 2001, 170-172.

447 Aqui somos influenciados pela clave analítica presente especificamente em: LARA, Silvia Hunold. Palmares \& Cucaú: o aprendizado da dominação. Tese para concurso de Professor Titular, Universidade Estadual de Campinas (UNICAMP), 2008, pp. 120-121. 
voraz do que a praticada na "guerra total", ou imposição de hegemonia continental, mas perene na longa duração dos contatos luso-africanos. ${ }^{448}$

Todos esses elementos percorreram o processo de escolha e avassalamento de Angola Aire, concretizado em outubro de 1626. Embora generalizante, uma breve explicação sobre como ocorria uma cerimônia de avassalamento foi documentada no “extenso relatório de Fernão de Sousa”, presente na $F H A$ e que aqui servirá como base de nossas considerações. Segundo o fragmento de informação, de maneira geral havia sucessão política entre os mbundu quando "sucedem nas terras por morte do último senhor da terra" ou "por causas justas e conforme a suas leis, e costumes lançam o senhor para fora de suas terras, e elegem os macotas, que são os do conselho, outro senhor". 449 Após a escolha feita "em conselho", pregava a tradição que os macotas comunicassem-na ao governador português, para que ele a "confirmasse" através da "unda", também reconhecida como "undamento". ${ }^{450} \mathrm{Na}$ opinião de Fernão de Sousa, era através desse ato que o funcionalismo régio conferiria o "endosso", ou aval institucional, validador da eleição de dignitário. Já os macotas interpretavam o undamento como um modo de "confirmá-lo na terra". ${ }^{451}$ Tal ato solene era executado da seguinte forma. O soba recémeleito se postava na frente do governador, de "peito por terra em sinal de vassalamento à Sua Majestade", e o governador "lançava" um pouco de farinha por cima do corpo do africano que, logo em seguida, recolhia a farinha com as mãos e a passava no peito e nos braços, "e então se tem por senhor da terra". Depois, a autoridade portuguesa ordenava que o eleito fosse vestido conforme a "qualidade e poder" dele. Em seguida, ainda em caráter formal e solene, o "soba lhe presenta [ao governador] o que quer" e também "a quem lhe

\footnotetext{
${ }^{448}$ Além do texto citado na nota acima, as leituras essenciais aqui são: SANTOS, Catarina Madeira. Administrative knowledge in a colonial context: Angola in the eighteenth century. The British Journal for the History of Science (BJHS), vol. 43, dezembro de 2010. Idem, Um governo "polido" para Angola: Reconfigurar dispositivos de domínio. (1750-c.1800). Tese de doutorado, Universidade Nova de Lisboa, 2005. HEINTZE, Beatrix. Angola nos séculos XVI e XVII [...]. Luanda: Kilombelombe, 2007, capítulos 9 e 10.

${ }^{449}$ Fernão de Sousa. O extenso relatório do governador aos seus filhos. S.d., 1625-1630. BAL, cód. 51-IX20, ff. 220-74v. IN: HEINTZE, Beatrix (coord.). Documento 30, FHA, vol. I, 1985, pp. 280-281

${ }^{450}$ Fizemos uma brevíssima apresentação sobre a "unda" no capítulo anterior. Para informações concisas sobre o assunto, conferir o "suplemento para alguns vocábulos africanos", inserido nesta dissertação.

${ }^{451} \mathrm{Na}$ verdade, no documento não fica muito claro se a escolha de dignitário africano era feita pelo próprio governador e, portanto, a eleição era apenas uma "formalidade", ou se ela era procedida pelos macotas, sendo apenas "oficializada" depois pelo governador. Consta no extenso relatório apenas que: "[sobre o escolhido pelos macotas] este tanto que é eleito o fazem saber ao governador pedindo-lhe que o haja por bem, e que queira undar [...]”. Ibidem, pp. 280-281.
} 
lança a farinha e a quem o veste", que poderiam ser autoridades como o "capitão da guarda, secretário ou tendala". No mais, pondera Fernão de Sousa, o undamento era encomendado em respeito à vontade do soba e conforme os "usos e costumes" locais, divididos em duas vertentes. Em primeiro lugar, "porque responde ao direito de confirmação, chancelaria, e mais direitos que o donatário paga pela confirmação", apontando que o preceito políticolegal do avassalamento poderia advir da antiga instituição dos amos. Em segundo lugar, "porque têm [os sobas] por grande desprezo não lhe[s] tomar o que por este modo dá", uma vez que a falta de undamento era encarada como uma forma indireta de declará-los "inimigos levantados". ${ }^{452}$

A cerimônia de avassalamento era um caso exemplar de coexistência e rearranjo, em três operações específicas: adição, substituição e anulação. Seguindo as ponderações feitas por Catarina Madeira Santos, o undamento pode ser interpretado como uma substituição, ou paralelo simbólico, em relação à chamada "investidura", por sua vez subdividida em duas partes, a de "vestir" e a de "peso". No caso centro-africano, o "peso" foi substituído pelo ato de recobrir o avassalado a princípio com "pemba", não farinha, como afirmara Fernão de Sousa. Outro elemento rearranjado foi a "encomendação", também chamada de "homenagem" ou "encomenda", conforme a prática na Península Ibérica. No contexto centro-africano, ela foi trocada por "um cerimonial proveniente dos costumes locais", segundo o qual as autoridades "aplaudiam, colocando as mãos na terra depois sobre o peito, ao mesmo tempo que juravam ser vassalos leais do rei de Portugal". 453 No geral, qualquer um desses atos e suas respectivas subdivisões poderiam ser adicionados ou anulados da cerimônia. Havia, no entanto, dois fatores imodificáveis. No plano do

\footnotetext{
${ }^{452}$ Fernão de Sousa. O extenso relatório do governador aos seus filhos. S.d., 1625-1630. BAL, cód. 51-IX20, ff. 220-74v. IN: HEINTZE, Beatrix (coord.). Documento 30, FHA, vol. I, 1985, p. 281. Na nota 225 dessa página, Beatrix Heintze explica que esse mesmo excerto pode ser encontrado em: FELNER, Alfredo Albuquerque. AASO, 1933, pp. 471-72.

${ }^{453}$ SANTOS, Catarina Madeira. Escrever o Poder: os Autos de Vassalagem e a Vulgarização da Escrita entre as Elites Africanas Ndembu. IN: HEINTZE, Beatrix; OPPEN, Achim von (Ed.). Angola on the Move: Transport Routes, Communications and History. Frankfurt am Main: Verlag Otto Lembeck, 2008, p. 176. SANTOS, Catarina Madeira. Écrire le pouvoir en Angola: Les archives Ndembu (XVIIe-XXe siècles). Annales. Histoire, Sciences Sociales. Paris: Éditions de l'EHESS, n. ${ }^{o}$ 64, 2009/4, pp. 775-776, tradução nossa. (No origina: "À la génuflexion du roi vassal, au moment où était prononcé le serment, se substitue une expression locale de soumission et de remerciement : les sobas applaudissent, en posant les mains à terre puis sur leur poitrine, tandis qu'ils jurent d'être des vassaux loyaux du roi du Portugal"). Para uma descrição minuciosa sobre os atos solenes que compunham a cerimônia de avassalamento, conferir: HEINTZE, Beatrix. Angola nos séculos XVI e XVII [...]. Luanda: Kilombelombe, 2007, pp. 402-405. Chama-nos atenção a seguinte afirmação da pesquisadora: "No undamento pelos portugueses, deitava-se farinha (ou barro branco) sobre os ombros do chefe africano que a esfregava pelo peito e pelo braços" (pp. 404-405).
} 
utilitário e do simbólico, o avassalamento era um "campo de intermediação" de via de mãodupla, uma vez que possibilitava a comunicação intersocial através da utilização de conceitos e termos intraduzíveis para ambos os lados. No plano da prática, ou "pragmática", o rearranjo com base nas possibilidades de adições, substituições e anulações chama a atenção para os desdobramentos empíricos, decorrentes da submissão política. Nesse sentido, o caso de eleição e avassalamento de Angola Aire é digno de destaque.

Uma das raras descrições coevas sobre a cerimônia solene de outubro de 1626 está registrada no extenso relatório de Fernão de Sousa. Destarte, é importante notar que não há nele menção à encomendação, motivo pelo qual supomos que o ato acabou excluído da solenidade política. Para compensar, Fernão de Sousa aglutinou ao cerimonial dois elementos tão importantes quanto os demais já citados, poderíamos aventar singulares para o contexto mbundu: o batismo seguido da "renomeação" da mais nova posição titular criada, cunhada então como "El-rei Angola Aire Filipe I". ${ }^{454}$ Isso, acreditamos, não ocorreu ao esmo. O novo soberano aceitara de bom grado o nome português, fornecido em homenagem a Filipe III de Portugal e IV de Espanha, "Muene Puto" para os sobas mbundu, de acordo com António de Oliveira de Cadornega. ${ }^{455}$ Também aceitou o batismo sem pestanejar. Mediante a uma perspectiva política mbundu, o recém-entronado "rei do Ndongo" ainda era tributário da insígnia política do ngola, só que dessa vez estava reforçado pelo prestígio e cumplicidade de honrarias políticas e simbólicas diferenciadas, antes apenas fornecidas aos importantes "reis do Kongo". O batismo era um exemplo desses. A soberania renovada no Ndongo estava revestida por uma panóplia de diferentes

\footnotetext{
${ }^{454}$ Atentando para o fato de que esse "auto" ou "contrato" de vassalagem misteriosamente desapareceu. Todavia, fica claro, através de outros documentos da $F H A$, que a e referência completa a esse africano era essa mesma como destacamos no corpo de texto. Sobre essas informações, conferir, por exemplo, a nota 148 e as informações do corpo de texto em: Fernão de Sousa. O extenso relatório do governador aos seus filhos. S.d., 1625-1630. BAL, cód. 51-IX-20, ff. 220-74v. IN: HEINTZE, Beatrix (coord.). Documento 30, FHA, vol. I, 1985, p. 255. Sobro batismo, não apenas dele, mas também de alguns de seus familiares, conferir o mesmo documento, p. 287.

${ }^{455}$ Citado por Beatrix Heintze, que ainda informou que o ato de "por peso", integrante da investidura ou undamento, era chamado localmente de "por o peso de Muene Puto", ou "del Rei de Portugal". Verificar: HEINTZE, Beatrix. Angola nos séculos XVI e XVII [...]. Luanda: Kilombelombe, 2007, pp. 404-405. CADORNEGA, António de Oliveira de. HGGA, vol. II, 1940, p. 225. Tais informações foram parafraseadas, com citações semelhantes às de Heintze, em: FONSECA, M.B. Nzinga Mbandi e as guerras de resistência em Angola [...]. Dissertação de mestrado em História Social, Universidade de São Paulo (USP), 2012, p. 63. Ainda segundo Heintze, em kimbundu e kikongo, Mputu significa "Portugal". Verificar: HEINTZE, Beatrix (coord.). Esclarecimentos sobre vocábulos africanos, FHA, vol. I, 1985, p. 122.
} 
insígnias políticas misturadas entre si, sendo uma verdadeira miscelânea que concatenava o respaldo de Luanda, o governo africano do Ndongo e a religião cristã.

São desencontradas as informações sobre a ocorrência de undamento na dita cerimônia solene, elemento indispensável aos olhos legalistas das autoridades mbundu. Há momentos do extenso relatório nos quais Fernão de Sousa afirma que ele não ocorreu, ${ }^{456}$ em outros o autor é furtivo e vago. ${ }^{457}$ Se foi undado ou não, talvez nunca saberemos, pois o auto de vassalagem de Angola Aire sumiu misteriosamente. Fato é que a matéria era controversa, devido a um motivo caro tanto para o lado português, quanto para o mbundu: o undamento mantinha íntima relação com as chamadas "promessas de pagamento de baculamento". Incorporado como parte do léxico institucional dos documentos inseridos na FHA, os termos "bacular" e "baculamento" eram aportuguesamentos da expressão "prestação de homenagem" - bakula, em kimbundu - e que, no emprego prático da escrita institucional ultramarina, traduzia-se no pagamento de tributos únicos que eram cobrados dos "sobas vassalos". Disso podemos fazer duas considerações. A primeira, mais simplista e hipotética, é a de que Angola Aire possivelmente não jurou encomenda a Fernão de Sousa, seja por ordem expressa de Fernão de Sousa, seja porque o africano não queria fazêlo, uma vez que com isso ficaria preso à obrigatoriedade de pagamento de tributação, conforme o costume mbundu - na interpretação portuguesa, "quem bacula deve pagar o baculamento". Isso acarreta em uma segunda consideração, muito mais relevante. Embora fosse simbólico o fato de o novo rei do Ndongo ter aceitado a submissão política à monarquia portuguesa, na figura de um "rei africano" que agora era "vassalo tributário" de

\footnotetext{
${ }^{456}$ Em resposta a uma das cartas de Bento Banha Cardoso, possivelmente emitida em junho de 1626, Fernão de Sousa ordenou-o para que ele não "undasse" o "Aire", demonstrando total descompasso entre a ação encomendada e uma expectativa mais lógica, que a princípio era a de undar e com isso angariar legitimidade. De todo modo, mesmo sem a unda, presumiu Fernão de Sousa, ficaria o africano "vassalo d'El-rei nosso senhor com feudo", pagando "o tributo que se tem apontado". Verificar: Fernão de Sousa. O extenso relatório do governador aos seus filhos. S.d., 1625-1630. BAL, cód. 51-IX-20, ff. 220-74v. IN: HEINTZE, Beatrix (coord.). Documento 30, FHA, vol. I, 1985, pp. 254-255.

${ }^{457}$ Contamos apenas um registro diminuto sobre a cerimônia de avassalamento de Angola Aire, inserido no "extenso relatório de Fernão de Sousa", onde está escrito: "[...] Aprovou o capitão-mor a eleição em nome de Sua Majestade, e meu, e El-rei aceitou a investidura com as condições e obrigações declaradas na escritura que fez [...]". O extenso relatório do governador aos seus filhos. S.d., 1625-1630. BAL, cód. 51-IX-20, ff. 220-74v. IN: HEINTZE, Beatrix (coord.). Documento 30, FHA, vol. I, 1985, pp. 256-257.
} 
Portugal ${ }^{458}$ os baculamentos nunca foram pagos ao fisco régio durante o governo de Fernão de Sousa. ${ }^{459}$

De fato, havia uma série de incoerências e ambivalências entre o discurso e a prática, enveredando para dois caminhos que articulavam e entrelaçavam os vieses mbundu e português. O primeiro dizia respeito à cadeia relacional constituída pelos quatro pontos encadeados e coligados entre si - avassalamento-undamento-baculamento-tributação -, formadora da imposição de domínio indireto na região. Tal cadeia relacional foi uma das maneiras encontradas para absorver um soberano mbundu dentro da rede de fidelidade política comandada por Luanda, classificando-o agora como "rei vassalo" de Portugal, através da incorporação de elementos da política mbundu - unda e bakula - subsumidos a conceitos advindos da Península Ibérica, o da vassalagem e o da tributação. Desse modo, sem ferir o princípio básico de coexistência por imbricação multilógica, ou simplesmente rearranjo que ultrapassa temporalidades e espacialidades extremamente limitadas ou relativas - por exemplo, noções conceituais expressas pelos termos "Idade Moderna" e "Era Medieval", ou "mundo português" e "mundo mbundu" -, que Luanda viabilizou uma política de tutela, cooperação e parceria. ${ }^{460}$ Do outro lado da moeda, a nova dinastia de Angola Aire não se curvaria tão facilmente aos propósitos externos, e esse é o segundo caminho em que devemos prestar atenção.

O sinal claro de uma contrarresposta mbundu aos intuitos ultramarinos está contido na frequência e forma com as quais um novo topônimo passará a incidir nas fontes escritas contidas na FHA: "Pungo Andongo". Suplantando as antigas "capitais" do Ndongo, conforme registrado nos documentos de época "Kabasa" e "Vunga", será após outubro de 1626 que o topônimo "Pungo Andongo" começará um lento processo de consolidação no

\footnotetext{
${ }^{458}$ Sobre isso, verificar especificamente o corpo de texto e as notas 148 e 152, em: O extenso relatório do governador aos seus filhos. S.d., 1625-1630. BAL, cód. 51-IX-20, ff. 220-74v. IN: HEINTZE, Beatrix (coord.). Documento 30, FHA, vol. I, 1985, pp. 255-257.

${ }^{459}$ Sobre isso, consultar o capítulo 4 desta dissertação.

${ }^{460}$ Apesar da prematuridade de qualquer conclusão, é possível cogitar que toda uma nomenclatura legalista sobre as taxas e tarifas extraordinárias e abusivas, encaradas como semilegais ou ilícitas pela administração ultramarina, era estipulada e definida por contraposição à cadeia avassalamento-undamento-baculamentotributação e aos chamados "direitos de passagem", ou "malafos". As semilegalidades e ilicitudes eram enquadradas em três grupos considerados amorfos, mesmo que acabassem evocados nos seguintes conjuntos: i) "infutas", "vestir" e "loandas"; ii) "infucas" e "ocambas"; iii) "prões" e "precalços". Para mais informações, consultar a entradas para cada um desses termos no "suplemento para alguns vocábulos africanos", inserido nesta dissertação. Todas essas práticas já foram comentadas brevemente em: HEINTZE, Beatrix. Angola nos séculos XVI e XVII [...]. Luanda: Kilombelombe, 2007, pp. 416 e 454-455.
} 
imaginário político dos mbundu e dos habitantes de Luanda. Aqui nos valeremos de uma breve reconstituição histórico-linguística feita por Beatrix Heintze, a fim de expor o processo de desenvolvimento do topônimo. Como lugar geográfico, Pungo Andongo, também registrada como "Pedras" ou somente "Pedra", é uma "fortificação natural de penedos" conhecida até hoje. Sua denominação ancestral, poderíamos dizer "originária”, é "Matadi Maupungo", ou em kimbundu, Matadi ma upungu, o que significa "Pedras Altas". Vulgarizado em português quinhentista e seiscentista, viraria "Maopungo", 461 a princípio uma referência geográfica situada dentro da então "província de Are". Aconteceu então que, depois de eleito e avassalado, Angola Aire instituiu nesse lugar sua "residência real", de modo que o termo "Maopungo" recebeu o acréscimo de "Ndongo". O resultado disso seria a criação da expressão matadi ma upungu wa Ndongo que, em um movimento de simplificação linguística, seria abreviada para "Matadi Mapungo a Ndongo e finalmente Pungo Andongo". ${ }^{462}$ Doravante, os registros escritos sobre "Kabasa" e "Vunga" minguarão, sendo esses topônimos relegados à memória tradicional sobre o nascimento da sociedade mbundu. ${ }^{463}$

\footnotetext{
${ }^{461}$ De uma forma geral, na FHA são dois os vocábulos mais utilizados para se referir a esse topônimo, "Pungo Andongo" e "Maopungo", sendo este o preferido por Fernão de Sousa. Anos mais tarde António de Oliveira de Cadornega utilizará a expressão "Pedras de Mapungo". Verificar: CADORNEGA, António de Oliveira de. $H G G A$, vol. I, 1940, pp. 167-68 n.

${ }^{462}$ Sobre essas afirmações, verificar a nota 43 de Beatrix Heintze para: Fernão de Sousa. História das relações entre a Angola portuguesa e o Ndongo 1624-1631. 6 de agosto de 1631. BAL, cód. 51-IX-20, ff. 362-63. IN: HEINTZE, Beatrix (coord.). Documento 25, FHA, vol. I, 1985, p. 202. Ver ainda: HEINTZE, Beatrix. Angola nos séculos XVI e XVII [...]. Luanda: Kilombelombe, 2007, p. 229.

${ }^{463}$ Explica Virgílio Coelho, a partir do conhecimento antropológico sobre os mbundu, que os termos Kákùlù e Kábàsà são "dois corpos gemelares" que estruturam o modelo de vida, ou "sistema de mundo múndòngò" (mbundu). Eles não eram necessariamente estruturas físicas ou tangíveis. Na proposta concisa de Coelho, Kábàsà quer dizer "mundo dos seres vivos, do homem, de todos aqueles que falam a língua Kímbùndù". O contraponto desse conceito é Kákùlù, o "mundo dos mortos, dos antepassados, mundo do criador de tudo quanto possuímos ou de quem herdamos e que é necessário reverenciar sempre que possível (e necessário); mundo dos começos, mundo do além, da negrura, da imensidão, mar, oceano Atlântico, Kálùngà." Verificar: COELHO, Virgílio. Em busca de Kábàsà: Uma tentativa de explicação da estrutura político-administrativa do "Reino de Ndongo". Actas do Seminário Encontros de povos e culturas em Angola. Luanda: Comissão Nacional para as Comemorações dos Descobrimentos Portugueses, 1995, pp. 461-462 e 471. Em sentido símile, verificar: Idem, "Em busca de Kábàsà!..." Estudos e reflexões sobre o "Reino" do Ndòngò: Contribuições para a História de Angola. Luanda: Kilombelombe, 2010, pp. 188-189. Idem, Os Túmúndòngò, os "génios" da natureza e o kílàmbà: Estudos sobre a sociedade e a cultura kímbùndù. Luanda: Kilombelombe, 2010 pp. 37-38. Sobre Kabasa como um espaço físico, onde residia o ngola, verificar a nota 75 , p. 210 , em: Fernão de Sousa. A Angola portuguesa e as regiões circunvizinhas: descrição topográfica e histórica da ocupação portuguesa. S.d., posterior a 4 de agosto de 1630. BAL, cód. 51-IX-20, ff. 220-74v. IN: HEINTZE, Beatrix (coord.). Documento 29, FHA, vol. I, 1985, pp. 210-216. Ver também: HEINTZE, Beatrix. Angola nos séculos XVI e XVII [...]. Luanda: Kilombelombe, 2007, pp. 227-229. Para uma sucinta explanação sobre o pensamento e as normas políticas mbundu, consultar as tabelas inseridas na seção "Uma cosmologia mbundu", contida nos anexos desta dissertação.
} 
A transferência física do núcleo da soberania política dos mbundu para Pungo Andongo indicava não apenas a fundação de uma nova "capital", agora comandada pela posição titular renovada de "Angola Aire Filipe”, mas também de uma redinamização do concerto político que estava nas mãos dos ndongo de Ambande. A partir de 1626, o "centro do mundo" da sociedade mbundu, representado pelo ngola, será realocado no proeminente ngundu da província de Are $^{464}$ e isso fez toda a diferença no xadrez geopolítico. Após a eleição e avassalamento de Angola Aire, não mais se tocou no assunto do deslocamento de Ambaca para a localidade de Hango. Afinal de contas, não havia necessidade, pois a nova elite dirigente do reino do Ndongo era conivente com Luanda. Além do mais, Angola Aire possivelmente via na construção avançada portuguesa uma forma de minar as chances de ressurgimento dos Ambande. ${ }^{465}$ Perpetuadas ao longo do tempo e do espaço, fundadas e mantidas por motivos políticos e econômicos diversos, construções como as de Ambaca são os indícios geopolíticos claros do enraizamento de uma posição dominante portuguesa na África, mesmo que seu impacto seja apenas local, com ajuda de elites e autoridades locais. $^{466}$

\footnotetext{
${ }^{464}$ Ficamos com a explicação sumária de Virgílio Coelho: "A capital do reino é justamente ali onde se encontra o rei: o Ngòla está no centro do mundo". COELHO, Virgílio. Em busca de Kábàsà [...]”. Actas do Seminário Encontros de povos e culturas em Angola. Luanda: Comissão Nacional para as Comemorações dos Descobrimentos Portugueses, 1995, 472-473. Assim, não é por menos que há uma confusão entre o que era o "reino de Angola", ou só "Angola", e o "reino do Ndongo", ou só "Dongo", como normalmente é grafado dos documentos de época. Como léxico reapropriado do kimbudu, "Angola" foi uma simplificação de "ngola", o título e o estatuto de soberania entre os mbundu e que, na terminologia portuguesa, acabou confundido também com um espaço soberano de mando e ordem, um "reino". Verificar: HEINTZE, Beatrix. Angola nos séculos XVI e XVII [...]. Luanda: Kilombelombe, 2007, nota 1, p. 278. Sobre o aumento da importância de Are com o deslocamento do núcleo político mbundu para lá, verificar esse mesmo texto de Virgílio Coelho, p. 467, além da obra de Heinte, pp. 191-192. Sobre Angola Aire e as suas "capacidades sobrenaturais" herdadas a partir de 1626, verificar esta obra, pp. 211-212.

${ }^{465}$ Aqui discordando um pouco de Beatrix Heintze, cuja opinião é a de que a demora no deslocamento do presídio de Ambaca ocorreu principalmente devido à fídelidade que Fernão de Sousa tinha em relação à monarquia, favorável à permanência do presídio lá onde estava. Nos termos da pesquisadora, "uma escrupulosidade extrema e algo formalista constituía um dos traços de caráter mais notáveis deste homem [Fernão de Sousa], que não só tinha uma dedicação incondicional o seu soberano, mas também se esforçava por servi-lo da melhor maneira possível [...]". Verificar: HEINTZE, Beatrix. Angola nos séculos XVI e XVII [...]. Luanda: Kilombelombe, 2007, p. 332. Sobre Ambaca e proximidade que ela mantinha em relação aos topônimos de Kabasa e Vunga, verificar: HEYWOOD, Linda M.; THORNTON, John K. Central Africans, Atlantic Creoles [...]. Cambridge: Cambridge University Press, 2007, p. 75.

${ }^{466}$ Lembrando que Ambaca era um "entroncamento das principais rotas comerciais de escravos ao sul do Dande, estava situada num espaço estrategicamente importante para todas as autoridades que ambicionavam controlar a Ilamba, o Lumbo, o Ari, o Museke, a Tunda e o Libolo", algo que certamente justificava a manutenção do presídio ali onde fora soerguido. Verificar: PARREIRA, Adriano. Economia e sociedade [...]. Lisboa: Editora Estampa, 1997, p. 190. Sobre a importância econômica que Ambaca passaria a exercer desde então, muito mais do que o reino do Ndongo propriamente dito, verificar: HEINTZE, Beatrix. Angola nos séculos XVI e XVII [...]. Luanda: Kilombelombe, 2007, p. 383.
} 
Terminamos então com algumas considerações finais a respeito da produção textual da série de lembranças e relações analisadas neste capítulo. Primeiramente, dentro de uma perspectiva histórica e crítica, remetida à análise perscrutada dos documentos inseridos na FHA, é possível afirmar que o punho que conduziu a "lembrança" sobre a ilegitimidade de Angola Aire foi guiado por interesses políticos, não pela análise neutra e desinteressada a respeito da elegibilidade e ingovernabilidade do novo rei do Ndongo. Tratava-se de uma "construção de ilegitimidade", um "estratagema" para divergir o olhar atento dos superiores reinóis dos erros cometidos na condução da Angola portuguesa, salientando o "bom serviço" prestado e primando pela justificativa das condutas passadas, mais do que um exame legal de justiça política e gentílica. Conjecturando um pouco, a estratégia de Fernão de Sousa era simples e eficiente: admitir um erro na averiguação legal da sucessão política seria grave, mas menos desonroso e indigno do que admitir a falha no cálculo político e econômico na administração da Angola portuguesa. Dito de outra forma, tratava-se da "escolha do mal menor", passando necessariamente pelo forjamento de um desserviço menos relevante. Em segundo lugar, a análise da série de lembranças e relações acima desenvolvida atesta para o malogro da "conquista do Ndongo", na medida em que o "antigo comércio" não foi reestabelecido e porque essa soberania africana não era subserviente às vontades de Luanda. Depois de ser eleito e avassalado, e a despeito das promessas feitas ao governador, Angola Aire demonstrou má-vontade em incentivar o aumento substancial das feiras de escravos, acumulando em contrapartida fazendas para si e para as linhagens que o apoiavam. Protegido na fortaleza natural de Pungo Andongo, o africano se sentia confortável em desacatar os interesses de Fernão de Sousa.

A terceira demanda estava ligada à produção de explicações convincentes sobre o fracasso da conquista do Ndongo, intimamente ligada à promoção dos Sousa como leais servidores da monarquia portuguesa. ${ }^{467}$ Demonstrando astúcia e inteligência, o português não queria manchar a reputação de sua família, além de possíveis promoções dos filhos dentro dos quadros do Antigo Regime. O serviço ultramarino era um legado deixado a eles e, mesmo que "imperfeito", deveria ser justificado nos moldes legais e institucionais da

\footnotetext{
${ }^{467}$ Fato é que o governador que sucedeu Fernão de Sousa, Dom Manuel Pereira Coutinho, afirmou aos superiores do Conselho da Fazenda que, na década de 1630, a Angola portuguesa ainda se encontrava em uma profunda crise política e econômica. Ou seja, havia uma grande diferença entre o discurso de Fernão de Sousa e a situação real das coisas no ultramar. Verificar: BIRMINGHAM, David. Trade and conflict in Angola [...]. Londres: Clarendon Press/ Oxford University Press, 1966, pp. 99-100.
} 
época. Mediante o cariz da escrita administrativa de Fernão de Sousa, as lembranças e relações podem ser interpretadas como um ato de organização e composição de um conjunto de provas de valor histórico, proposto para descrever aquilo que "deveria ter sido" os governos da Angola portuguesa, não necessariamente o que eles foram. Tratava-se de uma retroação deliberada do passado institucional da Angola portuguesa. Não é por menos que esse conjunto de memórias e narrativas imprime uma imagem positiva do governo de seu autor, Fernão de Sousa, dissociando-o qualitativamente dos governos precedentes. Nesse sentido, o tempo de Luís Mendes de Vasconcelos foi rememorado de maneira negativa, no qual praticamente só houve guerras injustas, o de João Correia e Sousa foi marcado pela ineficiência e os de Pedro de Sousa Coelho e Dom Frade Simão Mascarenhas foram épocas ingovernáveis. Duplamente como produto e produtor do processo histórico, as lembranças e relações de Fernão de Sousa foram elaboradas como um compêndio do "bom governo ultramarino". 


\section{O FUNCIONAMENTO DE UM ESPAÇO ADMINISTRATIVO E JURISDICIONAL NA ANGOLA PORTUGUESA}

\section{Apresentação}

No presente capítulo discorreremos sobre o funcionamento de um sistema administrativo misto, alinhado à configuração de um espaço jurisdicional e burocrático imaginado na confluência de legislações e interesses políticos distintos, um "jogo de forças" poderíamos resumir. Por um lado, jazia o respeito ao direito escrito reinante em Portugal e à transplantação de um aparato administrativo ao ultramar. Por outro lado, existia a necessidade de integrar alguns elementos dos costumes locais e certos agentes africanos, a fim aprimorar o comércio de escravos e atender às demandas e às pressões exercidas pelas autoridades centro-africanas, como as do Ndongo, Kongo e Dembo. No olho do furacão surgia a atuação incisiva de alguns indivíduos movidos por interesses particulares ou comunais, como a do capitão Henrique de Magalhães e a do mais novo "rei do Ndongo", Angola Aire. Privilegiaremos então três pontos basilares ligados à configuração do sistema administrativo ultramarino e do espaço jurisdicional, também reconhecida pelo modelo de "governadoria-geral de Angola". Primeiro, essa configuração funcionava em rede, mediante a qual alguns entrepostos avançados de apoio institucional, os chamados "presídios do interior" e algumas das banzas de sobas vassalos, figuravam como os nodos institucionais mantedores da autonomia e coerência das partes, conciliadas ao funcionamento coeso do sistema enraizado a partir de Luanda. ${ }^{468}$ Segundo, o aparato e órgãos portugueses transplantados para o interior estavam subordinados aos mecanismos de vigilância e fiscalização ordenados por funcionários e oficiais régios, mediante os quais a justiça era implementada e aplicada. Terceiro, o sistema administrativo foi moldado às adversidades e às pressões exercidas pelos povos africanos interioranos, de modo que a

\footnotetext{
${ }^{468}$ Somos então influenciados pelas considerações feitas em: THORNTON, John K. A Cultural History of the Atlantic World, 1250-1820. Cambridge: Cambridge University Press, 2012, pp. 253-254. O termo "entreposto" também é empregado em: SANTOS, Maria Emília Madeira. Nos caminhos de Africa: serventia e posse (Angola - Século XIX). Lisboa: Instituto de Investigação Científica Tropical, 1998, pp. 435-436, entre outras passagens.
} 
gestão do espaço jurisdicional só foi aperfeiçoada através da instrumentalização das operações de absorção de agentes e incorporação de elementos africanos.

\subsection{Penetração institucional rumo a Pungo Andongo (1624-1627)}

Nosso ponto de partida é um curto, mas importante fragmento de informação, contido em um dos mais ricos manuscritos criados por Fernão de Sousa, indexado à $F H A$ com o título de "O extenso relatório do governador aos seus filhos".

Prosseguindo com uma das narrativas existentes nessa fonte escrita, Fernão de Sousa afirmou que recebera uma carta de "Angola Aire, futuro Filipe I do Ndongo" "469, de 19 de fevereiro de 1627. Não conhecemos o conteúdo dessa correspondência, mas sabemos que a resposta ao africano foi feita em 26 de março de $1627 .{ }^{470} \mathrm{Na}$ resposta, Fernão de Sousa escreveu que proveria Domingos Pires à função de meirinho, em razão de sua elevação ao secretariado do rei do Ndongo e a pedidos pessoais de Angola Aire. Desse modo, explica o governador, o mais novo funcionário poderia "lançar do Reino os pombeiros e quimbares que andarem derramados pelo Reino", ${ }^{4}$ além de poder prender os que estivessem "fora" da feira de escravos que seria feita no Ndongo. Domingos Pires ainda poderia "tomar as fazendas que forem desmandadas conforme aos bandos, fazer tudo o que pertencer aos mucanos". ${ }^{472}$ Como veremos mais para frente, além da banza de Angola Aire, o provimento de meirinhos também ocorria nas feiras de escravos.

O ofício de meirinho naturalmente foi importado do reino de Portugal. Segundo António Manuel Hespanha, tal cargo aparece já no reinado de D. Afonso III (1248-1279), em 1254 ou 1261. Os meirinhos tinham inicialmente funções de "inspeção administrativa" e "correição judiciária", na medida em que eram encarregados pela investigação e recurso legal que chegassem ao conhecimento dos concelhos. No reinado seguinte, de Dom Dinis I (1279-1325), surgiram "outros funcionários com as mesmas áreas de atribuições, os corregedores" que, ao longo dos anos subsequentes, substituíram os meirinhos. Para todos os efeitos, meirinhos e corregedores eram oficiais reinóis com atribuições de inspeção e

\footnotetext{
${ }^{469}$ Mais informações acerca de Angola Aire serão disponibilizadas ao longo da presente dissertação.

${ }^{470}$ A carta de 19 de fevereiro de 1627 não consta na $F H A$. Conhecemos o conteúdo desse documento graças a uma cópia feita por Fernão de Sousa e inserida no meio de seu extenso relatório.

${ }^{471}$ Consultar o "suplemento para alguns vocábulos africanos", inserido nesta dissertação.

${ }^{472}$ Fernão de Sousa. O extenso relatório do governador aos seus filhos. S.d., 1625-1630. BAL, cód. 51-IX20, ff. 220-74v. IN: HEINTZE, Beatrix (coord.). Documento 30, FHA, vol. I, 1985, p. 281.
} 
correição, ou seja, de inspeção e recurso judiciários, tornando-se figuras características da "história administrativa e judiciária [de Portugal], de que a atual nomenclatura judicial ainda guarda memória". ${ }^{473}$ Sabemos ainda que, de acordo com as Ordenações Filipinas, ${ }^{474}$ os meirinhos do concelho foram funcionários considerados "menores ou executivos", encarregados de "executar as decisões dos órgãos dos concelhos e de fazer observar as posturas e regimentos locais", acumulando tarefas executivas e coadjutoras dos ouvidores, portanto no auxílio à justiça local. ${ }^{475}$ No âmbito local da administração judiciária, o ofício de meirinho jogava a favor da aquisição de títulos de nobreza, sendo preponderante o respeito ao costume local para a concessão de título nobiliárquico. ${ }^{476}$ Cabe também salientar que nenhum dos ofícios reinóis poderia ser dado pelos senhores locais, "salvo por doação". Nem sequer os "ofícios encarregados de exercer justiça senhorial (Ord. Fil.,II, 45, 3)" poderiam ser dados pelos senhores, já que o direito de designar e escolher os funcionários "decorria do caráter real deste direito, que era considerado sinal da suprema dignidade do rei". ${ }^{477}$ No caso de Luanda e dos presídios do interior, evidentemente, esse direito era transferido ao governador. De resto, havia certa continuidade entre as funções delegadas aos meirinhos do reino de Portugal e os que serviam no interior da Angola portuguesa. Isso, contudo, se fizermos algumas ressalvas, ou destacarmos algumas “singularidades". Em relação a Domingos Pires no Ndongo, a função de meirinho acabava implicando na execução de competências ampliadas e acúmulo de alçadas, que variavam da inspeção à correição judiciária - capacidade de lançar bandos e lidar com os mucanos -, tais quais os antigos meirinhos do tempo de Dom Afonso III. Por dedução, em dissonância com as diretrizes e o processo de desenvolvimento institucional no reino de Portugal, as competências delegadas a Domingos Pires condiziam mais com as responsabilidades inspecionais do que corretivas, cabendo-lhe tarefas voltadas à vigilância e à fiscalização, não à punição e à supervisão, mais propriamente ligadas ao ofício de corregedor nos séculos XVI e XVII.

473 HESPANHA, António. História das Instituições: época medieval e moderna. Coimbra: Livraria Almedina, 1982, p. 252.

${ }_{474}$ Daqui a diante apenas Ord. Fil.

${ }^{475}$ HESPANHA, António Manuel. As vésperas do Leviathan: instituições e poder politico. Portugal, século XVII. Coimbra: Editora Almedina, 1994, pp. 169-170, 184, 192-193.

${ }^{476}$ Ibidem, pp. 347-348.

${ }^{477}$ Ibidem, p. 399. Sobre isso, António Manuel Hespanha também acrescenta que as regras de doação e desígnio de oficialato valiam "para os meirinhos e alcaides (Ord. Fil., II, 45, 14), a não ser estando-lhes doada a correição; e, sobretudo, para os tabeliães (Ord. Fil., II, 45, 15)". 
Tal qual no reino europeu, no interior africano a função de meirinho também era considerada "mais baixa" e, não por coincidência, Domingos Pires respondia claramente a Angola Aire. No entanto, ao longo da montagem do aparato régio no interior do continente africano, a definição de competências de inspeção e execução - por exemplo, através do "lançamento de bandos" - e judiciais - por exemplo, ao proceder com os "mucanos" extrapolavam com a definição reinol de "ofício menor ou executivo". Paradoxalmente, a função de meirinho era hierarquicamente inferior, por exemplo, à de governador, mas não necessariamente de menos relevância. Assim, o secretário e meirinho Domingos Pires detinha competências extremamente importantes no que dizia respeito à vigilância, fiscalização e inspeção dos interesses régios no reino do Ndongo. Concomitantemente a isso, ele exercia algumas tarefas executivas, podendo "tomar fazendas" que estivessem "desmandadas", ou seja, desviadas do fisco régio e que burlassem as medidas legais promulgadas pelos órgãos institucionais ultramarinos. No final das contas - e esse é o cerne da argumentação -, esse homem detinha deveres mais amplos do que aqueles normatizados na Península Ibérica durante a época das Ord. Fil., exercendo tarefas de cunho local importantes, como as de "lançar bandos", "fazer mucanos" e "cuidar de diligências". Simplificando bastante, Domingos Pires tinha incumbências de ordem corretiva, judicial, fiscal e executiva. Além do mais, por exercer uma função bem próxima ao do rei do Ndongo, é possível cogitar que ele também levasse a cabo tarefas conselheiras e fosse responsável pela escrita de cartas oficiais, principalmente as enviadas para Luanda. O provimento do secretário do Ndongo à função de meirinho indicava continuidades institucionais em relação à linha de desenvolvimento institucional existente em Portugal, contudo um olhar mais atento indica também que, na banza do Ndongo, o recém-nomeado Domingos Pires passaria a deter competências ampliadas e acumularia alçadas diferentes, figurando como um agente local de relevância. Ocorriam mudanças ao longo da montagem do aparato régio nos pontos institucionais espalhados no interior, sinalizando que as transferências de cargos e ofícios reinóis ao ultramar, principalmente às regiões mais distantes da costa, implicavam em adaptações.

Os meirinhos que serviam no interior guardavam outras peculiaridades. Apesar de providos pelo governador residente em Luanda, eles poderiam ser escolhidos e responder a outros tipos de autoridades, como a de Angola Aire. Mas o que de fato é relevante diz 
respeito à existência de uma miríade de agentes que auxiliavam na manutenção e desenvolvimento da administração e da justiça regionais, em pontos institucionais bem localizados do continente, nomeadamente em Massangano, Cambambe, Muxima, Ambaca, banza de Pungo Andongo e feiras onde havia comércio, principalmente levadas a cabo no Ndongo e seus arredores. Havia dois traços essenciais a respeito dessa penetração institucional portuguesa. O primeiro era que o incremento administrativo e judiciário podia ser à primeira vista caótico e desorganizado, uma vez que alçadas análogas eram normalmente acumuladas entre autoridades que serviam em uma mesma localidade, podendo acirrar os conflitos locais, conforme verificaremos logo mais. O segundo traço era a existência de um caldeirão sociopolítico efervescente, no qual a participação de múltiplos agentes criava uma situação de permanente tensão social, embate político e atrito institucional. Nosso ponto é que um sistema administrativo trazido ao interior sofreu alterações advindas desse ambiente conflituoso, ou seja, as instituições portuguesas necessariamente foram adaptadas às condições locais encontradas ao longo da remontagem dos órgãos régios no interior africano. Assim, o aparente "caos" organizacional pode ser interpretado como sendo uma fórmula encontrada para enfrentar as adversidades deparadas em condições locais "peculiares". 478

Para ilustrar nosso ponto, podemos apresentar com maior profundidade um caso circunstanciado à prática e à aplicação do ato de "lançar bandos", para depois introduzirmos os papéis desempenhados por alguns dos agentes envolvidos na execução da justiça regional. De forma geral, esses "bandos" eram ordens escritas pelo governador e que deveriam ser lidas em voz alta em certos lugares, normalmente públicos, de tal forma que os habitantes das redondezas soubessem qual era o desejo do representante maior do monarca que residia em Luanda. A tendência é que essas ordens fossem sucintas e objetivas, determinando quais atividades seriam proibidas. Por exemplo, em 1 de outubro de 1624, Fernão de Sousa expediu um bando vetando que "pessoa de qualquer qualidade"

\footnotetext{
478 "Peculiar" foi uma palavra utilizada por Carlos Alberto de Moura Ribeiro Zeron para descrever a formação da sociedade colonial americana, que "deveria governar-se por meio de leis peculiares, porque peculiar também era a própria noção de bem comum, no contexto colonial e escravista". Verificar: ZERON, Carlos Alberto de Moura Ribeiro. A construção de uma ordem colonial nas margens americanas do Império português: discussões sobre o "bem comum" na disputa de moradores e jesuitas pela administração dos índios (XVI-XVII). Tese de livre-docência, Universidade de São Paulo, 2009. Idem, A ocidente do ocidente: linhas e perspectivas em confronto. Revista de História (USP). São Paulo: Universidade de São Paulo, n. 170, jan.-jun., 2014, pp. 93-94.
} 
fosse à "conquista pela terra adentro", a fim de "obrigar por força" os sobas vassalos a fornecer carregadores. Ficava também estabelecido que ninguém deveria "tomar por força as peruleiras de vinho deixando-as em casa dos ditos sobas ou à sua porta ou por outra qualquer via para depois lhe pedirem a valia delas em peças”. Era estritamente proibido que os sobas fossem obrigados a pagar peças, "por si nem ainda por mucano feito por tendala, nem por mani lumbo que não seja feito diante de capitães de presídio, ou de juiz competente". Contrariamente ao uso corriqueiro de mucanos, normalmente deturpados para finalidades pragmáticas de extorsão de sobas e roubo de escravos, Fernão de Sousa estipulou que seria terminantemente importante providenciar, durante a prática de mucanos, os "termos e autos judiciais necessários porque clara e distintamente se convença ao soba que deve a tal cousa", diferentemente do que o governador soube que maliciosamente acontecia nos presídios. ${ }^{479}$

O bando de outubro de 1624 explicita também uma separação entre dois polos de oposição e atração: os polos da legalidade e da ilegalidade. Isso não quer dizer que havia uma cisão instransponível e nem clara entre o lado dos "indivíduos da lei" e o lado dos “foras da lei". O simples fato de mucanos, uma forma de processo legal baseado na justiça costumeira, serem utilizados para extorquir peças dos sobas, já coloca em cheque qualquer divisão que não fosse fluida entre lícito e ilícito. O mesmo valia para caracterização das autoridades responsáveis pelo julgamento de mucanos: eles poderiam fazer uso da justiça para interesses próprios ou zelar pela lei. No caso de outubro de 1624, por exemplo, ocorre a menção a quatro agentes importantes encarregados do julgamento de processos legais de mucanos. Da parte africana, esses indivíduos podiam ser um tendala, um alto cargo africano de funções judiciais, ou mani lumbo, um importante título político encarregado de funções variadas. $^{480}$ Junto com os chamados "macotas", essas dignidades africanas pareceram ser as mais importantes no Ndongo. ${ }^{481}$ Da parte portuguesa, os agentes encarregados de um julgamento de mucano poderiam ser um capitão de presídio ou um juiz competente, ou seja,

\footnotetext{
${ }^{479}$ Fernão de Sousa [escrito por Luís Correa Coelho]. Bando de Fernão de Sousa. 1 de setembro de 1624. BAL, cód. 51-IX-21, ff. 146-46v. IN: HEINTZE, Beatrix (coord.). Documento 179, FHA, vol. II, 1988, p. 273. Nas palavras de Fernão de Sousa, a prática de extorsão era uma maneira maliciosa de forçar os "ditos sobas pagarem e darem por este modo peças sem as deverem".

${ }^{480}$ Aqui simplificamos os significados de "tendala" e "mani lumbo". Caso o leitor tenha interesse em conhecer as demais acepções para esses termos, consultar o "suplemento para alguns vocábulos africanos", inserido nesta dissertação.

${ }^{481}$ HEINTZE, Beatrix (coord.). Esclarecimentos sobre vocábulos africanos, FHA, vol. I, 1985, pp. 122 e 128 129. Sobre "macota", consultar o "suplemento para alguns vocábulos africanos" inserido nesta dissertação.
} 
possivelmente um juiz que fosse letrado e conhecedor da lei escrita. ${ }^{482} \mathrm{O}$ ponto central da ordem de Fernão de Sousa foi o de que a legitimidade de zelo pela justiça deveria ser delegada apenas aos agentes portugueses, o que em contrapartida deslegitimaria a autoridade judicial de tendalas e mani lumbos, dignidades africanas responsáveis pelas chamadas "leis gentílicas", às quais eram implicitamente imputadas as injustiças cometidas contra os sobas e tidas pelo funcionalismo régio como rústicas e, de certa forma, inferiores ao direito português. ${ }^{483}$ Além do mais, como veremos mais para frente, o prisma discursivo de Fernão de Sousa não poderia ser mais deturpador da realidade, pois eram os capitães de presídios que frequentemente, em nome da ordem e mando portugueses, cometiam os delitos e infrações contra os sobas e lesavam o fisco régio.

Tal movimento de descrédito de agentes e elementos africanos implicava em duas tendências. A primeira era a de enquadrar os tendalas e manis lumbos dentro de um estatuto judiciário de inferioridade, pelo menos no que dizia respeito à implementação da justiça nos presídios. A própria justiça de mucanos era muitas vezes encarada como "menos digna". A segunda era a de que havia embates constantes entre as autoridades africanas e os capitães de presídios e juízes, fato que fez com que Fernão de Sousa pendesse para o lado destes em detrimento daqueles. Assim sendo, se os polos da legalidade e ilegalidade eram fluidos, isso ocorria muitas vezes porque a relação entre agentes era conflituosa, não apenas girando em torno de atritos institucionais, mas abarcando tensões sociais e interesses econômicos criados em Ambaca, Massangano, Muxima, Cambambe e na banza de Pungo Andongo. Como está implícito no bando de outubro de 1624, o que pautava os novos conflitos internos e externos era o tráfico de escravos. Todas essas circunstâncias discernidas acima são características não apenas em um documento, mas também de outro bando emitido em 30 de abril de 1626 e nas medidas executadas no Ndongo em $1627 .{ }^{484}$

\footnotetext{
482 Em sentido análogo, verificar: SANTOS, Catarina Madeira. Um governo "polido" para Angola: Reconfigurar dispositivos de domínio. (1750-c.1800). Tese de doutorado, Universidade Nova de Lisboa, 2005, p. 163. Sobre a importância principalmente dos capitães de presídios, verificar: FERREIRA, Roquinaldo. Cross-Cultural Exchange in the Atlantic World: Angola and Brazil During the Era of the Slave Trade. Cambridge: Cambridge University Press, 2012, p. 103.

${ }^{483}$ Tal dissociação valorativa é proposta em: Fernão de Sousa. Fernão de Sousa sobre os tributos de vassalagem em Angola. 7 de dezembro de 1631. BAL, cód. 51-IX-20, ff. 367, 370-71v. IN: HEINTZE, Beatrix (coord.). Documento 39, FHA, vol. I, 1985, pp. 381-382. Para uma boa interpretação a respeito dessa matéria, verificar: FERREIRA, Roquinaldo. Cross-Cultural Exchange in the Atlantic World [...]. Cambridge: Cambridge University Press, 2012, pp. 103-104.

${ }^{484}$ Para mais informações, consultar: Fernão de Sousa. Bando de Fernão de Sousa. 30 de abril de 1626. BAL, cód. 51-IX-21, f. 150. IN: HEINTZE, Beatrix (coord.). Documento 186, FHA, vol. II, 1988, p. 278.
} 
Ao longo desse processo, podemos também destacar o importante papel que outro agente passaria a deter na cúpula de decisão judiciária e administrativa no Ndongo. Seu nome era Bento Rebelo Vilasboas. Conforme salientou Fernão de Sousa, em meados de 1627 os processos jurídicos levados a cabo no Ndongo, os chamados "mucanos", seriam sentenciados pelo "capitão e ouvidor Bento Rebelo Vilasboas", que passaria a residir em Pungo Andongo e teria incumbência sobre os mucanos "como lhe parecer justiça". ${ }^{485} \mathrm{~A}$ instalação do português no local tinha o intuito de combater os desvios de conduta e zelar pela aplicação da justiça. Começava em 1627 a implementação de uma série de medidas que visava coibir as várias "improbidades" e "artimanhas" cometidas contra os sobas, correntemente mascaradas sob a forma de mucanos, e que causavam "mal-estar" e transtornos ao "bem comum" das feiras e ao equilíbrio político regional. ${ }^{486}$ Nesse sentido, seguida da cópia da carta enviada a Angola Aire, de 26 de março de 1627 e que está inserida no extenso relatório de Fernão de Sousa, o governador registrou uma lista de onze instruções, ou "pontos", que deveriam ser cumpridos por Bento Rebelo Vilasboas. No sétimo ponto, o português fora encarregado de fazer os "mucanos com os vassalos" de Angola Aire. ${ }^{487}$ Esses mucanos estariam especificamente relacionados à questão de escravos fugidos, acolhidos e acobertados pelos sobas do Ndongo. ${ }^{488}$ Através da abertura de mucanos, o funcionário deveria "convencer" os sobas de que o acolhimento era injusto, de tal forma que os sobas restituíssem ou pagassem pelos escravos fugidos dentro de um período máximo de oito dias. Caso os sobas se recusassem a pagar por eles, Bento Rebelo Vilasboas tinha a ordem de "arrecadar pelo modo que puder ser", inclusive "pela fazenda de El-rei [Angola Aire]". ${ }^{489} \mathrm{O}$ capitão não era o único responsável pelos mucanos. No ponto 9, como salientado em outras passagens, Fernão de Sousa reafirmou a existências das

\footnotetext{
${ }^{485}$ Fernão de Sousa. O extenso relatório do governador aos seus filhos. S.d., 1625-1630. BAL, cód. 51-IX20, ff. 220-74v. IN: HEINTZE, Beatrix (coord.). Documento 30, FHA, vol. I, 1985, p. 282.

${ }^{486}$ Ocorre nas "Breves biografias de alguns europeus em Angola (1620-1630)", de Beatrix Heintze, uma omissão quanto ao plano de estadia desse português no Ndongo, onde apenas foi registrado que Bento Rebelo fora ouvidor e provedor dos defuntos em março de 1627. Talvez isso se justifique pelo fato de sua ausência no Ndongo durante os anos que se seguiram, como abordaremos mais para frente. Verificar: HEINTZE, Beatrix. Breves biografias de alguns europeus em Angola (1620-1630). FHA, vol. I, 1985, p. 112.

${ }^{487}$ Em poucas palavras, no começo do sétimo ponto está escrito o seguinte: "que os mucanos com seus vassalos se façam na sua banza [de Angola Aire]". Fernão de Sousa. O extenso relatório do governador aos seus filhos. S.d., 1625-1630. BAL, cód. 51-IX-20, ff. 220-74v. IN: HEINTZE, Beatrix (coord.). Documento 30, FHA, vol. I, 1985, p. 284.

${ }^{488}$ Sobre esse assunto, consultar os capítulos 2 e 4 desta dissertação.

${ }^{489}$ Fernão de Sousa. O extenso relatório do governador aos seus filhos. S.d., 1625-1630. BAL, cód. 51-IX20, ff. 220-74v. IN: HEINTZE, Beatrix (coord.). Documento 30, FHA, vol. I, 1985, p. 284.
} 
tarefas destinadas ao "meirinho da corte e do campo" Domingos Pires, que deveria "prender os desmandados" e "tomar as fazendas dos desencaminhados", sentenciando essas medidas na "forma dos bandos". De forma complementar aos demais documentos analisados no início deste item, Fernão de Sousa determinou que o secretário e meirinho agisse com "todo rigor" em relação às questões relativas à pólvora, armas, vinho, reclamações sobre "ocambas e infucas", ${ }^{490}$ devendo também prestar atenção nas "fazendas que passarem por Ndongo pelo prejuízo da feira". Ele deveria "lançar os bandos", encaminhando os quimbares ou pombeiros que acumulassem dívidas "de algum soba Vassalo de El-rei" à "banza d'El-Rei [Angola Aire] onde lhe faria mucano" e, 491 sendo comprovada a dívida, o montante devido seria pago dentro de 8 dias. ${ }^{492}$

A análise em conjunto das cartas de 19 de fevereiro e 26 de março, ordens enviadas a Angola Aire e instruções expedidas a Bento Rebelo Vilasboas apontam que o intuito de Fernão de Sousa era o de deliberadamente embaralhar as incumbências e tarefas institucionais ao longo da interiorização administrativa para o Ndongo, visando criar um cenário no qual a capacidade de "fazer mucanos" faria parte das competências partilhadas de Bento Rebelo Vilasboas e Domingos Pires. Assim, a condução do julgamento de caráter africano acabaria delegada a eles, obliterando a participação de autoridades africanas, como Angola Aire, macotas, tendalas e mani lumbos. Mas também é verdade que Angola Aire, Bento Rebelo Vilasboas e Domingos Pires poderiam lançar bandos, o que poderia a levar ao choque de interesses entre eles. Por outro lado, e isto é mais relevante, ao atribuir novas responsabilidades aos agentes da cúpula judicial e administrativa de Pungo Andongo, Fernão de Sousa redimensionava as relações de força locais em benefício de Luanda. É preciso ficar atento ao processo histórico como um todo. Conforme apresentado desde o início deste item, ao término do embalo inicial de expansão jurisdicional para o Ndongo, ocorrida entre 1624-1627, Angola Aire fora completamente destituído de suas funções judiciais regionais, não the cabendo mais responsabilidades sobre mucanos e diligências no Ndongo. Além disso, em termos materiais, seria ele o único lesado pela restituição de

\footnotetext{
${ }^{490}$ Sobre esses termos, consultar o "suplemento para alguns vocábulos africanos", inserido nesta dissertação.

${ }^{491}$ No documento não fica claro essas medidas diziam respeito aos sobas vassalos de Portugal ou do Ndongo. Nosso palpite é o de que eles eram vassalos do Ndongo, dado que normalmente Fernão de Sousa utilizava os pronomes de tratamento "vossa majestade" e "sua majestade" para se referir ao monarca.

${ }^{492}$ Fernão de Sousa. O extenso relatório do governador aos seus filhos. S.d., 1625-1630. BAL, cód. 51-IX20, ff. 220-74v. IN: HEINTZE, Beatrix (coord.). Documento 30, FHA, vol. I, 1985, p. 284.
} 
escravos fugidos de senhores portugueses. O término dessa penetração ultramarina culminaria na remontagem institucional de Pungo Andongo, mediante a qual o capitão e ouvidor Bento Rebelo Vilasboas obteria responsabilidades próximas às de controladoria e moderação, rivalizando um pouco com Domingos Pires na banza do Ndongo, mas certamente tendo mais peso do que ele, por contar com o apoio incondicional de Fernão de Sousa. ${ }^{493} \mathrm{O}$ resultado esperado no terceiro quartel de 1627 era o de estabelecimento de uma nova hierarquia local, responsável pela execução e aplicação da justiça, sendo a primeira autoridade a de Bento Rebelo Vilasboas, a segunda Domingues Pires e a terceira Angola Aire. Havia, no entanto, uma diferença entre intenção régia e experiência em campo. Veremos no momento oportuno que Angola Aire não será tão conivente ou passivo em relação às medidas promulgadas.

É de extrema importância não perder de vista que as fases de expansão e remontagem de um espaço jurisdicional em um ponto nodal do Ndongo, Pungo Andongo, foram marcadas por tensões, embates e atritos de abrangência regional, conforme já frisamos e voltaremos a tocar nos itens seguintes, além de um fenômeno sociopolítico peculiar e que consideramos ser um desdobramento vital no Ndongo. Nesses pontos de presença institucional incentivados por Luanda, serviam funcionários que, por estarem em contato direto com os mbundu e outros povos africanos, necessitavam conhecer as línguas, costumes e hábitos locais. Eles poderiam ser portugueses "experientes na terra", normalmente dotados de conhecimento militar, além de alguns serem conhecedores da escrita e contabilidade. Esse foi o caso de Bento Rebelo Vilasboas, português que talvez tenha nascido no ultramar africano, encarregado de diversos cargos institucionais que pressupunham a implementação de contato direto com as populações locais, como os de "cobrador dos tributos dos sobas" e "auditor de campo", durante os governos de Luís Mendes de Vasconcelos e Fernão de Sousa respectivamente, além de desempenhar funções políticas em missões diplomáticas, por exemplo quando fora enviado ao Ndongo por João Correia de Sousa, onde exercera a função de mediador. ${ }^{494}$ Poderiam também ser africanos

\footnotetext{
${ }^{493}$ Segundo Heintze, na segunda metade de 1627, Fernão de Sousa estava tão satisfeito com os serviços prestados por Bento Rebelo Vilasboas que o recomendou para o "cargo de tesoureiro dos defuntos e doentes". HEINTZE, Beatrix. Breves biografias de alguns europeus em Angola (1620-1630). FHA, vol. I, 1985, p. 112.

${ }^{494}$ HEINTZE, Beatrix. Breves biografias de alguns europeus em Angola (1620-1630). FHA, vol. I, 1985, p. 112. Beatrix Heintze ainda informa que, no começo da carreira, Bento Rebelo Vilasboas exerceu diversas atividades, entre elas a de escrivão das causas do mar.
} 
aportuguesados ou portugueses africanizados, configurando assim uma "via de mão-dupla" cultural, como parece ter sido o caso de Domingos Pires. Contudo, os aspectos de maior relevância eram a utilidade e o valor que esses indivíduos tinham para a administração ultramarina. O diferencial deles é que poderiam ser empregados para fins de intermediação entre as autoridades de Luanda e Pungo Andongo. Graças à capacidade de lidar e entender o comportamento dos mbundu, homens como Bento Rebelo Vilasboas e Domingos Pires eram peças fundamentais para que a comunicação oficial e a remontagem da cúpula judicial e administrativa do Ndongo obtivessem êxito. Não foi à toa que receberam postos de importância na nova hierarquia proposta para a cúpula interna do Ndongo. ${ }^{495}$

Finalmente, o último ponto que gostaríamos de frisar é o da existência de uma grande descontinuidade institucional entre Luanda e Pungo Andongo, algo que dificultava a vigilância do governador. Além disso, a cúpula do Ndongo era pequena e detinha bastante liberdade na execução de tarefas, para não dizer independência de ação. Embaralhar incumbências e tarefas era uma forma eficaz de fazer com que poucos funcionários operassem o máximo de tarefas possíveis, sem a supervisão do alto escalão. Em outras palavras, de maneira geral, estimular-se-ia a autonomia de presídios, feiras e banzas, priorizando o máximo de eficiência com o mínimo de gastos. Isso fica bastante evidente caso observemos, por exemplo, a maneira como o governador lidava com os entrepostos avançados de apoio institucional existentes no interior, principalmente no que diz respeito à comunicação oficial interna, na forma de cartas, portarias e bandos. Em um nível primário de circulação de informações, entre Luanda e os presídios ou a banza de Pungo Andongo, havia uma propensão à emissão de ordens objetivas e verticais, sendo que raramente havia nos documentos que circulavam entre esses espaços minuciosas explicações, ou longas explanações, sobre as razões que motivavam a tomada de decisão. A tendência era a de ser sucinto, como anteriormente indicamos, facilitando a autogestão local. Desse modo, os agentes que ali serviam apenas deveriam se preocupar em executar ordens simples.

Em outro nível de circulação de informações, de características secundárias ou terciárias, ou seja, com correspondências a princípio despachadas para o reino de Portugal e

\footnotetext{
${ }^{495}$ Quando acionamos a ideia de "remontagem institucional", estamos nos referindo à intromissão portuguesa dentro do processo de reafirmação de uma nova capital do Ndongo. Trata-se de dois movimentos ambivalentes e concomitantes, um remetido à preservação da tradição política das soberanias mbundu, o outro na forma de imposições de termos e condições externas por parte de Luanda. Para mais esclarecimentos, consultar o capítulo 1 e 2 desta dissertação.
} 
que ao mesmo tempo foram inseridas no extenso relatório, o embaralhamento era parcialmente desfeito. ${ }^{496}$ Isso aconteceu, por exemplo, nas onze incumbências destinadas a Bento Rebelo Vilasboas, inseridas no extenso relatório de Fernão de Sousa. Elucidativas quanto ao papel do funcionalismo régio no Ndongo, essas incumbências discerniam os campos de atuação gerais de Domingos Pires e Bento Rebelo, não ocorrendo, todavia, nenhuma referência direta a Angola Aire. Apesar de não ser dito com "todas as palavras" para autoridades africanas, ficava implícito que a atribuição de responsabilidades seguia um princípio de desnivelamento, concentrando os afazeres judiciais e administrativos nas mãos de Bento Rebelo Vilasboas, ao passo que obliterava a relevância da cúpula africana de direção da justiça. Repousaria sobre a autogestão de Pungo Andongo o olhar vigilante do governador. Além disso, havia nesse trecho da fonte uma ressalva sobre o papel africano. No ponto oitavo, Fernão de Sousa escreve que Bento Rebelo Vilasboas não poderia manter “comunicação" com "El-rei sem estar presente o dito padre [Francisco Pacónio], guardando-lhe decoro e cortesia como à minha pessoa [Fernão de Sousa]”, devendo o capitão e ouvidor explicar ao africano que "assim o faz o governador, e El-rei e senhores em Portugal porque tudo se deve aos gangas".

Em primeiro lugar, essa "comunicação" sobre a qual o governador fez referência dizia respeito à possibilidade de consulta de Angola Aire. De fato, o rei africano saberia melhor do que ninguém como proceder em relação à gente do Ndongo e, por isso, na ótica institucional portuguesa, Angola Aire figurava como uma autoridade consultiva e representativa. Isso de forma velada porque, abertamente, ele continuaria a ser o "rei do Ndongo". ${ }^{497}$ Há ainda um quarto agente citado, os "gangas" ou "ngangas", forma pela qual era como os mbundu chamavam os padres, conforme deduzimos a partir do excerto selecionado. ${ }^{498}$ Ainda de acordo com a pena de Fernão de Sousa, uma vez instalado em

\footnotetext{
496 Faremos mais considerações a respeito da distribuição e classificação desses níveis de informação no primeiro item da conclusão desta dissertação.

${ }^{497}$ Assim, em uma carta datada de março de 1629, Fernão de Sousa recriminou o então capitão-mor das forças armadas arregimentadas por Luanda, Paio de Araújo de Azevedo, pelo fato dele ter insultado Angola Aire de "cão". Em decorrência da descompostura cometida contra o africano, Fernão de Sousa pediu para que o capitão-mor se retratasse a ele, pois "ainda que é negro, tem nome de el-rei”, devendo-lhe Paio de Araujo "cortesia e respeito". Verificar: Fernão de Sousa. Carta de Fernão de Sousa a Paio de Araújo de Azevedo. 20 de março de 1629. BAL, cód. 51-IX-20, ff. 441-42v. IN: HEINTZE, Beatrix (coord.). Documento 197, FHA, vol. II, 1988, p. 288.

498 Segundo Beatrix Heintze, "ganga" ou "nganga" é uma "designação do kimbundu para os sacerdotes tradicionais e cristãos”. HEINTZE, Beatrix. Esclarecimentos sobre os vocábulos africanos. FHA, vol. I, 1985,
} 
Pungo Andongo, é possível afirmar que o padre Francisco Pacónio passaria a exercer uma importante função de intermediação na comunicação administrativa, sendo encarregado da interpretação e tradução do que fosse falado. Não seria de menos importante a presença do padre como um representante eclesiástico na banza de Pungo Andongo, a fim de "legitimar" as ações tomadas pela nova cúpula de decisão judicial e administrativa no Ndongo.

O curto período ente 1624 e 1627 atesta para o fato de que remontagem institucional existente em Pungo Andongo incluiu elementos exógenos dentro da banza do soberano mbundu, ao passo que não foi uma transplantação completa de instituições portuguesas ao Ndongo. Havia "plasticidade" de ambos os lados. De todo modo, o grupo responsável pela decisão judiciária era composto no topo por agentes como Fernão de Sousa, Bento Rebelo Vilasboas e Domingos Pires. Abaixo deles, pelo menos na ótica institucional da época, figuravam Angola Aire e o padre Francisco Pacónio, desempenhando papéis consultivos e de intermediação. Somado a isso, os presídios eram autogeridos e bastante independentes, dispondo dos poucos recursos humanos e materiais acessíveis de maneira independente, sempre preservando a jurisprudência de Luanda, o "coração" da Angola portuguesa. Os capitães desfrutavam de muita liberdade na condução dos afazeres administrativo-legais dos presídios e as populações que habitavam nos arredores dessas construções deveriam ser autossustentáveis no abastecimento de gêneros básicos de sobrevivência. Por sua vez, a cidade portuária era responsável pelo despacho da comunicação institucional mais relevante a nível transatlântico e continental, pela emissão de ordens jurídico-políticas e pela realização dos grandes empreendimentos e mobilizações regionais, como campanhas de guerra. Dessa forma, havia coerência local concatenada à coesão regional, ligando as partes com o todo, na figura de uma Angola portuguesa. No século XVII, tal regime ultramarino parece ter funcionado como um sistema administrativo interconectado, imbuído do intuito de "fazer valer" um espaço jurisdicional de ordem e mando portugueses, mas que de maneira alguma logrou êxito completo durante a época de Fernão de Sousa. Nesse sentido, por exemplo, Angola Aire gozava de muitas liberdade na condução da cúpula de governo do Ndongo.

p. 117. Para mais informações acerca dessas autoridades religiosas, consultar o "suplemento para alguns vocábulos africanos", inserido nesta dissertação. 


\subsection{Agentes, presídios e mecanismos de vigilância e fiscalização}

Não muito tempo após chegar a Luanda, em 25 de julho de 1624, Fernão de Sousa escreveu um regimento a João del Rincon Salazar, então capitão do presídio de Muxima, ${ }^{499}$ no qual estavam discernidas as normas de conduta e instruções régias que ele deveria seguir no comando do presídio. As ordens regimentares de julho de 1624 tinham um caráter regional, de tendência quase homogeneizante, uma vez que Fernão de Sousa determinou o despacho de normas "de mesmo teor" para Constantino Cadena, na época capitão de Cambambe, e Sebastião Dias Tição, incumbido do mesmo cargo em Massangano. A única exceção foi Ambaca, para onde as medidas do regimento não valeriam, possivelmente por ainda haver indecisões a respeito do futuro desse presídio. ${ }^{500}$ Baseadas nas premissas de manutenção de mecanismos de vigilância e fiscalização e no ordenamento do espaço jurisdicional ultramarino, ${ }^{501}$ uma submissão geral às normas institucionais de conduta tinha o objetivo de delimitar as responsabilidades e obrigações de cada um desses capitães de presídios, visando com isso à diminuição de tensões sociais existentes entre os habitantes de Massangano, Muxima e Cambambe, uma vez que tolheria os possíveis atritos institucionais que poderiam colocar essas autoridades em pé de guerra.

Especificamente sobre o caso de Muxima, Fernão de Sousa ordenou que os baculamentos atrasados da "capitania e presídio de Muxima" fossem quitados na presença do governador, em Luanda. O governador então propôs geral, proibindo a cobrança de tributos que não fossem baculamentos em Massangano e Cambambe, ou seja, não seria

\footnotetext{
499 A informação de que, nessa época, João del Rincon Salazar era capitão de Muxima, é fornecida por Beatrix Heintze na nota 9 de HEINTZE 1988, p. 267, para o seguinte documento: Fernão de Sousa [escrito por Luís Correa Coelho]. Regimento de Fernão de Sousa a João del Rincon Salazar, Constantino Cadena e Sebastião Dias Tição. 25 de julho de 1624. BAL, cód. 51-IX-21, ff. 124-24v. IN: HEINTZE, Beatrix (coord.). Documento 172, FHA, vol. II, 1988, pp. 267-268.

${ }^{500}$ Consultar o capítulo 2 desta dissertação. As informações de que Constantino Cadena e Sebastião Dias Tição eram respectivamente capitães de Cambambe e Massangano é fornecida por Beatrix Heintze na nota 9 para: Fernão de Sousa [escrito por Luís Correa Coelho]. Regimento de Fernão de Sousa a João del Rincon Salazar, Constantino Cadena e Sebastião Dias Tição. 25 de julho de 1624. BAL, cód. 51-IX-21, ff. 124-24v. IN: HEINTZE, Beatrix (coord.). Documento 172, FHA, vol. II, 1988, p. 267. Sabemos ainda, graças às informações suplementares fornecidas por Heintze, que a essa altura o capitão de Ambaca era João Carreira Fidalgo. Os regimentos de Constantino Cadena e Sebastião Dias Tição não constam em nosso conjunto documental. Verificar: HEINTZE, Beatrix (coord.). Tabela 6: Os capitães nos presídios de Angola nos anos de 1624-1630. FHA, vol. I, 1985, p. 70.

501 Necessidades que acompanhavam um maior aproveitamento das feiras e rotas de escravos, é preciso ressaltar, matérias então de principal importância principalmente após 1605, como adverte Beatrix Heintze. Verificar: HEINTZE, Beatrix. Angola nos séculos XVI e XVII: estudos sobre fontes, métodos e história. Luanda: Kilombelombe, 2007, pp. 280-281.
} 
mais possível "pedir loanda e infuta", cuja prática passava a ser "criminosa", 502 salientando que os sobas não deveriam ser importunados "e nem os obrigueis a tributo algum por força nem por outra alguma vexação e que os conserveis em paz", cabendo ao capitão fazer justiça "tirando os quimbares e brancos que os molestam". 503 Cabe notar que o regimento também é marcado por uma forte carga legalista e corretiva, prescrevendo a conduta que os capitães de modo geral deveriam ter. Assim, as medidas jurídico-administrativas internas, emitidas ao interior e inseridas na $F H A$, tinham como meta determinar as regras sobre a cobrança de tributos e limitar o convívio entre os mbundu do interior e os comerciantes que atravessavam o sertão, ou partiam de Luanda, através da remoção de pessoas e da restrição de passagens, principalmente de agentes denominados nas fontes escritas como "pombeiros". ${ }^{504}$ Inserida no processo histórico de expansão política e remontagem de um espaço jurisdicional em direção ao Ndongo, a limitação de convívio entre os enviados da costa e os habitantes do interior era uma diretriz geral demarcada nos regimentos emitidos em 1624 para Muxima, Massangano e Cambambe, totalmente em consonância com a série de bandos, portarias, provimentos e cartas escritas em 1624, 1626 e 1627, aos quais já fizemos referência no item anterior, todas elas visando reorganizar os espaços de comércio através de interdições de trânsito de pessoas, bloqueio de passagens e acesso aos mercados. Fornecendo meios facilitadores para a penetração institucional do Ndongo, concretizadas no terceiro quartel de 1627 , as medidas voltadas para a limitação de convívio entre pessoas e a reorganização de espaços eram dois pilares que faziam parte da implementação de mecanismos de vigilância e fiscalização nas regiões da conquista e nos presídios, restringindo com bases legais a travessia dos rios Dande e Cuanza e o acesso às feiras do Ndongo. Nesse sentido, em 1624, foram também expedidas duas portarias com essas mesmas finalidades, impedindo a travessia do Bengo para dificultar o acesso às terras dos

\footnotetext{
${ }^{502}$ Para mais informações sobre as loandas, infutas e vestir, consultar o "suplemento para alguns vocábulos africanos", inserido nesta dissertação.

${ }^{503}$ Fernão de Sousa [escrito por Luís Correa Coelho]. Regimento de Fernão de Sousa a João del Rincon Salazar, Constantino Cadena e Sebastião Dias Tição. 25 de julho de 1624. BAL, cód. 51-IX-21, ff. 124-24v. IN: HEINTZE, Beatrix (coord.). Documento 172, FHA, vol. II, 1988, pp. 267-268.

${ }^{504}$ Mas não apenas, como veremos mais para frente. Ao longo dos séculos XVI e XVII, os moradores de Luanda tinham o acesso oficial restringido à região da conquista, por isso enviavam agentes comerciais contratados, ou que serviam às suas casas, os chamados "pombeiros". Verificar: BIRMINGHAM, David. Central Africa to 1870: Zambezia, Zaïre and the South Atlantic. [1981]. Cambridge: Cambridge University Press, 2005, p. 35. HEINTZE, Beatrix. Angola nos séculos XVI e XVII [...]. Luanda: Kilombelombe, 2007, p. 493.
} 
sobas Camanga Cacaita e Caculo Cahohy. ${ }^{505}$ No mais, evidenciando as diversas formas de vigilância e fiscalização exercidas no redimensionamento dos mecanismos de justiça, e intuindo uma coordenação mais eficiente dos sobas que habitavam os arredores do Lucala, Capele e no Motemo, algumas correções administrativas foram adotadas entre 1629 e 1630, durante os anos em que Henrique de Magalhães dirigiu Ambaca, conforme será exposto no item seguinte deste capítulo.

${ }^{505}$ A portaria referente a Camanga Cacaita se encontra em: Fernão de Sousa [escrita por Luís Correa Coelho]. Portaria de Fernão de Sousa. 18 de julho de 1624. BAL, cód. 51-IX-21, f. 123v. IN: HEINTZE, Beatrix (coord.). Documento 171, FHA, vol. II, 1988, p. 267. Conforme a nota 8 de Heintze, para mais fontes relacionadas ao conteúdo dessa portaria, conferir documento de 12 de julho de 1624 , localizado em BAL, cód. 51-IX-21, f. 121, além do documento de 13 de agosto de 1624, localizado em BAL, cód. 51-IX-21, f. 120. Esses documentos foram publicados respectivamente em: FELNER, Alfredo Albuquerque de. AAOI, 1933, p. 520 (por engano registrado por Alfredo Albuquerque de Felner como f. 149, de acordo com Beatrix Heintze) e p. 522 (mais uma vez, por engano, datado por Alfredo de Albuquerque de Felner de 14 de agosto de 1624). A portaria referente a Cacullo Cahohy se encontra em: Fernão de Sousa [escrita por Luís Correa Coelho]. Portaria de Fernão de Sousa. 29 de julho de 1624. BAL, cód. 51-IX-21, f. 146. IN: HEINTZE, Beatrix (coord.). Documento 174, FHA, vol. II, 1988, p. 269. Conforme a nota 22 de Heintze, um documento suplementar ao conteúdo narrado nessa portaria está conservado em BAL, cód. 51-IX-21, f. 121. Trata-se do mesmo documento publicado por Alfredo Albuquerque de Felner que logo acima referenciamos, por engano com a indicação de f. 149. 


\section{Imagem 7: Os presídios, vias fluviais e as principais regiões circunvizinhas da}

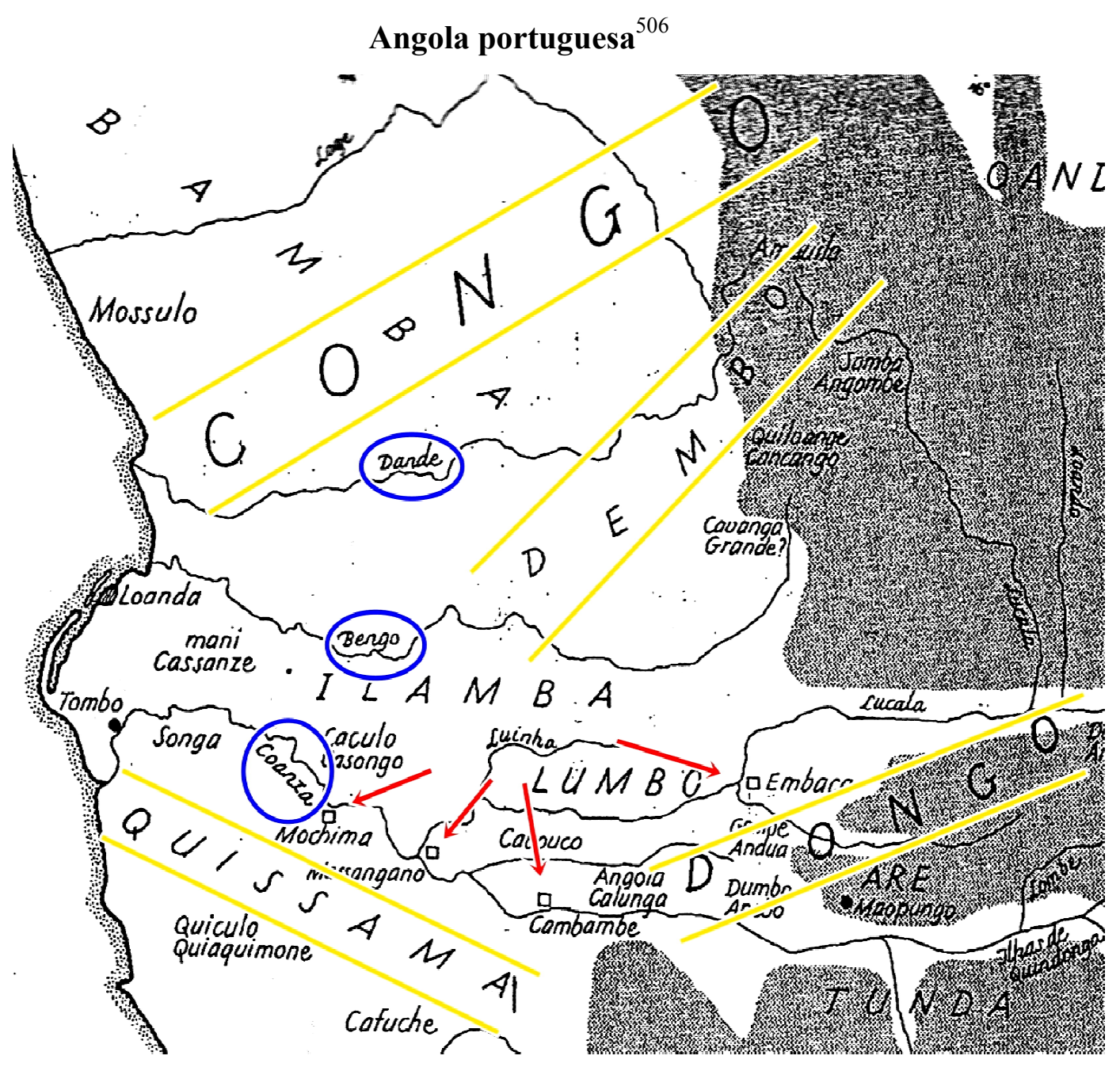

Legenda: i) As setas em vermelho demarcam os presídios; ii) As esferas em azul indicam os principais rios da região; iii) As linhas paralelas em dourado indicam as unidades sociopolíticas mais citadas nos documentos da FHA.

Queremos chamar a atenção para seguinte fato: a reiteração de mecanismos de vigilância e fiscalização e a interiorização do aparato administrativo não eram promovidas ao esmo. Frequentemente essas medidas estavam ligadas às tentativas de viabilizar a canalização de escravos para o porto de Luanda. Entre 1624 e 1627, houve um grande esforço para promover a gestão de feiras de escravos no interior. Via de regra, as feiras aconteciam em pontos específicos, mas dispersos, da conquista, como na banza de Angola

\footnotetext{
${ }^{506}$ A imagem que segue abaixo foi modificada a partir de: HEINTZE, Beatrix (coord.). Fig. 2: Ndongo e regiões circunvizinhas na época de Fernão de Sousa (ortografia da fonte), FHA, vol. I, 1985, p. 6.
} 
Aire, nos arredores de Massangano, Ambaca, Muxima e Cambambe e nas terras dos sobas vassalos normalmente fixados entre o Ndongo até o Lucala, havendo a possibilidade de feiras serem abertas em locais relativamente distantes, ou descoladas, dos entrepostos avançados de apoio institucional da Angola portuguesa, como ocorreu no caso das feiras promovidas no Haco e na Kissama. Competia para a gestão dessas feiras o provimento de cargos régios específicos, como os de meirinhos, guardas e de "manis quitandas", sendo estes últimos os de maior relevância local, pois na maioria das vezes eram eles os responsáveis pela prévia seleção de meirinhos e guardas locais, investidos sob o aval do governador. É importante também dizer que, de uma forma geral, "manis quitandas" eram "vigilantes de mercados colocados pelos portugueses" cujo cargo, nas palavras de Beatrix Heintze, durante o governo de Fernão de Sousa, foi exercido por um "africano ao serviço dos portugueses". 507

Devido à carência de portugueses na região, deduzimos que esses postos régios eram desempenhados frequentemente por africanos ou luso-africanos, que viam no serviço régio algum tipo de benefício ou ascensão social, à margem das formas endógenas de estruturação social. Tudo indica também que essa tríade de agentes a serviço de Luanda detinha um alto grau de relevância local, certamente porque sem ela não haveria a menor condição de gerir a "paz" e o "bem comum" das feiras, como os registros escritos fazem menção. Apesar de os registros sobre o funcionamento das feiras não serem vastos na $F H A$, há alguns vestígios e pistas que nos são de grande valia nas fontes escritas que temos em mãos, sobretudo a respeito dos manis quitandas. $\mathrm{O}$ primeiro deles diz respeito ao provimento de mani quitanda que consta no regimento de julho de 1624, no qual Fernão de Sousa ordenou que, "por meios brandos e suaves", o capitão de Muxima "fizesse" o soba Caculo Casongo "abrir as feiras que costuma fazer". Em troca do comércio, Luanda lhe defenderia de "todas as vexações", para que ele vivesse "livre" e como bem entendesse.

\footnotetext{
${ }^{507}$ Segundo Beatrix Heintze, "quitanda" faz referência a kitanda que, em kimbundu, significa "mercado" ou "feira" e, em kikongo, significa "mercado diário". Por sua vez, "mani" era um termo usado para designar um "título político no Kongo e no litoral sul d'a África Central" que, porventura, também poderia ser empregado como sentido de "funcionário do Ndongo". Por indicar a ocorrência de serviços prestados por africanos aos portugueses, Heintze ainda sugere que o cargo de "mani quitanda" seria análogo à função de "quimbar", pelo menos no sentido prático adotado pelo funcionalismo régio. Verificar: Esclarecimentos sobre vocábulos africanos, FHA, vol. I, 1985, pp. 121-122. Os significados para a palavra kitanda, em kimbundu, foram fornecidos por José Matias Delgado em: CADORNEGA, António de Oliveira de. HGGA, vol. I, 1940, p. 620. Mais informações podem ser consultadas no "suplemento para alguns vocábulos africanos", inserido nesta dissertação.
} 
Para assegurar a "paz" local, um "mani quitanda" seria nomeado para a feira, salientando que os mesmos "cuidados", tomados na feira de Caculo Casongo, deveriam ser instituídos na montagem da feira da Kissama e em Queso Atumba. ${ }^{508}$

Há no extenso relatório de Fernão de Sousa, além de algumas cartas que circulavam entre Luanda e os presídios, outras menções aos "manis quitandas". Por exemplo, um homem chamado António de Andrade, escravo de Domingos Luís de Andrade, foi nomeado em 15 de agosto de 1624 para ser "mani quitanda" da então recém-inaugurada "feira de Ambaca". Não muito tempo depois, em 1 de outubro de 1624, esse mesmo António de Andrade exerceria o posto de mani quitanda na feira de Caculo Cacabaça, quiçá acumulando serviços nessas duas feiras concomitantemente. Segundo Fernão de Sousa, por volta de 1627, António de Andrade ainda servia em pelo menos um desses postos, onde deveria ser acompanhado por "bons meirinhos" e "guardas", sob os quais tinha responsabilidade, podendo "retirá-los" caso julgasse necessário para o "bem comum da feira". ${ }^{509}$ Um ano depois, em 1628, António de Andrade já não era mais mani quitanda em nenhuma feira e "encontrava-se ilegalmente no interior do território ao serviço de seu senhor", Domingos Luís de Andrade. ${ }^{510}$

Outro caso interessante é o de Marcos Pires, "quimbar forro" que, nas palavras de Beatrix Heintze, "aparentemente sabia ler e escrever" e tinha origem africana. ${ }^{511}$ Marcos Pires provavelmente vivia em Massangano quando, em 1627, um indivíduo chamado João Lourenço, também de Massangano, levou-o "para Guizambande", ou "Gunza Ambande", para que Marcos Pires virasse "mani quitanda" da feira que ali seria inaugurada. Após alguns contratempos, o africano chegou às terras do soba, onde "solicitou portaria para mani quitanda e poder fazer oficiais, e pôr preços nas fazendas, e peças, e se the mandou [Fernão de Sousa]". ${ }^{512}$ De acordo com Heintze, na altura em que Marcos Pires recebia o

\footnotetext{
${ }^{508}$ Fernão de Sousa [escrito por Luís Correa Coelho]. Regimento de Fernão de Sousa a João del Rincon Salazar, Constantino Cadena e Sebastião Dias Tição. 25 de julho de 1624. BAL, cód. 51-IX-21, ff. 124-24v. IN: HEINTZE, Beatrix (coord.). Documento 172, FHA, vol. II, 1988, pp. 267-268. A denominação "Queso Atumba" provavelmente equivalia ao nome do soba que controlava o território onde a feira foi montada, de modo que antropônimo e topônimo se sobrepunham.

${ }^{509}$ Fernão de Sousa. O extenso relatório do governador aos seus filhos. S.d., 1625-1630. BAL, cód. 51-IX20, ff. 220-74v. IN: HEINTZE, Beatrix (coord.). Documento 30, FHA, vol. I, 1985, p. 285 e nota 233 de Heintze.

${ }_{510}^{510}$ Nota 233 de Heintze para ibidem, p. 285.

${ }^{511}$ Nota 241 de Heintze para ibidem, p. 289.

${ }^{512}$ Ibidem, p. 289.
} 
cargo de mani quitanda na feira de Gunza Ambande, sua filha se casaria com Gaspar Cardoso, "um africano que os portugueses classificaram de forro [e] sabia ler e escrever", com ressalva de que "não se veste à portuguesa, senão com panos ambundos", diferente de um de seus filhos que, assim como o pai, sabia ler e escrever, porém andava com trajes “à portuguesa". ${ }^{513}$ Ressaltando a importância de promover o comércio de escravos, no ano anterior a esse registro, em 26 de março de 1626, conforme escreveu Fernão de Sousa no extenso relatório, o meirinho e secretário Domingos Pires deveria alertar aos sobas que nenhum "quimbar, pombeiro, forro nem cativo" poderia ser acolhido nas banzas do Ndongo, dessa forma incentivando-os a comercializar na feira de Bumba Aquizanzo. ${ }^{514}$

Imagem 8: Algumas feiras que abasteciam o comércio atlântico (1624-1627)

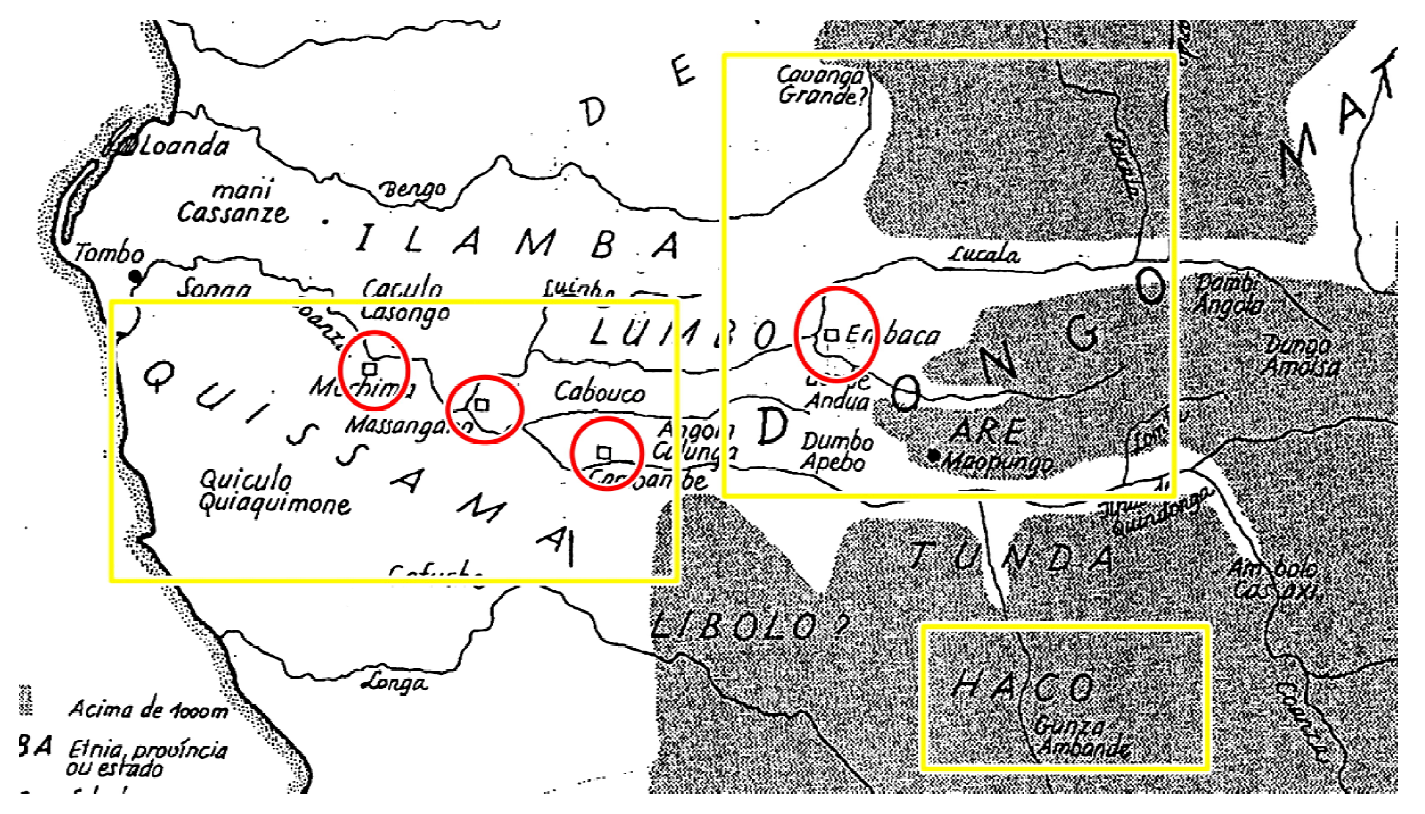

Legenda: $i$ ) Os quadrângulos dourados delimitam as regiões onde foram abertas feiras entre 1624-1627; ii) Os círculos vermelhos indicam os presídios portugueses.

\footnotetext{
${ }^{513}$ Informações extraídas de: Fernão de Sousa. O extenso relatório do governador aos seus filhos. S.d., 16251630. BAL, cód. 51-IX-20, ff. 220-74v. IN: HEINTZE, Beatrix (coord.). Documento 30, FHA, vol. I, 1985, nota 241, p. 289. Segundo a pesquisadora, sobre as informações de Gaspar Cardoso e seu filho, consultar: BAL, cód. 51- IX- 20, f. 399, (s.d). Ficamos também com algumas considerações interessantíssimas de Heintze: "Não era decerto invulgar o caso de um africano livre ou libertado por morte do seu proprietário, que vivia juntamente com alguns portugueses num dos chefados dos Mbundu, sabia ler e escrever (!) e dispunha ele próprio de uma aldeia com duzentos escravos". Verificar: HEINTZE, Beatrix. Angola nos séculos XVI e XVII [...]. Luanda: Kilombelombe, 2007, p. 490.

${ }^{514}$ Fernão de Sousa. O extenso relatório do governador aos seus filhos. S.d., 1625-1630. BAL, cód. 51-IX20, ff. 220-74v. IN: HEINTZE, Beatrix (coord.). Documento 30, FHA, vol. I, 1985, p. 282.

${ }^{515}$ A imagem que segue abaixo foi modificada a partir de: HEINTZE, Beatrix (coord.). Fig. 2: Ndongo e regiões circunvizinhas na época de Fernão de Sousa (ortografia da fonte), FHA, vol. I, 1985, p. 6.
} 
$\mathrm{Na}$ ótica defendida pelo autor da maioria das fontes aqui utilizadas, Fernão de Sousa, o mando político na conquista era compartilhado entre as autoridades africanas e portuguesas, uma vez que as medidas tomadas em relação aos africanos seriam "conciliadas" e fruto de um "comum acordo". ${ }^{516}$ Interessa-nos apenas retomar que, conforme sustentado no item anterior, a remontagem de uma cúpula judicial e administrativa em Pungo Andongo perpassava pelo princípio mental de mútuo acordo, contando em sua constituição com representantes de diversas proveniências e quadros, embora na prática os agentes africanos passassem a ter um peso muito menor do que os portugueses. A esse aspecto se somava o fato de algumas das funções régias, específicas a essas localidades mais distantes de Luanda, serem ocupadas por indivíduos de proveniência africana, como aconteceu nos casos de António de Andrade e Marcos Pires, mas também de pessoas versadas nas práticas e línguas locais, embora não saibamos se eram africanizadas ou africanas, como nos casos de Domingos Pires e Diogo Mendes, sendo este último um homem que exercia o cargo de intérprete, ou "língua", 517 e que residia em Massangano, como veremos no próximo item. Havia ainda outro agente importante citado nas fontes escritas, os chamados "espias", mas sobre os quais temos pouquíssimos vestígios. ${ }^{518}$

Em todo caso, homens como António de Andrade, Marcos Pires, Domingos Pires e Diogo Mendes compartilhavam características em comum. Eles provavelmente eram bilíngues e tinham hábitos dialógicos, dentre eles o de vestir roupas à portuguesa ou à africana, ou seja, seus "usos e costumes" podem ser classificados como "mistos". Pelo fato de poderem ser portugueses africanizados ou africanos aportuguesados, as influências e

\footnotetext{
${ }^{516}$ Consultar os capítulos 2 e 4 desta dissertação.

517 "Língua" é a palavra normalmente utilizada na documentação para designar "intérprete" e "tradutor". Por exemplo, durante a eleição do rei do Ndongo, em 1626, o mani lumbo Agostinho de Vasconcelos serviu de "língua" dos portugueses presentes na cerimônia de eleição (pp. 256-257). Em 1624, Gaspar Ferreira foi um samba tendala enviado ao Ndongo com a incumbência de negociar com "Dona Ana Ginga", pois "era entre eles de maior autoridade, e por ser língua", facilitando a negociação (pp. 226-227). Verificar o seguinte documento: Fernão de Sousa. O extenso relatório do governador aos seus filhos. S.d., 1625-1630. BAL, cód. 51-IX-20, ff. 220-74v. IN: HEINTZE, Beatrix (coord.). Documento 30, FHA, vol. I, 1985, pp. 217-362. Além do que foi dito, são escassas as informações que dispomos sobre os "línguas". Algumas considerações com as quais concordamos são feitas em: FERREIRA, Roquinaldo. Cross-Cultural Exchange in the Atlantic World [...]. Cambridge: Cambridge University Press, 2012, p. 107. Sobre o fenômeno da diglossia na administração ultramarina, verificar a p. 140 dessa mesma obra. Para mais informações, consultar a entrada para "mani lumbo", existente no "suplemento para alguns vocábulos africanos", inserido nesta dissertação

518 Segundo Catarina Madeira Santos, nos exércitos comandados por Luanda havia o cargo de "espia", que condizia com os afazeres de um soldado enviado para observar os inimigos e territórios alheios, como se fossem batedores ou espiões. Verificar: SANTOS, Catarina Madeira. Um governo "polido" para Angola [...]. Tese de doutorado, Universidade Nova de Lisboa, 2005, p. 284.
} 
aportes culturais tendiam a trafegar em ambos os sentidos, configurando uma "via de mãodupla" de graus e matizes variados. ${ }^{519}$ Eram versados em um saber técnico, como a escrita e a contabilidade, normalmente empregado para fins aplicados, ligados à gestão das feiras e à administração da justiça local. Em vista o espaço jurisdicional estendido da costa atlântica até as portas de Pungo Andongo, todos esses homens exerciam cargos e postos considerados de baixo escalão, caso os comparemos com as funções de governador, capitão e ouvidor, comuns ao espaço atlântico. ${ }^{520}$ Todavia, localmente, eles eram de suma importância para a remontagem de hierarquias locais e reorganização de espaços de comércio, contando com grande liberdade de atuação. Além disso, essas pessoas contavam com a confiança do governador, especialmente por serem indispensáveis agentes de intermediação e detentores de postos administrativos relacionados, diretamente ou indiretamente, com o tráfico de escravos. Por serem fundamentais na manutenção de mecanismos de controle e para a otimização da comunicação institucional entre os funcionários régios e os sobas que sediavam feiras em suas terras, homens como António de Andrade, Marcos Pires, Domingos Pires e Diogo Mendes serviam aos interesses das cúpulas de comando de Luanda e, em menor medida, aos sobas que cooperavam com os funcionários régios, figurando como elos importantes de ligação institucional. Isso também explicaria porque eles não foram perseguidos, ou tiveram suas atividades extraoficiais tolhidas, por qualquer entidade local ou regional.

Chegamos então a algumas importantes constatações. Um primeiro movimento marcante registrado na $F H A$ foi o de emprego de agentes dotados de usos e costumes

\footnotetext{
${ }^{519}$ Fenômeno parecido é compatível com o caso da Senegâmbia dos séculos XVII e XVIII, conforme a noção de "conjuntos de portadores culturais estrangeiros" e a relevância que tiveram no desenvolvimento do comércio atlântico na África, apresentada por Philip D. Curtin. Em nosso caso, é necessário lembrar que, por mais que os corpos de texto produzidos pela burocracia portuguesa tocassem em conhecimentos e saberes provenientes de diferentes aportes culturais, por outro lado eles não deixavam de ser vestígios de formas de dominação, figurando como "objetos formais e simbólicos de poder" que trazem à tona a "relação de subordinação do estado africano vassalo perante o governo estabelecido em Luanda". Verificar: SANTOS, Catarina Madeira. Escrever o Poder: os Autos de Vassalagem e a Vulgarização da Escrita entre as Elites Africanas Ndembu. IN: HEINTZE, Beatrix; OPPEN, Achim von (ed.). Angola on the Move: Transport Routes, Communications and History. Frankfurt am Main: Verlag Otto Lembeck, 2008, p. 175. SANTOS, Catarina Madeira. Écrire le pouvoir en Angola: Les archives ndembu (XVIIe-XXe siècles), Annales. Histoire, Sciences Sociales. Paris: Éditions de l'EHESS, n. ${ }^{\circ}$ 64, 2009/4, pp. 768-769. CURTIN, Philip D. Economic Change in Precolonial Africa: Senegambia in the Era of the Slave Trade. Wisconsin: University of Wisconsin, 1975, vol. I, pp. 5, 60 e capítulo 1.

${ }^{520}$ Conciliando algumas das práticas adotadas localmente com as diretrizes que integravam o projeto ultramarino português, construído em volta de um espaço atlântico de experiências compartilhadas. Consultar o capítulo 2 desta dissertação, item 3.
} 
mistos e que eram habilitados a executar tarefas técnico-aplicadas em nome de Luanda, aos quais doravante referirmos-ei como agentes de intermediação. Bem matizado e composto por diferentes grupos sociopolíticos, os indivíduos que faziam parte desse quadro de agentes eram claramente Bento Rebelo Vilasboas, Francisco Pacónio, António de Andrade, Marcos Pires, Domingos Pires e Diogo Mendes. Ao participarem de afazeres institucionais ligados diretamente ou indiretamente ao tráfico de escravos ou às contendas, políticas ou jurídicas, relacionadas à escravidão de tipo atlântica, eles contavam com o respaldo de sobas e do funcionalismo régio sediado na costa. Em consonância com as características culturais e sociais que discernimos acima, tais indivíduos, que exerciam as funções de mani quitanda, meirinhos, línguas e espias abdicavam de arrazoar e operar parcialmente as lógicas internas e mentais vinculadas à matriz cultural mbundu, para assim integrarem os quadros de baixo escalão do funcionalismo régio que serviam nas feiras e banzas, sobretudo concentradas no Ndongo. Não é possível afirmar que o contato com os portugueses modificou gravemente os arcabouços culturais desses agentes em uma primeira geração, embora tenha tido impacto na forma de percepção de si e do outro. O essencial é que eles deixavam de tecer vínculos sociopolíticos diretos com a cúpula política africana, não mais respondendo aos macotas, tendalas e mani lumbos, passando a dever satisfação a Luanda e a senhores privados. Em último caso, salvo os casos de Bento Rebelo Vilasboas e Francisco Pacónio, ${ }^{521}$ o restante dos agentes de intermediação era composto por um grupo, mais ou menos homogêneo, de pessoas "deslocadas" e parcialmente desenraizadas. Ainda são incertos quais eram os valores e objetivos que o quadro de agentes de intermediação perseguia, mas o certo é que esses homens figuravam como um elo importante de intermediação e comunicação, não podendo ser necessariamente categorizados como "marginalizados" sociais.

Um segundo movimento dizia respeito ao comércio e cooperação política. Os sobas que recebiam feiras em suas terras eram, na grande maioria, vassalos ou aliados políticos de

\footnotetext{
${ }^{521}$ Há no caso de Francisco Pacónio, por exemplo, o fato de ele ser um missionário, imbuído de saberes eclesiásticos e alinhado com as premissas da Companhia de Jesus. Apesar de muito importantes, as questões ligadas à fé e à religião serão aqui deixadas de lado, uma vez que abordá-las nos desviaria dos objetivos e anseios que inicialmente elencamos.
} 
Luanda. $^{522}$ Havia ainda a possibilidade de que as feiras fossem incentivadas em terras pertencentes aos "vassalos do rei do Ndongo". De todo modo, o fato crucial é que alguns sobas aceitavam abrir feiras em suas terras, outros não. Acreditamos que aqueles que aceitavam o comércio o faziam por dois motivos principais. O primeiro seria o de adquirir mercadorias que trouxessem prestígio às suas respectivas banzas e linhagens, como panos ou mercadorias importadas via comércio atlântico, entre elas contas de vidro ou artigos de metal. A abertura de feiras também poderia implicar no recebimento de presentes que, além de serem cobiçados como produtos "exóticos" pelos mbundu, também tinham a vantagem de serem exibidos como comprovações das relações políticas mantidas com Luanda, aumentando o prestígio dos sobas que os recebessem e, por consequência, reforçando a importância de sediar feiras. O segundo motivo advinha do respeito à vassalagem e à aliança política, com os quais os sobas esperavam intensificar o sentimento de pertencimento à rede de fidelidade política recriada por Luanda, como veremos no próximo capítulo. Evidentemente, em troca disso, eles esperavam contar com o apoio político do governador e dos capitães de presídios em momentos de necessidade, por exemplo quando estivessem envolvidos em pleitos políticos ou necessitassem de auxílio militar, além de poderem acionar o espaço jurisdicional português através da execução de justiça dos mucanos. De uma forma ou de outra, os sobas que recebessem feiras cooperavam com os processos históricos em voga na Angola portuguesa.

Um terceiro movimento acontece como reflexo do estabelecimento de medidas legais voltadas à limitação de convívio e reorganização do espaço comercial, conforme abordado no início deste item. A delimitação de uma "Angola portuguesa" e a modificação das formas de interação social tecidas entre os agentes representantes de Luanda - por exemplo, os agentes de intermediação - e as autoridades locais - sobas, tendalas e mani lumbo - ensaiavam reformulações socioespaciais que visavam o aumento do comércio e a manutenção da chamada "paz" portuguesa. Conformadores dos mecanismos de vigilância e fiscalização, tais medidas legais eram capazes de impactar diretamente na vida de algumas pessoas, principalmente nas envolvidas diretamente com o tráfico atlântico. Devido à sua importância no comércio interno das "peças", destacamos então o exemplo de certos

\footnotetext{
${ }^{522}$ Aprofundaremos a análise sobre a vassalagem e alianças políticas no próximo capítulo desta dissertação. Para uma análise muito boa sobre esses assuntos, consultar: HEINTZE, Beatrix. Angola nos séculos XVI e XVII: estudos sobre fontes, métodos e história [...]. Luanda: Kilombelombe, 2007, capítulo 9.
} 
indivíduos que figuravam como um quadro de agentes a serviço das altas camadas sociais de Luanda, genericamente composto por quimbares, maculuntos, pombeiros, forros e brancos. Aqui os chamaremos de agentes comerciais. Eles percorriam os caminhos entre a costa atlântica e as feiras do interior, à procura de escravos que abastecessem os tumbeiros que aportassem em Luanda. Como normalmente acontecia, tal quadro de agentes era composto por grupos sociopolíticos distintos. Os quimbares podiam ser "africanos ao serviço dos portugueses" que frequentavam as feiras e presídios do interior, não sendo possível determinar onde habitavam, sendo que entre os séculos XVI e XVII era a grande maioria deles escravos. ${ }^{523}$ Os maculuntos eram escravos enviados por seus senhores às feiras, a fim de trocar mercadorias por escravos. Os mais conhecidos ao longo dos séculos XVI e XVII eram aqueles que carregavam a designação de "pombeiro", fornecida a um mercador de origem africana, representante de um português ou grupo de portugueses estabelecidos em Luanda, que "visitava as feiras oficiais do sudoeste da África Central" para adquirir escravos, marfim e outras mercadorias. ${ }^{524} \mathrm{Na}$ costa, os pombeiros recebiam fazendas a crédito de seus representantes portugueses, visitavam as feiras do interior e depois regressavam a Luanda, fechando-se um circuito primário do comércio atlântico. ${ }^{525} \mathrm{O}$ termo "forro" é empregado na FHA com diversos significados, variando conforme o

${ }^{523}$ HEINTZE, Beatrix (coord.). Esclarecimentos sobre vocábulos africanos, FHA, vol. I, 1985, pp. 126-127. Idem, Angola nos séculos XVI e XVII [...]. Luanda: Kilombelombe, 2007, p. 493

${ }^{524}$ Ibidem, p. 124. Sucintas definições podem ser verificadas em: ALENCASTRO, Luiz Felipe de. $O$ trato dos viventes: A formação do Brasil no Atlântico Sul. São Paulo: Companhia das Letras, 2000, pp. 284, 302. BIRMINGHAM, David. Central Africa to 1870 [...]. [1981]. Cambridge: Cambridge University Press, 2005, p. 32. Idem, Trade and conflict in Angola: the Mbundu and their neighbours under the influence of the Portuguese 1483-1790. Londres: Clarendon Press/ Oxford University Press, 1966, p. 17, nota 1, pp. 78-79. PARREIRA, Adriano. Economia e sociedade em Angola na época da Rainha Jinga (século XVII). Lisboa: Editora Estampa, 1997, pp. 126-127.

${ }^{525}$ Sobre a atuação geral dos pombeiros, verificar: HEINTZE, Beatrix, Angola nos séculos XVI e XVII [...]. Luanda: Kilombelombe, 2007, pp. 493. Sobre um esboço geral a respeito do funcionamento do comércio atlântico, verificar: ALENCASTRO, Luiz Felipe de. O trato dos viventes [...]. São Paulo: Companhia das Letras, 2000, capítulo 7, em especial a p. 248. Atualmente, esse autor redimensionou suas ideias a respeito da bilateralidade e da complementação na formação de um sistema atlântico, verificar especificamente: Idem, The Ethiopic Ocean - History and Historiography, 1600-1975. IN: Idem (ed.). The South Atlantic, Past and Present. Dartmouth: Tagus Press at UMass Dartmouth, 2014, pp. 7-9. Para uma visão mais tradicional: NOVAIS, Fernando A. Portugal e Brasil na Crise do Antigo Sistema Colonial (1777-1808). [1979]. São Paulo: Editora Hucitec, 1995, capítulo 2. Sobre um resumo ainda aceito: SANTOS, Catarina Madeira. Portugal and the World Shipping Routes. Lisboa: Comissão Nacional para as Comemorações dos Descobrimentos Portugueses, 1997, p. 49, além da introdução para esse livro, feita por António Manuel Hespanha, em especial a p. 5. THORNTON, John K. Africa and Africans in the Making of the Atlantic World, 1400-1800. [1992]. Cambridge: Cambridge University Press, 1998, pp. 53-55, além do capítulo 2 como um todo. Sobre circuitos e rotas em outro contexto, mas de funcionamento parecido, verificar especificamente: SANTOS, Maria Emília Madeira. História Geral de Cabo Verde. Lisboa: Instituto de Investigação Científica Tropical, vol. II, 1995, pp. 82 e 91. 
contexto de aplicação. Aqueles que estavam envolvidos no comércio eram provavelmente homens africanos que habitavam dentro do espaço jurisdicional da Angola portuguesa e que serviam aos interesses de algum português senhor de escravos, que poderia ser um pequeno proprietário de terras ou um negociante de peças. ${ }^{526}$ Um quarto e último agente comercial citado eram os "brancos" que, possivelmente por não serem proeminentes moradores de Luanda ou simplesmente por não disporem de cabedal ligado ao comércio atlântico, desbravavam o interior em busca de mercadorias africanas. Eles formavam um grupo sociopolítico de pobres e marginalizados, ao qual chamaremos doravante de "arraiamiúda", desprovidos do acesso e meios para explorar a terra. Porventura eles poderiam ser classificados como indivíduos à margem da justiça, portanto próximos a uma "vida bandida" e de ilicitudes, dependentes de pequenas negociações para sobreviver e esporadicamente servindo às campanhas militares, onde mantinham a esperança de angariar alguma fazenda proveniente do butim de guerra e do roubo às aldeias. Era terminantemente vetado a esses "brancos" marginalizados, dados à própria sorte, que perambulassem indiscriminadamente pelo interior ou que fundassem povoamentos sem o consentimento régio. $^{527}$

Um elemento unificador desse quadro geral de agentes comerciais dizia respeito não apenas ao percurso que eles cumpriam nas vias comerciais africanas, ou "carreiras", a

\footnotetext{
${ }^{526}$ Sobre as acepções de "forro", por enquanto ficamos com as considerações de Heintze, apesar de serem demasiadamente gerais, mediante as quais eles eram na verdade "livres". Assim, nas fontes seiscentistas sobre a Angola portuguesa, o binômio "forro-livre" era definido por contraposição a outro binômio, "cativoescravizado". Verificar: HEINTZE, Beatrix. Angola nos séculos XVI e XVII: estudos sobre fontes, métodos e história [...]. Luanda: Kilombelombe, 2007, p. 503.

${ }^{527}$ Apesar de não serem amplamente citados na nossa documentação, entre os séculos XVIII e XIX ocorrerá o registro de mais outro agente comercial de ampla presença no interior, os chamados "sertanejos", homens experientes no comércio e que frequentemente eram mestiços. Verificar: FERREIRA, Roquinaldo. CrossCultural Exchange in the Atlantic World [...]. Cambridge: Cambridge University Press, 2012, pp. 135-136. HEYWOOD, Linda M.; THORNTON, John K. Central Africans, Atlantic Creoles, and the Foundation of the Americas, 1585-1660. Cambridge: Cambridge University Press, 2007, pp. 62-63. Os sertanejos do século XIX são descritos como pessoas pardas, brancas ou negras que moravam no interior. Viviam em pequenas fortificações de pau-a-pique e se dedicavam ao comércio do interior, investindo em grandes caravanas mercantis, conjugando algumas características fundamentais: $i$ ) Os sertanejos eram "agentes desintegrados das sociedades" portuguesa e africana; ii) Eles eram fulcrais no estabelecimentos dos contatos; iii) Praticavam uma disciplina abusiva, principalmente contra os carregadores que prestavam serviço nas caravanas transcontinentais; $i v$ ) Os sertanejos mantinham uma "solidariedade tácita" de grupo. Verificar: SANTOS, Maria Emília Madeira. Nos caminhos de África [...]. Lisboa: Instituto de Investigação Científica Tropical, 1998, pp. 5, 444-445, 471 e 473. DIAS, Jill. Caçadores, Artesãos, Comerciantes, Guerreiros: os Cokwe em perspectiva histórica. IN: SILVA, Armando Coelho Ferreira da; GONÇALVES, António Custódio (org.). A Antropologia dos Tshokwe e povos aparentados. Porto: Faculdade de Letras da Universidade do Porto, 2003, pp. 26-27.
} 
princípio inter-relacionando a costa atlântica com as feiras interioranas em sentido duplo, mas também em razão do tipo de atuação que eles detinham dentro da Angola portuguesa. Tal quadro de agentes, repetidamente citado na $F H A$, dispunha de aval régio mais livre para comerciar na região, em contraste a outros comerciantes, de ação mais restrita e cuja entrada nos territórios sob "legislação" portuguesa era frequentemente impedida. Eram eles os chamados "mobiris" e "guenzes". Os primeiros eram indivíduos pertencentes ao chamado "reino de Loango", situado entre o Kongo e o Oceano Atlântico. Os mobiris eram normalmente identificados pelos funcionários régios como "contrabandistas", atuantes no comércio secundário ou "ilegal", meio pelo qual trocavam fazendas africanas por produtos manufaturados trazidos pelas naus holandesas. ${ }^{528}$ Os segundos, os "guenzes", são raramente citados nas fontes escritas da $F H A$. Eles eram africanos negros de proveniência incerta, que vinham de algures da África Central em direção às feiras oficiais, a fím de abastecê-las com fazendas e produtos diversos, entre eles principalmente escravos, retornando às suas terras com fazendas locais. Para além da simplista dedução de que os reiterados esforços de delimitação das vias e dos sentidos de locomoção promoviam uma territorialização e legislação efetiva do solo africano, é possível assumir que esses repetidos esforços visavam ao bloqueio do livre-trânsito e à circulação de pessoas, estipulando quem eram os prováveis “infratores" da lei e, inversamente contrário ao propósito normativo, assumindo também que os mecanismos de fiscalização e vigilância eram frequentemente desrespeitados, não funcionando plenamente na Angola portuguesa. ${ }^{529}$

O fator unificador desses três movimentos era o interesse institucional e oficial do aparato ultramarino por agentes e grupos que tivessem alguma utilidade prática para a manutenção do espaço jurisdicional, tendo por objetivo último a reiteração do comércio atlântico. Sobretudo graças a um nível primário de circulação e produção de informação administrativa e burocrática, sabemos que os indivíduos citados participaram da montagem de feiras no interior, auxiliando, cooperando ou simplesmente sendo alvo de mecanismos

\footnotetext{
${ }^{528}$ Verificar: VANSINA, Jan. Paths in the Rainforests: Toward a History of Political Tradition in Equatorial Africa. Madison-Wisconsin: University of Wisconsin Press, 1990, pp. 201-202.

${ }_{529}$ De todo modo, isso não era um empecilho para o comércio, senão seu modo operante. Assim explica Heintze: "se, numa vez, imperava o enriquecimento privado de alguns, na outra tratava-se do enriquecimento oficial da potência colonial". HEINTZE, Beatrix. Angola nos séculos XVI e XVII: estudos sobre fontes, métodos e história [...]. Luanda: Kilombelombe, 2007, p. 383. Sobre o funcionamento geral do comércio, alguns agentes participantes e o trânsito de pessoas, verificar as pp. 488-489 dessa mesma obra. Para mais informações a respeito dos agentes comerciais citados no corpo de texto, consultar o "suplemento para alguns vocábulos africanos", inserido nesta dissertação.
} 
de vigilância e fiscalização reiterados em Ambaca, Massangano, Muxima, Cambambe, na banza de Pungo Andongo e nas feiras abertas em terras de sobas vassalos ou aliados. Ao longo das operações administrativa e institucional portuguesas, a tendência era a de que pessoas de diferentes grupos fossem classificadas através de critérios homogeneizantes, conformando um quadro genérico de agentes ligado ao processo de expansão jurisdicional em direção ao interior do continente, registrado em fragmentos ou em pequenos segmentos de informações contidas na FHA. À operacionalização desses grupos na forma de agentes daremos o nome de absorção, na medida em que tal movimento privilegiava a melhor gestão das feiras e banzas, por consequência objetivando a canalização de mais mercadorias a Luanda. Os indivíduos africanos, absorvidos como agentes que prestavam serviço à administração ultramarina, ou que corroboravam com os interesses e objetivos de Luanda, eram peças importantes não apenas na transplantação e na remontagem de centros institucionais e comerciais promovidas no interior do continente, mas também eram provas concretas de que certos africanos optaram pela parceria e cooperação em relação à Angola portuguesa.

Se nos itens anteriores deste capítulo acompanhamos a desenvolvimento de uma primeira fase de interiorização jurisdicional rumo ao Ndongo, chamando a atenção para o fato de que ela acompanhava tendências estruturantes do controle português ultramarino, no próximo item abordaremos a eficácia da resposta africana aos processos de domínio em voga.

\subsection{Da sindicância ao contragolpe de Angola Aire (1629-1630)}

Há no extenso relatório de Fernão de Sousa um interessante acontecimento políticojurídico, relacionado às irregularidades cometidas por Henrique de Magalhães na administração do presídio de Ambaca. Natural de Flandres, Henrique de Magalhães era um homem experiente na terra. Logo no primeiro ano de governo de Fernão de Sousa, fora nomeado capitão da fortaleza de Santa Cruz, em Luanda. Em 1629, virou capitão do presídio de Ambaca, onde era também "cabo da companhia regular de infantaria ali estacionada". No final de 1629 e princípios de 1630, chegaram ao conhecimento do governador "numerosas e graves queixas" contra ele. Henrique de Magalhães havia sido acusado de "mandar prender arbitrariamente sobas e outros africanos, e de se imiscuir na 
jurisdição dos sobas e extorquir deles ofertas e tributos legais", fato que faria com que fosse "admoestado severamente por Fernão de Sousa", nas palavras de Beatrix Heintze. ${ }^{530}$ Abaixo analisaremos outros documentos relacionados a esse caso, atendo-nos ao funcionamento da justiça e às práticas legais e ilegais vigentes em Ambaca.

A respeito dos eventos que marcaram a passagem de 1629 para 1630, Fernão de Sousa afirmou em seu extenso relatório que recebera queixas de Angola Aire e de um homem chamado Vunge, segundo as quais Henrique de Magalhães prendia os sobas e “quilambas" com a desculpa de fazer mucanos, além de se "intrometer em julgar os d'El-rei Angola com seus sobas", afazeres que não seriam de sua competência e que causava grande descontentamento e mal-estar entre os habitantes do Ndongo. ${ }^{531}$ Alguns sobas e quilambas eram presos com a "desculpa" de "fazer mucanos". O capitão também pedia "infutas" e "loandas" aos sobas, ${ }^{532}$ através de um homem chamado Estevão Fernandez Rego, alferes do presídio de Ambaca, ${ }^{533}$ além de enviar um indivíduo "preto", provavelmente escravo ou luso-africano, certamente familiarizado com a região e com o funcionamento de Ambaca, até a outra banda do Motemo, região situada ao norte do Dembo, mais especificamente entre a nascente do rio Onza ${ }^{534}$ e o rio Dande, para obrigar os sobas a "tomar juramento da terra que é gentílico [sic]". ${ }^{535}$ Em outro documento, Fernão de Sousa indicou novamente, como cúmplices do capitão de Ambaca, o tal Estevão Fernandez Rego e o mesmo indivíduo

\footnotetext{
${ }^{530}$ HEINTZE, Beatrix (coord.). Breves bibliografias de alguns europeus em Angola (1620-1630), FHA, vol. I, 1985, p. 97.

${ }^{531}$ Fernão de Sousa. O extenso relatório do governador aos seus filhos. S.d., 1625-1630. BAL, cód. 51-IX20, ff. 220-74v. IN: HEINTZE, Beatrix (coord.). Documento 30, FHA, vol. I, 1985, pp. 346-347.

${ }^{532}$ As "loandas", "infutas" (também "futas"; não confundir com "infuca" ou "enfuca") e também "vestir" eram tributos de origem africana, reconhecidos como "legítimos" pelos locais, mas que passariam a ser proibidos a partir do governo de Fernão de Sousa. Para mais informações, consultar o "suplemento para alguns vocábulos africanos", inserido nesta dissertação.

${ }_{533}$ Verificar a nota 401 de Beatrix Heintze em: Fernão de Sousa. O extenso relatório do governador aos seus filhos. S.d., 1625-1630. BAL, cód. 51-IX-20, ff. 220-74v. IN: HEINTZE, Beatrix (coord.). Documento 30, $F H A$, vol. I, 1985, p. 346. Heintze ainda pede para que se consulte BAL, cód. 51-IX-21, f. 288v, de 15 de novembro de 1629.

${ }^{534}$ Essas informações foram retiradas da figura 1, "África Central Ocidental na época de Fernão de Sousa (ortografia da fonte)", FHA, vol. I, 1985, p. 4. Nessa figura, Beatrix Heintze aponta o Motemo como sendo uma "localidade africana". No extenso relatório, Fernão de Sousa escreve que o capitão de Motemo era Henrique António Ferreira da Cunha. Não encontramos mais nenhuma informação sobre esse homem nem sobre a situação de Motemo na década de 1620. Verificar ainda o mapa inserido no início deste item. Conferir ainda o exemplo em: Fernão de Sousa. O extenso relatório do governador aos seus filhos. S.d., 1625-1630. BAL, cód. 51-IX-20, ff. 220-74v. IN: HEINTZE, Beatrix (coord.). Documento 30, FHA, vol. I, 1985, pp. $327,340,343$.

${ }^{535}$ Fernão de Sousa. O extenso relatório do governador aos seus filhos. S.d., 1625-1630. BAL, cód. 51-IX20, ff. 220-74v. IN: HEINTZE, Beatrix (coord.). Documento 30, FHA, vol. I, 1985, pp. 346-347.
} 
preto, acusando-os de "correr todos os sobas", ou coagi-los a pagar "peças" e outras fazendas, em nome da cobrança de "infutas e loandas" aos sobas da outra "banda do Lucala". Havia sido dessa forma que Henrique de Magalhães obrigara o soba Caculo Cacabaça a fornecer um "moleque", cinco "peças" e "panos", 536 sendo curioso notar que, poucos anos antes, uma série de feiras ocorrida nas terras de Caculo Cacabaça estava sob a supervisão do mani quitanda António de Andrade.

Por causa dessas graves acusações, continuou Fernão de Sousa no relatório, o governador escrevera a Henrique de Magalhães repreendendo sua conduta, afirmando que "procederia conforme ordem que lhe mandei que está registrado [sic] no livro da secretaria". ${ }^{537}$ A isso Fernão de Sousa acrescentou que enviara também uma "ordem ao sindicante [e] licenciado António Nunes Leitão", 538 funcionário incumbido de visitar os presídios do interior e que estava de passagem em Ambaca naquele momento, solicitando para que o sindicante "tomasse conhecimento do caso e fazer justiça dando apelação", não deixando de notar que o "agravo coube ao ouvidor geral". Caso a presença de Henrique de Magalhães em Ambaca atrapalhasse a investigação, António Nunes Leitão deveria enviá-lo a Cambambe, de tal forma que "o sindicante governasse em seu lugar enquanto durar seu impedimento [de Henrique de Magalhães]". 539

A ordem destinada a Henrique de Magalhães, sobre a qual Fernão de Sousa fez referência no relatório, encontra-se na $F H A$ e foi transcrita e intitulada por Beatrix Heintze como "Carta de Fernão de Sousa a Henrique de Magalhães". Nesse documento, datado de 7 de fevereiro de 1630, Fernão de Sousa afirmou que os sobas estavam se queixando sobre a conduta do capitão Henrique de Magalhães, pois "não se ocupava mais do que fazer mucanos", mediante os quais os sobas eram presos e obrigados a "tomar juramento de terra

\footnotetext{
${ }^{536}$ Fernão de Sousa. Carta de Fernão de Sousa a Henrique de Magalhães. 7 de fevereiro de 1630. BAL, cód. 51-IX-21, ff. 325-25v. IN: HEINTZE, Beatrix (coord.). Documento 214, FHA, vol. II, 1988, p. 318.

${ }^{537}$ Fernão de Sousa. O extenso relatório do governador aos seus filhos. S.d., 1625-1630. BAL, cód. 51-IX20, ff. 220-74v. IN: HEINTZE, Beatrix (coord.). Documento 30, FHA, vol. I, 1985, pp. 346-347. De acordo com informações de Beatrix Heintze, essa ordem foi enviada na carta de fevereiro de 1630 (BAL, cód. 51IX-21, ff. 325-25v) e é a mesma que analisaremos a seguir. Informação retirada da nota 402 de Heintze para o extenso relatório de Fernão de Sousa, p. 346.

${ }^{538}$ Pormenorizaremos as visitas oficiais feitas por António Nunes Leitão aos presídios no momento oportuno. Segundo a nota 403 de Beatrix Heintze, o documento referenciado por Fernão de Sousa não é conhecido. A pesquisadora pede para consultar: Fernão de Sousa. Portaria de Fernão de Sousa. 16 de março de 1630. BAL, cód. 51-IX-20, ff. 444v-43. IN: HEINTZE, Beatrix (coord.). Documento 215, FHA, vol. II, 1988, pp. 318319.

${ }^{539}$ Fernão de Sousa. O extenso relatório do governador aos seus filhos. S.d., 1625-1630. BAL, cód. 51-IX20, ff. 220-74v. IN: HEINTZE, Beatrix (coord.). Documento 30, FHA, vol. I, 1985, pp. 346-347.
} 
que é gentílica". ${ }^{540}$ Esse trecho parece ser de suma importância para Fernão de Sousa, uma vez que quase as mesmas palavras foram repetidas no extenso relatório. Portanto, a possibilidade de consulta da carta de 7 de fevereiro de 1630 no momento da composição do primeiro documento deve ser considerada. Prosseguindo com a lista de ilicitudes praticadas pelo capitão, Fernão de Sousa afirmou que os sobas do Ndongo acusavam Henrique de Magalhães de julgar os mucanos movidos na região, o que não era correto porque "mucanos de el-rei Ndongo e seus sobas [estavam] reservados a mim [Fernão de Sousa]" e que deixasse "el-rei e sua banza em paz, [ou] do contrário iria para baixo",541 algo que interpretamos aqui como sendo sinônimo ao de ser degredado à região sul da África Centro-Ocidental, ou seja, para Benguela, lugar de destino para vários indivíduos “jogados” na conquista de Angola, marginalizados e pobres que muitas vezes acabavam indiciados por crimes e contravenções, resultando em degredos ou penas ainda mais graves. ${ }^{542}$

Ainda sobre o trecho anterior, é importante frisar que, mesmo que o julgamento, ou veredito final sobre os mucanos, fosse uma prerrogativa reivindicada pelo governador, nos presídios era comum que os capitães os julgassem. De fato, a decisão jurídica sobre esses tipos de processos jurídicos de natureza "gentílica" era matéria controversa. Por um lado, o governador reivindicava que essa prerrogativa lhe estava "reservada", dado ser ele o representante do monarca no além-mar. A "exclusividade" de decisão sobre os mucanos, contudo, não impedia com que, em determinadas situações, o governador "delegasse" essa e outras instâncias judiciárias a outros funcionários, ato necessário porque a cabeça do governo, normalmente estacionada em Luanda, não poderia estar em vários lugares da conquista ao mesmo tempo. Advinha daí uma "excentricidade" da execução da justiça portuguesa, resultante das adaptações necessárias ao longo da transferência de pontos institucionais ao interior do continente. O que presenciamos claramente é que, entre 1629 e

\footnotetext{
${ }^{540}$ Fernão de Sousa. Carta de Fernão de Sousa a Henrique de Magalhães. 7 de fevereiro de 1630. BAL, cód. 51-IX-21, ff. 325-25v. IN: HEINTZE, Beatrix (coord.). Documento 214, FHA, vol. II, 1988, p. 317.

${ }^{541}$ Fernão de Sousa. Carta de Fernão de Sousa a Henrique de Magalhães. 7 de fevereiro de 1630. BAL, cód. 51-IX-21, ff. 325-25v. IN: HEINTZE, Beatrix (coord.). Documento 214, FHA, vol. II, 1988, pp. $317-318$.

542 Fato é que os degredos poderiam ser assacados aos pequenos infratores ou miseráveis, em nome da "limpeza do interior", sendo assim o resultado de manipulações que visavam atender aos planos políticos dos governadores. Sobre os degredados enviados a Benguela, verificar: CANDIDO, Mariana P. Los lazos que unen Centroamérica a un puerto africano del Atlántico Sur. Benguela y la Trata de esclavos, 1617-1800. Boletín AFEHC. Toulouse: Asociación para el Fomento de los Estudios Históricos en Centroamérica, n. ${ }^{\circ} 55,4$ de dezembro de 2012, p. 5. Idem, South Atlantic Exchanges: The Role of Brazilian-Born Agents in Benguela, 1650-1850. Luso-Brazilian Review. Madison: University of Wisconsin Press, vol. 50, n. ' 1, 2013, p. 56.
} 
1630, a exceção já havia se tornado regra, pelo menos em Ambaca e por um curto período de tempo. Decerto, na prática os capitães de presídios poderiam julgar os mucanos sem consultar ou ter permissão do governador para fazê-lo, acarretando, no final das contas, em desvios de conduta ou desgovernos. Subjacentes a essas "excentricidades corriqueiras" diagnosticáveis em Ambaca, existiam duas balizas importantes da administração ultramarina da Angola portuguesa. A primeira era a da autogestão, encadeada à atribuição vertical de amplas diretrizes que eram passíveis de serem interpretadas e implementadas livremente no âmbito local, viabilizando assim a coordenação mais ou menos eficiente dos presídios, feiras e banzas por Luanda. A segunda era o desenvolvimento de mecanismos de vigilância e fiscalização de espaços reorganizados de comércio, por um lado através da absorção de agentes locais e luso-africanos como parte do funcionalismo régio, por outro lado através da incorporação de elementos africanos para finalidades aplicadas e pragmáticas, como era o caso dos mucanos.

$\mathrm{O}$ caso de Henrique de Magalhães em Ambaca também advoga para um segundo aspecto. Havia uma relação conflituosa, mas fluida, entre correto e incorreto, permissivo e proibitivo, legalidade e ilegalidade e isso era determinado normalmente pelos agentes encarregados pela execução da justiça, beneficiando algumas poucas pessoas e lesando tantas outras. Nos exemplos extraídos da documentação, a justiça de mucanos era encarada como algo positiva e respeitável, normalmente legitimada em defesa de um aspecto recorrente no discurso oficial administrativo da época: a "paz". Virtualmente válida para todos que fossem abarcados pelo espaço jurisdicional reivindicado pela administração ultramarina, quem ditava oficialmente essa "paz" era a cúpula de governo sediada em Luanda. Em última instância, cabia a ela arbitrar pelo o que era "certo" e "errado", residindo em suas mãos, às vezes, uma tendência impositiva e pouco imparcial de comando. Nosso argumento é o de que, mesmo que os pontos institucionais responsáveis pelas esferas jurídicas e políticas contassem com "elementos" de cunho africano - a possibilidade de abertura de mucanos era exemplo disso - e que os órgãos institucionais ultramarinos tivessem a "contribuição" de agentes africanos - a nomeação de mani quitanda e meirinhos era exemplo disso -, sob a aparência de que o ordenamento do espaço jurisdicional concatenava "ordens" legais e "mandos" políticos compartilhados entre os estrangeiros e os mbundu, na prática a prerrogativa de julgamento estava circunscrita ao 
governador, sendo no máximo transferível a outros funcionários, sempre mediante aos interesses que partiam de Luanda. Quem delegava as alçadas, competências e definia atribuições aos funcionários régios era Fernão de Sousa, sempre em nome da "paz" ou termos correlatos a ela, como "justiça", "razão", "bem comum" e outros mais. O crivo de identificação e seleção daquilo que era legal, permitido e correto estava respaldado em predisposições comandadas pelo funcionalismo régio. Além disso, ao concentrar a capacidade de decisão oficial nas mãos do governador, porventura aos capitães e a altos funcionários, os órgãos ultramarinos minguavam as chances dos sobas serem beneficiados ou contemplados positivamente pela justiça implementada dentro do espaço jurisdicional ultramarino. Isso, pelo menos, durante o governo de Fernão de Sousa. Na prática, na maioria das vezes o que acontecia era exatamente o contrário, acabando os sobas do Ndongo, Lucala e Motemo usurpados pela justiça e paz oficiais, em nome da manutenção da Angola portuguesa.

Reiterando as acusações registradas na carta de fevereiro de 1630, Fernão de Sousa adicionou que Henrique de Magalhães enviou um homem preto para "correr todos os outros sobas até Capele", ordenando a todos os sobas que enviassem escravos a Ambaca. Os sobas se recusaram a enviá-los, respondendo que "corriam com o capitão [de] Motemo", Henrique António Ferreira da Cunha e, portanto, não deviam nada ao capitão de Ambaca. ${ }^{543}$

\footnotetext{
${ }^{543}$ Fernão de Sousa. Carta de Fernão de Sousa a Henrique de Magalhães. 7 de fevereiro de 1630. BAL, cód. 51-IX-21, ff. 325-25v. IN: HEINTZE, Beatrix (coord.). Documento 214, FHA, vol. II, 1988, p. 318.
} 


\section{Imagem 9: Algumas localidades citadas no caso das contravenções cometidas por Henrique de Magalhães (1629-1630) $)^{544}$}

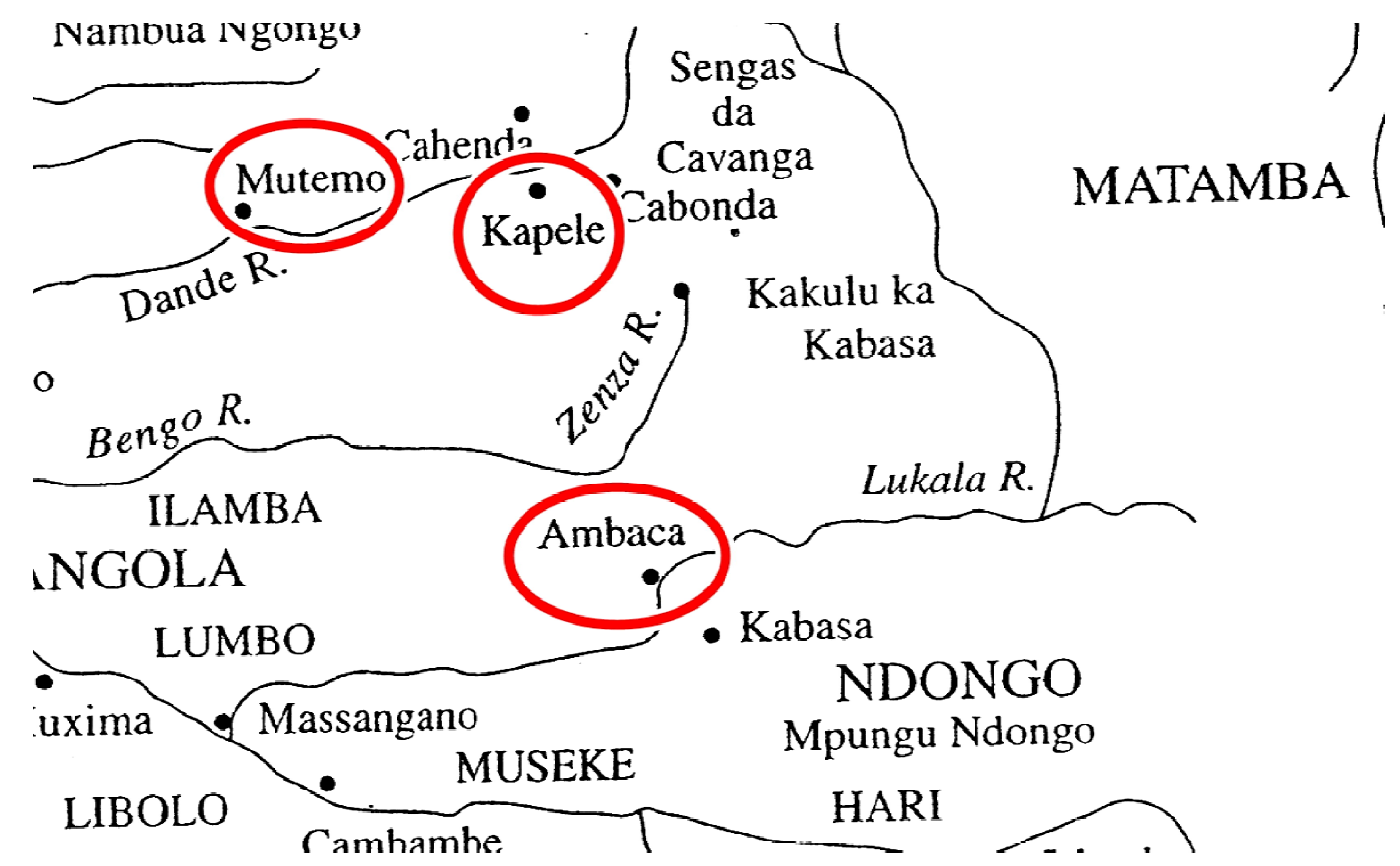

Legenda: As esferas em vermelho indicam algumas das localidades citadas nos documentos referentes aos casos-crime de Henrique de Magalhães.

Assumimos que os sobas do Ndongo e redondezas de Ambaca optaram pela submissão voluntária ao capitão de Motemo, Henrique António Ferreira da Cunha, ou se valeram retoricamente dela - o tal "correr com [alguém]" -, para escapar da brutalidade e dos desmandos cometidos por Henrique de Magalhães. Não foi por menos que, em represália à atitude dos sobas que cooperavam com o capitão de Motemo, Henrique de Magalhães escrevera a Luanda afirmando que esses africanos estavam "levantados" e não mais obedeciam Ambaca, o que justificaria uma guerra. Por mais que os sobas da região de Ambaca estivessem em estado de insurgência, o que de fato parece bastante plausível em vista do comportamento inescrupuloso de Henrique de Magalhães e das tensas relações políticas existentes entre o Ndongo e Luanda, derivadas do tempo de Luís Mendes de Vasconcelos, o que parece cabível aqui é afirmar que o capitão de Ambaca fez uso de uma

\footnotetext{
${ }^{544}$ Imagem retrabalhada a partir da figura existente em: HEYWOOD, Linda M.; THORNTON, John K. Central Africans, Atlantic Creoles [...]. Cambridge: Cambridge University Press, 2007, p. 50.
} 
situação real de sublevação africana para justificar uma expedição punitiva, dessa forma mascarando o intuito de roubar e saquear as aldeias dos sobas que habitavam as redondezas de Ambaca. Afinal de contas, como indicado ao longo desta dissertação, em última instância o que colocava em risco o mando legal e a ordem política da Angola portuguesa era a delicada situação pela qual passava Angola Aire em Pungo Andongo, sendo o ataque aos sobas de Ambaca meros paliativos políticos. Para conter o desequilíbrio regional, era necessário dar cabo à questão da chamada "conquista do Ndongo", e Henrique de Magalhães sabia disso. Além disso, e aqui temos outro vestígio de sobre quais eram os objetivos particulares do capitão de Ambaca, Fernão de Sousa não deixou de salientar que Henrique Magalhães desclassificara Henrique António Ferreira da Cunha, chamando-o de "pombeiro". Na ótica daquele capitão, deveriam os sobas obedecer a Ambaca em detrimento de Motemo, rebaixando por consequência a autoridade do oficial que ali servia. Como se recusavam a fazê-lo, a "punição" seria legítima. ${ }^{545}$ Havia tensões internas, acusações mútuas e trocas de ofensas entre os capitães que serviam no sertão, logicamente porque eles estavam mais próximos da fonte de riqueza da Angola portuguesa: os escravos ou "peças".

O que de fato movia as irregularidades cometidas por Henrique de Magalhães e inflamavam as tensões e atritos entre os capitães e o governador era a busca por riqueza pessoal, pouco importando se eram homens "bons" e "honestos" a serviço do monarca português. Para Fernão de Sousa, o "bom serviço prestado" em Luanda era uma importante forma de angariar mercês e favores do rei para a sua família, já para os capitães como Henrique Magalhães e Henrique António Ferreira da Cunha isso era menos relevante. Estes estavam provavelmente mais preocupados em comercializar escravos e, não por menos, Henrique António Ferreira da Cunha foi “insultado" de pombeiro. Por sua vez, o capitão de Ambaca liderava uma trupe de pessoas que ocupava formalmente ofícios típicos da carreira militar ultramarina, mas que "extraoficialmente" utilizava dessas posições para fins econômicos pessoais, ligados ao tráfico de escravos e apartados da carreira política na corte de Lisboa, em um modelo de ascensão social baseado no acúmulo de "peças" e "panos" de ráfia. É de suma importância lembrar que a vida desses homens já estava enraizada no

\footnotetext{
${ }^{545}$ Fernão de Sousa. Carta de Fernão de Sousa a Henrique de Magalhães. 7 de fevereiro de 1630. BAL, cód. 51-IX-21, ff. 325-25v. IN: HEINTZE, Beatrix (coord.). Documento 214, FHA, vol. II, 1988, p. 318.
} 
ultramar. O exemplo de Henrique de Magalhães mostra isso com clareza. Indivíduo simples, familiarizado com os povos locais e de ventura na conquista militar, esse capitão era um homem com experiência no "trato com o gentil" e que nunca mais voltaria ao reino de Portugal, já que faleceria no cárcere em Luanda, antes de maio de 1630, após mais de dez anos de serviços prestados no interior. ${ }^{546}$ Em suma, componentes de um grupo mais ou menos uniforme, homens como ele, Estevão Fernandez Rego e Henrique António Ferreira da Cunha visavam "fazer uma vida" no ultramar, nos moldes de uma ascensão social voltada ao comércio atlântico. Em último caso, devido ao fato de sobreviverem por meio de atividades conflitantes com as do erário régio, esse grupo de homens experientes na terra e versados na economia atlântica acabaria registrado nas fontes oficiais de forma genérica, mais ou menos identificada a um quadro de agentes corruptos. ${ }^{547}$

As acusações feitas pelos sobas foram somadas às reclamações de Angola Aire que, como salientamos desde o início deste capítulo, enviara diversas queixas ao governador. Uma, em especial, chama a atenção. Nela, o africano disse que Henrique de Magalhães havia recolhido o "quilamba Gombe Amotenda", fazendo-lhe "dano" e tomando sua "gente". Indignado com o tratamento recebido, Gombe Amotenda partiu "pelo caminho e recolhendo [a população] alevantada, e por não reconhecer Sua Majestade [rei de Portugal] se deixava estar nas terras de el-rei de Ndongo a que não reconhecia por ser de Ambaca". Desrespeitando os termos de vassalagem firmados e 1626, Angola Aire deu carta branca ao líder indômito, permitindo que o quilamba conduzisse os insurgentes do Ndongo. Assim sendo, liderados por esse quilamba, os sobas descontentes relutavam a prestar obediência às autoridades régias de Ambaca, procurando refúgio no Ndongo e junto de Angola Aire, que orquestrava um jogo no mínimo ousado: por um lado combatia Henrique de Magalhães através de mecanismos institucionais, por meio de recados nos quais transbordava humildemente respeito e lealdade a Fernão de Sousa; por outro lado, o soberano africano incentivava a insurgência de Gombe Amotenda e os compadrios malvistos por Luanda. No final das contas, a jogada de Angola Aire obteve êxito. Temeroso em relação ao levante que

\footnotetext{
${ }^{546}$ HEINTZE, Beatrix (coord.). Breves bibliografias de alguns europeus em Angola (1620-1630), FHA, vol. I, 1985, p. 97.

547 A “corrupção" é muitas vezes repudiada por Fernão de Sousa, indicando que não apenas ela existia, mas também que causava prejuízos relevantes à administração régia e à fazenda real. O mesmo tópico foi tratado especificamente em: SANTOS, Catarina Madeira. Um governo "polido" para Angola [...]. Tese de doutorado, Universidade Nova de Lisboa, 2005, p. 163.
} 
despertava na região, Fernão de Sousa escreveu a Henrique de Magalhães, ordenando-o a "recolher" o quilamba, caso ele estivesse mesmo "levantando" as gentes no Ndongo e vizinhanças, "com a razão a el-rei [Angola Aire] que é vassalo de Sua Majestade nosso senhor". 548 O soberano conseguiu o que queria. Sem Gombe Amotenda, os insurgentes ficariam sem um líder, mas isso não quer dizer que esqueceriam as queixas e nem que passariam a acatar as ordens de Ambaca. Mediante um cálculo estratégico simples, quem despontaria como potencial liderança para os descontentes seria Angola Aire. Ao mesmo tempo, a posição de Luanda estava cada vez mais fragilizada no interior, posto que Ambaca estava prestes a ser destituída de seu comandante e a maioria da gente de guerra estava ausente nos presídios, pois servia nas guerras contra Ginga Ambande. Ao incentivar veladamente os insurgentes, Angola Aire estremecia as relações entre Luanda, Ambaca e Ndongo, desbancando-as na região e paulatinamente figurando como uma líder político relevante.

Corroborando para o jogo orquestrado por Angola Aire, residia o fato de que os funcionários previamente designados para assumir postos régios em Ambaca e no Ndongo no geral eram omissos. Basta, por exemplo, voltar os olhos para o caso da feira de Caculo Cacabaça, uma importante fonte de escravos localizada nas proximidades de Ambaca. Como salientamos anteriormente, entre 1624 a 1627, a feira aberta nas terras desse soba contava com a supervisão de um mani quitanda, o escravo António de Andrade. ${ }^{549}$ Em 1628, ele já a havia abandonado e, entre os anos de 1629 a 1630, as acusações contra Henrique de Magalhães estouraram. Vale lembrar: acusações sobretudo feitas por Angola Aire. Inclusive, umas delas apontara que o capitão de Ambaca havia forçado Caculo Cacabaça a ceder peças e panos, em um momento no qual o mani quitanda já havia deixado seu posto sem maiores explicações. Ora, com exceção de António de Andrade, quem mais poderia apontar os desvios de Henrique de Magalhães? À parte de Angola Aire, as demais autoridades responsáveis pela direção do Ndongo foram totalmente omissas. Bento Rebelo

\footnotetext{
${ }^{548}$ Fernão de Sousa. Carta de Fernão de Sousa a Henrique de Magalhães. 7 de fevereiro de 1630. BAL, cód. 51-IX-21, ff. 325-25v. IN: HEINTZE, Beatrix (coord.). Documento 214, FHA, vol. II, 1988, p. 318. Sobre as ordens inicialmente destinadas a Henrique de Magalhães, ver também: Filipe III de Portugal [escrito por Cristovão Soares]. 19 de março de 1624. BAL, cód. 51-IX-20, ff. 13-14v. IN: HEINTZE, Beatrix (coord.). Documento 3, FHA, vol. I, 1985, pp. 136-139.

549 Notando que separações irreconciliáveis e intransponíveis entre o "mundo da escravidão" e o da "liberdade" devem ser colocadas abaixo, pelo menos quando tratamos no funcionamento de uma Angola portuguesa nos séculos XVI e XVII. Nesse sentido, verificar: HEINTZE, Beatrix. Angola nos séculos XVI e XVII [...]. Luanda: Kilombelombe, 2007, p. 503.
} 
Vilasboas esteve grande parte do tempo ausente do Ndongo, tendo partido com o quilombo de guerra que combateu Ginga Ambande, onde exerceu as funções de "auditor de campo", ouvidor e provedor dos defuntos e dos ausentes. ${ }^{550}$ Entre 1626 e 1629, ele esteve em trânsito constante pelo interior do continente e, em 1630, provavelmente voltou a Luanda, onde comemorou a expulsão em definitivo de Ginga Ambande do Ndongo. ${ }^{551} \mathrm{Na}$ realidade, parece que o português nunca chegou a assumir o posto institucional que Fernão de Sousa lhe designara no Ndongo, apesar de as cartas régias serem bastante claras quanto à obrigatoriedade dele. Destino incerto pareceu ter igualmente o padre Francisco Pacónio, sobre o qual não encontramos mais informações em nosso levantamento documental e nem sabemos o paradeiro em 1630. Outro importante agente que servia em Pungo Andongo, Domingos Pires, eximiu-se de qualquer opinião ou advertência sobre os acontecimentos ocorridos em Ambaca e redondeza nos últimos três anos, possivelmente por apoiar Angola Aire.

Foi em meio a esse clima de acusações que, pouco mais de um mês após o governador repreender os atos de Henrique de Magalhães, em 7 de fevereiro de 1630, uma portaria foi emitida em Luanda, em 16 de março de 1630. Ela chegaria ao presídio de Ambaca pelas mãos de António Nunes Leitão, “que andava na conquista fazendo diligência por meu mando [de Fernão de Sousa]”. Na portaria, Fernão de Sousa avisou às populações locais que o capitão enviava "soldados pelos sobas d'aquele distrito a lhes pedir peças com violência e extorsões que cometiam para os obrigarem a lhas dar contra a instrução de Vossa Majestade", chegando a espancar os sobas para arrancar escravos deles. Henrique de Magalhães cometia "injustiças aos sobas nos mucanos", no qual "era juiz levando-lhe metade do que julgava e obrigando-os a que lhe vendessem a outra metade", além de prender muitos "negros no corpo de guarda sem haver culpa obrigatória". 552 O governador explicitou ainda dois casos de desmedidas ocorridas em Ambaca, até então inéditos nas fontes, os quais ilustram algumas características sobre o modo operante das ilicitudes. O primeiro dizia respeito à injustiça cometida contra o soba "Gonga Moiza", para quem

\footnotetext{
${ }^{550}$ HEINTZE, Beatrix. Breves biografias de alguns europeus em Angola (1620-1630). FHA, vol. I, 1985, p. 112.

${ }^{551}$ Como tocado no capítulo anterior e voltaremos abordar no seguinte.

${ }^{552}$ Fernão de Sousa. Portaria de Fernão de Sousa. 16 de março de 1630. BAL, cód. 51-IX-20, ff. 444v-43. IN: HEINTZE, Beatrix (coord.). Documento 215, FHA, vol. II, 1988, p. 319.
} 
Henrique de Magalhães prometera um "julgamento gentílico"553 em troca de trinta peças das índias, o que nunca fora feito, apesar de o soba ter dado cerca de vinte peças ao capitão. Injuriado com o comportamento de Gonga Moiza, pois considerou a recusa do africano um ato de rebeldia e desacato à autoridade, Henrique de Magalhães prendeu os seus "tendala" e "samba tendala", 554 afirmando que só os liberariam após o pagamento das peças que faltavam. Não encontramos informações sobre o desfecho da contenda judicial. O segundo caso se referia ao encarceramento de quatro sobas na casa do "tendala Manoel Ferreira Arco", aos quais Henrique de Magalhães prometera restituir a liberdade em troca de algumas "peças". Devido à recusa dos sobas em cedê-las, o capitão bateu nos africanos, açoitou um deles e lhes deu "muitas pancadas". O documento não explicita as razões ou álibis utilizados para justificar o aprisionamento dos sobas, dando a entender que o cárcere fora motivado exclusivamente em razão de extorsão. ${ }^{555}$ Em vista desse quadro geral, Fernão de Sousa ordenou ao licenciado António Nunes Leitão para que ele abrisse uma "devassa do dito capitão Henrique Magalhães pelos ditos capítulos". 556 Durante o período de elaboração do processo, o que duraria em média vinte dias, Henrique de Magalhães seria movido a Pungo Andongo. Uma vez feita a devassa, o capitão retornaria a Ambaca, onde receberia como adjunto o capitão Pedro do Rego Pimentel, ${ }^{557}$ que o acompanharia até o veredito final do julgamento, feito por Fernão de Sousa. ${ }^{558}$ Finalmente, ainda em 1630, Henrique de Magalhães acabou enviado a Luanda, onde faleceu na prisão.

A partir do caso de Ambaca podemos depreender algumas generalizações. Como autoridades máximas nos presídios, os capitães poderiam ser responsáveis, por exemplo,

\footnotetext{
${ }^{553}$ Em relação à expressão "julgamento gentílico", registrada pelo governador, entendemos que ela se referia à "justiça dos mucanos", ou simplesmente mucanos.

554 Segundo Beatrix Heintze, tanto "tendala" quanto "samba tendala" eram "títulos e/ou políticos dos mbundu" distintos entre si. Na chamada "guerra preta", ou tropas africanas que integravam os exércitos portugueses, "tendala designava a patente máxima, samba tendala a segunda". Durante o governo de Fernão de Sousa, ocorreu a tentativa de eliminação do cargo de "samba tendala", contudo sem obter êxito. Por fim, é interessante notar que samba, em kikongo, significa "ajudante". Verificar: HEINTZE, Beatrix. Esclarecimentos sobre os vocábulos africanos. FHA, vol. I, 1985, p. 127. Para mais considerações, consultar o "suplemento para alguns vocábulos africanos", inserido nesta dissertação.

${ }^{555}$ Fernão de Sousa. Portaria de Fernão de Sousa. 16 de março de 1630. BAL, cód. 51-IX-20, ff. 444v-43. IN: HEINTZE, Beatrix (coord.). Documento 215, FHA, vol. II, 1988, p. 319.

${ }_{556}$ Provavelmente aqui Fernão de Sousa se referia aos "capítulos" do regimento entregue a António Nunes Leitão. Consultar: Fernão de Sousa. Regimento de Fernão de Sousa a António Nunes Leitão. 12 de junho de 1629. BAL, cód. 51-IX-21, ff. 278-79v. IN: HEINTZE, Beatrix (coord.). Documento 200, FHA, vol. II, 1988, pp. 299-301.

${ }^{557}$ Ou "Pero" em vez de "Pedro", como é grafado no documento.

${ }^{558}$ Fernão de Sousa. Portaria de Fernão de Sousa. 16 de março de 1630. BAL, cód. 51-IX-20, ff. 444v-43. IN: HEINTZE, Beatrix (coord.). Documento 215, FHA, vol. II, 1988, p. 319.
} 
pela execução quase completa da cadeia de afazeres judiciários locais, competindo-lhes fiscalizar, julgar e punir. Por não serem supervisionados de perto por nenhuma autoridade régia, eles gozavam de grande independência administrativa e judicial. Beneficiados por esses privilégios e ávidos por riquezas, sendo a principal os escravos, eles cometiam atrocidades contra os sobas e burlavam o fisco régio, desviando mercadorias e enriquecendo à custa dos sobas. Guiados por interesses pessoais, à guisa de uma ascensão social voltada ao comércio atlântico e evocando princípios relacionados às noções de "justiça", “julgamento" e "lei”, eles cometiam as mais diversas desmedidas, impropriedades, desmandos e desonestidades na região da conquista. É importante salientar que a cúpula de governo de Luanda tinha conhecimento da regularidade disso. As diligências destinadas a António Nunes Leitão visavam resolver, ou minimizar, a frequência desses atos locais. O intuito da missão delegada ao oficial régio era também o de fiscalizar e corrigir, ou seja, "zelar pela justiça" regionalmente, dentro do espaço jurisdicional de domínio ultramarino, a Angola portuguesa. Além disso, havia a elaboração das chamadas tarefas "extrajudiciais", conforme prescrito na "Instrução de Fernão de Sousa a António Nunes Leitão", de 11 de junho de 1629, mediante as quais o diligente fora encarregado, por exemplo, de assegurar o envio de "peças de bronze rebentadas" ao capitão de Massangano, João do Couto, e levar a cabo "diligência[s] com os sobas sobre os baculamentos", caso fosse necessário. ${ }^{559}$

A tentativa de manter um controle jurisdicional a partir de Luanda é defendida no extenso relatório. Isso era um plano geral, ou diretriz traçada por Fernão de Sousa, evidentemente em consonância com a vontade do monarca português e do Conselho da Fazenda. Todavia, essa tentativa de implementação de jurisprudência tinha resultados rasos. A análise minuciosa de um nível primário de informação, de produção e circulação de

\footnotetext{
${ }^{559}$ Fernão de Sousa. Instrução de Fernão de Sousa a António Nunes Leitão. 11 de junho de 1629. BAL, cód. 51- IX-21, ff. 174-77v. IN: HEINTZE, Beatrix (coord.). Documento 199, FHA, vol. II, 1988, p. 299. Além da instrução de junho de 1629, António Nunes Leitão também carregava consigo o documento intitulado "Regimento de Fernão de Sousa a António Nunes Leitão", inserido em HEINTZE 1985, entre as pp. 299-301. Há nesse regimento uma lista de 29 pontos, sendo que cada um deles conta com uma descrição pormenorizada sobre os afazeres encarregado ao "bacharel [...] na forma de meu Regimento [...] e isto além dos poderes e jurisdições que levais por minhas provisões". Verificar: Fernão de Sousa. Regimento de Fernão de Sousa a António Nunes Leitão. 12 de junho de 1629. BAL, cód. 51-IX-21, ff. 278-79v. IN: HEINTZE, Beatrix (coord.). Documento 200, FHA, vol. II, 1988, p. 299. Sobre o regimento de Fernão de Sousa, consultar: Dom Diogo de Castro [feito por António Correa e escrito por Cristovão Soares]. Regimento do governador de Angola. 20 de março de 1624. BAL, cód. 51-IX-20, ff. 7-11. IN: HEINTZE, Beatrix (coord.). Documento 4, FHA, vol. I, 1985, pp. 140-153.
} 
documentos internamente, permite duas deduções claras sobre os limites de Luanda. A despeito da sindicância como um meio de integração institucional de Luanda a Ambaca, Massangano, Muxima e Cambambe, ela foi inofensiva contra o principal motivador das injustiças levadas a cabo por Henrique de Magalhães: o enriquecimento fácil, nos moldes como já descritos. A segunda dedução é a de que a sindicância, como forma de mediar as tensões sociais existentes entre grupos sociopolíticos divergentes, era muitas vezes inócua. De um lado, Angola Aire era o apoiador dos insurgentes, representados por autoridades africanas como Gombe Amotenda, Caculo Cacabaça e Gonga Moiza, aos quais podemos somar também alguns sobas espalhados pelo Ndongo, Lucala e lá e acolá até Capele. Do outro lado, liderado por Henrique de Magalhães, jazia a trupe composta por Estevão Fernandes Rego e Manoel Ferreira Arco, todos eles militares enraizados na terra e que procuravam uma ascensão social voltada ao comércio em mercadorias locais, ${ }^{560}$ acompanhados de seus cúmplices e capangas, que poderiam ser indivíduos pretos ou soldados miseráveis portugueses. Contra Henrique de Magalhães jazia também outro grupo, sob a liderança do capitão de Motemo, Henrique António Ferreira da Cunha. Nesse jogo político local, havia tensão social, atrito institucional, embate entre autoridades africanas e portuguesas e interesse comercial. Competia para o acirramento dessa série de conflitos a omissão e ausência de um quarto grupo, composto por Bento Rebelo Vilasboas, Domingos Pires, Angola Aire e Francisco Pacónio, responsável pela decisão judiciária e administrativa de Pungo Andongo. Isso ocorreu seja porque as campanhas de guerra contra Ginga Ambande desarranjaram a "paz" e o "bem comum" das banzas, feiras e presídios situados no Ndongo e seus arredores, seja porque alguns desses agentes participavam de um jogo duplo, cooperando com Luanda por um lado, mas perseguindo seus interesses pessoais por outro lado, como foram os casos de Angola Aire e Henrique Magalhães.

Se no capítulo anterior indicamos com base em fontes secundárias que um golpe político orquestrado no Ndongo não havia logrado o êxito esperado, sobretudo ressaltando que a "marionete" política Angola Aire não era inapta ao governo político - advogamos exatamente para o contrário -, tampouco se mostrava facilmente manipulável como se supunha, neste capítulo temos os indícios claros e primários de que o novo soberano do Ndongo respondia aos intentos de Luanda com um contragolpe aos objetivos oficias de

\footnotetext{
${ }^{560}$ Cabendo notar que Manoel Ferreira Arco também pode ser caracterizado como um "luso-africano".
} 
Portugal. Basta aqui destrinchar alguns níveis de circulação das informações institucionais, desmontando os discursos e as retóricas que envolviam os registros documentais, para então penetrar no âmago da produção textual. Em um nível de circulação transcontinental, a imagem que se pinta é a de um "rei do Ndongo" submisso e avassalado à monarquia portuguesa, colmatando os desejos profissionais e pessoais de Fernão de Sousa: o estabelecimento de tutela de um "imponente rei africano". Esse é um dos motivadores para a escrita da serie de lembranças e relações que analisamos no capítulo anterior. Em um nível mais "terreno", ou seja, primário e de trocas de missivas entre as autoridades que serviam exclusivamente na Angola portuguesa, a ilusão do estabelecimento de uma dominação portuguesa intransigente, em território centro-africano, é desfeita. Entre 1629 e 1630, cresceram as reclamações e descontentamentos contra Angola Aire, que cada vez mais se recusava a pagar os baculamentos, pouco fazia para engrandecer o comércio de escravos e se mostrava pouco propenso em empunhar armas contra os inimigos da Coroa portuguesa, sendo a principal delas Ginga Ambande. No final de contas, ele não era o "fantoche" que se esperava. Protegido e concentrando recursos nos penedos naturais de Pungo Andongo, o novo ngola arquitetava algum tipo de manobra política, que envolvia uma maior articulação entre as províncias de Are e Lembo, inquietando com isso Paio de Araújo de Azevedo e Fernão de Sousa. Quiçá, a fim de aplacar a contrarreação do soberano mbundu, ou divergir o olhar avaliador que tão logo recairia sobre ele após o regresso a Lisboa, que o recriminaria e puniria assim que a farsa fosse descoberta, com isso manchando o nome de sua família, ${ }^{561}$ Fernão de Sousa empreendeu a "construção de ilegitimidade" de Angola Aire. No final das contas, esse é um vestígio escrito que atesta para o engenho pessoal de Fernão de Sousa, à luz do direito português e da gramática política da época, ao passo que menos relevante como um atestado sobre as normas políticas e jurídicas aceitas no Ndongo. ${ }^{562}$

\subsection{Justiça e as elites em Massangano e Muxima}

No ano de 1629, em meio às diligências extrajudiciais encarregadas a António Nunes Leitão, foram registrados três mucanos em andamento em Massangano. Dois deles

\footnotetext{
${ }^{561}$ Sobre o malogro da "conquista do Ndongo", verificar: HEINTZE, Beatrix. Angola nos séculos XVI e XVII [...]. Luanda: Kilombelombe, 2007, p. 383.

${ }_{562}$ Reafirmando nossas as considerações feitas no capítulo 2 desta dissertação.
} 
haviam sido trazidos por um homem preto chamado "Tumba", a respeito de um indivíduo igualmente preto de nome "Capopo". Pelo contexto, é possível sugerir que Capopo era um intermediário ou negociante de escravos, quiçá pombeiro ou quimbar, ${ }^{563}$ havendo também a possibilidade dele ter sido um guenze. ${ }^{564}$ Como decorrência do papel mercantil desempenhado por esse homem e graças ao contato que mantinha com a gente de Massangano, também é possível dizer que Capopo entendia português e que detinha o conhecimento técnico para efetuar o comércio de escravos, como contar e avaliar o valor de peças e panos. Naturalmente ele figurava como uma via de mão-dupla de influência cultural, transitando entre os mundos africano e português, com a ressalva de que preservava o nome africano e, por consequência, possivelmente mantinha uma identidade local mais forte, caso contrário teria adotado um nome completo, ou parcialmente composto, com denominações portuguesas, como tantos outros luso-africanos fizeram.

Seja como for, o primeiro mucano que apresentaremos neste item teve início porque dois homens, "Gola" e "Caquende", após serem vendidos por Capopo a um indivíduo chamado Manoel Castanho, reivindicaram ser "forros da murinda de Gonga Aquitulo". 565 Em primeiro lugar, cogitamos que Manoel Castanho poderia ser um pequeno proprietário de escravos ou pombeiro. Em segundo lugar, e isso para a nossa análise é mais relevante, é preciso der cautela com a expressão "forros de murinda". Segundo Beatrix Heintze, "murinda" era uma designação usada "em contraste com os escravos, [ou] quizicos", sendo assim a "população livre do Ndongo". 566 No português brasileiro contemporâneo, o sentido lato para "forro" é de "liberto" ou "alforriado", possivelmente não se distanciando da acepção seiscentista corrente, pois no Voc. port. de Raphael Bluteau (1638-1734) há o registro de que "escravo forro" era aquele que o "seu próprio senhor dava liberdade". 567

\footnotetext{
${ }^{563}$ Fernão de Sousa. Instrução de Fernão de Sousa a António Nunes Leitão. 11 de junho de 1629. BAL, cód. 51- IX-21, ff. 174-77v. IN: HEINTZE, Beatrix (coord.). Documento 199, FHA, vol. II, 1988, p. 297.

${ }^{564}$ Ressaltando que, mediante o primeiro cenário, Capopo atuaria na carreira Luanda-feiras. No segundo cenário, a atuação ocorreria no sentido feiras-interior.

${ }^{565}$ Fernão de Sousa. Instrução de Fernão de Sousa a António Nunes Leitão. 11 de junho de 1629. BAL, cód. 51- IX-21, ff. 174-77v. IN: HEINTZE, Beatrix (coord.). Documento 199, FHA, vol. II, 1988, p. 297.

${ }^{566}$ Heintze ainda acrescenta que a palavra podia ser grafada como morinda. Verificar: HEINTZE, Beatrix (coord.). Esclarecimentos sobre vocábulos africanos, FHA, vol. I, 1985, p. 123. Para mais informações sobre esse termo, consultar o consultar o "suplemento para alguns vocábulos africanos", disponibilizado nesta dissertação.

567 BLUTEAU, Raphael. Voc. Port. [1713]. Hildesheim: Georg Olms Verlag, vol. IV, 2002, verificar especificamente a entrada para "forro" na p. 182. Nas palavras de Silvia Hunold Lara, o frade Raphael Bluteau era um "grande filólogo" de cultura enciclopédica que "participava ativamente das tertúlias
} 
Ora, os "forros" citados por Fernão de Sousa não poderiam ser "libertos", pelo menos não no sentido de terem conquistado a liberdade após serem escravizados, uma vez que, segundo a ótica africana, as noções de "liberdade" e "escravidão" estavam relacionadas ao sentimento de pertencimento às "murindas" ou aos "quizicos" que, por sua vez, mantinham íntima ligação com a condição de nascimento. Condições, pertencimentos e papéis sociais eram representados pela divisão "murinda" e "quizico", passando ao largo das ideias de “isenção de impostos”, “autodeterminação", "aquisição de alforria” e outras noções comuns à Península Ibérica. Conhecedor das discrepâncias existentes entre as noções de escravidão e liberdade existentes entre centro-africanos e peninsulares, ao propor uma tradução por escrito das condições sociais de Gola e Caquende, Fernão de Sousa optou por uma simplificação da condição africana de liberdade, aproximando-a da ideia genérica de "forro". Mas por que "forro" e não "livre"? Conforme o pensamento padrão da época, evidentemente em descompasso com a realidade social endógena, a condição de murinda confirmava um "estado de exceção" entre os mbundu, ficando subentendido que, entre essas populações locais, a escravidão era "generalizável”, como se todos os mbundu da região fossem escravos "por natureza", com a exceção de poucos indivíduos, entre eles os "murindas", "sobas", "macotas" e "reis". 568 Tratava-se não apenas de um discurso legitimador da escravização africana, portanto tangencialmente baseado nos usos e costumes dos "gentis", mas também de uma ideologia abertamente escravista, voltada à apreensão de saberes autóctones que corroborassem para a construção de conhecimentos sobre a realidade observada, no final das contas úteis para a justificação, em bases legais,

intelectuais na casa dos Ericeira no final do século XVII e início do XVIII". Verificar: LARA, Silvia Hunold. Fragmentos setecentistas: escravidão, cultura e poder na América portuguesa. São Paulo: Companhia das Letras, 2007, nota 1, pp. 293-294. Sobre as poucas e sumárias informações disponíveis sobre a África no Voc. Port. de Bluteau, em sensível disparate em relação à América portuguesa, verificar as pp. 233-234. Sobre o papel importante da casa dos Ericeira em relação a uma tradição ilustrada em Portugal, verificar: SANTOS, Catarina Madeira. Um governo "polido" para Angola [...]. Tese de doutorado, Universidade Nova de Lisboa, 2005, p. 284, p. 31.

${ }_{568}$ Constatação parecida, não necessariamente verdadeira, foi feita em 1576 pelo padre Garcia Simões, conforme explica David Birmingham: "O padre Simões disse, por exemplo, que quase todos os habitantes do Ndongo pareciam ser escravos do rei [do Ndongo] e que uma forma corrente de punição por crimes, como os de roubo ou adultério, era ser vendido para os portugueses" (no original: "Father Simões said, for instance, that nearly all the inhabitants of Ndongo appeared to be slaves of the king and that the usual form of punishment for crime such as robbery or adultery was to be sold to the Portuguese [...]."). BIRMINGHAM, David. Trade and conflict in Angola [...]. Londres: Clarendon Press/ Oxford University Press, 1966, p. 50. 
do comércio atlântico de pessoas. ${ }^{569}$ Dito de outra forma, o procedimento de tradução não era apenas simplificador e baseado em termos aproximados de transposição de sentidos, mas subjacente a ele havia uma gama de ideias que enviesavam a escolha de termos traduzíveis, como também determinavam as simplificações e aproximações passíveis de serem normatizadas, na procura da legitimação jurídica de atos oficias ou na busca por autocomprovação de medidas tomadas no âmbito institucional. ${ }^{570}$

Ajustando a clave de análise aos nossos interesses, havia certamente um conflito entre concepções de escravidão na execução de mucanos, mas isso não impedia que diferentes ideias de liberdade e cativeiro fossem manejadas e imbricadas entre si, em prol da legitimação dos mucanos. O ponto vital de nossa argumentação é que os registros de alguns elementos africanos, ou simplesmente "vocábulos" e conceitos, na FHA implicavam em distorções e deturpações. No caso de Gola e Caquende, o que estava em jogo era a criação de uma cadeia relacional de acepções sobrepostas - "forro-livre-murinda" - que, mediante a realidade observada por um administrador português, versado nos termos políticos e jurídicos do início da Idade Moderna e recém-familiarizado com o mundo

569 Sobre a escravidão como algo "institucionalizado" entre os mbundu, destinada a grupos subalternos e específicas de pessoas, que desempenhavam regimes de trabalhos "equiparados" pelos europeus à escravidão, verificar: HEINTZE, Beatrix. Angola nos séculos XVI e XVII [...]. Luanda: Kilombelombe, 2007, pp. 479-480 e 481-482. Sobre como a busca por legitimação influenciava na detecção de "escravidão", verificar a mesma obra, p. 419. Sobre a chamada "estratificação social mbundu", ou como preferimos "hierarquia social", verificar o capítulo 6, especialmente as pp. 205-206, e o capítulo 11, especificamente as pp. 484-485. Sobre a relevância das questões legais durante a expansão ultramarina portuguesa, proposta inicialmente para $o$ contexto americano, mas que acreditamos valer também para a Angola portuguesa, na forma de uma "síntese teológico-jurídica" que permeava uma "política católica da monarquia portuguesa", verificar: ZERON, Carlos Alberto de Moura Ribeiro. A ocidente do ocidente [...]. Revista de História (USP). São Paulo: Universidade de São Paulo, n. 170, janeiro/junho, 2014, pp. 80-81, 83 e 89. Idem, Linha de fé: a Companhia de Jesus e a Escravidão no Processo de Formação da Sociedade Colonial (Brasil, Séculos XVI e XVII). São Paulo: Editora da Universidade de São Paulo, 2011, pp. 36, 39 e 226. Idem, A construção de uma ordem colonial nas margens americanas do Império português [...]. Universidade de São Paulo, 2009, pp. 27-28 e pp. 73-74. Idem, Interpretações das relações entre cura animarum e potestas indirecta no mundo luso-americano. Clio: Revista de Pesquisa Histórica. Recife: Universidade Federal de Pernambuco (UFPE), n. ${ }^{\circ} 27-1,2009$, p. 150.

${ }^{570}$ Destacado que, a despeito de "Fernão de Sousa seguir com o rigor a ordem da Coroa em não empregar expressões africanas na correspondência oficial sem a correspondente tradução portuguesa", como lembra Heintze, fica claro que as traduções e interpretações propostas eram frequentemente simplistas e enviesadas, conquanto úteis e importantes às autoridades reinóis e aos historiadores. Verificar: HEINTZE, Beatrix (coord.). A Colectânea Documental de Fernão de Sousa, FHA, vol. I, 1985, p. 57. Sobre os perigos que a utilização de traduções contemporâneas acobertam, verificar: Idem, Translations as Sources for African History. History in Africa. Nova Jersey: African Studies Association, vol. 11, 1984. Mais considerações a respeito das traduções e interpretações existentes nas fontes escritas serão feitas na conclusão desta dissertação. 
atlântico, ${ }^{571}$ processava as informações jurídicas com o intuito de utilizá-las como argumentos legalmente aceitos nos pleitos e contendas, movidos tanto nos presídios, quanto em inquéritos feitos em Portugal. Assim, na prática, o manuseio de acepções distintas só obtinha êxito porque a sobreposição "forro-livre-murinda" estava respaldada na possibilidade de legitimação do cativeiro de alguns indivíduos pretos, por um lado, e na viabilização da comunicação formal entre o governador, capitães e sobas locais, por outro lado. Em suma, era preciso encontrar argumentos legais respaldados no denominado "direito das gentes", portanto sob a pretensa forma de uma "justiça gentílica", fundada na identificação de "leis gentílicas" que pudessem ser incorporadas, ou reutilizadas, dentro de uma esfera jurídica defendida por Luanda. ${ }^{572}$ Afinal de contas, a própria definição de "gentil" não se dava ao esmo, já que vinha acompanhada implicitamente de contrastes associados a outros termos comuns ao léxico quinhentista e seiscentista, como "infiel” e "vassalo". ${ }^{573}$ Para cada uma dessas designações era destinada uma forma de tratamento, e

${ }^{571}$ Levantando a temática da formação de um "mundo atlântico", a partir da década de 80 os estudos africanistas foram fortemente influenciados pela historiografia francesa, nomeadamente pelos trabalhos de Fernand Braudel, Frédéric Mauro e Pierre e Huguette Chaunu. Seguindo as últimas tendências, aqui encaramos que o desenvolvimento do "mundo atlântico" foi um dos propulsores para a progressão da globalização e avanço do pré-capitalista às demais partes do globo. Sobre a influência da historiografia francesa nesse pensamento, verificar: HAVIK, Philip J.; GREEN, Tobias. Introduction: Brokerage and the Role of Western Africa in the Atlantic World. IN: GREEN, Tobias (ed.). Brokers of Change: Atlantic Commerce and Cultures in Precolonial Western Africa. Oxford: The British Academy/ Oxford University Press, 2012, pp. 1 e 6. THORNTON, John K. Africa and Africans in the Making of the Atlantic World [...]. [1992]. Cambridge: Cambridge University Press, 1998, pp. 13-14 e 17. Sobre formas diversas de abordar esses temas, verificar: CURTIN, Philip D. Economic Change in Precolonial Africa [...]. Wisconsin: University of Wisconsin, 1975, vol. I, pp. 64-65, 165-166, 325 e 342. CURTIN, Philip D. et. al. African History: From Earliest Times to Independence. [1978]. Edimburgo: Longman Pearson Education, 1995, pp. 152-153, 164-165, 242. HAVIK, Philip J.; GREEN, Tobias. Introduction [...]. GREEN, Tobias (ed.). Brokers of Change [...]. Oxford: The British Academy/ Oxford University Press, 2012, pp. 1, 24-26. MILLER, Joseph C. Way of Death: Merchant Capitalism and the Angolan Slave Trade, 1730-1830. Madison: The University of Wisconsin Press, 1988, pp. xvi-xvii e xx-xxi. Sobre uma perspectiva nova e interessante de abordagem sobre esse assunto, consultar a seguinte obra: THORNTON, John K. A Cultural History of the Atlantic World [...]. Cambridge: Cambridge University Press, 2012.

${ }^{572} \mathrm{O}$ entendimento seiscentista era o de que algumas "legitimações", entre elas a de título e exame de escravidão, poderiam ser extraídas a partir do chamado "direito das gentes", que simplificando bastante se traduzia na validação jurídica dos chamados "usos e costumes" de povos tradicionais, perante o direito canônico. Dito de outra forma, o direito das gentes era aceito como argumento jurídico pelas instituições judiciárias, subsumido ao direito natural. Por excelência, portanto, o direito das gentes fazia parte do direito natural. Sobre isso, verificar: ZERON, Carlos Alberto de Moura Ribeiro. Linha de fé [...]. São Paulo: Editora da Universidade de São Paulo, 2011, pp. 221, 226-227 (principalmente a nota 63) e 387. Para as chamadas "questões gentílicas" na Angola portuguesa, mediante as quais "gentílicos" seriam indivíduos africanos que não eram avassalados à Coroa de Portugal, verificar: FERREIRA, Roquinaldo. Cross-Cultural Exchange in the Atlantic World [...]. Cambridge: Cambridge University Press, 2012, p. 106.

573 Isso sem contar na questão dos "gentílicos", ou seja, portugueses nascidos ou enraizados na terra, conforme a acepção mais usual na documentação utilizada. Todavia, é bem verdade que a classificação em 
isso vazia toda a diferença: contra o infiel a guerra e os castigos eram soluções autoexplicativas, ao passado que contra gentios e vassalos era necessário examinar as justiças de guerra. No mais, mesmo que os procedimentos de tradução e o processamento de informações perpetuassem uma validade dialógica dos elementos incorporados, tanto perante a justiça existente nos presídios, quanto perante as estruturas endógenas do "direito africano", conforme os termos de Catarina Madeira Santos, ${ }^{574}$ no âmbito da justiça aplicada a incorporação figurava como uma importante operação de intermediação, capaz de favorecer os grupos sociopolíticos que tivessem acesso a ela e estivessem dispostos a manejá-la. Por essa razão, é necessário prestar atenção aos aspectos políticos e sociais que permeavam as vicissitudes da incorporação de elementos africanos.

Prosseguindo com o caso do mucano movido em Massangano, para que a análise do litígio jurídico fosse procedida, Fernão de Sousa determinou que um macota do "soba Quiloange Candalo Camba", sobre o qual nada mais é informado, fosse chamado ao encontro das autoridades portuguesas, a fim de justificar por que Caquende fora "dado" a Capopo, ainda na época em que o governador de Angola era Luís Mendes de Vasconcelo, entre 1617 a $1621 .^{575}$ Depreendemos desse curto trecho que, ao longo de sua trajetória como escravo, primeiro Caquende passara pelas mãos de Quiloange Candalo Camba, para depois acabar com Capopo. As transferências de Caquende poderiam ter ocorrido em razão de diversos cenários, não necessariamente isolados entre si: litígio político, punição judicial, pagamento de tributo, penhora, venda por falta de mantimentos básicos, comutação, butim de guerra, banditismo, abdução por ciladas montadas em estradas, rapto

estatutos com diferenças e reciprocidades entre si - "gentil”, "gentílico", "mouro", "infiel”, entre outros - era matéria controversa, bem como era problemático o emprego de nomenclaturas ligadas à cor da pele e aos sentimentos de pertencimento. Seja como for, esse conjunto de termos e conceitos tinha grande importância no que dizia respeito à busca por legitimação. Por exemplo, como explica Heintze: "os portugueses que vendiam armas aos africanos, bem como os seus defensores, procuravam justificar-se com argumentos de que a coroa tinha apenas proibido a venda de armas aos 'mouros', mas não aos 'gentios' [...]". Verificar: HEINTZE, Beatrix. Angola nos séculos XVI e XVII [...]. Luanda: Kilombelombe, 2007, nota 11, p. 280.

${ }^{574}$ Nos termos dessa pesquisadora, o cerne da questão derivaria, em primeira instância, da necessidade de compreender as "matrizes de organização política e social" relacionadas ao "modelo social português do Antigo Regime", por um lado e, por outro lado, "às estruturas africanas endógenas". Verificar: SANTOS, Catarina Madeira. Entre deux droits: les Lumières en Angola (1750-v. 1800). Annales. Histoire, Sciences Sociales. Paris: Éditions de l'EHESS, n. ${ }^{\circ}$ 60, 2005/4, p. 818. Idem, Administrative knowledge in a colonial context: Angola in the eighteenth century. The British Journal for the History of Science (BJHS), vol. 43, dezembro de 2010, p. 540.

${ }^{575}$ Fernão de Sousa. Instrução de Fernão de Sousa a António Nunes Leitão. 11 de junho de 1629. BAL, cód. 51- IX-21, ff. 174-77v. IN: HEINTZE, Beatrix (coord.). Documento 199, FHA, vol. II, 1988, p. 297. Sobre o governo de Luís Mendes de Vasconcelos, verificar: HEINTZE, Beatrix (coord.). Apêndice: governadores de Angola, 1575 - 1639, FHA, vol. I, 1985, p. 393. 
por saque a aldeias, penhora e outros cenários. ${ }^{576} \mathrm{Em}$ última instância, o litígio estava "emperrado" em Massangano devido à dificuldade de examinar os títulos de escravidão adquiridos em situações históricas determinadas, ligadas ao processo de conquista do Ndongo, não somente às discussões sobre justiça e proveniência.

Como inicialmente ressaltado, Capopo estava metido não em um, mas dois mucanos. O segundo deles fora movido por "Cristovão Gunga Ambundo", que afirmava que o Capopo era "peça sua e que lhe pertence tudo o que tiver de seu". Por conselho de Diogo Mendes, o intérprete que fizera as traduções no ato de recolha das informações, Fernão de Sousa determinou que os testemunhos orais, comuns aos "mucanos", fossem feitos por "intérpretes desinteressados". 577 O governador acrescentou que, caso não pudessem ser resolvidos em Massangano, os mucanos de Capopo seriam transferidos a Cambambe, onde inicialmente o capitão Francisco de Vilória Pinto tentara solucioná-los, não obtendo êxito. ${ }^{578}$ Apesar de o registro escrito não fornecer mais informações sobre Cristovão Gunga Ambundo, é possível inferir que esse homem era um homem dotado de

\footnotetext{
576 Muitos desses cenários são muitas vezes hipotéticos ou de comprovação problemática, embora as modalidades de aquisição de peças por parte da administração ultramarina sejam muito mais conhecidas. Suscitamos aqui a longa clássica discussão sobre as formas de obtenção de escravos e os modelos das guerras africanas. Para interessantes considerações sobre o debate, conferir: THORNTON, John K. Africa and Africans in the Making of the Atlantic World [...]. [1992]. Cambridge: Cambridge University Press, 1998, pp. 83-84 e pp. 100-102. Sucintamente, Thornton é contrário à teoria do "subdesenvolvimento africano", de Walter Rodney, e por consequência crítico ao modelo do "transformismo", de Paul E. Lovejoy. Também é cético quanto à abordagem voltada aos "ciclos armas-cavalos-escravos", já defendida por Roquinaldo Ferreira. Sobre a teoria do "subdesenvolvimento africano", verificar: RODNEY, Walter. How Europe Underdeveloped Africa. [1972]. Oxford: Pambazuka Press, 2012, pp. xi, xvii e 27-28. Sobre o "transformismo", verificar: LOVEJOY, Paul E. A escravidão na África: uma história de suas transformações. [1983]. Rio de Janeiro: Civilização Brasileira, 2002, pp. 20-21. Sobre os "ciclos armas-cavalos-escravos", verificar: FERREIRA, Roquinaldo. The Supply and Deployment of Horses in Angolan Warfare (17th and 18th centuries). IN: HEINTZE, Beatrix; OPPEN, Achim von (ed.). Angola on the Move [...]. Frankfurt am Main: Verlag Otto Lembeck, 2008, pp. 41-42, 50. THORNTON, John K. Africa and Africans in the Making of the Atlantic World [...]. [1992]. Cambridge: Cambridge University Press, 1998, pp. 98-99, 100, 102 e 105106. Sobre as formas mais comuns de aquisição de escravos, o atual consenso é o de que a maioria dos escravos transportados via Atlântico eram provenientes de guerras interafricanas, levados a cabo por causa de conflitos políticos entre os vários "estados africanos" do continente. Assim sendo, a "escravização militar" era altamente aceita na África como um todo, sendo os estados beligerantes incapazes de manter uma "ordem" local ou regional, sendo coniventes com o comércio indiscriminado de pessoas. Verificar: THORNTON, John K. A Cultural History of the Atlantic World [...]. Cambridge: Cambridge University Press, 2012, pp. 65-67, 74 e 86.

${ }^{577}$ Informação análoga foi fornecida em: FERREIRA, Roquinaldo. Cross-Cultural Exchange in the Atlantic World [...]. Cambridge: Cambridge University Press, 2012, pp. 112-113.

${ }^{578}$ Fernão de Sousa. Instrução de Fernão de Sousa a António Nunes Leitão. 11 de junho de 1629. BAL, cód. 51- IX-21, ff. 174-77v. IN: HEINTZE, Beatrix (coord.). Documento 199, FHA, vol. II, 1988, p. 297.
} 
identidade dupla, ${ }^{579}$ dado a miscelânea de elementos que compunha seu nome, misturando vocábulos africanos a um nome português. Outro ponto importante é de que, se Cristovão Gunga Ambundo movera um mucano para reivindicar a posse de Capopo, então provavelmente ele era um homem de posses em Massangano. Isso é possível de ser deduzido porque, como veremos mais para frente, a chamada "justiça gentílica" era na prática inacessível à arraia-miúda. Cristovão Gunga Ambundo poderia ser um pequeno dono de terras ou, o que era mais provável, um negociante de escravos, posto que a atividade de maior lucro econômico nos presídios tendia a ser o comércio de peças.

O terceiro mucano era o de "Ango Aquicaito" e se referia às vacas de Diogo Teixeira Fonseca. A narrativa é um pouco conturbada, mas tudo parece ter acontecido da seguinte forma. No passado, aconteceu que o português Diogo Teixeira da Fonseca dera ao soba Ango Aquicaito cem vacas "para guardar", ou seja, para que ele tomasse conta delas por um tempo. Quando o português foi pegar de volta as vacas, o soba entregara a ele apenas sessenta delas vivas, sendo que o restante havia morrido. Diogo Teixeira da Fonseca então se queixou a Baltazar Fernandes Reinol, "capitão que foi de Cambambe", que por sua vez favoreceu Ango Aquicaito, determinando que o soba não devia nada ao português. O tempo passou e Diogo Teixeira faleceu. Sua mulher, então viúva, casou-se com João da Costa Leal. Este "não teve pelo julgado" do caso, tomando de "Ango Aquicaito um negro que tem em seu poder", ou seja, que acabou aprisionado, mandando alguns de seus

\footnotetext{
${ }^{579}$ Nossa influência direta são as ideias acerca do surgimento de adaptações, identidades e multiplicidade, desenvolvidas por uma série de pesquisadores como Peter Mark e Georg E. Brooks, a princípio na África Ocidental. Atualmente, o historiador de maior destaque, participante dessa linha de pesquisa, talvez seja Tobias Green. As principais ideias levantadas por eles estão refletidas na seguinte assertiva, cunhada especificamente a respeito dos cristãos-novos na África Ocidental: “[...] como uma cultura adaptativa, os judeus eram capazes de adaptar; e criptojudeus, possuindo alguns aspectos diferentes de identidade, estavam aptos a fundir esse hibridismo em um espaço cultural onde atributos culturais necessitavam ser híbridos" (tradução nossa). GREEN, Tobias. Masters of Difference: Creolization and the Jewish presence in Cabo Verde, 1497-1672. Tese de doutorado, Universidade de Birmingham, 2007, pp. 336-337 ("As an adaptive culture, Jews were able to adapt; and crypto-Jews, possessing several different aspects of identity, were able to fuse this hybridity into a space where cultural attributes needed to be hybrid"). Para os principais argumentos levantados por esse pesquisador, conferir também as pp. 28-29, 63 e 83. Consultar ainda: MARK, Peter. "Portuguese" style and Luso-African identity: precolonial Senegambia, sixteenth-nineteenth centuries. Blooming \& Indianapolis: Indiana University Press. 2002. BROOKS, George E. Eurafricans in the Western Africa: Commerce, Social Status, Gender, and Religious Observance from the Sixteenth to the Eighteenth Century. Athens: Ohio University Press/ Oxford: James Currey, 2003.
} 
escravos "dar na murinda do soba [,] sem ordem da justiça", forçando o africano a pagar as quarenta vacas que haviam morrido. ${ }^{580}$

No geral, os mucanos de Massangano compartilhavam algumas características em comum. O julgamento de ordem "gentílica" não aceitava o veredito de soberanos ou dignidades, como já frisamos no início deste capítulo, a não ser que ele fosse feito na presença de capitães de presídios ou juízes portugueses. Seus reivindicantes, ou pessoas que moviam os processos legais, deveriam estar inseridas no espaço jurisdicional representado por alguma autoridade reconhecida por Luanda. Os espaços de implementação da justiça eram qualquer ponto institucional português, mas como na prática a responsabilidade judicial tendia a residir nas mãos dos capitães de presídios, temos apenas registros sobre Massangano, Ambaca, Cambambe e Muxima. Sabemos também que os mucanos podiam ser julgados sem o aval do governador, por capitães inescrupulosos que os utilizavam como desculpa para surrupiar as riquezas dos sobas, além de figurar como um subterfúgio para não declará-las ao fisco régio, desorganizando e "corrompendo" o ordenamento das coisas institucionais e legais, como ocorreu no caso de Henrique de Magalhães.

Outro aspecto importante dos mucanos dizia respeito às pessoas neles envolvidas. Seja réu, acusador ou oficial, essas pessoas tinham algum tipo de conhecimento, em maior ou menor grau, sobre a vida e o cotidiano dos mbundu. Figuras como o reivindicante Cristovão Gunga Ambundo e o intérprete Diogo Mendes são exemplos de como homens africanos, ou versados na cultura africana e conhecedores do cotidiano local, podiam transitar entre mundos distintos. Essas pessoas desempenhavam papéis de via de mãodupla, como tantos outros homens citados na $F H A$, os tais "agentes de intermediação", como Domingos Pires, António de Andrade, Marcos Pires e Manuel Ferreira Arco. Todavia, jazia em Cristovão Gunga Ambundo uma ressalva importante: a figura desse indivíduo é o exemplo mais claro de luso-africano, dotado de identidade dual, que alcançara algum prestígio em Massangano de forma legítima. ${ }^{581}$ Seja como lavrador ou granjeador de terras, seja como negociante de peças, o cabedal de Cristovão Gunga Ambundo originava da exploração da escravidão ou do negócio negreiro, estando à

\footnotetext{
${ }^{580}$ Fernão de Sousa. Instrução de Fernão de Sousa a António Nunes Leitão. 11 de junho de 1629. BAL, cód. 51-IX-21, ff. 174-77v. IN: HEINTZE, Beatrix (coord.). Documento 199, FHA, vol. II, 1988, p. 297.

${ }^{581}$ Neste último ponto ele se diferenciava de Manuel Ferreira Arco, que enriquecera à custa de roubos e extorsões.
} 
margem das formas de prestígio locais, como o pertencimento às murindas ou adoção de algum título político africano, como os de soba, macota, tendala, mani lumbo, entre outros. O contraexemplo mais claro em relação a esse luso-africano é Capopo. Este não adotou um nome português e, até onde é possível cogitar, não enriqueceu e tampouco contou com o apoio de algum soba da região, quiçá porque era totalmente estranho às linhagens mbundu locais, clamando pertencimento e solidariedade a outro povo africano.

O peso da participação de grupos locais na execução de mucano fica mais claro por meio da análise de um último litígio registrado na instrução régia carregada por António Nunes Leitão. Ele dizia respeito ao inquérito sobre o caso de "um negro que matou outro [negro]", acorrido em Muxima. Essa questão jurídica ganhou destaque devido ao relato de um "forro" que apareceu em Luanda, fugido de alguma parte do interior. Segundo Fernão de Sousa, o forro dissera que havia sido intimado pelo assassinato de um "escravo", crime sobre o qual alegava ser inocente, "porque [o] obrigaram a pagá-lo sem ter culpa na morte”. Ao que tudo indica, o governador aceitou os argumentos do fugitivo, ordenando ao oficial encarregado das diligências que sentenciasse o veredito de que "não se proceda contra negro que matou outro [,] pagando [o capitão de Muxima] ${ }^{582}$ a valia dele a seu senhor", ${ }^{583}$

$\mathrm{O}$ caso do negro que matou outro negro ilustra a possibilidade de acionamento da justiça portuguesa por um "forro", possivelmente um "homem preto de murinda" e, assim sendo, livre de nascimento. Além disso, a sentença desse caso atesta para uma espécie de "excentricidade". Houve deferimento favorável tanto para forro, quanto para o senhor de escravos. No final das contas, o homem acusado seria absolvido e o senhor de escravos acabaria ressarcido pela morte do escravo. ${ }^{584}$ Também é interessante notar que no documento não há nenhuma indicação sobre o motivo que suscitou a morte de um dos "negros" citados no litígio. Sabemos apenas que a ação jurídica havia sido inicialmente

\footnotetext{
${ }^{582}$ Seguindo a suposição de Beatrix Heintze, achamos que Henrique Teles de Melo era capitão de Muxima na época. Verificar a nota 103 de Heintze para: Fernão de Sousa. Instrução de Fernão de Sousa a António Nunes Leitão. 11 de junho de 1629. BAL, cód. 51-IX-21, ff. 174-77v. IN: HEINTZE, Beatrix (coord.). Documento 199, FHA, vol. II, 1988, p. 296. Consultar: HEINTZE, Beatrix. Tabela 6: Os capitães nos presídios de Angola nos anos de 1624-1630, FHA, vol. I, 1985, p. 70.

${ }^{583}$ Fernão de Sousa. Instrução de Fernão de Sousa a António Nunes Leitão. 11 de junho de 1629. BAL, cód. 51-IX-21, ff. 174-77v. IN: HEINTZE, Beatrix (coord.). Documento 199, FHA, vol. II, 1988, p. 296. Sobre isso, Heintze pede na nota 106, desse mesmo documento, para consultar: Filipe III de Portugal. Carta régia a Fernão de Sousa. 7 de agosto de 1626. BAL, cód. 51- IX-20, f. 78. IN: HEINTZE, Beatrix (coord.). Documento 17, FHA, vol. II, 1988, p. 57.

${ }^{584}$ Fernão de Sousa. Instrução de Fernão de Sousa a António Nunes Leitão. 11 de junho de 1629. BAL, cód. 51-IX-21, ff. 174-77v. IN: HEINTZE, Beatrix (coord.). Documento 199, FHA, vol. II, 1988, p. 296.
} 
movida por um forro fugitivo vindo do interior, acusado formalmente pela morte de um homem de coloração preta e que era “escravo". Quem era o acusador? Teria sido feito mucano sobre isso? Na fonte escrita não ocorre o registro dessas informações. A narrativa apenas sugere que se tratava de um caso de "justiça de mucanos", uma vez que e os demais casos jurídicos descriminados no documento são tratados como tal.

$\mathrm{O}$ fato de o forro ter que fugir e apelar ao governador por sua inocência é um indício relevante. Se dermos razão ao forro, considerando que ele fora injustamente indiciado, podemos também assumir que a acusação legal visava conseguir o ressarcimento financeiro pela morte de um escravo, cuja causa do falecimento não sabemos qual foi, mas que no final das contas pouco importa para o desfecho do litígio. Fato é que o escravo morreu e o indivíduo forro recebera a culpa injustamente por isso. A análise com cautela desse caso legal, ou mucano, escancara que a lei poderia ser manuseada em benefício de pessoas mais "abonadas" da terra, logicamente senhores de escravos ou negociantes, não necessariamente responsáveis por ofício régios, prejudicando assim a arraia-miúda, composta por pretos livres de nascimento e moradores brancos pobres, detentora de aportes culturais mistos e interessada no tráfico atlântico. De todo modo, novas elites locais poderiam ser representadas por homens como Cristovão Gunga Ambundo, em Massangano, e Manoel Ferreira Arco, em Ambaca. Ainda que de forma tímida, eles são exemplos de como grupos locais faziam uso do espaço jurisdicional para solucionar tensões sociais e embates políticos, acirrados evidentemente por causa de guerras e pela caça aos escravos.

O crescimento das contendas que giravam em torno da escravidão atlântica explica, por exemplo, porque Fernão de Sousa ordenou António Nunes Leitão a fazer "diligência de quem toma por dívidas escravos sem ordem da justiça[,] fazendo cárcere privado que se entenda em todos os presídios", penalizando os infratores com a abertura de processos legais. ${ }^{585}$ Com certeza, entre 1629 e 1630, em todos os presídios os sobas ainda eram coagidos a ceder "peças" em nome das mais diversas razões - mucanos, liberações, dívidas, entre outras - e os infratores eram normalmente acobertados pelos capitães e funcionários régios que nessas localidades prestavam serviço, possivelmente por lucrarem também com as práticas desonestas. A assunção de que a execução de mucanos, ou acusações legais

\footnotetext{
${ }^{585}$ Fernão de Sousa. Instrução de Fernão de Sousa a António Nunes Leitão. 11 de junho de 1629. BAL, cód. 51-IX-21, ff. 174-77v. IN: HEINTZE, Beatrix (coord.). Documento 199, FHA, vol. II, 1988, p. 297.
} 
feitas localmente em nome da lei gentílica, pudessem ser movidas de acordo com algum interesse financeiro, admite a possibilidade de que a justiça de mucanos podia ser "instrumentalizada" para a obtenção de indenizações e compensações financeiras. Os órgãos institucionais não eram operados necessariamente em prol da busca pela justiça comunitária, ou somente em nome do "bem comum", outro termo presente na documentação, mas sim como reflexo de novas prerrogativas hierárquicas, não necessariamente ligadas às formas de prestígio importadas do reino de Portugal ou típicas dos mbundu. Na prática, uma vez em andamento, a justiça dos mucanos era normalmente operada em prol de interesses ligados ao comércio de escravos via Oceano Atlântico.

\subsection{Espaço jurisdicional, paz e harmonia}

O processo histórico que marcou o governo de Fernão de Sousa pode ser dividido em duas fases. Entre 1624 a 1628, ocorreu um avanço da expansão institucional rumo ao Ndongo, culminando na remontagem de uma cúpula administrativa e judiciária em Pungo Andongo. Em consonância com isso, ocorreu o despacho de diversas ordens e medidas, todas elas visando fortalecer os mecanismos de vigilância e fiscalização nos arredores dos entrepostos avançados de apoio institucional espalhados pelo interior, divididos sucintamente entre presídios, feiras ou banzas. Cabe notar que essas localidades figuravam como espécies de "limites" reivindicados e imaginados ${ }^{587}$ pelo funcionalismo régio e pela monarquia como "arraias", termo normalmente empregado nos documentos inseridos na $F H A .{ }^{588}$ Mal concluída essa

\footnotetext{
${ }^{586}$ Abdicamos aqui da palavra "fronteira" por acreditar que ela pode conotar um sentido muito rijo de "linha" geopolítica e fronteiriça, estática e de convenção geral. Isso não fazia sentido nem no reino de Portugal, nem entre os mbundu, pois de acordo com Heintze, "tal como para o Kongo, também para os Mbundu o Estado não assentava prioritariamente num território rigorosamente delimitado, mas sim nas pessoas". Verificar: HEINTZE, Beatrix. Angola nos séculos XVI e XVII [...]. Luanda: Kilombelombe, 2007, pp. 182-183. Verificar ainda as críticas de Benedict Anderson, principalmente o conceito de "comunidade imaginada", em: ANDERSON, Benedict. Imagined Communities. Reflection on the origin and spread of Nationalism. [1983]. Nova Iorque e Londres: Verso, 1991, p. 6.

${ }^{587}$ No sentido empregado por Edward W. Said, principalmente no que diz respeito aos conceitos de criação de diversas imagens imperialistas sobre os povos subjugados, no caso generalizado do chamado "Oriente". Verificar: SAID, Edward W. Orientalismo: O Oriente como invenção do Ocidente. [1978]. São Paulo: Companhia das Letras, pp. 40-41 e 52. Sobre a visão de "si" e do "outro" como "espaços de familiaridade", verificar a mesma obra, p. 91. Sobre as imagens da "barbárie" locais, "intimamente atada à mundanidade, isto é, ao poder, posição e interesses" dos invasores, verificar: Idem. Humanismo e crítica democrática. [2003]. São Paulo: Companhia das Letras, 2007, p. 71.

${ }_{588}$ Consultar a entrada para o vocábulo "bambe", no "suplemento para alguns vocábulos africanos", inserido nesta dissertação.
} 
primeira fase, insurgências e desmandos abalaram a chamada "paz" e o "bem comum", principalmente em Ambaca e no Ndongo. Eles durariam entre 1628 a 1630, ou seja, foram constantes até o final do mandato de Fernão de Sousa. Isso sem contar as guerras feitas contra Ginga Ambande e as investidas holandesas de 1624, sob os comandos de Philip van Zuylen e Piet Heyn, que eram matérias mais relevantes para Lisboa e Madri do que a organização dos presídios. Seja como for, além de mudanças, os seis anos de governo que aqui analisamos foram marcados também por permanências. Abaixo elencaremos algumas delas.

No final das contas, na queda de braço entre o direito português o os costumes locais, entre a jurisprudência régia e a justiça dos mucanos, a tendência era a de prevalecer os primeiros sobre os segundos, não porque o direito escrito e enraizado em Portugal fosse superior às formas de justiça locais e costumeiras, mas porque os entrepostos institucionais ultramarinos obtinham êxito em impor a ordem e mando de Luanda no interior. Para ser mais preciso, normalmente o que acontecia era a aplicação das normas escritas mediante o interesse de capitães e do governador, ou seja, a utilização de direitos e leis era pragmática. Além disso, os encarregados pela esfera jurídica absorviam alguns grupos sociopolíticos locais, africanos e luso-africanos, ao espaço jurisdicional, de modo que fossem transformados em agentes de intermediação necessários ao serviço ultramarino. Os mucanos e ações jurídicas movidos em Massangano, Muxima e Ambaca foram todos avaliados por capitães e pessoas influentes e, em nenhum dos casos aqui analisados, as populações mbundu foram plenamente beneficiadas pelas medidas legais. Isso quando não acabaram roubadas ou espoliadas, como a sindicância de 1629 chama a atenção. No geral, a justiça promovida pelo funcionalismo régio abarcava os sobas locais e suas gentes, absorvendo-os dentro de uma lógica que se apresentava como plural, mas que na prática era restrita a poucos. Não coincidentemente, na prática, apenas quem tinha acesso às leis, respaldo sociopolítico e preponderância para "ser ouvido" se beneficiava dos frutos da justiça. O restante era passível de ser marginalizado ou escravizado e, raramente, pleiteava por alguma causa na justiça dos mucanos. ${ }^{589}$

\footnotetext{
${ }^{589}$ Rigorosamente falando, havia um alto grau de descentralização da malha judiciária na Angola portuguesa, além de uma óbvia descontinuidade jurisdicional do espaço de mando e ordem reivindicado pelos oficiais e funcionários régios. Os primeiros passos para fortalecer e estender a jurisprudência de Luanda serão concretizados principalmente no século XVIII, com a instituição dos chamados "tribunais de mucanos" nessa
} 
Do ponto de vista da administração portuguesa, o ordenamento de um espaço jurisdicional pode ser encarado como uma forma menos desgastante de resolver os diversos conflitos locais - tensões sociais, atritos institucionais e embates políticos -, levando a cabo a montagem de um aparato administrativo regional, baseado em entrepostos avançados de apoio institucional, autogestores e locais, interconectados entre si e coordenados através da emissão de diretrizes de Luanda. Embora contasse com apoio de alguns sobas e de Pungo Andongo, o espaço jurisdicional da Angola portuguesa era um lugar privilegiado de ordem e mando do funcionalismo régio, onde mais ou menos vigorava os mecanismos de vigilância e fiscalização ultramarinos. Apesar de existir um domínio português, baseado em presídios e povoações, não havia hegemonia portuguesa, de tal forma que a dominação imposta aos mbundu não era extensiva ou avassaladora, mas vamos reafirmar "indireta", de maneira símile à empregada por Beatrix Heintze. ${ }^{590}$ Por mais que a ordem portuguesa estivesse restrita aos territórios descontínuos e pouco povoados que conformavam o sistema administrativo português, o domínio ultramarino existia e, através dele, milhares de africanos foram direcionados ao comércio atlântico, enriquecendo capitães, governadores e o físco régio, ao passo que a reiteração desses domínios atendia às demandas e às

cidade, onde doravante acabarão concentradas as competências e responsabilidades de avaliação e julgamento dos litígios que envolviam as partes africanas. Verificar: FERREIRA, Roquinaldo. Cross-Cultural Exchange in the Atlantic World [...]. Cambridge: Cambridge University Press, 2012, pp. 99-101 e 105. SANTOS, Catarina Madeira. Esclavage africain et traite atlantique confrontés: transactions langagières et juridiques (à propos du tribunal de mucanos dans l'Angola des XVIIe et XVIIIe siècles). Brésil(s). Paris: Éditions de la Maison des Sciences de l'Homme, n. ${ }^{\circ}$ 1, 2012, pp. 132-138. Cabe ressaltar que os impulsos iniciais em direção à verticalização dos afazeres judiciários a partir de Luanda foram inscritos pelo punho do nosso governador: Fernão de Sousa. Fernão de Sousa sobre os tributos de vassalagem em Angola. 7 de dezembro de 1631. BAL, cód. 51-IX-20, ff. 367, 370-71v. IN: HEINTZE, Beatrix (coord.). Documento 39, FHA, vol. I, 1985, pp. 379-382.

${ }^{590}$ Retomamos conceitos já introduzidos no capítulo 1 desta dissertação. Sucintamente, nas palavras de Heintze, no início do século XVII, "a política de conquista deveria ser abandonada a partir de então e a soberania portuguesa imposta apenas por meios pacíficos. O objectivo era o domínio indirecto apenas por meios pacíficos". Por outro lado, tal "domínio indireto" também estava baseado na "colaboração" de alguns sobas. Sobre as considerações de Heintze, verificar respectivamente: HEINTZE, Beatrix. Angola nos séculos XVI e XVII [...]. Luanda: Kilombelombe, 2007, pp. 280 e 438. Essa forma de imposição política, menos unilateral, mas efetiva, também foi abordada por Carlos Alberto de Moura Ribeiro Zeron no contexto das missões, descimentos e reduções da Companhia de Jesus na América portuguesa seiscentista, processo no qual também estava em voga um "projeto de tutela de toda a sociedade colonial", concatenado a uma "política indigenista". Verificar: ZERON, Carlos Alberto de Moura Ribeiro. Linha de fé [...]. São Paulo: Editora da Universidade de São Paulo, 2011, p. 40. Idem, A construção de uma ordem colonial nas margens americanas do Império português [...]. Universidade de São Paulo, 2009, p. 154. Voltaremos a tocar na questão da tutela, vassalagem e domínio no próximo capítulo. 
exigências de autoridades africanas, cada vez mais próximas e que procuravam benefícios advindos do tráfico atlântico. ${ }^{591}$

Além da absorção de agentes, a montagem desse aparato administrativo operou a incorporação de elementos africanos dentro do espaço jurisdicional ultramarino, não apenas através da adoção de um léxico jurídico em kimbundu, mas também na aplicação e prática cotidianas de uma justiça inteligível aos povos mbundu. A incorporação de elementos exógenos não se restringia apenas aos procedimentos de tradução ou processamento de informações, mas também contava com um alto grau de envolvimento de autoridades africanas, por exemplo através da cooperação de sobas do Ndongo e de Angola Aire. Os grandes beneficiados pela "justiça" e "paz”, porém, não eram eles. Quem ganhava com as operações de absorção de agentes e incorporação de elementos eram alguns grupos sociopolíticos locais, normalmente compostos por indivíduos experientes e enraizados na terra e que procuravam alguma forma de ascensão social nos molde da economia atlântica, além é claro do fisco régio, já que ambas as frentes corroboravam para a moldagem de um sistema administrativo misto, capaz de canalizar o máximo de escravos ao porto de Luanda.

Reafirmando algumas das considerações feitas nos capítulos iniciais desta dissertação, aqui é possível sustentar que na terceira fase de expansão e contato do reino de Portugal no Ndongo (1617-1630) ocorreu uma recalibração e uma remodelagem dos alicerces daquilo que identificamos como sendo uma inclinação histórica de Lisboa para uma "política de cooperação e parceria", só que implementada na Angola portuguesa a partir da experiência ultramarina, ou seja, em razão das adversidades e das condições sociopolíticas existentes na esfera regional. A partir 1607, o sistema administrativo e institucional da governadoria geral foi capaz de lidar com a coordenação dos "sobas vassalos" de uma maneira mais rígida, cuja gestão ficava concentrada nas mãos de funcionários e oficiais régios que serviam na cidade portuária de Luanda e nos entrepostos avançados de apoio institucional espalhados pelo interior, reformulando o antigo molde das instituições dos amos. A Angola portuguesa perpetuava com isso as bases históricas da cooperação e parceria luso-africanas, passando a coordenar os sobas vassalos em prol de

\footnotetext{
${ }^{591}$ Em consonância com: VANSINA, Jan. L'homme, les forêts et le passé en Afrique. Annales. Économies, Sociétés, Civilisations. Paris: Éditions de l'EHESS, ano 40º n. ${ }^{\circ}$ 6, 1985, pp. 1328-1329. SANTOS, Maria Emília Madeira. Nos caminhos de África [...]. Lisboa: Instituto de Investigação Científica Tropical, 1998, p. 267.
} 
interesses complementares entre ambas as partes. Paradoxalmente, o excessivo equilíbrio político propagado no palco político regional limitava o alcance de qualquer mobilização militar de relevo, algo que ficou comprovado no tempo de Luís Mendes de Vasconcelos. No governo de Fernão de Sousa, em movimento análogo ao ocorrido entre 1580-1590, o belicismo trouxe à tona o quão frágil era a sustentação política de Luanda, revestida por uma película de amenidade, mas que na prática era truculenta, gerando um turbilhão de confrontos e tensões, externos e internos, entre 1617-1621. ${ }^{592}$ Mesmo assim, um dos grandes feitos de Fernão de Sousa foi o de se valer de uma política histórica, baseada em quatro pontos fundamentais - cooperação, pareceria, coordenação e complementaridade para empreender uma grande operação militar em nome da "paz, justiça e bem comum" dos povos e do comércio, planejando e executando a chamada "conquista de Angola". Maquinação paradoxal e repleta de ambivalências, mas compreensível. Reinserindo o antigo no novo, realocando a paz na guerra em prol da "pacificação" da Angola portuguesa, Fernão de Sousa cumpriu as prescrições contidas no regimento entregue pela monarquia, sem deixar de atender as demandas dos diferentes grupos políticos que viviam no ultramar, assim zelando pela prosperidade material de todos os envolvidos no tráfico de escravos e prezando pela elevação de sua carreira institucional-política como um dos quadros administrativos de boa fama de Portugal. ${ }^{593}$

O processo de formação desse sistema envolveu contatos assimétricos. Por mais que ele jogasse com a coexistência e rearranjo de elementos políticos-jurídicos africanos e portugueses, como os trabalhos de Catarina Madeira Santos chamam a atenção, ${ }^{594}$ é razoável não perder de vista que o tráfico de escravos impactava diretamente no modo como a ordem e o mando eram implementados nessas regiões, uma vez que o tráfico era uma engrenagem de suma importância para o funcionamento do aparato administrativo ultramarino, conduzido e azeitado por agentes cada vez mais interessados no comércio atlântico. Por mais que Ginga Ambande tenha combatido bravamente o quilombo

\footnotetext{
${ }^{592}$ Como expostos nos capítulos 1 e 2 desta dissertação.

${ }^{593}$ Voltaremos a tocar nesse assunto no próximo capítulo.

594 SANTOS, Catarina Madeira. Entre deux droits [...]. Annales. Histoire, Sciences Sociales. Paris: Éditions de l'EHESS, n. ${ }^{\circ}$ 60, 2005/4, p. 826. Idem, Administrative knowledge in a colonial context [...]. The British Journal for the History of Science (BJHS), vol. 43, dezembro de 2010, pp. 554-555.
} 
português $^{595}$ e Angola Aire tivesse utilizado os planos de Luanda para projetar sua linhagem no xadrez político regional, a expansão e a manutenção da Angola portuguesa havia dado um passo importante rumo ao Ndongo durante o governo de Fernão de Sousa. As negociações e conversações na busca por apoio político e estratégico eram constantes, e por isso figurarão como o foco de nossas atenções no próximo capítulo.

\footnotetext{
595 Não podemos deixar de mencionar o trabalho de Mariana Bracks Fonseca, ao destacar o início da transformação da líder africana em um "símbolo de resistência antiportuguesa", logo após os primeiros ataques que promovera aos estrangeiros. Ideia ambiciosa e inovadora, porém de difícil comprovação empírica. Verificar resumo em: FONSECA, Mariana Bracks. Nzinga Mbandi e as guerras de resistência em Angola. Século XVII. Dissertação de mestrado, Universidade de São Paulo, 2012, p. 135.
} 


\section{POLÍtica ULTRAMARINA E UM ESTADO DE GUERRA ECONÔMICA}

\section{Apresentação}

Neste capítulo analisaremos o funcionamento das guerras centro-africanas, alguns dos impulsos que porventura as alavancaram e os elementos que compuseram as famosas campanhas militares, também registradas como "jornadas de guerra", contra Ginga Ambande. Mesclaremos nossa investigação interassociando algumas considerações sobre a produção de fontes escritas, de cunho administrativo-burocrático, com a participação de algumas elites na tomada de decisão sobre os assuntos militares. Ademais, chamaremos a atenção para o auxílio militar e logístico prestado por algumas autoridades africanas durante a arregimentação e armação da "gente de guerra".

\subsection{A partida da primeira jornada contra Ginga Ambande (1626-1627)}

Após as longas discussões e debates ocorridos em 1625, finalmente no início de 1626 havia sido encaminhada, de maneira legítima e acordada entre os principais grupos interessados na Angola portuguesa e no Ndongo, ${ }^{596}$ a constatação de guerra justa contra a principal inimiga centro-africana da monarquia portuguesa, Ginga Ambande, dando com isso o primeiro passo rumo à série de operações militares que marcaria o governo de Fernão de Sousa. Entre outras coisas, ficou determinado que o objetivo dessas guerras, pelo menos público e oficial, era o de capturar a líder africana. Ao mesmo tempo que eram procedidas as negociações e discussões em torno da legitimidade de confronto bélico, outro ponto importante ainda estava indefinido. Quem comandaria o exército português? Muito mais do que um simples "escolhido" ou um "preferido" do monarca ou do governador, a nomeação do chamado "capitão-mor do quilombo português", como assim é registrado nos documentos que compõem a $F H A$, esconde três aspectos fulcrais e intimamente relacionados ao emprego e à utilização da gente de guerra. Em primeiro lugar, o comandante deveria ser competente e à altura do cargo. Em segundo lugar, ele deveria atender às demandas e aos interesses daqueles que colocavam suas contas em risco, ao

\footnotetext{
${ }^{596}$ Conforme abordado também no capítulo 2 desta dissertação.
} 
decretarem a justiça de guerra contra Ginga Ambande, ou seja, os agentes e grupos sociopolíticos que atuavam na Câmara de Luanda, no Colégio da Companhia de Jesus e no bispado de Angola, como vimos no segundo capítulo desta dissertação e retomaremos aqui. ${ }^{597}$ Por fim, essa pessoa deveria ter "meios" para fazer a guerra, ou seja, capital para investir na mobilização militar, estando assim diretamente comprometido com o sucesso da empreitada. Por motivos intimamente ligados à carreira e aos interesses pessoais de uma pessoa experiente no serviço militar-ultramarino, o encarregado para a missão foi Bento Banha Cardoso.

Um dos mais prestigiados indivíduos que serviam no alto escalão português da África Centro-Ocidental, Bento Banha Cardoso era "Cavaleiro fidalgo da casa do rei” e desde 1592 habitava na África. ${ }^{598}$ Prestou serviços como "lugar-tenente", alferes, capitão de infantaria, capitão-mor de guerra e capitão de Cambambe, galgando uma ascensão tão rápida que se deu ao luxo de recusar a função de "capitão e ouvidor de todos os Portugueses no Kongo", com a desculpa de que estava descontente pelo fato de não ter sido agraciado com o "hábito de Cristo". O auge da sua vida pública a serviço da monarquia foi alcançado entre 1611 a 1615, quando Bento Banha Cardoso foi eleito como governador interino de Angola, logrando dois feitos que seriam rememorados pela posterioridade: a conquista da província de Lumbo, também conhecida como Ilamba Alta, e a construção do presídio de Ango, ${ }^{599}$ perto do Lucala. Após o término do serviço administrativo, retornou a Portugal, onde foi alvo de acusações e processos, dos quais se safou e teve "sua fortuna restituída por alvará real". Em 1 de setembro de 1625 estava de volta em Luanda, agora como capitão-mor nomeado por Filipe III de Portugal, além de receber o soldo anual condizente com o ofício. Como a guerra era iminente na Angola portuguesa, Bento Banha Cardoso trouxe consigo um "reforço de duzentos soldados". Observador e versado na política palaciana, o português deixou uma boa impressão entre os membros do círculo de influência do monarca, tanto que recebeu, por ordem de Filipe III de Portugal, a condução

\footnotetext{
${ }^{597}$ A "diocese de Angola" foi fundada em 1579, pouco tempo depois da criação da "cidade de São Paulo de Luanda". O colégio da Companhia de Jesus, incumbido da formação educacional e espiritual da região, foi erguido em 1623. Verificar: FERREIRA, Roquinaldo. Cross-Cultural Exchange in the Atlantic World: Angola and Brazil During the Era of the Slave Trade. Cambridge: Cambridge University Press, 2012, p. 141. ALENCASTRO, Luiz Felipe de. The Economic Network of Portugal's Atlantic World. IN: BETHENCOURT, Francisco; CURTO, Diogo Ramada (ed.). Portuguese Oceanic Expansion, 1400-1800. Cambridge: Cambridge University Press, 2007, p. 110.

${ }_{598} \mathrm{O}$ português chegou à Angola portuguesa na companhia do governador Dom Francisco de Almeida.

${ }^{599}$ Também grafado "Hango".
} 
da primeira campanha de guerra contra Ginga Ambande, que partiu de Luanda em 7 de fevereiro de $1626 .^{600}$

O evento histórico que mais nos intriga na carreira desse homem ocorreu quando vagou a função de governador de Benguela, após o falecimento de Manuel Cerveira Pereira, em 9 de abril de $1626 .{ }^{601}$ Por recomendação de Fernão de Sousa, o primeiro candidato para tomar o posto de comando do domínio sulista foi Bento Banha Cardoso. Este, contudo, ao invés de se aventurar em Benguela, preferiu ficar no comando do quilombo de guerra português, alegando que o domínio "não era de grande proveito para a Coroa, e que o cargo não era remunerado, não tendo ele capital necessário para manter os soldados". Além do mais, como salientou Beatrix Heintze, o português receava ter o nome manchado, caso perdesse o domínio para os holandeses. ${ }^{602}$ No entanto, todas essas alegações nos geram certa estranheza e suscitam alguma desconfiança, certamente porque os holandeses não mais navegavam em águas centro-africanas desde 1 de dezembro de 1624 e, além disso, pois Bento Banha Cardoso não era novato e nem inocente. ${ }^{603}$ Ele sabia que Ginga Ambande contava com apoio regional e que abrir guerra contra ela seria uma árdua tarefa, tão ou mais difícil do que governar Benguela. Aliás, qualquer empreendimento ultramarino, seja de guerra ou governadoria, necessitava da aplicação de capital, ${ }^{604}$ motivo que igualmente não justifica a preterição de Benguela.

Como experiente na terra e conhecedor dos meandros da administração da Angola portuguesa, Bento Banha Cardoso sabia que a guerra era mais lucrativa do que a governadoria ultramarina. ${ }^{605}$ Talvez desiludido com o futuro de uma carreira política na

\footnotetext{
${ }^{600}$ HEINTZE, Beatrix (coord.). Apêndice: Tabela Cronológica, 1618-1630. FHA, vol. I, 1985, p. 395. Idem. Breves biografias de alguns europeus em Angola (1620-1630). FHA, vol. I, 1985, pp. 79-80.

${ }^{601}$ Fernão de Sousa. Carta de Fernão de Sousa ao Governo. 1 de julho de 1627. BAL, cód. 51-IX-20, ff. 33737v, 338. IN: HEINTZE, Beatrix (coord.). Documento 92. FHA, vol. II, 1988, p. 180.

${ }^{602}$ HEINTZE, Beatrix. Breves biografias de alguns europeus em Angola (1620-1630). FHA, vol. I, 1985, p. 80 .

${ }^{603}$ Idem, Apêndice: Tabela Cronológica, 1618-1630. FHA, vol. I, 1985, pp. 395-396.

${ }^{604} \mathrm{Na}$ documentação inserida na FHA, a aplicação de capital é visível através de simples investimentos em dinheiro e por meio de doação de fazendas. Por exemplo, em 1625 Fernão de Sousa doou "800 alqueires de farinha para Manuel Cerveira Pereira e para os doentes de Benguela", como lembra Beatrix Heintze. Em meados de 1627, Lopo Soares Lasso investiria uma soma considerável de recursos em Benguela, como veremos no último item deste capítulo. Verificar: HEINTZE, Beatrix. A Colectânea Documental de Fernão de Sousa, FHA, vol. I, 1985, pp. 37-38

${ }^{605}$ Além disso, por mais que a opinião pública da época pregasse que ele havia perdido "toda a sua fortuna a serviço da Coroa e que não possuía escravos", e mesmo que Fernão de Sousa achasse que "ainda que não tem escravos é bem quisto dos soldados,... me dizem que não é cobiçoso...", é difícil de crer que Bento Banha Cardoso fosse um miserável nos últimos anos de vida, já que faleceu em uma das suas quintas no Lembo, em
} 
corte portuguesa, ou resignado com a vida no ultramar, houve uma escolha deliberada desse homem, que preferiu deixar de lado o "bom serviço" administrativo para se dedicar ao enriquecimento dentro dos moldes da economia atlântica, visível por meio da aquisição de escravos e que na época foi impulsionada pelo incentivo à guerra. Coerente com sua trajetória de vida e contando com o respaldo institucional necessário para a empreitada, a preferência de Bento Banha Cardoso pela guerra de mobilização do quilombo, em 1626, é um ponto-chave para a compreensão de como ocorria a utilização das forças armadas e as operações militares. Subjacente à missão política de captura de Ginga Ambande, divididas em duas "jornadas de guerra", a primeira entre 1626-1627 e a segunda entre 1628-1629, havia um objetivo exclusivamente econômico: gerar lucro para os envolvidos.

Retomando o fio narrativo, após as deliberações na Câmara de Luanda e nomeação de Bento Banha Cardoso como comandante da empreitada militar, em 7 de fevereiro de 1626 partiu de Luanda o exército português. O primeiro choque entre o capitão-mor e as forças Ginga Ambande ocorreu nas ilhas de Quindonga, baluarte mbundu que seria invadido por tropas portuguesas e retomado pela africana duas vezes, uma em 1626 e outra em 1628, sinalizando a importância que Quindonga tinha para Ginga Ambande, sua linhagem e seus seguidores. ${ }^{606}$ No assalto português às ilhas, a "gente de guerra" de Bento Banha Cardoso rompeu as defesas locais e penetrou domínios de Ginga Ambande em 12 de julho de 1626, forçando a fuga dos invadidos para o interior do continente. ${ }^{607}$ A partir de então, começou um segundo episódio da perseguição a Ginga Ambande, registrado nos documentos inseridos na FHA como a "travessia do Lucala", a respeito do qual nos deteremos com mais vagar neste item.

\footnotetext{
8 de agosto de 1628, e depois foi sepultado em Massangano. No mínimo, a família Cardoso detinha cabedal material - terras, dinheiro para investir na guerra e pagar o sepultamento, além do soldo régio - e imaterial as graças de Fernão de Sousa, do rei que lhe concedera o título honorífico de capitão-mor e a condução do exército português -, e não há motivos para duvidarmos da influência de seu nome na Câmara de Luanda, entre os moradores de Massangano e gente de guerra em geral. HEINTZE, Beatrix. Breves biografias de alguns europeus em Angola (1620-1630). FHA, vol. I, 1985, pp. 79-80.

${ }^{606}$ Segundo Joseph C. Miller, para Ginga Ambande, ou "Njinga Mbande", as "ilhas de Kindonga" eram uma espécie de "capital simbólica" onde estavam enterrados os "ancestrais reais" representantes da linhagem que, antes de 1624, estava no governo do Ndongo. MILLER, Joseph C. Poder político e parentesco: Os antigos estados Mbundu em Angola. [1976]. Luanda: Arquivo Histórico Nacional, 1995, p. 26.

${ }^{607}$ HEINTZE, Beatrix (coord.). Apêndice: Tabela Cronológica, 1618-1630. FHA, vol. I, 1985, p. 396.
} 


\section{Imagem 10: O "reino de Matamba" (século XVII) ${ }^{608}$}

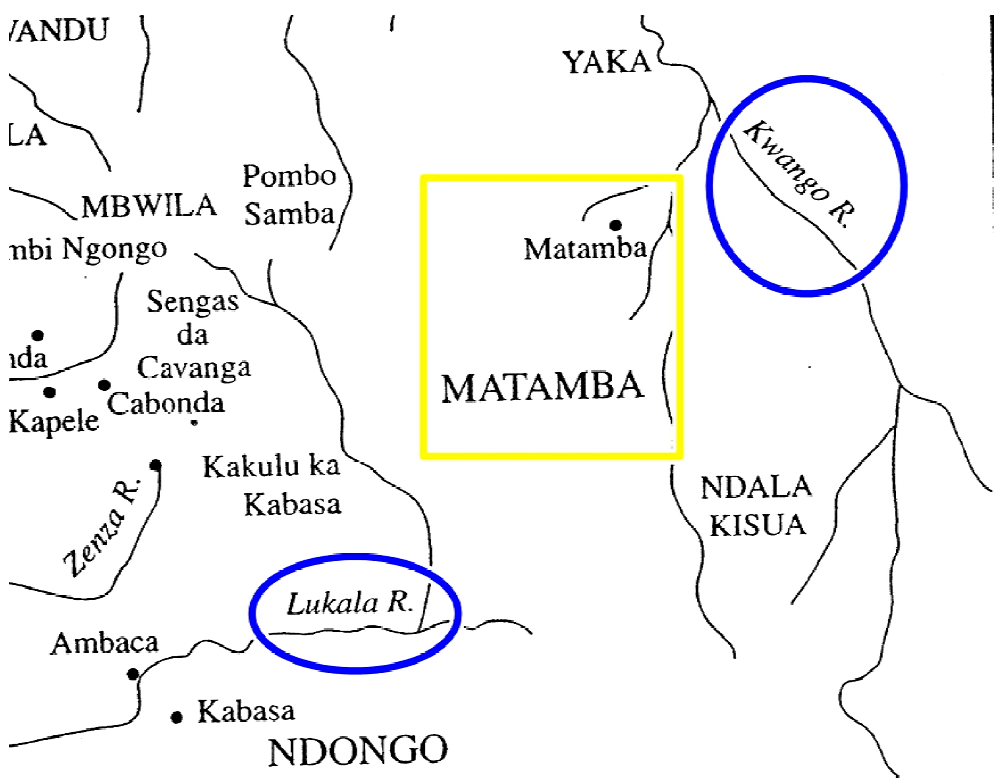

Legenda: i) $O$ retângulo em dourado indica a área de Matamba, hipoteticamente encerrada entre dois rios; ii) As circunferências em azul assinalam cursos de água.

A primeira informação relevante que temos em mãos deriva de uma notícia anotada no extenso relatório de Fernão de Sousa. Em certa altura, reportou o governador que, em uma carta de 23 de julho de 1626, ${ }^{609}$ Bento Banha Cardoso havia lhe dito que continuaria a perseguir Ginga Ambande continente adentro e, por isso, atravessaria o rio Lucala, ato que de fato aconteceu em algum momento perto do final de 1626 e meados de março de 1627..$^{610} \mathrm{O}$ capitão-mor também advertiu que trazia consigo a missão de acalmar os

\footnotetext{
${ }^{608}$ Imagem retrabalhada a partir de: HEYWOOD, Linda M.; THORNTON, John K. Central Africans, Atlantic Creoles [...]. Cambridge: Cambridge University Press, 2007, p. 50. Para a localização da "antiga região de Mátàmbà", em "algures no rio Kwàngù", na atual província de Malanje, verificar: COELHO, Virgílio. Os Túmúndòngò, os "génios" da natureza e o kílàmbà: Estudos sobre a sociedade e a cultura kímbùndù. Luanda: Kilombelombe, 2010, p. 182.

${ }^{609}$ Como a maioria dos documentos referenciados por Fernão de Sousa no extenso relatório, essa carta de julho de 1626, escrita a princípio pelo capitão-mor Bento Banha Cardoso, não consta no corpo documental aqui consultado. A única carta de autoria comprovada de Bento Banha Cardoso, disponível na $F H A$, é: Carta de Bento Banha Cardoso a el-rei e parecer do Conselho da Fazenda. 6 de outubro de 1625 e posterior. AHU, Angola, cx. 2, n. ${ }^{\circ}$ 83. IN: HEINTZE, Beatrix (coord.). Documento 248, FHA, vol. II, 1988, pp. 348-349. De todo modo, seguimos a intuição de Heintze, para quem: “[...] Como se tratava de uma questão central para os portugueses, presume-se que as informações de Cardoso sobre este assunto e as posteriores [inseridas no extenso relatório] correspondam à verdade [...]". Verificar: HEINTZE, Beatrix. Angola nos séculos XVI e XVII: estudos sobre fontes, métodos e história. Luanda: Kilombelombe, 2007, p. 347.

${ }^{610}$ Sugerimos aqui que os planos provavelmente tiveram início entre a eleição e investidura de Angola Aire como rei vassalo de Portugal, em 12 de outubro de 1626, e o primeiro indício concreto de existência do planejamento da travessia, registrado no documento sobre o qual discorremos a seguir, datado de 5 de março de 1627. De todas as informações disponíveis, também é possível deduzir que o exército ficou estacionado nas redondezas de Quindonga - não quer dizer inoperante - por entre quatro a oito meses, até de fato transpor
} 
"alvoroços" e "transtornos" que sublevavam o Ndongo e a Matamba. Há então aqui uma informação de grande valia. Apesar de descrente quanto à possibilidade de "pacificação" dos sobas descontentes, ${ }^{611}$ Bento Banha Cardoso concordava com o governador que a tentativa de capturar Ginga Ambande seria um bom álibi, além de ato público de força, que "serviria para trazer os sobas daquele distrito à nossa devoção, e os confirmar em nossa amizade obrigando-os com eles a não darem favor [a Ginga Ambande], nem amparo algum". ${ }^{612}$ Aqui é necessário chamar a atenção para três termos-chave da narrativa de Fernão de Sousa. Quando o governador menciona a necessidade de "acalmar" a situação de insurgência, ele se referia diretamente à necessidade de deter os inúmeros "alvoroços", "rebeldias", "rebeliões" e "levantamentos" promovidos por Ginga Ambande e sustentados pelo sobas que a apoiavam, cujo efeito secundário era o êxodo de escravos que procuravam o "amparo" de Ginga Ambande. ${ }^{613}$ Em segundo lugar, a expressão "confirmar a devoção" diz respeito ao avassalamento formal dos chamados "sobas amigos", procedimento de vinculação política sobre o qual voltaremos a tocar no momento oportuno. Juntos, “avassalar" e "acalmar" conformavam a desculpa perfeita para o ato de "conquistar", terceiro termo-chave registrado no extenso relatório. Conforme o léxico político e

o Lucala. Para o leitor se situar nos principais eventos da época, conferir: HEINTZE, Beatrix (coord.). Apêndice: Tabela Cronológica, 1618-1630. FHA, vol. I, 1985, pp. 395-396. Nesse material de apoio não há menção ao episódio de travessia do Lucala.

${ }^{611}$ Nesse trecho, Fernão de Sousa apenas afirma que a descrença de Bento Banha Cardoso derivava da suposição de que os sobas dificilmente abandonariam a líder africana, não fornecendo mais explicações.

${ }^{612}$ Fernão de Sousa. O extenso relatório do governador aos seus filhos. S.d., 1625-1630. BAL, cód. 51-IX20, ff. 220-74v. IN: HEINTZE, Beatrix (coord.). Documento 30, FHA, vol. I, 1985, p. 254. Na prática portuguesa quinhentista e seiscentista, normalmente a "pacificação" poderia ser alcançada através de uma "acordo de paz", escrito ou verbalizado, ou por meio de confrontos militares.

${ }^{613}$ Essas fugas foram constantemente alertadas pelos senhores de escravos portugueses entre 1623 e meados de 1626, despertando a apreensão de Fernão de Sousa, como dito no capítulo 2. Aqui cabe apenas esclarecer alguns pontos relevantes, em consonância com o que já foi dito. Segundo Birmingham, Ginga Ambande, ou apenas "Nzinga", acolhia os escravos fugitivos de "colonos" portugueses e "escravos de guerra", os tais "quimbares". Em contrapartida, no Ndongo cresciam as "tendências neutralistas entre os vassalos portugueses", dando sinais de que os sobas locais estavam pouco propensos a brandir as armas contra a líder africana. De todo modo, como efeito colateral da eminência de guerra e resultado prático dos confrontos militares, ocorreu o despovoamento de vastas áreas perto da costa, através das fugas, aprisionamento de gente e intensas migrações, principalmente nas "regiões fronteiriças" do Mbondo, Matamba e Tunda. Igualmente corroboraram para a queda da densidade populacional os fatores epidemiológicos, climatológicos e a fome que, em grande ou pequena medida, acompanhavam ou vinham em seguida às grandes guerras. De todo modo, esses quatro pontos estavam constantemente associados entre si. BIRMINGHAM, David. Trade and conflict in Angola: the Mbundu and their neighbours under the influence of the Portuguese 1483-1790. Londres: Clarendon Press/ Oxford University Press, 1966, pp. 92-93. Sobre o despovoamento da costa centroatlântica, verificar: HEINTZE, Beatrix. Angola nos séculos XVI e XVII [...]. Luanda: Kilombelombe, 2007, pp. 333, 380-381. MILLER, Joseph C. The Significance of Drought, Disease and Famine in the Agriculturally Marginal Zones of West-Central Africa. The Journal of African History. Cambridge: Cambridge University Press, vol. 23, n. ${ }^{\circ}$ 1, 1982, pp. 20-21, 23-25 e 30-31. 
pragmático de Fernão de Sousa e Bento Banha Cardoso, “conquistar" estava ligado não somente à ofensiva militar e ao uso da força bélica, mas também ao "avassalamento" de sobas situados nas duas bandas do Lucala, de Aire Aquiloange, Angola Aire e, em último caso, remete-se ao processo histórico que acarretará na conquista de Pungo Andongo, em $1671 .^{614}$ Virtualmente, "conquistar" era também "avassalar", por intermédio da força, os sobas que "traíam a confiança" do governador, como também negociar, com base em ameaças e demonstrações de força, com aqueles mais propensos à aproximação política. Através de uma leitura atenta às vicissitudes da documentação, é possível destacar sucintamente que as práticas de submissão, subjugação ou sujeição políticas - formas de dominação, portanto - estavam eventualmente entrelaçadas a formas de intermediação vassalagem, alianças e negociações -, que normalmente acarretavam na "oferta da paz" portuguesa.

Pois bem, uma vez apresentado quais assuntos pautariam a travessia do Lucala, o extenso relatório relata que o capitão-mor Bento Banha Cardoso solicitou alguns cavalos e três "tololões, ${ }^{615}$ por estarem gastados o que levava". Com eles, o militar português marcharia rapidamente em direção ao Lucala, durante o "veranico de luco",616, onde "daria nos rebeldes". Sinalizando positivamente e concedendo aval institucional para a empreitada, Fernão de Sousa ordenou ao militar para que ele prontamente colocasse "guerra em campo", observando que seria conveniente dispor "o quilombo em sítio que

${ }^{614}$ Durante o governo de Francisco de Távora (1669-1676). A chamada "conquista de Pungo Andongo", então "capital do Ndongo", pôs fim ao processo histórico disparado com o início dos contatos, na segunda metade do século XVI, culminando no término da independência do reino africano, segundo Beatrix Heintze. Nos termos de Joseph C. Miller, a guerra entre Luanda e Pungo Andongo, em 1671, foi decorrente do enfraquecimento interno do detentor do título de "Angola Aire", ou "Ngola Hari", e reforçado pela reaproximação do funcionalismo régio com Ginga Ambande, ambos os movimentos ocorridos na década de 1660. Em decorrência da tomada de Pungo Andongo, seria construído um fortim nas margens do rio Cuango, o que para Luiz Felipe de Alencastro indicaria uma nova "baliza do domínio luso em Angola, a qual só será ultrapassada em meados do século XIX. A feira de trato aberta na área - encruzilhada das trilhas demandando Benguela e Luanda - leva ao surgimento de novos 'pumbos', mercados de escravos sertanejos, acessíveis aos 'pombeiros' dos angolistas." Verificar: MILLER, Joseph C. Legitimacy and Political Power: Queen Njinga, 1624-1663. The Journal of African History. Cambridge: Cambridge University Press, vol. 32, n. ${ }^{\circ}$ 1, 1991, pp. 39-40. HEINTZE, Beatrix. Angola nos séculos XVI e XVII [...]. Luanda: Kilombelombe, 2007, p. 235. ALENCASTRO, Luiz Felipe de. O trato dos viventes: A formação do Brasil no Atlântico Sul. São Paulo: Companhia das Letras, 2000, p. 302.

${ }^{615}$ Possivelmente "tolollões" eram "tendas de campo". Para mais informações, consultar o "suplemento para alguns vocábulos africanos", inserido nesta dissertação.

616 "Veranico de luco" era um "nome para curto tempo seco". HEINTZE, Beatrix (coord.). Esclarecimentos sobre vocábulos africanos, $F H A$, vol. I, 1985, p. 129. Informação extraída de: CADORNEGA, António de Oliveira de. $H G G A$, vol. II, 1940, p. 413. 
tenha mantimentos perto dos inimigos, e afastados dos amigos porque com a vizinhança os obrigaria ao obedecerem". Frases e expressões iguais a essas serão repetidas inúmeras vezes no extenso relatório e em outros documentos inseridos na $F H A$, destacando a importância que tinham nos planos e intenções das autoridades. Nos momentos oportunos voltaremos a tocar nelas. Por enquanto, cabe explicarmos a importância de outro termo bastante recorrente nos escritos com os quais trabalhamos, o tal do "quilombo" ao qual Fernão de Sousa fizera menção tantas vezes.

O significado geral de "quilombo", existente no extenso relatório de Fernão de Sousa e em outros documentos de sua autoria, era o de "exército", ou "gente de guerra", arregimentado e comandado por portugueses que carregavam as patentes de capitão-mor e capitão, caso por exemplo de Bento Banha Cardoso, como já introduzido. Esses quilombos eram compostos por tropas mistas que guerreavam lado a lado, sendo as principais delas as "companhias de infantaria", dentre as quais existiam a "gente de guerra branca", ou simplesmente "guerra branca", composta por soldados que normalmente serviam em Luanda e nos presídios de Ambaca, Muxima, Cambambe e Massangano, e a "gente de guerra preta", ou só "guerra preta", 617 composta pelos chamados "tendalas", "quimbares" e "quiamboles". ${ }^{618}$ Os africanos que lutavam no quilombo de guerra português poderiam ser convidados a pegar nas armas, ser cedidos pelos senhores de escravos que habitavam na Angola portuguesa ou serem compelidos a participar das operações militares, contudo o mais comum era que eles fossem recrutados pelos "sobas vassalos", que os enviavam em respeito aos termos de vinculação política firmados com Luanda. Uma vez convocados, a gente de guerra era organizada mediante a uma hierarquia militar. Como já dito, no topo de comando do quilombo jazia o capitão-mor. Ao redor dele figurava uma cúpula militar de subcomando, auxiliar na condução das operações militares, composta por capitães

\footnotetext{
${ }^{617}$ THORNTON, John K. Warfare in Atlantic Africa 1500-1800. [1999]. Londres e Nova Iorque: Routledge, 2003, pp. 119-120.

${ }^{618}$ Salientando desde já que os altos quadros da guerra preta podiam ser ricos africanos a serviço de Luanda, tidos como "prestativos" e de "confiança" pelo oficialato régio, mas que suscitavam certa desconfiança por parte dos funcionários de Luanda. Os militares de nível mediano e de proximidade ao funcionalismo régio eram normalmente "temidos" e "odiados" pelas aldeias mbundu, que desconfiavam dos afazeres que eles prestavam aos estrangeiros. De uma forma geral, todos esses cargos da guerra preta poderiam ser oferecidos, ou investidos, a escravos. Verificar: HEINTZE, Beatrix. Angola nos séculos XVI e XVII [...]. Luanda: Kilombelombe, 2007, p. 490. HEYWOOD, Linda M.; THORNTON, John K. Central Africans, Atlantic Creoles, and the Foundation of the Americas, 1585-1660. Cambridge: Cambridge University Press, 2007, pp. 75-78.
} 
portugueses, encarregados também da direção das companhias de guerra. Os poucos registros que temos sobre os quadros africanos também permitem deduzir que havia um subcomando africano, encabeçado por "tendalas", mas que provavelmente não participava das deliberações político-militares existentes nos "conselhos", montados a cada paragem do quilombo a fim de decidir os rumos da mobilização militar. ${ }^{619}$ Abaixo deles figuravam os quiamboles, ${ }^{620}$ provavelmente responsáveis pela direção de pelotões, tropas e outras subdivisões necessárias para a organização da gente de guerra. Na base da força militar estavam os quimbares, ${ }^{621}$ componentes de uma infantaria leve e acima de tudo preparada para o combate corpo-a-corpo. ${ }^{622} \mathrm{O}$ corpo de infantaria local também podia ser composto por outros oficiais de médio ou baixo escalão, chamados de "quilambas", todavia não há informações sobre a frequência com a qual eles compunham as mobilizações militares. ${ }^{623}$ Quase não havia cavalaria, os mosquetes e arcabuzes eram parcos e frequentemente ineficientes nas batalhas ocorridas abaixo do Equador. As escassas peças de artilharia, quando levadas a campo, às vezes estavam quebradas. ${ }^{624}$

${ }^{619}$ Para mais informações sobre o que eram os "tendalas", consultar o "suplemento para alguns vocábulos africanos", inserido nesta dissertação.

${ }^{620}$ De acordo com o conteúdo narrado no documento, o "quiambole" era um "comandante" da guerra preta, provavelmente de origem mbundu. Para mais informações, consultar o "suplemento para alguns vocábulos africanos", inserido nesta dissertação.

${ }^{621}$ Para mais acepções para o termo "quimbar", consultar o "suplemento para alguns vocábulos africanos", inserido nesta dissertação.

${ }^{622}$ Havia uma preponderância de infantaria leve em todos os exércitos que guerreavam na África CentroOcidental seiscentista. Ela era normalmente disposta de maneira espaçada no campo de batalha, privilegiando a modalidade de guerra regional, baseada na habilidade individual dos soldados em darem golpes astutos, saltos e piruetas, algo também conhecido como "sanguar" ou "sangar". Nas forças armadas comandadas pelo Kongo, havia também os chamados "adargueros" ou "adargueiros", espécie de infantaria pesada e famosa pela utilização de escudos. Nos exércitos do Ndongo eram também comuns os "gunzes", caracterizados pelos oficiais portugueses como sendo as "flores de Angola", hábeis atiradores que futuramente seriam denominados "empacaceiros", segundo Thornton. Os soldados portugueses, quando empregados no campo de batalha, exerciam o papel de infantaria pesada. Eles usualmente trajavam armaduras e empunhavam espadas, além de contar com os disparos de mosquetes e arcabuzes. Verificar: THORNTON, John K. Warfare in Atlantic Africa [...]. [1999]. Londres e Nova Iorque: Routledge, 2003, pp. 104-105, 107, 121. Idem, The Art of War in Angola, 1575-1680. Comparative Studies in Society and History. Cambridge: Cambridge University Press, vol. 30, n. ${ }^{\circ} 2$, abr. de 1988, pp. 375-376. Sobre a chamada "arte de sanguar", "sangar" ou "sangamento", verificar especificamente a primeira obra, p. 105. Sobre os "ardagueiros", conferir especificamente o segundo artigo, pp. 364-365. Sobre os "gunzes", verificar a primeira obra de Thornton, pp. 107 e 121. Sobre o termo ngunza, em kikongo e kimbundu, do qual provavelmente derivou "gunze", verificar: VANSINA, Jan. How Societies Are Born: Governance in West Central Africa before 1600. Charlottesville: University of Virginia Press, 2004, pp. 242-243, principalmente a nota 108.

${ }^{623}$ Para mais informações, consultar o "suplemento para alguns vocábulos africanos", inserido nesta dissertação.

${ }^{624}$ Sobre o uso de artilharia, verificar: THORNTON, John K. Warfare in Atlantic Africa [...]. [1999]. Londres e Nova Iorque: Routledge, 2003, p. 121. Idem, The Art of War in Angola [...]. Comparative Studies in Society and History. Cambridge: Cambridge University Press, vol. 30, n. ${ }^{\circ}$ 2, abr. de 1988, p. 375. Sobre a ausência de 
Outra característica importante da composição do quilombo de guerra português é a imbricação que nele havia entre as formas de dominação e intermediação. Para além do fato de a síntese da guerra luso-africana implicar em uma total mistura entre táticas e habilidades de guerra europeias e locais, quiçá com mais componentes "à africana" do que europeus, como sustenta John K. Thornton, ${ }^{625}$ não é menos evidente que a passagem desse exército gerava violência e medo entre os locais. O simples fato de o termo "quilombo" ser uma corruptela, ou vulgarização, de um vocábulo endógeno, kilombo, é um indício forte disso. ${ }^{626}$ Olhando a partir de uma perspectiva continental, no sentido proposto por Joseph. C. Miller e sustentado por Jan Vansina, o kilombo era uma instituição sociomilitar, baseada nos saques às aldeias, no infanticídio daqueles que nasciam do seio do kilombo e no recrutamento de "adolescentes escravizados" do sexo masculino, que passariam a ser integrados ao grupo como membros regulares após a submissão a rituais de iniciação social. $^{627}$ Outra marca registrada dessas pessoas que "viviam em kilombos" era a

cavalaria, verificar o segundo artigo, pp. 267-268. O consenso atual é o de que o modo de guerra europeu não obteve sucesso na África e, por consequência, o impacto estrangeiro através dos avanços militares foi pequeno, colocando a baixo hipóteses ligadas à ideia dos "ciclos armas-cavalos-escravos", por exemplo. Sobre o equilíbrio militar entre locais e estrangeiros na África Centro-Ocidental, verificar a primeira obra supracitada de Thornton, pp. 124-125. Ver também a segunda obra, p. 374. Sobre as hipóteses dos ciclos e duas posições divergentes, verificar: FERREIRA, Roquinaldo. The Supply and Deployment of Horses in Angolan Warfare (17th and 18th centuries). IN: HEINTZE, Beatrix; OPPEN, Achim von (Ed.). Angola on the Move: Transport Routes, Communications and History. Frankfurt am Main: Verlag Otto Lembeck, 2008. THORNTON, John K. Africa and Africans in the Making of the Atlantic World, 1400-1800. [1992]. Cambridge: Cambridge University Press, 1998, pp. 98-99, 100, 102 e 105-106. Idem, A Cultural History of the Atlantic World, 1250-1820. Cambridge: Cambridge University Press, 2012, pp. 68-69, 71, 98-99. Segundo Thornton, a vantagem europeia na guerra africana apenas seria alcançada com a invenção do mosquete de disparo com ferrolho de pederneira (flintlock), mais eficiente do que o antigo fecho de mecha (matchlock). Sobre isso, verificar a primeira obra supracitada de Thornton, pp. 24-28.

${ }^{625}$ Em especial, verificar: THORNTON, John K. The Art of War in Angola [...]. Comparative Studies in Society and History. Cambridge: Cambridge University Press, vol. 30, n. ${ }^{\circ}$ 2, abr. de 1988, pp. 371-373 e 377. Ver ainda a postura militar tomada no tempo de Luís Mendes de Vasconcelos, que inicialmente ordenou que as tropas lutassem de modo compacto, mas depois, a pedido dos próprios soldados, permitiu que eles guerreassem "à africana". Verificar: THORNTON, John K. Warfare in Atlantic Africa [...]. [1999]. Londres e Nova Iorque: Routledge, 2003, p. 106. Sobre o século XVIII, opinião similar é sustentada em: SANTOS, Catarina Madeira. Um governo "polido" para Angola: Reconfigurar dispositivos de domínio. (1750-c.1800). Tese de doutorado, Universidade Nova de Lisboa, 2005, pp. 284-285.

${ }^{626}$ Catarina Madeira Santos salienta que muitos outros diversos termos, de pelo menos três matrizes linguísticas constatáveis - português, kimbundu e kikongo -, compunham o léxico bélico-militar envolvida na arregimentação e no exercício das guerras luso-africanas. Os registros escritos advogam para a existência de polissemia e coexistência lexical e de práticas de guerra em geral, dissociadas em níveis conflituosos da estruturação interna dos exércitos. Verificar: SANTOS, Catarina Madeira. Um governo "polido" para Angola [...]. Tese de doutorado, Universidade Nova de Lisboa, 2005, pp. 277-278.

${ }^{627}$ MILLER, Joseph C. Legitimacy and Political Power [...]. The Journal of African History. Cambridge: Cambridge University Press, vol. 32, n. ${ }^{\circ} 1,1991$, p. 31. Sobre o assassinato de crianças em rituais de preparação para a guerra, comuns aos imbangala, além da utilização disseminada de corpos de crianças em 
"errância", traço que fez com que pesquisadores contemporâneos correlacionassem diversos bandos vagueadores a grupos sociais envolvidos em “ondas migratórias", iniciadas na Lunda e que, em algum momento do século XVI, ${ }^{628}$ teriam chegado na parte sul do Cuanza por volta de 1600. Após perambular pelas regiões próximas à costa atlântica, esses bandos se fixariam principalmente na Baixa do Cassanje, onde fundariam o chamado "reino de Kassanje", pouco depois de $1630 .{ }^{629}$ Os grupos associados ao kilombo ficaram

cerimônias ligadas à convocação de chuvas, verificar especialmente: Idem, The Significance of Drought, Disease and Famine [...]. The Journal of African History. Cambridge: Cambridge University Press, vol. 23, n. $.^{\circ} 1,1982$, p. 27.

${ }^{628}$ Tais migrações são também relatadas nas tradições orais, às vezes reconhecidas como "fundadoras", dos povos cokwe-lwena, songo e imbangala, registradas acima de tudo no século XIX, mas também presentes em alguns documentos do século XVII. Consultar: BIRMINGHAM, David. Trade and conflict in Angola [...]. Londres: Clarendon Press/ Oxford University Press, 1966, sobretudo o capítulo 4 e as pp. 12-14. VANSINA, Jan. How Societies Are Born [...]. Charlottesville: University of Virginia Press, 2004, pp. 249-250. De modo geral, a ideia de que tais ondas migratórias "bantu" existiram presume, na maioria das vezes, uma origem única e comum para a família linguística bantu, sendo altamente tributária das informações contidas em tradições orais e, sobretudo, defendida por estudos ligados à linguística histórica. Assim, são traçadas as tendências de difusão, convergência e divergência, sociais e culturais entre os povos centro-africanos. Verificar especificamente: VANSINA, Jan. Paths in the Rainforests: Toward a History of Political Tradition in Equatorial Africa. Madison-Wisconsin: University of Wisconsin Press, 1990, pp. 251, 258 e nota 13. Para a história tradicional dos lunda, conferir a mesma obra, em especial a nota 1, pp. 10-11, e pp. 14-17. No que diz respeito à "história de fundação de Kassanje", um levantamento e avaliação bem feitos, sobre o material etno-histórico disponível atualmente, pode ser conferido em: Idem, The Foundation of the Kingdom of Kasanje. The Journal of African History. The Journal of African History. Cambridge: Cambridge University Press, vol. 4, n. ${ }^{\circ}$ 3, 1963, pp. 355-374. Apesar de algumas incoerências e desatualizações, o pressuposto de separação das ondas migratórias que partiram dos lunda-luba em duas guinadas, defendido desde então por Vansina, tem se mostrado correto. Verificar especificamente: Idem, More on the Invasions of Kongo and Angola by the Jaga and the Lunda. The Journal of African History. Cambridge: Cambridge University Press, vol. 7, n. ${ }^{\circ} 3,1966$, pp. 421-422. Para a tradição oral imbangala, sobre as quais Joseph C. Miller aborda apenas as tradições genealógicas na forma de musendo, e os "episódios narrativos chamados malunda", verificar: MILLER, Joseph C. Poder político e parentesco [...]. [1976]. Luanda: Arquivo Histórico Nacional, 1995, pp. 16-17. Sobre a análise de Miller a partir dessas tradições, consultar o capítulo 6 dessa obra. No contexto africanista dos Estados Unidos, parte da base teórica que fundamenta o método de pesquisa voltado à tradição oral foi desenvolvida a partir do pressuposto de que, no alicerce de todas as sociedades, residiria uma "tradição original", ou "fundadora", sobre a qual seriam erguidas as instituições políticas e sociais. Por um lado, essa tradição estimularia a criação de novos dispositivos de legitimação da ordem sociopolítica. Por outro lado, a tradição original é também um aspecto cultural hereditário e perpétuo, estruturante das visões de mundo e ideologias, capaz de fornecer coesão ao corpo social, o que faz com as tradições originais carreguem traços "estruturais", "naturais" e "biológicos" das sociedades. Verificar a primeira obra supracitada de Jan Vansina, p. 2, além da segunda obra, pp. 5-6, 8-9, 31 e 33. Algumas explicações para a fundamentação teórica desse pensamento, em grande medida baseadas em generalizações e leis da biologia, podem ser conferidas especificamente na primeira obra de Vansina supracitada, pp. 7-8, além da segunda, pp. 8-9. Para uma síntese do pensamento, verificar: CURTIN, Philip D. Why People Move. Waco: Baylor University Press, 1995, pp. 67. Sobre a atual reutilização desse método no contexto de pesquisa angolana, verificar: LUANSI, Lukonde. Angola: Movimentos migratórios e Estados pré-coloniais - Identidade nacional e autonomia regional. IN: Angola on the Move: Transport Routes, Communication and History, Berlim, 2003, p. 2. Para mais explicações sobre o funcionamento e interpretação das tradições fundadoras, consultar o capítulo 1 desta dissertação.

${ }^{629}$ As explicações de Joseph C. Miller são demasiadamente extensas para serem resumidas satisfatoriamente aqui. Consultar, de maneira geral: MILLER, Joseph C. Poder político e parentesco [...]. [1976]. Luanda: 
conhecidos pelos oficiais e funcionários da Coroa genericamente pelo nome de "jagas", guardando muitas reciprocidades e equivalências com o contemporâneo grupo étnico “imbangala”. Qualquer um que desbravar as produções científicas de Jan Vansina, Joseph C. Miller e Virgílio Coelho, levadas a cabo a partir de uma análise crítica que mescla as tradições fundadoras com as fontes escritas, notará que as contribuições trazidas por esses pesquisadores são inegáveis. Por mais que muitas indagações ainda permaneçam em aberto, sendo umas delas advinda da clássica controvérsia sobre quem eram os temidos "jagas”, fato é que ainda é cedo para se descartar os esforços e avanços proporcionados por uma historiografia firmada na antropologia histórica. ${ }^{630}$

Sobretudo a partir do século XVII, os bandos jagas-imbangala passaram a lutar ao lado dos exércitos que guerreavam na África Centro-Ocidental, como "soldados mercenários". ${ }^{631}$ Destemidos, violentos e dilapidadores que viviam exclusivamente à base de razias, eles participavam de operações militares em troca da permissão de roubar, pilhar e receber um butim de guerra condizente com o serviço prestado, rendendo-lhes uma fama refletida na tríade violência-razia-errância. Não seria à toa, portanto, que o oficialato autodenominaria as forças militares portuguesas de "quilombo", valendo-se de um termo intimamente ligado à estrutura social interna dos jagas-imbangala como alcunha de autodenominação do exército português. Respaldado na fama dos bandos guerreiros e

Arquivo Histórico Nacional, 1995, capítulo 7. Para breves explicações e resumos do pensamento do pesquisador, verificar: Idem, The Significance of Drought, Disease and Famine [...]. The Journal of African History. Cambridge: Cambridge University Press, vol. 23, n. ${ }^{\circ}$ 1, 1982, pp. 26-27. Ver também: Legitimacy and Political Power [...]. The Journal of African History. Cambridge: Cambridge University Press, vol. 32, n. ${ }^{\circ}$ 1,1991, p. 31.

${ }^{630}$ A grande discussão sobre quem seriam os tais "jagas" ultrapassa os limites desta dissertação. Para uma fórmula sintética para o atual consenso, verificar: CURTIN, Philip D. et. al. African History: From Earliest Times to Independence. [1978]. Edimburgo: Longman Pearson Education, 1995, p. 230. Ela é reafirmada em: VANSINA, Jan. How Societies Are Born [...]. Charlottesville: University of Virginia Press, 2004. Parte relevante do que se escreve atualmente sobre eles derivam dos pretensos relatos de um marinheiro chamado Andrew Battell. Faremos mais considerações a respeito desse homem ao longo deste capítulo. Sobre Battell e os escritos atribuídos aos seus relatos orais, consultar do mesmo autor: On Ravenstein's Edition of Battell's Adventures in Angola and Loango. History in Africa. Nova Jersey: African Studies Association, vol. 34, 2007. Para mais considerações e outros dados relevantes sobre a questão jaga-imbangala, consultar o termo "quilombo", contido no "suplemento para alguns vocábulos africanos" desta dissertação. Recomendamos também a leitura do seguinte texto: HEINTZE, Beatrix. The Extraordinary Journey of the Jaga Through the Centuries: Critical Approaches to Precolonial Angolan Historical Sources. History in Africa. Nova Jersey: African Studies Association, vol. 34, 2007.

${ }^{631}$ Sobre a utilização dos imbangala-jagas como membros integrantes da gente de guerra portuguesa, verificar: THORNTON, John K. Warfare in Atlantic Africa [...]. [1999]. Londres e Nova Iorque: Routledge, 2003, pp. 116-117. Sobre a participação desses grupos durante o tempo de Luís Mendes de Vasconcelos, verificar: THORNTON, John K. A Cultural History of the Atlantic World [...]. Cambridge: Cambridge University Press, 2012, p. 185. 
mercenários, comumente em contato e aliança com as forças militares de Luanda, o empréstimo terminológico se encaixava perfeitamente aos intuitos do quilombo português, engajado com a guerra e a propagação do medo, tal qual o "kilombo". Além disso, como um meio poroso onde vigoravam africanização e aportuguesamento, o quilombo incorporou o hábito de derrubar as palmeiras das aldeias invadidas e devastadas ao longo das marchas da gente de guerra, igualmente como fazia o kilombo imbangala, ${ }^{632}$ além de adotar táticas de guerra locais e absorver quadros militares africanos que, obviamente, lutavam "à maneira da terra". Fica também sugerido que a encomenda de alguns "tololões", entendidos então como barracas e acampamentos temporários, indica uma inclinação ou evocação aos princípios de mobilidade militar do kilombo, além das evidentes praticidade e comodidade que eles forneciam ao deslocamento constante da gente de guerra. No final das contas, a relação entre quilombo-kilombo adverte para a existência de um campo de intermediação de via de mão-dupla, entremeado de empréstimos, incorporações e absorções, com uma diferença fulcral: o quilombo estava interessado na aquisição de escravos exportáveis via Atlântico, ao passo que o kilombo almejava potenciais membros e agregados, associados à estrutura dos grupos guerreiros. ${ }^{633}$

A sobreposição entre formas de dominação e intermediação não se manifestava apenas na estruturação interna mista do quilombo português, ${ }^{634}$ mas também na evocação e

\footnotetext{
${ }^{632}$ A partir de relatos creditados a um marinheiro inglês capturado pelos bandos jagas, Andrew Battell, cuja experiência como prisioneiro foi registrada em algumas "extraordinárias memórias" editadas por Samuel Purchas e, postumamente, reeditadas por Ernst Georg Ravenstein, no início do século XX, Joseph C. Miller escreveu: "Os Imbangala faziam um enorme e generalizado uso do vinho de palma nos seus rituais, decepando as árvores [...] para obter o fruto, que comiam, e o vinho, que bebiam [...]. Os seus destruidores métodos de obter o vinho de palma distinguiam-nos das populações locais, que sangravam as árvores em vez de as deitar abaixo, como faziam os Imbangala". Deduções similares são feitas por Luiz Felipe de Alencastro, a partir da mesma edição de Ravenstein, porém com o interessante adendo de que o "vinho de palma", ou malafo, era extraído de três variedades de palmeiras, a Raphia gentili, a Raphia laurenti - da qual também "tira-se a fibra usada na feitura de tecidos" -, e a Elaeis guineesis, transplantada para a América portuguesa, onde viria a ser popularmente conhecida como "dendezeiro". Verificar: MILLER, Joseph C. Poder político e parentesco [...]. [1976]. Luanda: Arquivo Histórico Nacional, 1995, nota 6, pp. 175-176. Idem, The Significance of Drought, Disease and Famine [...]. The Journal of African History. Cambridge: Cambridge University Press, vol. 23, n. ${ }^{\circ}$ 1, 1982, p. 26. ALENCASTRO, Luiz Felipe de. $O$ trato dos viventes [...]. São Paulo: Companhia das Letras, 2000, pp. 311-312 e nota 265. Ver também: BIRMINGHAM, David. Trade and conflict in Angola [...]. Londres: Clarendon Press/ Oxford University Press, 1966, p. 54.

${ }^{633} \mathrm{~A}$ isso poderia ser adicionado que o quilombo português "emulava" as hierarquias constitutivas dos exércitos do Ndongo, como já salientado. Verificar: THORNTON, John K. Warfare in Atlantic Africa [...]. [1999]. Londres e Nova Iorque: Routledge, 2003, pp. p. 115-116.

${ }^{634}$ Apreciação igualmente feita por Catarina Madeira Santos para o século XVIII. Verificar: SANTOS, Catarina Madeira. Um governo "polido" para Angola [...]. Tese de doutorado, Universidade Nova de Lisboa, 2005, pp. 280, 283-284.
} 
mobilização dele como uma extensão bélica e política de Luanda, empregado na execução de tarefas ligadas à coerção, intimidação, roubo e demonstração da força do aparato ultramarino. Assim, como um instrumento de força direto e indireto, quer dizer, sob a forma de um órgão executivo de coerção, coação, punição e militarização, a utilização do quilombo estava intimamente ligada com a imposição de avassalamento aos sobas, ao saque às aldeias - meio pelo qual a gente de guerra conseguiria o sustento para as longas marchas e cercos aguardados nas jornadas, além da maior parte do lucro angariado após o término do estado de guerra $-{ }^{635}$ e ao confronto direto contra o inimigo, como é possível deduzir do trecho anteriormente separado do extenso relatório. Às formas de domínio diretas e indiretas, poderíamos correlacionar a ofensiva e defensiva militares, igualmente registradas no extenso relatório. Assim, a certa altura dele, Fernão de Sousa escreveu que, como muitos soldados foram alistados no quilombo de guerra, a vigilância dos presídios acabaria delegada aos "extravagantes". ${ }^{636}$ A situação de exceção na guarda da Angola portuguesa duraria até o término das jornadas de guerra contra Ginga Ambande, "pelo muito que convinha ao serviço de El-rei nosso senhor ficar por esta vez obedecendo tudo a sua Coroa [...] [para a] segurança dos baculamentos ${ }^{637}$ que os sobas pagam a sua Real Fazenda", de modo que a "gente de armas" fosse empregada em múltiplas funções, como a vigilância e o guarnecimento dos presídios, a proteção dos sobas "amigos, obedientes e confederados" e a "segurança dos baculamentos que os sobas pagam". 638 Tanto o guarnecimento dos presídios, quanto o ato de "conquistar", implicavam na utilização de instrumentos de força direta e indireta para, internamente, defender a Angola portuguesa de intrusos e insurgências e, externamente, penetrar e "domar" politicamente os sobas que resistissem aos planos de Luanda. Como no xadrez, ou em qualquer jogo de estratégia que

\footnotetext{
${ }^{635}$ Nesse sentido, verificar o breve comentário feito por Beatrix Heintze em: HEINTZE, Beatrix. Angola nos séculos XVI e XVII [...]. Luanda: Kilombelombe, 2007, pp. 491-492.

${ }^{636}$ Os tais "extravagantes" referidos no documento provavelmente diziam respeito a um contingente militar não profissional, utilizado em momentos de apuros. Em termos contemporâneos, eles poderiam ser uma espécie de "milícia", ou corpo de pessoas capazes de empunhar armas e que permaneciam "na reserva". Veja, por exemplo, como Raphael Bluteau definiu o termo "desembargador extravagante" no seu Vocabulário português: "é aquele que não é do número, mas quando é necessário supre o lugar do que faltou, por estar ausente, ou doente". Verificar: BLUTEAU, Raphael. Voc. Port. [1712]. Hildesheim: Georg Olms Verlag, vol. III, 2002, p. 404.

${ }^{637} \mathrm{O}$ sentido lato dessa palavra está relacionado ao pagamento de tributo por parte dos africanos. Logo mais faremos considerações mais profundas sobre o que eram os baculamentos.

${ }^{638}$ Fernão de Sousa. O extenso relatório do governador aos seus filhos. S.d., 1625-1630. BAL, cód. 51-IX20, ff. 220-74v. IN: HEINTZE, Beatrix (coord.). Documento 30, FHA, vol. I, 1985, pp. 260-261.
} 
mimetize a guerra e a política, o sucesso da empreitada militar girava em torno das relações entre defesa, ofensiva e recrudescimento militares.

Não muito depois de discorrer sobre o plano de travessia do Lucala, Fernão de Sousa inseriu no extenso relatório uma cópia de uma carta enviada ao capitão-mor Bento Banha Cardoso, datada de 5 de março de 1627. Nela, cujo original não se encontra na $F H A,{ }^{639}$ o governador afirmou que havia recebido uma mensagem do comandante do quilombo, na qual avisava que enfim as tropas haviam cruzado o Lucala. Em virtude da notícia, o governador desejou "bom sucesso que sem dano fiquem essas províncias obedientes", adicionando uma série de recomendações sobre como o capitão-mor deveria proceder em relação aos sobas de além-Lucala. Primeiramente, caso o militar encontrasse sobas inimigos em algures, enviar-lhes-ia "recado [para] que obedeçam, e não o fazendo declare-os por rebeldes" através da escrita de alguns "autos [...] e de suas respostas com que justificará Vossa Mercê [Bento Banha Cardoso], a guerra, e a razão de obedecer”. Caso aceitassem "ser obedientes", o capitão-mor deveria perguntar "o que querem pagar por sua livre vontade de baculamento cada ano a Sua Majestade, de que se farão autos”. O tal "baculamento" citado por Fernão de Sousa dizia respeito à tributação única e oficial que, durante o seu governo, passaria a ser arrecadada de maneira "legítima", através do envio de um "baculador" às terras dos sobas vassalos ou da visita de um "quilamba" a Luanda. Derrogava-se com isso a recebimento, pelos menos oficialmente, de outras formas de taxação tradicionalmente aceitas pelos funcionários e oficiais régios, baseado em tributos seculares cobrados entre os mbundu, denominados "loandas", "infutas" e "vestir". ${ }^{640}$ Seja como for, pagando corretamente os baculamentos, Bento Banha Cardoso não faria guerra aos sobas, prometendo-lhes em troca "Vossa Mercê em nome de Sua Majestade favor, e ajuda contra seus inimigos, estando em sua obediência". ${ }^{641}$

Os trechos da carta de março de 1627 que foram inseridos no extenso relatório são provas de que, em nome da obediência das chamadas "províncias", o capitão-mor Bento

\footnotetext{
${ }^{639}$ Haveria de fato um original? Algumas pistas sobre a veracidade dessas informações podem ser procuradas em: Fernão de Sousa. Carta de Fernão de Sousa ao governo. 26 de junho de 1626. BAL, cód. 51-IX-20, f. 332v. IN: HEINTZE, Beatrix (coord.). Documento 71, FHA, vol. II, 1988, p. 158. Fernão de Sousa. Carta de Fernão de Sousa ao governo. BAL, cód. 51-IX-20, ff. 333-33v. IN: HEINTZE, Beatrix (coord.). Documento 72, FHA, vol. II, 1988, pp. 159-160.

${ }^{640}$ Sobre definições e mais considerações a respeito desses termos, consultar o "suplemento para alguns vocábulos africanos" desta dissertação.

${ }^{641}$ Fernão de Sousa. O extenso relatório do governador aos seus filhos. S.d., 1625-1630. BAL, cód. 51-IX20, ff. 220-74v. IN: HEINTZE, Beatrix (coord.). Documento 30, FHA, vol. I, 1985, pp. 276-277.
} 
Banha Cardoso poderia utilizar o quilombo a fim de forçar a submissão política e o cumprimento das condições de vassalagem impostas aos sobas. Dessa forma, os arcabuzes e as flechas poderiam ser empregados tanto para expandir a rede de fidelidade política encabeçada por Luanda, quanto para promover a estabilidade política interna, necessária à manutenção de uma rede de sobas designada amorfamente de "vassalos, amigos e confederados". Seja através da imposição da vinculação política, seja por meio de atos de coerção e intimidação dos sobas de além-Lucala, a esses africanos restavam três opções: ficar à mercê das diretrizes estabelecidas pelos mecanismos de controle e fiscalização dos portugueses, não se render e partir para batalha ou fugir. Similar tendência de utilização dos instrumentos de força é reiterada em uma carta escrita por Fernão de Sousa aos seus superiores, em 2 de agosto de 1627. Há nesse documento dois núcleos de apelo que não aparecem, ou que foram omitidos, no extenso relatório. Um será esclarecido desde já, o outro retomaremos mais para frente, no terceiro item deste capítulo. Na correspondência de agosto de 1627, o governador reiterou que Bento Banha Cardoso fora ordenado a postar o quilombo entre "os inimigos [da Coroa] com ordem que recebesse os [sobas] obedientes e suas culpas pagando os tributos que deviam, e aos que não estavam obrigasse a declarar, o que poderiam pagar por sua livre vontade na forma de meu Regimento". ${ }^{642}$ Partindo desse tópico, portanto em respeito ao regimento que Fernão de Sousa recebera do monarca, embora violador do princípio de justiça de guerra, seriam repetidas ao longo do documento diversas frases que camuflavam a urgência e violência empregadas - "obrigasse a declarar", "pelos meios necessários” e outras - na cobrança de baculamentos e imposição de vassalagem aos sobas. Indubitavelmente, a "máquina de guerra"643 serviria tanto para submeter os "inimigos", ou sobas contrários aos interesses de Luanda, quanto para cobrar tributos dos sobas obedientes, com base na coerção.

\footnotetext{
${ }^{642}$ Fernão de Sousa. Carta de Fernão de Sousa ao governo. 2 de agosto de 1627. BAL, cód. 51-IX-20, ff. 338-339. IN: HEINTZE, Beatrix (coord.). Documento 95, FHA, vol. II, 1988, p. 184. Segundo Beatrix Heintze, (nota 385, p. 184) trata-se do regimento datado de 20 de março de 1624 e que fora entregue a Fernão de Sousa em decorrência do seu envio ao além-mar. Consultar: Filipe III de Portugal [feito por António Correa e escrito por Cristovão Soares]. Regimento do governador de Angola. 20 de março de 1624. BAL, cód. 51-IX-20, ff. 7-11. IN: HEINTZE, Beatrix (coord.). Documento 4, FHA, vol. I, 1985, pp. $140-153$. Conferir especificamente: $\S 8$, p. 145 .

${ }^{643}$ Trata-se de um empréstimo que fizemos de Catarina Madeira Santos. Verificar, especialmente: SANTOS, Catarina Madeira. Um governo "polido” para Angola [...]. Tese de doutorado, Universidade Nova de Lisboa, 2005, pp. 284-285 e 291.
} 
O belicismo e o avassalamento eram matérias intimamente conectadas à maneira com a qual o funcionalismo régio e os órgãos institucionais portugueses conduziam oficialmente, portanto de maneira formal e respaldada em leis, o contato entre portugueses e africanos, colaborando para a criação de uma rede de fidelidade política encabeçada pelos representantes do monarca português no além-mar. A atuação desses representantes da monarquia frente à condução dos contatos estava também associada à implementação de um mando político e uma ordem jurídica baseados na gestão dos sobas vassalos, por um lado, e na coerção e coação dos sobas "indóceis", "levantados" ou que simplesmente não se curvariam aos planos de Luanda, por outro lado. O episódio das duas margens do Lucala não é um reflexo isolado do expansionismo português, mediante o qual ocorria a utilização de instrumentos de forças direta e indireta, de maneiras sobrepostas entre si e misturando ofensiva a defensiva militar. Se havia um ponto de concatenação entre os três atos elementares da fidelidade política enunciados no começo deste item - avassalar, pacificar e conquistar - é que aqueles que estivessem na mira de Luanda estavam igualmente à mercê da máquina de guerra portuguesa, ou seja, de um "tratamento" capaz de articular o funcionamento de ambivalências que hoje nos parecem estranhas e dissociáveis, mas que na época funcionavam muito bem em conjunto: guerrear e policiar, expandir e proteger. ${ }^{644}$

No final das contas, o quilombo português era uma extensão bélica e política de Luanda. Era movido por interesses econômicos, de múltiplos agentes interessados no tráfico de escravos atlântico, como também por interesses ligados à carreira institucional, mediante a qual o "bom serviço ao monarca" rendia possibilidades de promoções dentro dos quadros do oficialato e funcionalismo régios. Necessariamente, as grandes mobilizações de guerra estavam respaldadas em discussões legais, obrigatórias para a legitimação institucional da empreitada. Nesse caso, um dos princípios mais evocados era o

\footnotetext{
${ }^{644}$ Empregamos o termo "policiar" no sentido de ações respaldadas na justiça e que visavam à coerção interna de membros da Angola portuguesa, portanto inerentes a um espaço jurisdicional e ultramarino, reivindicado como estando sob o comando de Luanda e, por consequência, da monarquia portuguesa. Assim sendo, e utilizando alguns dos termos levantados por Catarina Madeira Santos, mas divergindo dela em algumas considerações, aventamos que é possível fazer uso de uma noção de "polícia", refletida obrigatoriamente na "justiça" e em uma "arte de governo" dos séculos XVI e XVII, desvirtuando-a da ideia de uma obrigatória invenção iluminista, atada à disciplina e ao saber da "ciência política", como advoga a pesquisadora. Como prática e ideia, a "polícia" era operante desde há muito tempo, acabando por ser incrementada e reconfigurada ao longo dos anos e dos espaços. Verificar: SANTOS, Catarina Madeira. Um governo "polido" para Angola [...]. Tese de doutorado, Universidade Nova de Lisboa, 2005, pp. 26-28. A própria pesquisadora não deixa de ressaltar, especificamente na nota 48 da p. 28, que o conceito de "polícia" preexistia nos escritos atribuídos a Aristóteles.
} 
de justificação de avanço militar, com base na "guerra justa". O decreto de guerra oficial necessitava do acionamento de todo um saber jurídico e de uma ampla confluência de interesses regionais, além de discursivamente levantar uma série de motivações por escrito, enviadas às autoridades competentes residentes em Portugal, a fim de convencê-las da necessidade de interferência militar. Assim, para todos os "males" e indolências africanas, poderia ser sustentado um tratamento dos sobas baseado na utilização da máquina de guerra, representado nos documentos inseridos na $F H A$ por termos análogos a "castigos", "amparos", "socorros" e "remédios". Resumidamente, tal qual uma panaceia para todos os malefícios, o quilombo poderia ser usado como uma solução para as generalizadas desestabilizações advindas dos contatos e, inserido no extenso relatório de Fernão de Sousa, como se fosse um receituário médico, havia normatizações e prescrições sobre como empreender o "correto" uso da máquina de guerra, em prol da governança da Angola portuguesa. Tal tendência acabaria evocada ao longo das mobilizações militares levadas a cabo entre 1626 a 1627, como vimos aqui, e igualmente reapareceria em um episódio que marcou o retorno da segunda campanha de guerra, como veremos no próximo item.

\subsection{O regresso da segunda jornada contra Ginga Ambande (1628-1629)}

Em 21 de julho de 1627, Bento Banha Cardoso regressou a Luanda, dando cabo à primeira jornada contra Ginga Ambande. Pouco tempo depois, em fins de 1627, o militar português partiu para Massangano, onde iniciou os preparativos para a segunda investida contra a africana. Por mais de um ano Bento Banha Cardoso juntou recursos, pessoas e apoio político necessários para reconstituir a máquina de guerra, em um longo e vão processo de desgaste pessoal e que, dizia o povo, drenou soma considerável de seus recursos pessoais. O desfecho de tudo não seria favorável ao experiente capitão-mor português, que acabou acometido por enfermidades e faleceu em 3 de agosto de $1628 .{ }^{645} \mathrm{O}$

\footnotetext{
${ }^{645}$ HEINTZE, Beatrix (coord.). Apêndice: Tabela Cronológica, 1618-1630. FHA, vol. I, 1985, pp. 395-396. Cerca de dois anos antes, em 12 de outubro de 1626, a varíola, uma doença altamente contagiosa e chamada na época popularmente de "bexigas", levara a óbito Aire Aquiloange. Antes dele, Garcia I, "rei exilado do Kongo", também havia morrido por causa desse mal. Segundo Beatrix Heintze, na década de 1620 ocorreu uma "eclosão", ou surto, da doença na região, retardada apenas em Quindonga devido ao seu isolamento. Outro tipo de doença comum na região eram algumas febres endêmicas, conhecidas como "calenturas", que vitimavam muitos estrangeiros que não tinham imunidades contra elas. Verificar: MILLER, Joseph C. The Significance of Drought, Disease and Famine [...]. The Journal of African History. Cambridge: Cambridge University Press, vol. 23, n. ${ }^{\circ}$ 1, 1982, p. 23. HEINTZE, Beatrix. Angola nos séculos XVI e XVII [...]. Luanda: Kilombelombe, 2007, pp. 351.
} 
comando da segunda investida militar passou ao português Paio de Araújo de Azevedo, nomeado para a função de capitão-mor, em 23 de agosto desse mesmo ano. Meses depois, no dia 9 de setembro de 1628, ele partiu de Luanda, atravessando o continente por mais de oito meses, seguindo os rastros de Ginga Ambande. Paio de Araújo de Azevedo levava a ordem de capturar a líder mbundu a qualquer preço, porém não logrou êxito. Contando com o apoio dos povos de além-Lucala até a Quina Grande, ${ }^{646}$ montando escaramuças e despistando o quilombo português, Ginga Ambande acharia refúgio, pelo menos temporariamente, nas longínquas terras dos "Songas", povos afamados por comer carne humana. Paio de Araújo de Azevedo se deu por satisfeito e regressou a Luanda em 8 de novembro de 1629 , após certos contratempos enfrentados na viagem de volta. ${ }^{647}$

Um desses contratempos ocorreu em 1629, em um episódio que se desenrolou dentro de um período de cerca de três meses e meio, dividido em duas etapas importantes. Em algum momento da marcha de volta para Luanda, entre junho e junho de 1629, o quilombo português fez uma parada no Ndongo, onde possivelmente permaneceu por volta de um mês. A seguinte etapa seria o planejamento da transferência da gente de guerra para junto de Tango Angonga. De acordo com os fragmentos de informações que dispomos na $F H A$, tudo pareceu ocorrer da seguinte forma. Em 24 de agosto de 1629, Fernão de Sousa escreveu uma ordem a Paio de Araújo de Azevedo, afirmando que não havia consenso na Câmara de Luanda, nem ordem régia havia chegado de Portugal, sobre o que fazer com o quilombo de guerra após o desaparecimento de Ginga Ambande no interior continental. Efetivamente, a perseguição contra ela se encerraria em decisão tomada entre maio e junho de $1629 .{ }^{648}$ A partir dos meses seguintes, entre julho e agosto de 1629, a indecisão institucional giraria em torno de duas opções a serem tomadas, o desmanche imediato do quilombo, ou o aproveitamento do exército em outras missões. Somado a isso, havia um detalhe relevante. Fernão de Sousa acreditava que o quilombo apenas prestava para

\footnotetext{
${ }^{646}$ A "Quina Grande" foi o último ponto de referência geográfico descrito por Paio de Araújo de Azevedo durante a perseguição. Verificar: HEINTZE, Beatrix (coord.). Apêndice: Tabela Cronológica, 1618-1630. FHA, vol. I, 1985, p. 396.

${ }^{647}$ Ibidem, pp. 395-396. Estariam os observadores da época se referindo ao atual grupo étnico "songo"?

${ }^{648}$ Lembrando que dois eventos competem para a estipulação desse período. O primeiro é o da captura das irmãs de Ginga Ambande, acontecida em maio de 1629. O segundo evento é o da chegada das irmãs Ambande, Maria Cambo e Gracia Funge, em Luanda, no dia 20 de julho de 1629. Em algum momento desse período, que variou de três a quatro meses, Paio de Araújo de Azevedo ordenou o regresso das tropas. Verificar: HEINTZE, Beatrix (coord.). Apêndice: Tabela Cronológica, 1618-1630. FHA, vol. I, 1985, p. 396.
} 
"oprimir" e causar as chamadas "vexações" e "desmandos" contra os locais ${ }^{649}$ ficando então subentendido que as tropas estavam ultrajando as morindas e quizicos do Ndongo, com ações que poderiam variar do pequeno furto ao molestamento de pessoas. Assim sendo, e a despeito das indecisões institucionais existentes em Luanda e Lisboa, para que os soldados não ficassem "desocupados" e salientando a Paio de Araújo de Azevedo que "as melhores certidões para Sua Majestade lhe fazer mercê hão de ser" a de cobrança de alguns baculamentos devidos, Fernão de Sousa ordenou ao capitão-mor para que ele deslocasse o exército português "por onde haja mantimento de inimigos afastando-se do Ndongo e dos sobas amigos". ${ }^{650} \mathrm{O}$ fisco régio ganharia o triplo com isso, promovendo a harmonia política com os vizinhos, explorando as fazendas locais através da intimidação política e difundindo a "disciplina" e os "bons modos" entre os sobas de aquém e além Lucala.

De acordo com o planejamento de Fernão de Sousa, o quilombo de guerra português deveria ser postado "no alto de Tango Angonga", de onde exploraria os "bambes de Matamba", quer dizer, "os limites" da Matamba com o Ndongo, através do envio de recados aos sobas "de uma e de outra banda" dos rios Loando ou Lucala, para que eles pagassem os baculamentos devidos. ${ }^{651}$ Tal intuito era uma repetição do que havia sido arquitetado entre 1626 e 1627, ainda no tempo em que Bento Banha Cardoso comandava o quilombo, medida essa, vale lembrar, fundada em uma tendência institucional de utilização de instrumentos de força direto e indireto, a fim de atender às demandas e interesses daqueles interessados na arregimentação e mobilização da gente de guerra, conforme vimos no item anterior. Nesse sentido, a fim de diminuir os distúrbios trazidos pelas campanhas de guerra e prevenir novas insurgências, Fernão de Sousa frisou a Paio de Araújo de Azevedo para que ele "não obrigue aos que mandarem pagar a ir em pessoa ao quilombo por se não homiziarem[,] mas segurando-os na amizade, e na obediência pelos não consumir com guerra”. Cético quanto aos escrúpulos dos soldados e temeroso quanto às possibilidades de novas revoltas, que poderiam estremecer as relações com o Ndongo e se alastrar para Matamba, nenhum representante de soba deveria visitar a gente de guerra postada em

\footnotetext{
${ }^{649}$ Fernão de Sousa. Ordem de Fernão de Sousa a Paio de Araújo de Azevedo. 24 de agosto de 1629. BAL, cód. 51-IX-21, ff. 282-82v. IN: HEINTZE, Beatrix (coord.). Documento 204, FHA, vol. II, 1988, p. 306. 650 Fernão de Sousa. Ordem de Fernão de Sousa a Paio de Araújo de Azevedo. 24 de agosto de 1629. BAL, cód. 51-IX-21, ff. 282-82v. IN: HEINTZE, Beatrix (coord.). Documento 204, FHA, vol. II, 1988, p. 306.

${ }^{651}$ Para mais informações sobre o termo "bambe", consultar o "suplemento para alguns vocábulos africanos", fornecido nesta dissertação.
} 
Tango Angonga, sendo que os pagamentos de baculamento deveriam ser despachados diretamente para Luanda, por intermédio de "uma quilamba". ${ }^{652}$

Imagem 11: A incursão do quilombo português e alguns pontos de referência ${ }^{653}$

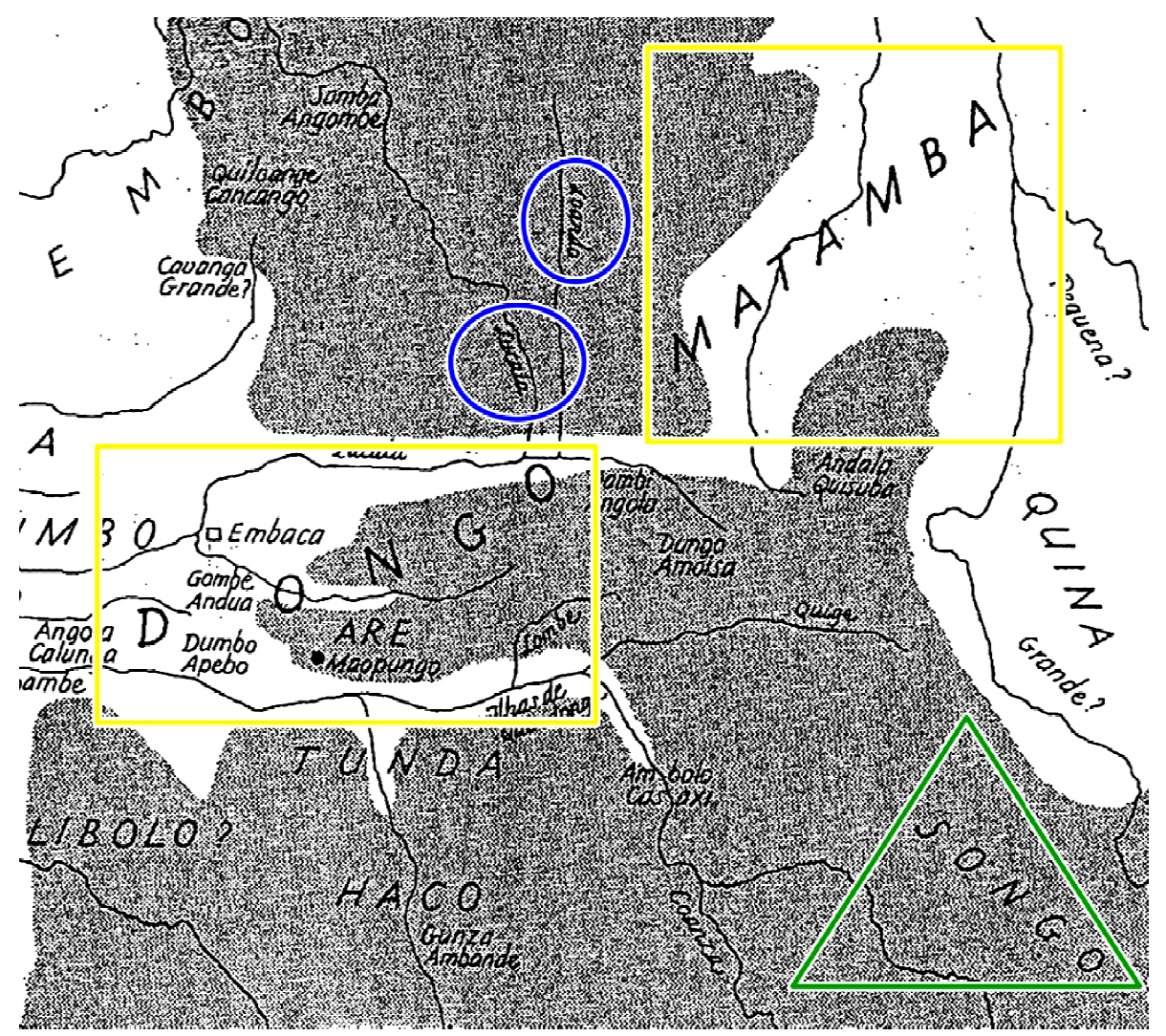

Legenda: $i$ ) Os quadrângulos em dourado indicam os dois reinos africanos citados na documentação; ii) As circunferências destacam dois rios que separam o Ndongo de Matamba; iii) $O$ triângulo esverdeado marca a hipotética localização de Ginga Ambande após 1629.

Admoestando o capitão-mor, Fernão de Sousa ordenou-lhe que desistisse da "vexação que faz aos sobas vassalos desta banda [de Angola] porque se resolveu pelo Senhor Bispo, e padres da Companhia [de Jesus] se the não pode dar guerra antes de fazer com ele esta diligência em que consiste a razão de ser justa". Aqui há um dado de suma importância. Havia uma tensão entre as posições do administrador régio, desejoso pela "pacificação" da região, e Paio de Araújo de Azevedo, capitão-mor que relutava em abaixar as armas, provavelmente por lucrar com os saques e pilhagens conseguidos no Ndongo. Tal

\footnotetext{
${ }^{652}$ Fernão de Sousa. Ordem de Fernão de Sousa a Paio de Araújo de Azevedo. 24 de agosto de 1629. BAL, cód. 51-IX-21, ff. 282-82v. IN: HEINTZE, Beatrix (coord.). Documento 204, FHA, vol. II, 1988, p. 306.

${ }^{653}$ A imagem que segue abaixo foi modificada a partir de: HEINTZE, Beatrix (coord.). Fig. 2: Ndongo e regiões circunvizinhas na época de Fernão de Sousa (ortografia da fonte), FHA, vol. I, 1985, p. 6.
} 
qual Bento Banha Cardoso, a trajetória de vida de Paio de Araújo de Azevedo chama a atenção pela paulatina ascensão social após o estabelecimento no ultramar, mediante a um currículo oficial preenchido por cargos administrativo-militares, por um lado, e pelo acúmulo de cabedal ligado ao espaço atlântico, como terras e escravos, por outro lado.

Residente na África desde 1602, quando aportara em Luanda junto do governador João Rodrigues Coutinho, o português Paio de Araújo de Azevedo ocupou diversos cargos a serviço do aparato ultramarino, dentre eles o de "capitão lugar-tenente" em 1606 e juiz ordinário em 1623. Veio depois a obter o título honorífico de capitão-mor, sem contudo exercer nenhum ofício à altura da honraria. ${ }^{654}$ Por volta do verão de 1625 , foi nomeado “ouvidor geral, provedor da fazenda, da comarca, das causas do mar, e juiz dos órfãos” e, em 1627, foi "auditor da guerra" da primeira campanha contra Ginga Ambande. Homem experiente na terra e ativo na vida política da Câmara de Luanda, Bento Banha Cardoso era bastante estimado por Fernão de Sousa, que o considerava o "mais honrado morador de Luanda". ${ }^{655}$ Foi considerado apto para concorrer à sucessão de Manuel Cerveira Pereira, quando esse morreu e deixou vago o governo de Benguela, em 1627. Não recebeu a governadoria, mas graças ao apreço que detinha nos círculos de influência em Luanda, como também devido às fazendas que possuía e que poderiam ser empreendidas na montagem da máquina de guerra portuguesa, no ano seguinte seria encarregado da segunda campanha contra Ginga Ambande, que no final das contas lhe rendeu ainda mais "glórias", escravos e outras riquezas, materiais e imateriais. ${ }^{656}$ No mais, não seriam menos desinteressadas as suas insistências em permanecer no Ndongo: lá havia mercados de escravos e circulação de fazendas que poderiam ser negociadas - por valores nem sempre justos, é preciso lembrar - ou simplesmente roubadas.

A breve visita à vida pública de Paio de Araújo de Azevedo permite depreender um traço que aqui nos é caro. Ao negar a inclinação que até então demonstrava pelos cargos judiciários e funções administrativas - a maioria obtida durante a sua carreira, como se nota acima, pelo menos até meados de 1628 - para assumir o comando do quilombo de guerra -

\footnotetext{
${ }^{654}$ Não temos a data exata da nomeação, mas graças a Beatrix Heintze se sabe que ocorreu antes da chegada de Fernão de Sousa em Luanda.

${ }^{655}$ Nos termos de Beatrix Heintze, Paio de Araújo de Azevedo era "morador de Luanda e possuía aqui, ou muito perto, 'senzalas' (pequenas aldeias) o que significa, provavelmente, que vivia aí um numero considerável dos seus escravos".

${ }^{656}$ HEINTZE, Beatrix. Breves biografias de alguns europeus em Angola (1620-1630). FHA, vol. I, 1985, pp. 73-74.
} 
ele poderia ter pleiteado por Benguela ou simplesmente abandonado a direção do quilombo -, o capitão-mor declinara de posições que mais trariam crédito ao seu nome - como o de juiz ou mesmo a de ouvidor-geral, que no geral eram mal remunerados, apesar de relevantes - para adquirir mais benefícios materiais advindos de butins, saques ou de roubos infligidos contra os sobas do Ndongo, Matamba e Tango Angonga. Também é importante notar que, se a partida das jornadas de guerra costumava ser onerosa aos cofres régios e aos bolsos daqueles que apostavam na empreitada bélica, o retorno era lucrativo, sendo possível também depreender, através da interpretação documental, que havia uma ordem lógica entre a primeira jornada de guerra contra Ginga Ambande - ocorrida entre fevereiro de 1626 a julho de 1627 , aparentemente mais voltada ao avassalamento de sobas "por todas as formas" possíveis - em relação à segunda - ocorrida entre setembro de 1628 a novembro de 1629, definitivamente mais direcionada para a cobrança de baculamentos de sobas vassalos e não-vassalos -, entregando que o quilombo regressaria a Luanda abarrotado de fazendas, de proveniências diversas, mas principalmente mbundu. ${ }^{657}$ Assim sendo, o aceite pessoal de Paio de Araújo de Azevedo era óbvio. Ele indicava que, em meados de 1628, o capitão-mor já apostava em um tipo de enriquecimento inserido nos moldes atlânticos, intimamente ligado à guerra e angariação de fazendas, principalmente escravos. Na ótica institucional, a entrega da direção da máquina de guerra a esse português também foi premeditada. De grandes proporções e onerosa, a armação do quilombo necessitava do investimento de pessoas interessadas na empresa bélica e que acumulassem experiência na terra, soubessem lidar com os mbundu e que conhecessem os "atalhos" para a legitimação da justiça de guerra. Em 1628, Paio de Araújo caía como uma luva para os anseios do governador.

Em contrapartida, o revés viria no ano seguinte, quando os interesses do capitãomor passariam a divergir dos de Fernão de Sousa, como sugere sutilmente a correspondência de agosto de 1629 . A própria consulta que o governador afirmou ter feito

\footnotetext{
${ }^{657}$ Por mais que sejam pouco precisos e que suscitem discussão, a julgar pelos números e evidências europeias mais recentes sobre o comércio oficial de escravos, o volume de escravos abarrotados apenas em tumbeiros portugueses, durante o período compreendido entre 1601-1650, foi muito maior do que nos períodos precedentes e mesmo posteriores, pelos menos até 1726-1750. Esses levantamentos também indicam que o período de maior volume de pessoas comercializadas via Atlântico se confundiu com o de guerras generalizadas pela África Centro-Ocidental. Sobre os números, verificar as tabelas fornecidas em: ELTIS, David; BEHRENDT, Stephen D.; RICHARDSON, David. A participação dos países da Europa e das Américas no tráfico transatlântico de escravos: novas evidências. Afro-Ásia. Salvador: Universidade Federal da Bahia (UFBA), n. ${ }^{\circ} 24,2000$, pp. 39 e 49.
} 
ao bispo de Angola, autoridade regional máxima do padroado secular, e à Companhia de Jesus, detentora de um colégio em Luanda e especialista no direito político-eclesiástico da época, não foi despretensiosa. ${ }^{658}$ Visava reforçar uma posição contrária à do capitão-mor que, ao incursionar no Ndongo, atravancava a "paz" regional. Aliás, a utilização do apoio eclesiástico abarcava ainda um segundo aspecto de importância. Às avessas do que aconteceu entre 1626 a 1627, durante a travessia do Lucala, como também ao longo de todo o ano de 1628, no qual as batalhas não tiveram trégua, a partir de agosto de 1629 algumas autoridades régias e eclesiásticas chegaram ao consenso de que o estado de guerra deveria cessar imediatamente, à revelia da posição de Paio de Araújo de Azevedo. ${ }^{659} \mathrm{O}$ episódio do estacionamento do quilombo no Ndongo sinalizava para uma mudança na atitude institucional de Fernão de Sousa, sobretudo no que dizia respeito à penetração exploratória do continente sob a "legítima" perseguição evocada contra Ginga Ambande. A partir de então, o governador passou a ver com desinteresse o estado de guerra que perdurava quase que ininterruptamente desde 1626. Um motivo que explica essa mudança advinha do pavor régio que se tinha em relação ao agravamento das contrarreações promovidas por Angola Aire e seus aliados, ${ }^{660}$ como abordado no capítulo anterior. ${ }^{661}$ Outro aspecto relevante derivava das esperanças que Fernão de Sousa semeava de retornar o quanto antes a Portugal - o tempo de serviço de cada governador durava em média três anos e, por isso, o prognóstico era o de que o mandato de Fernão de Sousa expirasse no ano seguinte, como de fato ocorreu -, desejo que o inquietava e fazia que com ele atonicamente revertesse o estado de guerra em vigor entre 1626 a 1629, de modo a criar uma pretensa "paz" na

\footnotetext{
${ }^{658}$ Sobre as "doações à Sociedade de Jesus", ainda no tempo de Paulo Dias de Novais e as mais bem documentadas que se tem notícia, Beatrix Heintze escreve: "As suas propriedades tinham frequentemente dimensões consideráveis; um dos chefados dos Jesuítas, entendia-se, por exemplo, desde o Lukala até ao Zenza. Outros espalhavam-se pelas duas margens do Kwanza, ao longo do Zenza, na província da Ilamba, na confluência do Lukala com o Kwanza, na província de Musseque e na Ndongo junto ao Lutete". HEINTZE, Beatrix. Angola nos séculos XVI e XVII [...]. Luanda: Kilombelombe, 2007, p. 254.

${ }^{659}$ Como veremos mais para frente, em meados de 1627 alguns representantes da Companhia de Jesus já haviam se desentendido com Fernão de Sousa, discordando da necessidade de se perpetuar o estado de guerra então vigente.

${ }^{660}$ Nelas eram feitas acima de tudo inquéritos, registrados por um sindicante, além de executadas algumas tarefas extrajudiciais. Sobre o funcionamento da sindicância, consultar o item 3 do capítulo 2 desta dissertação.

${ }^{661} \mathrm{O}$ acirramento dos desentendimentos entre Angola Aire e Paio de Araújo de Azevedo ocorreu principalmente após o episódio conhecido como o da "queima do quilombo", momento no qual o capitão-mor chamou o rei africano de "cão", despertando a ira deste. Verificar: Paio de Araújo de Azevedo [traslado feito por Sebastião Tavares Saraiva]. Auto da entrega das duas companhias a Henrique de Magalhães. 16 de outubro de 1629. BAL, cód. 51-IX-20, ff. 446-47v. IN: HEINTZE, Beatrix (coord.). Documento 208. FHA, vol. II, 1988, p. 313.
} 
Angola portuguesa, encarecidamente encomendada por Filipe III de Portugal no regimento de 1624 destinado ao governador. ${ }^{662}$

Decidido a persuadir Paio de Araújo de Azevedo a esquecer do Ndongo, Fernão de Sousa levantou a hipótese de executar uma "diligência ${ }^{663}$ [...] para tirar a verdade dos fatos", ou seja, para determinar se a justiça de guerra estava sendo respeitada. Assim, inquéritos seriam recolhidos e analisados. A partir do material coletado em campo, Fernão de Sousa frisou que ficaria a cargo do "Senhor Bispo [...] constatar as razões" de guerras, a fim de determinar a "justiça" que as circunscreviam. A ratificação dessa autoridade era um fator de suma importância, podendo "deslegitimá-las" ou “desautorizá-la”, residindo nas entrelinhas dessas palavras uma sutil ameaça de Fernão de Sousa: se insistisse nos desmandos, Paio de Araújo de Azevedo teria que se acertar com o bispo. Isso nos remete a uma consideração mais relevante. Os parcos registros históricos analisados neste e no próximo item atestam para a existência de uma ala eclesiástica que participava ativamente de conluios e discussões acerca dos planos políticos que seriam orquestrados em âmbito regional e local, podendo cooperar ou rivalizar com o funcionalismo régio, no que dizia respeito à tutela política das soberanias africanas, agora sob a forma da vassalagem. Representadas por duas instituições de peso, a Companhia de Jesus e o Bispado do Congo e Angola, os integrantes dessa ala eclesiástica são reconhecidos na $F H A$ por meio de enquadramentos funcionais, um hierarquicamente mais alto, representado pelo reitor do colégio jesuíta de Luanda e o bispo de Congo e Angola, e outro mais baixo, representado amorfamente por padres e jesuítas. À guisa da divisão proposta no conjunto documental, portanto mantendo-nos fiéis aos escritos de época, aqui chamaremos esse grupo sociopolítico, ligado à disseminação da fé católica e prestigiado pela seara institucional de Fernão de Sousa, genericamente como agentes eclesiásticos. ${ }^{664}$ Eles eram sujeitos importantes na mediação institucional ultramarina e sustentavam o papel de conhecedores da lei, colaborando com o funcionamento do espaço jurisdicional português e figurando

${ }^{662}$ Dom Diogo de Castro [escrito por Antonio Correa, sob ordem de Cristovão Soares]. Regimento do governador de Angola. 20 de março de 1624. BAL, cód. 51-IX-20, ff. 7-10. IN: HEINTZE, Beatrix (coord.). Documento 4, FHA, vol. I, pp. 140-153.

${ }^{663}$ Fernão de Sousa. Ordem de Fernão de Sousa a Paio de Araújo de Azevedo. 24 de agosto de 1629. BAL, cód. 51-IX-21, ff. 282-82v. IN: HEINTZE, Beatrix (coord.). Documento 204, FHA, vol. II, 1988, pp. 306307.

${ }^{664}$ Paradoxalmente à importância que detinham como engrenagens do sistema, especialmente os jesuítas incitavam a discórdia e conflitavam muitas vezes com os demais agentes, como abordaremos no próximo item. 
como peças auxiliares na construção de uma rede de fidelidade política incentivada por Luanda, além é claro de serem úteis na intermediação dos contatos, participação nos conselhos citadinos e na consulta de processos legais. Dissociada da ala eclesiástica, figuravam como membros de uma ala régia dois sujeitos de importância, o governador em Luanda e o capitão-mor do quilombo estacionado no Ndongo. O primeiro era o representante de maior destaque de um enquadramento institucional, ao qual chamaremos de agentes reinóis. O segundo, integrante de peso no cenário político da Angola portuguesa, pode ser enquadrado institucionalmente como um agente colonial. ${ }^{665}$

Havia internamente e entre essas alas uma série de tensões sociais e atritos institucionais. Como uma espécie de tabuleiro, no qual a arma do jogo eram discursos e retóricas, a busca por resoluções sociopolíticas na Angola portuguesa encontrava respaldo no acionamento de uma arena político-jurídica, composta por círculos de interesse e sociabilidade integrados por Fernão de Sousa, Bento Banha Cardoso, Paio de Araújo de Azevedo, os jesuítas e o bispo. Cada um desses atores tinha interesses e vontades fundados nas formas de ascensão social, ora pendentes para o Atlântico, ora para a Península Ibérica. ${ }^{666}$ Irrequieto quanto à existência dessas disputas e rivalidades e conhecedor das regras do jogo - "a política é feita de ações e as ações são movidas por interesses",

\footnotetext{
${ }^{665}$ Faremos mais considerações sobre esses agentes na parte final deste capítulo. As noções de agentes reinóis e coloniais encontram respaldo nas ideias de "homem ultramarino" e "homem colonial", guardadas as devida diferenças, apresentados por Luiz Filipe de Alencastro da seguinte forma: "o primeiro faz sua carreira no ultramar buscando lucro, recompensas e títulos desfrutáveis na corte. O segundo circula em diversas regiões do Império, mas joga todas as suas fichas na promoção social e econômica acumulada numa determinada praça, num enclave colonial que às vezes não o viu nascer mas onde possui bens, herdeiros e tumba reservada". Verificar: ALENCASTRO, Luiz Felipe de. O trato dos viventes [...]. São Paulo: Companhia das Letras, 2000, pp. 103-104. Ver também as considerações feitas em: BICALHO, Maria Fernanda Baptista. Conquista, Mercês e Poder Local. A nobreza da terra na América portuguesa e a cultura política do Antigo Regime. Almanack Braziliense. São Paulo: Universidade de São Paulo (USP)/ Instituto de Estudos Brasileiros (IEB), n. ${ }^{\circ}$ 2, novembro de 2005, pp. 21-34, nota 44, p. 33. CUNHA, Mafalda Soares da. Governo e governantes do Império português do Atlântico (século XVII). IN: BICALHO, Maria Fernanda Baptista; FERLINI, Vera Lúcia Amaral (org.). Modos de governar: idéias e práticas politicas no Império português, séculos XVI-XIX. São Paulo: Alameda, 2005, pp. 79-81. Ao analisar a "sociedade colonial", Georges Balandier destacou o importante papel de "facções" e "clãs" que existiam no seio da "sociedade colonial" - os "administrativos", o "pessoal das empresas comerciais", os "militares" e os "missionários" eram alguns deles, segundo o próprio autor -, sendo que tais agentes eram "mais ou menos fechados uns aos outros, mais ou menos rivais (as oposições Administração-Missões, Administração-Comércio são frequentes), que tem sua própria política indígena (a tal ponto que alguns antropólogos ingleses fizeram, de cada um deles, um "agente" provocando a culture change) e suscitam reações muito diversas." Verificar: BALANDIER, Georges. A situação colonial: abordagem teórica. [1951]. Cadernos CERU. São Paulo: Universidade de São Paulo (USP), série 2, vol. 25, n. ${ }^{\circ}$, junho de 2014, p. 48.

${ }^{666}$ No caso dos eclesiásticos havia uma dinâmica própria, não aprofundada aqui por extrapolar os limites da dissertação.
} 
poderíamos sintetizar -, Fernão de Sousa sabia que não governava sozinho e, por mais que às vezes fosse ríspido e autoritário, para manter a governabilidade regional frequentemente ele dialogava e cedia. Assim, no final da ordem de agosto de 1629, o administrador fez uma ressalva: em caráter de exceção e "segredo", Paio de Araújo de Azevedo poderia "para estes intentos marchar por outra parte, e fazer auto em outro sítio o fará Vossa Mercê com parecer dos capitães, e brevissimamente irá resolução". ${ }^{667}$ Se por um lado a esfera jurídica era uma importante arena de mediação de conflitos sociais, políticos e institucionais, como salientado em boa parte da ordem de agosto de $1629,{ }^{668}$ por outro lado, na prática, o impedimento legal de guerra e as prescrições do direito português poderiam ser "driblados", à revelia do bispo e dos padres da Companhia de Jesus. Abrindo brechas para uma "ilegitimidade velada" e contradizendo a si mesmo, pois todos os argumentos inseridos no documento até então advogavam contra a guerra e a pilhagem, Fernão de Sousa atendeu aos anseios de Paio de Araújo de Azevedo, permitindo que ele angariasse fazendas a partir de Tango Angonga. Afinal de contas, dessa forma o "sol brilharia para todos", ninguém ficaria demasiadamente descontente e os planos obteriam o êxito esperado.

O regresso do quilombo português também foi mencionado no extenso relatório de Fernão de Sousa, praticamente com as mesmas informações com as quais trabalhamos acima, salvo por um detalhe que, em nossa análise, faz toda a diferença. Exploraremos inicialmente as continuidades, para depois abordar a diferença. A partir de uma carta datada de 3 de julho de 1629, cujos original e traslado não constam na $F H A$, Fernão de Sousa reportou que o então capitão-mor do exército português, Paio de Araújo de Azevedo, confirmara-lhe que o quilombo a essa altura "oprimia o Reino do Ndongo". Em razão do "aviso" do capitão-mor, ${ }^{669}$ o governador ordenara-lhe o deslocamento do quilombo "por onde tivesse mantimentos de inimigos", afastando-o do "Ndongo, e dos amigos", já que certamente a "gente de guerra" infringiria as aldeias do Ndongo na busca de pilhagens e riquezas. A isso foi acrescentado que Paio de Araújo de Azevedo deveria alojar o exército

\footnotetext{
${ }^{667}$ Fernão de Sousa. Ordem de Fernão de Sousa a Paio de Araújo de Azevedo. 24 de agosto de 1629. BAL, cód. 51-IX-21, ff. 282-82v. IN: HEINTZE, Beatrix (coord.). Documento 204, FHA, vol. II, 1988, pp. 306307.

${ }^{668}$ Conforme igualmente abordado no capítulo anterior.

${ }^{669}$ Essa informação também foi reportada logo no início documento anterior. Verificar: Fernão de Sousa. Ordem de Fernão de Sousa a Paio de Araújo de Azevedo. 24 de agosto de 1629. BAL, cód. 51-IX-21, ff. 282-82v. IN: HEINTZE, Beatrix (coord.). Documento 204, FHA, vol. II, 1988, p. 306.
} 
no alto de Tango Angonga, "para se prover dos mantimentos dos bambes de Matamba”, de onde ele enviaria alguns recados aos sobas "de uma e outra banda que deviam, e não pagavam baculamentos que prometeram", tendo a cautela de não obrigá-los a "pagar a ir em pessoa ao quilombo por se não homiziarem mais do que estavam, segurando-os em amizade, e obediência", de modo que a cobrança de baculamento fosse feita por intermédio de um quilamba. ${ }^{670}$ Reaparecem aqui informações iguais aos da carta de agosto de 1629, sugerindo a consulta deste documento para a composição do relatório, outrossim ocorrendo a confirmação da tendência de tratamento já analisada sobre o caso de Lucala, entre 1626 e 1627, provavelmente repetida ao longo do ano de 1628. De um lado, havia a preocupação com o chamado "tratamento destinado aos sobas", baseada na utilização coordenada de instrumentos de força direta e indireta, a fim de promover incursões militares e "policiamento" interno da Angola portuguesa, conforme ressaltamos no item anterior. Por outro lado, havia uma necessidade da máquina de guerra responder às expectativas dos agentes envolvidos, ou interessados, no empreendimento bélico, como neste item aprofundamos. No invólucro de admoestações, ordens e contra-argumentos lançados de todos os lados, conformando aquilo que denominamos arena político-jurídica, os interesses acordados pela ala régia penderam para uma posição favorável às formas de ascensão social fundadas na economia atlântica.

A nuança que gostaríamos de frisar é a de que, no extenso relatório, desapareciam as preocupações quanto à questão da legitimidade, às controvérsias legais e às tensões sociais existentes entre Fernão de Sousa, Paio de Araújo de Azevedo e os agentes eclesiásticos. Melhor dizendo, todas as informações que entregassem a existência de disputas e interesses divergentes, encenados e inseridos em uma arena político-jurídica, foram omitidas. Afinal de contas, tal como uma composição escrita na qual Fernão de Sousa legaria às gerações vindouras seus "bons serviços prestados", a imagem recriada deveria ser a de um governo em que todos remavam em um só sentido, em prol de uma Angola portuguesa sem fissuras institucionais e rachaduras políticas. Tal imagem destoava completamente da ordem de 24 de agosto 1629, feita para a circulação interna e cujo conteúdo aborda importantes características das relações tecidas no seio do funcionamento

\footnotetext{
${ }^{670}$ Fernão de Sousa. O extenso relatório do governador aos seus filhos. S.d., 1625-1630. BAL, cód. 51-IX20, ff. 220-74v. IN: HEINTZE, Beatrix (coord.). Documento 30, FHA, vol. I, 1985, p. 339.
} 
interno da Angola portuguesa. O dito em uma correspondência podia ser desdito, ou melhor, omitido, em outro documento, dependendo em grande medida do propósito que o conteúdo escrito tinha face às relações remetente-destinatário, ou locutor-interlocutor. ${ }^{671}$

Pouco depois dos planejamentos e discussões levados acabo entre julho a agosto, em 14 de setembro de 1629, Fernão de Sousa enviou outra ordem a Paio de Araújo de Azevedo, dessa vez ordenando o desmanche por completo do quilombo. ${ }^{672}$ As companhias de soldados seriam desmontadas aos poucos, para que os "soldados obrigados nos presídios" retomassem aos seus postos “com [uma] carta de Vossa Mercê na qual avisará quantos são, e pôr seus nomes" e os homens "extravagantes" fossem "assentar praça nas companhias, e na fortaleza [de Ambaca]". Havia um esforço grande em reorganizar ordenadamente a chamada "gente de guerra", para que voltassem a "zelar" pela proteção dos sobas e vigiassem as feiras de escravos, tendo a atenção em não deixar os homens "soltos" pela terra, onde criariam "alvoroços" ou poderiam se amancebar com as locais. ${ }^{673}$ Fernão de Sousa fez questão de frisar que "os baculamentos que Vossa Mercê puder mandar cobrar dos sobas e boamente o fará com tanto que não haja detença por esse respeito em se desfazer o quilombo", tomando especial atenção às dividas de Angola Aire que, apesar das promessas firmadas em escritura, não pagava tributação. ${ }^{674} \mathrm{~A}$ despeito da ordem, Paio de Araújo de Azevedo demoraria ainda cerca de dois meses para regressar a Luanda, chegando aí apenas em 8 de novembro de 1629. Afinal de contas, não era viável negligenciar os lucros auferidos em Tango Angonga.

\subsection{Os conflitos ligados ao impasse de Boila (1626-1629)}

Nos vários documentos que compõe a $F H A$, há menções a um tipo de fonte escrita, denominado "escritura" ou "auto", no cariz de registros válidos para a comprovação de

\footnotetext{
${ }^{671}$ Conforme frisamos na introdução desta dissertação e retomaremos na conclusão.

${ }^{672}$ É possível ressaltar que o desmonte do quilombo também foi motivado pela necessidade de cessar com o despovoamento regional, agravado pelas secas e pelas "bexigas" mortais que se alastravam pela região, além de deter a transferência de populações e refugiados cada vez mais para o interior do continente, que buscavam abrigos em lugares onde não havia guerra. Verificar: HEINTZE, Beatrix. Angola nos séculos XVI e XVII [...]. Luanda: Kilombelombe, 2007, pp. 380-381.

${ }^{673}$ Verificar: FERREIRA, Roquinaldo. Cross-Cultural Exchange in the Atlantic World [...]. Cambridge: Cambridge University Press, 2012, pp. 35-36.

${ }^{674}$ Fernão de Sousa. Ordem de Fernão de Sousa a Paio de Araújo de Azevedo. 14 de setembro de 1629. BAL, cód. 51-IX-21, ff. 282v-83. IN: HEINTZE, Beatrix (coord.). Documento 205, FHA, vol. II, 1988, pp. 308309.
} 
avassalamento. Eles eram aceitos como provas jurídicas em vários tipos de litígios, sendo então utilizados na moção de processos simples - caso uma das partes envolvidas fosse africana, o mesmo seria entendido como um "mucano" -, reivindicações de punição arbitrária por causa de dívidas de baculamento, exames de escravidão abertas junto à administração ultramarina e em casos de comprovação de justiça de guerra. Assim, de forma resumida, esses documentos burocrático-administrativos poderiam ser acionados sempre que houvesse alguma contestação relacionada aos estatutos políticos ligados à "vassalagem", à "amizade" e à "obediência" dos sobas que compunham a rede de fidelidade política orquestrada por Luanda. Outro aspecto de importância residia na utilidade político-administrativa deles. Confeccionados também como documentos burocráticos e de natureza administrativa, portanto figurando como provas palpáveis e perenes sobre o enquadramento institucional destinado aos chamados "sobas vassalos", nas escrituras e nos autos estavam registrados os direitos, deveres e obrigações que cada parte contemplada no ato de filiação política se prontificava a respeitar e a cumprir. Assim, conforme os moldes de um pacto "perpétuo" entre linhagens e títulos de soberania, os autos e escrituras eram vigentes durante o mandato de um titular político, renovável a cada vez que ocorresse uma sucessão julgada "legítima". ${ }^{675}$ Cabe também frisar que a maioria dos conceitos inseridos e pactuados nas escrituras e autos de vassalagem estava encapsulada no âmago de uma nomenclatura de fidelidade política feudo-vassala, respaldada nas condições de reciprocidade típicas do Antigo Regime, sendo assim mediadas pelas relações sociopolíticas derivadas de noções como as de "majestade" e "súditos", mas que também podiam lançar mão de conceitos feudo-medievais anteriores aos da Idade Moderna, respaldados no binômio "suserano" e "vassalo". 676 Do lado centro-africano, princípios

\footnotetext{
${ }^{675}$ Sobre isso, Beatrix Heintze considerou que os chamados "contratos de vassalagem" eram firmados "para todo o sempre", no sentido de que serem "indissolúveis, mesmo que essa cláusula não contasse do documento. Esta realidade podia também ser veiculada, na medida em que o vassalo assinava o contrato em seu nome e no de todos os seus sucessores" (p. 410). A renovação das juras de fidelidade e amizade também era incentivada através de "visitas obrigatórias". Verificar: HEINTZE, Beatrix. Angola nos séculos XVI e XVII [...]. Luanda: Kilombelombe, 2007, pp. 422-423.

"676 A acepção alargada de "vassalo" como "súdito" derivava do processo histórico da passagem da Idade Média à Moderna e, como explica Heintze, "o termo designava o laço que unia um súdito nascido num território do Estado, ao seu soberano e que lhe impunha o dever de lealdade e fidelidade". (pp. 388-389). No contexto ultramarino centro-africano, havia ainda um segundo traço de dissociação do feudalismo: “o mero facto de o rei se poder fazer representar pelo seu governador mostra até que ponto a relação de vassalagem já se afastara do paradigma medieval e também que já só a nível formal se tratava de uma relação pessoal de dependência”. Verificar: HEINTZE, Beatrix. Angola nos séculos XVI e XVII [...]. Luanda: Kilombelombe,
} 
como os de prestígio e reciprocidade eram importantes critérios de soberania respeitados pelos direitos e gramáticas políticas locais. ${ }^{677}$

De todo modo, além de servirem como fontes de legitimação e comprovação legal, as escrituras e autos eram também uma forma de "assentar", e com isso preservar, os termos que haviam sido acordados, ou como era mais comum, "impostos", no momento da vinculação política e que, por sua vez, poderiam ser consultados futuramente. O registro administrativo-burocrático funcionava através de crivos, meios pelos quais as informações eram filtradas e avaliadas como "úteis" à monarquia, sendo por fim classificadas conforme o direito português e avaliados de acordo com os interesses régios. Além disso, e este é um segundo ponto relevante sobre o processamento dos contatos na forma de dados e informações burocrático-administrativas, os autos e escrituras eram essenciais para a formalização de "bancos de dados", compostos por materiais escritos e desenhados, que poderiam contribuir para a formação de arquivos e acervos em Luanda e Lisboa, de grande utilidade judiciária e política para o funcionalismo régio de além e aquém-mar, além de

2007, p. 406. Sobre o desenvolvimento estatal moderno, fiquemos com a fórmula clássica proposta por Perry Anderson, segundo a qual uma "antiga aristocracia feudal" passaria por uma "reconversão de classe", vindo a receber novas ocupações, como as de "oficial disciplinado, de funcionário letrado, de cortesão raffiné e de proprietários fundiários mais ou menos esclarecidos". Verificar: ANDERSON, Perry. Classes e Estados: Problemas de Periodização. [1976]. IN: HESPANHA, António Manuel (ed.). Poder e instituições na Europa do Antigo Regime: coletânea de textos. Lisboa: Fundação Calouste Gulbenkian, 1984, p. 130. As considerações completas desse pesquisador podem ser consultadas em: ANDERSON, Perry. Linhagens do estado Absolutista. [1974]. São Paulo. Editora Brasiliense, 2004.

${ }^{677}$ Aqui presumimos que os princípios e as estruturas mbundu descritos no capítulo 1 desta dissertação também valiam, em graus diferentes e com especificidades inexploradas neste trabalho, para as sociedades ndembu e bakongo. No que diz respeito à tensão entre continuidades e mudanças ao longo da Idade Média e do Antigo Regime, em consonância com as considerações feitas na nota acima, destacamos que havia não apenas uma cisão importante entre as noções de majestade-súditos e senhor-vassalo, como lembra Beatrix Heintze, mas também que a própria concepção de "direito moderno", diferenciado do medieval, era relevante para o equilíbrio de comunidades juridicamente estabelecidas. Não necessariamente concordando com o enfoque dado por António Manuel Hespanha, mas aceitando a problemática em discussão levantada por esse pesquisador, o desafio daquele tempo estava situado na afirmação de um "Estado-que-mantém-os-direitos", ou "Estado jurisdicional", frente a um sistema político tradicional existente desde o período medieval-feudal. Assim sendo, as predisposições de composição do Antigo Regime seriam marcadas por três centros de força: i) "paradigma de ação político-administrativa", ou "jurisdicionalista"; ii) "modelo de organização de governo poli-sinodal"; iii) "estilo de processamento", designado também como "processo burocrático". Verificar: HESPANHA, António Manuel. História das Instituições: época medieval e moderna. Coimbra: Livraria Almedina, 1982, pp. 439-442. Idem, Para uma teoria da história institucional do Antigo Regime. [1982]. IN: Idem (ed.). Poder e instituições na Europa do Antigo Regime [...]. Lisboa: Fundação Calouste Gulbenkian, 1984, p. 29. Idem, As vésperas do Leviathan: instituições e poder político. Portugal, século XVII. Coimbra: Editora Almedina, 1994, p. 278. HEINTZE, Beatrix. Angola nos séculos XVI e XVII [...]. Luanda: Kilombelombe, 2007, pp. 388-390. 
serem úteis para incitar o imaginário europeu e os saberes reinóis sobre os povos centroafricanos. $^{678}$

As duas claves que até agora introduzidas, regidas pelos pares legitimaçãooficialização e informação-formalização, são os pontos de partida para a análise proposta neste item. Repousam nelas os fundamentos para o processamento de dados e informações, ou simplesmente "burocratização", dos sobas em contato com os órgãos ultramarinos. Quer dizer, uma vez despertado o interesse na vinculação política por parte do funcionalismo régio, as autoridades africanas eram "processadas", sob a égide de informações e dados articuláveis aos intuitos de membros que compunham um determinado círculo de interesse e sociabilidade, composto por membros da elite local de Luanda. Por meio dos canais de circulação institucional criados e perpetuados em terras de além e aquém Atlântico, os conhecimentos manipuláveis em prol do planejamento político em Luanda circulavam, porventura vindo a parar em Lisboa. Hoje em dia, alguns desses documentos continuam a ser preservados, sendo valorizados pelos especialistas por serem fontes históricas e obrigatórias na criação de diversos saberes - propagandistas, militantes, acadêmicos, entre outros.

Um caso relatado na $F H A$ e que traz à tona elementos importantes sobre as relações entre a comunicação burocrática e a criação de saberes administrativos está ligado ao chamado “impasse de Boila". Elencaremos alguns vestígios existentes no corpo documental a fim de apresentá-lo, destarte ressaltando que ele atingiu considerável repercussão política entre 1626 a 1629, culminando em um pico de tensão em 1627. O primeiro vestígio encontrado ocorre no extenso relatório e se refere a um período impreciso entre outubro a dezembro de 1626, no qual Fernão de Sousa afirmou que o "soba Boila, ${ }^{679}$ tendo feito auto

\footnotetext{
${ }^{678}$ Sobre a formação dos repositórios de saberes ultramarinos e a caracterização dos diferentes tipos de documentos neles alojados, verificar: SANTOS, Catarina Mandeira. Un Monde Excessivement Nouveau savoirs africains et savoirs missionnaires: fragments, appropriations et porosités dans l'œuvre de Cavazzi di Montecúccolo. IN: CASTELNAU-L'ESTOILE et al. (ed.). Missions d'évangélisation et circulation des savoirs (XVIe-XVIIIe siècle). Madri: Casa de Velázquez, 2011, p. 308.

${ }^{679}$ Também conhecido como o soba Boyla, Buila, Ambuila, Mbwila e Ambwila. Por indicação de Beatrix Heintze, sabemos que em BAL 21, ff. 252-53v também ocorre a grafia de "Builla". Verificar a nota 383 para: Fernão de Sousa. Carta de Fernão de Sousa ao governo. 2 de agosto de 1627. BAL, cód. 51-IX-20, ff. 33839. IN: HEINTZE, Beatrix (coord.). Documento 95, FHA, vol. II, 1988, p. 183. No caso da $F H A$, "Boila" se refere tanto a título político perpétuo de mbwila, respeitadíssimo entre os ndembu e de grande relevância na região situada ao norte de Ambaca, quanto à pessoa que detinha a posição titular. Assim sendo, ele foi registrado tanto como "chefe" quanto como "chefia". Seguindo algumas considerações de Joseph C. Miller, em 1680 a posição titular ndembu uniu-se ao título de kabuku ka ndonga, título lunda de proveniência análoga
} 
de vassalagem por dois sobas seus", nomeadamente "Cheque" e "Cabonda", 680 arrependera-se do acordo firmado e os acolheu em sua banza, negando "dá-los" ao governador, ou seja, eles não mais seriam transplantados à rede de fidelidade política comandada por Luanda, tornando-se "vassalos" de Portugal. Além disso, Boila alertou que se recusava a pagar mais baculamentos, já que não havia recebido as terras prometidas pelo governador. Fernão de Sousa retrucou que não cederia as terras porque elas pertenciam a Casanga Cacaita, sobre o qual nada mais é dito. Boila então se queixou ao rei do Kongo sobre "a força que lhe eu [Fernão de Sousa] fazia sendo [Boila] vassalo seu [do Kongo]" e, a pedidos dele, o rei africano escreveu ao governador, reclamando sobre a situação do soba. Fernão de Sousa respondeu ao Kongo que o "Boila era vassalo do rei de Angola e que Sua Majestade [Filipe III de Portugal] era senhor deste Reino [de Angola]" e, a fim de justificar sua posição, o governador adicionou "que de presente o [Boila] estava do de [sic] Ndongo [para Filipe III de Portugal] com o lançar das ilhas Dona Ana Ginga Ambande”, não deixando de ressaltar que o então rei do Ndongo, Angola Aire, era "rei eleito vassalo seu". 681

ao de kinguri, "numa repetição do habitual padrão de mudança de títulos, para refletir novas fontes de legitimação". Em um primeiro momento, o amalgama entre as duas posições resultou na criação de kabuku ka mbwila para, em um segundo momento, ser registrado vulgarmente, na documentação setecentista portuguesa, através do nome genérico "Dembo Kabuku". Mediante a uma perspectiva ndembu, é possível sustentar que "o kabuku transferira a sua obediência para o mais poderoso sistema local de títulos políticos, as vizinhanças posições ndembu, na parte sul do Kongo". Verificar MILLER, Joseph C. Poder político e parentesco [...]. [1976]. Luanda: Arquivo Histórico Nacional, 1995, p. 203 e nota 81. O kabuku ka ndonga foi registrado nas fontes escritas portuguesas como "Kandonga" e "Cabuco". Verificar a mesma obra de Miller, pp. 156 e 166, respectivamente para cada uma das terminologias.

${ }^{680}$ Essa informação é fornecida esporadicamente nos documentos. Para apenas um exemplo, verificar: Fernão de Sousa. O extenso relatório do governador aos seus filhos. S.d., 1625-1630. BAL, cód. 51-IX-20, ff. 22074v. IN: HEINTZE, Beatrix (coord.). Documento 30, FHA, vol. I, 1985, pp. 258-259.

${ }^{681}$ Fernão de Sousa. O extenso relatório do governador aos seus filhos. S.d., 1625-1630. BAL, cód. 51-IX20, ff. 220-74v. IN: HEINTZE, Beatrix (coord.). Documento 30, FHA, vol. I, 1985, pp. 258-259. Graças a esse último trecho, sabemos que os desentendimentos com Boila esquentaram a partir da consolidação do processo de avassalamento de Angola Aire, finalizado em 12 de outubro de 1626. HEINTZE, Beatrix (coord.). Apêndice: Tabela Cronológica, 1618-1630. FHA, vol. I, 1985, p. 396. 


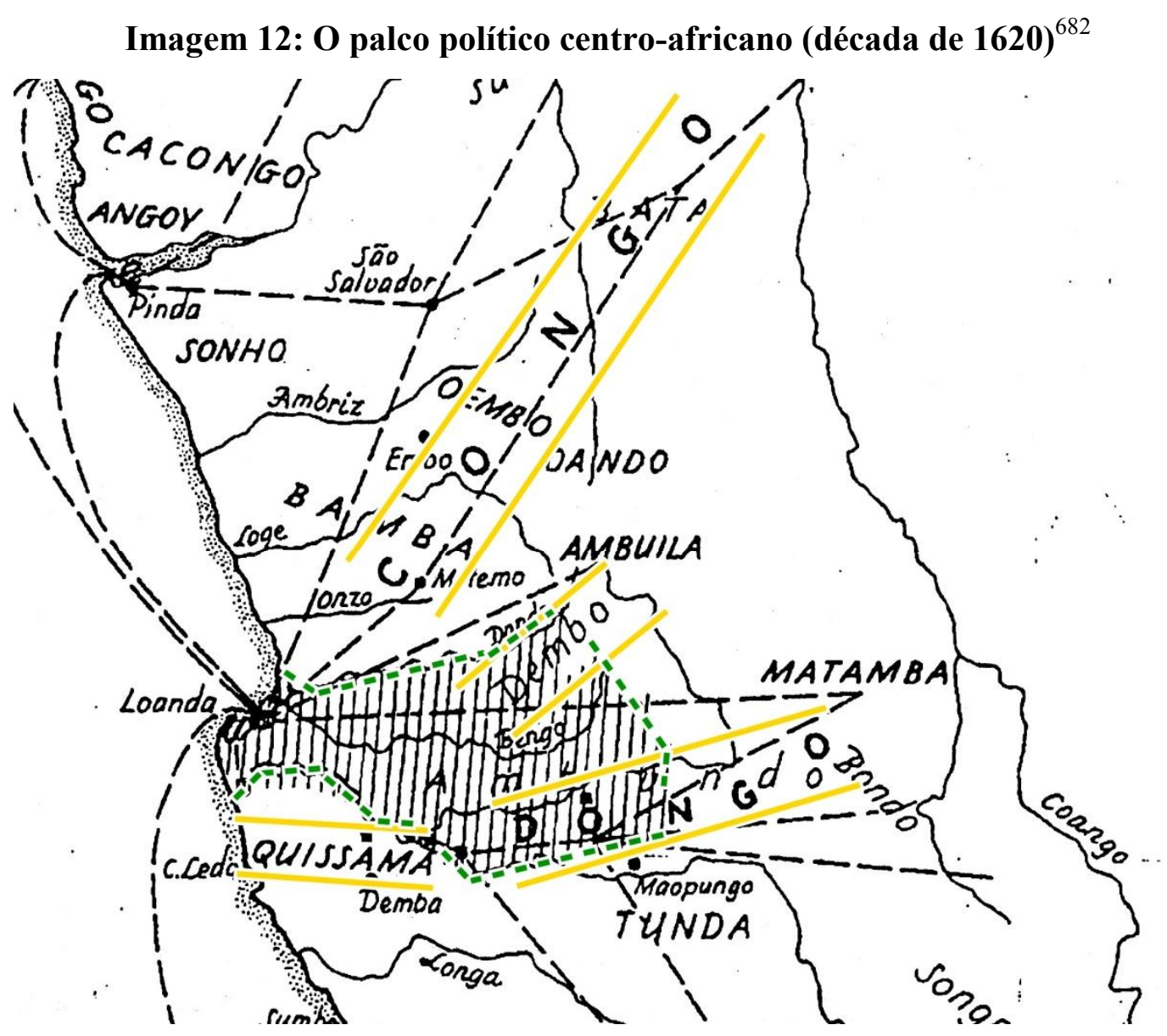

Legenda: i) As duas hastes paralelas em dourado representam algumas regiões importantes para a política ultramarina; ii) A área delineada com linhas pontilhadas em verde e internamente preenchida com linhas verticais negras é a Angola portuguesa.

Nesse trecho do extenso relatório, o administrador régio ainda fez importantes considerações sobre o avassalamento de Boila, citando um "auto" que provaria a verdade das informações levantadas, porém que infelizmente não consta na $F H A$. De acordo com as informações reportadas, o tal "auto de vassalagem" seria um documento de ordem institucional análogo à escritura de Angola Aire, baseado assim em termos que recorrentemente são acionados na documentação, separados nos seguintes tópicos: obrigatoriedade de pagamento de baculamentos, cooperação com a "paz portuguesa", fornecimento de ajuda político-militar no caso de "desarmonias internas e externas" e inauguração das chamadas "feiras", de onde provinha grande parte dos escravizados que

${ }^{682}$ A imagem que segue abaixo foi retrabalhada a partir de: HEINTZE, Beatrix (coord.). Fig. 1: A África Central Ocidental na época de Fernão de Sousa (ortografia da fonte), FHA, vol. I, 1985, p. 4. 
alimentavam o tráfico de escravos. ${ }^{683}$ Como sinal de gratidão, em troca da "obediência" dos vassalos, Luanda em teoria disporia os órgãos institucionais ultramarinos em benefício aos sobas, fornecendo os chamados "socorros" militares e "remédios" políticos a eles. $\mathrm{Na}$ prática, contudo, o avassalamento era uma maneira legítima de articular Boila e sua gente a um ordenamento comum, conduzido pelo aparato administrativo régio e deixando-o à mercê dos mecanismos de vigilância e fiscalização da Angola portuguesa. Dessa forma, ao contestar as normas de vassalagem, Boila gerou um mal-estar político entre o Kongo, Ndongo, e Luanda.

A argumentação de Fernão de Sousa chama a atenção para um primeiro ponto de importância. Provavelmente antes de firmado o auto de vassalagem, havia ocorrido as chamadas "conversações", ou seja, negociações políticas sobre os termos que acabariam pactuados e firmados em documento. Foi nessa etapa, preliminar portanto à formalização do acordo político, que certos sobas e terras poderiam ser trocados ou cobrados, em função das relações hierárquicas de sujeição política. Residia neles um valor cambiável, medido de acordo com a importância que detinham nas redes de fidelidade e no xadrez político regional, como é possível de perceber nos casos de Boila, Cheque e Cabonda. Disso podemos depreender um aspecto de grande relevância: as autoridades "negociadoras" tinham maior expressão que as que eram "negociadas". Havia um palco político regional e hierarquicamente constituído, separado em pelo menos em três patamares. No topo residiam Luanda e o Kongo, atores que de fato tomavam as rédeas do debate. Depois vinham o Ndongo e Boila, que contavam com uma margem de manobra considerável. Na base estavam Cabonda e Cheque e que, a despeito das poucas informações registradas, é possível dizer que foram encarados pelo funcionalismo régio como os "vassalos dos vassalos" e, portanto, seriam periféricos em vista dos grandes concertos políticos. Em última instância, todos esses atores políticos foram "codificados" e simplificados na forma

\footnotetext{
${ }^{683}$ Aqui foram expostos apenas os termos e condições que normalmente são citados no caso de escritura de vassalagem de Angola Aire, como abordado no capítulo 2 desta dissertação, dentre uma "grande lista de direitos e obrigações" que deveriam ser cumpridos pelas partes pactuadas ao término do ato de vinculação política, mediante a qual, "em troca de paz e proteção, os chefes africanos juravam lealdade ao rei de Portugal". Verificar : SANTOS, Catarina Madeira. Entre deux droits: les Lumières en Angola (1750-v. 1800). Annales. Histoire, Sciences Sociales. Paris: Éditions de l'EHESS, n. ${ }^{\circ}$ 60, 2005/4, p. 825. Muitas vezes, esses termos, ou condições, eram tão "evidentes" que não foram explicitados, figurando então como princípios subjacentes aos chamados "contratos de vassalagem". Sobre o teor implícito dos "conceitos" e "cláusulas" neles existentes, verificar: HEINTZE, Beatrix. Angola nos séculos XVI e XVII [...]. Luanda: Kilombelombe, 2007, pp. 412-423.
} 
de dados administrativos constituintes da documentação, através de práticas consideradas "legítimas" perante a condução régia e em nome de uma pretensa "harmonização" entre os mandos políticos locais, caso lembremos de algumas considerações feitas por Catarina Madeira Santos. ${ }^{684}$ Além disso, os crivos de enquadramento praticados durante os registros escritos contemplavam também finalidades utilitaristas, de modo que as relações de superioridade e inferioridade políticas, pretensamente reivindicadas pelos atores, podem ser relativizadas e questionadas com crítica e cautela. No caso do impasse de Boila, por exemplo, cada um desses atores regionais rogava laços políticos e de fidelidade que divergiam entre si, atestando para o fato de existirem manobras e planejamentos distintos entre os envolvidos na contenda.

Fernão de Sousa então complementa o relatório sustentando que Boila estava “assentado nas listas dos sobas que foram ao Reino [de Angola]", documento que até agora não foi encontrado, mas que, por informações respingadas nos escritos integrantes da $F H A$ e graças às considerações feitas por Beatrix Heinte, é possível deduzir que essa lista continha o registro de "81 antigos sobas, vassalos portugueses, e alguns recentes com os respectivos acordos de tributo" e que de fato fora despachada ao monarca, em 8 de julho de 1626. ${ }^{685}$ Ademais, continuou Fernão de Sousa no relatório, ele igualmente remetera à "Vossa Majestade" o traslado do avassalamento de Boila, Cheque e Cabonda, como prova de que falava a verdade e que "não cresse em Boila, nem lhe desse ocasião para usar das traições que costumava fazer de que podia resultar tirar-lhes as terras, e dá-las a quem por direito pertencessem". ${ }^{686}$ Cabe notar que expressões ligadas ao ato de "tirar" e "colocar" na terra são novamente repetidas no documento, entregando a importância que elas tinham na argumentação de Fernão de Sousa. Mais para frente voltaremos a esse assunto. O extenso relatório prossegue com outras narrativas, até certo momento em que há a inserção de uma

\footnotetext{
${ }^{684}$ SANTOS, Catarina Madeira. Entre deux droits [...]. Annales. Histoire, Sciences Sociales. Paris: Éditions de l'EHESS, n. ${ }^{\circ}$ 60, 2005/4, p. 835. Idem, Écrire le pouvoir en Angola: Les archives Ndembu (XVIIe-XXe siècles). Annales. Histoire, Sciences Sociales. Paris: Éditions de l'EHESS, n. ${ }^{\circ}$ 64, 2009/4, pp. 777-778. Sobre os conflitos regionais que envolviam o Ndongo, Kongo e os títulos políticos existente no Ndembu, com destaque às disputas e às reivindicações divergentes de soberania e vassalagem existentes entre eles, verificar: HEYWOOD, Linda M.; THORNTON, John K. Central Africans, Atlantic Creoles, and the Foundation of the Americas [...]. Cambridge: Cambridge University Press, 2007, p. 74.

${ }^{685}$ Fernão de Sousa. O extenso relatório do governador aos seus filhos. S.d., 1625-1630. BAL, cód. 51-IX20, ff. 220-74v. IN: HEINTZE, Beatrix (coord.). Documento 30, FHA, vol. I, 1985, nota 187, p. 269.

${ }^{686}$ Fernão de Sousa. O extenso relatório do governador aos seus filhos. S.d., 1625-1630. BAL, cód. 51-IX20, ff. 220-74v. IN: HEINTZE, Beatrix (coord.). Documento 30, FHA, vol. I, 1985, p. 259.
} 
"cópia da relação que foi ao secretário de Estado Francisco Lucena", escrita em 30 de janeiro de 1627 , cujo original ainda é desconhecido. ${ }^{687}$ Está escrito nessa cópia que o rei do Kongo havia dito que o soba Boila era "vassalo seu [em relação a Filipe III de Portugal] sendo o d'El-rei de Angola, e por essa razão era de Sua Majestade, e avassalado pela lista que mandei". ${ }^{688}$ Trata-se da mesma lista citada anteriormente. ${ }^{689}$

Até agora, abordamos dois polos de profusão ligados às discussões e às contendas entre autoridades africanas e régias. De um lado, havia o ato de burocratizar para "fazer comunicar e circular", sem que com isso fossem perdidos de vista dois eixos-chave do processamento de dados institucionais: o primeiro ligado à legitimação de ações tomadas, o segundo vinculado à composição de autos, escrituras, traslados e listas como fontes de informações minimamente confiáveis, transmitidos e retransmitidos entre os capitães dos presídios, governadores ultramarinos e as instituições reinóis, variando da escala local à transatlântica. Do outro lado, havia a realidade observada e anotada, imersa em conflitos e desentendimentos que podiam estar distribuídos entre três áreas de concentração: tensões sociais, atritos institucionais, embates políticos. O dito, redito e não-dito das fontes escritas é movido pela dinâmica daquilo que poderia, ou deveria, ser sustentado e colocado em circulação, além de objetivar a criação de resoluções para os problemas enfrentados no conturbado palco político regional. Mais do que isso porque, como veremos a seguir, o impasse de Boila igualmente envolvia desentendimentos e brigas entre algumas autoridades régias, responsáveis pela ordem e mando da Angola portuguesa. ${ }^{690}$

\footnotetext{
${ }^{687}$ Essa relação está enumerada, sendo que cada um dos números discernidos por Fernão de Sousa equivale a um parágrafo do regimento entregue pelo monarca ao governador. Heintze afirma que essa relação era "um relatório de Fernão de Sousa à Coroa sobre o seu governo até então [1627]". Em informação posterior, Fernão de Sousa disse que escrevera no documento o "que me pareceu conveniente mudar e acrescentar no Regimento dos governadores para se dar ao que me fosse suceder". De acordo com Heintze, conferir: 7 de dezembro de 1631. BRÁSIO, António (col. e anot.). MMA. Série 1, vol. VIII, 1960, p. 91. Consultar também: Dom Diogo de Castro [feito por António Correa e escrito por Cristovão Soares]. Regimento do governador de Angola. 20 de março de 1624. BAL, cód. 51-IX-20, ff. 7-11. IN: HEINTZE, Beatrix (coord.). Documento 4, FHA, vol. I, 1985, pp. 140-153.

${ }^{688}$ Essa é uma pista interessante sobre como Boila foi registrado na tal "lista" e, posteriormente, como esse registro foi utilizado como prova jurídica na busca por uma resolução ao impasse.

${ }^{689}$ Beatrix Heintze complementa a informação afirmando que a lista dos 81 sobas fora redigida em cumprimento ao seguinte documento: Filipe III de Portugal [escrito por Cristovão Soares]. 19 de março de 1624. BAL, cód. 51-IX-20, ff. 13-14v. IN: HEINTZE, Beatrix (coord.). Documento 3, FHA, vol. I, 1985, pp. 136-139. Sobre o envio de lista, Heintze pede para que se confira: Fernão de Sousa. Carta de Fernão de Sousa sobre os tributos de vassalagem dos sobas. 8 de julho de 1626. BAL, cód. 51-IX-20, ff. 331-32v. IN: HEINTZE, Beatrix (coord.). Documento 31, FHA, vol. I, 1985, pp. 363-365.

${ }^{690}$ Ficamos também com algumas das considerações feitas por Beatrix Heintze, que ressaltou a importância dos registros escritos, "embora nas fontes esses testemunhos funcionem menos como observação
} 
Descontente com o caos político vivido no norte da Angola portuguesa, Fernão de Sousa tentou, desde a segunda metade de 1626, convencer o monarca português das desonestidades de Boila, salientando com frequência que o africano perpetrara desestabilidades e desobediências que poderiam colocar a perder o governo de Angola. Assim, no ano seguinte, em 2 de agosto de 1627, Fernão de Sousa escreveu uma carta aos seus superiores. Trata-se de um documento já abordado no primeiro item deste capítulo, no qual o governador havia sido enfático quanto à necessidade de mudança de postura em relação aos sobas das bandas do Lucala. Cabe também relembrar que, na carta de agosto de 1627, há dois núcleos de apelo, o primeiro elegendo os tópicos "rigor" e "belicismo" como palavras de ordem do discurso do governador, indo assim na contramão dos "legalismos" e "pacifismos" pregados no extenso relatório. O segundo, e esse é o aspecto que não havíamos comentado anteriormente e que é pertinente a este item, está voltado à sustentação de um planejamento expansionista-exploratório rumo ao norte e ao nordeste da Angola portuguesa, sucintamente baseado na abertura de uma guerra punitiva contra Boila, seguida por um golpe político contra o Kongo, pouco esmiuçado no documento, mas cujo desenvolvimento, de acordo com as projeções de Fernão de Sousa, será apresentado ao longo desta carta de agosto de 1627. Dessa forma, passando a focar nesse segundo núcleo de apelo, Fernão de Sousa frisou que o único empecilho para o planejamento não sair do papel residia na reprovação da Companhia de Jesus, que sustentava ser ilegítimo fornecer um "castigo" a Boila "pelas armas" porque, tal qual a maioria dos confrontos bélicos promovidos pelo governador, “dar guerra ao soba Boila pelo baculamento que prometeu, nem [era justo] obrigá-lo a dar os sobas vassalos de Vossa Majestade porque basta deixarem suas terras", ${ }^{691}$ além de ser evidente que "não se pode fazer guerra aos que não pagam os tributos que prometeram a Vossa Majestade por não ser causa justa". 692

Por detrás do planejamento de Fernão de Sousa, havia uma arena político-jurídica em jogo, mediante a qual era "lícito" - não necessariamente "justo" - manipular as informações disponíveis em prol da sustentação de uma argumentação político-jurídica. Em

\footnotetext{
pormenorizada de uma realidade, do que como argumento retórico na luta político-econômica dos diversos grupos europeus rivais em Angola". Verificar: HEINTZE, Beatrix. Angola nos séculos XVI e XVII [...]. Luanda: Kilombelombe, 2007, pp. 479-480.

${ }^{691}$ Fernão de Sousa. Carta de Fernão de Sousa ao governo. 2 de agosto de 1627. BAL, cód. 51-IX-20, ff. 338-339. IN: HEINTZE, Beatrix (coord.). Documento 95, FHA, vol. II, 1988, p. 184.

692 Ibidem, p. 184.
} 
último caso, tratava-se de um movimento no qual o discurso e a retórica passavam a enviesar uma "instrumentalização" dos dados e informações veiculadas na documentação, procedimento que, em menor grau, subsistia nos argumentos levantados pelos jesuítas e, em maior grau, nos conceitos e ideias sustentados por Fernão de Sousa. Peguemos, por exemplo, um dos argumentos jesuíticos que mais são recorrentes na $F H A$, relacionado à forma como o direito de usufruto da terra mantinha ligação com as regras de vassalagem, juridicamente respaldada no convencionado "juramento de terra gentílica" e explícita nas evocações de "tirar" e "colocar" na terra, como foi exposto no parágrafo anterior. Em desacato à Companhia de Jesus, o argumento de Fernão de Sousa pressupunha que a vassalagem portuguesa, originariamente feudal, deveria estar ligada ao direito de uso da terra e que, sob o álibi da cobrança de baculamentos, seria legítimo conquistar o Dembo e infringir dano aos sobas endividados. ${ }^{693}$ Portanto, havia uma concepção feudo-vassala, enraizada em Portugal, por detrás do que ele sustentava. Todavia, sagazmente, os jesuítas contra-argumentaram, lançando mão do legítimo respeito aos usos e costumes locais, partindo do conhecimento prévio, ou saber adquirido localmente e que não necessariamente respeitava a autodeterminação dos povos africanos, de que os ndembu, tais quais os mbundu, deixariam suas terras sem oferecer grande resistência ao serem intimidados ou compelidos a tal. O mais notável é que o argumento jesuítico estava realmente assente em um princípio reivindicado em âmbito local, sobretudo pelos mbundu. Basta evocarmos uma das explicações propostas por Joseph C. Miller, mediante a qual, de acordo com ótica legalutilitária mbundu, cada aldeia-linhagem desse povo ocupava temporariamente uma gleba de terra, denominada $i x i$, onde era possível plantar, caçar e coletar frutos que a natureza fornecia espontaneamente. Os mbundu viviam sobretudo da agricultura rotativa, ou seja, dentro de um ixi eram produzidos gêneros alimentares, como o sorgo e o painço, enquanto outro ixi, intermitentemente exaurido, descansava a espera da reutilização. ${ }^{694}$ Muitos ixi

\footnotetext{
693 Confirmando duas traves-mestras constatadas por Beatrix Heinte, sendo a primeira a de que o estabelecimento de vínculo político, sob a forma do avassalamento e firmamento de um contrato de vassalagem, estava baseado na "capitulação e submissão que estabeleciam uma relação de dependência unilateral entre os chefados africanos e supremacia portuguesa". A segunda trave-mestra reside no fato de que a vinculação política perpetuava "elementos das relações feudais de vassalagem da Europa ocidental", resistentes não apenas em "nível terminológico", mas também em "nível de conteúdo". HEINTZE, Beatrix. Angola nos séculos XVI e XVII [...]. Luanda: Kilombelombe, 2007, pp. 425-426.

${ }^{694}$ MILLER, Joseph C. Poder político e parentesco [...]. [1976]. Luanda: Arquivo Histórico Nacional, 1995, p. 43. VANSINA, Jan. How Societies Are Born [...]. Charlottesville: University of Virginia Press, 2004, p. 76. Além disso, os mbundu também criavam gado miúdo. Verificar: HEINTZE, Beatrix. Angola nos séculos XVI
} 
poderiam ser reivindicados por uma linhagem-aldeia, conformando um perímetro territorial tido como pertencente ao grupo que a utilizava. Para além de alimentos, as linhagens responsáveis por cada ixi plantavam uma árvore na entrada de cada aldeia, chamada de mulemba, sinalizando que aquele era um terreno apropriado, "enraizado" no grupo de parentesco alargado, ao redor do qual aconteciam as "deliberações" da aldeia. ${ }^{695}$ Resumidamente, a utilização da terra entre os mbundu intercalava dois princípios básicos, a itinerância de um lado, com base em um percurso pré-estabelecido, e a apropriação temporária e simbólica de outro lado, sendo esses dois princípios endógenos o fundo "real" por detrás do prisma jesuítico. ${ }^{696}$

e XVII [...]. Luanda: Kilombelombe, 2007, p. 278. De acordo com JanVansina, três eram os tipos de uso da terra na África Central. Havia o "sistema de campo único" (single-field system), sobretudo praticado em florestas tropicais. Além dele, existia também o método de "dois campos anuais" (two fields annually), intercalando o aproveitamento e granjeio de terras ao sul das florestas tropicais e as intersecções com a savana. O terceiro último sistema era o da "agricultura sudanesa" (sudanese agriculture), comum no norte das florestas tropicais, em Ubangi e Uele. Verificar: VANSINA, Jan. Paths in the Rainforests [...]. MadisonWisconsin: University of Wisconsin Press, 1990, p. 88.

${ }^{695}$ MILLER, Joseph C. Poder político e parentesco [...]. [1976]. Luanda: Arquivo Histórico Nacional, 1995, pp. 47-48. Segundo o pesquisador, a árvore mulemba, cujo atual nome científico é ficus psilopoga, era também um "mediador entre os membros vivos e mortos da linhagem" e "simbolizava a integridade do grupo de parentesco" (pp. 63-64). Consultar ainda as considerações feitas no capítulo 1 desta dissertação.

${ }^{696}$ Por esses motivos, é inútil qualquer tentativa de "territorialização", "mapeamento" ou proposição de cartografia estática dos povos mbundu, ndembu, imbangala, uma vez que o lugar de habitação e convivência deles não era imóvel, como salientam Catarina Madeira Santos e Maria da Conceição Neto. Contudo, é possível delimitar perímetros de convivência e espaços de reivindicação e pertencimento das comunidades locais. Assim, ficamos com um pequeno comentário de Neto: "circular é uma palavra quase mágica e talvez o direito mais universalmente reivindicado em Angola". Verificar: SANTOS, Catarina Madeira. Um governo "polido" para Angola [...]. Tese de doutorado em História, Universidade Nova de Lisboa, 2005, pp. 100, 125126. NETO, Maria da Conceição. Nas Malhas da Rede: Aspectos do impacto económico e social do transporte rodoviário na região do Huambo c. 1920 - c. 1960. IN: HEINTZE, Beatrix; OPPEN, Achim von (ed.). Angola on the Move [...]. Frankfurt am Main: Verlag Otto Lembeck, 2008, pp. 117 e 129. Nos últimos anos, Virgílio Coelho tem chamado atenção para a importância das enchentes do rio Cuanza, dos alagamentos de algumas porções da savana e, por consequência, para a cíclica inundação de habitações como um conjunto de fatores que influencia na alta mobilidade e dificuldade de mapeamento das libatas. Assim, o uso e a ocupação de terras estariam intimamente ligados ao regime de chuvas e às estações secas. Verificar: COELHO, Virgílio. Os Túmúndòngò, os "génios" da natureza e o kílàmbà [...]. Luanda: Kilombelombe, 2010, pp. 105-106. Para uma acepção mais metafórica e ligada ao mundo espiritual, segundo a qual a noção de ixi estava entrelaçada à ideia de "abóboda celeste", verificar: Idem, "Em busca de Kábàsà!..." Estudos e reflexões sobre o "Reino" do Ndòngò: Contribuições para a História de Angola. Luanda: Kilombelombe, 2010, pp. 146-147. No que diz respeito à discussão científico-acadêmica atual, as formas de aproveitamento e beneficiamento da terra, as relações de trabalho e produção de bens e alimentos e os modelos de organização das sociedades centro-africanas despertaram diversas considerações, sobretudo a respeito dos processos humanos de nomadismo, transumância e sedentarização ao longo do tempo. Sobre o desenvolvimento social bantu de acordo com essa perspectiva, verificar: VANSINA, Jan. Paths in the Rainforests [...]. MadisonWisconsin: University of Wisconsin Press, 1990, pp. 64-66. Idem, How Societies Are Born [...]. Charlottesville: University of Virginia Press, 2004, pp. 88. Sobre a complexidade das sociedades agropastoris ao longo do tempo e a difusão das línguas njila, verificar esta última obra, pp. 68,74 . Sobre a transumância e pastoreio, verificar a mesma obra, pp. 83-85, 87. Para Jan Vansina, a finalização desses processos consolidaria uma "bantuização" das sociedades centro-africanas. Verificar as pp. 102-103, 261 e pp. 263-264. 
De todo modo, o ápice da crítica jesuítica estava ligado à forma como a ordem se apoiou nos princípios de vassalagem para refutar, novamente de maneira legalista e comum à retórica escolástica, ${ }^{697}$ a legitimidade das operações militares que ocorriam desde 1626. Destarte, para entender o trunfo jesuítico, é preciso ter em mente como a Angola portuguesa funcionava à luz de um projeto português ultramarino e que, em razão dele, era jurídica e politicamente crucial que qualquer guerra fosse justificada em nome da manutenção dos domínios ultramarinos. Assim, repetindo algo já dito nesta dissertação, como princípio guiador da administração ultramarina na África Centro-Ocidental, figurava o modelo de imposição de vassalagem como fórmula política para assegurar a cooperação de grupos locais e, dessa forma, viabilizar a pontual ocupação de territórios no além-mar. A noção político-jurídica aplicada aqui era a de "domínio indireto", ou "tutela", ${ }^{698}$ totalmente oposta ao que podemos chamar de "domínio direto", sob a forma então de uma "guerra total” de sujeição. Embasada em ideias políticas e na esfera jurídica do direito natural, a Companhia de Jesus lançou mão do respeito ao avassalamento africanos, portanto ligada à "correta" imposição de domínio indireto incontestável perante o oficialato e funcionalismo reinol e ultramarino, para constatar que todas as guerras até então desrespeitavam os princípios de vassalagem - era ilícito cobrar tributo atrasado por meio das armas - e da

${ }^{697}$ A retórica e o debate escolásticos giravam em torno de "aspectos morais e históricos". Entre os séculos XVI e XVII, a pauta em discussão frequentemente enquadrava "assertivas dogmáticas" em meio ao "discurso jurídico", sendo essa a engenharia do raciocínio escolástico. Pensemos, por exemplo, nas discussões acerca do trabalho escravo. Elas giravam em torno de "títulos jurídicos de redução à escravidão", reconhecidos como "moralmente legítimos" e que funcionavam como "denominadores comuns", ou "universais", aplicáveis às comunidades e povos reinóis, ilhéus e continentais, sempre considerando os preceitos do direito natural e do bem comum. Na prática, os títulos jurídicos de escravidão eram: "a guerra justa, a comutação de uma pena de condenação à morte, a alienação da pessoa própria, ou de sua progenitura, em casos de necessidade e, enfim, o nascimento". Verificar: ZERON, Carlos Alberto de Moura Ribeiro. Linha de fé: a Companhia de Jesus e a Escravidão no Processo de Formação da Sociedade Colonial (Brasil, Séculos XVI e XVII). [1998]. São Paulo: Editora da Universidade de São Paulo, 2011, pp. 71-72, 109-110, 206-207.

${ }^{698}$ Caso não tenha ficado claro, o domínio indireto estava ligado à "colaboração das elites locais" com a administração ultramarina, de tal modo que os funcionários e oficiais régios "controlam as relações externas dos chefados, mas se abstinham em grande medida de qualquer interferência directa dos seus assuntos internos", apesar de sustentar a tributação como um dos alicerces do domínio. Verificar: HEINTZE, Beatrix. Angola nos séculos XVI e XVII [...]. Luanda: Kilombelombe, 2007, p. 438. Atualmente, há esforços em relacionar o sistema administrativo português adotado em Angola, altamente baseado na vassalagem e na interconexão de redes de entrepostos continentais, ao modelo adotado em Goa e na carreira das Índias. Consultar, caso haja interesse: SANTOS, Catarina Madeira. Goa á a chave de toda a Índia: perfil político da capital do Estado da Índia (1505-1570). Lisboa: Comissão Nacional para as Comemorações dos Descobrimentos Portugueses, 1999. Idem, Entre Velha Goa e Panguim: a capital do Estado da Índia e as reformulações da política ultramarina, séculos XVI-XIX. Lisboa: Instituto de Investigação Científica Tropical, 2001. SALDANHA, António Vasconcelos. Iustum Imperium. Dos Tratados como Fundamento do Império dos Portugueses no Oriente. Estudo de História do Direito Internacional e do Direito Português. Lisboa: Fundação Oriente, 1997. THOMAZ, Luís Felipe F. R. De Ceuta a Timor. Linda-a-velha: Difel, 1994. 
guerra justa - dívidas de tributos não justificavam uma guerra. $\mathrm{O}$ cheque-mate que a ordem deu no governador ocorreu através do desbaratamento dos planejamentos do governador, uma vez que eles contrariavam as diretrizes régias da política jurídico-ultramarina sustentada pela monarquia. Assim, demovia-se a máscara de legalidade clamada por Fernão de Sousa.

Na queda de braço jurídico-política o governador havia perdido. Frustrado e na procura de novos argumentos que fundamentassem a sua posição, Fernão de Sousa prosseguiu a carta de agosto de 1627 indicando que o mal-estar político gerado pelo líder do Dembo acarretava na "má reputação deste Reino [de Angola]", prejudicando também na "tardança na resposta" e "perda da Fazenda Real por serem os sobas destas províncias belicosos, Boila soberbo, e poderoso por traições". Em defesa da governabilidade de Angola, ultrajada pelo comportamento do africano, ele advertiu que "ficando sem castigo a cabeça dos rebeldes [Boila] será grande padastro [deles], e não há dúvida que provocará todos, e El-rei de Ndongo que se levante, e será necessário conquistá-lo de novo". ${ }^{699} \mathrm{O}$ impasse era o indício de "retrocesso" em relação ao sucesso logrado no Ndongo, "conquistado" e "amansado". Mesmo que esse argumento se provasse uma inverdade dentro de poucos anos, ${ }^{700}$ o relevante aqui é notar que Fernão de Sousa deixou de lado os argumentos que evocavam as concepções jurídicas e políticas da época para lançar mão de moralismos políticos. Tratava-se de uma nova guinada no discurso institucional do governador, que deixou de evocar princípios jurídicos ligados à guerra justa, ao direito das gentes e à vassalagem, em uma estratégia típica de instrumentalização de informações burocrático-administrativas, para ganhar tons ideológicos e moralizantes, perceptíveis em três sinais.

O primeiro sinal disso reside na utilização da expressão "cabeça de rebeldes", conforme o qual a "cabeça" - como "caputo" ou direção de um corpo político - estava subsumida à metaforização da hierarquia política típica do Antigo Regime, em um

\footnotetext{
${ }^{699}$ Fernão de Sousa. Carta de Fernão de Sousa ao governo. 2 de agosto de 1627. BAL, cód. 51-IX-20, ff. 338-339. IN: HEINTZE, Beatrix (coord.). Documento 95, FHA, vol. II, 1988, p. 184.

700 A semiconquista alcançada pelo governador, através da eleição e avassalamento de Angola Aire, logo degringolaria para uma situação de indisposição política entre Pungo Andongo e Luanda, como ressaltado no capítulo anterior.
} 
processamento de "codificação",701 emparelhado a outra metáfora, a do "compadrio", presente na identificação do soba Boila como "padastro" dos "insurgentes" e elemento nocivo ao interesse régio. Através da elaboração de codificação-metaforização, ${ }^{702} \mathrm{o}$ efeito alcançado era o de criação de um bloco indistinto de sobas - genericamente rotulados na documentação da FHA como "rebeldes", "rebelados", "levantados", “inimigos", “desobedientes", além de outros termos ligados à insurgência e à hostilidade - que conluiam contra Fernão de Sousa, o "pai" dos “obedientes" e responsável pela ordem e mando na Angola portuguesa. Dito de outra forma, o governo ultramarino acabaria inserido em um polo de ordem, em oposição a Boila, representante de um polo da desordem. ${ }^{703}$ É claro que, na retórica defendida pelo governador, esta não poderia ficar impune.

Reforçando a necessidade de oprimir o polo de desordem, da "eminente insurgência”, o governador adicionou à carta de agosto de 1627 a frase que, segundo Beatrix Heintze, ${ }^{704}$ exprimia seu ponto de vista pessoal sobre os povos centro-africanos e o tratamento que deveria ser destinado a eles: "o tempo, e a experiência deste gentio têm mostrado que obedece aos arcabuzes, e não a recados, como parece aos padres, e que convém castigá-lo quando merece". A evocação da história recente dos contatos, ou a experiência empírica na Angola portuguesa, concretizaria o segundo sinal de mudança discursiva. A solicitação para uma reavaliação sobre qual rumo tomar a respeito do impasse

\footnotetext{
701 De outra forma, apesar de se basearem em um contexto bem diferente do apresentado, fazemos das palavras de Silvia Hunold Lara as nossas: “As avaliações [do administrador régio] aqui seguem critérios classificatórios constitutivos da hierarquia social do Antigo Regime, e é no interior desse contexto que seus significados devem ser compreendidos". Verificar: LARA, Silvia Hunold. Fragmentos setecentistas: escravidão, cultura e poder na América portuguesa. São Paulo: Companhia das Letras, 2007, pp. 140-141.

${ }^{702}$ Sendo relevante destacar que as situações de contato foram capazes de criar "metaforizações da política que se revelam permeáveis uma a outra, permitindo a comunicação" entre matrizes culturais distintas, como afirma Catarina Madeira Santos, com a ressalva de que não necessariamente essas matrizes eram preservadas como conteúdo intacto, ou imutável, ao serem integradas ao sistema administrativo. Verificar: SANTOS, Catarina Madeira. Entre deux droits [...]. Annales. Histoire, Sciences Sociales. Paris: Éditions de l'EHESS, n. ${ }^{\circ}$ $60,2005 / 4$, p. 826, tradução nossa. No original: "On assiste ici à une sorte de transcodage, qui résulte de l'articulation entre l'invocation d'une filiation symbolique, recourant au vocabulaire africain de la parenté perpétuelle - à près de la génération, « fils » (sujets) au sens sociopolitique du terme, avec les hiérarchies et les classifications que cette parenté implique -, et le vocabulaire européen construit autour de l'amitié politique et de l'univers domestique, considérés comme modèles du monde politique, qui caractérisent l'Ancien Régime. Ces deux systèmes distincts de métaphorisation du politique se révèlent perméables l'un à l'autre, en permettant la communication."

${ }^{703}$ A utilização de "nomenclaturas" era politizada e muitas vezes baseada em estereótipos, estigmatizando as populações tipificadas, classificadas e enquadradas pelos oficiais e funcionários régios. Verificar, por exemplo, algumas conclusões sobre a chamada "nomenclatura das cores" em: LARA, Silvia Hunold. Fragmentos setecentistas [...]. São Paulo: Companhia das Letras, 2007, pp. 279-280.

${ }^{704}$ HEINTZE, Beatrix. Sobre a biografia de Fernão de Sousa, FHA, vol. I, 1985, p. 40.
} 
de Boila estava alicerçada nas lições aprendidas sobre o gentio ao longo do tempo, atualizadas na época de Fernão de Sousa e que perfaziam a criação de um saber histórico acumulado, capaz de justificar os planejamentos do governador. Como um fundo de razão autoexplicativo, a rememoração histórica virava o álibe para atacar Boila e disciplinar os demais sobas insurgentes e as autoridades que desagradavam Fernão de Sousa, competindo para uma melhor arrecadação dos "tributos dos sobas que desobedeceram, e não pagaram para Vossa Majestade [por] ser bem servido, e não se darem culpa arrecadá-los por força ou perdê-los a Fazenda Real por descuido, ou fraqueza". ${ }^{705}$

O terceiro sinal adentrava não apenas em um plano de conquista e expansão política como um ato "civilizador", ideológico e moral, mas também o relacionava ao âmbito da ação concreta do quilombo de guerra ao longo de 1626 a 1629. Tomando a dianteira das operações e sem contar com aval régio, Fernão de Sousa informou aos superiores que Bento Banha Cardoso já havia sido ordenado a solicitar "passagem” a Boila para "pegar" os elementos subversivos e, "negando-a ou impedindo-a dava justa causa para lhe fazer guerra porque tinha Vossa Majestade postestade [sic], e direito de cobrar o seu". Em desacordo com o prisma jesuítico, o governador acrescentou que dessa forma a "justa causa de potestade" poderia ser acionada também contra o rei do Kongo, no caso dele enviar “defensão dos sobas (como se dizia)" que acompanhavam Boila. Caso o Kongo agisse contra Luanda, a desculpa oficial para a dupla-ofensiva seria a reivindicação das minas de cobre do Kakongo "e com essa ocasião se fazer senhor delas", 706 Em nome da "reputação" e da "honra" da Angola portuguesa, o governador desacatava a lei escrita.

Na última parte da correspondência, Fernão de Sousa ainda frisou que, "mandando Vossa Majestade castigar Boila, e defendendo-o El-rei [do Kongo] com essa ocasião se poderá sujeitar, e ficando vassalo de Vossa Majestade far-se-ão as eleições dos reis como convém, e melhorará aquela cristandade", de modo parecido com o que acontecera no Ndongo, só que dessa vez claramente em nome da disciplina e do ordenamento das coisas políticas. Logo em seguida ele acrescentou que, em caso de decisão reinol favorável ao plano de conquista, a expansão rumo ao norte renderia benefícios econômicos à fazenda

\footnotetext{
${ }^{705}$ Fernão de Sousa. Carta de Fernão de Sousa ao governo. 2 de agosto de 1627. BAL, cód. 51-IX-20, ff. 338-339. IN: HEINTZE, Beatrix (coord.). Documento 95, FHA, vol. II, 1988, p. 184.

706. Verificar: Fernão de Sousa. Carta de Fernão de Sousa ao governo. 2 de agosto de 1627. BAL, cód. 51-IX20, ff. 338-339. IN: HEINTZE, Beatrix (coord.). Documento 95, FHA, vol. II, 1988, p. 184.
} 
real, pois "serão os resgates de mais proveito porque darão peças, e muita quantidade de panaria, e ficará Vossa Majestade senhor das minas de ouro, prata, e cobre de que a Coroa se valerá pelas suas despesas". ${ }^{707}$ Misturado à ideologia, à disciplina e à moralidade de Fernão de Sousa, o interesse que movia suas palavras era a aquisição de panos, escravos e metais preciosos. Apesar de não haver referência a isto, não seria menos relevante o fato de a região do Dembo, onde habitava Boila, estar situada estrategicamente no meio das rotas que abasteciam o "comércio secundário" de escravos, por onde os cativos eram desviados do porto de Luanda e acabavam escoados para a feitoria de Pinda, onde abasteciam as naus holandesas. $^{708}$

De um modo geral, os fragmentos de informações analisadas neste item atestam para a existência de duas marcas importantes do tempo de Fernão de Sousa, mais especificamente do que seria uma "arte de governo" ultramarino. A primeira está intimamente ligada aos níveis de circulação de informações. No que diz respeito à riqueza de informações e dados veiculados, o mais completo deles, o extenso relatório de Fernão de Sousa, fornece relevantes informações sobre como os registros administrativos e a busca pela legitimidade eram processados coordenadamente a partir dos conhecimentos e novidades advindos dos contatos, em contrapartida omitindo valiosos eventos sobre os malogros e insucessos que acometeram os seis anos de governo de Fernão de Sousa. Em

\footnotetext{
${ }^{707}$ Uma faceta crucial da ideia de "resgate" estava relacionada à noção cristã de "salvação das almas", defendida pelos missionários jesuítas, de acordo com Mariana Bracks Fonseca. Nas palavras da pesquisadora: "O negro seria resgatado do inferno em que vivia para alcançar as graças do cristianismo através da ação do colonizador branco". De outra forma, a pesquisadora afirma que a palavra "resgatar" aparece "na documentação como sinônimo de escravizar". Apesar de a "salvação das almas" ser um argumento em voga na época, na documentação institucional de Fernão de Sousa o sentido preponderante desse termo é outro. A rigor, emprego do termo "resgate" estava associado aos chamados "contratos de arrendamentos dos direitos de resgate do Reino de Angola". Portanto, o sentido prático do termo se referia ao "comércio", mais propriamente às mercadorias trazidas da África para a América, contabilizadas oficialmente pelo erário régio. Por sua vez, os dados contabilizados serviriam como base para o cálculo do valor do contrato de arrendamento negociado em Lisboa. Normalmente as mercadorias mais registradas eram os "cativos" ou "peças" e, por isso, os "resgates" levados pelas naus transatlânticas normalmente eram escravos. De todo modo, em vista do discurso legitimador, os "resgates" continuavam a fazer referência à "salvação das almas", mas na prática equivaliam muito mais ao processo de reificação dos escravizados na forma de "peças" e mercadorias negociáveis, cujos valores seriam estipulados através de algo próximo ao critério de "valor de mercado". Verificar: FONSECA, M.B. Nzinga Mbandi e as guerras de resistência em Angola: século XVII. Dissertação de mestrado, Universidade de São Paulo (USP), 2012, p. 75. Para mais considerações acerca desse termo, consultar o capítulo 2 desta dissertação.

${ }^{708}$ MILLER, Joseph C. Poder político e parentesco [...]. [1976]. Luanda: Arquivo Histórico Nacional, 1995, p. 206. Mais informações sobre a participação holandesa no tráfico, em um período posterior ao de Fernão de Sousa, verificar: Idem, O Atlântico escravista: açúcar, escravos e engenhos. Afro-Ásia. Salvador: Universidade Federal da Bahia (UFBA), n. ${ }^{\circ}$ 19/20, 1997.
} 
caminho oposto, as cartas postas em circulação imediatamente após o término da composição - portanto, que eram despachadas da Angola portuguesa para Lisboa, ou viceversa, logo após serem escritas - atestam para o fato de que a atuação e os planejamentos expansionista-exploratórios podiam ser falhos e que Fernão de Sousa às vezes era "derrotado" nas discussões e debates levados a cabo nas arenas político-jurídicas, o que fazia da governadoria uma árdua e muitas vezes frustrante posição de responsabilidade política e jurídica. A querela em torno de Boila é um exemplo prático disso, pois, ao que tudo indica, permaneceu sem resolução até o final do governo de Fernão de Sousa, ${ }^{709}$ vindo possivelmente a ser um dos fatores históricos embrionários que reforçaram os desentendimentos políticos que culminaram na chamada "guerra de Ambuila", em 1665, pondo fim ao reino unificado do Kongo. ${ }^{710}$

A segunda marca está ligada à função de governador como um agente reinol, enviado ao ultramar centro-africano e que, sem passar incólume pelas adversidades enfrentadas no além-mar, regressaria ao reino de Portugal parcialmente versado na experiência atlântica. O ponto de viragem na vida do enviado português, ou seja, o momento no qual Fernão de Sousa deu o braço a torcer e se mostrou publicamente convencido de que o zelo pela "justiça", "paz" e "bem comum" não renderia nada de palpável e interessante aos envolvidos na Angola portuguesa, está impresso na correspondência de agosto de 1627 . Um primeiro indício disso está na própria mudança

\footnotetext{
${ }^{709}$ Em nosso levantamento, conseguimos apenas três vestígios que corroboram para essa hipótese, ambos datados de 1629. Verificar: Fernão de Sousa. Ordem de Fernão de Sousa a Paio de Araújo de Azevedo. 24 de agosto de 1629. BAL, cód. 51-IX-21, ff. 282-82v. IN: HEINTZE, Beatrix (coord.). Documento 204, FHA, vol. II, 1988, p. 306. Fernão de Sousa. Ordem de Fernão de Sousa a Paio de Araújo de Azevedo. 14 de setembro de 1629. BAL, cód. 51-IX-21, ff. 282v-83. IN: HEINTZE, Beatrix (coord.). Documento 205, FHA, vol. II, 1988, p. 309. Fernão de Sousa. O extenso relatório do governador aos seus filhos. S.d., 1625-1630. BAL, cód. 51-IX-20, ff. 220-74v. IN: HEINTZE, Beatrix (coord.). Documento 30, FHA, vol. I, 1985, pp. 339-440.

${ }^{710}$ A guerra de Ambuila seria lembrada pela historiografia como um marco importante para a consolidação das pretensões portuguesas no continente, tendo como um dos desdobramentos a morte do então rei do Kongo, António I. Assim, teria início o chamado "colapso" do reino africano e o massacre de comunidades portuguesas estabelecidas em sua capital, chamada de São Salvador ou Mbanza Kongo. No mais, a vitória dos portugueses e seus aliados apontaria para o aumento da importância que Luanda passaria a exercer regionalmente a partir de 1665. Verificar: THORNTON, John K. The Kongolese Saint Anthony: Dona Beatriz Kimpa Vita and the Antonian Movement, 1684-1706. [1998]. Cambridge: Cambridge University Press, 2009, p. 69. Idem, A Cultural History of the Atlantic World, 1250-1820. Cambridge: Cambridge University Press, 2012, p. 253. Idem, THORNTON, John K. Warfare in Atlantic Africa [...]. [1999]. Londres e Nova Iorque: Routledge, 2003, p. 103. VANSINA, Jan. Paths in the Rainforests [...]. Madison-Wisconsin: University of Wisconsin Press, 1990, p. 220. SANTOS, Catarina Madeira. Um governo "polido" para Angola [...]. Tese de doutorado, Universidade Nova de Lisboa, 2005, p. 89.
} 
interna do discurso, no que dizia respeito à relevância das matérias tratadas. Do meio até o final desse documento, aconteceu uma inflexão da argumentação de Fernão de Sousa, passando a se fundar em argumentos que transitavam do convencimento à comoção da monarquia, reforçados pelo interesse econômico nos resgates e fazendas. Ora, não seria por menos que entre 1626, até meados de 1629, o estado de guerra foi mantido: ele era a chave para a prosperidade material e engrandecimento da fazenda régia. Discurso e retória jogavam a favor de uma economia atlântica em pleno vapor. Um segundo indício que também entrega um momento de viragem reside no aprendizado adquirido por Fernão de Sousa e como ele ingeriu mudanças "à moda atlântica" no reinol. Prestemos atenção em alguns importantes detalhes.

Há duas versões da carta de 2 de agosto de 1627 que, atualmente, estão guardadas na Biblioteca da Ajuda de Lisboa. ${ }^{711}$ Em uma delas, 51-IX-21, existe um aditamento inexistente em 51-IX-20. No acréscimo está escrito que seria "conveniente" à cristandade que, uma vez submetido ao avassalamento, o governo do reino do Kongo fosse entregue ao bispo ou ao "patriarca da Companhia de Jesus". Os detalhes faziam toda a diferença. Assumindo a derrota na arena jurídico-política, Fernão de Sousa estava disposto a ceder os “anéis dos dedos", abrindo mão da direção do Kongo em benefício do bispo ou de alguma autoridade jesuítica, para com isso atingir um equilíbrio político favorável à governabilidade regional. Todos ganhariam dessa forma e, com a cooperação do bispado ou da Companhia de Jesus - o importante era ter apoio eclesiástico -, a monarquia vislumbraria o florescimento da "religião, e guardada nossa santa lei governar-se-á em paz, e justiça, será Vossa Majestade senhor dos resgates, e dos metais que nele há, com grande acrescentamento da Coroa, e dilatação da nossa santa fé". ${ }^{712}$ Afinal de contas, como considerou em ultimo caso Fernão de Sousa, "havendo este Reino [de Angola] bispo separado, e nesta Cidade [de Luanda] [igreja da] Sé, e governo político, aumentar-se-ão todos os Reinos [Kongo, Angola e Benguela] por todas as vias". ${ }^{713}$

\footnotetext{
${ }^{711}$ As informações sobre essas duas versões e os aditamentos são fornecidas na nota 380 para: Fernão de Sousa. Carta de Fernão de Sousa ao governo. 2 de agosto de 1627. BAL, cód. 51-IX-20, ff. 338-339. IN: HEINTZE, Beatrix (coord.). Documento 95, FHA, vol. II, 1988, p. 183.

${ }^{712}$ Fernão de Sousa. Carta de Fernão de Sousa ao governo. 2 de agosto de 1627. BAL, cód. 51-IX-20, ff. 338-339. IN: HEINTZE, Beatrix (coord.). Documento 95, FHA, vol. II, 1988, p. 185.

${ }^{713}$ Ibidem, p. 185.
} 
Governar era de fato uma "arte" que necessitava de engenho e maleabilidade, mas também de capacidade para manter uma ordem judiciária e um mando político que zelariam pela "paz", em algo similar ao que poderíamos sintetizar sob a forma de uma arte de governo da paz. Mediante os ditames de um governo entendido como sendo "político", em oposição clara aos governos africanos, desclassificados como "apolíticos", vigoraria uma noção de "justiça", frequentemente pragmática e aplicável, capaz de proporcionar a dilatação da fé e a prosperidade econômica dos resgates. Nesse sentido, e tal qual em uma orquestra, o epicentro de uma governança efetiva estava situada na regência de agentes e grupos sociopolíticos diversos, tanto internamente - os jesuítas, capitães, comerciantes, representantes de contratadores, conquistadores entre outros - quanto externamente - os vários sobas que compunham os palcos políticos locais -, de modo que a arte de governo da paz implicava na aquisição de saberes diversos, especialmente úteis na África CentroOcidental, mas que também podiam circular pelo espaço atlântico e influenciar outros contextos. $^{714}$ Em Luanda e nos pontos administrativos espalhados pelo continente, não bastava deter o conhecimento técnico e administrativo proveniente do reino de Portugal, já dominados muito bem por Fernão de Sousa, a julgar pelo extenso relatório e outros documentos inseridos na $F H A$, mas apreender, através da experiência atlântica, novas formas de negociações, em razão dos agentes coloniais e eclesiásticos diferenciados que serviam no ultramar centro-africano. Além disso, não era menos importante o fato de a África Centro-Ocidental contar com uma panóplia diversificada de autoridades africanas, como o Kongo, Ndongo, Boila e a inumerável quantidade de sobas que ia das bandas do Lucala até a Quina Grande, cada qual com a sua especificidade e possibilidades distintas de intersecção nos contatos. Governar era dominar saberes de várias naturezas e, através da

\footnotetext{
${ }^{714}$ Concordando então com a noção de "níveis de domínio", salientada por Rodrigo Faustinoni Bonciani. Nas palavras dele: "Cada um dos agentes coloniais, da Coroa aos moradores, participa e se beneficia de uma parte do processo de exploração colonial [...]. A justiça e o poder régio, nas sociedades escravistas e senhoriais ultramarinas, definem-se pela capacidade de ordenar essas relações de dominium, em que cada membro recebe o benefício da exploração colonial de acordo com seu lugar naquela sociedade, na lógica aristotélica da justiça distributiva". Assim, pelo menos na perspectiva global de formação dos reinos ibéricos e desenvolvimento de domínios ultramarinos, "as monarquias ibéricas modernas se formaram em relação dialética com o império atlântico". Verificar: BONCIANI, Rodrigo Faustinoni. O dominium sobre os indígenas e africanos e a especificidade da soberania régia no Atlântico: Da colonização das ilhas à política ultramarina de Felipe III (1493-1615). Tese de doutorado, Universidade de São Paulo (USP), 2010, pp. 275276. Para mais considerações, ver também as pp. 274-275.
} 
apreensão e percepção aguçadas, Fernão de Sousa foi paulatinamente imbuído de "calos ultramarinos", impregnando-se de modos e costumes da terra.

\subsection{Institucionalização, populações e uma arte de governo da paz}

Sem exceção, todas as situações de contato registradas nos documentos da FHA passaram pelo processamento da informação administrativo-burocrática, dentro do qual os sobas eram transformados em informações legais e dados burocráticos, passíveis de serem manejados administrativamente após a codificação e a inscrição em papel. A isso chamamos anteriormente de "burocratização", definindo-a como um processamento informacional necessariamente guiado pelos pares legitimação-oficialização e informaçãoformalização, resultando na preparação de material escrito necessário para que as autoridades régias tomassem conta de, ou muitas vezes refletissem sobre, quem eram as pessoas e quais eram os objetos com os quais lidavam na África Centro-Ocidental. Afinal de contas, era preciso conhecer para governar. Posto dessa forma, havia um "grau um" na institucionalização da vida no ultramar e das práticas governamentais adotadas na Angola portuguesa. Tal grau era visível na aquisição de conhecimento útil para a cunhagem de saberes provenientes dos contatos, na forma de um material confiável e que depois seria constantemente atualizado e reutilizado em prol de planejamentos políticos traçados em Luanda, sendo úteis também para os tais planos e projetos aos quais fizemos menção em outro momento. ${ }^{715}$

No grau um de institucionalização e governabilidade da Angola portuguesa, residia uma prática de aquisição de conhecimentos "em campo", geradora de material informativo que assim fluiria dos presídios para Luanda, Lisboa e depois vice-versa. Em outras palavras, como um "fio condutor" de interconexão e influência dual, revestido de formas de dominação e intermediação interpoladas entre si, a comunicação institucional interligava as experiências advindas dos contatos com as maquinações operadas em Luanda e Lisboa, por meio de um conteúdo registrável e comunicável, destituído de uma pretensa "pureza" ou "perfeição". Por isso, as atuais fontes oficiais inseridas na $F H A$ não são vestígios fiéis à realidade observada, senão documentos comprometidos com as necessidades administrativas, comunicacionais e legitimadoras com as quais os membros de um círculo

\footnotetext{
${ }^{715}$ Consultar o capítulo 2 desta dissertação.
} 
de influência e sociabilidade, responsáveis pela tomada de decisão institucional ultramarina, lidavam ao conduzir os interesses da Angola portuguesa. Nada do que foi registrado em papel e acabou amontoado em arquivos empoeirados, vulgarmente conhecidos como os "maços da conquista", 716 é neutro ou imaculado.

No plano prático do processamento informacional, comunicação institucional e criação de saberes oficiais, havia o ensaio daquilo que chamaremos de triagem dos sobas, mediante as esferas burocrática e administrativa, possível de ser dividida em quatro procedimentos. No primeiro deles, onde jazia por consequência a extremidade inicial do fio condutor, ocorria a deteç̧ão de quem era passível de submissão, subjugação e sujeição, na medida em que seriam "atacáveis", "defensáveis", "sustentáveis" ou "tributáveis", tudo de acordo com os interesses das autoridades régias. O segundo procedimento era a seleção de uma posição, ou tomada de partido, no ato de inserção de Luanda nos palcos políticos locais: combater o Kongo e Boila no norte em 1627 e avançar sobre os sobas do Lucala até as proximidades da Quina Grande, entre 1626 a 1629. O papel de agentes coloniais era aqui crucial, pois eram esses indivíduos que conservavam as experiências de vida e os conhecimentos necessários para determinar qual posição, ou inserção política, seria mais conveniente a tomar, ou seja, eles tinham a "manha" e a "dissimulação" da região, como constatou Rodrigo Faustinoni Bonciani. ${ }^{717}$ Alguns desses agentes mais importantes foram Bento Banha Cardoso, Paio de Araújo de Azevedo e Lopo Soares Lasso, cada qual com a sua trajetória de vida própria, mas unidos como um grupo sociopolítico enraizado na Angola portuguesa, que não semeava a vontade de retornar ao reino de Portugal e cujos herdeiros continuariam a habitar nas terras africanas. Tais indivíduos eram conhecedores da "conquista" e do "sertão", venturosos na guerra e na carreira político-administrativa, versados nos "usos e costumes" locais e no "tratamento do gentio", possuidores de cabedal, principalmente para investir na máquina de guerra ou em governadorias, e detinham conhecimento técnico mínimo, como saber ler e escrever, além de serem influentes e

\footnotetext{
${ }^{716}$ Ver, por exemplo: Fernão de Sousa. O extenso relatório do governador aos seus filhos. S.d., 1625-1630. BAL, cód. 51-IX-20, ff. 220-74v. IN: HEINTZE, Beatrix (coord.). Documento 30, FHA, vol. I, 1985, p. 300.

${ }^{717}$ No contexto de expansão ultramarina e fundamentação da experiência de domínio extraeuropeu dos séculos XVI e XVII, o sentido de "manha" passava a ser o de "experiência política" angariada através da empiria, expressa pela "metáfora tátil" e coeva de "meter a mão na experiência". A "dissimulação" deve ser compreendida como um invólucro de "fingimento", "espécie de prudência" e "malícia dos homens". Tais definições foram ensaiadas, a partir do Voc. Port. de Bluteau, em: BONCIANI, Rodrigo Faustinoni. $O$ dominium sobre os indígenas e africanos [...]. Tese de doutorado, Universidade de São Paulo (USP), 2010, p. 224.
} 
altamente interessados nas coisas que afetavam a Angola portuguesa. Até as chagas da vida pareciam compartilhar. Curiosamente, o governador fez questão de salientar que Bento Banha Cardoso não tinha um olho e três dedos de uma mão, e que Lopo Soares Lasso ficara cego do olho esquerdo, no verão de 1627. Apesar de conservar os membros do corpo, Paio de Araújo perdeu todos os herdeiros homens em confrontos militares, em $1648 .{ }^{718} \mathrm{Em}$ contrapartida, os agentes reinóis - simbolizados normalmente pelo governador, provedores da fazenda e ouvidores-gerais - tendiam a ser novatos na região e tinham a expectativa de regressarem a Portugal, sendo raras as vezes que se aventuravam na região. Nesse sentido, cabe notar que, desde o desembarque em Luanda, Fernão de Sousa nunca deixou a dita “cidade", salvo para retornar a Lisboa. Durante os seis anos de permanência na África, o governador foi totalmente dependente da circulação de informações e ideias vindas do interior, na forma das cartas expedidas pelo oficialato, que normalmente servia nos presídios, e das "idas e vindas" de macunzes, ${ }^{719}$ sem as quais seu mandato seria inexequível. Seja em escala local ou transcontinental, a circulação e a comunicação foram cruciais para a manutenção da Angola portuguesa e do estreitamento das relações entre agentes coloniais e reinóis.

O terceiro procedimento era a vinculação política, que poderia ser ensaiada na forma de alianças ou de simples aproximação diplomática, mas cuja concretude era de fato alcançada com o avassalamento. Era através dele que, na prática, firmava-se o estreitamento de laços políticos entre Luanda e as cabeças políticas do Ndongo e Dembo. Uma das vantagens da vassalagem residia na reassociação de um léxico feudo-vassálico, em coexistência imbricada com alguns princípios que estruturavam as sociedades mbundu, bakonga e ndembu, pelo menos. Além disso, em termos de governabilidade política, uma segunda vantagem dizia respeito ao prestígio. O avassalamento português era aceito, inclusive às vezes procurado pelos sobas, porque fortalecia o prestígio interno que moldava o "correto" governo das linhagens, estruturado em torno de grupos de parentesco fiéis ao comando político de um soba ou "rei africano", capazes assim de conter as rivalidade e clivagens desagregadoras e pulverizadoras que impediam a prosperidade da centralização

\footnotetext{
718 Sobre Bento Banha Cardoso, verificar: HEINTZE, Beatrix. Breves biografias de alguns europeus em Angola (1620-1630). FHA, vol. I, 1985, pp. 79-80. Sobre Paio de Araújo de Azevedo, verificar pp. 73-74 dessa mesma obra, e Lopo Soares Lasso, a p. 93.

${ }^{719}$ Consultar o "suplemento para alguns vocábulos africanos", inserido nesta dissertação.
} 
política. Em terceiro lugar, na ótica africana, o avassalamento também rendia parcerias políticas de peso dentro dos palcos políticos locais do Dembo, Ndongo, bandas do Lucala, bambes de Matamba, entre outras localidades, passíveis de serem utilizadas pelas autoridades africanas para abrir guerra contra um inimigo em comum. Uma vez selado o pacto político, a expectativa era a de que as autoridades africanas angariassem auxílio militar e respaldo político. ${ }^{720}$ Dessa forma, prestígio interno e parceria externa faziam com que algumas autoridades centro-africanas cooperassem com Luanda, em detrimento de outras que poderiam ser saqueadas, pilhadas, roubadas, combatidas ou esquecidas pelo funcionalismo régio.

$\mathrm{O}$ ponto mais alto do processamento informacional era atingido exatamente em seguida, no quarto procedimento. À margem do interesse africano, todas as informações e conhecimentos sobre a vinculação política eram fixados na forma de "autos", "escrituras", "listas" e correspondências que, no geral, eram inacessíveis às autoridades africanas. Circunscrita à comunicação institucional e normalmente circulante entre as autoridades do alto escalão português - internamente entre o governador e os capitães, externamente entre o governador e os notáveis da monarquia -, os registros repetiam designações e termos políticos essenciais para a tomada de decisão institucional. Ao virarem informações burocráticas e administráveis, ou seja, serem "burocratizados", os sobas acabavam classificados através de estatutos que sustentavam qualificativos como "obediente", "vassalo", "confederado", “amigo" e seus antagônicos, como "levantado", "rebelado", "rebelde" e "inimigo". Era com base nessa nomenclatura, ou estatutos políticos cunhados para os sobas, tão repetida e gasta na $F H A$, que o governador e os capitães justificavam as ações e posições que seriam adotadas publicamente. O cerne de nossa argumentação é entender que, uma vez processados como informações e dados inseridos nos canais de comunicação portugueses, atores africanos como Boila, Ginga Ambande, Aire Aquiloange, Angola Aire e os vários sobas não nomeados, mas citados homogeneamente como "os sobas da Matamba" ou do Ndongo, eram integrados aos planejamentos portugueses arquitetados em Luanda e Lisboa.

Ao término do fio condutor, os "reis africanos", sobas e suas gentes acabavam destituídos de autodeterminação e alteridade - hoje em dia evocadas pelas terminologias

\footnotetext{
${ }^{720}$ Nesse sentido, verificar a par prestígio-reciprocidade comentado no capítulo 1 desta dissertação.
} 
étnicas, como bakonga, mbundu e ndembu -, para serem enquadrados através de designações pouco matizadas entre si, implicadas em qualificativos bastante suspeitos e subsumidos às vontades dos que atuavam e conduziam política e administrativamente a Angola portuguesa. Uma vez triados e integrados como informações burocráticoadministrativas, eles passavam a abastecer os centros de tomada de decisão, sendo o principal deles Luanda. Na dita cidade, havia espaços onde os debates e as discussões políticas eram incentivados, como no colégio da Companhia de Jesus e na Câmara de Luanda. $^{721}$ Representante direto da monarquia na África Centro-Ocidental, Fernão de Sousa era autoridade régia de maior importância na região, sendo então o responsável maior pela análise e avaliação de tudo que chegava lá. Todavia, como já dito, ele não governava sozinho. A atuação política era deliberada entre o governador e o seu círculo de sociabilidade institucional, composta pelos capitães-mores Bento Banha Cardoso, Paio de Araújo de Azevedo e Lopo Soares Lasso, além é claro das chamadas “consultas" aos jesuítas e ao bispo. O termo "sociabilidade" deve ser interpretado com cautela. Unidos pela vivência em comum e por alguns propósitos convergentes, pelo menos no que dizia respeito à direção administrativa e à política da Angola portuguesa, o ato de unir sujeitos distintos dentro de um alto círculo político previa a existência de empatia e identificação interpessoais entre eles. Dessa forma, em um primeiro momento, era necessário que esses agentes fossem sagazes o bastante para apreender as circunstâncias e as experiências enfrentadas pelos companheiros, portanto alheias ao "eu", sendo assim capazes de se colocar na posição de outrem. Mantinham, portanto, laços sociais alimentados por empatia e objetivos convergentes. Em um segundo momento, os membros de um círculo de sociabilidade institucional deveriam reconhecer aquilo que compartilhavam em comum, separando os pontos de intersecção das matérias e tópicos de divergência, de modo a contemplar o maior número de demandas e interesses "profícuos", de mútuo acordo, que existia entre a elite influente de Luanda. O próximo passo seria colocá-los em voga nas rodadas de negociações e discussões, acerca das ações políticas e econômicas a serem tomadas. Na maioria das vezes, a sociabilização e politização, em âmbito local e regional,

\footnotetext{
721 Sobre a importância dessas instituições no concerto político de Luanda, consultar o capítulo 2 desta dissertação.
} 
giravam em torno de um só objetivo: conseguir mão-de-obra escrava e cativos que abastecessem o tráfico de escravos transatlântico.

Dessa forma, uma vez filtradas e procedidas as triagens, as informações e os dados comunicados a Luanda não eram operados friamente, mas sim articulados às consultas e às deliberações institucionais, que podiam ser feitas em âmbito "privado" ou "público". Nessas arenas político-jurídicas, as informações e os dados poderiam ser fundidos a discursos e à retórica, na forma de argumentos institucionalmente lícitos. Por consequência, acabavam colocados em cena para embasar os planejamentos contra o Kongo, Boila, Angola Aire e sobas espalhados entre as bandas do Lucala, bambes de Matamba e redondezas até a Quina Grande. Sob a redoma de uma arena político-jurídica, pincelada por múltiplos argumentos e divisões sociopolíticas, podemos dizer "encenadas" ou "teatralizadas", 722 existiam tensões sociais, atritos institucionais e embates políticos latentes. Internamente, a Angola portuguesa não era homogênea, sendo que cada um dos agentes que citamos ao longo deste capítulo - genericamente etiquetados como reinóis, coloniais e eclesiásticos - sustentava interesses próprios, que às vezes convergiam em prol de um só intuito, mas às vezes não. Um dos ápices de rivalidade e discórdia aconteceu no impasse de Boila, mais especificamente em 1627, momento no qual ficou claro que distorções e falácias poderiam ser sustentadas em nome de planejamentos políticos que visavam somente ao expansionismo e à exploração. Residia nessa espécie de política interna o "grau dois" da institucionalização das populações ultramarinas e das práticas governamentais da Angola portuguesa, no qual informações e dados, previamente selecionados e comunicados, eram manejados de acordo com o interesse das autoridades régias.

Sem exceção, em todos os planejamentos políticos descritos neste e no segundo capítulo que compõem esta dissertação, houve a participação de um círculo sociopolítico de influência e sociabilidade institucional, como já dito, formado por agentes reinóis, coloniais

\footnotetext{
${ }^{722}$ Em termos próximos aos de Clifford Geertz, conforme explicado no capítulo 2 desta dissertação. Para não nos alongarmos demais na questão, basta conferir igualmente as considerações feitas por Jan Vansina a respeito da noção de "imaginação coletiva", além de como ela é operante na teatralização política existente no âmago de construção e recriação dos governos centralizados e piramidais. Verificar: VANSINA, Jan. How Societies Are Born [...]. Charlottesville: University of Virginia Press, 2004, pp. 204-205, com ênfase no breve comentário da nota 121. Sobre a definição sucinta de "imaginação coletiva", verificar essa mesma obra, pp. 268-269. Sobre uma perspectiva "historicizada" da análise cultural, verificar: RESENDE, Maria Leônia Chaves de. Visões da conquista: verso e reverso (As missões jesuíticas nos séculos XVI/XVII). Dissertação de mestrado, Universidade de Campinas, 1993, pp. 23 e 34.
} 
e eclesiásticos. Tais indivíduos foram absorvidos nos entrepostos que faziam parte do aparato administrativo ultramarino, desempenhando dessa maneira atividades militares, administrativas e judiciais. Cabe aqui revisitar o papel fulcral de uma dessas searas, a dos agentes coloniais, pormenorizando certos aspectos. Descritos como prestativos e leais à Coroa, portanto dissociados na documentação de certos agentes encarados como "corruptos", como descrevemos no capítulo anterior, além de serem combativos em relação às insurgências e às subversões de líderes africanos, como as propagadas por Boila desde 1626 e Angola Aire entre 1629 a 1630, esses homens eram experientes na terra, de carreira renomada regional, provenientes de um grupo sociopolítico extremamente útil à ocupação efetiva da terra e que detinha a confiança do governador. Os holofotes, por assim dizer, devem ser direcionados para a experiência histórica. Todos os agentes coloniais aqui abordados ascenderão socialmente como quadros administrativo-militares de importância regional, enriquecendo a partir da aquisição de propriedades, do acúmulo de fazendas regionais e do comércio atlântico. Portanto, tratava-se de um modelo de ascensão social desprendido das amarras do Antigo Regime e que, a certa altura, ficou mais atraente do que a prestação de serviços régios e a busca por mercês do monarca. Apesar de importante, a economia simbólica do privilégio não seria mais do que uma "atividade-meio" para impulsionar os interesses materialistas. A "atividade-fim", o combustível que fazia mover as engrenagens e maquinações, era o tráfico de escravos. Anteriormente salientamos que isso foi perceptível em 1627, quando Bento Banha Cardoso e Paio de Araújo de Azevedo foram cotados para assumir o governo de Benguela, porém preteriram a governadoria em preferência à máquina de guerra movida contra Ginga Ambande, muito mais rentável e lucrativa. Mas e Benguela? Como ressalta Beatrix Heintze, a situação ficara "subitamente crítica" após a morte de seu governador Manuel Cerveira Pereira, em 9 de abril de 1626. Com a recusa das duas primeiras opções de sucessão, Lopo Soares Lasso acabaria sendo nomeado às pressas como "capitão-mor e conquistador do Reino de Benguela", tomando o governo em 7 de maio de 1627, não sem antes investir " 25.000 cruzados para o equipamento, inclusive um adiantamento de soldos de seis meses para os soldados". 723 Devido ao estado de miséria do domínio sulista e à ânsia de reaver a soma investida na

\footnotetext{
${ }^{723}$ HEINTZE, Beatrix. Breves biografias de alguns europeus em Angola (1620-1630). FHA, vol. I, 1985, p. 93.
} 
empreitada administrativa, o governador-conquistador promoveu as chamadas "saídas para o sertão", todas elas de legalidade no mínimo contestável. Nelas, a gente de guerra de Benguela partia para o interior a fim apenas de trucidar as aldeias consideradas subversivas e escravizar o maior número de pessoas possível. Em todos os cenários, o resultado era o mesmo: mais cedo ou tarde, os agentes pendiam para a ascensão social baseada no tráfico atlântico e na escravidão do gentio.

A única ressalva talvez fique a cargo dos agentes eclesiásticos. Separados entre a Companhia de Jesus e o padroado régio, eles tinham dinâmicas e rivalidades, internas e externas, dissociadas da atuação política de Luanda. Mesmo assim, apesar de não poderem ser encarados, ou interpretados, como entidades unidas ao oficialato e funcionalismo régios, os agentes eclesiásticos prestavam serviços como quadros político-jurídicos vitais ao funcionamento institucional de Luanda. Como especialistas do direito da época, eles participavam de deliberações feitas em conselhos e especialmente o bispo e o reitor do colégio dos jesuítas eram consultados por Fernão de Sousa. De uma maneira geral, desde que fosse minimamente competente para tal, qualquer uma dessas autoridades poderia servir na mediação de contendas político-jurídicas, por exemplo abertas entre o governador e os capitães-mores, como vimos no caso do impasse de Boila. Além disso, jesuítas como Francisco Pacónio e António Machado prestavam auxílio na intermediação entre autoridades africanas e portuguesas. Devido à importância que detinham, ficava implícito que as autoridades eclesiásticas participavam ativamente das rodadas de debate $\mathrm{e}$ conspirações em Luanda. Assim, mais do que intrometidos ou "xeretas" da vida política e social do ultramar, após a queda da política ultramarina que sustentava a "instituição dos amos", como levantado no primeiro capítulo desta dissertação, a Companhia de Jesus e o padroado régio foram reacomodados na nova arena político-jurídica, existente nos espaços de discussão e debate político de Luanda, agora sob a forma de quadros judiciários importantes no zelo pela justiça portuguesa. Dessa forma, mediante a uma perspectiva administrativa ultramarina, eles eram úteis para a intermediação, legitimação e mediação das tensões sociais e atritos institucionais que faziam parte da vida política interna da Angola portuguesa, figurando assim, de modo geral, como auxiliares na implementação do 
espaço jurisdicional e úteis para a consolidação de uma rede de fidelidade política, ambos pilares necessários para a perpetuação do domínio ultramarino. ${ }^{724}$

Finalmente, desdobrado do círculo sociopolítico de influência e sociabilidade institucional encabeçado por Fernão de Sousa, residia o "grau três" da institucionalização da vida no ultramar e das práticas governamentais adotadas na Angola portuguesa. Dele emanava a ação efetiva. Após serem burocratizados e manejados, as informações e dados advindos dos contatos eram “instrumentalizados” pelas mãos de Fernão de Sousa, Bento Banha Cardoso, Paio de Araújo de Azevedo, Lopo Soares Lasso, da Companhia de Jesus e do padroado régio. Por mais que houvesse discórdias e rivalidades entre esses indivíduos, para manter a governabilidade era necessário chegar a um consenso. As divergências eram negociadas, cedia-se mais sobre uma matéria, batia-se o pé sobre aquilo inarredável. As convergências eram concatenadas e as diferenças momentaneamente esquecidas. No final das contas, o objetivo que deveria ser alcançado era sempre o mesmo, expandir para explorar, atendendo às demandas do círculo de influência e sociabilidade em Luanda. Assim sendo, era a partir de resoluções internas que se propunha uma política externa de intervenção, sempre em nome da "paz", "justiça" e "bem comum” dos povos. Se nos graus um e dois as informações e dados poderiam ser distorcidos, no grau três a deturpação deles era algo frequente, visando sempre ao pragmatismo político e à aplicação da justiça. Exemplo mais claro de como a instrumentalização delineava o caminho da ação efetiva aconteceu entre 1626 a 1629, durante as campanhas de guerra contra Ginga Ambande. Em razão de um conjunto múltiplo de fatores - os mais preponderantes deles foram os interesses régios, coloniais, o aval reinol, a confirmação legal feita pelos eclesiásticos e

\footnotetext{
${ }^{724}$ Dessa forma, reconsideramos o chamado "padrão real de conquista" proposto por John K. Thornton, para quem a invasão estrangeira estava entrelaçada a uma "política de aliança" indiscriminadamente disseminada em toda a África. Segundo Thornton, tal ideia é explicada por duas prerrogativas bélico-militares cruciais. A primeira era o baixo número de soldados que empunhavam armas nos exércitos comandados pelos invasores. A segunda era a existência de "ambientes ecológicos" pouco conhecidos pelos ditos "conquistadores" e militares europeus, figurando como um impeditivo ao avanço militar e à penetração do continente. No caso específico da Angola portuguesa, a máxima estabelecida por Thornton é a de que houve uma incapacidade portuguesa de "conquistar nem que seja um só grande governo africano". THORNTON, John K. A Cultural History of the Atlantic World, 1250-1820. Cambridge: Cambridge University Press, 2012, pp. 160-161 e 182. Para uma perspectiva inversa a essa, que refuta a importância decisiva de uma pretensa "fraqueza portuguesa", derivada dos poucos contingentes populacionais enviados ao além-mar, carência de recursos financeiros e inferioridade bélica, verificar: BETHENCOURT, Francisco; CURTO, Diogo Ramada. Introduction. IN: Idem (ed.). Portuguese Oceanic Expansion, 1400-1800. Cambridge: Cambridge University Press, 2007, pp. 13-14. Faremos mais considerações pertinentes ao impacto português na conclusão desta dissertação, mais especificamente no item 4.
} 
logicamente a própria resposta africana à presença do quilombo nas vizinhanças do Ndongo com Matamba -, que os tipos de tratamentos destinados aos sobas foram determinados. Sucintamente, esses tratamentos podem ser dissociados entre os que eram diretos - coerção, guerra ou "belicismo" - e os indiretos - coação, avassalamento e "pacificação" -, sendo perceptíveis através do emprego de nomenclaturas políticas empregadas na documentação. Tal qual uma panaceia, e essa foi a metáfora proposta no primeiro item deste capítulo, os tratamentos destinados aos sobas imbricavam dois binômios essenciais - guerrear e policiar, expandir e proteger - como fórmula de solução para os problemas vigentes nas duas bandas do Lucala, em Tanto Angonga, nos bambes de Matamba e possivelmente alhures até a Quina Grande. O funcionamento do todo girava em torno não apenas da perpetuação da Angola portuguesa, referida na documentação através de expressões ligadas à "proteção", "segurança" e "defesa" dos tais sobas "amigos", "confederados" e "vassalos", mas também do ataque bélico que visava o beneficiamento pessoal dos que participavam das guerras, do engrandecimento do erário régio através da pilhagem e do crescimento do tráfico atlântico.

No final das contas, os pares "guerra econômica-guerra política" e "investimento público-investimento privado" não eram dicotômicos e nem excludentes entre si, como o senso comum atualmente prega. Não eram e tampouco foram ao longo do processo histórico. Em uma perspectiva alargada de tempo, a associação dialética inter e intra pares e binômios foi um aspecto constante entre as guerras levadas a cabo por Paulo Dias de Novais (1580-1590), Luís Mendes de Vasconcelos (1617-1621) e Fernão de Sousa (16261629) no que dizia respeito ao funcionamento político e econômico da Angola portuguesa, vislumbrado através de um processo histórico de constante formação e reconstrução das formas de dominação e intermediação ao longo dos contatos luso-africanos. ${ }^{725}$

Para finalizar, podemos resumir os resultados aqui obtidos da seguinte forma. $\mathrm{O}$ funcionamento institucional voltado à gestão dos povos ultramarinos encontrava respaldo

\footnotetext{
${ }^{725}$ Interessante é notar que o exercício político de Mem de Sá na governadoria-geral do Estado do Brasil, entre 1558-1572, pareceu seguir essa mesma tendência. Ficamos então com o comentário de Rodrigo Faustinoni Bonciani, de acordo com o qual "uma guerra de sujeição, comandada pelo governador em nome do rei, [...] não desfaz a possibilidade de apropriação privada do butim e a contradição entre dominium privado/doméstico e a autoridade régia. Essa guerra planejada, para ser eficaz do ponto de vista das relações coloniais, deve favorecer os diferentes grupos sociais da colônia em formação, por meio da concessão de diferentes modalidades de dominium sobre os indígenas, segundo os serviços e a condição social dos participantes." Verificar: BONCIANI, Rodrigo Faustinoni. O dominium sobre os indigenas e africanos [...]. Tese de doutorado, Universidade de São Paulo (USP), 2010, pp. 161-162.
} 
em algumas das ações e medidas adotadas no governo-geral da Angola portuguesa, ambos podendo ser divididos em graus de profundidade, variando daquilo que era mais basilar, a informação em si, até a instância mais impactante, assente na ação efetiva. A linha de condução da atuação institucional, apesar de misturar formas de dominação e intermediação, sempre começava por intermediar os contatos, achando maneiras de engendrar a comunicação e a coabitação de indivíduos diferentes, genericamente identificados como "portugueses" e "africanos", mas que de fato eram matizados entre agentes e grupos diferentes, em um mesmo espaço, para enfim propor formas de subjugar, submeter ou sujeitar os contatados. O governo da Angola portuguesa lograva êxito apenas quando a atuação política dos membros que compunham o círculo de influência e sociabilidade do alto comando de Luanda, responsável pela decisão institucional e reunido em "coalizões de searas", superasse as diferenças e chegasse a um consenso sobre como agir e reagir frente aos desafios enfrentados no Kongo, Dembo, Ndongo até as portas de Matamba. Assim, primeiro era preciso resolver a política interna, para então lidar com a externa. A autoridade de maior peso no concerto político de Luanda, o agente reinol Fernão de Sousa, tinha grande peso nisso: era ele o responsável em fazer com que as partes funcionassem pelo todo. Sobre isso, é importante ter em mente que, mais do que tino ou genialidade pessoal, para um governador obter memorável passagem na Angola portuguesa, como conseguiu Fernão de Sousa, era preciso que ele soubesse governar e que conhecesse os governados e, portanto, que estivesse em constante aprendizagem e reciclagem de ideias e conceitos. Durante o governo de Fernão de Sousa, aquilo que anteriormente chamamos de ponto de viragem, ou inflexão, do comportamento político e público do reinol, foi expresso nas opiniões e proposições que ele enviou a Lisboa especialmente a partir de 1627, em visível descompasso com as descrições e apreciações mantidas geralmente no extenso relatório. Ao experimentar e adquirir saberes e conhecimentos locais, tanto sobre a vida em Luanda quanto a repeito dos povos mbundu, ndembu e bakongo, Fernão de Sousa aprendeu que, no domínio ultramarino atlântico, a escravidão, o comércio e a guerra eram tônicas indissociáveis da "paz", "justiça" e do "bem comum”, tanto encomendados pelo monarca português emblemáticos nos regimentos de Angola. Doravante, fica claro que ele havia dominado a arte de governo da paz. 


\section{CONCLUSÃO}

Todo o livro de história digno de nome deveria comportar um capitulo ou [,caso prefira], inserida nos pontos de inflexão da exposição, uma série de parágrafos que se intitulariam algo como "Como saber o que vou lhes dizer?". Estou convencido de que, ao tomar conhecimento dessas confissões, inclusive os leitores que não são do ofício experimentariam um verdadeiro prazer intelectual. O espetáculo da busca, com seus sucessos e reveses, raramente entedia. É o tudo pronto que espalha o gelo e o tédio. ${ }^{726}$

Marc Bloch

Os temas tratados neste estudo foram desenvolvidos de modo a encontrarmos respostas para duas questões, predispostas da seguinte forma na introdução desta dissertação: i) Como medir ou qualificar o impacto estrangeiro? Como as novidades do tempo se impunham às continuidades do passado? ii) Como analisar o potencial inovador, quiçá criador, dos contatos? A título de conclusão, abaixo ensaiaremos algumas considerações finais, a fim de respondê-las.

Para tal, em primeiro lugar elucidaremos alguns dos escopos de análise que pautaram a investigação documental aqui executada, "porque o minucioso trabalho de laboratório não deve permanecer escondido, e a receita não deve permanecer um segredo do cozinheiro", como aconselha Giovanni Levi. ${ }^{727}$ Em segundo lugar, reconsideraremos algumas das formas de dominação e intermediação em voga na Angola portuguesa, a fim de reacessarmos dois paradigmas da teoria política. Visando responder às questões supracitadas, em terceiro lugar discorreremos sobre um tipo de mudança advindo do impacto atlântico, tentando qualificar o teor da ingerência externa, importado da Península Ibérica, nos assuntos internos e pertinentes às sociedades centro-africanas. Assim sendo, proporemos algumas generalizações a partir dos resultados até então alcançados. Em quarto lugar, elencaremos algumas características do sistema administrativo adotado na África Centro-Ocidental, dando especial atenção à natureza mista e ao formato em rede desse

\footnotetext{
${ }^{726}$ BLOCH, Marc Leopold Benjamin. Apologia da história, ou, O Ofício de historiador. [1949]. Rio de Janeiro: Zahar, 2001, p. 83.

${ }^{727}$ LEVI, Giovanni. Microanálise e história social. IN: ALMEIDA, Carla Maria Carvalho de, OLIVEIRA, Mônica Ribeiro de (org.). Exercícios de micro-história. Rio de Janeiro: Editora Fundação Getúlio Vargas (FGV), 2009, p. 13.
} 
sistema. Reside nesse item uma tentativa de responder à segunda pergunta acima colocada, sustentando que qualquer solução analítica, humanística ${ }^{728}$ e autorreflexiva para ela deve espelhar algumas dinâmicas e complexidades vividas no ultramar centro-africano.

\section{Escopos de análise, esferas de investigação e crítica das fontes}

Evocamos na presente investigação um escopo de análise que privilegia quatro esferas de esquadrinhamento e crítica das fontes contidas na $F H A$. Na introdução desta dissertação, fizemos uma breve menção a essas esferas, para que o leitor ficasse atento à importância da parafernália teórico-metodológica que aqui nos pauta, sem que com isso perdesse de vista as vicissitudes documentais que perpassam a escrita de uma história baseada na documentação contida na $F H A$. Além disso, destacamos que tais esferas tempo, espaço, pessoas e informações - trazem no bojo duas características fundamentais. A primeira é a de serem interseccionadas uma na outra, ou seja, uma pode estar contida na outra e não há cisão efetiva entre elas. A segunda é a de que essas esferas podem conter subdivisões em escala decrescente ou crescente, quer dizer, do mais geral ao mais específico e vice-versa, de modo que tais patamares de divisão não são necessariamente verticalizados e unívocos. Ao lançar mão desse escopo de análise, o que nos interessou aqui foi muito mais uma "análise processual", conforme os termos de Simona Cerutti. Desse modo, a presente empreitada analítica está respaldada nas experiências e vivências de algumas pessoas e comunidades instaladas na África Centro-Ocidental, meio pelo qual visamos à superação das dicotomias entre macroescala e microescala. ${ }^{729}$

\footnotetext{
${ }^{728}$ Aqui ficamos com algumas palavras de ordem escritas por Edward W. Said: "Não perceber que a essência do humanismo é compreender a história humana como um processo contínuo de auto-compreensão e autorealização, não apenas para nós, brancos, do sexo masculino, europeus, americanos, mas para todo mundo, é perceber absolutamente nada. Há outras tradições eruditas no mundo, nas outras culturas, há outros gênios". Retirado de: SAID, Edward W. Humanismo e crítica democrática. [2004]. São Paulo: Companhia das Letras, 2007, pp. 48-49.

729 Simona Cerutti aborda as "relações de escalas" e a "decalagem de informações", entremeadas às pluralidades dos níveis de análise e aos laços de sociabilidade, existentes em uma municipalidade italiana do século XVII. Verificar o resumo da proposta em: CERUTTI, Simona. Processo e experiência: indivíduo, grupos e identidades em Turim no século XVII. IN: REVEL, Jacques (org.). Jogos de escalas: a experiência da micro-análise. [1996]. Rio de Janeiro: Editora Fundação Getúlio Vargas (FGV), 1998, pp. 179 e 196. Nesse mesmo sentido, verificar a importância da "série ou a rede das relações interpessoais" ressaltada por Edoardo Grendi, mediante a qual a "história social é a história das relações entre pessoas e grupos". GRENDI, Edoardo. Microanálise e história social. IN: ALMEIDA, Carla Maria Carvalho de, OLIVEIRA, Mônica Ribeiro de (org.). Exercícios de micro-história. Rio de Janeiro: Editora Fundação Getúlio Vargas (FGV), 2009, pp. 35-36.
} 
A primeira esfera que compõe o escopo de análise aqui utilizado é a multiplicidade de tempos, como anunciada por Fernand Braudel - a longa duração ou o tempo estrutural, a conjuntura ou o tempo cíclico e a curta duração, também conhecido como tempo factual -, sendo que o nosso foco analítico inverteu a lógica braudeliana dos fatores de interesse, ${ }^{730}$ no intuito de forjar uma conciliação entre a microanálise dos pequenos eventos temporais com a ânsia analítica de atingir a totalidade da estrutura, ${ }^{731}$ a afamada "vida material" e o “quotidiano" de Braudel. ${ }^{732}$ Esforço, portanto, de evocação do eixo diacrônico sobreposto ao sincrônico, mediante o qual a análise das fontes primárias e secundárias objetivou a reconstrução regressiva do processo histórico, cindido em fases cronológicas para a escrita de uma história das expansões e dos contatos luso-africanos.

Ao longo desta dissertação, esboçamos alguns assuntos de interesse que nos guiaram na análise dos tempos múltiplos e coexistentes. De forma dúbia, pairava sobre a Angola portuguesa o espectro das "grandes políticas" ultramarinas, que ora pendiam para a cooperação e parceria luso-africanas, ora visavam à expansão política e à exploração econômica, firmadas ambas na consolidação de um mundo econômico atlântico. Certamente ocorreram ajustes e recálculos durante o processo histórico que envolveu os diferentes contextos da expansão portuguesa e a participação das sociedades centro-

\footnotetext{
${ }^{730}$ Basta verificar a indexação proposta originalmente na obra clássica desse autor, dividida em três partes. A primeira e mais importante é destinada às estruturas temporais dos meios geográficos e à interação humana junto ao espaço físico, escapando com isso de determinismos geográficos. A segunda à coletividade e aos movimentos econômicos e a terceira à política e aos acontecimentos fulcrais: BRAUDEL, Fernand. $O$ Mediterrâneo e o Mundo Mediterrânico na época de Filipe II. [1966]. Lisboa: Editora Martins Fontes/ Publicações Dom Quixote, vol. I e II, 1983-1984. Para uma exposição bastante sucinta dos tempos históricos de Braudel, verificar: Idem, A Longa Duração. [1958]. IN: História e Ciências Sociais. Lisboa: Editorial Presença, 1972, pp. 11-13.

${ }^{731}$ Ficamos com sábias palavras do mestre: "A totalidade da história pode, em todo o caso, ter resposta como a partir de uma infraestrutura em relação a estas camadas de história lenta [dos traços seculares da longa duração]. Todos os níveis, todos os milhares de níveis, todos os milhares de fragmentações do tempo da história, se compreendem a partir desta profundidade, desta semi-imobilidade; tudo gravita em torno dela". Verificar: BRAUDEL, Fernand. A Longa Duração. [1958]. IN: História e Ciências Sociais. Lisboa: Editorial Presença, 1972, p. 27.

${ }^{732}$ BRAUDEL, Fernand. A Dinâmica do Capitalismo. Lisboa: Editorial Teorema, 1985, capítulo 1 e em especial as pp. 15-16. Sobre a postura aqui adotada, diria Sanjay Subrahmanyam, torna-se inviável ensaiar uma "macro-história" sem que "enlameemos as botas no brejo" da micro-história. Verificar: SUBRAHMANYAM, Sanjay. Connected Histories: Notes towards a Reconfiguration of Early Modern Eurasia. Modern Asian Studies. Cambridge: Cambridge University Press, vol. 31, n. ${ }^{\circ}$ 3, julho de 1997, p. 750, tradução nossa (no original: "This means in turn that we cannot attempt a 'macrohistory' of the problem without muddying our boots in the bogs of 'micro-history'.").
} 
africanas nesse mesmo processo, como lembra Maria da Conceição Neto, ${ }^{733}$ mas aspectos como a imposição de domínio indireto às comunidades centro-africanas e o fomento à "paz portuguesa" foram perenes, bem como a implementação de uma Angola portuguesa necessariamente voltada ao comércio atlântico de escravos. O tempo não é imutável ou permanente, conservado em si mesmo e inerte, mas marcado por um extenso processo histórico regido pelas lentas mudanças, no qual alguns topoi do projeto expansionista português são reclicados e modificados de acordo com as mentalidades e os contextos de diferentes períodos, como já destacou Beatrix Heintze. ${ }^{734}$ No cotidiano, nas banalidades da vida mundana, o fenômeno que mais nos interessou foi o vagaroso surgimento de microcosmos luso-africanos, ${ }^{735}$ apreensíveis na longa duração das repetições ordinárias e nas corriqueiras trocas triviais da vida material. ${ }^{736}$ Para o leitor pouco familiarizado com esses conceitos e termos, cabem algumas explicações. Quando evocamos a importância do cotidiano e da banalidade do mundano, estamos nos referindo aos "inumeráveis gestos herdados, confusamente acumulados, infinitamente repetidos para chegarem até nós, ajudam-nos a viver, aprisionam-nos, decidem por nós, ao longo de toda a nossa existência", como discorreu belamente Fernand Braudel, acrescentando que a vida material - essa "parte da vida activa dos homens, por natureza, simultaneamente criadores e rotineiros" remonta aos "confins dos tempos". Assim, "antiquíssimo e sempre vivo, um passado multissecular deságua no presente, tal como o Amazonas lança no Atlântico a enorme massa das suas águas turvas". 737

Nas conjunturas do tempo cíclico, de parábolas econômicas que indicam as recessões e os recrudescimentos financeiros, o interesse estava sempre alicerçado no tráfico

\footnotetext{
${ }^{733}$ Em um dos pontos que discorre para invalidar as teses do luso-tropicalismo, Maria da Conceição Neto descarta a ideia de existência de uma "política colonial portuguesa" una entre os séculos XV e XX. Segundo Neto, foram várias as políticas ultramarinas no que tangeram as "circunstâncias, intenções, orientações e fundamentos ideológicos", opondo-as ao pretenso "carácter essencial da colonização portuguesa". Verificar: NETO, Maria da Conceição. Ideologias, contradições e mistificações da colonização de Angola no século XX. Lusotopie. Bordeux: Centre d'étude d'Áfrique noire/ Centre national de recherche scientifique, 1997, p. 328.

${ }^{734}$ Analisando alguns "estereótipos intemporais" como topoi imutável de análise dos regimentos seiscentistas, Heintze argumenta que a repetição de "cláusulas de formulação estereotipadas" são muitas vezes respostas e reações a contextos específicos. Verificar: HEINTZE, Beatrix. Angola nos séculos XVI e XVII: estudos sobre fontes, métodos e história. Luanda: Kilombelombe, 2007, pp. 99 e 113.

${ }^{735}$ Voltaremos a fazer menção a ele no terceiro item desta conclusão.

${ }^{736}$ Permutações e comutações existentes nos mercados locais, bem diferentes da vida econômica, marcada pela negociação a crédito, pela utilização de letras de câmbio e pelo comércio de longa distância. Verificar: BRAUDEL, Fernand. A Dinâmica do Capitalismo. Lisboa: Editorial Teorema, 1985, pp. 28-29.

${ }^{737}$ Ibidem, 1985, p. 15.
} 
transatlântico de escravos. Interessou-nos aqui destacar o vigor de uma economia capaz de acoplar as rotas de longa distância, uma via Atlântico e outra que cortava a África, paradoxalmente refém das modalidades diversas de aquisição de escravos. Traficar pressupunha escravizar, ou algo que condizia à submissão ou à classificação de pessoas sob diferentes estatutos sociais, cindindo governantes e governados em diferentes graus de organização do trabalho, produção, governo e instituições. Devido aos limites de tempo, foi inviável adentrar nas inúmeras discussões e questões voltadas ao escravismo atlântico e africano, interessadas normalmente em indagar sobre as modalidades de exportação de escravos e problematizar os vários cenários hipotéticos de escravização. ${ }^{738}$ Seja como for, é inegável que soberanos e autoridades centro-africanos alimentavam o comércio interno, os mercados continentais e os diferentes agentes comerciais ligados ao tráfico transatlântico de gente africana. A amplitude do negócio negreiro entre os séculos XVI e XVII era vasta, extrapolando os limites dos mercados de Lisboa e Sevilha, de tal modo que é contraproducente entender o funcionamento de um sistema administrativo instalado nos trópicos atlânticos - um dos nossos maiores interesses, é preciso insistir - sem antes considerar que o real motivo para a transplantação dos órgãos régios ao ultramar era fundamentalmente um: a gestão do tráfico transatlântico de escravos para as Américas.

As altas e baixas demográficas estavam ligadas às inconstâncias da economia, como também ao deslocamento e à locomoção de comunidades inteiras que fugiam de suas aldeias e sobados natais por temerem as guerras, epidemias, carestia ou qualquer outro motivo que afetasse a vida cotidiana e a situação material de comunidades inteiras. Era na situação de penúria trazida pelas secas ou tórridas chuvas, ou devido ao estado de insegurança e terror ocasionado pelas guerras, que a inconstância econômica cruzava-se

\footnotetext{
${ }^{738}$ Em ensaio recente, Isabel Castro Henriques sintetizou alguns campos de força que ultrapassam esses limites. Articuladas à dupla-pressão exercida pelas "formas de captura e comercialização" - cenários e modalidades, como fizemos menção no corpo de texto -, surgem dúvidas sobre como ocorreu a "projeção do escravo tal como ele é concebido" nas diferentes sociedades colocadas em situação de contato (p. 80). Henriques discerne quatro eixos-chave a respeito disso: $i$ ) Quando encarada como uma ideia universal, a escravidão virou uma maneira de "autorização" de formas de dominação, dependência e exclusão (p. 66); ii) A escravidão moderna europeia estava baseada em um "sistema de dominação" que transformava as pessoas escravizadas em "coisas" ou "mercadorias" (p. 68); iii) Vários documentos escritos desde o século XVI até o XIX emparelham as relações entre pais-filhos com as existentes entre senhores-escravos, de modo que a "via da integração sexo-matrimonial" estava sobreposta ao "princípio da integração dos recém-vindos" (pp. $61 \mathrm{e}$ $68) ; i v$ ) Devido à alta reflexibilidade e à variedade das sociedades endógenas, os "escravos" podem ser vistos como equivalentes a "dependes" na África Centro-Ocidental, mesmo que as relações de parentesco sejam encaradas como simbólicas ou não (pp. 70 e 74). Verificar: HENRIQUES, Isabel Castro. Reflexões sobre o "escravo" africano. IN: O Pássaro do mel: Estudos de História Africana. Lisboa: Edições Colibri, 2003.
} 
com a curta duração dos fatos políticos. Assim, mesmo que de soslaio, como uma pequena amostra daquilo que realmente acontecia na época, vislumbramos um ambiente conflituoso, marcado por tensões sociais, atritos institucionais e embates políticos, mas também por negociações, acertos e tratados de paz. Sobre a gente que habitava a Angola portuguesa e suas vizinhanças pairava o medo, ou até mesmo a esperança, trazido pelas mobilizações e campanhas militares, além de o olhar atento dos mecanismos de vigilância e fiscalização, ineficientes em grande medida, mas que não deixavam de zelar pelo mando e a ordem promulgados a partir de Luanda, sempre em nome da Coroa portuguesa. No mais, a curta duração dos fatos estava revestida de conluios, maquinações, complôs, conchavos, conspirações, mancomunações e escaramuças entre os diversos sujeitos históricos, protagonistas ou coadjuvantes, que fazem parte da reconstrução de uma "grande história" política, subordinada à perspectiva elitista da época.

A segunda esfera diz respeito aos espaços pertinentes, clivados entre três campos distintos e confluentes: local, regional e transcontinental. Indagar sobre esses espaços também é problematizar os limites de definição e disposição deles em mapeamentos e cartografias distintos, de modo que a "espacialização" de um território obrigatoriamente desperta a necessidade de estipular divisões - mesmo que passageiras ou apenas "ideais", a espera de serem superadas - entre o "nosso espaço" e o "espaço deles", remetendo-nos automaticamente à problemática dos "limites" entre o "eu" e o "outro". 739 Explorados mais como práticas conceituais do que dados empíricos, alguns espaços e limites com os quais trabalhamos podem ser definidos da seguinte forma, mesmo que os esforços de territorialização e a delimitação de linhas divisórias de comum acordo fossem insípidos. No século XVII, havia um entendimento implícito de que existia um espaço político e jurisdicional mencionado aqui como a Angola portuguesa, comumente evocado em contraste aos denominados "reinos" e "províncias" centro-africanas, como o Kongo, Dembo, Matamba e Kissama. Para além de algumas referências geográficas que auxiliavam na definição de espaços e limites, como montanhas e rios - os marcos geográficos mais citados eram, por exemplo, os rios Cuanza e Bengo, que não por acaso eram as regiões que concentravam alguma gente portuguesa -, três eram os critérios que corroboravam para a

\footnotetext{
${ }^{739}$ A respeito disso, verificar as considerações feitas sobre a "grelha somática" e o "implícito cultural", ou "sistema de valores", existentes em: HENRIQUES, Isabel Castro. Reflexões sobre o "escravo" africano. IN: O Pássaro do mel [...]. Lisboa: Edições Colibri, 2003, pp. 62-63.
} 
definição de espaços geopolíticos. O primeiro era o sentimento de pertencimento a sociedades diferentes, de línguas e culturas específicas, de modo que nas fontes escritas analisadas é perceptível a ocorrência de uma divisão implícita entre os mbundu, bakongo e ndembu com base em línguas "vernáculas" - kimbundu ou kikongo $-{ }^{740}$ e na reivindicação e evocação de tradições fundadoras específicas, ligadas ao surgimento de posições titulares e insígnias políticas relacionadas ao ngola, manikongo e mbwila. ${ }^{741}$ No caso da Angola portuguesa, por consequência, poderíamos dizer que a utilização do português como língua preferencial e materna, principalmente entre os habitantes de Luanda e que há poucas gerações tinham se mudado para o ultramar, bem como a lealdade à Coroa real lusitana, apontavam para um sentimento de pertencimento ao Império português. ${ }^{742}$ Esses eram os "portugueses", um grupo matizado e de muitas distinções internas, homogeneizado e classificado através de termos genéricos - os "lusos", os "portugueses" e os "brancos" são os rótulos mais utilizados e que ainda persistem no imaginário de muitas pessoas - por parte de uma historiografia mais clássica. $\mathrm{O}$ segundo critério estava ligado à identificação de soberanias políticas, de forma que a imagem pintada é a de que "reis" e "chefes" africanos organizavam e coordenavam populações específicas em diferentes hierarquias legislativas, geopolíticas e institucionais. Havia uma gradação judiciária e política nesse sentido. Ser "soberano" pressupunha deter algumas prerrogativas de legislar, mas não de maneira incondicional e autoritária: os chefes provinciais o faziam na escala infrarregional

\footnotetext{
${ }^{740}$ Lembrando que tais etnônimos e línguas bantu foram catalogados e registrados de uma forma sistemática apenas no século XIX, o que obviamente não quer dizer que foram "criados" ou "inventados" pelas comunidades locais no momento do registro colonial. Talvez o caso mais emblemático desse tipo de falsa interpretação tenha ocorrido com os cokwe, grupos que apenas despertaram o interesse colonial a partir do século XIX, acarretando na equivocada presunção de que eles eram "populações formadas" recentemente. Sobre isso, consultar o capítulo 1 desta dissertação.

${ }^{741}$ Para todas as convenções aqui adotadas, consultar os capítulos 1, 4 e o "esclarecimento sobre os nomes, topônimos e demais termos utilizados" inseridos nesta dissertação.

${ }^{742}$ Porém não necessariamente como parte da composição identitária singular de uma "elite imperial", como às vezes dá-se a entender. Para um resumo das discussões sobre as elites, identidades, escrita, línguas e memórias, verificar: SANTOS, Catarina Madeira. De "antigos conquistadores" a "angolenses". Cultura: Revista de História e Teoria das Ideias. Lisboa: Universidade Nova de Lisboa/ Centro da Cultura, vol. 24, 2007, pp. 196-197. XAVIER, Ângela Barreto; SANTOS, Catarina Madeira. Cultura intelectual das elites coloniais. Cultura [...]. Lisboa: Universidade Nova de Lisboa/ Centro da Cultura, vol. 24, 2007, pp. 21-22. Não esquecendo que o português foi encarado como uma "língua franca" nos séculos XVI e XVII, sendo paulatinamente suplantado pela "estandartização" de uma forma de kimbundu ao longo do tempo. Verificar: HEINTZE, Beatrix. A lusofonia no interior da África Central na era pré-colonial: Um contributo para a sua história e compreensão na actualidade. Cadernos de Estudos Africanos. Lisboa: Centro de Estudos Internacionais/ Instituto Universitário de Lisboa (ISCTE-IUL), n. ${ }^{\circ}$ 7/8, 2005, p. 182.
} 
e os chefes de aldeias atuavam localmente. ${ }^{743}$ Não obstante as nuanças regionais e as especificidades da África Centro-Ocidental, o esforço régio perpetrado a partir de Lisboa e Luanda foi sempre o de procurar incessantemente pelos grandes "reinos" e "monarcas" africanos. Quiçá deslumbrados e seduzidos pelos relatos de "conquistadores” como Hernán Cortés e Francisco Pizarro, ${ }^{744}$ ou porventura estarem um pouco decepcionados por não terem encontrado grandes impérios nessa parte da África, os cronistas e anotadores portugueses às vezes exageravam nas suas descrições sobre o poderio do Kongo e do Ndongo. Nisso poderiam ter sido municiados com informações obtidas de manis e sobas que, através dos clamores de envolvimento com as posições titulares regionalmente consagradas e de pertencimento às linhagens políticos-perpétuos mais renomadas, exaltavam a sua força. Mas fato é que havia um grande equilíbrio no palco político regional, ocupado por atores políticos vindos de além-mar - os enviados da Coroa portuguesa e os comerciantes holandeses -, do interior do continente - os "jagas" são os exemplos mais claros - ou que habitavam na região havia um tempo considerável, como as soberanias do Ndongo e do Kongo.

Para fins práticos, nossa análise suscitou uma interface histórica focada nas relações entre localismos e regionalismos, visando com isso extrair alguns subsídios para o entendimento de um ordenamento transcontinental português, como também do funcionamento político-institucional de uma soberania mbundu, focando na situação de contato que vigorou entre 1624 e 1630. Foi através desse esforço que tentamos compreender as relações de pertinência entre os espaços transcontinentais e locais, atendonos à analise de um corpo documental específico e ajustando a óptica de nosso escopo mediante os desafios encontrados. Assim, e como fruto prematuro do "jogo de escalas",745 aqui empreendido, adiantamos que a realidade histórica vislumbrada nesta pesquisa não diz respeito a um mundo "globalizado" ou "mundializado", mas mundos em trânsitos globalizantes, visíveis no entremeio do microlocal para o macrolocal e contidos no meio-

\footnotetext{
${ }^{743}$ Nesse sentido, verificar: COELHO, Virgílio. “Em busca de Kábàsà!...” Estudos e reflexões sobre o "Reino" do Ndòngò: Contribuições para a História de Angola. Luanda: Kilombelombe, 2010, pp. 184-185.

${ }^{744}$ Verificar o as breves considerações tecidas em: SUBRAHMANYAM, Sanjay. O Império Asiático Português 1500-1700: Uma História Política e Econômica. [1993]. Linda-a-velha: Difel, 1995, pp. 153-154.

${ }^{745}$ Não necessariamente construídos nos moldes de: REVEL, Jacques. Microanálise e construção do social. IN: REVEL, Jacques (org.). Jogos de escalas [...]. [1996]. Rio de Janeiro: Editora Fundação Getúlio Vargas (FGV), 1998.
} 
termo entre o enfoque epistemológico especialista e generalista. ${ }^{746}$ De todo modo - e por mais que não seja o caso de falar de um mundo globalizado e excessivamente moderno,$-{ }^{747}$ é preciso destacar que havia um esforço efetivo de conexão de economias, exploração de mão-de-obra e fomento de modos de produção cada vez mais interligados ao comércio de longa distância e ao escravismo atlântico. Era exatamente essa nova economia marítima, exclusivamente voltada às carreiras que atravessavam o Atlântico e que acabavam acopladas ao comércio de longa distância que cortava o coração da África, que causava impactos locais. ${ }^{748}$ Portanto, o terceiro critério que jogou a favor da demarcação de espaços e limites desta pesquisa diz respeito ao panorama e à amplitude de enraizamento e penetração de uma economia oceânica e escravista, podendo regredir ou recrudescer mediante as marés conjunturais movidas pelos circuitos e rotas comerciais. Jazia nos limites dessa economia pré-capitalista uma fronteira da escravidão, de demarcações pouco rígidas e porosas, onde os modos de produção de riqueza, arregimentação de mão-de-obra, trocas comerciais e prestação de serviços giravam em torno da reiteração de uma sociedade escravista. $^{749}$

A terceira esfera está respaldada na atuação de agentes e grupos sociopolíticos, principalmente no que dizia respeito ao ambiente conflituoso que perpassava o governo ultramarino, entrecortado por tensões, atritos e embates que envolviam as elites e a cúpula

\footnotetext{
${ }^{746}$ Aqui somos diretamente influenciados pelas considerações feitas em: SUBRAHMANYAM, Sanjay. Connected Histories [...]. Modern Asian Studies. Cambridge: Cambridge University Press, vol. 31, n. ${ }^{\circ}$ 3, julho de 1997, pp. 745, 747-748.

${ }^{747}$ Trata-se da "ordem global", portanto dissociada da noção de "economia-mundo", como indicado em: BRAUDEL, Fernand. A Dinâmica do Capitalismo. Lisboa: Editorial Teorema, 1985, capítulo 3, principalmente a p. 87. Para outra perspectiva a respeito do termo "globalização" e como ele pode ser utilizado para descrever realidades econômicas dos séculos XVI e XVII, verificar: HUTZ, Ana. Homem de Nação e de Negócio: redes comerciais no Mundo Ibérico (1580-1640). Tese de doutorado, Universidade de São Paulo (USP), 2014, p. 165. Seja como for, cabe ressaltar que o termo "globalização" hoje em dia é empregado com diversas acepções, como destacado em: PRATT, Mary Louise. Globalización, desmodernización y el retorno de los monstruos. Revista de História (USP). São Paulo: Universidade de São Paulo, n. ${ }^{\circ} 156,1^{\circ}$ semestre de 2007.

${ }^{748}$ Lembrando que os caminhos continentais eram "franqueados" pelos povos centro-africanos: SANTOS, Maria Emília Madeira. Nos caminhos de África: serventia e posse (Angola - Século XIX). Lisboa: Instituto de Investigação Científica Tropical, 1998, pp. 435, 437 e diversos outros trechos.

${ }^{749}$ A proposta de "fronteira da escravidão" foi rediscutida e utilizada na década de 80 por Joseph C. Miller, como indicamos na introdução desta dissertação. Para uma crítica a ela, verificar: CANDIDO, Mariana P. O limite tênue entre liberdade e escravidão em Benguela durante a era do comércio transatlântico. Afro-Ásia. Salvador: Universidade Federal da Bahia (UFBA), n. ${ }^{\circ} 47,2013$, pp. 241-242. Alguns diriam que tal economia atlântica pode ser caracterizada como "capitalista" ou "capitalista comercial", ficando a questão evidentemente em aberto: MAURO, Frédéric. Portugal, o Brasil e o Atlântico (1570-1560). [1960]. Lisboa: Editorial Estampa, vol. I, 1989, pp. 263, 266, 279-280.
} 
maior de direção régia da Angola portuguesa, comandada por Fernão de Sousa. ${ }^{750}$ Governar a Angola portuguesa era uma arte, como já dissemos, que pressupunha o zelo pelo equilíbrio institucional e a atenuação dos conflitos internos e externos, sempre em nome da "paz", "justiça" e do "bem comum". Aqui podemos falar de um concerto orquestrado, regido e perceptível por intermédio de palcos, xadrezes e arenas imersos em um ambiente conflituoso, ou seja, marcado por disputas e desavenças sociopolíticas, ${ }^{751}$ sobre os quais proporemos maiores explanações no quarto item desta conclusão. Antevemos apenas que, nesse sentido, estamos imbuídos do historicismo crítico de Ranajit Guha e Dipesh Chakrabart, membros da seara que se autodenomina estudos subalternos, composta por intelectuais que mantêm uma posição contrária ao pensamento que universaliza os conceitos científicos europeus, modificando as "histórias particulares" e moldando os sujeitos históricos locais, a fim de caracterizá-los como "apolíticos", "bárbaros", “selvagens", "primitivos" e entregues a uma cultura "tradicional”, destituída de história. ${ }^{752}$ Também são avessos a simplismos e fórmulas preconcebidas, repudiando o uso de termos genéricos - por exemplo, o "campesinato" ou os "indianos" - e a aplicação de teorias sem prévia desconstrução - por exemplo, o entendimento de que todas as camadas sociais do Antigo Regime eram controladas ou corroboravam univocamente com a "monarquia absolutista". Em sentido contrário, tentamos destacar a relevância e o protagonismo de alguns sujeitos africanos e portugueses que atuavam local ou regionalmente, como Angola Ambande, Ginga Ambande, Henrique Magalhães, Paio de Araújo de Azevedo e outros. ${ }^{753}$

\footnotetext{
750 Aqui somos influenciados por alguns pesquisadores envolvidos com a micro-história italiana, mais especificamente interessados em um enfoque analítico sobre a constituição do tecido social, utilização de classificações sociais, cruzamento de fontes e relações entre as culturas de camadas sociais e tempos distintos. Tais perspectivas de pesquisa foram sucintamente elencadas em: CERUTTI, Simona. Processo e experiência [...]. IN: REVEL, Jacques (org.). Jogos de escalas [...]. [1996]. Rio de Janeiro: Editora Fundação Getúlio Vargas (FGV), 1998, pp. 181-183. Apesar de não ser o foco da presente pesquisa, cabe também mencionar a importância das relações estratégicas existentes entre uma "cultura de elite" e uma "cultura popular", no esforço que elucidação de uma "história vista de baixo", conforme destacou Edoardo Grendi a partir de Carlos Ginzburg. Verificar: GRENDI, Edoardo. Repensar a micro-história?. IN: REVEL, Jacques (org.). Jogos de escalas [...]. [1996]. Rio de Janeiro: Editora Fundação Getúlio Vargas (FGV), 1998, pp. 252-253. GINZBURG, Carlo. O queijo e os vermes: o cotidiano e as ideias de um moleiro perseguido pela Inquisição. [1976]. São Paulo: Companhia das Letras, 2010.

${ }^{751}$ Para maiores explicações, consultar os capítulos 2, 3 e 4 desta dissertação.

752 CHAKRABARTY, Dipesh. Provincializing Europe:Postcolonial Thought and Historical Difference. [2000]. Princeton: Princeton University Press, 2008, pp. xiv-xv, 4 e 15. Sobre as contribuições de Ranajit Guha, verificar a obra de Dipesh Chakrabarty: Habitations of modernity: essays in the wake of subaltern studies. Chicago: The University of Chicago Press, 2002, p. 12.

${ }^{753}$ Tal impulso metodológico pode ser verificado em: CHAKRABARTY, Dipesh. Habitations of modernity [...]. Chicago: The University of Chicago Press, 2002, pp. 96-97. Apesar de sustentar uma posição
} 
Nessa mesma toada, compartilhamos da posição firmada por Edward W. Said e Homi K. Bhabha, perpetradores dos chamados estudos pós-coloniais. Tal grupo de acadêmicos e intelectuais advoga pela "suspensão dos véus" e pela "dispersão das névoas" que recobrem a realidade observada por anotadores, cronistas e observadores de época. ${ }^{754} \mathrm{~A}$ luz desse apelo crítico, sobretudo voltado à importância dos conteúdos inscritos e vertidos nas fontes primárias e secundárias, propusemos uma quarta e última esfera de investigação e análise, ligada aos níveis de informação. Aqui tentamos investigar a variedade de tipologias documentais, condições de produção e diferentes sentidos de circulação dos documentos, através da exploração de uma miríade de redundâncias, contradições, incoerências, dissonâncias e incongruências averiguadas e sondadas na $F H A .{ }^{755}$ Assim, focamos na atuação política e nas diferentes motivações e interesses registrados em papel dissemos em vários momentos, ligados ao jogo de discursos, retóricas, estereótipos e estigmas operados pelos observadores e anotadores coevos -, lembrando sempre que parte fulcral desses "descaminhos" estava relacionada aos níveis de divulgação e veiculação de informações para os supervisores e representantes mais próximos da Coroa portuguesa, de modo que a compreensão sobre o dito, redito e não-dito pressupõe uma análise panorâmica, ao passo que paradoxalmente minuciosa, das fontes históricas.

Para que fique mais claro ao leitor, um esquema sucinto sobre os sentidos e instâncias de circulação de alguns documentos seiscentistas pode ser elencado da seguinte forma, tendo sempre em mente que estamos nos referindo à realidade documental existente na FHA. Destacamos basicamente três características "programáticas" dos textos postos em circulação: tipologia, condições de produção do conteúdo inscrito e sentidos de transmissão e recepção. No nível primário de circulação, residem os bandos, portarias, ordens, alguns

metodológica e ter objetos de pesquisa distintos dos nossos, vale a pena conferir a forma como Sanjay Subrahmanyam aborda as relações entre os agentes e grupos na Ásia portuguesa, aliando alguns interesses específicos, sustentados por certos quadros sociais do ultramar, ao enfoque global da expansão portuguesa. Consultar: SUBRAHMANYAM, Sanjay. O Império Asiático Português 1500-1700 [...]. [1993]. Linda-avelha: Difel, 1995, capítulos 3 e 4.

${ }^{754}$ Hoje clássicas, algumas obras essenciais desses autores são: SAID, Edward W. Orientalismo: O Oriente como invenção do Ocidente. [1978]. São Paulo: Companhia das Letras, 2007. BHABHA, Homi K. The Location of Culture. Londres e Nova Iorque: Routledge, 1994. Nesse e em muitos outros sentidos, os estudos pós-coloniais e subalternos levantam pontos semelhantes, como é possível verificar em: CHAKRABARTY, Dipesh. Habitations of modernity [...]. Chicago: The University of Chicago Press, 2002, pp. 7-8 e 16.

${ }^{755}$ Posição que também guarda reciprocidades com a adotada em: CHAKRABARTY, Dipesh. Provincializing Europe [...]. [2000]. Princeton: Princeton University Press, 2008, pp. 43-44. Habitations of modernity [...]. Chicago: The University of Chicago Press, 2002, p. 12. 
regimentos e outras fontes primárias que fluíam dentro da Angola portuguesa. Tais documentos constituem uma forma de comunicação institucional diligente e pragmática, cujo conteúdo é normalmente breve e objetivo. No nível secundário, existem algumas cartas e correspondências que normalmente circulavam entre Luanda e os presídios, ou Luanda e Lisboa, nunca diretamente entre os presídios portugueses da África CentroOcidental e o núcleo político do reino de Portugal. Quase sempre, tais fontes primárias se delongavam em argumentos e descrições que visavam legitimar as ações políticas e institucionais tomadas em campo, abrindo margem para uma troca efetiva de missivas entre remetente e destinatário. No nível terciário estão as lembranças e relações produzidas por funcionários reinóis, documentos que poderiam ser conservados como uma "memória" pessoal ou despachados para os acervos e bibliotecas de Lisboa, onde possivelmente figurariam como uma espécie de prova oficiosa dos serviços prestados. Como fontes secundárias, muitas vezes esses documentos narram fatos ocorridos em um passado recente, com base no relato dos chamados "homens bons" da terra. Tais informações e dados eram posteriormente sintetizados em conteúdo textual, com o intuito de comprovar a validar algumas medidas que estavam sendo maquinadas no ultramar. No quarto nível de circulação residem algumas cartas e "informações" compostas no reino de Portugal, sobre assuntos e matérias que diziam respeito a acontecimentos que haviam sido vividos no ultramar. No caso específico de alguns dos textos escritos por Fernão de Sousa, as razões que ocasionaram a composição deles são evidentes: o ex-governador passava por uma fase de inquérito e investigação institucional. Não é à toa que o conteúdo registrado é, em grande medida, de cunho explicativo e justificativo. Eles foram produzidos para serem as "provas cabais" de alguns acontecimentos passados, em detrimento de outros que nem chegavam a ser mencionados, prezando pela montagem de uma defesa pessoal e institucional de Fernão de Sousa, em razão de certos contextos específicos ligados à sua posição social no reino de Portugal e em resposta à carreira profissional que perseguia como um dos quadros do Antigo Regime. Em última instância, quando visível a falta de imparcialidade de Fernão de Sousa pode ser interpretada como constituinte do mister e da eloquência da posição de governador. 


\section{Uma composição institucional mista e em rede da Angola portuguesa (início do} século XVII)

Nesta dissertação, abordamos três tipos de fenômenos ligados à dominação. O primeiro, mais nocivo às populações mbundu, ocorreu através da armação de uma máquina de guerra portuguesa, legitimada por meio de uma argumentação que atestava para o fracasso da diplomacia e do estreitamento amigável das relações entre a Angola portuguesa e o Ndongo. A partir de 1625, a guerra de conquista foi planejada em nome da integridade da "paz, justiça e bem comum" das feiras, presídios e povoados que constituíam o domínio ultramarino. O segundo fenômeno estava ligado ao estabelecimento de um domínio indireto no Ndongo, através da imposição de tutela em Pungo Andongo. Tal guinada políticoadministrativa ocorreu através do processo de eleição e avassalamento de Angola Aire, concretizado em 1626. Concomitantemente a isso, ocorreu um terceiro fenômeno. Tratavase do revigoramento e da consolidação de mecanismos de vigilância e fiscalização dos órgãos institucionais transplantados à África, objetivando com isso o direcionamento controlado de bens, fazendas, documentos e relatos orais a Luanda. ${ }^{756} \mathrm{Sem}$ exceção, em todos esses casos, a arregimentação e aplicação da força bruta implicaram na articulação das seguintes ambivalências: guerrear e policiar, expandir e proteger.

Além disso, tais fenômenos engendraram duas operações de intermediação, sendo uma delas a de incorporação de elementos centro-africanos - por exemplo, sinalizados pela adoção de práticas como as de mucano, unda, bacula e malafo - e outra a de absorção de agentes locais, como representantes e servidores do aparato administrativo transplantado ao ultramar - por exemplo, através de serviços prestados por mani quitandas, quilambas, tendalas e outros mais -, proporcionando uma maneira eficaz de gerir e administrar os contatos intersociais ocorridos no espaço ultramarino. Aqui vislumbramos outras

\footnotetext{
756 Pelos caminhos que cortavam o sertão, chegavam à cidade portuária desde escravos, marfim, panos e outras mercadorias apreciadas pelos comerciantes, até uma série de informações e dados sobre os povos do interior, inscritos em documentos e reproduzidos oralmente, na forma de relatos ou conversas despretensiosas. Todo esse conteúdo informativo sobre a "conquista" e o "sertão" poderia ser alojado nos arquivos burocráticos de Luanda, ser preservado sob a forma de uma memória coletiva ou acabar despachado para Portugal. Sobre o funcionamento dessas vias e caminhos, em realidades do século XIX parecidas com as dos contextos do século XVII, verificar: SANTOS, Maria Emília Madeira. Nos caminhos de África [...]. Lisboa: Instituto de Investigação Científica Tropical, 1998, p. 469, principalmente sobre o esquema de troca de missivas e comunicação entre litoral e a costa. WISSENBACH, Maria Cristina Cortez. Dinâmicas históricas de um porto centro-africano: Ambriz e o Baixo Congo nos finais do tráfico atlântico de escravos (1840-1870). Revista de História (USP). São Paulo: Universidade de São Paulo, n. ${ }^{\circ}$ 172, janeiro/junho, 2015, pp. 169-170, onde há uma relação dos produtos comercializados na bacia do rio Congo.
} 
ambivalências: era preciso apropriar para desapropriar, articular para desarticular. No final das contas, os sobas cooptados ou subjugados ficavam à mercê de adversidades sobre as quais não tinham ingerência direta, tais como uma justiça pragmática aplicada nos presídios, os desrespeitos e crueldades provocados por funcionários e oficiais régios, as punições resultantes dos mecanismos de vigilância e fiscalização e as formas de coação e coerção gestadas no âmago do sistema administrativo e de guerra.

Ainda que não tenhamos todas as respostas, os resultados até aqui obtidos permitem a revisitação de dois paradigmas das ciências humanas. O primeiro deles está encapsulado em uma reafirmação proposta por João Adolfo Hansen, a partir de certas ideias de Michel Foucault, segundo a qual uma política indígena na América portuguesa dos séculos XVI e XVII seria a "continuação da guerra em tempos de paz", não a "continuação da política por outros meios", como estabelecera Carl won Clausewitz. ${ }^{757}$ Nem um, nem outro, caso observemos o caso centro-africano. Em nossa análise das fontes primárias, presenciamos as duas tendências imbricadas entre si: a guerra era a extensão dos desejos e interesses de círculos políticos institucionais condensados na política beligerante de Luanda, igualmente figurando como uma resposta às pressões exercidas por atores políticos africanos. Assim, estes eram capazes de forçar e execução de medidas mais drásticas e enfáticas, influenciando parte dos círculos de influência e sociabilidade que compunham a cúpula de decisão institucional em Luanda. Aliás, nesse sentido, lembram Flávio Gomes e Roquinaldo Ferreira que, na primeira metade do século XVII, havia uma "correlação direta entre militarismo e embarques de escravos em Luanda". 758 Tão fortes eram as relações entre o tráfico transatlântico e as guerras econômicas - quer dizer, campanhas militares alavancadas pela necessidade de aprisionamento de escravos -, que juntos interesse político e motivação econômica perfaziam a tomada de decisão institucional. ${ }^{759}$ Entre a guerra e a paz, há uma série de variáveis que ultrapassam as dicotomias pouco problematizadas entre

\footnotetext{
${ }^{757}$ HANSEN, João Adolfo. A servidão natural do selvagem e a guerra justa contra o bárbaro. IN: NOVAES, Adauto (org.). A descoberta do homem e do mundo. Rio de Janeiro: Minc-FUNARTE/ Companhia das Letras, São Paulo, 1998, pp. 348-349.

${ }^{758}$ GOMES, Flávio; FERREIRA, Roquinaldo. A miragem da miscigenação. Novos estudos. São Paulo: CEBRAP, n. ${ }^{\circ} 80$, março de 2008, p. 150.

${ }^{759}$ Características também presentes em outros domínios ultramarinos, caso verifiquemos o que afirma os autores do seguinte artigo sobre as relações entre as tropas de guerra, o resgate de índios e a "internação" no sertão amazônico: CHAMBOULEYRON, Rafael; BONIFÁCIO, Monique da Silva; MELO, Vanice Siqueira de. Pelos sertões "estão todas as utilidades". Trocas e conflitos no sertão amazônico (século XVII). Revista de História (USP). São Paulo: Universidade de São Paulo, n. ${ }^{\circ} 162,1^{\circ}$ semestre de 2010, pp. 18-19 e 21.
} 
os momentos tempestuosos e turbulentos de guerra, em relação à calmaria e à bonança dos momentos pacíficos.

Das relações entre a guerra e a política doméstica partimos para o outro paradigma, do qual sobressaem fatores como a coerção e a diplomacia. Aqui nos referimos a algumas elucubrações promovidas por Luiz Felipe de Alencastro, que especula se algumas políticas internas figurariam como uma espécie de "ignição" para um discurso ideológico de "guerra preemptiva", ou "guerra preventiva", capaz de propulsionar expansionismos efetivos no início da Idade Moderna. ${ }^{760}$ Os resultados alcançados neste trabalho permitem sustentar que, se por um lado todos os esforços de legitimação e o despertar de alardes sobre os "caos e crises" político-econômicos moveram a opinião reinol em prol de campanhas de conquista e de punição, por outro lado os esforços de antecipação, como também a agilização das declarações e dos preparativos de guerra, tornavam o processo político oficial-formal inviável. Havia tempo de maturação e discussão para tudo, até para se decidir pelo confronto militar ou não. Nada é mais elucidador do que as relações entre as teorizações e os empirismos relatados na documentação: a guerra contra o Ndongo vingou, ao passo que o planejamento da conquista do Dembo não saiu do papel. Primeiramente, isso aconteceu porque faltou apoio das elites locais em prol da guerra, de modo que as quatro alas de representatividade dos grupos sociopolíticos - administradores, senhores, militares, comerciantes e eclesiásticos $-{ }^{761}$ que compunham o governo de Luanda precisariam estar conciliadas e harmonizadas para que o quilombo português fosse armado. Pelo menos, essa foi a tônica durante o governo de Fernão de Sousa, em clara dissonância com o de Luís Mendes de Vasconcelos que, ao agir unilateralmente, mergulhou a Angola portuguesa em uma profunda desarmonia política. Em segundo lugar, o esforço de legitimação e o exame de "guerra justa" eram coisas sérias demais para serem feitas às pressas, demandando tempo, tinta e papel. Em terceiro lugar, não havia apoio africano para o novo empreendimento bélico, sem o qual era inviável abrir duas frentes de batalhas e inserir um fantoche ou soba subserviente a Luanda no Dembo.

\footnotetext{
${ }^{760}$ ALENCASTRO, Luiz Felipe de. A economia política dos descobrimentos. IN: NOVAES, Adauto (org.). $A$ descoberta do homem e do mundo. Rio de Janeiro: Minc-FUNARTE/ Companhia das Letras, São Paulo, 1998, pp. 193-194 e nota 3, p. 205.

${ }^{761}$ Dependendo do contexto político e dos interesses, os diferentes grupos poderiam propor pactos ou firmar acordos entre si, fortalecendo-se em alas institucionais temporárias ou duráveis. Dessa forma, nem sempre um grupo sociopolítico agia sozinho ou era uno: divisões internas e associações poderiam ocorrer. Para mais informações, consultar os capítulos 2 e 4 desta dissertação.
} 
De fato, as formas de dominação estavam imbricadas às de intermediação, de modo que as ambivalências, articulações e os interstícios auxiliavam na conformação de um sistema administrativo ultramarino misto, ${ }^{762}$ feito para "fazer valer" a ordem e o mando harmonizados e negociados entre o centro irradiador e gravitacional de Luanda, os entrepostos de apoio distribuídos pelo interior centro-africano e os soberanos e autoridades africanos, de acordo com uma arte de governo da paz pleiteada em benefício da manutenção da Angola portuguesa. Assim, o funcionamento do sistema administrativo implicou em um impacto na vida dos habitantes da costa centro-africana e das suas vizinhanças mais próximas, embora nem de longe o governo de Luanda fosse hegemônico ou irradiasse uma cultura portuguesa dominante continente adentro. ${ }^{763}$ Outras mudanças e inovações criadas a partir da expansão ultramarina e do convívio entre sociedades distintas serão destacadas no item seguinte, atentando para o fato de que muitos outros

\footnotetext{
${ }^{762}$ Posto que atualmente "voltou à moda" o interesse pela "mestiçagem" e "hibridismos", como atentamente destacou Francisco Bethencourt, cabe aqui destacarmos algumas leituras atuais sobre o tema, com a ressalva de que comentaremos as contribuições de pesquisadores brasileiros e angolanos no momento oportuno. Sobre a sucinta proposição de "hibridismo" com a qual dialogamos, mas não necessariamente acatamos em sua plenitude, verificar: BHABHA, Homi K. The Location of Culture. Londres e Nova Iorque: Routledge, 1994, p. 2. Para um exemplo de "produto cultural" híbrido, verificar essa mesma obra, p. 58. Ver também: BETHENCOURT, Francisco. Creolization of the Atlantic World: The Portuguese and the Kongolese. Portuguese Studies. Cambridge: Modern Humanities Research Association, vol. 27, $1^{\circ}$ semestre de 2011, p. 1-3, com especial atenção para as ideias de "hibridismo" e "plasticidade" nas pp. 3-4 e 5-6. Nos últimos anos, as discussões acerca dos hibridismos culturais gravitam em torno de um amplo debate sobre as questões interdisciplinares voltadas às possibilidades de tradução ou não-tradução de termos, expressões, conceitos ou até modos de vida. Aqui não dispomos de espaço suficiente para fazer o mapeamento de todo debate, de modo que nos limitaremos a indicar algumas leituras essenciais. Além evidentemente da obra supracitada de Homi K. Bhabha, consultar: HALL, Stuart. A identidade cultural na pós-modernidade. [1992]. Rio de Janeiro: DP\&A, 2006, especialmente as pp. 88-89. CHAKRABARTY, Dipesh. Provincializing Europe [...]. [2000]. Princeton: Princeton University Press, 2008, com ênfase nas pp. 71 e 86-89, onde há considerações sobre o aspecto histórico ligado aos fenômenos do hibridismo e da interpretação intersocial, com destaque aos problemas da "obscuridade da tradução", intercompreensão da mensagem traduzida e incorporação de signos, conceitos e ideias. Desse mesmo autor, verificar: Habitations of modernity [...]. Chicago: The University of Chicago Press, 2002, onde há o discernimento da "tradução entre sociedades" como um problema, nas pp. xxii-xxiii e 32. LATOUR, Bruno. Jamais fomos modernos: ensaio de antropologia simétrica. [1991]. Rio de Janeiro: Editora 34, 2011, principalmente as considerações inicias, onde são expostos os três campos de força que perpassaram o conjunto de ensaios de Latour: i) A existência de um "nó górdio"; ii) O indivíduo como um "híbrido" e o ato de descrição da trama social; iii) A existência de uma rede como o fio de Ariadne (pp. 89).

${ }^{763}$ Discordando da suposição de Thornton e Heywood, para quem o ano de 1625 figuraria como um divisor de águas para a disseminação de uma "cultura crioula atlântica" para o interior da África Central. Verificar: HEYWOOD, Linda M.; THORNTON, John K. Central Africans, Atlantic Creoles, and the Foundation of the Americas, 1585-1660. Cambridge: Cambridge University Press, 2007, pp. 197-198. Para o resumo das ideias desenvolvidas por esses pesquisadores, ver também pp. 98 e 169-170. Para uma crítica muito boa a respeito da noção de "cultura dominante" e sobre algumas contingências culturais, verificar: BHABHA, Homi K. The Location of Culture. Londres e Nova Iorque: Routledge, 1994, p. 5.
} 
desdobramentos podem ser alcançados como fruto da exploração e investigação histórica com base nas fontes primárias.

\section{Nada mais... porém muito além do que o tráfico de escravos}

Apesar dos ceticismos suscitados a respeito das noções ligadas à existência de uma "economia de estado" africana ou mesmo europeia nos séculos XVI e XVII, bem como as críticas lançadas contra a "tese da transformação" sustentada por Paul E. Lovejoy e outros pesquisadores, ${ }^{764}$ fato é que o comércio atlântico competiu para mudanças de alguns parâmetros da vida econômica e social, tanto de reinóis que morassem e se enraizassem no domínio ultramarino, quanto por parte das comunidades africanas locais. Para todos os efeitos, o tráfico transatlântico de escravos passou a ser um grande atrativo, de modo que a perseguição de uma carreira política ou institucional, típica do Antigo Regime, ficasse menos atraente. Aliás, mesmo os reinóis que aspiravam retornar ao reino de Portugal enriqueciam com tráfico, como parece ter acontecido nos casos de Fernão de Sousa e Luís Mendes de Vasconcelos. Nos trópicos do Atlântico, a atuação e inserção econômica de administradores, burocratas, oficiais, senhores, comerciantes e representantes de contratadores aconteciam através da participação efetiva no comércio negreiro. Afinal de contas, a administração ultramarina e o povoamento efetivo do território existiam sobretudo para engrandecer a fazenda real e cuidar do erário régio, além é claro de garantir o abastecimento dos tumbeiros que aportavam em Luanda.

No contexto ultramarino centro-africano, as rendas e os lucros derivavam da exportação de escravos e da exploração do trabalho forçado, portanto, não é exagero afirmar que todos os moradores, inclusive os "homens do rei", eram ávidos por "peças". Por mais que a maioria dos integrantes do oficialato e funcionalismo continuasse a jurar

\footnotetext{
${ }^{764}$ Por "economia política", entende-se o processo de formação estatal que cinde as sociedades em classes, sendo essas, por sua vez, mediadas por relações de força - punição, coerção, coação, violência, entre outras formas - integradas da seguinte forma, segundo o esquema de "modo de produção escravista" proposto por Paul E. Lovejoy: i) Há uma institucionalização disruptiva, responsável pela ordenação das relações de produção e a divisão do trabalho; ii) É também necessária a consolidação de uma infraestrutura integrativa, responsável por garantir as conexões entre os polos produtores, os circuitos comerciais e os mercados consumidores; iii) Motivadas por forças externas e adaptações internas, os contatos acarretariam em "transformações" nas economias políticas africanas. Verificar: LOVEJOY, Paul E. A escravidão na África: uma história de suas transformações. [1983]. Rio de Janeiro: Civilização Brasileira, 2002, pp. 119 e 395 , além dos dois prefácios inseridos na edição brasileira, com especial atenção para as considerações nas pp. 14 e 20-21. Os críticos de Lovejoy normalmente afirmam que a sua proposta de análise é extremamente modularaplicada e economicista, acarretando em anacronismos e demasiadas distorções.
} 
fidelidade à Coroa portuguesa, mantivesse fiel aos seus postos e se autoidentificasse "portuguesa", exercendo papéis sociais e "atividades-meio" condizentes com as normas e os quadros do Antigo Regime, nada impedia que funcionários e oficiais buscassem "atividades-fim" atreladas à aquisição de escravos e permutação de panos para o enriquecimento pessoal. Desse modo, prosperava desde meados do século XVII um modo de ascensão social atlântico, enraizado nas relações que a Angola portuguesa mantinha com o comércio transatlântico e que era diferenciado daqueles existentes de maneira tradicional na Península Ibérica ou no restante da África Centro-Ocidental, sem contudo invalidar as típicas formas de clientelismo imersas dentro de uma política patrimonial, de um imaginário judiciário fundado na organização social feudo-moderna, baseada no corpo místico do monarca, e de toda uma economia redistributiva fundada na lógica de retribuição real que proliferava no Antigo Regime, funcional por meio da concessão da honra, mercês, comendas, títulos, foros e da graça. Tudo isso continuava válido no ultramar, com a exceção de que as novas composições sociais e a diferenciada base econômica do além-mar engendraram mudanças nos contextos externos aos da Península Ibérica.

Influenciados por novas discussões levadas a cabo no âmbito europeu das décadas de 70 e $80,{ }^{765}$ nos últimos anos uma seara de pesquisadores brasileiros tem sustentado a existência de um “Antigo Regime nos trópicos" na América portuguesa, visível através de uma "nobilitação" da elite colonial congregada nas câmaras municipais. ${ }^{766}$ É como se uma "nobreza da terra" se "apoderasse" de alguns espaços políticos legítimos, por exemplo as câmaras municipais, sem com isso acarretar no rompimento de uma lógica de compromisso

\footnotetext{
${ }^{765}$ Para um resumo da atmosfera política vivida nesses anos, bem como a influência que ela teve na implementação de pesquisas científicas, conferir: BONCIANI, Rodrigo Faustinoni. Descolonização e Racismo: atualidade e crítica, Diáspora e Colonização. Sankofa: Revista de História da África e de Estudos da Diáspora Africana. São Paulo: Universidade de São Paulo (USP), n. ${ }^{o}$ 8, ano IV, dezembro de 2011, pp. 2425. Aqui seguimos o bom arrazoado proposto para o debate clássico brasileiro, além das críticas endereçaras para a noção de "Antigo Regime nos trópicos" - a autora usa a expressão "calcanhar de Aquiles" -, existentes em: SOUZA, Laura de Mello e. Política e Administração colonial: problemas e perspectivas. IN: SOUZA, Laura de Mello e; FURTADO, Júnia Ferreira; BICALHO, Maria Fernanda (org.). O governo dos povos. São Paulo: Alameda, 2009, com especial atenção às críticas feitas nas pp. 76-77 e 82-83.

${ }^{766}$ BICALHO, Maria Fernanda Baptista. As câmaras ultramarinas e o governo do Império. IN: FRAGOSO, João; BICALHO, Maria Fernanda Baptista; GOUVÊA, Maria de Fátima Silva (org.). O Antigo Regime nos trópicos: a dinâmica imperial portuguesa (séculos XVI-XVIII). Rio de Janeiro: Civilização Brasileira, 2001, p. 270. Ver também, da mesma autora: Conquista, Mercês e Poder Local. A nobreza da terra na América portuguesa e a cultura política do Antigo Regime. Almanack Braziliense. São Paulo: Universidade de São Paulo (USP)/ Instituto de Estudos Brasileiros (IEB), n. ${ }^{\circ}$ 2, novembro de 2005, pp. 23-24.
} 
entre reis, súditos e as câmaras ultramarinas. ${ }^{767} \mathrm{Com}$ isso, abria-se "brechas e fissuras"768 para a subversão velada, ou às vezes escancarada, da organização institucional e política entre centro e periferia, através da capacidade de negociação e diálogo propagada através das vias de comunicação atlântica. ${ }^{769}$ De todo modo, essa emergência nos trópicos teria sido impulsionada por uma elite colonial ainda muito apegada a uma "economia moral do dom", ou “economia política dos privilégios", como forma simbólica e real de ascensão social, monopolizada pela Coroa portuguesa. ${ }^{770}$ Não descartamos a validade dessas assunções, em grande medida tributárias de mimeses e até emulações refletidas dos quadros e contextos ibéricos, cujas contribuições são inegáveis. Porém, suspeitamos da capacidade de generalizá-las para os demais contextos tropicais e atlânticos dos séculos XVI e XVII, sem antes efetuar trabalhos empíricos e analíticos mais vultuosos, ${ }^{771}$ além é claro do "patente perigo" de naturalizar o papel de agentes "subalternizados" na construção de um

${ }^{767}$ BICALHO, Maria Fernanda Baptista. Conquista, Mercês e Poder Local [...]. Almanack Braziliense. São Paulo: Universidade de São Paulo (USP)/ Instituto de Estudos Brasileiros (IEB), n. ${ }^{\circ}$ 2, novembro de 2005, pp. 29-30.

${ }^{768}$ Aqui reaproveitamos alguns dos termos empregados por outro pesquisador: MONTEIRO, Nuno Gonçalo F. Trajetórias sociais e governo das conquistas: notas preliminares sobre os vice-reis e governadores-gerais do Brasil e da Índia nos séculos XVII e XVIII. IN: FRAGOSO, João; BICALHO, Maria Fernanda Baptista; GOUVÊA, Maria de Fátima Silva (org.). O Antigo Regime nos trópicos [...]. Rio de Janeiro: Civilização Brasileira, 2001, pp. 251-252.

${ }_{769}$ Mais recentemente, Maria Fernanda Baptista Bicalho destacou a importância de uma "pluralidade de modelos jurídicos" e da "multiplicidade de canais de comunicação política" entre centro e periferias, algo que estamos integralmente de acordo. Verificar: BICALHO, Maria Fernanda Baptista. Entre a teoria e a prática: dinâmicas político-administrativas em Portugal e na América portuguesa (séculos XVII e XVIII). Revista de História. São Paulo: Universidade de São Paulo, n. ${ }^{\circ}$ 167, julho/dezembro de 2012, p. 98. Aceitando as premissas expostas no corpo de texto, ficamos também com um axioma detectado por Nuno Gonçalo F. Monteiro, segundo o qual a "centralidade do centro" convivia necessariamente com uma comunicação política de via de mão-dupla, além de estar imbuída de uma flexibilidade capaz de garantir ao sistema a sustentação e a perduração das relações entre as partes com o todo. Verificar em especial: MONTEIRO, Nuno Gonçalo F. Trajetórias sociais e governo das conquistas [...]. IN: FRAGOSO, João; BICALHO, Maria Fernanda Baptista; GOUVÊA, Maria de Fátima Silva (org.). O Antigo Regime nos trópicos [...]. Rio de Janeiro: Civilização Brasileira, 2001, pp. 282-283.

${ }_{770}$ BICALHO, Maria Fernanda Baptista. As câmaras ultramarinas [...]. IN: FRAGOSO, João; BICALHO, Maria Fernanda Baptista; GOUVÊA, Maria de Fátima Silva (org.). O Antigo Regime nos trópicos [...]. Rio de Janeiro: Civilização Brasileira, 2001, pp. 219-221. GOUVÊA, Maria de Fátima Silva. Poder político e administração na formação do complexo atlântico português (1645-1808). IN: FRAGOSO, João; BICALHO, Maria Fernanda Baptista; GOUVÊA, Maria de Fátima Silva (org.). O Antigo Regime nos trópicos [...]. Rio de Janeiro: Civilização Brasileira, 2001, p. 287. Sobre a "elitização" de nascidos ou enraizados no ultramar e a importância da monarquia na integração desses indivíduos, verificar especificamente: CUNHA, Mafalda Soares da. Governo e governantes do Império português do Atlântico (século XVII). IN: BICALHO, Maria Fernanda Baptista; FERLINI, Vera Lúcia Amaral (org.). Modos de governar: idéias e práticas políticas no Império português, séculos XVI-XIX. São Paulo: Alameda, 2005, pp. 87-88.

${ }_{771}$ Verificar, por exemplo, as considerações tecidas sobre a "independência dos contextos locais" em detrimento do "teste" de modelos globais ou regionais, conforme sustentado em: SUBRAHMANYAM, Sanjay. O Império Asiático Português 1500-1700 [...]. [1993]. Linda-a-velha: Difel, 1995, pp. 305-306. 
mundo ultramarino de lógicas e processos pretensamente harmônicos. ${ }^{772}$ Fato é que o caso da Angola portuguesa, por exemplo, foge claramente da existência de um "novo Portugal" nos trópicos. ${ }^{773}$ Nesse domínio periférico centro-africano, por mais que uma economia política importada do reino de Portugal tivesse validade, uma composição social muito diferente da do centro político, além é claro da necessidade de operacionalização de uma economia escravista por parte do aparato administrativo régio, reproduziam novas hierarquias, matizes e distinções. Por consequência, nos deparamos com renovadas estratégias de mobilidade social e ascensão política e econômica. Isso sem contar que havia outras variáveis e diversidades africanas inexistentes no contexto ibérico, como por exemplo as pressões exercidas pelos mbundu e bakongo, para ficar apenas nos povos mais conhecidos na África Centro-Ocidental.

Do lado africano outros desdobramentos são perceptíveis. Alguns indivíduos foram atraídos ou seduzidos pela riqueza material e simbólica trazida pelos estrangeiros, viabilizando a política ultramarina voltada à cooperação e à parceria luso-africanas. A maioria, contudo, continuará a viver ao modo endógeno, passando ao largo das novidades transatlânticas. Dos que haviam se aproximado dos moradores portugueses e dos funcionários e oficiais régios, uma pequena parcela, a exceção é preciso refrisar, passaria a morar nas redondezas de Luanda e dos presídios, onde prestariam serviços e comercializariam com os estrangeiros. Seriam eles os tais "luso-africanos", identificados pela historiografia como grupos sociopolíticos locais e que adotaram saberes, usos e costumes "à europeia". Um mundo diferente era vislumbrado através da "emergência de

\footnotetext{
${ }^{772}$ Reconfigurando uma clave analítica destacada por Rodrigo Faustinoni Bonciani, que alerta sobre os perigos de focar exageradamente nas ações e posições de agentes nativos, em detrimento dos "processos de dominação sobre as populações africanas e indígenas na colonização". Acreditamos que o mesmo vale para os agentes coloniais, na medida em que muitas vezes as relações tecidas entre as diversas matizes de atores políticos do centro e das periferias eram conflituosas. Verificar: BONCIANI, Rodrigo Faustinoni. Descolonização e Racismo [...]. Sankofa [...]. São Paulo: Universidade de São Paulo (USP), n. ${ }^{\circ}$ 8, ano IV, dezembro de 2011, pp. 25-26.

${ }^{773}$ No final do século XVI, fundar o "novo Portugal" em terras americanas era uma das intenções defendidas pelo jesuíta Fernão Cardim. Isso, contudo, nunca chegou a acontecer, pois como bem lembra Carlos Alberto de Moura Ribeiro Zeron, "essa sociedade [da América portuguesa] deveria governar-se por meio de leis peculiares, porque peculiar também era a própria noção de bem comum, no contexto colonial e escravista". Verificar: ZERON, Carlos Alberto de Moura Ribeiro. A ocidente do ocidente: linhas e perspectivas em confronto. Revista de História (USP). São Paulo: Universidade de São Paulo, n. ${ }^{\circ} 170$, jan.-jun., 2014, pp. 9394. Em uma perspectiva geral, consultar: Idem, A construção de uma ordem colonial nas margens americanas do Império português: discussões sobre o "bem comum" na disputa de moradores e jesuitas pela administração dos indios (XVI-XVII). Tese de livre-docência, Faculdade de Filosofia, Letras e Ciências Humanas (FFLCH)/ Departamento de História, Universidade de São Paulo (USP), 2009.
} 
interstícios", como ressaltou à sua maneira Homi K. Bhabha, onde a intersubjetividade e a experiência coletiva estão imbuídas de um "espírito de revisão e reconstrução" e permeadas de "estratégias de empoderamento", onde o "novo" e o "velho", o "eu" e o "outro", encontravam-se e efetivamente foram entrelaçados e revisionados. ${ }^{774}$ Doravante, o potencial criador da convivência mútua fez com que diferentes culturas fossem sobrepostas e agregadas uma nas outras, veiculando certos procedimentos de neutralização, anulação e substituição multilógicos que, no processo histórico advindo dos encontros e contatos, poderiam acarretar em amalgamas e fusões culturais e sociais. Assim, desde o final do século XVI e ao longo da primeira metade do XVII, um microcosmo de transformação estava em fase de criação e desenvolvimento na região. ${ }^{775}$

Embora ainda haja muitas incertezas sobre como abordar certos assuntos e matérias ligados aos fenômenos socioculturais referenciados - hibridismos culturais, sincretismos religiosos, conexões e desconexões entre os fenômenos de mestiçagens e crioulizações, aquisição linguística, desenvolvimento cognitivo e educacional, o impacto de minorias sociológicas e a adoção de nomenclaturas e tipologias estrangeiras são algumas das veredas ainda em desbravamento,$-{ }^{776}$ fato é que a presente pesquisa foi capaz de indicar que a

${ }^{774}$ BHABHA, Homi K. The Location of Culture. Londres e Nova Iorque: Routledge, 1994, pp. 2-3. Quando esse autor se refere às oposições recíprocas entre "velho" e "novo", ele apenas faz menção ao clássico entendimento histórico sobre a dialética entre as persistências do passado e as mudanças advindas com passagem do tempo. Não se trata, portanto, de uma dicotomia entre "modernos" e "primitivos".

${ }_{775}$ Influenciados por algumas ideias de Peter Mark, George E. Brooks, José da Silva Horta e das mais novas considerações feitas por John K. Thornton, reanimamos algumas ideias tributárias da noção de "impacto transformacional" de Paul E. Lovejoy, sem contudo inferir que o comércio atlântico e a escravidão moderna teriam "transformado" as sociedades africanas em "sociedades escravocratas" separadas em classes. Verificar: LOVEJOY, Paul E. A escravidão na África [...]. [1983]. Rio de Janeiro: Civilização Brasileira, 2002, pp. 5, 20-21, 177-179 e 210-211. THORNTON, John K. A Cultural History of the Atlantic World, 1250-1820. Cambridge: Cambridge University Press, 2012, sobretudo os capítulos 8, 9 e 10. MARK, Peter. "Portuguese" style and Luso-African identity: precolonial Senegambia, sixteenth-nineteenth centuries. Blooming \& Indianapolis: Indiana University Press. 2002. BROOKS, George E. Eurafricans in the Western Africa: Commerce, Social Status, Gender, and Religious Observance from the Sixteenth to the Eighteenth Century. Athens: Ohio University Press/ Oxford: James Currey, 2003. HORTA, José da Silva. A "Guiné do Cabo Verde": produção textual e representações (1578-1648). [2002]. Tese de doutorado, Universidade de Lisboa, 2010.

${ }^{776}$ Aqui nos referimos a alguns pontos de "curto-circuito" no debate angolano, para tomar emprestada uma expressão de Francisco Manuel Antunes Soares. As atuais posições em Angola podem ser dissociadas em pelo menos três vertentes bastante simplificadas, encabeçadas por esse intelectual, Lukonde Luansi e Virgílio Coelho. Para sínteses de cada uma dessas posições, verificar especificamente: SOARES, Francisco Manuel Antunes. Crioulizações internas: processos de transculturação nos Bantu angolanos. Almanack. Guarulhos: Universidade Federal de São Paulo (UNIFESP), n. ${ }^{\circ}$ 8, $2^{\circ}$ semestre de 2014, pp. 85-86 e 103. LUANSI, Lukonde. Angola: Movimentos migratórios e Estados pré-coloniais - Identidade nacional e autonomia regional. IN: Angola on the Move: Transport Routes, Communication and History, Berlim, 2003, p. 8. COELHO, Virgílio. “Em busca de Kábàsà!...” [...]. Luanda: Kilombelombe, 2010, pp. 28-29, onde o autor 
emergência de um ambiente conflituoso, existente nesses espaços de coabitação e coexistência, impulsionou alguns africanos em busca de formas inovadas de sobreviver e ascender socialmente, contanto que não perdessem as heranças culturais e as tradições adquiridas desde o berço. Assim sendo, assumir uma identidade diferenciada - nem "peninsular", nem "centro-africana", mas "luso-africana" - era acionar um artifício cultural, uma válvula de escape e fluidez identitária, em resposta às condições e às situações impostas pelos novos contextos político-econômicos e pelas adversidades do meio. Desse modo, a luso-africanidade propiciava ao seu detentor, um agente comercial por exemplo, uma maneira efetiva de desfrutar de benefícios econômicos advindos do comércio atlântico de longa distância, sem com isso perder obrigatoriamente os sentimentos de pertencimento e proveniência endógenos. Por assim dizer, à guisa de um dispositivo valvular de identidade acionável e cambiável mediante o interesse pessoal ou comunitário, preservava-se um certo grau de transição e maleabilidade necessário para a interconexão de economias e a intercomunicação entre sociedades e culturas distintas. As relações entre os agentes e identidades não são estáticas, como se fossem alteridades irreconciliáveis e intransigentes entre as pessoas, ${ }^{777}$ mas maleáveis e que poderiam ser geridas pela vontade de seus possuidores, mediante os contextos e as contingências de cada espaço ultramarino e em razão das condições sociais e políticas específicas. ${ }^{778}$

explicita o método de investigação baseado na antropologia histórica e a importância das tradições. Sobre a questão das "crioulizações" e "mestiçagens" no contexto angolano, conferir os principais argumentos e os campos de divergência em: NETO, Maria da Conceição. Ideologias, contradições e mistificações [...]. Lusotopie. Bordeux: Centre d'étude d'Áfrique noire/ Centre national de recherche scientifique, 1997, p. 332. VENÂNCIO, José Carlos. Mestiços em África: Mediadores Culturais Naturais. IN: LOUREIRO, Rui Manuel; GRUZINSKI, Serge (coord.). Passar as Fronteiras: Actas do II Colóquio Internacional sobre Mediadores Culturais, Séculos XV a XVIII. Braga: Centro de estudos Gil Eanes, 1999, pp. 182 e 184. FERREIRA, Roquinaldo. "Ilhas crioulas": o significado plural da mestiçagem cultural na África Atlântica. Revista de História (USP). São Paulo: Universidade de São Paulo, n. ${ }^{\circ} 155,2^{\circ}$ semestre de 2006, pp. 18 e 29. Para uma discussão recente sobre a mestiçagem no contexto atlântico, com foco nas relações entre Brasil e Angola, consultar: MARQUESE, Rafael de Bivar. A dinâmica da escravidão no Brasil: resistência, tráfico negreiro e alforrias, séculos XVII a XIX. Novos estudos. São Paulo: CEBRAP, n. ${ }^{\circ} 74$, março de 2006. GOMES, Flávio; FERREIRA, Roquinaldo. A miragem da miscigenação. Novos estudos. São Paulo: CEBRAP, n. ${ }^{\circ} 80$, março de 2008. O leitor mais inquieto pode encontrar subsídios para uma reflexão sobre os contatos e as trocas entre "culturas políticas" distintas em: LARA, Silvia Hunold. Palmares \& Cucaú [...]. Tese para concurso de Professor Titular, Universidade Estadual de Campinas (UNICAMP), 2008, pp. 96, 98-99 e 113-118.

${ }^{777}$ Como Balandier chamou atenção ao discorrer sobre o surgimento de novas "formas de sociabilidade" em Angola. Verificar: BALANDIER, Georges. A situação colonial: abordagem teórica. [1951]. Cadernos CERU. São Paulo: Universidade de São Paulo (USP), série 2, vol. 25, n. ${ }^{\circ}$ 1, junho de 2014, p. 54.

${ }_{778}$ Nesse sentido, verificar o que afirma Bhabha sobre uma "transformação da agência histórica" e o "processo de significação" em: BHABHA, Homi K. The Location of Culture. Londres e Nova Iorque: Routledge, 1994, pp. 12-13 e 45. Também é interessante a noção de "mimetismo" desse mesmo intelectual 
A análise histórica até então desenvolvida advoga para o não surgimento de uma "nova cultura angolana", ou outra espécie de "neocultura", em meados do século XVII. Havia claros sinais e pistas de que pequenos focos de mudanças germinariam em alguns entrepostos e povoados espalhados pelo interior, impulsionados pela aquisição linguística e mistura de práticas e costumes em sentidos variados, abrindo alas para transculturações e para a cunhagem de identidades muitas vezes transitivas e cambiáveis. Assumindo uma posição marginal em relação a Luanda e a Pungo Andongo, essas comunidades situadas nas "franjas" de jurisdições e mundos distintos manipulavam saberes técnicos, uma espécie de "saber-fazer" rudimentar em letras e matemática, capacitando alguns agentes para a gestão comercial. Ao passo que atuavam como gestores e práticos do tráfico de escravos - o exemplo dos "manis quitandas" é o mais emblemático de todos, mas poderíamos também citar o importante papel de "quimbares" e "pombeiros" no comércio interiorano -, esses agentes nutriam luso-africanidades repletas de "duplas linguagens" e "códigos diferentes", tornando-os intermediadores eficazes no trato comercial. Paradoxalmente à grande flexibilidade que tinham em se adaptar às condições adversas impostas pelos meios sociais e ambientais, em torno dos quais trafegavam e se movimentavam com frequência, tais indivíduos estavam muitas vezes isolados no interior e, de certa forma, excluídos e desenraizados tanto das sociedades centro-africanas quanto das ibéricas. Como um dos desdobramentos disso, ao contrário de serem propagadores dos ideais defendidos por Luanda ou por Pungo Andongo, eles figuravam muito mais como um empecilho para a “difusão dos valores morais e jurídicos" continente adentro, uma vez que desempenhavam seus afazeres com relativa eficiência e, por isso, tornavam desnecessária a transferência para o interior de um sistema requintado de gestão do negócio escravista, com juízes que zelassem pelas leis escritas e autoridades eclesiásticas que legitimassem os títulos de escravidão. O sistema misto e em rede era eficiente o bastante para garantir a finalidade maior da Angola portuguesa: provir Luanda de escravos. Assim sendo, e relendo as

(mimicry), entendida então como uma forma de criar, através da "apropriação colonial" e da "zombaria" adotada por parte dos colonizados, uma estratégia de "revide" que atesta para as falhas da estratégia colonizadora. Verificar a mesma obra de Homi K. Bhabha, especificamente as pp. 85-86 e 89. Ver também: CHAKRABARTY, Dipesh. Provincializing Europe [...]. [2000]. Princeton: Princeton University Press, 2008, p. 40. Sobre a noção de identidade como um "dispositivo valvular", somos influenciados pelas considerações de Stuart Hall, principalmente no que diz respeito à "natureza desconcertante e cambiante de identidades possíveis" capazes de se deslocar e serem modificadas, tanto no tempo quanto no espaço. Verificar: HALL, Stuart. A identidade cultural na pós-modernidade. [1992]. Rio de Janeiro: DP\&A, 2006, pp. 12-13 e 60-61. 
principais considerações tecidas por Carlos Alberto de Moura Ribeiro Zeron a respeito das "gentes intermediárias" - no caso desse autor, propriamente os tangomaus e pombeiros -, podemos adicionar que os agentes que articulavam a administração régia aos mercados africanos e, por consequência, atuavam no negócio escravista, figuravam mais como "atravessadores culturais" do que mediadores, pelo menos na Angola portuguesa. ${ }^{779}$

A despeito do impacto cultural estrangeiro na vida local, certamente a manifestação de múltiplas identidades fluidas foi efêmera em relação às sobrevivências e às resiliências vinculadas às tradições e às culturas políticas que continuariam a estruturar a maioria das sociedades e soberanias centro-africanas do século XVI até pelo menos o final do XVIII. Ressaltamos com isso a necessidade e importância de reacessar o passado dessas diferentes culturas políticas, conforme elas são documentadas e expostas até hoje, entendendo que as comunidades locais emanam especificidades culturais e que são sujeitos de sua própria história. No final das contas, trata-se de reformar os nossos próprios enviesamentos humanísticos e universalismos modernos, a partir das experiências centro-africanas e portuguesas em contato. ${ }^{780}$

\footnotetext{
${ }^{779}$ Atentando para o fato de que tais considerações não valem necessariamente para o caso de missionários, padres e diplomatas, mas somente para os agentes diretamente comprometidos com o tráfico de pessoas. Verificar as "hipóteses emitidas" e algumas conclusões em: ZERON, Carlos Alberto de Moura Ribeiro. Pombeiros e tangomaus, intermediários do tráfico de escravos na África. IN: LOUREIRO, Rui Manuel; GRUZINSKI, Serge (coord.). Passar as Fronteiras [...]. Braga: Centro de estudos Gil Eanes, 1999, pp. 30-31, 37-38. Ver nesse mesmo sentido: BALANDIER, Georges. A situação colonial [...]. [1951]. Cadernos CERU. São Paulo: Universidade de São Paulo (USP), série 2, vol. 25, n. ${ }^{\circ}$ 1, junho de 2014, pp. 49-50. Por consequência, duvidamos de alguns resultados parciais apresentados por José Carlos Venâncio, baseados na assunção de que uma gama amorfa de agentes "mestiços" - sem defini-los de maneira crítica, de acordo com Maria da Conceição Neto - exercia a função de "mediadores culturais naturais". Verificar: VENÂNCIO, José Carlos. Mestiços em África [...]. IN: LOUREIRO, Rui Manuel; GRUZINSKI, Serge (coord.). Passar as Fronteiras [...]. Braga: Centro de estudos Gil Eanes, 1999, p. 186. NETO, Maria da Conceição. Ideologias, contradições e mistificações [...]. Lusotopie. Bordeux: Centre d'étude d'Áfrique noire/ Centre national de recherche scientifique, 1997, p. 332.

${ }^{780}$ Em um intuito parecido com o de Sanjay Subrahmanyam, mas certamente levado a cabo por outros meios. Verificar: SUBRAHMANYAM, Sanjay. Connected Histories [...]. Modern Asian Studies. Cambridge: Cambridge University Press, vol. 31, n. ${ }^{\circ} 3$, julho de 1997, p. 739. Em um artigo posterior, Subrahmanyam esclarece que o seu intuito é o de abordar "questões de dimensão global", como o "milenarismo" e o uso de dinheiro, através de "manifestações locais bastante diferentes", em um esforço de "elaborar uma macrohistória da questão sem nos atolarmos em uma forma de micro-história", modificando ligeiramente algumas considerações feitas anos atrás. Verificar: Idem, Du Tage au Gange au XVIe siècle: une conjoncture millénariste à l'échelle eurasiatique. Annales. Histoire, Sciences Sociales. Paris: Éditions de l'EHESS, n. ${ }^{\circ}$ 56, 2001/1. p. 56 (no original: "Le millénarisme - comme l'argent - nous permet d' aborder un problème de dimension globale, mais dont les manifestations locales diffèrent beaucoup. Cela signifie que nous ne pouvons pas tenter d'élaborer une macro-histoire de la question sans nous enliser dans une forme de microhistoire"). Lembrar também do impulso humanístico ressaltado por Edward W. Said no início desta conclusão.
} 


\section{Dinâmicas e complexidades na administração da governadoria ultramarina no} início do século XVII

No início desta dissertação, suscitamos os prolegômenos para um estudo aprofundado a respeito do funcionamento de um sistema administrativo misto, chamando atenção para a relevância de analisar em conjunto as variadas expressões e os desdobramentos engendrados pelas formas de dominação e intermediação em voga ao longo da formação histórica da Angola portuguesa. Nesse sentido, acrescentamos igualmente que os contatos intersociais, inaugurados a partir das grandes navegações modernas, não passaram incólumes ao processo histórico: eles estão inscritos de maneira decisiva na confecção orgânica da documentação. Como produto e reflexo do processo histórico de construção do sistema de governadoria ultramarina na África Centro-Ocidental, a FHA é um corpo textual no qual estão contidos os potenciais elementos para a compreensão dos fenômenos e manifestações vinculados à administração ultramarina portuguesa, perscrutados aqui à luz do estabelecimento de um domínio ultramarino em perpétua situação de contato. Tal era uma administração institucional do ultramar, capaz de lidar com essa gente "esquisita", "excêntrica" e "exótica" aos olhos dos cronistas e observadores de época, ao passo que atendia aos anseios e às demandas de grupos e entidades diversos. Além disso, para garantir a existência da governadoria-geral de Angola, a Coroa e os vários agentes envolvidos na empreitada ultramarina ensejaram algumas dinâmicas institucionais e governamentais. De maneira bem sucinta, elencaremos abaixo algumas delas, depreendidas através da análise empírica da documentação. ${ }^{781}$

Uma primeira dinâmica está ligada à noção de política como uma ação exercida por alguns grupos sociopolíticos preponderantes em Luanda, ora em esferas públicas, onde os interesses pessoais eram acionados, ora no íntimo da privacidade, onde os interesses da ordem comunitária estavam presentes e que, porventura, poderiam ser documentados de maneira escrita. Seja como for, essas decisões teriam necessariamente que abarcar três

\footnotetext{
${ }^{781}$ Considerando outrossim que somos influenciados por algumas das seis hipóteses clássicas arquitetadas para repensar a história político-institucional nos séculos XVI e XVII, elencadas por Jaime Vicens Vives: $i$ ) A mentalidade e pensamento medievais e o exercício dos cargos régios (p. 221); ii) A burguesia e a participação no funcionalismo régio (p. 222); iii) A mediocridade e a incompetência dos funcionários (pp. 223-224); iv) Rentabilidade e atração para o cargo administrativo (pp. 224-225); v) Os abusos e a corrupção do aparelho administrativo (pp. 226-227); vi) A venalidade dos ofícios e sua relação com o "balcão de negócios" (p. 227). Informações retiradas de: VIVES, Jaime Vicens. A estrutura administrativa estadual nos séculos XVI e XVII. [1960]. IN: HESPANHA, António Manuel (ed.). Poder e instituições na Europa do Antigo Regime: coletânea de textos. Lisboa: Fundação Calouste Gulbenkian, 1984.
} 
variáveis. Na raiz de tudo residiam os palcos políticos, integrados por atores protagonistas e coadjuvantes, que suscitavam interesses organizados em hierarquias e divisões internas e externas variadas. Ao longo desta dissertação, os atores mais mencionados foram o Ndongo, Kongo, Casanze e Boila. Se havia palcos, também existiam xadrezes, nas quais se desenrolaram enredos e movimentações políticas - táticas, estratégias, manobras ou qualquer outro impulso que levasse à ação efetiva -, de modo que a política era um jogo constituído de ações e reações, bem como de expectativas e frustrações. Repousamos por fim onde de fato eram encapsuladas todas as dinâmicas institucionais e governamentais, visíveis no cariz de uma arena político-jurídica. Nessa última instância reside a materialidade da documentação histórica disponível para consulta, onde as informações e os dados registrados em papel estão envolvidos em discursos, retóricas, estereótipos, estigmas, moralismos e legitimações acionados pelos anotadores coevos. ${ }^{782} \mathrm{Na}$ forma de conteúdo produzido, tudo era passível de instrumentalização por parte do autor-escritor, como se a realidade observada fosse interpelada por uma bruma, um verdadeiro "véu" que deixa transparecer apenas uma sombra. Para que a imagem ocultada seja "revelada", é necessário que os fragmentos históricos sejam filtrados, ou submetidos ao "pente-fino" do historiador de ofício, para que depois estejam prontos para serem abordados e aprofundados. Em suma, por detrás da escrita institucional e política portuguesa, havia uma miríade de concertos políticos e sociais, orquestrados através de planos individuais de ordem local, planejamentos regionais debatidos entre as elites ultramarinas e projetos monárquicos expansionistas e exploratórios. ${ }^{783}$

\footnotetext{
${ }^{782}$ Como lembra Homi K. Bhabha, no discurso do colonizador os estereótipos figuram como uma "sutura", uma espécie de explicação elaborada para tentar resolver as contradições e contrassensos recriados no discurso de dominação. Verificar: BHABHA, Homi K. The Location of Culture. Londres e Nova Iorque: Routledge, 1994, p. 80. Sobre a produção de "regimes" de verdade, originalidade (originality) e estigmas, verificar: pp. 67, 70-71 e 81-83.

${ }^{783}$ Exemplos análogos para outros contextos não faltam: CANDIDO, Mariana P. Os agentes não europeus na comunidade mercantil de Benguela, c. 1760-1820. Sceculum: Revista De História. João Pessoa: Universidade Federal da Paraíba (UFPB), n. ${ }^{\circ}$ 29, julho/dezembro de 2013, pp. 98 e 102-103, onde fica claro que ocorria uma proliferação de agentes ligados ao tráfico de escravos e que as relações entre eles era assimétrica. XAVIER, Ângela Barreto; SANTOS, Catarina Madeira. Cultura intelectual das elites coloniais. Cultura [...]. Lisboa: Universidade Nova de Lisboa/ Centro da Cultura, vol. 24, 2007 pp. 13-14 e 16-17, onde as autoras explanam uma definição para "agência" a tecem considerações sobre as diferentes "elites". Para uma apresentação sobre dois tipos de elites fundamentais no reino de Portugal e no ultramar lusitano, sendo uma "imperial" e outra "colonial", verificar: SANTOS, Catarina Madeira. De "antigos conquistadores" a "angolenses". Cultura [...]. Lisboa: Universidade Nova de Lisboa/ Centro da Cultura, vol. 24, 2007, pp. 195197. A existência de vários grupos sociais específicos, que cofabulam em espaços políticos e que aspiram por escravos, são traços também visíveis na América portuguesa: ZERON, Carlos Alberto de Moura Ribeiro. Les
} 
Uma segunda dinâmica institucional e governamental estava ligada às cadeias relacionais que perpassam os escritos da FHA. A lógica formal dos registros oficiais prescrevia a existência de dois raciocínios elementares, fundados na institucionalização da vida no ultramar e nas práticas governamentais adotadas na Angola portuguesa, capazes juntos de distorcerem ou deturparem a realidade observada. Ante as práticas de anotação e inscrição de informações e dados em papel, chamamos atenção para dois casos. Um primeiro dizia respeito à cadeia que relacionava quatro pontos conjugados à aproximação diplomática e à vinculação política: vassalagem-undamento-baculamento-tributação. ${ }^{784}$ Tal cadeia pode ser entendida em oposição a um conjunto amorfo de taxas e tarifas extraordinárias e abusivas, encaradas como semilegais ou ilícitas perante o físco régio de Luanda. Embora o assunto ainda necessite de mais investigações, nos documentos da FHA subjaz a ideia de que essas últimas taxas e tarifas podiam ser agrupadas em dois subconjuntos, mais ou menos vinculados ao que se entendia como os "usos", "costumes" e "tradições" locais. ${ }^{785}$ No primeiro constavam os impostos e presentes recebidos

Jésuites et le commerce d'esclaves entre le Brésil et l'Angola à la fin du XVIe siècle: contribution à un débat. Traverse: Zeitschrift für Geschichte. Zurique: Éditions Chronos, n. ${ }^{\circ}$ 1, 1996, pp. 35-36.

${ }^{784}$ Consultar os capítulos 2 e 4.

${ }^{785}$ Esclarecendo que há uma diferença entre a percepção legal da época - havia uma divisão básica entre as "normas próprias" (iura propria) e as "normas gerais" (ius commune) - e a forma como algumas apropriações contemporâneas distorcem as relações entre as prescrições político-jurídicas e a prática em campo. Promulga esse tipo de abordagem António Manuel Hespanha, defensor de uma "arquitetura do direito comum europeu" incoerente ou mesmo excêntrica, encetada a partir de uma "constituição pluralista do Império, em que cada nação submetida podia gozar do privilégio de manter seu direito, garantido por tratado ou pela própria doutrina do direito comum, de acordo com a qual o âmbito de um sistema jurídico era marcado pela naturalidade". Afora dos interesses contemporâneos de Hespanha, reproduzidos de forma não tão subjacente no excerto anterior, concordamos que o direito português dos séculos XVI e XVII garantia aos povos locais ou "nativos" alguns "direitos específicos", próprios ou "naturais" a eles, porém com uma ressalva: na prática, a "doutrina do direito comum" era utilizada muito mais para legitimar ações pragmáticas. Tais ações tinham um caráter político e eram perpetradas por uma elite local ou reinol, que podia ou não ser letrada, visando atender aos interesses pessoais ou corporativos dessas mesmas elites. O que moviam a ação política, a escrita institucional e as formulações ideológicas eram os interesses de uma camada social privilegiada, não o legalismo ou o respeito ao outro e ao direito português. Pelo menos, essa foi tendência vislumbrada no caso da Angola portuguesa. As citações foram retiradas de: HESPANHA, António Manuel. A constituição do Império português. Revisão de alguns enviesamentos correntes. IN: FRAGOSO, João; BICALHO, Maria Fernanda Baptista; GOUVÊA, Maria de Fátima Silva (org.). O Antigo Regime nos trópicos [...]. Rio de Janeiro: Civilização Brasileira, 2001, pp. 172-173. Em obra posterior, Hespanha respondeu aos seus críticos sustentando que uma "pluralidade de jurisdições (arbor iurisdictionum) concorrentes, de limites imprecisos, por vezes sobrepostos, redefiníveis pelo uso, porosas em relação aos agentes - que podiam estar, ao mesmo tempo, sujeitos a várias delas" conformava uma "constelação de redes quasi-contratuais", "multipactada" e permeada de "multicentrismos" jurídicos e políticos, todos eles conjugados e flexionados ao corpo místico do rei. Novamente, há aqui a presunção de que a teoria legal-jurídica seria capaz de moldar novas realidades sociais e históricas. Verificar: Idem, Por que é que foi "portuguesa" a expansão portuguesa? ou $\mathrm{O}$ revisionismo nos trópicos. IN: SOUZA, Laura de Mello e; FURTADO, Júnia Ferreira; BICALHO, Maria 
tradicionalmente pelo ngola e que haviam sido "invalidados" no tempo de Fernão de Sousa - poderíamos citar cadeia tripontual loanda-infuta-vestir como um exemplo -, no segundo os malefícios causados a alguns sobas - os exemplos recorrentes são os das ocambas e infucas -, existentes desde uma época anterior à chegada portuguesa àquela parte da África. O segundo caso dizia repeito à outra cadeia relacional, subsumida à separação estática e rígida entre os conceitos de "liberdade" e "escravidão", 786 assumindo uma ordenação baseada nas relações forro-livre-murinda e que era definida em oposição à cadeia antitética cativo-escravo-quizico. A busca de traduções inteligíveis para realidades nunca antes vistas pelo monarca e sua corte, além é claro dos vários funcionários peninsulares que porventura consultassem o material escrito, engendrava uma prática processual de escrita administrativa mediante a qual definições eram ensaiadas por meio do estabelecimento de dicotomias e de inúmeras classificações impostas à realidade observada, artificializando o resultado inscrito em papel. Isso quer dizer que muito do que era registrado e vertido nos manuscritos acabava sendo um reflexo da cognição e da capacidade explicativa de certo observador, não o fruto da anunciação "pura" e isenta do observado, frequentemente privado do acesso ao material produzido e destituído de instrumentos necessários - pena, papel, tinta, conhecimentos técnicos e outros - para remodelar a redação régia de acordo com o seu ponto de vista. Assim sendo, em última instância, tal postura institucional prezava para que os dados e as informações documentados ficassem mais inteligíveis e “informativos” para os superintendentes e órgãos reinóis que os lessem, estando igualmente à mercê de influências externas e do modo de ver do anotador. ${ }^{787}$

Terceira dinâmica: havia uma linha tênue que separava a "legalidade" da “ilegalidade", o interesse "público" do "privado" e as variadas formas de ascensão social

Fernanda (org.). O governo dos povos. São Paulo: Alameda, 2009, pp. 48 (destaque para a nota 30), 55-56 e 59.

${ }^{786}$ Sobre a excessiva rigidez e a impropriedade dessas noções para os contextos centro-africanos, verificar: HENRIQUES, Isabel Castro. Reflexões sobre o "escravo" africano. IN: O Pássaro do mel [...]. Lisboa: Edições Colibri, 2003, p. 62. Não à toa, essas "nuanças programáticas" e "universos irreconciliáveis" também marcaram algumas polaridades que perpassaram as discussões clássicas, levadas a cabo pela historiografia sobre a escravidão atlântica, conforme indicado em: LARA, Silvia Hunold. Conectando historiografias: a escravidão africana e o Antigo Regime na América portuguesa. IN: BICALHO, Maria Fernanda Baptista; FERLINI, Vera Lúcia Amaral (org.). Modos de governar [...]. 1 1a edição. São Paulo: Alameda, 2005, pp. 2223.

${ }^{787}$ Descrevemos diversos procedimentos e formas processuais nos capítulos 2 e 4 desta dissertação. Para as relações entre as diferentes cadeias relacionais, consultar também o capítulo 3, além é claro do "suplemento para alguns vocábulos africanos" que consta nesta dissertação. 
vigentes na Angola portuguesa. São relativamente frequentes as referências que Fernão de Sousa faz à corrupção de funcionários régios e oficiais militares, ao comércio secundário operado por holandeses e que contava com a conivência do Kongo e Loango, ao contrabando de mercadorias por parte de agentes comerciais a serviço de Luanda e às ilicitudes na cobrança de taxas e tributos. Muitas vezes essas críticas eram legalistas e moralizantes, discursando em nome do "correto" serviço administrativo, do enriquecimento do erário régio e do zelo pela "paz, justiça, domínio e bem comum” da Angola portuguesa. Mas com frequência não deixavam os oficiais e funcionários régios mais prestigiados e graduados, em teoria os que defenderiam com mais afinco os interesses da monarquia, de serem eles mesmos coniventes ou passíveis em relação às ilegalidades. Linha tênue, como dissemos, entre os planos da ordem e da desordem, bem como panorâmica: eficiência e lealdade, ineficiência e deslealdade eram características desses indivíduos, detentores de um pé firmado na legalidade e outro na ilegalidade. Intimamente tributária dessa dinâmica poderíamos salientar outra, ligada às inúmeras ambivalências que permeavam a organização social que compunha o domínio ultramarino centro-africano. Os limites pouco precisos e fluidos entre os espaços privado e público, o ambiente conflituoso e as tensões existentes entre a liberdade, o trabalho escravo, o tráfico transatlântico e a produção escravista faziam com que uma economia atlântica e a renovada composição social do domínio ultramarino engendrassem novos desafios institucionais e governamentais. Havia ainda uma coexistência entre diferentes formas de ascensão social, vigorando nesse sentido a distribuição da honra e graça de proveniência feudal, as comendadorias e profissionalizações modernas das mercês, a importância da herança genealógica e matrimonial e o enriquecimento através da exploração da mão-de-obra compulsória e do comércio de escravos, sendo esses dois últimos pontos os mais relevante no ultramar do que no reino de Portugal. ${ }^{788}$ No final das contas, tratava-se também das resiliências de um passado medieval, das imposições modernas vividas na Península Ibérica, das modificações pelas quais passavam os moradores ultramarinos estabelecidos nas franjas da periferia

\footnotetext{
${ }^{788}$ No além-mar do Atlântico vigorava então o "sentido comercial", as "relações escravistas" e as "práticas do Antigo Regime" já resumidas por: BICALHO, Maria Fernanda Baptista. Conquista, Mercês e Poder Local [...]. Almanack Braziliense. São Paulo: Universidade de São Paulo (USP)/ Instituto de Estudos Brasileiros (IEB), n. ${ }^{\circ}$, novembro de 2005, p. 22.
} 
ultramarina, das pressões engendradas pelas populações centro-africanas e do impulso embrionário de um capitalismo insípido, mas vitorioso na longa duração.

Funcional em relação a essas dinâmicas, o governo ultramarino da Angola portuguesa envolvia algumas complexidades elementares, capazes de garantir a expansão política e a exploração econômica do interior do continente, além de sustentarem a ordem e o mando superiores concentrados em Luanda. Uma dessas complexidades dizia respeito ao funcionamento de um sistema administrativo misto e que operava em rede, acionando os diferentes nodos institucionais, também identificados nesta pesquisa como "entrepostos". A governadoria ultramarina era então capaz de preservar uma coerência entre as partes - os vários presídios e banzas dos sobas vassalos e simpáticos à Coroa - juntamente com uma coesão ao todo - o entendimento da Angola portuguesa como constituinte do Império ultramarino -, "enredando" aqueles que estivessem na mira da imposição tutelar ultramarina. O núcleo populacional e político desse domínio, responsável pela interconexão e a redistribuição de serviços e bens entre o centro reinol e as suas periferias, era a "cidade de São Paulo de Luanda". Nela ocorriam as orquestrações políticas, mediante as quais eram regidos, discutidos e negociados os projetos, planejamentos e planos que viabilizariam a tomada de decisão oficial e formal, todos eles determinantes para o futuro material e econômico dos moradores, funcionários, oficiais e representantes de investidores e contratadores dos direitos de comércio. Luanda era um espaço de constantes reengenharias político-econômicas, onde diferentes elites competiam entre si e havia uma real mobilidade hierárquica, inaugurando e reinventando algumas possibilidades de enriquecimento e engrandecimento de cabedal, material e imaterial, de cúpulas e searas cristalizadas ou ainda em modificação na primeira metade do século XVII.

No final das contas, o estudo sobre uma história das expansões e dos contatos lusoafricanos indica que as "novidades" trazidas pelos estrangeiros se sobrepunham às formas políticas e econômicas tradicionais dos centro-africanos, havendo na grande maioria dos casos aqui analisados influências mútuas. Em contrapartida, as dinâmicas e complexidades indicadas neste item atestam para a pujança e o fortalecimento de uma Angola portuguesa paulatinamente impactante nos assuntos costeiros da África Centro-Ocidental, mesmo que não fosse um domínio supremo e nem hegemônico. No interior, o impacto era evidentemente diluído ou mesmo pontual. O potencial inovador ou destrutivo, 
desenvolvimentista ou subdesenvolvimentista, progressista ou conservador estão assentes no conjunto de dinâmicas e complexidades ligado às formas de dominação e intermediação, em voga no processo de formação histórica da Angola portuguesa. Doravante, o comércio atlântico e a capacidade atrativa do litoral ficariam aos poucos maiores, fazendo de Luanda o centro gravitacional e a ponte de conexão entre os reinos centro-africanos e o mercado global. De todo modo, todo o potencial da cidade ultramarina e o ápice de seu comando mercantil seriam apenas atingidos no devir dos séculos XIX e XX.

A título de consideração final, algumas polarizações acadêmicas levadas a cabo nas últimas décadas precisam ser superadas. As posições normalmente estão divididas entre aqueles que derrogam a exclusividade da "perspectiva euro-centrada" de um lado e, do outro lado, os que refutam a chamada "retórica antieurocêntrica". ${ }^{789} \mathrm{Em}$ impulso crítico análogo, por exemplo, Tobias Green chama atenção para a importância de um "combate anti-hegeliano", descredenciando a ideia de uma "África sem História", ao passo que sustenta a possibilidade de analisar as reações de agentes africanos frente às mazelas causadas pela violência escravista, em prol da construção de um "mundo atlântico" e "moderno". 790 Os pressupostos e premissas colocados em voga nesses debates giram em torno de parâmetros clássicos ligados ao tamanho do território ocupado, à quantidade populacional europeia ou africana e à disposição financeira de estados e companhias privadas. Os resultados aqui alcançados permitem reafirmar tais critérios, porém com uma complementação. Assim como Jacques Le Goff justificou o estudo histórico das cidades medievais em uma época em que apenas uma pequena fatia da população europeia era urbana, ou Georges Balandier pintou os autóctones da colônia de Angola como minorias sociológicas relevante - ambos frisaram a participação ou marginalização de grupos sociais na vida econômica que compunha o capitalismo embrionário ou nascente,$-{ }^{791}$ durante os

\footnotetext{
${ }^{789}$ Para o primeiro posicionamento, verificar: WISSENBACH, Maria Cristina Cortez. Dinâmicas históricas de um porto centro-africano [...]. Revista de História (USP). São Paulo: Universidade de São Paulo, n. ${ }^{\circ}$ 172, janeiro/junho, 2015, p. 195. SANTOS, Maria Emília Madeira. Nos caminhos de África [...]. Lisboa: Instituto de Investigação Científica Tropical, 1998, p. XIII e 432-433. Para o segundo, verificar o resumo em: BETHENCOURT, Francisco; CURTO, Diogo Ramada (ed.). Portuguese Oceanic Expansion, 1400-1800. Cambridge: Cambridge University Press, 2007, pp. 10-13.

${ }^{790}$ GREEN, Tobias. Beyond an Imperial Atlantic: trajectories of Africans from Upper Guinea and WestCentral Africa in the early Atlantic World. Past and Present. Oxford: Oxford University Press, n. ${ }^{\circ} 230$, fevereiro de 2016, pp. 94-96.

${ }^{791}$ LE GOFF, Jacques. Por amor às cidades: conversações com Jean Lebrun. São Paulo: Fundação Editora da UNESP, 1998. BALANDIER, Georges. A situação colonial [...]. [1951]. Cadernos CERU. São Paulo:
} 
séculos XVI e XVII os agentes da Angola portuguesa exerceram pressão constante sobre os habitantes continentais, de modo que os indivíduos implicados na empreitada ultramarina estavam interessados na aquisição de escravos e na resolução rápida de abalos políticos. Do lado português, primava-se pela reiteração de uma economia escravista e atlântica, exportadora de mão-de-obra para a América portuguesa. Por sua vez, autoridades e soberanos africanos contrapressionavam os representantes da Coroa portuguesa, isolandoos em Luanda e nos presídios portugueses. Através disso, por exemplo, soberanias como as do Kongo e a do Ndongo asseguraram uma "entrada na modernidade segundo as regras locais", 792 conforme os termos de Maria Emília Madeira Santos. Dessa maneira, continua a pesquisadora, os pares litoral-interior e pressão-contrapressão encontram respaldo na assertiva de que "o impacto externo junto das sociedades africanas fora, até as últimas décadas do séc. XIX, indirecto, limitado e dependente, visto ser accionado a partir de centros motores no litoral e apenas captar géneros coloniais através da resposta/ extracção africana". ${ }^{793}$ A isso pesou o fato de a economia escravista não necessitar de uma vasta ocupação territorial para garantir a operacionalização dos portos exportadores de mercadorias africanas, tampouco era essa economia refém da ineficiência dos mecanismos de fiscalização e vigilância de Luanda. A despeito da baixa quantidade de população "portuguesa" e dos poucos funcionários e oficiais régios que lá serviam, muitas vezes mal remunerados e carentes de alimentos e água, a Angola portuguesa era funcional em razão dos interesses econômicos e sociopolíticos de seus habitantes. Assim, em último caso, foi junto com o fomento do negócio atlântico-escravista que prosperou a articulação entre sociedades, culturas e economias distintas nesse domínio ultramarino.

Universidade de São Paulo (USP), série 2, vol. 25, n. ${ }^{\circ}$ 1, junho de 2014, pp. 46-47, onde o pesquisador explica as razões pelas quais uma "minoria numérica não é uma minoria sociológica".

${ }^{792}$ SANTOS, Maria Emília Madeira. Nos caminhos de África [...]. Lisboa: Instituto de Investigação Científica Tropical, 1998, p. 472.

${ }^{793}$ Ibidem, p. 498. 


\section{APÊNDICE}

\section{Suplemento para alguns vocábulos africanos}

Muitos dos termos centro-africanos mais relevantes e recorrentes na FHA apresentam controvérsias e dissonâncias, principalmente no que diz respeito à polissemia suscitada ao longo dos empregos e interpretações vocabulares, encapsulada nos textos de época e reinterpretada pelos pesquisadores contemporâneos. Além disso, e atentos ao perigo de se fiar em uma realidade observada e registrada por observadores estrangeiros, cujo sentido de escrita era muitas vezes guiado por interesses próprios e interpretado à luz de conceitos importados da Península Ibérica, cabe aqui não apenas apresentar uma multiplicidade de acepções vocabulares ao leitor, mas também indicar quais são os sentidos de interpretação mais comuns existentes na FHA. Posto dessa forma, o presente suplemento terminológico é uma tentativa de auxiliar tanto na leitura das fontes escritas portuguesas, sobretudo válida para os escritos quinhentistas e seiscentistas, quanto de fornecer ao leitor um suporte complementar à análise desenvolvida nesta dissertação, com exposições de sentidos e definições aplicados para alguns vocábulos centro-africanos.

À parte de dois termos aqui registrados, "prões" e "vestir", a quase totalidade dos termos abaixo expostos tem raízes etimológicas kimbundu, kikongo e umbundu. Como léxico incorporado à escrita administrativa portuguesa, é difícil traçar os sentidos e significados "originais" que essas palavras detinham em suas comunidades locais, todas elas ágrafas até então. De todo modo, a tendência observada é a de que as operações de incorporação lexical foram todas capazes de preservar os sentidos africanos de termos "análogos", mas incompletos, existente no léxico português de época. Aliás, à guisa de imbricações semânticas de conceitos e noções convergentes entre as a visões de mundo exógena e endógena, na prática a incorporação lexical em âmbito institucional resultava na possibilidade de comunicação interpessoal e oficial entre autoridades portuguesas e locais, sem que com isso houvesse necessariamente compreensão plena entre ambas as partes. Se por um lado o empréstimo e o uso de palavras estrangeiras foi bastante comum, por outro lado traduzi-las era um ato simplificador e limitador. A título de sugestão, por detrás da utilização de termos estrangeiros procedida pela administração ultramarina, ocorriam 
operações de incorporação associadas às simplificações tradutológicas de termos indispensáveis à formalização e à oficialização dos contatos luso-africanos, tão importantes à burocratização dos órgãos administrativos reinóis e ultramarinos e de suma relevância para a legitimação do domínio ultramarino de Angola.

\section{Anzico (também grafado como anziko)}

"Anzicos" eram populações atualmente conhecidas como "tios"794 ou "teke". Nos séculos XVI e XVII, foram registradas como pertencentes ao "reino Tyo", 795 cujo soberano era detentor de emblemas e mantinha interlocução com o sobrenatural, representado pelo espírito nkíra. ${ }^{796}$ Quiçá fundado no século XIV, ${ }^{797}$ ainda dispomos de poucas informações sobre esse reino e os anzicos. ${ }^{798}$ Sabe-se que no Tyo eram tecidas diversas variedades de panos de ráfia e que, nos séculos XVI e XVII, ocorreram choques militares entre esse reino e o do Kongo. ${ }^{799}$ No início do século XVII, havia o consenso de que alguns escravos “anzicos", exportados pelo Kongo via Luanda, não eram de grande proveito para a travessia transcontinental, devido à alta mortalidade que eles tinham. ${ }^{800}$

\footnotetext{
${ }^{794}$ Verificar propriamente a nota 12, p. 197, para: Fernão de Sousa. História das relações entre a Angola portuguesa e o Ndongo 1617 - setembro de 1625. 6 de setembro de 1625. BAL, cód. 51-IX-20, ff. 326-27. IN: HEINTZE, Beatrix (coord.). Documento 24, FHA, vol. I, 1985, pp. 197-201. Conforme indicações de Heintze, consultar: VANSINA, Jan. Kingdoms of the Savanna. Madison: University of Wisconsin Press, 1966, pp. 102-109.

${ }^{795}$ Aceita-se a grafia "Tio". Também chamado de "reino Nziko".

${ }^{796}$ VANSINA, Jan. Paths in the Rainforests: Toward a History of Political Tradition in Equatorial Africa. Madison-Wisconsin: University of Wisconsin Press, 1990, pp. 152-153. Segundo Heywood e Thornton, o rei do povo teke foi registrado como sendo o "Emcuquaanzico", ou "Nkuku a Nziko". HEYWOOD, Linda M.; THORNTON, John K. Central Africans, Atlantic Creoles, and the Foundation of the Americas, 1585-1660. Cambridge: Cambridge University Press, 2007, pp. 54-55, especificamente a nota 5.

${ }^{797}$ VANSINA, Jan. Paths in the Rainforests [...]. Madison-Wisconsin: University of Wisconsin Press, 1990, pp. 155-156. Idem, How Societies Are Born: Governance in West Central Africa before 1600. Charlottesville: University of Virginia Press, 2004, pp. 188-189.

${ }^{798}$ Os registros etnográficos não são consensuais sobre as origens do dito reino. O que é possível dizer é que reivindicavam surgimento nas distantes terras dos norte. Verificar: VANSINA, Jan. Paths in the Rainforests [...]. Madison-Wisconsin: University of Wisconsin Press, 1990, p. 156.

799 HEYWOOD, Linda M.; THORNTON, John K. Central Africans, Atlantic Creoles [...]. Cambridge: Cambridge University Press, 2007, pp. 54-55. VANSINA, Jan. Paths in the Rainforests [...]. MadisonWisconsin: University of Wisconsin Press, 1990, p. 201. BIRMINGHAM, David. Trade and conflict in Angola: the Mbundu and their neighbours under the influence of the Portuguese 1483-1790. Londres: Clarendon Press/ Oxford University Press, 1966, p. 64.

${ }^{800}$ HEINTZE, Beatrix. Angola nos séculos XVI e XVII: estudos sobre fontes, métodos e história. Luanda: Kilombelombe, 2007, pp. 294-296.
} 


\section{Baculamento (derivado do kimbundu, bakula ou lubaku, ou do kikongo,} vakula) $)^{801}$

Os baculamentos eram uma resposta oficial e institucional de Luanda ao crescimento da cobrança de taxas e tarifas extraordinárias e abusivas, encaradas como semilegais ou ilícitas pela administração ultramarina, pelo menos no tempo de Fernão de Sousa. Tais "ilicitudes" eram representadas pelas práticas de "infuta”, "loanda", "vestir", "prões", “ocamba" e "infuca". Ao passo que foram condenadas e proibidas pela administração ultramarina, ocorreu o incentivo de pagamento oficial de apenas um tributo anual, jurado pelos sobas vassalos e que receberia o nome de "baculamento". Além disso, algumas sugestões a respeito do termo "baculamento" podem ser feitas a nível etimológico e lexical. Derivado do vocábulo bakula, que segundo Jan Vansina consistia no ato tradicional de "prestação de homenagem" entre os mbundu, ${ }^{802}$ é possível associar a cerimônia de avassalamento - mais especificamente um de seus passos, a chamada "homenagem", "encomendação" ou "encomenda",803 - à promessa de pagamento de baculamento, praticado como uma forma de retribuição ao estreitamento de amizade e aos juramentos de fidelidade prometidos pelas duas partes pactuadas após concretizada a cerimônia de avassalamento, mas que na prática seria somente paga pela parte avassalada. $^{804}$

Intimamente ligado ao discurso legalista e legitimador do aparato ultramarino, a validade de imposição de baculamentos, por meio da sujeição à vassalagem, foi justificada oficialmente como uma substituição as "loandas", cuja cobrança por parte dos governadores e oficiais portugueses passou a ser encarada como ilícita. Doravante, os sobas

${ }^{801}$ HEINTZE, Beatrix (coord.). Esclarecimentos sobre vocábulos africanos, $F H A$, vol. I, 1985, p. 114. Idem, Angola nos séculos XVI e XVII [...]. Luanda: Kilombelombe, 2007, p. 415. Para mais considerações, consultar os capítulos 2 e 3 desta dissertação.

${ }^{802}$ VANSINA, Jan. How Societies Are Born [...]. Charlottesville: University of Virginia Press, 2004, pp. 194195.

${ }^{803}$ SANTOS, Catarina Madeira. Escrever o Poder: os Autos de Vassalagem e a Vulgarização da Escrita entre as Elites Africanas Ndembu. IN: HEINTZE, Beatrix; OPPEN, Achim von (ed.). Angola on the Move: Transport Routes, Communications and History. Frankfurt am Main: Verlag Otto Lembeck, 2008, p. 176. SANTOS, Catarina Madeira. Écrire le pouvoir en Angola: Les archives Ndembu (XVIIe-XXe siècles). Annales. Histoire, Sciences Sociales. Paris: Éditions de l'EHESS, n. ${ }^{\circ}$ 64, 2009/4, pp. 775-776. HEINTZE, Beatrix. Angola nos séculos XVI e XVII [...]. Luanda: Kilombelombe, 2007, pp. 402-405.

${ }^{804}$ Lembrando que a lógica dual contribuição-retribuição estava assente na evocação de "mucanos". No caso dos baculamentos, fica claro que a retribuição era apenas ativada para a parte avassalada, ficando o avassalador isento de qualquer oferta ou pagamento aos sujeitados. 
vassalos deveriam apenas pagar um único tributo oficial a Luanda, na forma de escravos. ${ }^{805}$ De acordo com uma perspectiva analítica a respeito dos contatos luso-africanos, é possível afirmar que a apropriação dos baculamentos por parte da administração régia indicou para o estabelecimento de uma cadeia relacional de incorporação e absorção, constituída por quatro pontos encadeados e coligados entre si: avassalamento-undamento-baculamentotributação. $^{806}$

\section{Bambe (em kikongo, $m b a m b i)^{807}$}

Na $F H A$, vocábulo mais empregado por Fernão de Sousa para traduzi-lo é "arraia", no sentido sinonímico à "fronteira", "limite", "linha divisória" ou "região fronteiriça". 808

\section{Banza (em kikongo, mbanza) ${ }^{809}$}

Há duas acepções para esse termo, uma específica e outra lata. Mediante a primeira, "banzas" seriam as residências de sobas, responsáveis pelo governo de chefados, províncias e do próprio "reino do Ndongo". Em sentido mais amplo, "banzas" eram também aglomerados populacionais comparados a cidades, onde ficavam as sedes de governos africanos. Não por menos, algumas vezes eram também traduzidas como "capitais". 810

${ }^{805}$ HEINTZE, Beatrix. Angola nos séculos XVI e XVII [...]. Luanda: Kilombelombe, 2007, pp. 383 e 415. Entre 1670-1671, ocorreu no Conselho Ultramarino uma série de discussões sobre as vantagens e desvantagens ligadas à arrecadação ilícita de baculamentos, culminando na abolição deles. Isso, contudo, não interrompeu a arrecadação ilícita de tributos e a prática de compelir os sobas vassalos a "oferecer" presentes e serviços aos capitães. Verificar: LARA, Silvia Hunold. Palmares \& Cucaú: o aprendizado da dominação. Tese para concurso de Professor Titular, Universidade Estadual de Campinas, 2008, nota 143, p. 167.

${ }^{806}$ Para mais informações sobre isso, consultar o capítulo 2 desta dissertação.

${ }^{807}$ HEINTZE, Beatrix (coord.). Esclarecimentos sobre vocábulos africanos, FHA, vol. I, 1985, p. 114.

${ }^{808}$ HEINTZE, Beatrix (coord.). Esclarecimentos sobre vocábulos africanos, FHA, vol. I, 1985, p. 114. Os exemplos fornecidos por Heintze condizem com os que separamos para ilustrar a definição acima, retirados de: Fernão de Sousa. O extenso relatório do governador aos seus filhos. S.d., 1625-1630. BAL, cód. 51-IX20, ff. 220-74v. IN: HEINTZE, Beatrix (coord.). Documento 30, FHA, vol. I, 1985, pp. 217-363. Ao discorrer sobre as campanhas de guerra levadas a cabo por Bento Banha Cardoso, em 1626, a certo momento Fernão de Sousa escreveu que o quilombo comandado pelo capitão-mor chegou em "Samba Aquizenzele que são os limites do Reino [de Angola] a que chamam bambes" (pp. 255). Sobre os fatos relativos ao ano seguinte, 1627, Fernão de Sousa cogitou que Ginga Ambande estava "no sítio de Samba Aquizenzele bambes do Reino [de Angola]" (p. 294). Perto do final da narrativa sobre as jornadas de guerra contra a líder africana, ao discorrer sobre alguns eventos pertinentes ao ano de 1629, Fernão de Sousa define "bambes" como "arraias" (pp. 377-378).

${ }^{809}$ Para mais informações, consultar o capítulo 1 desta dissertação.

${ }^{810}$ HEINTZE, Beatrix. Angola nos séculos XVI e XVII [...]. Luanda: Kilombelombe, 2007, pp. 205-206. Sentidos análogos existiram no século XVIII. Verificar: SANTOS, Catarina Madeira. Um governo "polido" para Angola: Reconfigurar dispositivos de domínio. (1750-c.1800). Tese de doutorado, Universidade Nova de Lisboa, 2005, p. 617. 
Como bem resume Beatrix Heintze, via de regra "banzas" eram "povoações de certa importância" ou "lugares principais". ${ }^{811}$ No que diz respeito à nomenclatura centro-africana empregada nos registros escritos portugueses, as "banzas" são descritas como centros populacionais mais importantes, mais densamente povoadas do que as chamadas "libatas" (consultar infra). ${ }^{812}$

\section{Canda (em kikongo, kanda) $)^{813}$}

No antigo reino do Kongo, uma kanda era um "grupo de descendência matrilinear". Apesar de as funções de uma canda ainda serem incertas, sabe-se que esse tipo de grupo de filiação era relativamente independente, responsável pelas jurisdições e pelo equilíbrio social a nível supralocal. Segundo Beatrix Heintze e John K. Thornton, esse mesmo termo foi empregado para descrever a realidade mbundu, a princípio a partir de 1576 e ao longo do século XVII. ${ }^{814}$

\section{Ganga (derivado do kimbundu, nganga. Sinônimo de kimbanda) ${ }^{815}$}

“Ganga” era a designação pela qual os mbundu chamavam os padres cristãos, termo análogo utilizado para designar os sacerdotes tradicionais, adivinhos e curandeiros locais. ${ }^{816}$ Segundo Joseph C. Miller, eles eram “profissionais especializados” capazes de atravessar

${ }^{811}$ HEINTZE, Beatrix (coord.). Esclarecimentos sobre vocábulos africanos, FHA, vol. I, 1985, p. 114.

${ }^{812}$ Para mais informações, consultar o capítulo 1 desta dissertação.

${ }^{813}$ HEINTZE, Beatrix (coord.). Esclarecimentos sobre vocábulos africanos, FHA, vol. I, 1985, p. 115. O termo kanda é forma singular, enquanto que a forma plural aceita duas possibilidades, dikanda e makanda.

814 Todas essas informações podem ser verificadas em: HEINTZE, Beatrix (coord.). Esclarecimentos sobre vocábulos africanos, FHA, vol. I, 1985, p. 115. HEYWOOD, Linda M.; THORNTON, John K. Central Africans, Atlantic Creoles [...]. Cambridge: Cambridge University Press, 2007, p. 73 e nota 93.

${ }^{815}$ HEINTZE, Beatrix (coord.). Esclarecimentos sobre vocábulos africanos, FHA, vol. I, 1985, p. 117. Em kimbundu, nganga é o singular, jinganga o plural. Nessa mesma língua, kimbanda é o singular, yimbanda o plural. MILLER, Joseph C. Poder político e parentesco: Os antigos estados Mbundu em Angola. [1976]. Luanda: Arquivo Histórico Nacional, 1995, p. 50.

${ }^{816}$ HEINTZE, Beatrix (coord.). Esclarecimentos sobre vocábulos africanos, FHA, vol. I, 1985 , p. 117. Segundo Linda M. Heywood e John K. Thornton, a mesma associação foi feita entre os bakongo, para quem os padres cristãos eram chamados de nganga a ukisi, expressão que pode ser traduzida como um "especialista religioso com a característica dos ídolos". Verificar: HEYWOOD, Linda M.; THORNTON, John K. Central Africans, Atlantic Creoles [...]. Cambridge: Cambridge University Press, 2007, pp. 63-64, tradução nossa (no original: "religious specialist with the characteristic of idols"). Segundo Catarina Madeira Santos, no século XVIII os “quimbandas” eram médicos e feiticeiros. SANTOS, Catarina Madeira. Um governo "polido” para Angola [...]. Tese de doutorado, Universidade Nova de Lisboa, 2005, p. 620. 
as relações de parentesco entre as linhagens, ${ }^{817}$ configurando relações de respeito e solidariedade corporativas.

\section{Guenze (derivado do kimbundu, ngenzi) ${ }^{818}$}

São esporádicas as referências feitas aos "guenzes" na $F H A$, tampouco dispomos de profundas análises sobre quem eram esses indivíduos. Aqui seguimos as breves considerações feitas por Beatrix Heinte. Ao que parece, "guenze" era um mercador africano de escravos, estrangeiro aos povos que habitavam a costa centro-atlântica. Em contraste aos pombeiros e maculuntos (ver infra), a serviço normalmente de um senhor português e que transitavam entre as rotas que conectavam o porto de Luanda às feiras do interior, "os guenzes parecem ter sido os negociantes africanos das regiões do interior, que levavam os escravos às feiras portuguesas". ${ }^{819}$

\section{Libata}

Aqui ficaremos com a sucinta definição fornecida por Heintze, segundo a qual "libata" era um "aglomerado, aldeola, pequena aldeia dos mbundu". Ao conjunto de muitas libatas, dava-se o nome de "libataria". ${ }^{820}$ No que diz respeito à nomenclatura centroafricana empregada nos registros escritos portugueses, as "libatas" eram menos importantes e povoadas do que as chamadas "banzas" (consultar supra). ${ }^{821}$

\section{Loanda (grafado também como luanda. Não confundir com a sede do governo} da Angola portuguesa, a “cidade de São Paulo de Luanda")

Em um parágrafo do extenso relatório de Fernão de Sousa, "loanda" é definida como sendo um "tributo de reconhecimento de vassalagem, de vassalo para senhor, que os

\footnotetext{
${ }^{817}$ MILLER, Joseph C. Poder político e parentesco [...]. [1976]. Luanda: Arquivo Histórico Nacional, 1995, p. 50 .

818 HEINTZE, Beatrix (coord.). Esclarecimentos sobre vocábulos africanos, FHA, vol. I, 1985, p. 118. Também grafado como ngênji, no singular, jingênji no plural. Para mais informações, consultar o capítulo 3 desta dissertação.

${ }^{819}$ HEINTZE, Beatrix (coord.). Esclarecimentos sobre vocábulos africanos, FHA, vol. I, 1985, p. 118. Idem, Angola nos séculos XVI e XVII [...]. Luanda: Kilombelombe, 2007, pp. 488-489.

${ }^{820}$ HEINTZE, Beatrix (coord.). Esclarecimentos sobre vocábulos africanos, FHA, vol. I, 1985, p. 119.

${ }^{821}$ Para mais informações, consultar o capítulo 1 desta dissertação.

${ }^{822}$ Demais considerações sobre essa e outras taxas e tarifas extraordinárias e abusivas, encaradas como semilegais ou ilícitas pelo funcionalismo régio, podem ser consultadas no capítulo 3 desta dissertação.
} 
sobas pagavam ao rei de Angola". A certa altura dos contatos e aproximações políticas, os governadores, capitães-mores e capitães dos presídios “introduziram em si o exemplo d'Elrei de Angola" e passaram a cobrar as loandas dos sobas vassalos. Na explicação mais bem acabada fornecida pelo governador, ocorreu que, em um período posterior e indeterminado dos contatos, as loandas acabariam substituídas pelos baculamentos, sendo que "somente a Sua Majestade pertence este tributo". 823

Aconteceria então que, juntamente com as "infutas", "vestir", "loandas" e outros tributos, taxas e tarifas tradicionalmente aceitos pelos mbundu acabariam proibidos em algum momento da primeira metade do século XVII. Durante o governo de Fernão de Sousa, essas "ilicitudes" foram combatidas pelo governador, por meio do despacho de portarias e regimentos. ${ }^{824} \mathrm{~A}$ pedidos do Conselho da Fazenda, em 7 de dezembro de 1631 , Fernão de Sousa escreveu uma correspondência afirmando que a cobrança de "loanda, futa, vestir e outros modos" inicialmente havia sido "introduzida pelo gentio à imitação dos reis de Angola", passando a ser incorporada por Luanda graças à "opulência dos sobas era tão grande naquele tempo" e que permitia a cobrança tributária múltipla. $\mathrm{Na}$ atual situação da Angola portuguesa, continuou Fernão de Sousa, o quadro de "pobreza" e "inveja" geravam o endividamento e a inadimplência dos sobas. ${ }^{825}$ A fim de não exauri-los com a alta carga tributária, a administração ultramarina barrou a cobrança desses vários impostos, adotando apenas uma forma de tributação, aceita pelos mbundu e conhecidos como "baculamentos" (verificar baculamento, supra). ${ }^{826}$

\footnotetext{
${ }^{823}$ Fernão de Sousa. O extenso relatório do governador aos seus filhos. S.d., 1625-1630. BAL, cód. 51-IX20, ff. 220-74v. IN: HEINTZE, Beatrix (coord.). Documento 30, FHA, vol. I, 1985, p. 279.

${ }^{824}$ Fernão de Sousa [escrita por Luís Correa Coelho]. Portaria de Fernão de Sousa. 29 de julho de 1624. BAL, cód. 51-IX-21, f. 146. IN: HEINTZE, Beatrix (coord.). Documento 174, FHA, vol. II, 1988, p. 269). Segundo Beatrix Heintze, informações análogas estão contidas em um documento conservado em BAL, cód. 51-IX21, f. 121, publicado por Alfredo Albuquerque de Felner, por engano, com a indicação de f. 149. Verificar: FELNER, Alfredo Albuquerque. AASO. Coimbra, 1933, p. 520. ${ }^{824}$ Fernão de Sousa [escrito por Luís Correa Coelho]. Regimento de Fernão de Sousa a João del Rincon Salazar, Constantino Cadena e Sebastião Dias Tição. BAL, cód. 51-IX-21, ff. 124-24v. IN: HEINTZE, Beatrix (coord.). Documento 172, FHA, vol. II, 1988, pp. 267-268.

${ }^{825} \mathrm{Na}$ ótica de Fernão de Sousa, o tal "período de crise" ficaria cristalizado a partir do final do governo de Luís Mendes de Vasconcelos, ao longo dos insucessos de João Correia de Sousa (1621-1623) e nas conturbadas passagens de Pedro Sousa Coelho (1623) e Dom Frei Simão Mascarenhas (1623-1624) no governo de Angola. Verificar as datas em: Sobre esse período, verificar: HEINTZE, Beatrix (coord.). Apêndice: governadores de Angola, 1575 - 1639, FHA, vol. I, 1985, p. 393.

${ }^{826}$ Fernão de Sousa. Fernão de Sousa sobre os tributos de vassalagem em Angola. 7 de dezembro de 1631. BAL, cód. 51-IX-20, ff. 367, 370-71v. IN: HEINTZE, Beatrix (coord.). Documento 39, FHA, vol. I, 1985, pp. 381-382.
} 
Apesar de vaga e parcialmente verdadeira, ${ }^{827}$ a explicação contida na carta de dezembro de 1631 confirma algumas informações que, aglutinadas à breve definição fornecida por Fernão de Sousa no extenso relatório, possibilita o ensaio de uma redefinição sucinta para o vocábulo "loanda", ainda que passível de revisão. Por excelência, "loanda" era o tributo ou imposto "que uma parte dos chefes mbundu tinham de pagar ao ngola, o rei do Ndongo", como explica Beatrix Heintze. Foi substituído oficialmente pelos baculamentos e, a partir de então, as "loandas" seriam uma espécie de "taxas extraordinárias semi-legais e ilegais", ou “oportunidades de chantagem" vislumbradas por qualquer português mal-intencionado, que figurariam dentre as várias cobranças adicionais e contribuições especiais que compunham uma lista extensa de injustiças cometidas contra os sobas. $^{828}$

\section{Infuca (grafado também como emfuca ou enfuca. Derivado do kikongo, mfuka,} ou do kimbundu, fuka) ${ }^{829}$

Em um dos trechos de seu extenso relatório, Fernão de Sousa explicou que "enfuca" era o ato de "vender de fiado" para depois, por meio de "palavras", convencer os sobas endividados de que ainda deviam pagamento aos fiadores. Acontecia também de os capitães de presídios e indivíduos portugueses fornecerem "fazendas por rogos, ou por força" a alguns sobas, para depois forçá-los ao pagamento injustificado e que "dessem infucas". Se os sobas não cedessem às ameaças, os capitães prendiam as mulheres, filhos e vassalos, "a que chamam filhos de murinda e que são forros". Caso nada fosse feito, "amarrados sem ordem de justiça”, essas pessoas eram enviadas a Luanda e vendidas como

\footnotetext{
${ }^{827}$ Beatrix Heintze salienta que a inadimplência e a dívida dos sobas derivavam em grande medida das pressões exercidas por Luís Mendes de Vasconcelos, muito mais do que uma pretensa "antiga riqueza" deles. HEINTZE, Beatrix. Angola nos séculos XVI e XVII [...]. Luanda: Kilombelombe, 2007, pp. 454-455, principalmente a nota 38 .

${ }^{828}$ HEINTZE, Beatrix. Angola nos séculos XVI e XVII [...]. Luanda: Kilombelombe, 2007, 415-416 e 454455. Fato é que o conjunto de taxas e tarifas extraordinárias e abusivas, encaradas como semilegais ou ilícitas, era bastante comum na região, despertando gradativamente a atenção dos funcionários honestos e leais à monarquia portuguesa. Isso porque muita gente lucrava "com essas contribuições especiais; em primeiro lugar o governador, depois os capitães-mores dos presídios, os coletores de tributos e em Luanda o capitão de guarda, o secretário, o tandala da guerra preta, o feitor, o escrivão da Fazenda Real e todos os outros funcionários da cidade", como ressalta Beatrix Heintze (pp. 454-455).

${ }^{829}$ HEINTZE, Beatrix (coord.). Esclarecimentos sobre vocábulos africanos, FHA, vol. I, 1985, p. 118. Idem, Angola nos séculos XVI e XVII [...]. Luanda: Kilombelombe, 2007, p. 416. Para mais informações sobre essa e outras taxas e tarifas extraordinárias e abusivas, consultar o capítulo 3 desta dissertação.
} 
peças. Por tal motivo, os escravos apenas poderiam ser negociados "nas feiras, pumbos e pombeiros". 830

Durante a época de Fernão de Sousa, foi determinado por meio de despacho de bandos que os métodos abusivos de angariar escravos, tais como as "infucas" e "ocambas", deveriam ser proibidos, uma vez que causavam "todos os mucanos com brancos" e davam margem ao contrabando, de modo que "comprando e vendendo na feira não haverá engano". ${ }^{831}$ Enquadrada pelo governador como parte de um conjunto ilícito de taxas ou tarifas amorfas, as infucas deveriam ser combatidas, o que não quer dizer que foram extintas.

\section{Infuta (derivado do kimbundu, futa, ou do kikongo, mfuta) ${ }^{832}$}

Conforme explicou Fernão de Sousa no extenso relatório, "futa" corresponde a um "presente" que um "inferior" oferece a um "superior", ou como um "caseiro ao senhorio". Como há de se notar, estava intimamente ligada com as aproximações diplomáticas e acerto de vassalagem. Tratado em um primeiro momento dos contatos como uma oferta de aliança e uma amostra de amizade recíproca, válida tanto para ótica mbundu quanto para a portuguesa, na qual as duas partes contatadas deveriam trocas presentes ou futas, em um segundo momento essas ofertas já eram encaradas como uma obrigação por parte dos vassalos centro-africanos, de modo que "soba nenhum ir à presença de capitão de presídio sem levar futa" e“se descuida [o soba] pede-lhe a sua infuta". A mudança do costume fez

${ }^{830}$ Fernão de Sousa. O extenso relatório do governador aos seus filhos. S.d., 1625-1630. BAL, cód. 51-IX20, ff. 220-74v. IN: HEINTZE, Beatrix (coord.). Documento 30, FHA, vol. I, 1985, p. 280. Definição análoga fornecida por Beatrix Heinte, segundo a qual a "infuca" era um termo incorporado e proveniente do kikongo, mfuka, significando "dívida", "crédito", "empréstimo". Pode também ter derivado do termo em kimbundu fuka, que quer dizer "objeto revirado, retorcido". A infuca consistia na venda de "mercadorias fraudulentas a crédito", de tal forma que os negociantes portugueses, capitães e seus parceiros ofertavam, com "palavras aliciantes", produtos "com condições aparentemente vantajosas" aos sobas vassalos. Todavia, passado um tempo, exigiam "inesperadamente pagamento" que, caso não fosse dado, seria usado como justificativa para a escravização de mulheres e crianças, exportadas para a América via Atlântico. Em suma, os praticantes de infuta lucravam com a aquisição barata de escravos, enquanto que os sobas vassalos acabavam lesados. Verificar: HEINTZE, Beatrix (coord.). Esclarecimentos sobre vocábulos africanos, FHA, vol. I, 1985, p. 118. Parte essencial das informações são retiradas de: CADORNEGA, António de Oliveira de. HGGA, vol. III, 1942, p. 319. Verificar ainda: HEINTZE, Beatrix. Angola nos séculos XVI e XVII [...]. Luanda: Kilombelombe, 2007, pp. 416 e 454-455.

${ }^{831}$ Fernão de Sousa. O extenso relatório do governador aos seus filhos. S.d., 1625-1630. BAL, cód. 51-IX20, ff. 220-74v. IN: HEINTZE, Beatrix (coord.). Documento 30, FHA, vol. I, 1985, pp. 282-283.

${ }^{832}$ HEINTZE, Beatrix (coord.). Esclarecimentos sobre vocábulos africanos, FHA, vol. I, 1985, p. 119. Para mais informações sobre essa e outras taxas e tarifas, encaradas como semilegais ou ilícitas pelo funcionalismo régio, consultar o capítulo 3 desta dissertação. 
com que os capitães de presídios passassem a convocar, ou como se dizia na época, “chamar", os sobas vassalos às visitas constantes aos presídios, apenas para exigir presentes, ou como os capitães preferiam chamar, "prões e precalços" (verificar prões, infra). Do mesmo embuste os mal-intencionados lançavam mão quando faziam "diligência por mandado dos governadores pela terra adentro", exigindo dos sobas infutas "pela força de violência". 833

Nos documentos que compõe a $F H A$, as infutas são comumente associadas a um conjunto de taxas e tarifas extraordinárias e abusivas, encaradas como semilegais ou ilícitas por Fernão de Sousa. Mais especificamente, e como um subconjunto integrante das práticas locais de fidelidade política, as infutas normalmente são associadas à cobrança de loandas e vestir, ligadas aos juramentos e pactos de vassalagem (sobretudo verificar loanda, supra).

\section{Macota (em kimbundu, makota) ${ }^{834}$}

Os "macotas" eram os mais velhos de uma linhagem, ou anciões, encarregados de aconselhar os sobas ou o ngola, como guardiões das posições titulares mbundu. ${ }^{835}$ Eram eles encarregados da eleição desses dignitários, sendo também citados como autoridades africanas que participavam das cerimônias de avassalamento. ${ }^{836} \mathrm{~A}$ importância dos macotas

\footnotetext{
${ }^{833}$ Fernão de Sousa. O extenso relatório do governador aos seus filhos. S.d., 1625-1630. BAL, cód. 51-IX20, ff. 220-74v. IN: HEINTZE, Beatrix (coord.). Documento 30, FHA, vol. I, 1985, p. 279. Adiciona Fernão de Sousa que a mesma cobrança indevida de presentes eram feitas pelos "brancos quando os mandam seus capitães a diligência, ou vão a negócio de que os sobas recebem com grande opressão". Informações análogas são fornecidas em: HEINTZE, Beatrix. Angola nos séculos XVI e XVII [...]. Luanda: Kilombelombe, 2007, pp. 416 e $454-455$.

${ }^{834}$ Makota é o plural, kota ou dikota é o singular. MILLER, Joseph C. Poder político e parentesco [...]. [1976]. Luanda: Arquivo Histórico Nacional, 1995, pp. 17-18 e 46-47. Para mais considerações, consultar os capítulos 1 e 2 desta dissertação.

${ }^{835}$ Conforme definem brevemente Beatrix Heintze, Jan Vansina e Joseph C. Miller. Verificar: VANSINA, Jan. How Societies Are Born [...]. Charlottesville: University of Virginia Press, 2004, pp. 194-195. HEINTZE, Beatrix (coord.). Esclarecimentos sobre vocábulos africanos, FHA, vol. I, 1985, p. 120. MILLER, Joseph C. Poder politico e parentesco [...]. [1976]. Luanda: Arquivo Histórico Nacional, 1995, pp. 17-18. LARA, Silvia Hunold. Palmares \& Cucaú [...]. Tese para concurso de Professor Titular, Universidade Estadual de Campinas, 2008, pp. 163-164. O mesmo sentido lato também valia para o século XVIII, atentando para o fato de que, nessa época, aparentemente os povos ndembu e os "jagas" também sustentavam posições "macota". Verificar: SANTOS, Catarina Madeira. Um governo "polido" para Angola [...]. Tese de doutorado, Universidade Nova de Lisboa, 2005, p. 616.

${ }^{836}$ Verificar, por exemplo, o que afirma Bento Banha Cardoso sobre a eleição de "rei natural" no Ndongo: Fernão de Sousa. O extenso relatório do governador aos seus filhos. S.d., 1625-1630. BAL, cód. 51-IX-20, ff. 220-74v. IN: HEINTZE, Beatrix (coord.). Documento 30, FHA, vol. I, 1985, p. 254. Sobre o avassalamento: SANTOS, Catarina Madeira. Escrever o Poder [...]. IN: HEINTZE, Beatrix; OPPEN, Achim von (ed.). Angola on the Move [...]. Frankfurt am Main: Verlag Otto Lembeck, 2008, p. 176. SANTOS,
} 
no processo de escolha política era preponderante, como explicou Fernão de Sousa em uma de suas correspondências internas, endereçadas ao capitão João Carreira Fidalgo. Nela diz o administrador que a nomeação e eleição da "pessoa que há de governar" como soba estava a cargo dos macotas, "porque [eles] sabem melhor a quem direito pertence esta eleição". No mais, embora o papel dos capitães nesses processos de eleição fosse grande, não era "servido [para] que os capitães dos presídios sejam senhores dos sobas e que somente seus governadores em nome de Sua Majestade o devem ser”, deixando em contrapartida claro que a intromissão de oficiais era grande no momento da escolha de sucessor político. ${ }^{837}$

\section{Maculunto (derivado do kikongo, nkulunto, ou do kimbundu, mukulunda) ${ }^{838}$}

Há vestígios desencontrados sobre o que seriam os "maculuntos". Em sentido lato, eles eram "capatazes". No contexto português da Angola seiscentista, eram frequentemente "escravos em posição de confiança, que vigiavam outros escravos e que tinham o direito de castigar", conforme explica Beatrix Heintze. ${ }^{839}$ Durante o governo de Fernão Sousa, houve tentativas de facilitação do acesso de "maculuntos com fazendas" nas feiras de escravos, indicando que eles também atuavam como agentes comerciais. ${ }^{840}$

Sendo escravo e atuando na supervisão e nos negócios de escravos, a posição de maculunto possivelmente tinha uma "margem de manobra" considerável na Angola portuguesa, como lembra Heintze. ${ }^{841}$ Mesmo que fosse difícil transpô-la, a linha de separação entre a escravidão e a liberdade não era tão rija como o senso-comum atualmente prega.

Catarina Madeira. Écrire le pouvoir en Angola [...]. Annales. Histoire, Sciences Sociales. Paris: Éditions de l'EHESS, n. ${ }^{\circ}$ 64, 2009/4, pp. 775-776.

${ }^{837}$ Fernão de Sousa. Portaria de Fernão de Sousa. 12 de julho de 1624. BAL, cód. 51-IX-21, f. 123. IN: HEINTZE, Beatrix (coord.). Documento 170. FHA, vol. II, 1988, p. 266.

${ }^{838}$ HEINTZE, Beatrix (coord.). Esclarecimentos sobre vocábulos africanos, $F H A$, vol. I, 1985, p. 120. Idem, Angola nos séculos XVI e XVII [...]. Luanda: Kilombelombe, 2007, p. 499. Atentando para o fato de que mukulunda em kimbundu é o singular, sendo o plural mikulunda. Heintze ainda acrescenta que os registros escritos portugueses podiam marcar uma distinção de gênero, através do emprego do termo "maculunta". Para mais informações, consultar o capítulo 3 desta dissertação.

${ }^{839}$ HEINTZE, Beatrix (coord.). Esclarecimentos sobre vocábulos africanos, FHA, vol. I, 1985, p. 120. Idem, Angola nos séculos XVI e XVII [...]. Luanda: Kilombelombe, 2007, p. 499.

${ }^{840}$ Fernão de Sousa. Ordem de Fernão de Sousa a Paio de Araújo de Azevedo. 14 de setembro de 1629. BAL, cód. 51-IX-21, ff. 282v-83. IN: HEINTZE, Beatrix (coord.). Documento 205, FHA, vol. II, 1988, pp. 308309.

${ }^{841}$ HEINTZE, Beatrix. Angola nos séculos XVI e XVII [...]. Luanda: Kilombelombe, 2007, p. 503. 


\section{Macunze (derivado do kikongo, nkunzi) $^{842}$}

"Macuzes" eram africanos responsáveis por carregar missivas e mensagens. De modo sucinto, eram "mensageiros", "emissários", “embaixadores” ou "delegados” que, segundo Fernão de Sousa, levavam consigo recados decorados e depois os declamavam na presença de autoridades competentes. ${ }^{843}$ Tais recados eram chamados de "milongas". 844 Também era possível que carregassem cartas ou lembretes escritos, mas o mais comum era que atuassem oralmente. Juntos, macunzes e milongas conformavam um método de transmissão e retransmissão de informações, cujo teor poderia ser "sigiloso", "oficial”, "diplomático" ou "público". O veículo de comunicação macunze-milonga era amplamente difundido na África Centro-Ocidental, sendo vital para a circulação de informações em canais de comunicação portugueses e africanos. ${ }^{845}$

\section{Malafo (derivado do kikongo, malavu, ou do kimbundu, diluvu) ${ }^{846}$}

No século XVII, os "malafos" provavelmente diziam respeito às taxas pagas pelos negociantes de escravos "ao rei do Ndongo, pela travessia do seu território e pela visita à feira [do Ndongo]", além de designarem um tipo de recompensa "que um português tinha de pagar à pessoa que lhe restituía um escravo fugido". ${ }^{847}$

\footnotetext{
${ }^{842}$ HEINTZE, Beatrix (coord.). Esclarecimentos sobre vocábulos africanos, FHA, vol. I, 1985, p. 120.

${ }^{843}$ Ibidem, p. 120. Idem, Angola nos séculos XVI e XVII [...]. Luanda: Kilombelombe, 2007, pp. 224-225. Para "embaixador", verificar: Fernão de Sousa. O extenso relatório do governador aos seus filhos. S.d., 16251630. BAL, cód. 51-IX-20, ff. 220-74v. IN: HEINTZE, Beatrix (coord.). Documento 30, FHA, vol. I, 1985, p. 279.

${ }^{844}$ Verificar, por exemplo: Fernão de Sousa. O extenso relatório do governador aos seus filhos. S.d., 16251630. BAL, cód. 51-IX-20, ff. 220-74v. IN: HEINTZE, Beatrix (coord.). Documento 30, FHA, vol. I, 1985, p. 300 .

${ }^{845}$ Sobre a participação dos macunzes na circulação de informações e os possíveis percalços que a dificuldade de tradução e entendimento impunham à comunicação, verificar: GONÇALVES, Rosana. África Indômita: Missionários capuchinhos no Reino do Congo (século XVII). Dissertação de mestrado, Universidade de São Paulo (USP), 2008, p. 19, 21-22.

${ }^{846}$ HEINTZE, Beatrix (coord.). Esclarecimentos sobre vocábulos africanos, FHA, vol. I, 1985, p. 121. Em outro texto, Heintze explica que em kimbundu diluvu é o singular, sendo o plural maluvu, malufu. Em kikongo, dilavu é o singular, sendo malavu a forma plural. Verificar: HEINTZE, Beatrix. Angola nos séculos XVI e XVII [...]. Luanda: Kilombelombe, 2007, nota 33, p. 489. Para mais considerações, consultar os capítulos 3 e 4 desta dissertação.

${ }^{847}$ HEINTZE, Beatrix (coord.). Esclarecimentos sobre vocábulos africanos, FHA, vol. I, 1985, p. 121. Pelo fato de "malafo" derivar do vocábulo em kikongo "malavu", significando nessa língua africana "vinho de palma", é possível aventar a possibilidade de que, em tempos anteriores, essas taxas eram pagas em vinho. Por causa de uma relação lógica, o nome do produto coincidia com o da taxa. No entanto, é sabido que no tempo de Fernão de Sousa os malafos eram pagos em diversas mercadorias. Sobre os malafos como taxas de passagem ou de pedágio no Ndongo, Heintze acrescenta que quem os pagasse obtinha "livre-trânsito pelo Ndongo e livre acesso às feiras". Idem, Angola nos séculos XVI e XVII [...]. Luanda: Kilombelombe, 2007,
} 


\section{Mani lumbo (possivelmente derivado do termo em kimbundu, lumbu) (48 $^{848}$}

Ainda são inexatas as acepções possíveis aceitas para "mani lumbo". Beatrix Heintze explica que se tratava de um "título político no Kongo e entre os mbundus", tão importante quanto o título de "tendala" e que acompanhava a "guerra preta" nas guerras travadas pelos portugueses (verificar tendala, infra). ${ }^{849}$ Ainda segundo a pesquisadora, o cronista seiscentista António de Oliveira de Cadornega escreveu que "moenelumbo", ou "mani lumbo", era aquele "por quem corria todo o concerto de sua casa e Corte [do "rei de Angola"] tendo cuidado de guardar o mais precioso e cousas de mais estima do que possuía seu Rei e Senhor e tudo o que era conserto de casas e muros corriam por sua conta". 850 Quiçá influenciado por essa definição, e justapondo-a a outras interpretações e traduções, John K. Thornton escreveu que o cargo de "mani lumbo" condizia com o de um "majordomo", ou só "mordomo", que era "um dos mais poderosos e atuantes membros do conselho real" e que atuava no "corpo de servidores domésticos que influenciavam a política e administração" no Kongo. ${ }^{851}$

De acordo com algumas informações de Fernão de Sousa, o cargo de "mani lumbo" podia prestar o serviço de "língua", palavra utilizada na $F H A$ para designar "intérprete" ou “tradutor". Por exemplo, durante a eleição do rei do Ndongo, em 1626, o mani lumbo Agostinho de Vasconcelos serviu de "língua" dos portugueses presentes na cerimônia de eleição. $^{852}$

pp. 488-489. Para um exemplo de como os malafos poderiam servir de recompensa em caso de devolução de escravos, verificar: Fernão de Sousa. O extenso relatório do governador aos seus filhos. S.d., 1625-1630. BAL, cód. 51-IX-20, ff. 220-74v. IN: HEINTZE, Beatrix (coord.). Documento 30, FHA, vol. I, 1985, p. 282. ${ }^{848}$ HEINTZE, Beatrix (coord.). Esclarecimentos sobre vocábulos africanos, $F H A$, vol. I, 1985, p. 122.

${ }^{849}$ HEINTZE, Beatrix (coord.). Esclarecimentos sobre vocábulos africanos, FHA, vol. I, 1985, p. 122. Segundo Heintze, lumbu em kimbundu significa "sebe, cercado", enquanto que mani lumbu em kikongo significa "mordomo".

${ }^{850}$ CADORNEGA, António de Oliveira de. $H G G A$. vol. I, 1940, p. 29.

${ }^{851}$ A definição de Thornton foi retirada de: SOUZA, Marina de Mello e. Reis negros no Brasil escravista: história da festa de coroação de Rei Congo. [2002]. Belo Horizonte: Editora UFMG, 2006, nota 76, p. 340. Sobre "mani lumbo", ver também a p. 94 dessa obra.

${ }^{852}$ Verificar: Fernão de Sousa. O extenso relatório do governador aos seus filhos. S.d., 1625-1630. BAL, cód. 51-IX-20, ff. 220-74v. IN: HEINTZE, Beatrix (coord.). Documento 30, FHA, vol. I, 1985, pp. 256-257. 
Mani quitanda (possivelmente derivado do termo em kikongo, kitanda, ou do kimbundu, itanda) ${ }^{853}$

Acompanhando a interpretação proposta por Beatrix Heintze, em consonância com o emprego prático registrado na $F H A$, "mani quitanda" era uma espécie de "vigilante de mercados colocados pelos portugueses", cujo cargo era exercido por um "africano ao serviço dos portugueses". Ainda cabe lembrar que a composição do termo considerou a junção de dois vocábulos. "Quitanda" faz referência a kitanda que, em kimbundu, significa "mercado" ou "feira" e, em kikongo, significa "mercado diário". "Mani" era um termo usado para designar um "título político no Kongo e no litoral sul da África Central” que, porventura, também poderia ser empregado como sentido de "funcionário do Ndongo". 854 Sublinhando a importância dos "manis quitandas" como funcionários menores nomeados e que representavam o olhar intruso de Luanda nas feiras abertas por sobas vassalos, é possível fazer como Heintze e sugerir que o cargo de "mani quitanda" seria análogo à função de "quimbar", pelo menos no sentido prático adotado pelo funcionalismo régio. ${ }^{855}$

\section{Mobire (também grafado como mubire) ${ }^{856}$}

"Mobire" era o nome pelo qual os observadores e cronistas de época identificavam o povo de "Loango" ou "Luango", também chamado de "maloango"857 e atualmente identificado pelo etnônimo "vili". ${ }^{858}$ Junto com o Kongo e o Tyo, o Loango foi registrado como uma das importantes soberanias regionais no norte da África Centro-Ocidental, mencionando em sua tradição fundadora algum tipo de conexão com "bungu”, reconhecido

\footnotetext{
${ }^{853}$ HEINTZE, Beatrix (coord.). Esclarecimentos sobre vocábulos africanos, FHA, vol. I, 1985, p. 122. Para mais informações sobre isso, consultar o capítulo 3 desta dissertação.

${ }^{854}$ Ibidem, pp. 121-122.

${ }^{855}$ Ibidem, p. 122. Ficamos também com a sucinta definição de Beatrix Heintze, fidedigna ao que há registrado na FHA: "Os mercados de escravos oficiais, chamados quitanda (kimbundu: kitanda, pl. itanda), estavam sob fiscalização de um africano ao serviço dos portugueses (quimbares, kimbundu: kimbari, pl. imbari), nomeado pelo governador, o mani kitanda, do qual dependia um número desconhecido de outros funcionários africanos (por exemplo meirinhos)". Verificar: Idem, Angola nos séculos XVI e XVII [...]. Luanda: Kilombelombe, 2007, pp. 493-494. Lembrando que esses mercados eram reconhecidos como as "feiras" registradas nos documentos escritos. Sobre elas e o papel dos mani quitandas, conferir essa mesma obra de Heintze, pp. 488-489.

${ }^{856}$ Para mais informações sobre isso, consultar o capítulo 3 desta dissertação.

857 SANTOS, Catarina Madeira. Um governo “polido” para Angola [...]. Tese de doutorado, Universidade Nova de Lisboa, 2005, p. 617.

${ }^{858}$ VANSINA, Jan. Paths in the Rainforests [...]. Madison-Wisconsin: University of Wisconsin Press, 1990, p. 202.
} 
como a dinastia fundadora do Kongo e localizado originariamente no baixo Congo. ${ }^{859} \mathrm{Tal}$ reivindicação mítica é, de certo modo, corroborada pelo fato dos atuais vili falarem uma língua não correlacionada às mais populares na região, como o kikongo e o kimbundu, mas bastante parecida com a falada pelo povo bembe, cuja história tradicional também remete ao antigo "reino de Bungu". 860

Os mobires eram reconhecidos como um povo africano dado ao comércio produtor de excelentes panos de ráfia. Atuavam no comércio de marfim e madeira tintorial, nas rotas que alcançavam a parte da atual República Gabonesa, além de comerciar pano de ráfia e escravos nas rotas comerciais que partiam do lago Malebo. De acordo com Jan Vansina, Loango começou a ter papel importante no comércio atlântico a partir de 1593, quando a costa começou a ser visitada por comerciantes holandeses, que lá buscavam marfim e madeira. Seria apenas por volta de 1630 que Loango encetaria uma participação constante no tráfico atlântico, mas de maneira ainda insípida, com poucas "peças" exportadas. ${ }^{861}$ Descrições sobre o papel comercial dos mobires são repetidas no século XVIII, com o importante acréscimo e de que, em 1759, o surgimento de uma pequena comunidade mobire acompanhou a fundação do presídio de Encôge, no Dembo. ${ }^{862}$

${ }^{859}$ VANSINA, Jan. Paths in the Rainforests [...]. Madison-Wisconsin: University of Wisconsin Press, 1990, p. 156. Ainda segundo Vansina, os alicerces de do reino de Loango já eram visíveis a partir de 1600, verificar as pp. $221-222$.

${ }_{860}$ BIRMINGHAM, David. Trade and conflict in Angola [...]. Londres: Clarendon Press/ Oxford University Press, 1966, pp. 9-10. É precipitada qualquer afirmação mais contundente sobre as relações entre os reinos africanos, como propõe John K. Thornton, ao afirmar que os "descendentes" do Kongo haviam fundado Loango e o Ndongo. Verificar: THORNTON, John K. Warfare in Atlantic Africa 1500-1800. [1999]. Londres e Nova Iorque: Routledge, 2003, p. 99.

${ }^{861}$ VANSINA, Jan. Paths in the Rainforests [...]. Madison-Wisconsin: University of Wisconsin Press, 1990, pp. 201-202. THORNTON, John K. Africa and Africans in the Making of the Atlantic World, 1400-1800. [1992]. Cambridge: Cambridge University Press, 1998, p. 51. Há registros na FHA indicando a participação dos mobires no comércio, à revelia da vontade régia de Luanda, motivo que fazia com que os funcionários do monarca português os encarassem como contrabandistas. Verificar: Fernão de Sousa. Bando de Fernão de Sousa. 30 de abril de 1626. BAL, cód. 51-IX-21, f. 150. IN: HEINTZE, Beatrix (coord.). Documento 186, $F H A$, vol. II, 1988, p. 278. Para um período aproximado entre a segunda metade do século XVII e início do XVIII, Luiz Felipe de Alencastro ponderou que "o tráfico sertanejo dependia dos regatões nativos - os "pombeiros" e os "mubiris" (da etnia vili) -, apalavrados com os sobas que circulavam nas feiras de aldeias fazendo escambos por conta dos negociantes luandenses". Verificar: ALENCASTRO, Luiz Felipe de. O trato dos viventes: A formação do Brasil no Atlântico Sul. São Paulo: Companhia das Letras, 2000 p. 284.

${ }^{862}$ SANTOS, Catarina Madeira. Um governo "polido" para Angola [...]. Tese de doutorado, Universidade Nova de Lisboa, 2005, p. 617. Para informações sobre os mobires como importantes agentes comerciais e de intermediação, até o século XIX, verificar: DIAS, Jill. Mudanças nos padrões de poder no «hinterland» de Luanda: o impacto da colonização sobre os Mbundu (c. 1845-1920). Penélope: revista de história e ciências sociais. Lisboa: Cooperativa Penélope, Fazer e Desfazer a História, n. ${ }^{\circ}$ 14, 1994, p. 45. 


\section{Moleque (derivado dos termos análogos em kikongo e kimbundu, muleke) ${ }^{863}$}

Na atual Republica Federativa do Brasil, a palavra "moleque" é empregada como um sinônimo coloquial para "menino" ou "criança", equivalendo em Portugal ao uso corrente da palavra "miúdo". Nesse sentido, em Raphael Bluteau lê-se: "veio-nos esta palavra do Brasil, \& val [sic] tanto, como pequeno escravo negro". ${ }^{864}$ Atualmente, essa mesma acepção é válida para um termo equivalente em kimbundu e kikongo, muleke. Em contrapartida, no contexto português da África Centro-Ocidental seiscentista, os tais "moleques" aportuguesados dos vernáculos centro-africanos diziam respeito a um "escravo jovem, moço, de cerca de 13 a 14 anos". ${ }^{865}$ Ensaiamos que o contraste nas acepções pode ser explico da seguinte forma. Aos olhos dos negociantes e comerciantes, além dos capitães de tumbeiros, é possível cogitar que esses adolescentes embarcados fossem ainda "crianças", em razão da grande massa de pessoas amontoadas nas naus nos portos, mais velhas e viris, classificadas como "peça da índia" ou somente "peça". Na $F H A$, "peça" é o termo sinonímico para "cativo" e que acabou inserido na lógica comercial e de produção escravista. Por sua vez, "peça da índia" era um escravo de bom porte, plena saúde, era do sexo masculino e estava em boa idade de trabalho, atingindo altos valores no mercado atlântico. Seja como for, via de regra "moleques" e "peças" são termos submetidos aos “ares da escravidão atlântica", mediante os quais pessoas eram reificadas em mercadorias, passando a deter valores de mercado baseados no potencial de trabalho nas lavouras americanas.

\section{Mubica (também grafado como mobica. Derivado do termo em kimbundu, mubika) ${ }^{866}$}

O termo "mubica" não é citado na $F H A$, mas foi evocado em alguns textos de época. Apesar das controversas e do desconhecimento que ainda se tem a respeito dele, aqui ficaremos com uma definição mais corrente adotada pela historiografia, preconizada

\footnotetext{
${ }^{863}$ HEINTZE, Beatrix (coord.). Esclarecimentos sobre vocábulos africanos, $F H A$, vol. I, 1985, p. 123. Idem, Angola nos séculos XVI e XVII [...]. Luanda: Kilombelombe, 2007, nota 192, pp. 205-206. Atentando para o fato de que muleke é o singular, baleke o plural.

${ }^{864}$ BLUTEAU, Raphael. Voc. Port. [1712]. Hildesheim: Georg Olms Verlag, vol. V, 2002, p. 541.

${ }^{865}$ HEINTZE, Beatrix (coord.). Esclarecimentos sobre vocábulos africanos, $F H A$, vol. I, 1985, p. 123. Heintze ainda acrescenta que, caso houvesse distinção de gênero, "moleque designava o escravo e moleca a escrava".

${ }^{866}$ HEINTZE, Beatrix. Angola nos séculos XVI e XVII [...]. Luanda: Kilombelombe, 2007, p. 484. Mubika é o singular, abika o plural. Para mais informações sobre isso, consultar o capítulo 1 desta dissertação.
} 
por Beatrix Heintze e Jan Vansina. "Mubicas" eram escravos que podiam ser vendidos de maneira legítima, perante as normas legais e hierárquicas no Ndongo. ${ }^{867}$ Além disso, é possível sugerir que ao longo do século XVII ocorreu algum tipo de anulação dessa camada social, ou operação de rearranjo lexical, engendrando uma renovada percepção sobre a realidade social observada naquela parte da África. No que dizia repeito ao registro escrito português, é possível aludir que houve uma fusão entre os termos "mubicas" e os "quizicos" (ver quizico em infra), na tendência daquilo que Jan Vansina constatou como sendo "uma grande simplificação que não levava em conta outros status ou papéis". ${ }^{868}$ Também é possível sugerir que os mubicas podem ter desaparecido do Ndongo, seja porque foram todos exportados via Atlântico, seja porque o ngola e os sobas decidiram abolir tal estatuto do reino africano.

\section{Mucano (também grafado como mocano e mukano. Derivado dos termos em} kikongo, mukano e $n k a n u)^{869}$

Há vários sentidos e significados aceitos para o termo "mucano". $\mathrm{Na} F H A$, os mucanos são interpretados através do crivo de formas legais fundadas no "costume da terra" e na "justiça gentílica", o que na prática resultava na abertura e na execução de processos ou ações jurídicas baseados na oralidade, ou em um julgamento que poderia ser procedido nos terreiros de sobas ou nos presídios portugueses, por parte de autoridades africanas e portuguesas. Dentre elas, as mais referidas são os macotas e capitães de presídios, mas também sabemos que esses julgamentos poderiam contar com a participação do ngola e do governador português. Mucanos também poderiam ser trazidos e resolvidos

${ }^{867}$ VANSINA, Jan. How Societies Are Born [...]. Charlottesville: University of Virginia Press, 2004, p. 196. HEINTZE, Beatrix. Angola nos séculos XVI e XVII [...]. Luanda: Kilombelombe, 2007, pp. 205-206 e 484. ${ }^{868}$ VANSINA, Jan. How Societies Are Born [...]. Charlottesville: University of Virginia Press, 2004, p. 196.

${ }^{869}$ HEINTZE, Beatrix (coord.). Esclarecimentos sobre vocábulos africanos, FHA, vol. I, 1985, p. 123. Fato é que o entendimento português sobre os mucanos adveio dos primeiros contatos abertos com o Kongo, o que explica o empréstimo lexical e os posteriores reusos e aplicações, promovidos pela administração régia, abrangendo os demais povos da África Centro-Ocidental. Verificar: HEYWOOD, Linda M.; THORNTON, John K. Central Africans, Atlantic Creoles [...]. Cambridge: Cambridge University Press, 2007, p. 59. A despeito da raiz etimológica kikongo, é sabido que no século XVIII o termo "mucanu", ou propriamente "mukanu", fazia parte do léxico kimbundu. Verificar: SANTOS, Catarina Madeira. Um governo "polido" para Angola [...]. Tese de doutorado, Universidade Nova de Lisboa, 2005, p. 617. Para mais informações sobre isso, consultar o capítulo 3 desta dissertação. 
em Luanda e nas banzas dos reis do Ndongo, mas não sabemos com que frequência isso ocorria. $^{870}$

A importância dos mucanos decorria de dois principais desdobramentos. O primeiro advinha da multiplicidade de sentidos interconectados e sobrepostos ao conceito de "lei", como sustenta Catarina Madeira Santos. Um desses sentidos dizia respeito a uma breve definição fornecida por António de Oliveira de Cadornega, para quem um "mucano" condizia a um “delito, crime, erro e processo [jurídico] que se ligava também a um tipo de julgamento verbal, ou simplesmente a um desacordo qualquer entre os Mbundu". ${ }^{871} \mathrm{O}$ conceito de "mucano" também pode ser entendido como um "juízo de liberdade", na forma de um "litígio resolvido verbalmente" acompanhado de diversas "categorias de crime" ou "especificações sobre o tipo de delito", como morte violenta, feitiçaria, acumulação de dívidas, roubo, injuria e quitação de dívida, sendo que nesse último caso o "mucano é simultaneamente o crime e a multa que se paga". ${ }^{872}$ A multiplicidade de sentidos que gravitava em torno do conceito de "lei" acionava o conceito de "reparação" pelas partes que moviam e procediam com os mucanos, sendo que o "objetivo não era o de punir e reprimir[,] mas de restabelecer o equilíbrio e a paz" em torno de um xadrez político harmônico, de modo que ocorressem a "formalização e subordinação de práticas sociais locais principalmente ligadas à organização e à legitimação do poder político”, em prol da "harmonia entre autoridades coloniais e africanas". 873

\footnotetext{
${ }^{870}$ Para um exemplo de como os mucanos eram legislados na banza de Angola Aire, verificar: Fernão de Sousa. O extenso relatório do governador aos seus filhos. S.d., 1625-1630. BAL, cód. 51-IX-20, ff. 220-74v. IN: HEINTZE, Beatrix (coord.). Documento 30,FHA, vol. I, 1985, p. 281. Devido à profundidade e à complexidade da discussão acerca dos mucanos, aqui não teremos espaço o suficiente para fazer todas as considerações necessárias sobre esse tipo de justiça. De todo modo, um documento fundamental para entendêlo é o seguinte: Fernão de Sousa. Fernão de Sousa sobre os tributos de vassalagem em Angola. 7 de dezembro de 1631. BAL, cód. 51-IX-20, ff. 367, 370-71v. IN: HEINTZE, Beatrix (coord.). Documento 39, FHA, vol. I, 1985, pp. 379-382.

${ }^{871}$ CADORNEGA, António de Oliveira de. HGGA, vol. II, 1972, p. 61.

${ }^{872}$ SANTOS, Catarina Madeira. Entre deux droits: les Lumières en Angola (1750-v. 1800). Annales. Histoire, Sciences Sociales. Paris: Éditions de l'EHESS, n. ${ }^{\circ} 60,2005 / 4$, pp. 822-823.

${ }^{873}$ Catarina Madeira Santos também usa expressões como "território do meio" e "campo de embate político". Verificar: SANTOS, Catarina Madeira. Entre deux droits [...]. Annales. Histoire, Sciences Sociales. Paris: Éditions de l'EHESS, n. ${ }^{\circ}$ 60, 2005/4, 2005, pp. 834-835, tradução nossa (completo no original: "D'une manière générale, dans le champ du droit pénal indigène, on n'inflige pas des sanctions mais des compensations, ces dernières étant négociées entre les parties engagées. C'est donc le principe de la réparation qui est appliqué, moyennant le paiement d'amendes (pour "payer la mort qu'il a causé », en cas de crime par exemple), très souvent au moyen d'esclaves. L'objectif n'est pas de punir et réprimer mais de rétablir l'équilibre et la paix". Idem, Écrire le pouvoir en Angola [...]. Annales. Histoire, Sciences Sociales. Paris: Éditions de l'EHESS, n. ${ }^{\circ}$ 64, 2009/4, pp. 777-778
} 
O segundo desdobramento relativo às práticas de mucanos estava ligado ao "teor pragmático que altera e determina a aplicação prática dos direitos evocados”, de tal forma que os "modelos de organização" da justiça eram muitas vezes "distorcidos", ou "instrumentalizados", em razão das situações e contextos locais que desafiavam, ou limitavam, a imposição do domínio ultramarino português. Replicando as palavras de Santos, a "ordem pragmática torna mais evidente o dispositivo legal que estabelece e determina a ação do colonizador". ${ }^{874}$ A isso também é possível acrescentar o elevado teor de "justiça aplicada" existente na evocação dos mucanos, que passaram a fazer parte dos mecanismos de físcalização e vigilância promovidos nos presídios. Decorria disso o manuseio da justiça costumeira para fins privados, apartados de uma possível jurisprudência unívoca e pública dirigida apenas por Luanda.

\section{Murinda (ou morinda. Proveniente do kimbundu, murinda) $)^{875}$}

Nos documentos que compõem a $F H A$, a noção de "murinda" está intimamente associada à contraposição em relação a outro termo, "quizico" (ver infra). Sucintamente, o termo "murinda" remete à noção de "liberdade", fazendo referência a um conjunto de indivíduos considerados "livres", enquanto que a segunda estava entrelaçada à noção de “escravidão" e condizia a aglomerados populacionais considerados como sendo constituído de "escravos". ${ }^{876}$ Inseparáveis e imbricadas uma na outra, as noções de "murinda" e "quizico" compunham o raciocínio institucional português representado pela cadeia relacional "forro-livre-murinda". Para além de uma separação estatutária e ideológica, a

\footnotetext{
${ }^{874}$ SANTOS, Catarina Madeira. Entre deux droits [...]. Annales. Histoire, Sciences Sociales. Paris: Éditions de l'EHESS, n. ${ }^{\circ}$ 60, 2005/4, 2005, p. 847, tradução nossa (no original: "Finalement, le droit apparaît relatif, parce qu'il y a toujours un ordre pragmatique qui altère et détermine l'application pratique des droits invoqués. [...] l'ordre pragmatique rend plus évident encore l'artifice juridique qui fonde et détermine l'action du colonisateur."

${ }^{875}$ Murinda é o singular, arinda o singular.Verificar: HEINTZE, Beatrix. Angola nos séculos XVI e XVII [...]. Luanda: Kilombelombe, 2007, pp. 205-206. Para mais considerações, consultar os capítulos 1 e 3 desta dissertação.

${ }^{876}$ Seguindo o que afirma Beatrix Heintze, para quem o termo "murinda" era a "população livre do Ndongo", definida assim "em contraste com os escravos quizicos". Verificar: HEINTZE, Beatrix (coord.). Esclarecimentos sobre vocábulos africanos, FHA, vol. I, 1985, pp. 122-123. Idem, Angola nos séculos XVI e $X V I I$ [...]. Luanda: Kilombelombe, 2007, p. 485. Sentido parecido emprega Jan Vansina, para quem as murindas são "pessoas de aldeias livres", em contraposição aos quizicos, definidos como "escravos comunais inalienáveis". Verificar: VANSINA, Jan. How Societies Are Born [...]. Charlottesville: University of Virginia Press, 2004, p. 196. O mesmo esquema é repetido em: THORNTON, John K. Africa and Africans [...]. [1992]. Cambridge: Cambridge University Press, 1998, p. 94. LARA, Silvia Hunold. Palmares \& Cucaú [...]. Tese para concurso de Professor Titular, Universidade Estadual de Campinas, 2008, pp. 163-164.
} 
noção de "murinda" também implicava em uma disposição diferenciada dos "murindas" no espaço geográfico. Eles estavam situados em linhagens matrilineares, regidas por um soba que encabeçava um chefado e que, por sua vez, reconhecia o ngola como autoridade soberana. $^{877}$

\section{Ocamba (também grafado como occamba. Derivado do kikongo, $k a m b a)^{878}$}

Em um trecho do extenso relatório de Fernão de Sousa, há uma definição sucinta sobre o que eram as "ocambas", dividida em dois tipos de ocorrências. Primeiramente, uma "ocamba" podia ser uma prática mediante a qual os capitães de presídios, ou qualquer outro indivíduo português, dirigiam-se a um soba com peruleiras de vinho, panos ou qualquer outra fazenda, com "intenção de lhe pagar os sobas com fingimento de amizade e boa correspondência". Quando os sobas não aceitavam a oferta, os capitães "os obrigavam a tomá-las por boas palavras” e, assim, conseguiam peças deles. Em segundo lugar, Fernão de Sousa também explica que uma ocamba ocorria quando, por malícia e esperteza dos capitães portugueses, os sobas eram ludibriados em transações comerciais e promessas de amizades mentirosas, arrecadando “deles em peças das Índias por três, ou quatro preços mais do que valia". 879

Devido aos descontentamentos que as falsidades despertavam entre os sobas lesados, Fernão de Sousa determinou por meio de despacho de bandos que os métodos abusivos de angariar escravos, tais como as "infucas" e "ocambas", fossem proibidos, uma vez que causavam "todos os mucanos com brancos" e davam margem ao contrabando, de modo que "comprando e vendendo na feira [de Ndongo] não haverá engano". 880 Haverá nesse sentido um esforço de fixar o "preço certo" das peças nas feiras oficias, não sendo

877 HEINTZE, Beatrix. Angola nos séculos XVI e XVII [...]. Luanda: Kilombelombe, 2007, p. 278. HEYWOOD, Linda M.; THORNTON, John K. Central Africans, Atlantic Creoles [...]. Cambridge: Cambridge University Press, 2007, pp. 72-73.

${ }^{878}$ HEINTZE, Beatrix (coord.). Esclarecimentos sobre vocábulos africanos, FHA, vol. I, 1985, p. 124. Para mais informações sobre essa e outras taxas e tarifas extraordinárias e abusivas, encaradas como semilegais ou ilícitas pelo funcionalismo régio, consultar o capítulo 3 desta dissertação.

${ }^{879}$ Fernão de Sousa. O extenso relatório do governador aos seus filhos. S.d., 1625-1630. BAL, cód. 51-IX20, ff. 220-74v. IN: HEINTZE, Beatrix (coord.). Documento 30, FHA, vol. I, 1985, p. 280. Trata-se das mesmas explicações fornecidas por Heintze, segundo as quais "ocamba" podia ser um "ato de indução à aquisição de bens" ou uma "proposta de compra injusta". Verificar: HEINTZE, Beatrix (coord.). Esclarecimentos sobre vocábulos africanos, FHA, vol. I, 1985, p. 124.

${ }^{880}$ Fernão de Sousa. O extenso relatório do governador aos seus filhos. S.d., 1625-1630. BAL, cód. 51-IX20, ff. 220-74v. IN: HEINTZE, Beatrix (coord.). Documento 30, FHA, vol. I, 1985, pp. 282-283. 
“os sobas obrigados a pagá-las" caso o valor estipulado fosse abusivo. ${ }^{881}$ Enquadrada pelo governador como parte de um conjunto de taxas ou tarifas de natureza ilícita, de maneira um tanto quanto amorfa, as ocambas deveriam ser combatidas, ${ }^{882}$ o que não quer dizer que foram extintas.

\section{Pemba (também grafado como mpemba) ${ }^{883}$}

A "pemba” era um pó de argila branco e de grande importância simbólica, espiritual e ritualística entre os povos mbundu, bakongo e luba, principalmente nos atos solenes identificados como pertences à "investidura" africana. Assim, segundo Wyatt MacGaffey, os povos autodenominados bakongo, a leste da atual República do Congo, e os povos luba, que habitam o miolo do continente, ambos seguindo convenções endógenas e em respeito às suas respectivas tradições ancestrais, acreditam que os seus "reis fundadores" vieram de algum lugar remoto, comumente identificado como uma "terra dos espíritos (Bupemba, Mpemba e Upemba)". Tal topônimo místico seria vislumbrado pelos "adivinhos" no "reflexo das águas", resguardadas em lugares como cemitérios, cavernas, bosques ou lagos. Nesses recintos, onde o sagrado e o mítico se encontram, eram feitos os "exames" e a “investiduras" dos chefes. Lá eram também os lugares onde os "grupos de pessoas de poderes especiais eram marcados com uma argila de caulinita branca, mpemba". Durante esses rituais de iniciação, continua a descrever Wyatt MacGaffy, as "histórias de migração" e "mitos" tradicionais eram recontados para quem estivesse presente. ${ }^{884}$

Para além do emprego em cerimônias de ordem política e simbólica, a pemba mantinha associação simbólica com os ciclos humanos da vida e da morte. No caso específico dos bakongo, Wyatt MacGaffey explica que a "terra dos mortos (nsi a bafwa)" -

\footnotetext{
${ }^{881}$ Fernão de Sousa. O extenso relatório do governador aos seus filhos. S.d., 1625-1630. BAL, cód. 51-IX20, ff. 220-74v. IN: HEINTZE, Beatrix (coord.). Documento 30, FHA, vol. I, 1985, p. 280.

${ }^{882}$ HEINTZE, Beatrix. Angola nos séculos XVI e XVII [...]. Luanda: Kilombelombe, 2007, p. 416.

${ }^{883}$ Para mais considerações, consultar os capítulos 1 e 2 desta dissertação.

${ }^{884}$ MACGAFFEY, Wyatt. Crossing the River: Myth and Movement in Central Africa. IN: HEINTZE, Beatrix; OPPEN, Achim von (ed.). Angola on the Move [...]. Frankfurt am Main: Verlag Otto Lembeck, 2008, p. 235. Ao se referir a "pemba" ou "mpemba", Wyatt MacGaffey utiliza o termo em inglês "white kaolin clay", traduzido aqui por "argila de caulinita branca". A pemba também pode ser identificada como uma "argila de porcelana branca", simplesmente. A fim de ressaltar as semelhanças entre os rituais e tradições dos africanos que habitam a leste e oeste da África Central, MacGaffey afirma que "os rituais de chefatura no Kongo são lidos como uma versão reduzida, ou provincial, daqueles encontrados entre os Luba". (no orginal, na mesma página supracitada: "In much more detail than it is possible to recount here, Kongo chiefship rituals read like a reduced or provincial version of those found among Luba").
} 
“terra dos mortos" e "terra dos espíritos" são então transformadas na mesma coisa - está presente em terrenos como "florestas, cemitérios, no outro lado do rio, no outro lado do Atlântico e debaixo da água". A cor branca está assim relacionada à morte, à inocência, à pureza e ao esclarecimento. Outra cor importante para os bakongo, a vermelha, está relacionada ao "movimento entre os mundos" dos vivos e mortos, ao "nascer do sol, poente ou ao sangue". Conclui MacGaffey que, por causa disso, os "defuntos e corpos daqueles que retornaram da iniciação eram pintados de vermelho". ${ }^{885}$ Cores similares interavam a cosmovisão dos mbundu, mas com funções distintas. Entre eles, os chefes dos grupos de linhagem - lemba dya ngundu, em kimbundu - distribuíam um pó vermelho, de nome takula, entre os membros homens, ao passo que as mulheres recebiam um pó branco, a tal pemba. Na sociedade mbundu, a distribuição deste pó branco sinalizava a concessão de fertilidade às mulheres e, por consequência, a reiteração da vida desse povo. ${ }^{886}$

Em última instância, entre os bakongo a pemba era um "ingrediente universal" na confecção dos minkisi (sing. nkisi), objetos sagrados e típicos da identidade bakonga. ${ }^{887}$ Sobre essas insígnias, Wyatt MacGaffey afirma que elas "são habitações e corporificações de personalidades provindas da terra dos mortos, através dos quais os poderes de tais espíritos estariam disponíveis aos vivos”, meio pelo qual "[os minkisi] seriam espíritos dos mortos metonicamente capturados em uma armadilha metafórica". ${ }^{888}$ Influenciado pelas ideias de Luc de Heusch a respeito dos luba, a ideia sucinta de MacGaffey é a de que uma “corrente metonímica" vincula os minkisi à fundação mítica da sociedade, enquanto que o "componente metafórico" os conecta às relações sociais e às expectativas do presente.

885 MACGAFFEY, Wyatt. Kongo Political Culture: The Conceptual Challenge of the Particular. Bloomington-Indiana: Indiana University Press, 2000, p. 27.

${ }^{886}$ MILLER, Joseph C. Poder político e parentesco [...]. [1976]. Luanda: Arquivo Histórico Nacional, 1995, p. 50, pp. 47-48. A mesma noção para ter sido válida para o contexto setecentista, verificar: SANTOS, Catarina Madeira. Um governo “polido” para Angola [...]. Tese de doutorado, Universidade Nova de Lisboa, 2005, p. nota 602, p. 239.

${ }^{887}$ MACGAFFEY, Wyatt. Complexity, Astonishment and Power: The Visual Vocabulary of Kongo Minkisi. Journal of Southern African Studies. Taylor \& Francis Ltd, vol. 14, n. o 2, janeiro de 1988, p. 191. Idem, Kongo Political Culture [...]. Bloomington-Indiana: Indiana University Press, 2000, pp. 27 e 82.

${ }^{888}$ Idem, Kongo Political Culture [...]. Bloomington-Indiana: Indiana University Press, 2000, p. 79, tradução nossa (no original: "The Kongo term nkisi relates etymologically to other Central African words often translated as 'spirit'. Such a translation captures the important fact that minkisi are local habitations and embodiments of personalities from the land of the dead, through which the powers of such spirits are made available to the living"). Ver ainda a p. 84, onde ocorre a citação do famoso comentário de Luc de Heusch sobre os bwanga dos luba, segundo o qual eles eram "spirits of the dead metonymically caught in an metaphorical trap". Ver ainda: Idem. Complexity, Astonishment and Power [...]. Journal of Southern African Studies. Taylor \& Francis Ltd, vol. 14, n. ${ }^{\circ}$, janeiro de 1988, p. 190. 
Presume-se assim que tais concepções de mundo, encapsuladas no uso ritualístico dos minkisi, poderiam ser alargadas para todos os povos que habitam o território compreendido entre a República dos Camarões e a República de Angola. ${ }^{889}$ Nessa vasta área, o valor simbólico e o uso de objetos e materiais com essa coloração é comum, embora as identidades autodeclaradas pelas diferentes comunidades locais e os usos ritualísticos que elas fazem desses mesmos objetos sejam diferentes.

Sabe-se que a pemba viria a ser incorporada às cerimônias de avassalamento executadas pelos funcionários e oficiais régios portugueses, ${ }^{890}$ todavia ainda é incerto se tal prática foi copiada dos mbundu ou se foi reinventada pelas autoridades régias, quiçá influenciadas pelas convenções e tradições dos bakongo ou de outro povo africano.

\section{Pombeiro (também grafado como pumbeiro. Derivado do topônimo mpumbu) ${ }^{891}$}

Durante o tempo de Fernão de Sousa, os "pombeiros" eram mercadores enviados às feiras do interior em nome de um "patrão português", normalmente residente na costa africana. Os pombeiros traziam consigo mercadorias cedidas a credito pelo patrão, na expectativa de negociá-las por escravos e outros produtos africanos. Uma vez processadas as trocas nas feiras, eles retornavam aos seus respectivos patrões, que embarcavam os escravos nos tumbeiros. Ao que parece, na maioria das vezes os pombeiros eram "escravos de confiança" de comerciantes portugueses estabelecidos em Luanda e redondezas, sendo possível cogitar que uma parcela pequena desses agentes comerciais fosse mestiça ou mesma de "forros". Aglutinada ao caso dos maculuntos (ver supra), a condição de escravo

\footnotetext{
${ }^{889}$ MACGAFFEY, Wyatt. Kongo Political Culture [...]. Bloomington-Indiana: Indiana University Press, 2000 , p. 1. Para Vansina, os povos que habitam essa região compartilham de uma mesma unidade sociocultural. Verificar: VANSINA, Jan. Paths in the Rainforests [...]. Madison-Wisconsin: University of Wisconsin Press, 1990, pp. 5-6.

${ }^{890}$ HEINTZE, Beatrix. Angola nos séculos XVI e XVII [...]. Luanda: Kilombelombe, 2007, pp. 404-405. SANTOS, Catarina Madeira. Escrever o Poder [...]. IN: HEINTZE, Beatrix; OPPEN, Achim von (ed.). Angola on the Move [...]. Frankfurt am Main: Verlag Otto Lembeck, 2008, p. 176. SANTOS, Catarina Madeira. Écrire le pouvoir en Angola [...]. Annales. Histoire, Sciences Sociales. Paris: Éditions de l'EHESS, n. ${ }^{\circ} 64,2009 / 4$, pp. $775-776$.

${ }^{891}$ Segundo Beatrix Heintze, mpumbu era o termo especificamente utilizado para designar a "grande praça da feira de Malebo", um importante centro comercial da época. A partir da apropriação lexical portuguesa desse termo, mpumbu, ou a forma aportuguesada "pumbo", foi utilizada para designar os "mercados no Kongo de certa importância" no século XVII. Verificar: HEINTZE, Beatrix (coord.). Esclarecimentos sobre vocábulos africanos, FHA, vol. I, 1985, p. 124. Sobre a primeira acepção, verificar: BIRMINGHAM, David. Trade and conflict in Angola [...]. Londres: Clarendon Press/ Oxford University Press, 1966, nota 1, p. 17. No século XVIII, o termo "pumbo" era empregado para se referir "todas as terras donde vem negros". Verificar: SANTOS, Catarina Madeira. Um governo "polido" para Angola [...]. Tese de doutorado, Universidade Nova de Lisboa, 2005, p. 618. Para mais informações, consultar o capítulo 3 desta dissertação.
} 
na Angola portuguesa aceitava matizes, fornecendo uma "margem de manobra considerável" para alguns tipos de escravos. ${ }^{892}$

\section{Prões (também identificado como precalços) $)^{893}$}

Às vezes confundidas com as "infutas", ou explicadas mentirosamente como uma troca de presentes e "agrados", a prática de "prões" consistia em atrair "tendalas, mani lumbos, escravos forros e cativos" em torno de uma armação contra algum soba. Uma vez montado a escaramuça, os capitães dos presídios convocavam as vítimas a fornecer qualquer tipo de tarefa de maneira abusiva e repetitiva, como prestar auxílio de guerra ou “fazer baluartes e obras nos presídios em tempos de suas sementeiras, ou de nojos, ou de outras necessidades que não podem ir". Se os sobas recusassem a comparecer à presença do capitão de presídio ou a fazer o ordenado, seriam acusados de "levantamento", o que para os capitães se transformava em um álibi para extorquir peças dos sobas, com a desculpa de se "redimirem" da "vexação". Podia também acontecer de os sobas comparecerem aos presídios, mas não receberem "audiência" dos capitães, com a desculpa de terem prestado um serviço malfeito. Os sobas acabavam retidos no "sol no terreiro", sendo obrigados a fornecer peças para que fossem liberadas "as suas pessoas e se livram dessas vexações". 894

${ }^{892}$ HEINTZE, Beatrix (coord.). Esclarecimentos sobre vocábulos africanos, $F H A$, vol. I, 1985, p. 124. Idem, Angola nos séculos XVI e XVII [...]. Luanda: Kilombelombe, 2007, pp. 493-503. David Birmingham acrescenta que, no início da participação portuguesa no comércio local, os pombeiros não eram africanos. Devido à alta mortalidade que tinham, eles acabariam sendo substituídos por escravos de confiança e mestiços. Verificar: BIRMINGHAM, David. Trade and conflict in Angola [...]. Londres: Clarendon Press/ Oxford University Press, 1966, pp. 78-78. Jan Vansina caracteriza os "pombeiros" como "mascates", livrando-os do estatuto de escravo. Verificar: VANSINA, Jan. Paths in the Rainforests [...]. MadisonWisconsin: University of Wisconsin Press, 1990, pp. 200-201. Thornton chega a dizer que eles eram "agentes" comerciais africanos, atuantes por exemplo no Kongo. Verificar: THORNTON, John K. A Cultural History of the Atlantic World, 1250-1820. Cambridge: Cambridge University Press, 2012, p. 253. Na feição de mercadores mestiços, os pombeiros também despertaram analogias em relação aos chamados "lançados" e "tangomaos". Verificar: RODNEY, Walter. A History of the Upper Guinea Coast, 1545 to 1800. [1970]. Nova Iorque: Monthly Review Press, 1989, p. 81. ZERON, Carlos Alberto de Moura Ribeiro. Pombeiros e tangomaus, intermediários do tráfico de escravos na África. IN: LOUREIRO, Rui Manuel; GRUZINSKI, Serge (coord.). Passar as Fronteiras: Actas do II Colóquio Internacional sobre Mediadores Culturais, Séculos XV a XVIII. Braga: Centro de estudos Gil Eanes, 1999.

${ }^{893}$ Para mais informações sobre essa e outras taxas e tarifas abusivas, encaradas como semilegais pelo funcionalismo régio, consultar o capítulo 3 desta dissertação.

${ }^{894}$ Fernão de Sousa. O extenso relatório do governador aos seus filhos. S.d., 1625-1630. BAL, cód. 51-IX20, ff. 220-74v. IN: HEINTZE, Beatrix (coord.). Documento 30, FHA, vol. I, 1985, p. 280. 


\section{Quiambole (ou ngolambole. Derivado do kimbundu, ngola a mbole) (95 $^{8}$}

No geral, "quiambole" era um termo empregado pelo funcionalismo régio seiscentista para designar algum "chefe militar e comandante das tropas dos mbundu", sendo relevante ressaltar que o termo aceitava uma polissemia de interpretações. ${ }^{896}$ Como um dos quadros militares integrante do exército comandado pelos oficiais portugueses, os quiamboles exerciam uma espécie de comando intermediário da "guerra preta", figurando abaixo dos "tendalas" e acima dos "quimbares" (ver infra). Tal ordenamento militar da gente de guerra possivelmente mimetizava a organização política do Ndongo, onde os quiamboles eram uma espécie de "segundo oficial" detentor de funções administrativas e encarregado da arregimentação e mobilização dos exércitos mbundu. De uma forma geral, os quiamboles eram convocados entre os chamados "quizicos" (ver infra). ${ }^{897}$

\section{Quilamba (derivado do kimbundu, kilamba) ${ }^{898}$}

Termo bastante utilizado nos documentos que compõem a $F H A$, mas de definição controversa. Atualmente, a acepção mais adotada é a empregada por Beatrix Heintze e Joseph C. Miller. "Quilamba" então seria um "oficial africano na guerra preta que gozava de especial confiança dos portugueses”, adicionando Miller que um indivíduo como esse batalhava ao lado do exército português "em troca das suas terras". Decorre desse último elemento um fator particularmente intrigante. Em troca do serviço militar prestado a Luanda, eram doadas aos quilamba, e às demais autoridades que porventura auxiliassem militarmente o exército liderado por Luanda, "terras dentro do território português, por concessão do governador e não por direito hereditário", rompendo com a lógica de usufruto e posse das terras como tradicionalmente ocorria entre os mbundu, baseada no controle dos

\footnotetext{
${ }^{895}$ HEINTZE, Beatrix (coord.). Esclarecimentos sobre vocábulos africanos, FHA, vol. I, 1985, p. 125. Para mais considerações, consultar os capítulos 1 e 4 desta dissertação.

${ }^{896}$ HEINTZE, Beatrix (coord.). Esclarecimentos sobre vocábulos africanos, FHA, vol. I, 1985, p. 125. Idem, Angola nos séculos XVI e XVII [...]. Luanda: Kilombelombe, 2007, pp. 222-224.

${ }^{897}$ HEYWOOD, Linda M.; THORNTON, John K. Central Africans, Atlantic Creoles [...]. Cambridge: Cambridge University Press, 2007, pp. 75-76, 77-78.

${ }^{898}$ No singular, kilamba. No plural, ilamba. Verificar: HEINTZE, Beatrix. Angola nos séculos XVI e XVII [...]. Luanda: Kilombelombe, 2007, pp. 451-452. Para mais considerações, consultar os capítulos 3 e 4 desta dissertação.
} 
recursos naturais por parte de um grupo de filiação, encabeçado por um soba que reivindicava pertencimento ancestral ao solo. ${ }^{899}$

Apesar de não serem consensuais, Jan Vansina fornece algumas ponderações valiosas acerca desse termo. De acordo com o pesquisador, "quilambas" eram "representantes especiais" de algumas localidades mbundu que orbitavam ao redor do Ndongo, encarregados de tarefas como a implementação local da vontade do ngola, a supervisão do pagamento de tributos e a atualização das novidades que chegavam à corte mbundu. Inclusive, nas referências escritas e mais antigas que fazem menção aos quilambas, por volta do início da década de 1580, havia a menção de que "nas terras dos homens nobres eles [as autoridades que vinham de fora] chamam Quelamba". Ainda conforme Vansina, o cronista e militar António de Oliveira de Cadornega escreveu que tais cargos de origem africana estavam "diretamente subordinados aos portugueses" e considerado um "estrangeiro na localidade em que era fixado". Outro vestígio valioso é o linguístico. "Quilamba” provém de kilamba que, por sua vez, mantém associação com as palavras "kalamba" e "mulambo", a primeira significando "um tipo de chefe", a segunda um "tributo". 900 Tais informações são de especial importância porque, nos documentos inseridos na $F H A$, há constantes menções aos quilambas como representantes dos sobas vassalos, encarregados de trazer os baculamentos ao fisco régio. ${ }^{901}$

Além de servirem como oficiais militares e auxiliarem na cobrança de tributos, os quilambas ainda desempenhavam uma terceira função em benefício da administração ultramarina, a da “espionagem”, motivo pelo qual “eram odiados pelas populações locais". 902

\footnotetext{
${ }^{899}$ HEINTZE, 1985, p. 126. MILLER, Joseph C. Poder político e parentesco [...]. [1976]. Luanda: Arquivo Histórico Nacional, 1995, p. 215 e nota 120.

${ }^{900}$ VANSINA, Jan. How Societies Are Born [...]. Charlottesville: University of Virginia Press, 2004, pp. 195196. Sobre as informações utilizadas, verificar: CADORNEGA, António de Oliveira de. HGGA, vol. III, 1942, pp. 236-239. BRÁSIO, António (ed.). MMA. 1952-1988, série 1, vol. XV, p. 365.

${ }^{901}$ Por exemplo: Fernão de Sousa. Ordem de Fernão de Sousa a Paio de Araújo de Azevedo. 24 de agosto de 1629. BAL, cód. 51-IX-21, ff. 282-82v. IN: HEINTZE, Beatrix (coord.). Documento 204, FHA, vol. II, 1988 , p. 306. Heintze explica que os quilambas responsáveis pelo auxílio na cobrança de tributos eram nomeados pelos capitães dos presídios. Verificar: HEINTZE, Beatrix. Angola nos séculos XVI e XVII [...]. Luanda: Kilombelombe, 2007, pp. 451-452.

${ }^{902}$ HEINTZE, Beatrix. Angola nos séculos XVI e XVII [...]. Luanda: Kilombelombe, 2007, pp. 451-452. Heintze também escreve: "Devido à sua lealdade para com os portugueses que o encarregavam (com o apoio de alguns soldados negros) por exemplo da cobrança de tributos, dívidas e outras extorsões nos chefados sempre sob forma de escravos - e devido aos serviços que efectuavam os portugueses, os ilamba eram temidos e odiados pela população mbundu local." Verificar a mesma obra da pesquisadora, p. 490. O
} 


\section{Quilombo (ou kilombo. Proveniente do kimbundu, lumbo, quiçá também do} umbundu, lombo) $)^{903}$

Atualmente, há uma vasta polissemia que abrange o termo "quilombo". Enumeramos a seguir os possíveis sentidos que esse termo poderia suscitar na documentação seiscentista, advogando para o fato de que existiam linhas tênues de separação para esse termo entre as diversas acepções válidas para época. Normalmente, "quilombos" se referem a: $i$ ) acampamentos de guerra pertencentes aos jagas; ii) estabelecimento de escravos fugidos, tanto na América quanto na África; iii) acampamento provisório construído pelas caravanas comerciais no século XIX em Angola. ${ }^{904}$ Somado a isso, Joseph C. Miller acrescenta que os funcionários régios foram incapazes de apreender as "implicações sociais e políticas para o sistema de parentesco dos mbundu", mediante o qual o vocábulo quilombo, ou kilombo, dizia respeito a uma instituição transversal originária da "sociedade iniciática masculina dos Ovimbundu". ${ }^{905}$ Trazido à costa atlântica pelos grupos migratórios lunda que atravessavam o continente, em meados do século XVII os mbundu depararam com um quilombo na forma de um agregado interinstitucional (iv), fruto do contato entre os migrantes e os povos ovimbundu, cokwe e lwena. Esse agregado era uma "mistura de títulos perpétuos Lunda, de posições mavunga orientadas entre os Ovimbundu, e dum culto guerreiro desenvolvido algures em terras do kulembe". 906

Além disso, nos documentos inseridos na $F H A$, um "quilombo" poderia significar: v) "Acampamento de guerra" ou "arraial" do exército português em trânsito (exemplo: “quilombo de Paio de Araújo"); vi) "exército" ou "tropas", no sentido mais lato (exemplo: “quilombo que atravessou o Lucala”). ${ }^{907}$ Essas duas acepções foram também depreendidas

importante papel militar que os quilambas detinham, além da proximidade que eles mantinham em relação aos capitães de presídios, é reiterado nos registros setecentistas. Verificar: SANTOS, Catarina Madeira. Um governo "polido" para Angola [...]. Tese de doutorado, Universidade Nova de Lisboa, 2005, pp. 618-619.

${ }_{903}$ HEINTZE, Beatrix (coord.). Esclarecimentos sobre vocábulos africanos, $F H A$, vol. I, 1985, p. 126. Para mais informações, consultar o capítulo 4 desta dissertação.

${ }_{904}$ MILLER, Joseph C. Poder político e parentesco [...]. [1976]. Luanda: Arquivo Histórico Nacional, 1995, nota 37 pp. 159-160.

${ }^{905}$ Ibidem, nota 37 pp. 149 e 159-160.

${ }^{906}$ Ibidem, pp. 159-160.

${ }^{907}$ Verificar: HEINTZE, Beatrix. Angola nos séculos XVI e XVII [...]. Luanda: Kilombelombe, 2007, nota 99, p. 304. Para uma lista dos textos mais relevantes publicados sobre os "jagas" nos últimos quarenta anos, conferir: HORTA, José da Silva. A "Guiné do Cabo Verde": produção textual e representações (1578-1648). Tese de doutorado, Universidade de Lisboa, 2010, nota 69, p. 355. GOMES, Flávio; FERREIRA, Roquinaldo. 
por Beatrix Heintze, para quem o termo aceitava ainda um último sentido (vii) nos séculos XVI e XVII, denotando uma aldeia erigida por náufragos de Angola em São Tomé. ${ }^{908}$

\section{Quimbar (também grafado como kimbar) ${ }^{909}$}

Nos documentos da $F H A$, os "quimbares" são descritos como sendo escravos enviados às feiras de escravos, em nome de um negociador fixado no litoral, ou como sendo soldados que participavam das campanhas militares e integravam o grosso da "guerra preta". Todavia, ainda são desencontrados os empregos e funções que exerciam. Reafirmando o sentido prático impresso na documentação, Beatrix Heintze definiu que "quimbares" eram "africanos ao serviço dos portugueses", 910 por exemplo nos presídios e nas feiras de escravos, mas que também poderiam ser "africanos que eram obrigados, por um tratamento de vassalagem do seu soba, a prestar serviços militares aos portugueses" e que respondiam às ordens dos capitães de presídios. Do ponto de vista de John K. Thornton, eles eram as forças militares profissionais e permanentes, servidoras de Portugal e cuja origem provavelmente remetia ao Ndongo. ${ }^{911}$

\section{Quizico (derivado do kimbundu, kizico) ${ }^{912}$}

Nos documentos que compõem a $F H A$, a noção de "quizico" contrapõe a de outro termo, "murinda" (ver supra). A partir das assunções dos observadores portugueses, é possível afirmar que "quizicos" eram "aqueles mdundus que tinham uma posição semelhante à dos escravos" e cujo estatuto social derivava do nascimento, mais especificamente do não-pertencimento às linhagens mbundu locais, passível de modificação

A miragem da miscigenação. Novos estudos. São Paulo: CEBRAP, n. ${ }^{\circ} 80$, março de 2008, nota 24, p. 151, além das obras citadas e comentadas nos capítulos 2 e 4 desta dissertação, a respeito principalmente da polêmica jaga-imbangala, migrações lunda e dissociação dos títulos de kasanje e kaza. Para os mais curiosos, ver as indicações feitas em: SANTOS, Catarina Madeira. Um governo "polido" para Angola [...]. Tese de doutorado, Universidade Nova de Lisboa, 2005, nota 275, p. 109.

${ }^{908}$ HEINTZE, Beatrix (coord.). Esclarecimentos sobre vocábulos africanos, FHA, vol. I, 1985, p. 126.

${ }^{909}$ Para mais considerações, consultar os capítulos 3 e 4 desta dissertação.

${ }^{910}$ Mediante a esse sentido, aproximavam-se da função de "mani quitanda" (ver supra). Verificar: HEINTZE, Beatrix (coord.). Esclarecimentos sobre vocábulos africanos, $F H A$, vol. I, 1985, pp. 121-122.

${ }_{911}$ HEINTZE, Beatrix (coord.). Esclarecimentos sobre vocábulos africanos, FHA, vol. I, 1985, p. 126. THORNTON, John K. Warfare in Atlantic Africa [...]. [1999]. Londres e Nova Iorque: Routledge, 2003, pp. 115-116. Cabe ressaltar que o sentido do termo "quimbar" irá se modificar bastante no século XVIII, quando sobretudo passará a se referir a "homens livres", não mais escravos. Verificar: SANTOS, Catarina Madeira. Um governo "polido" para Angola [...]. Tese de doutorado, Universidade Nova de Lisboa, 2005, p. 619.

${ }_{912}$ Kijiku é plural, ijiku o singular. Verificar: HEINTZE, Beatrix. Angola nos séculos XVI e XVII [...]. Luanda: Kilombelombe, 2007, p. 278. 
com o passar das gerações. ${ }^{913}$ Mediante a uma perspectiva mbundu, é relevante ressaltar que os quizicos eram "escravos comunais inalienáveis", em contraposição a outra camada social, os chamados "mubicas" (ver supra). ${ }^{914}$

A forma de ocupação do espaço também é um indício de como ocorria a hierarquização da sociedade mbundu. Os quizicos habitavam em aldeias apartadas e próprias para eles, caracterizadas por John K. Thornton como "lugares povoados cujos residentes são escravos do dito rei [do Ndongo]", onde eram administrados por um funcionário do ngola, o "mopolo". A função social e a inserção no mundo do trabalho também fornecem pistas de qual era a importância dessa gente. Muitos em quantidade, os quizicos formavam a base de funcionamento e reprodução da vida em comum no Ndongo $\mathrm{e}$, como tal, poderiam ser adquiridos, incorporados às linhagens por meio de casamentos e servir como trabalhadores braçais ou soldados. Eram, portanto, indispensáveis para a produção econômica e para a reiteração da vida material entre os mbundu. ${ }^{915}$

Tributária e grande medida da camada social dos quizicos, a escravidão mbundu não era rija e nem simples de compreender. Primeiro porque os quizicos ascendiam socialmente, na forma de quadros políticos e administrativos que integravam as banzas do ngola e dos sobas mais importantes, exercendo cargos como os de tendala e quiambole (ver infra e supra, respectivamente). ${ }^{916}$ Segundo porque os quizicos tinham uma "margem de manobra" considerável na sociedade mbundu, não sendo apenas submissos e cegos servidores de seus senhores. ${ }^{917}$

\footnotetext{
${ }^{913}$ HEINTZE, Beatrix (coord.). Esclarecimentos sobre vocábulos africanos, FHA, vol. I, 1985, pp. 123 e 127. 914 VANSINA, Jan. How Societies Are Born [...]. Charlottesville: University of Virginia Press, 2004, p. 196. Lembrar das considerações já feitas sobre a cadeia relacional "forro-livre-murinda" (ver supra, murinda).

915 THORNTON, John K. Africa and Africans [...]. [1992]. Cambridge: Cambridge University Press, 1998, p. 94, tradução nossa (no original: "populated places whose residents are slaves of the said king"). Em grande medida, devido à importância dos quizicos na forma da exploração do trabalho e da produção econômica, Silvia H. Lara caracterizou o Ndongo como um "sistema corporativo e hierarquizado", por onde "a riqueza, medida em produtos e escravos, circulava e podia ser acumulada". Verificar: LARA, Silvia Hunold. Palmares \& Cucaú [...]. Tese para concurso de Professor Titular, Universidade Estadual de Campinas, 2008, pp. 162164. Todos esses pontos são sumariamente apontados em: HEINTZE, Beatrix. Angola nos séculos XVI e XVII [...]. Luanda: Kilombelombe, 2007, p. 485. Ficamos também com a relevante síntese proposta por Heintze, para quem o conjunto de quizicos estava "agregada em aldeias e, segundo parece, também em aglomerações maiores, que se encontrava fora do sistema de linhagem dos Mbundu e que constituía em larga medida os domínios dinásticos do rei e de sobas poderosos. Quando eram já descendentes de escravos, geralmente não eram vendidos." (p. 278).

${ }^{916}$ Isso sem contar quando não prestavam serviços a Luanda, como quimbares e mani quitandas (ver supra), entre outros cargos.

${ }^{917}$ HEINTZE, Beatrix. Angola nos séculos XVI e XVII [...]. Luanda: Kilombelombe, 2007, pp. 485-486.
} 


\section{Soba (ou sova) $)^{918}$}

Entre os séculos XVI e XVII, os chefes que carregavam o título político de "sobas" ou foram combatidos pelo exército liderado por Luanda, ou acabaram incorporados como agentes cooperadores da expansão portuguesa. As relações que o funcionalismo régio mantinha com eles eram ambivalentes. Em parte, elas visavam à sujeição política e ao estabelecimento de um domínio ultramarino, muitas vezes indesejado a nível regional. Por outro lado, a viabilização das aproximações políticas pressupunha a existência de negociações e do incentivo à diplomacia, em prol de um ordenamento legal e político da região, entendido pela monarquia portuguesa e pelos conselheiros reinóis através do crivo da "paz e justiça" ultramarinas. A política de cooperação e parceria luso-africana que pautou esse tipo de contato foi aqui interpretada através do conceito de "domínio indireto" ou "tutela", por sua vez tributário da noção de "bem comum". Uma vez distendido através da expansão ultramarina portuguesa, o domínio indireto previa "um equilíbrio dos interesses particulares mantido pela subordinação voluntária de todo corpo místico à cabeça do Império, o rei". ${ }^{919}$

Do ponto de vista mbundu, os sobas detinham um peso político de importância, principalmente no que dizia respeito às hierarquias e às organizações políticas e sociais dos mbundu. Nos termos de Jan Vansina, eram eles quem sustentavam os títulos de liderança dos "chefados monocefálicos" ${ }^{920}$ existentes nas regiões agrícolas e pastoris situadas ao sul do planalto central da atual República de Angola, reconhecidos também como "sobados". ${ }^{921}$ A autoridade dos sobas derivava de três competências e predisposições: $i$ ) o "dom do palavreado", com o qual resolvia os abalos internos da comunidade; ii) a associação de sua linhagem à ideia de fundação ancestral da chefatura, lógica inerente às

\footnotetext{
${ }^{918}$ Para mais considerações, consultar os capítulos 1 e 3 desta dissertação.

${ }^{919}$ ZERON, Carlos Alberto de Moura Ribeiro. A construção de uma ordem colonial nas margens americanas do Império português: discussões sobre o "bem comum" na disputa de moradores e jesuitas pela administração dos índios (XVI-XVII). Tese de livre-docência, Universidade de São Paulo, 2009, pp. 27-28. ${ }^{920}$ Aqui optamos por traduzir o termo "monocephalic chiefdom", em inglês, por "chefatura monocefálica".

${ }^{921}$ Sobre "sobado", verificar: SANTOS, Catarina Madeira. Entre deux droits [...]. Annales. Histoire, Sciences Sociales. Paris: Éditions de l'EHESS, n. ${ }^{\circ}$ 60, 2005/4, 2005, nota 5, p. 818. Sobre os "sobas" como indivíduos que sustentam "titulares autóctones" de relevância, ou "chefaturas", em contrastes a outros títulos, como os de "quilamba", verificar: MILLER, Joseph C. Poder político e parentesco [...]. [1976]. Luanda: Arquivo Histórico Nacional, 1995, nota 120, p. 215.
} 
tradições orais centro-africanas; iii) Do controle dos poderes sobrenaturais, com os quais manipulavam o regime das chuvas e organizavam os rituais de semeadura e colheita. ${ }^{922}$

Há uma polissemia grande que compreende os entendimentos e interpretações que perpassam o termo "soba". O sentido consensual adotado pela historiografia é o de interpretá-lo através do substantivo genérico "chefe", conforme fazem Beatrix Heintze e Catarina Madeira Santos. ${ }^{923}$ Havia ainda uma dissociação entre eles. Os de maior importância tendiam a frequentar ou integrar a corte real, ou mesmo a residência, do ngola. Outros eram chefes provinciais, mas não governavam sozinhos, apenas as representavam em assuntos estrangeiros e concentravam parte da força política em suas mãos. Os de menor relevância, de respaldo apenas local ou nem isso, sendo mais "subchefes" ou "chefes simbólicos", eram chamados de "sobetas". ${ }^{924}$ Apesar de os níveis de importância serem onicientes e perceptíveis nas fontes escritas coevas, como acontece nas contidas na $F H A$, há na pena administrativa seiscentista um forte descaso quanto à descrição e à tipificação densas desses sobas. Por mais que incorporassem e rearranjassem o vocábulo "soba" conforme os interesses de um discurso régio e oficial, a apropriação lexical operada pelos funcionários administrativos frequentemente resultava no oferecimento de um

${ }^{922}$ VANSINA, Jan. How Societies Are Born [...]. Charlottesville: University of Virginia Press, 2004, pp. 143, 160, 162-163 e 165. A etimologia da palavra "soba" resgata a função social e histórica desse título. Segundo Vansina, "soba" em kimbundu deriva de -sompá, palavra constitutiva de algumas línguas que compõem um sub-bloco moxico, tendo na raiz o sentido de "tentar, arbitrar". Similar a -sompá é também a palavra -sòpa, que em diversas línguas centro-africanas têm um sentido análogo, ou complementar, ao das incumbências e expectativas atribuídas a um soba: "apresentar as evidências de um caso, confabular" (em lwena); "investigar, julgar, provar um caso" (em cokwe); entre outros. Verificar a mesma obra de Jan Vansina, p. 163 e a nota 7. Nas notas 6 e 7, o pesquisador fornece diversas outras palavras que derivam de "-sompá", com significados parecidos ou complementares aos fornecidos nos exemplos mostrados.

${ }_{923}$ Para a primeira, "chefe de tribo". Para a segunda, "chefe político africano", mas também apenas "chefe". Verificar: HEINTZE, Beatrix (coord.). Esclarecimentos sobre vocábulos africanos, FHA, vol. I, 1985, p. 127. SANTOS, Catarina Madeira. Entre deux droits [...]. Annales. Histoire, Sciences Sociales. Paris: Éditions de l'EHESS, n. ${ }^{\circ}$ 60, 2005/4, 2005, nota 5, p. 818. Idem, Écrire le pouvoir en Angola [...]. Annales. Histoire, Sciences Sociales. Paris: Éditions de l'EHESS, n. ${ }^{\circ}$ 64, 2009/4, p. 789. Thornton usa às vezes a acepção de "senhor local", outras vezes as de "fidalgo" ou "nobre menor". Verificar respectivamente: THORNTON, John K. Warfare in Atlantic Africa [...]. [1999]. Londres e Nova Iorque: Routledge, 2003, p. 115. HEYWOOD, Linda M.; THORNTON, John K. Central Africans, Atlantic Creoles [...]. Cambridge: Cambridge University Press, 2007, pp. 72-73.

${ }^{924}$ SANTOS, Catarina Madeira. Entre deux droits [...]. Annales. Histoire, Sciences Sociales. Paris: Éditions de l'EHESS, n. ${ }^{\circ}$ 60, 2005/4, 2005, nota 5, p. 818. 
entendimento incompleto sobre o termo registrado, anulando as incumbências sociais detidas pelos sobas e simplificando seus papéis políticos na sociedade mbundu. ${ }^{925}$

Apesar de não ser consensual, nesta dissertação sustentamos que, como termo cunhado pelos observadores de época, os tais "sobas" foram padronizações terminológicas inscritas em papéis, ao passo que eram igualmente tributárias de um "fundo de realidade". Nesse sentido, sobas e sobetas - termos cunhados e depois aportuguesados - encontram respaldo em termos endógenos, fundados na experiência empírica dos anotadores e cronistas, tais quais lemba ou "lémbă". Segundo Jan Vansina, essas duas palavras significam "apaziguar, presentear" ou "fornecer dote à família da esposa", nascendo com o florescimento de uma "liderança" ou "chefia" concentrada na imagem de uma única autoridade, responsável pela "administração da riqueza, encarregada de comprar escravos e atrair filhos". Somados aos princípios de matrilianeidade, virilocalidade e residência dos filhos nas aldeias dos pais, pelo menos até que eles fossem maduros o bastante para fundar aldeias auxiliares às dos pais, os lemba detinham grande importância simbólica como sendo "chefias linhageiras" e rememorados como fundadores de comunidades e aldeias, acabando porventura evocados em companhia de outro termo, o fumu, ou simplesmente o "chefe", vivo e responsável pela direção das comunidades. ${ }^{926}$

\section{Tendala (ou tandala) ${ }^{927}$}

"Tendala" era um título político mbundu de importância. No Ndongo, ele era um dignitário superior, ou "uma espécie de primeiro-ministro com funções judiciais", provavelmente convocado ou arregimentado entre os quizicos (ver supra). Pessoas que carregavam esse mesmo título comandavam a denominada "guerra preta" que acompanhava o exército português, tendo pleno comando sobre os seus guerreiros. Como um quadro militar incorporado nas forças bélicas de Luanda, "tendala designava a patente

\footnotetext{
${ }^{925}$ Como explicado em: VANSINA, Jan. How Societies Are Born [...]. Charlottesville: University of Virginia Press, 2004, pp. 141 e 143. Parte das divisões aqui propostas acerca do título de "soba" foi esboçada em: HEINTZE, Beatrix. Angola nos séculos XVI e XVII [...]. Luanda: Kilombelombe, 2007, pp. 205-206.

${ }^{926}$ Jan Vansina adverte que o termo lémbà não deve ser confundido com outro, lèmbà, este relacionado ao surgimento da palavra mulemba, uma árvore sagrada entre os mbundu e bastante comum entre os pende. Todas as informações aqui oferecidas podem ser verificadas em: VANSINA, Jan. How Societies Are Born [...]. Charlottesville: University of Virginia Press, 2004, pp. 239-243. Lembrando que as considerações de Vansina são compartilhadas com Joseph C. Miller.

${ }^{927}$ Para mais considerações, consultar os capítulos 1 e 4 desta dissertação.
} 
máxima", sendo arregimentado normalmente entre os quizicos. ${ }^{928}$ Outro cargo de menor calibre, ou uma espécie de subtítulo com algum tipo de relação com o tendala, era o "samba tendala", segundo no comando da guerra preta. ${ }^{929}$ De acordo com Beatrix Heintze, nos séculos XVI e XVII havia ainda uma outra acepção para o termo "tendala", segundo a qual esse título foi transformado em uma "extensão e vulgarização semântica" empregada para denominar os "cabecilhas" de alguns dos escravos que haviam fugido no tempo do exgovernador Luís Mendes de Vasconcelos e que, em tempos posteriores, vieram a promover saques pela Angola portuguesa. ${ }^{930}$

\section{Tungar (derivado do kimbundu e kikongo, kutunga)}

Seguimos aqui a definição proposta por Beatrix Heintze a partir documentos inseridos na $F H A$, segundo a qual "tungar" quer dizer "fixar-se" ou "estabelecer-se", de forma lata. $^{931}$

\section{Tutulo (também grafado como tololus. Quiçá a mesma coisa que tolollões)}

Em uma das passagens de seu extenso relatório, Fernão de Sousa lista diversas providências militares que haviam sido tomadas antes da partida do exército que perseguiria Ginga Ambande, entre elas a preparação de “dois, ou três tolollões" Apesar de ainda ser incerto o que isso significa, aqui ficamos com a interpretação de Beatrix Heintze,

\footnotetext{
${ }^{928}$ Beatrix Heintze afirma que os tendalas eram arregimentados entre os escravos locais. Verificar: HEINTZE, Beatrix. Angola nos séculos XVI e XVII [...]. Luanda: Kilombelombe, 2007, p. 482. THORNTON, John K. Warfare in Atlantic Africa [...]. [1999]. Londres e Nova Iorque: Routledge, 2003, p. 115-116.

929 Como uma de suas subfunções, os "sambas tendalas" exerciam o papel de línguas quando preciso. Por exemplo, em 1624, Gaspar Ferreira foi um samba tendala enviado ao Ndongo com a incumbência de negociar com "Dona Ana Ginga", pois "era entre eles de maior autoridade, e por ser língua", facilitando o diálogo. Verificar: Fernão de Sousa. O extenso relatório do governador aos seus filhos. S.d., 1625-1630. BAL, cód. 51-IX-20, ff. 220-74v. IN: HEINTZE, Beatrix (coord.). Documento 30, FHA, vol. I, 1985, pp. 226-227.

${ }^{930}$ HEINTZE, Beatrix (coord.). Esclarecimentos sobre vocábulos africanos, $F H A$, vol. I, 1985, pp. 128-129. Sobre as demais informações, verificar também: Idem, Angola nos séculos XVI e XVII [...]. Luanda: Kilombelombe, 2007, pp. 221-222. Thornton sustenta que os tendalas eram "vice-reis", com a capacidade de governar em caso de absenteísmo do ngola. Verificar a última obra de Heintze supracitada, pp. 75-76. As responsabilidades dos tendalas, principalmente no que tangia à função de tradutores nas missões diplomáticas e à importância de comando militar que detinham nos exércitos mbundu e portugueses, persistiam durante o século XVIII. Verificar: SANTOS, Catarina Madeira. Um governo "polido" para Angola [...]. Tese de doutorado, Universidade Nova de Lisboa, 2005, p. 620.

${ }^{931}$ HEINTZE, Beatrix (coord.). Esclarecimentos sobre vocábulos africanos, FHA, vol. I, 1985, p. 129
} 
para quem, de acordo com o cronista e militar António de Oliveira de Cadornega, "tololus" era "tenda de campo". ${ }^{932}$

\section{Undamento (ou apenas unda. Derivado do verbo undar)}

"Undamento" era um dos passos solenes que integravam a cerimônia de avassalamento, acompanhado de outros que normalmente eram citados, sendo os mais frequentes deles a troca de presentes, a encomendação e o firmamento do auto de vassalagem. $\mathrm{O}$ undamento condizia com aquilo que os administradores régios entendiam como sendo algo similar à prática político-medieval da "investidura". Ele era dividido em dois atos, o de "vestir" e o de "peso". Na primeira o avassalado recebia roupas condizentes com a sua importância, na segunda era jogada pemba, ou farinha, por cima dele. Além de ser um ato simbólico importante, o undamento conferia legitimidade ao investido perante aos olhos dos mbundu e dos oficiais e funcionários régios, sendo obrigatório nas cerimônias de avassalamento centro-africanas. ${ }^{933}$ Em último caso, de acordo com uma perspectiva analítica a respeito dos contatos luso-africanos, é possível afirmar que a apropriação dos baculamentos por parte da administração régia indicou para o estabelecimento de uma cadeia relacional de incorporação e absorção, constituída por quatro pontos encadeados e coligados entre si: avassalamento-undamento-baculamentotributação. ${ }^{934}$

\section{Vestir (ou vestimentos) $)^{935}$}

Em certo momento do extenso relatório, Fernão de Sousa explicou que a prática de "vestir" consistia em um modo de pedir peças aos sobas, considerado irregular perante as ordens da monarquia e ao fisco régio. Funcionava da seguinte maneira: os governadores de Angola enviavam um macunze, "que corresponde a embaixador", com "panos de seda com sua empondas" e "farregoulos [...] que é vestido dos negros". De lábia na boca e por serem

\footnotetext{
${ }^{932}$ Verificar: Fernão de Sousa. O extenso relatório do governador aos seus filhos. S.d., 1625-1630. BAL, cód. 51-IX-20, ff. 220-74v. IN: HEINTZE, Beatrix (coord.). Documento 30, FHA, vol. I, 1985, p. 260 e a nota 163, além das passagens nas pp. 241-242 e a nota 104. Consultar também: CADORNEGA, António de Oliveira de. $H G G A$, vol. III, 1940, pp. 73-74; ver também vol. I, 1940, pp. 402, 512; vol. II, 1940, p. 101.

${ }^{933}$ Verificar: HEINTZE, Beatrix (coord.). Esclarecimentos sobre vocábulos africanos, $F H A$, vol. I, 1985, p. 129. SANTOS, Catarina Madeira. Um governo "polido" para Angola [...]. Tese de doutorado, Universidade Nova de Lisboa, 2005, tese, p. 620.

${ }_{934}$ Para mais informações sobre isso, consultar o capítulo 2 desta dissertação.

${ }^{935}$ Para mais informações, consultar o capítulo 4 desta dissertação.
} 
"pessoas doutas nesta negociação", os macunzes normalmente diziam que haviam sido enviados em nome do governador, o que era mentira, a fim de pedir "loanda" (ver supra). Através desse e de outros argumentos enganosos, "despiam o melhor o que podiam a cada soba com práticas a que chamam milongas", de modo que fornecessem aos "governadores, macunze, lingoa, e companheiros as peças que não podiam dar". 936

Fernão de Sousa segue afirmando que certas vezes algumas pessoas se disponibilizavam a cometer o ato impúdico de livre e espontânea vontade, "por certa quantidade de peças por contrato" e "alguns eram tão devotos que se ofereciam a fazê-lo a suas custas", conseguindo por conta própria os produtos necessários para os "vestimentos". Esses homens então atravessavam as províncias dos mbundu, apresentavam-se em uma "cadeira d'espaldas" e chantageavam os sobas a fornecer até dez "peças", caso fossem "poderosos", mas se fossem modestos cobravam cinco peças, apenas para o líder da falsa missão diplomática. Isso sem contar, frisa Fernão de Sousa, as peças fornecidas à companhia e aos acompanhantes da "embaixada", que recebiam "agasalhado necessário em que às vezes entrava mulheres, filhos dos sobas, com grande desacato seu, que eles muito sentiam". Mesmo comportamento desleal tinham os capitães dos presídios, "mandando macunzes pelos sobas a imitação dos governadores". 937

Seguindo a mesma hipótese ventilada por Beatrix Heintze, parece perfeitamente possível associar os "vestimentos" a uma "variante profana" do undamento (ver supra). O nome "vestir", ou "vestimento", advém possivelmente do fato de que as extorsões cometidas por esses macunzes de má-fé resultassem na aquisição acima de tudo de "panos", não só de escravos. ${ }^{938}$ Durante o tempo de Fernão de Sousa, diversas foram as tentativas de impedir as "ilicitudes", sendo que muitas vezes as práticas de "loanda, infuta e vestir" eram combatidas em conjunto.

\footnotetext{
${ }^{936}$ Fernão de Sousa. O extenso relatório do governador aos seus filhos. S.d., 1625-1630. BAL, cód. 51-IX20, ff. 220-74v. IN: HEINTZE, Beatrix (coord.). Documento 30, FHA, vol. I, 1985, p. 279.

${ }^{937}$ Fernão de Sousa. O extenso relatório do governador aos seus filhos. S.d., 1625-1630. BAL, cód. 51-IX20, ff. 220-74v. IN: HEINTZE, Beatrix (coord.). Documento 30, FHA, vol. I, 1985, pp. 279-280.

${ }^{938}$ HEINTZE, Beatrix. Angola nos séculos XVI e XVII [...]. Luanda: Kilombelombe, 2007, p. 416.
} 


\section{Alguns agentes e indivíduos citados na $F H A$}

\section{Tabela 1: Alguns africanos em contato com os portugueses (década de 1620)}

Segue abaixo uma breve apresentação sobre alguns indivíduos africanos em contato com os oficiais régios. Aqui demos preferência aos sujeitos e indivíduos africanos que só raramente são abordados em trabalhos acadêmicos. Todos eles foram registrados na FHA e em algum momento foram citados nesta dissertação. Além disso, a tabela disponível abaixo foi pensada para facilitar o acesso a algumas informações que encontramos ao longo desta pesquisa, porventura relevantes para outros pesquisadores.

No mais, é necessário fazer alguns esclarecimentos sobre os critérios que competiram para o tabelamento proposto. Os "nomes" e "localizações" dispostos abaixo podem variar muito de documento para documento, figurando então apenas como indicativos. Todos os agentes estavam comprometidos em um ou mais "casos", de maior ou menor repercussão, que no geral despertaram a atenção de Fernão de Sousa. Disporemos abaixo uma breve descrição sobre cada um deles. Por "identificação", entendemos ser os estatutos sociais e políticos registrados nos documentos de época, que ora variavam de acordo com a natureza do caso evocado, ora pelo interesse do punho do anotador das informações. Finalmente, para cada agente descrito, foi referenciada apenas uma fonte primária ou secundária, que conta com uma maior riqueza de dados e informações. Para ultrapassar os limites dessas breves descrições, o leitor deverá ler esta dissertação. 


\begin{tabular}{|c|c|c|c|c|c|}
\hline Nome & Localização & Caso & Identificação & Descrição & Documentos \\
\hline $\begin{array}{c}\text { Ango } \\
\text { Aquicaito }\end{array}$ & $\begin{array}{l}\text { Proximidades } \\
\text { de } \\
\text { Massangano. }\end{array}$ & $\begin{array}{c}\text { Mucano aberto } \\
\text { por Diogo } \\
\text { Teixeira } \\
\text { Fonseca. }\end{array}$ & $\begin{array}{l}\text { No documento } \\
\text { consta apenas } \\
\text { que ele era um } \\
\text { soba. }\end{array}$ & $\begin{array}{l}\text { Contemplado } \\
\text { pela justiça } \\
\text { dos mucanos. } \\
\text { Não há } \\
\text { informações } \\
\text { sobre o } \\
\text { deferimento do } \\
\text { litígio. }\end{array}$ & $\begin{array}{c}\text { Fernão de } \\
\text { Sousa. Instrução } \\
\text { de Fernão de } \\
\text { Sousa a António } \\
\text { Nunes Leitão. } \\
11 \text { de junho de } \\
\text { 1629. BAL, cód. } \\
\text { 51-IX-21, ff. } \\
\text { 174-77v. IN: } \\
\text { HEINTZE, } \\
\text { Beatrix (coord.). } \\
\text { Documento 199, } \\
\text { FHA, vol. II, } \\
\text { 1988, pp. 296- } \\
299 .\end{array}$ \\
\hline $\begin{array}{l}\text { Andala } \\
\text { Catungo }\end{array}$ & $\begin{array}{c}\text { Proximidades } \\
\text { de Ambaca }\end{array}$ & $\begin{array}{l}\text { Eleição de } \\
\text { dignatário }\end{array}$ & $\begin{array}{l}\text { No documento } \\
\text { consta apenas que } \\
\text { ele era um soba. }\end{array}$ & $\begin{array}{c}\text { Não era } \\
\text { desafeto de } \\
\text { Luanda. } \\
\text { Aceitava a } \\
\text { aproximação } \\
\text { política. }\end{array}$ & $\begin{array}{c}\text { Fernão de } \\
\text { Sousa. Portaria } \\
\text { de Fernão de } \\
\text { Sousa. } 12 \text { de } \\
\text { julho de } 1624 . \\
\text { BAL, cód. } 51- \\
\text { IX-21, f. 123. } \\
\text { IN: HEINTZE, } \\
\text { Beatrix (coord.). } \\
\text { Documento 170, } \\
\text { FHA, vol. II, } \\
\text { 1988, pp. 266- } \\
\text { 267. }\end{array}$ \\
\hline Boila & Dembo & $\begin{array}{c}\text { Impasse } \\
\text { político-jurídico }\end{array}$ & Soba insurgente & $\begin{array}{c}\text { Fernão de } \\
\text { Sousa achava } \\
\text { que o melhor } \\
\text { seria “dar" no } \\
\text { soba Boila. }\end{array}$ & Vários \\
\hline
\end{tabular}




\begin{tabular}{|c|c|c|c|c|c|}
\hline Nome & Localização & Caso & Identificação & Descrição & Documentos \\
\hline $\begin{array}{c}\text { Bumba } \\
\text { Aquizanzo }\end{array}$ & $\begin{array}{l}\text { Perto ou } \\
\text { inserido no } \\
\text { Reino do } \\
\text { Ndongo }\end{array}$ & $\begin{array}{l}\text { Organização de } \\
\text { feira de escravos }\end{array}$ & $\begin{array}{l}\text { Era um soba de } \\
\text { responsabilidade } \\
\text { de Angola Aire }\end{array}$ & $\begin{array}{l}\text { Aberto para } \\
\text { o comércio }\end{array}$ & $\begin{array}{c}\text { Fernão de } \\
\text { Sousa. O } \\
\text { extenso relatório } \\
\text { do governador } \\
\text { aos seus filhos. } \\
\text { S.d., 1625-1630. } \\
\text { BAL, cód. 51- } \\
\text { IX-20, ff. 220- } \\
\text { 74v. IN: } \\
\text { HEINTZE, } \\
\text { Beatrix (coord.). } \\
\text { Documento 30, } \\
\text { FHA, vol. I, } \\
\text { 1985, pp. 217- } \\
362 .\end{array}$ \\
\hline Cabonda & Dembo & $\begin{array}{c}\text { Impasse } \\
\text { político-jurídico }\end{array}$ & Soba insurgente. & $\begin{array}{l}\text { Junto com } \\
\text { Cheque, o } \\
\text { soba Cabonda } \\
\text { "corria com" } \\
\text { Boila. }\end{array}$ & Vários \\
\hline $\begin{array}{c}\text { Caculo } \\
\text { Cacabaça }\end{array}$ & $\begin{array}{c}\text { Proximidades } \\
\text { de Ambaca }\end{array}$ & $\begin{array}{l}\text { Organização de } \\
\text { feira de escravos }\end{array}$ & $\begin{array}{c}\text { Em 1624, a feira aberta } \\
\text { em suas terras contava } \\
\text { com um mani quitanda } \\
\text { provido pelo } \\
\text { governador. }\end{array}$ & $\begin{array}{l}\text { Aberto para } \\
\text { o } \\
\text { comércio. }{ }^{939}\end{array}$ & $\begin{array}{c}\text { Fernão de } \\
\text { Sousa. O } \\
\text { extenso relatório } \\
\text { do governador } \\
\text { aos seus fillhos. } \\
\text { S.d., 1625-1630. } \\
\text { BAL, cód. 51- } \\
\text { IX-20, ff. 220- } \\
\text { 74v. IN: } \\
\text { HEINTZE, } \\
\text { Beatrix (coord.). } \\
\text { Documento 30, } \\
\text { FHA, vol. I, } \\
\text { 1985, pp. 217- } \\
362 .\end{array}$ \\
\hline
\end{tabular}

${ }^{939}$ Em 1629, Caculo Cacabaça foi alvo das chamadas "corridas" de Henrique Magalhães, então capitão de Ambaca. Verificar: Fernão de Sousa. Carta de Fernão de Sousa a Henrique de Magalhães. 7 de fevereiro de 1630. BAL, cód. 51-IX-21, ff. 325-25v. IN: HEINTZE, Beatrix (coord.). Documento 214, FHA, vol. II, 1988, p. 318. 


\begin{tabular}{|c|c|c|c|c|c|}
\hline Nome & Localização & Caso & Identificação & Descrição & Documentos \\
\hline $\begin{array}{l}\text { Caculo } \\
\text { Cahohy }\end{array}$ & Kissama (?) & $\begin{array}{c}\text { Restrição de trânsito } \\
\text { de pessoas para as } \\
\text { suas terras. }\end{array}$ & $\begin{array}{l}\text { No documento } \\
\text { consta apenas que } \\
\text { ele era um soba. }\end{array}$ & $\begin{array}{c}\text { Segundo } \\
\text { Fernão de } \\
\text { Sousa, o soba } \\
\text { deveria ser } \\
\text { mantido em } \\
\text { "amizade" e } \\
\text { "paz. }\end{array}$ & $\begin{array}{c}\text { Fernão de Sousa } \\
\text { [escrita por Luís } \\
\text { Correa Coelho]. } \\
\text { Portaria de } \\
\text { Fernão de } \\
\text { Sousa. } 29 \text { de } \\
\text { julho de } 1624 . \\
\text { IN: HEINTZE, } \\
\text { Beatrix (coord.). } \\
\text { Documento 174, } \\
\text { FHA, vol. II, } \\
\text { 1988, pp. 269- } \\
\text { 270. }\end{array}$ \\
\hline $\begin{array}{l}\text { Caculo } \\
\text { Casongo }\end{array}$ & $\begin{array}{l}\text { Proximidades } \\
\text { de Muxima }\end{array}$ & $\begin{array}{l}\text { Abertura de } \\
\text { feira }\end{array}$ & $\begin{array}{l}\text { No documento } \\
\text { consta apenas } \\
\text { que ele era um } \\
\text { soba. }\end{array}$ & $\begin{array}{c}\text { Para que a } \\
\text { feira fosse } \\
\text { aberta, o soba } \\
\text { deveria ser } \\
\text { tratado com } \\
\text { "brandura", } \\
\text { assegurando } \\
\text { dessa forma a } \\
\text { "paz" para o } \\
\text { comércio. }\end{array}$ & $\begin{array}{c}\text { Fernão de Sousa } \\
\text { [escrito por Luís } \\
\text { Correa Coelho]. } \\
\text { Regimento de } \\
\text { Fernão de Sousa } \\
\text { a João del } \\
\text { Rincon Salazar, } \\
\text { Constantino } \\
\text { Cadena e } \\
\text { Sebastião Dias } \\
\text { Tição. 25 de } \\
\text { julho de 1624. } \\
\text { BAL, cód. 51- } \\
\text { IX-21, ff. 124- } \\
24 \mathrm{v} . \text { IN: } \\
\text { HEINTZE, } \\
\text { Beatrix (coord.). } \\
\text { Documento 172, } \\
\text { FHA, vol. II, } \\
\text { 1988, pp. 267- } \\
268 .\end{array}$ \\
\hline
\end{tabular}




\begin{tabular}{|c|c|c|c|c|c|}
\hline Nome & Localização & Caso & Identificação & Descrição & Documentos \\
\hline Cafuche & Kissama & $\begin{array}{l}\text { Xadrez } \\
\text { político } \\
\text { africano. }\end{array}$ & $\begin{array}{l}\text { No documento } \\
\text { consta apenas que } \\
\text { ele era um soba. }\end{array}$ & $\begin{array}{c}\text { Por volta de } 1629, \\
\text { o grupo composto } \\
\text { por Enguele, } \\
\text { Cafuche e Cumbi } \\
\text { Ryamgumbo } \\
\text { rivalizava contra o } \\
\text { grupo de Quiculo } \\
\text { Quiaquimone e } \\
\text { Songa. Este último } \\
\text { grupo contava com } \\
\text { a simpatia de } \\
\text { Luanda. }{ }^{940}\end{array}$ & $\begin{array}{c}\text { Fernão de } \\
\text { Sousa. O } \\
\text { extenso relatório } \\
\text { do governador } \\
\text { aos seus filhos. } \\
\text { S.d., } 1625-1630 . \\
\text { BAL, cód. 51- } \\
\text { IX-20, ff. 220- } \\
\text { 74v. IN: } \\
\text { HEINTZE, } \\
\text { Beatrix (coord.). } \\
\text { Documento 30, } \\
\text { FHA, vol. I, } \\
\text { 1985, pp. 217- } \\
362 .\end{array}$ \\
\hline $\begin{array}{c}\text { Caita Cala } \\
\text { Balanga }\end{array}$ & $\begin{array}{c}\text { Ndongo ou } \\
\text { proximidades. }\end{array}$ & $\begin{array}{l}\text { Guerra de Luís } \\
\text { Mendes de } \\
\text { Vasconcelos } \\
\text { contra Angola } \\
\text { Ambande, na } \\
\text { época soberano } \\
\text { do Ndongo. }\end{array}$ & $\begin{array}{l}\text { Era aliado de } \\
\text { Angola } \\
\text { Ambande, quiçá } \\
\text { "vassalo" dele. }\end{array}$ & $\begin{array}{l}\text { A fim de justificar } \\
\text { e convencer os } \\
\text { habitantes de } \\
\text { Luanda sobre a } \\
\text { necessidade abrir } \\
\text { guerra contra o } \\
\text { Ndongo, Luís } \\
\text { Mendes de } \\
\text { Vasconcelos } \\
\text { afirmara que } \\
\text { Angola Ambande } \\
\text { "fomentava" as } \\
\text { subversões de } \\
\text { Caita Cata } \\
\text { Balanga contra } \\
\text { Luanda. }\end{array}$ & $\begin{array}{c}\text { Fernão de } \\
\text { Sousa. História } \\
\text { das relações } \\
\text { entre a Angola } \\
\text { portuguesa e o } \\
\text { Ndongo 1617- } \\
\text { 1624. S.d., por } \\
\text { volta do outono } \\
\text { de 1624. BAL, } \\
\text { cód. 51- IX-20, } \\
\text { ff. 414-14v. IN: } \\
\text { HEINTZE, } \\
\text { Beatrix (coord.). } \\
\text { Documento 23, } \\
\text { FHA, vol. I, } \\
\text { 1985, pp. 195- } \\
\text { 197. }\end{array}$ \\
\hline
\end{tabular}

${ }^{940}$ Em 1624, Cafuche foi descrito como um soba inimigo do jaga Zenza. Nessa ocasião, Fernão de Sousa decidiu que o melhor seria auxiliar o Zenza para que ele derrotasse Cafuche. Verificar: Fernão de Sousa [escrito por Luís Correa Coelho]. Passo de uma carta de Fernão de Sousa. 26 de julho de 1624. BAL, cód. 51IX-21, f. 136v, IN: HEINTZE, Beatrix (coord.). Documento 173, FHA, vol. II, 1988, p. 269. 


\begin{tabular}{|c|c|c|c|c|c|}
\hline Nome & Localização & Caso & Identificação & Descrição & Documentos \\
\hline $\begin{array}{c}\text { Camanga } \\
\text { Cacaita }\end{array}$ & Kissama (?) & $\begin{array}{l}\text { Restrição de trânsito } \\
\text { de pessoas para as } \\
\text { suas terras. }\end{array}$ & Soba baculador. & $\begin{array}{c}\text { Não poderia } \\
\text { ser incorrido } \\
\text { em } \\
\text { mucanos. }\end{array}$ & $\begin{array}{c}\text { Fernão de Sousa } \\
\text { [escrita por Luís } \\
\text { Correa Coelho]. } \\
\text { Portaria de } \\
\text { Fernão de } \\
\text { Sousa. } 18 \text { de } \\
\text { julho de } 1624 . \\
\text { BAL, cód. 51- } \\
\text { IX-21, f. 123v. } \\
\text { IN: Documento } \\
\text { 171, FHA, vol. } \\
\text { II, 1988, p. } 267 .\end{array}$ \\
\hline $\begin{array}{c}\text { Cambo } \\
\text { Ambande }^{941}\end{array}$ & Ndongo & $\begin{array}{c}\text { Capturada pelo } \\
\text { exército } \\
\text { comandado por } \\
\text { Paio de Araújo } \\
\text { de Azevedo, em } \\
25 \text { de maio de } \\
1629 .\end{array}$ & $\begin{array}{l}\text { Era irmã de Ginga } \\
\text { Ambande, a } \\
\text { eminente sucessora } \\
\text { do trono do } \\
\text { Ndongo após a } \\
\text { morte de Angola } \\
\text { Aire. }\end{array}$ & $\begin{array}{c}\text { Fernão de Sousa } \\
\text { cogitou colocá-la } \\
\text { como rainha do } \\
\text { Ndongo, caso } \\
\text { Angola Aire não } \\
\text { se sustentasse no } \\
\text { cargo. Ela era } \\
\text { respeitadíssima no } \\
\text { Ndongo e } \\
\text { apoiadora da irmã } \\
\text { Ginga Ambande. }\end{array}$ & Vários \\
\hline Capopo & $\begin{array}{l}\text { Redondezas } \\
\text { de } \\
\text { Massangano }\end{array}$ & $\begin{array}{c}\text { Envolvimento } \\
\text { em dois } \\
\text { mucanos. }\end{array}$ & $\begin{array}{l}\text { Possivelmente era } \\
\text { um pombeiro ou } \\
\text { intermediador do } \\
\text { tráfico de escravos. }\end{array}$ & $\begin{array}{c}\text { Era réu em } \\
\text { dois mucanos } \\
\text { em andamento } \\
\text { em } \\
\text { Massangano. } \\
\text { Não há } \\
\text { informações } \\
\text { sobre o que } \\
\text { acabou } \\
\text { decidido. }\end{array}$ & $\begin{array}{c}\text { Fernão de } \\
\text { Sousa. Instrução } \\
\text { de Fernão de } \\
\text { Sousa a António } \\
\text { Nunes Leitão. } \\
11 \text { de junho de } \\
\text { 1629. BAL, cód. } \\
\text { 51- IX-21, ff. } \\
\text { 174-77v. IN: } \\
\text { HEINTZE, } \\
\text { 1988, } \\
\text { documento } 199 .\end{array}$ \\
\hline
\end{tabular}

${ }^{941}$ Também conhecida como "Maria Cambo Ambande". 


\begin{tabular}{|c|c|c|c|c|c|}
\hline Nome & Localização & Caso & Identificação & Descrição & Documentos \\
\hline Caquende & Massangano & $\begin{array}{l}\text { Envolvimento } \\
\text { em mucano. }\end{array}$ & $\begin{array}{l}\text { Fora escravizado, } \\
\text { porém reivindicou } \\
\text { ser "forro da } \\
\text { morinda de Gonga } \\
\text { Aquitulo". }\end{array}$ & $\begin{array}{l}\text { Pleiteava a } \\
\text { liberdade } \\
\text { através do } \\
\text { acionamento } \\
\text { da justiça } \\
\text { dos } \\
\text { mucanos. }\end{array}$ & $\begin{array}{c}\text { Fernão de } \\
\text { Sousa. Instrução } \\
\text { de Fernão de } \\
\text { Sousa a António } \\
\text { Nunes Leitão. } \\
11 \text { de junho de } \\
\text { 1629. BAL, cód. } \\
\text { 51- IX-21, ff. } \\
\text { 174-77v. IN: } \\
\text { HEINTZE, } \\
\text { Beatrix (coord.). } \\
\text { Documento 199, } \\
\text { FHA, vol. II, } \\
\text { 1988, pp. 296- } \\
299 .\end{array}$ \\
\hline $\begin{array}{l}\text { Casanga } \\
\text { Cacaita }\end{array}$ & Dembo & $\begin{array}{l}\text { Citado no } \\
\text { Impasse de } \\
\text { Boila. }\end{array}$ & $\begin{array}{l}\text { No documento } \\
\text { consta apenas que } \\
\text { ele era um soba. }\end{array}$ & $\begin{array}{c}\text { Fernão de } \\
\text { Sousa afira } \\
\text { que não cedera } \\
\text { as terras } \\
\text { almejadas por } \\
\text { Boila por } \\
\text { serem de } \\
\text { Casanga } \\
\text { Cacaita. }\end{array}$ & $\begin{array}{c}\text { Fernão de } \\
\text { Sousa. O } \\
\text { extenso relatório } \\
\text { do governador } \\
\text { aos seus filhos. } \\
\text { S.d., 1625-1630. } \\
\text { BAL, cód. 51- } \\
\text { IX-20, ff. 220- } \\
\text { 74v. IN: } \\
\text { HEINTZE, } \\
\text { Beatrix (coord.). } \\
\text { Documento 30, } \\
\text { FHA, vol. I, } \\
\text { 1985, pp. 217- } \\
362 .\end{array}$ \\
\hline
\end{tabular}




\begin{tabular}{|c|c|c|c|c|c|}
\hline Nome & Localização & Caso & Identificação & Descrição & Documentos \\
\hline $\begin{array}{c}\text { Casa } \\
\text { Cangola }^{942}\end{array}$ & $\begin{array}{l}\text { Imprecisa. Por } \\
\text { volta de } 1628 \text {, } \\
\text { ele estava em } \\
\text { algum lugar do } \\
\text { interior do } \\
\text { continente. }\end{array}$ & $\begin{array}{l}\text { Jornadas de } \\
\text { guerra contra } \\
\text { Ginga } \\
\text { Ambande. }\end{array}$ & $\begin{array}{c}\text { Jaga que "corria } \\
\text { com" Ginga } \\
\text { Ambande. }\end{array}$ & $\begin{array}{c}\text { Apesar de } \\
\text { apoiar Ginga, } \\
\text { não havia } \\
\text { contra ele } \\
\text { "mucano". } \\
\text { Portanto, ele } \\
\text { não foi } \\
\text { perseguido por } \\
\text { Luanda. }\end{array}$ & \begin{tabular}{|c} 
Fernão de \\
Sousa. O \\
extenso relatório \\
do governador \\
aos seus filhos. \\
S.d., 1625-1630. \\
BAL, cód. 51- \\
IX-20, ff. 220- \\
74v. IN: \\
HEINTZE, \\
Beatrix (coord.). \\
Documento 30, \\
FHA, vol. I, \\
1985, pp. 217- \\
362 (entre outros \\
documentos).
\end{tabular} \\
\hline Casanze $^{943}$ & $\begin{array}{c}\text { Imprecisa. Por } \\
\text { volta do início } \\
\text { de } 1630 \text {, ele } \\
\text { possivelmente } \\
\text { estava na "Baixa } \\
\text { do Cassanje", } \\
\text { onde fundaria o } \\
\text { respeitado } \\
\text { "reino de } \\
\text { Kassanje". }\end{array}$ & $\begin{array}{c}\text { Esteve } \\
\text { implicado na } \\
\text { desestabilização } \\
\text { do reino do } \\
\text { Ndongo, ainda } \\
\text { durante o tempo } \\
\text { de Angola } \\
\text { Ambande. }\end{array}$ & $\begin{array}{l}\text { Era um dos mais } \\
\text { temidos jagas } \\
\text { durante a década de } \\
\text { 1620, porém } \\
\text { ganhará mais } \\
\text { importância a partir } \\
\text { da segunda metade } \\
\text { do século XVII. }\end{array}$ & $\begin{array}{c}\text { A } \\
\text { administração } \\
\text { régia via como } \\
\text { temerário o } \\
\text { crescimento da } \\
\text { importância do } \\
\text { jaga Casanze. } \\
\text { Mesmo assim, } \\
\text { foi } \\
\text { complacente } \\
\text { com os ataques } \\
\text { que o jaga } \\
\text { promoveu } \\
\text { contra o } \\
\text { Ndongo. }\end{array}$ & Vários \\
\hline
\end{tabular}

942 O termo aceita variantes, como "Caza Cangolla". Também conhecido como "Dom João Casa Cangola" pelo funcionalismo régio.

943 O termo aceita variantes, como "Cassanje" ou "Kassanje”. Era também conhecido como "Dom João Casanze" pelo funcionalismo régio. 


\begin{tabular}{|c|c|c|c|c|c|}
\hline Nome & Localização & Caso & Identificação & Descrição & Documentos \\
\hline Cheque & Dembo & $\begin{array}{c}\text { Impasse } \\
\text { político-jurídico }\end{array}$ & Soba insurgente. & $\begin{array}{l}\text { Junto com } \\
\text { Cheque, o } \\
\text { soba Cabonda } \\
\text { "corria com" } \\
\text { Boila. }\end{array}$ & Vários \\
\hline $\begin{array}{l}\text { Cristovão } \\
\text { Gunga } \\
\text { Ambundo }\end{array}$ & $\begin{array}{l}\text { Redondezas } \\
\text { de } \\
\text { Massangano }\end{array}$ & $\begin{array}{c}\text { Abertura de } \\
\text { mucano }\end{array}$ & $\begin{array}{c}\text { Não há } \\
\text { informações. }\end{array}$ & $\begin{array}{c}\text { Acionara a } \\
\text { justiça dos } \\
\text { mucanos para } \\
\text { pleitear a } \\
\text { posse de } \\
\text { Capopo como } \\
\text { escravo seu. }\end{array}$ & $\begin{array}{c}\text { Fernão de } \\
\text { Sousa. Instrução } \\
\text { de Fernão de } \\
\text { Sousa a António } \\
\text { Nunes Leitão. } \\
11 \text { de junho de } \\
\text { 1629. BAL, cód. } \\
\text { 51- IX-21, ff. } \\
\text { 174-77v. IN: } \\
\text { HEINTZE, } \\
\text { Beatrix (coord.). } \\
\text { Documento 199, } \\
\text { FHA, vol. II, } \\
\text { 1988, pp. 296- } \\
299 .\end{array}$ \\
\hline $\begin{array}{c}\text { Cumbi } \\
\text { Ryamgumbo }\end{array}$ & Kissama & $\begin{array}{l}\text { Xadrez } \\
\text { político } \\
\text { africano. }\end{array}$ & $\begin{array}{c}\text { No documento } \\
\text { consta apenas que } \\
\text { era um jaga }\end{array}$ & $\begin{array}{c}\text { Por volta de } 1629, \\
\text { o grupo composto } \\
\text { por Enguele, } \\
\text { Cafuche e Cumbi } \\
\text { Ryamgumbo } \\
\text { rivalizava contra o } \\
\text { grupo de Quiculo } \\
\text { Quiaquimone e } \\
\text { Songa. Este último } \\
\text { grupo contava com } \\
\text { a simpatia de } \\
\text { Luanda. }\end{array}$ & $\begin{array}{c}\text { Fernão de } \\
\text { Sousa. O } \\
\text { extenso relatório } \\
\text { do governador } \\
\text { aos seus filhos. } \\
\text { S.d., 1625-1630. } \\
\text { BAL, cód. 51- } \\
\text { IX-20, ff. 220- } \\
\text { 74v. IN: } \\
\text { HEINTZE, } \\
\text { Beatrix (coord.). } \\
\text { Documento 30, } \\
\text { FHA, vol. I, } \\
\text { 1985, pp. 217- } \\
362 .\end{array}$ \\
\hline
\end{tabular}




\begin{tabular}{|c|c|c|c|c|c|}
\hline Nome & Localização & Caso & Identificação & Descrição & Documentos \\
\hline Enguele & Kissama & $\begin{array}{l}\text { Xadrez } \\
\text { político } \\
\text { africano. }\end{array}$ & $\begin{array}{c}\text { No documento } \\
\text { consta apenas que } \\
\text { era um soba }\end{array}$ & $\begin{array}{c}\text { Por volta de 1629, } \\
\text { o grupo composto } \\
\text { por Enguele, } \\
\text { Cafuche e Cumbi } \\
\text { Ryamgumbo } \\
\text { rivalizava contra o } \\
\text { grupo de Quiculo } \\
\text { Quiaquimone e } \\
\text { Songa. Este último } \\
\text { grupo contava com } \\
\text { a simpatia de } \\
\text { Luanda. }\end{array}$ & $\begin{array}{c}\text { Fernão de } \\
\text { Sousa. O } \\
\text { extenso relatório } \\
\text { do governador } \\
\text { aos seus filhos. } \\
\text { S.d., 1625-1630 } \\
\text { BAL, cód. 51- } \\
\text { IX-20, ff. 220- } \\
74 \text { v. IN: } \\
\text { HEINTZE, } \\
\text { Beatrix (coord.) } \\
\text { Documento 30, } \\
\text { FHA, vol. I, } \\
\text { 1985, pp. 217- } \\
362 .\end{array}$ \\
\hline Gola & Massangano & $\begin{array}{l}\text { Envolvimento } \\
\text { em mucano. }\end{array}$ & $\begin{array}{l}\text { Fora escravizado, } \\
\text { porém reivindicava } \\
\text { ser "forro da } \\
\text { morinda de Gonga } \\
\text { Aquitulo". }\end{array}$ & $\begin{array}{l}\text { Pleiteava a } \\
\text { liberdade } \\
\text { através do } \\
\text { acionamento } \\
\text { da justiça } \\
\text { dos } \\
\text { mucanos. }\end{array}$ & $\begin{array}{c}\text { Fernão de } \\
\text { Sousa. Instrução } \\
\text { de Fernão de } \\
\text { Sousa a António } \\
\text { Nunes Leitão. } \\
11 \text { de junho de } \\
\text { 1629. BAL, cód. } \\
\text { 51- IX-21, ff. } \\
\text { 174-77v. IN: } \\
\text { HEINTZE, } \\
\text { Beatrix (coord.) } \\
\text { Documento 199, } \\
\text { FHA, vol. II, } \\
\text { 1988, pp. 296- } \\
299 .\end{array}$ \\
\hline
\end{tabular}




\begin{tabular}{|c|c|c|c|c|c|}
\hline Nome & Localização & Caso & Identificação & Descrição & Documentos \\
\hline $\begin{array}{c}\text { Gombe } \\
\text { Amotenda }\end{array}$ & $\begin{array}{l}\text { Redondezas } \\
\text { de Ambaca }\end{array}$ & $\begin{array}{c}\text { Espoliação } \\
\text { dos sobas. }^{944}\end{array}$ & $\begin{array}{c}\text { No documento } \\
\text { consta apenas que } \\
\text { ele era um } \\
\text { quilamba }\end{array}$ & $\begin{array}{l}\text { Fora injuriado pelo } \\
\text { capitão Henrique } \\
\text { de Magalhães. Em } \\
\text { decorrência disso, } \\
\text { estava "levantado" } \\
\text { e "recolhia a gente } \\
\text { alevantada" do } \\
\text { Ndongo. }\end{array}$ & $\begin{array}{c}\text { Fernão de } \\
\text { Sousa. Carta de } \\
\text { Fernão de Sousa } \\
\text { a Henrique de } \\
\text { Magalhães. } 7 \text { de } \\
\text { fevereiro de } \\
\text { 1630. BAL, cód. } \\
\text { 51-IX-21, ff. } \\
\text { 325-25v. IN: } \\
\text { HEINTZE, } \\
\text { Beatrix (coord.). } \\
\text { Documento 214, } \\
\text { FHA, vol. II, } \\
\text { 1988, pp. 317- } \\
318 .\end{array}$ \\
\hline $\begin{array}{l}\text { Gonga } \\
\text { Aquitulo }\end{array}$ & Massangano & $\begin{array}{l}\text { Envolvimento } \\
\text { em mucano. }\end{array}$ & $\begin{array}{l}\text { Os escravizados } \\
\text { Gola e Caquende } \\
\text { reivindicavam ser } \\
\text { "forros" de sua } \\
\text { morinda. }\end{array}$ & $\begin{array}{c}\text { Em } 1629 \text { o } \\
\text { litígio } \\
\text { estava em } \\
\text { andamento. }\end{array}$ & $\begin{array}{c}\text { Fernão de } \\
\text { Sousa. Instrução } \\
\text { de Fernão de } \\
\text { Sousa a António } \\
\text { Nunes Leitão. } \\
11 \text { de junho de } \\
\text { 1629. BAL, cód. } \\
\text { 51- IX-21, ff. } \\
\text { 174-77v. IN: } \\
\text { HEINTZE, } \\
\text { Beatrix (coord.). } \\
\text { Documento 199, } \\
\text { FHA, vol. II, } \\
\text { 1988, pp. 296- } \\
299 .\end{array}$ \\
\hline
\end{tabular}

${ }^{944}$ Nas fontes aqui consultadas, casos como esses imprimiam o sentido de "privação de justiça", ao qual era somado a algum ato de roubo violento cometido contra os sobas. 


\begin{tabular}{|c|c|c|c|c|c|}
\hline Nome & Localização & Caso & Identificação & Descrição & Documentos \\
\hline $\begin{array}{l}\text { Gonga } \\
\text { Moiza }\end{array}$ & $\begin{array}{l}\text { Redondezas } \\
\text { de Ambaca }\end{array}$ & $\begin{array}{l}\text { Espoliação } \\
\text { dos sobas. }\end{array}$ & $\begin{array}{l}\text { No documento } \\
\text { consta apenas que } \\
\text { ele era um soba. }\end{array}$ & $\begin{array}{c}\text { Foi } \\
\text { convencido a } \\
\text { ceder escravos } \\
\text { em troca de } \\
\text { um } \\
\text { "julgamento } \\
\text { gentílico" } \\
\text { favorável para } \\
\text { si. }\end{array}$ & $\begin{array}{c}\text { Fernão de } \\
\text { Sousa. Carta de } \\
\text { Fernão de Sousa } \\
\text { a Henrique de } \\
\text { Magalhães. } 7 \text { de } \\
\text { fevereiro de } \\
\text { 1630. BAL, cód. } \\
\text { 51-IX-21, ff. } \\
\text { 325-25v. IN: } \\
\text { HEINTZE, } \\
\text { Beatrix (coord.). } \\
\text { Documento 214, } \\
\text { FHA, vol. II, } \\
\text { 1988, pp. 317- } \\
318 .\end{array}$ \\
\hline $\begin{array}{c}\text { Gunza } \\
\text { Ambande }^{945}\end{array}$ & $\begin{array}{c}\text { Vizinhança } \\
\text { de } \\
\text { Massangano }\end{array}$ & $\begin{array}{l}\text { Organização de } \\
\text { feira de escravos }\end{array}$ & $\begin{array}{l}\text { No documento } \\
\text { consta apenas que } \\
\text { ele era um soba. }\end{array}$ & $\begin{array}{c}\text { Em 1627, esse } \\
\text { soba estava } \\
\text { propenso a } \\
\text { sediar uma } \\
\text { feira de } \\
\text { escravos em } \\
\text { suas terras. } \\
\text { Essa feira } \\
\text { contaria com } \\
\text { um mani } \\
\text { quitanda. }\end{array}$ & $\begin{array}{c}\text { Fernão de } \\
\text { Sousa. O } \\
\text { extenso relatório } \\
\text { do governador } \\
\text { aos seus filhos. } \\
\text { S.d., 1625-1630. } \\
\text { BAL, cód. 51- } \\
\text { IX-20, ff. 220- } \\
\text { 74v. IN: } \\
\text { HEINTZE, } \\
\text { Beatrix (coord.). } \\
\text { Documento 30, } \\
\text { FHA, vol. I, } \\
\text { 1985, pp. 217- } \\
362 .\end{array}$ \\
\hline
\end{tabular}

${ }^{945}$ Também conhecido como "Guizambande". 


\begin{tabular}{|c|c|c|c|c|c|}
\hline Nome & Localização & Caso & Identificação & Descrição & Documentos \\
\hline $\begin{array}{l}\text { Queso } \\
\text { Atumba }\end{array}$ & $\begin{array}{l}\text { Vizinhança } \\
\text { de Muxima }\end{array}$ & $\begin{array}{c}\text { Abertura de } \\
\text { feira }\end{array}$ & $\begin{array}{l}\text { No documento } \\
\text { há apenas uma } \\
\text { referência geral } \\
\text { a ele. }\end{array}$ & $\begin{array}{c}\text { Para que a } \\
\text { feira fosse } \\
\text { aberta, o soba } \\
\text { deveria ser } \\
\text { tratado com } \\
\text { "brandura", } \\
\text { assegurando a } \\
\text { "paz" para o } \\
\text { comércio. }\end{array}$ & $\begin{array}{c}\text { Fernão de Sousa } \\
\text { [escrito por Luís } \\
\text { Correa Coelho]. } \\
\text { Regimento de } \\
\text { Fernão de Sousa } \\
\text { a João del } \\
\text { Rincon Salazar, } \\
\text { Constantino } \\
\text { Cadena e } \\
\text { Sebastião Dias } \\
\text { Tição. 25 de } \\
\text { julho de 1624. } \\
\text { BAL, cód. 51- } \\
\text { IX-21, ff. 124- } \\
24 \mathrm{v} \text {. IN: } \\
\text { HEINTZE, } \\
\text { Beatrix (coord.). } \\
\text { Documento 172, } \\
\text { FHA, vol. II, } \\
\text { 1988, pp. 267- } \\
268 .\end{array}$ \\
\hline $\begin{array}{c}\text { Quiloange } \\
\text { Candalo } \\
\text { Camba }\end{array}$ & $\begin{array}{l}\text { Vizinhanças } \\
\text { de } \\
\text { Massangano }\end{array}$ & $\begin{array}{l}\text { Citado em } \\
\text { caso de } \\
\text { mucano. }\end{array}$ & $\begin{array}{l}\text { No documento } \\
\text { consta apenas } \\
\text { que ele era um } \\
\text { soba. }\end{array}$ & $\begin{array}{c}\text { Um de seus } \\
\text { macotas } \\
\text { fora } \\
\text { convocado a } \\
\text { depor nos } \\
\text { litígios } \\
\text { movidos por } \\
\text { Gola e } \\
\text { Caquende }\end{array}$ & $\begin{array}{c}\text { Fernão de } \\
\text { Sousa. Instrução } \\
\text { de Fernão de } \\
\text { Sousa a António } \\
\text { Nunes Leitão. } \\
11 \text { de junho de } \\
\text { 1629. BAL, cód. } \\
\text { 51- IX-21, ff. } \\
\text { 174-77v. IN: } \\
\text { HEINTZE, } \\
\text { Beatrix (coord.). } \\
\text { Documento 199, } \\
\text { FHA, vol. II, } \\
\text { 1988, pp. 296- } \\
\text { 299. }\end{array}$ \\
\hline
\end{tabular}




\begin{tabular}{|c|c|c|c|c|c|}
\hline Nome & Localização & Caso & Identificação & Descrição & Documentos \\
\hline $\begin{array}{c}\text { Quiculo } \\
\text { Quiaquimone }\end{array}$ & Kissama & $\begin{array}{l}\text { Xadrez } \\
\text { político } \\
\text { africano. }\end{array}$ & $\begin{array}{c}\text { No documento } \\
\text { consta apenas que } \\
\text { era um soba }\end{array}$ & $\begin{array}{c}\text { Por volta de 1629, } \\
\text { o grupo composto } \\
\text { por Enguele, } \\
\text { Cafuche e Cumbi } \\
\text { Ryamgumbo } \\
\text { rivalizava contra o } \\
\text { grupo de Quiculo } \\
\text { Quiaquimone e } \\
\text { Songa. Este último } \\
\text { grupo contava com } \\
\text { a simpatia de } \\
\text { Luanda. }\end{array}$ & $\begin{array}{c}\text { Fernão de } \\
\text { Sousa. O } \\
\text { extenso relatório } \\
\text { do governador } \\
\text { aos seus filhos. } \\
\text { S.d., 1625-1630. } \\
\text { BAL, cód. 51- } \\
\text { IX-20, ff. 220- } \\
\text { 74v. IN: } \\
\text { HEINTZE, } \\
\text { Beatrix (coord.). } \\
\text { Documento 30, } \\
\text { FHA, vol. I, } \\
\text { 1985, pp. 217- } \\
362 .\end{array}$ \\
\hline $\begin{array}{c}\text { Quifunge } \\
\text { Ambande }^{946}\end{array}$ & Ndongo & $\begin{array}{c}\text { Capturada pelo } \\
\text { exército } \\
\text { comandado por } \\
\text { Paio de Araújo } \\
\text { de Azevedo, em } \\
25 \text { de maio de } \\
1629\end{array}$ & $\begin{array}{c}\text { Irmã de Ginga } \\
\text { Ambande }\end{array}$ & $\begin{array}{c}\text { Com irmã de } \\
\text { Angola Ambande, } \\
\text { ela era muito } \\
\text { respeitada pelos } \\
\text { mbundu. Todavia, } \\
\text { parecia ser menos } \\
\text { importante do que } \\
\text { as irmãs Ginga e } \\
\text { Cambo Ambande. }\end{array}$ & Vários \\
\hline Songa $^{947}$ & Kissama & $\begin{array}{l}\text { Xadrez } \\
\text { político } \\
\text { africano. }\end{array}$ & $\begin{array}{l}\text { No documento } \\
\text { consta apenas que } \\
\text { era um soba. }\end{array}$ & $\begin{array}{c}\text { Por volta de 1629, } \\
\text { o grupo composto } \\
\text { por Enguele, } \\
\text { Cafuche e Cumbi } \\
\text { Ryamgumbo } \\
\text { rivalizava contra o } \\
\text { grupo de Quiculo } \\
\text { Quiaquimone e } \\
\text { Songa. Este último } \\
\text { grupo contava com } \\
\text { a simpatia de } \\
\text { Luanda. }\end{array}$ & $\begin{array}{c}\text { Fernão de } \\
\text { Sousa. O } \\
\text { extenso relatório } \\
\text { do governador } \\
\text { aos seus filhos. } \\
\text { S.d., 1625-1630. } \\
\text { BAL, cód. 51- } \\
\text { IX-20, ff. 220- } \\
\text { 74v. IN: } \\
\text { HEINTZE, } \\
\text { Beatrix (coord.). } \\
\text { Documento 30, } \\
\text { FHA, vol. I, } \\
\text { 1985, pp. 217- } \\
362 .\end{array}$ \\
\hline
\end{tabular}

${ }^{946}$ Também conhecida como "Funge Ambande". Ela carregava também um nome português, "Gracia".

${ }^{947}$ Também conhecido como "Quimone Quiasonga". 


\begin{tabular}{|c|c|c|c|c|c|}
\hline Nome & Localização & Caso & Identificação & Descrição & Documentos \\
\hline Zenza & Kissama & $\begin{array}{l}\text { Xadrez } \\
\text { político } \\
\text { africano }\end{array}$ & $\begin{array}{l}\text { Identificado } \\
\text { como um jaga. }\end{array}$ & $\begin{array}{c}\text { Jaga em } \\
\text { constante } \\
\text { contato com as } \\
\text { autoridades } \\
\text { portuguesas. }\end{array}$ & Vários \\
\hline
\end{tabular}


Tabela 2: Alguns funcionários e auxiliares que serviam no interior (década de 1620)

Segue abaixo uma breve apresentação sobre alguns indivíduos que serviam na administração ultramarina da Angola portuguesa e que foram registrados na $F H A$. Muitos deles eram portugueses vindos do espaço peninsular, havendo uma minoria proveniente de outras partes da Europa, como da Península Itálica e Flandres. Alguns desses indivíduos eram centro-africanos absorvidos como agentes úteis à administração ultramarina, outras eram pessoas autodeclaradas "portuguesas" e que haviam nascido na África. Também é relevante destacar que todos os agentes aqui arrolados foram no geral pouco estudados por pesquisadores contemporâneos, seja porque as poucas informações e dados sobre esses agentes estão dispersos em vários fragmentos de documentação, dificultando o trabalho de investigação, seja porque a maioria dessas pessoas não integrava a elite ultramarina. Assim, esperamos que o presente inventário ajude em futuras pesquisas, comprometidas com a busca de maiores informações sobre a arraia-miúda que morava no além-mar.

Foram utilizados os seguintes critérios para o tabelamento abaixo proposto. Dependendo do documento consultado, a grafia relacionada aos "nomes" e às "localizações" de agentes pode variar, de modo que optamos por um tipo de grafia homogênea e mais palatável ao leitor contemporâneo. Por "função", "tarefa" e "âmbito", mencionamos às características de cargos e ofícios desempenhados institucionalmente, sempre descritas do ponto de vista administrativo português. Quando indicamos uma "proveniência", estamos nos referindo ao lugar de nascimento e à trajetória de vida de determinado agente, aludindo portanto ao tipo de experiência acumulado por ele. Em “documentos", referenciamos apenas uma fonte primária e secundária de suma importância para a caracterização do agente evocado, cabendo ao leitor procurar maiores informações e dados por meio da leitura desta dissertação. 


\begin{tabular}{|c|c|c|c|c|c|c|}
\hline Nome & Localização & Função & Tarefas & Âmbito & Proveniência & Documentos \\
\hline $\begin{array}{l}\text { António } \\
\text { de } \\
\text { Andrade }\end{array}$ & Ambaca & $\begin{array}{c}\text { Mani quitanda } \\
\text { (provimento } \\
\text { de 1624). }\end{array}$ & $\begin{array}{l}\text { Escolher oficiais } \\
\text { (meirinho } \\
\text { guardas), } \\
\text { estipular os } \\
\text { preços das } \\
\text { fazendas, zelar } \\
\text { pelo "bem } \\
\text { comum" da feira } \\
\text { e pela "paz". }\end{array}$ & Fiscal & $\begin{array}{c}\text { Africana. } \\
\text { Era escravo } \\
\text { de } \\
\text { Domingos } \\
\text { Luís de } \\
\text { Andrade. }\end{array}$ & \begin{tabular}{|} 
Fernão de \\
Sousa. O \\
extenso \\
relatório do \\
governador aos \\
seus filhos. \\
S.d., 1625- \\
1630. BAL, \\
cód. 51-IX-20, \\
ff. 220-74v. \\
IN: HEINTZE, \\
Beatrix \\
(coord.). \\
Documento 30, \\
FHA, vol. I, \\
1985, pp. 217- \\
362.
\end{tabular} \\
\hline $\begin{array}{l}\text { António } \\
\text { Correia } \\
948\end{array}$ & Ndongo & $\begin{array}{c}\text { "Rei } \\
\text { fantoche". }\end{array}$ & $\begin{array}{l}\text { Servir como um } \\
\text { soberano } \\
\text { artificial sob as } \\
\text { ordens de Luís } \\
\text { Mendes de } \\
\text { Vasconcelos. }\end{array}$ & $\begin{array}{l}\text { A princípio teria } \\
\text { todas as } \\
\text { atribuições de } \\
\text { um rei mbundu, } \\
\text { mas o plano de } \\
\text { Luís Mendes de } \\
\text { Vasconcelos não } \\
\text { obteve êxito. }\end{array}$ & Africana & $\begin{array}{c}\text { Fernão de } \\
\text { Sousa. História } \\
\text { das relações } \\
\text { entre a Angola } \\
\text { portuguesa e o } \\
\text { Ndongo 1617- } \\
\text { 1624. S.d., por } \\
\text { volta do outono } \\
\text { de 1624. BAL, } \\
\text { cód. 51- IX- } \\
\text { 20, ff. 414- } \\
\text { 14v. IN: } \\
\text { HEINTZE, } \\
\text { Beatrix } \\
\text { (coord.). } \\
\text { Documento 23, } \\
\text { FHA, vol. I, } \\
\text { 1985, pp. 195- } \\
\text { 197. }\end{array}$ \\
\hline
\end{tabular}

${ }^{948}$ Também conhecido pelo nome da terra de "Samba Antumbo". 


\begin{tabular}{|c|c|c|c|c|c|c|}
\hline Nome & Localização & Função & Tarefas & Âmbito & Proveniência & Documentos \\
\hline $\begin{array}{l}\text { António } \\
\text { Nunes } \\
\text { Leitão }\end{array}$ & $\begin{array}{l}\text { Residente } \\
\text { em } \\
\text { Em vuanda. } \\
\text { oficial aos } \\
\text { presídios } \\
\text { desde } \\
1629 .\end{array}$ & $\begin{array}{c}\text { Licenciado } \\
\text { e } \\
\text { sindicante. } \\
949\end{array}$ & $\begin{array}{l}\text { Fazer diligências e } \\
\text { cumprir com uma } \\
\text { lista de tarefas } \\
\text { "judiciais" e } \\
\text { "extrajudiciais". }\end{array}$ & $\begin{array}{c}\text { Judiciário e } \\
\text { correição. }\end{array}$ & $\begin{array}{l}\text { Portuguesa } \\
\text { e cristão- } \\
\text { velho. }^{950}\end{array}$ & Vários \\
\hline $\begin{array}{c}\text { Baltazar } \\
\text { Fernandes } \\
\text { Reinol }\end{array}$ & $\begin{array}{c}\text { Muxima } \\
(1626) \mathrm{e} \\
\text { Cambambe } \\
\text { (1628). }\end{array}$ & Capitão & $\begin{array}{c}\text { "Fazer mucanos", } \\
\text { zelar pela proteção } \\
\text { dos sobas, segurança } \\
\text { dos baculamentos, } \\
\text { benefíciamentos das } \\
\text { feiras, defesa da } \\
\text { conquista, } \\
\text { guarnecimento dos } \\
\text { presídios e } \\
\text { conservação da } \\
\text { "paz". }\end{array}$ & $\begin{array}{l}\text { Jurisdicional, } \\
\text { militar, penal. }\end{array}$ & $\begin{array}{c}\text { Portuguesa } \\
\text { e "soldado } \\
\text { velho desta } \\
\text { conquista". } \\
951\end{array}$ & $\begin{array}{c}\text { Fernão de } \\
\text { Sousa. } \\
\text { Instrução de } \\
\text { Fernão de } \\
\text { Sousa a } \\
\text { António Nunes } \\
\text { Leitão. 11 de } \\
\text { junho de 1629. } \\
\text { BAL, cód. 51- } \\
\text { IX-21, ff. 174- } \\
\text { 77v. IN: } \\
\text { HEINTZE, } \\
\text { Beatrix } \\
\text { (coord.). } \\
\text { Documento } \\
\text { 199, FHA, vol. } \\
\text { II, 1988, pp. } \\
\text { 296-299. }\end{array}$ \\
\hline
\end{tabular}

${ }^{949}$ Em 13 de agosto de 1628, Fernão de Sousa proveu António Nunes Leitão à função de ouvidor, juiz de órfãos e provedor da comarca (espécie de juiz inquiridor). Verificar: HEINTZE, Beatrix. Breves biografias de alguns europeus em Angola (1620-1630). FHA, vol. I, 1985, p. 94.

${ }_{950}$ Segundo Beatrix Heintze, António Nunes Leitão tinha sido "procurador da Coroa" antes de receber os provimentos de Fernão de Sousa. Verificar: Ibidem, p. 94. Teria sido ele reinol ou nascido na terra?

${ }_{951}$ Palavras de Betrix Heintze. Ainda segundo ela, Baltazar Fernandes Reinol fora nomeado capitão de Muxima em 16 de maio de 1626. Em reconhecimento aos bons serviços prestados na Ilamba, o capitão fora designado para a direção de Cambambe, em 23 de outubro de 1628, posto no qual acabou preterido em favor de Miguel Barreiros de Brito, "que chegara a Angola com o respectivo documento real de nomeação". HEINTZE, Beatrix. Breves biografias de alguns europeus em Angola (1620-1630). FHA, vol. I, 1985, p. 104. 


\begin{tabular}{|c|c|c|c|c|c|c|}
\hline Nome & Localização & Função & Tarefas & Âmbito & Proveniência & Documentos \\
\hline $\begin{array}{c}\text { Bento } \\
\text { Banha } \\
\text { Cardoso }\end{array}$ & $\begin{array}{c}\text { Atravesso } \\
\text { u o } \\
\text { continente } \\
\text { em busca } \\
\text { de Ginga } \\
\text { Ambande. }\end{array}$ & $\begin{array}{l}\text { Capitão- } \\
\text { mor. }^{952}\end{array}$ & $\begin{array}{l}\text { Como capitão-mor } \\
\text { do quilombo que } \\
\text { procurava Ginga } \\
\text { Ambande, o } \\
\text { português foi } \\
\text { responsável por } \\
\text { arregimentar a } \\
\text { "gente de guerra", } \\
\text { traçar operações } \\
\text { bélicas, comandar as } \\
\text { companhias e } \\
\text { esquematizar as } \\
\text { táticas de ofensiva } \\
\text { militar. }\end{array}$ & $\begin{array}{l}\text { Militar, } \\
\text { tributário e } \\
\text { coercitivo. } \\
\text { Foi também } \\
\text { encarregado } \\
\text { de submeter } \\
\text { os sobas. }\end{array}$ & $\begin{array}{l}\text { Portuguesa } \\
\text { e reinol. }\end{array}$ & Vários \\
\hline $\begin{array}{c}\text { Bento } \\
\text { Rebelo } \\
\text { Vilasboas }\end{array}$ & $\begin{array}{c}\text { Atravessou o } \\
\text { continente em } \\
\text { busca de Ginga } \\
\text { Ambande. Por } \\
\text { volta de 1627, } \\
\text { Bento Rebelo } \\
\text { Vilasboas foi } \\
\text { ordenado a } \\
\text { residir na banza } \\
\text { de Angola Aire. }\end{array}$ & $\begin{array}{c}\text { Auditor do } \\
\text { campo, } \\
\text { ouvidor e } \\
\text { provedor dos } \\
\text { defuntos e } \\
\text { ausentes. }^{954}\end{array}$ & $\begin{array}{c}\text { Na banza de } \\
\text { Ndongo, o português } \\
\text { deveria "fazer } \\
\text { mucanos", garantira } \\
\text { devolução dos } \\
\text { escravos fugidos aos } \\
\text { seus senhores, ou } \\
\text { ressarci-los às custas } \\
\text { da "fazenda de El- } \\
\text { rei”. }\end{array}$ & $\begin{array}{l}\text { Judiciário e } \\
\text { supervisão } \\
\text { geral. }\end{array}$ & $\begin{array}{c}\text { Portuguesa } \\
955\end{array}$ & Vários \\
\hline
\end{tabular}

952 Antes do governo de Fernão de Sousa, Bento Banha Cardoso exercera diversas outras funções em benefício do aparato administrativo, como as de "alferes, capitão-mor de guerra e capitão de Cambambe". Chegou inclusive a ocupar o posto interino de governador em Luanda, entre 1611 e 1615, após a morte de Manuel Pereira Forja. HEINTZE, Beatrix. Breves biografias de alguns europeus em Angola (1620-1630). FHA, vol. I, 1985, pp. 80-81. A relação dos primeiros governadores de Angola pode ser conferida em: Idem, Apêndice: governadores de Angola, 1575 - 1639, FHA, vol. I, 1985, p. 393.

${ }^{953}$ Segundo Beatrix Heintze, Bento Banha Cardoso era "cavaleiro fidalgo da Casa do rei" e chegara a África em 1592, acompanhando o então governador D. Francisco de Almeida. HEINTZE, Beatrix. Breves biografias de alguns europeus em Angola (1620-1630). FHA, vol. I, 1985, p. 80.

${ }^{954}$ Segundo Bestrix Heintze, Bento Rebelo Vilasboas foi nomeado auditor do campo em 30 de janeiro de 1626. As nomeações para as funções de ouvidor e provedor dos defuntos e ausentes vieram em março de 1627. Ibidem, p. 112.

${ }^{955}$ Há suspeitas de que Bento Rebelo Vilasboas havia nascido em território africano. HEINTZE, Beatrix. Breves biografias de alguns europeus em Angola (1620-1630). FHA, vol. I, 1985, p. 112. 


\begin{tabular}{|c|c|c|c|c|c|c|}
\hline Nome & Localização & Função & Tarefas & Âmbito & Proveniência & Documentos \\
\hline $\begin{array}{l}\text { Constantin } \\
\text { o Cadena }\end{array}$ & $\begin{array}{l}\text { Cambamb } \\
\text { e }\end{array}$ & Capitão & \begin{tabular}{|c} 
"Fazer mucanos", \\
zelar pela proteção \\
dos sobas, segurança \\
dos baculamentos, \\
beneficiamentos das \\
feiras, defesa da \\
conquista, \\
guarnecimento dos \\
presídios, \\
conservação da \\
"paz" e viagens de \\
prospeção de \\
minas.
\end{tabular} & $\begin{array}{c}\text { Jurisdicional, } \\
\text { militar, penal } \\
\text { e viagens } \\
\text { para a } \\
\text { descoberta de } \\
\text { minas. }\end{array}$ & $\begin{array}{l}\text { Portuguesa } \\
\text { e reinol }^{956}\end{array}$ & $\begin{array}{c}\text { Fernão de } \\
\text { Sousa [escrito } \\
\text { por Luís Correa } \\
\text { Coelho]. Passo } \\
\text { de uma carta de } \\
\text { Fernão de } \\
\text { Sousa. } 26 \text { de } \\
\text { julho de } 1624 . \\
\text { BAL, cód. 51- } \\
\text { IX-21, f. 136v, } \\
\text { IN: HEINTZE, } \\
\text { Beatrix } \\
\text { (coord.). } \\
\text { Documento } \\
\text { 173, FHA, vol. } \\
\text { II, 1988, p. 269 } \\
\text { (entre outros). }\end{array}$ \\
\hline $\begin{array}{c}\text { Diogo } \\
\text { Mendes }\end{array}$ & Massangano & $\begin{array}{l}\text { Intérprete } \\
\text { ou tradutor. }\end{array}$ & $\begin{array}{l}\text { Fazer a tradução } \\
\text { e interpretação } \\
\text { dos depoimentos } \\
\text { orais durante } \\
\text { mucanos e } \\
\text { inquéritos. }\end{array}$ & Técnico & $\begin{array}{c}\text { Provavelmente } \\
\text { africana. }\end{array}$ & \begin{tabular}{|} 
Fernão de \\
Sousa. \\
Instrução de \\
Fernão de \\
Sousa a \\
António Nunes \\
Leitão. 11 de \\
junho de 1629. \\
BAL, cód. 51- \\
IX-21, ff. 174- \\
77v. IN: \\
HEINTZE, \\
Beatrix \\
(coord.). \\
Documento \\
199, FHA, vol. \\
II, 1988, pp. \\
296-299.
\end{tabular} \\
\hline
\end{tabular}

${ }^{956}$ Segundo Beatrix Heintze, Constantino Cadena era um "cavaleiro fidalgo". Antes de aparecer na África, Constantino Cadena servira na América portuguesa, onde em 6 de outubro de 1622 foi nomeado capitão da "capitania de Cambambe", exercendo o cargo por três anos. Em março de 1628, regressaria ao Reino de Portugal, via Pernambuco. Verificar: HEINTZE, Beatrix. Breves biografias de alguns europeus em Angola (1620-1630). FHA, vol. I, 1985, p. 78. 


\begin{tabular}{|c|c|c|c|c|c|c|}
\hline Nome & Localização & Função & Tarefas & Âmbito & Proveniência & Documentos \\
\hline $\begin{array}{l}\text { Dionísio } \\
\text { de Faria } \\
\text { Barreto }\end{array}$ & $\begin{array}{l}\text { Quando não } \\
\text { estava em } \\
\text { missão, } \\
\text { possivelmente } \\
\text { residia em } \\
\text { Luanda. }\end{array}$ & Padre & $\begin{array}{c}\text { Além de } \\
\text { missões de } \\
\text { proselitismo da } \\
\text { fé católica, foi } \\
\text { enviado junto de } \\
\text { Dionísio Faria } \\
\text { Barreto ao } \\
\text { encontro de } \\
\text { Ginga } \\
\text { Ambande, para } \\
\text { fins de } \\
\text { diplomacia. }\end{array}$ & $\begin{array}{l}\text { Missionário e } \\
\text { diplomático. }\end{array}$ & $\begin{array}{l}\text { Africana } \\
\text { (veio de } \\
\text { Matamba) }\end{array}$ & $\begin{array}{c}\text { Fernão de } \\
\text { Sousa. História } \\
\text { das relações } \\
\text { entre a Angola } \\
\text { portuguesa e o } \\
\text { Ndongo 1617- } \\
\text { 1624. S.d., por } \\
\text { volta do outono } \\
\text { de 1624. BAL, } \\
\text { cód. 51- IX- } \\
\text { 20, ff. 414- } \\
\text { 14v. IN: } \\
\text { HEINTZE, } \\
\text { Beatrix } \\
\text { (coord.). } \\
\text { Documento 23, } \\
\text { FHA, vol. I, } \\
\text { 1985, pp. 195- } \\
\text { 197. }\end{array}$ \\
\hline $\begin{array}{c}\text { Domingos } \\
\text { Pires }\end{array}$ & Ndongo & $\begin{array}{c}\text { Secretário e } \\
\text { meirinho. }\end{array}$ & $\begin{array}{c}\text { Interditar o } \\
\text { trânsito de } \\
\text { pessoas pelo } \\
\text { Ndongo, } \\
\text { expulsar pessoas } \\
\text { "indesejadas", } \\
\text { "lançar bandos" } \\
\text { e "tomar } \\
\text { fazendas } \\
\text { desmandadas". }\end{array}$ & $\begin{array}{c}\text { Corretivo e } \\
\text { fiscal. }\end{array}$ & $\begin{array}{c}\text { Provavelmente } \\
\text { africana. }\end{array}$ & $\begin{array}{c}\text { Fernão de } \\
\text { Sousa. O } \\
\text { extenso } \\
\text { relatório do } \\
\text { governador aos } \\
\text { seus filhos. } \\
\text { S.d., 1625- } \\
\text { 1630. BAL, } \\
\text { cód. 51-IX-20, } \\
\text { ff. 220-74v. } \\
\text { IN: HEINTZE, } \\
\text { Beatrix } \\
\text { (coord.). } \\
\text { Documento 30, } \\
\text { FHA, vol. I, } \\
\text { 1985, pp. 217- } \\
362 .\end{array}$ \\
\hline
\end{tabular}




\begin{tabular}{|c|c|c|c|c|c|c|}
\hline Nome & Localização & Função & Tarefas & Âmbito & Proveniência & Documentos \\
\hline $\begin{array}{l}\text { Francisco } \\
\text { Antunes da } \\
\text { Silva }\end{array}$ & $\begin{array}{l}\text { Interior da } \\
\text { Angola } \\
\text { portuguesa. }\end{array}$ & $\begin{array}{c}\text { Era capitão } \\
\text { português de } \\
\text { presídio. }\end{array}$ & $?$ & $?$ & Portuguesa & $\begin{array}{c}\text { Fernão de } \\
\text { Sousa. História } \\
\text { das relações } \\
\text { entre a Angola } \\
\text { portuguesa e o } \\
\text { Ndongo 1617- } \\
\text { 1624. S.d., por } \\
\text { volta do outono } \\
\text { de 1624. BAL, } \\
\text { cód. 51- IX- } \\
\text { 20, ff. 414- } \\
\text { 14v. IN: } \\
\text { HEINTZE, } \\
\text { Beatrix } \\
\text { (coord.). } \\
\text { Documento 23, } \\
\text { FHA, vol. I, } \\
\text { 1985, pp. 195- } \\
\text { 197. }\end{array}$ \\
\hline $\begin{array}{l}\text { Francisco } \\
\text { Soveral }^{957}\end{array}$ & $\begin{array}{l}\text { Luanda e } \\
\text { São } \\
\text { Salvador } \\
\text { (Mbanza } \\
\text { Kongo) }\end{array}$ & $\begin{array}{l}\text { Era "bispo } \\
\text { de Congo e } \\
\text { Angola". }\end{array}$ & $\begin{array}{c}\text { Autoridade } \\
\text { eclesiástica } \\
\text { de maior peso } \\
\text { na África } \\
\text { Centro- } \\
\text { Ocidental }\end{array}$ & $\begin{array}{c}\text { Para além das } \\
\text { responsabilidade } \\
\text { s sacerdotais, } \\
\text { participava } \\
\text { ativamente das } \\
\text { decisões políticas } \\
\text { tomadas em } \\
\text { Luanda }\end{array}$ & Portuguesa & $\begin{array}{c}\text { Fernão de } \\
\text { Sousa. A } \\
\text { ilegitimidade } \\
\text { do novo rei do } \\
\text { Ndongo, } \\
\text { Angola Aire. } \\
\text { S.d., entre } 20 \\
\text { de julho e } 14 \\
\text { de setembro de } \\
\text { 1629. BAL, } \\
\text { cód. } 51-\text {-IX-20, } \\
\text { ff. } 415-15 \mathrm{v} \text {. } \\
\text { IN: HEINTZE, } \\
\text { Beatrix } \\
\text { (coord.). } \\
\text { Documento 28, } \\
\text { FHA, vol. I, } \\
\text { 1985, pp. 209- } \\
210\end{array}$ \\
\hline
\end{tabular}

${ }^{957}$ Reconhecido também como "Dom Francisco Soveral". 


\begin{tabular}{|c|c|c|c|c|c|c|}
\hline Nome & Localização & Função & Tarefas & Âmbito & Proveniência & Documentos \\
\hline $\begin{array}{c}\text { Francisco } \\
\text { Pacónio }\end{array}$ & $\begin{array}{c}\text { Atravessou o } \\
\text { continente em } \\
\text { busca de Ginga } \\
\text { Ambande. Por } \\
\text { volta de 1627, } \\
\text { Francisco } \\
\text { Pacconio foi } \\
\text { ordenado a } \\
\text { residir na banza } \\
\text { de Angola Aire. }\end{array}$ & $\begin{array}{l}\text { Padre } \\
\text { jesuíta. }\end{array}$ & $\begin{array}{c}\text { Acompanhou o } \\
\text { quilombo durante as } \\
\text { jornadas de guerra } \\
\text { contra Ginga } \\
\text { Ambande, assistiu à } \\
\text { eleição de Angola } \\
\text { Aire e rezou a } \\
\text { primeira missa na } \\
\text { igreja erguida em } \\
\text { Pungo Andongo. }\end{array}$ & $\begin{array}{c}\text { Tutelar e } \\
\text { supervisão. }\end{array}$ & Italiana & Vários \\
\hline $\begin{array}{c}\text { Gabriel } \\
\text { de } \\
\text { Moraes }\end{array}$ & Dembo & $\begin{array}{l}\text { Cobrador de } \\
\text { baculamentos. }\end{array}$ & $\begin{array}{l}\text { Responsável por } \\
\text { "correr com os } \\
\text { baculamentos". } \\
\text { Podia ser } \\
\text { considerado um } \\
\text { "baculador". }\end{array}$ & Tributário & $\begin{array}{l}\text { Provavelmente } \\
\text { africana. }\end{array}$ & $\begin{array}{c}\text { Fernão de } \\
\text { Sousa. O } \\
\text { extenso } \\
\text { relatório do } \\
\text { governador aos } \\
\text { seus filhos. } \\
\text { S.d., 1625- } \\
\text { 1630. BAL, } \\
\text { cód. } 51-\text { IX-20, } \\
\text { ff. 220-74v. } \\
\text { IN: HEINTZE, } \\
\text { Beatrix } \\
\text { (coord.). } \\
\text { Documento 30, } \\
\text { FHA, vol. I, } \\
\text { 1985, pp. 217- } \\
362 .\end{array}$ \\
\hline
\end{tabular}

${ }^{958}$ Aqui compreendemos que o padre Francisco Pacónio era responsável pela direção moral, ensino e zelo dos "bons comportamentos" que o novo rei do Ndongo deveria ter. Além disso, foi responsável pela supervisão de "justiça de guerra" ao longo das campanhas militares levadas a cabo contra Ginga Ambande. 


\begin{tabular}{|c|c|c|c|c|c|c|}
\hline Nome & Localização & Função & Tarefas & Âmbito & Proveniência & Documentos \\
\hline $\begin{array}{c}\text { Henrique } \\
\text { António } \\
\text { Ferreira da } \\
\text { Cunha }^{959}\end{array}$ & Motemo & Capitão & $?$ & $?$ & $?$ & $\begin{array}{l}\text { Fernão de } \\
\text { Sousa. Carta de } \\
\text { Fernão de } \\
\text { Sousa a } \\
\text { Henrique de } \\
\text { Magalhães. } 7 \\
\text { de fevereiro de } \\
\text { 1630. BAL, } \\
\text { cód. 51-IX-21, } \\
\text { ff. 325-25v. } \\
\text { IN: HEINTZE, } \\
\text { Beatrix } \\
\text { (coord.). } \\
\text { Documento } \\
\text { 214, FHA, vol. } \\
\text { II, 1988, pp. } \\
\text { 317-318. }\end{array}$ \\
\hline $\begin{array}{l}\text { Henrique } \\
\text { de } \\
\text { Magalhães }\end{array}$ & Ambaca & $\begin{array}{l}\text { Capitão } \\
\text { (corrupto) }\end{array}$ & $\begin{array}{c}\text { "Fazer } \\
\text { mucanos", zelar } \\
\text { pela proteção } \\
\text { dos sobas, } \\
\text { segurança dos } \\
\text { baculamentos, } \\
\text { beneficiamentos } \\
\text { das feiras, } \\
\text { defesa da } \\
\text { conquista, } \\
\text { guarnecimento } \\
\text { dos presídios e } \\
\text { conservação da } \\
\text { "paz". }\end{array}$ & $\begin{array}{c}\text { Jurisdicional, } \\
\text { militar e } \\
\text { penal }\end{array}$ & Portuguesa & $\begin{array}{c}\text { Fernão de } \\
\text { Sousa. Carta de } \\
\text { Fernão de } \\
\text { Sousa a } \\
\text { Henrique de } \\
\text { Magalhães. } 7 \\
\text { de fevereiro de } \\
\text { 1630. BAL, } \\
\text { cód. } 51-\text {-IX-21, } \\
\text { ff. 325-25v. } \\
\text { IN: HEINTZE, } \\
\text { Beatrix } \\
\text { (coord.). } \\
\text { Documento } \\
\text { 214, FHA, vol. } \\
\text { II, 1988, pp. } \\
\text { 317-318 (entre } \\
\text { outros). }\end{array}$ \\
\hline
\end{tabular}

${ }^{959}$ Não encontramos informações sobre quem era esse homem, suas tarefas, funções e âmbitos de atuação, salvo o comentário depreciativo de Henrique de Magalhães, que chamou-o de "pombeiro". Verificar: Fernão de Sousa. Carta de Fernão de Sousa a Henrique de Magalhães. 7 de fevereiro de 1630. BAL, cód. 51-IX-21, ff. 325-25v. IN: HEINTZE, Beatrix (coord.). Documento 214, FHA, vol. II, 1988, p. 318. 


\begin{tabular}{|c|c|c|c|c|c|c|}
\hline Nome & Localização & Função & Tarefas & Âmbito & Proveniência & Documentos \\
\hline $\begin{array}{c}\text { Jerônimo } \\
\text { Vogado }\end{array}$ & Luanda & $\begin{array}{l}\text { Reitor do } \\
\text { Colégio da } \\
\text { Companhia } \\
\text { de Jesus. }\end{array}$ & $\begin{array}{c}\text { Administrava o } \\
\text { colégio } \\
\text { jesuítico, } \\
\text { aconselhava o } \\
\text { governador de } \\
\text { Angola e tinha } \\
\text { voz ativa na } \\
\text { Câmara de } \\
\text { Luanda. No } \\
\text { tempo de Fernão } \\
\text { de Sousa, ficou } \\
\text { a cargo de uma } \\
\text { missão } \\
\text { diplomática } \\
\text { enviada a Ginga } \\
\text { Ambande. }\end{array}$ & $\begin{array}{c}\text { Religioso, } \\
\text { judiciário } \\
\text { (direito } \\
\text { eclesiástico) e } \\
\text { diplomático. }\end{array}$ & Portuguesa & $\begin{array}{c}\text { Fernão de } \\
\text { Sousa. História } \\
\text { das relações } \\
\text { entre a Angola } \\
\text { portuguesa e o } \\
\text { Ndongo 1617- } \\
\text { 1631. 6 de } \\
\text { agosto de 1631. } \\
\text { BAL, cód. 51- } \\
\text { IX-20, ff. 362- } \\
\text { 63. IN: } \\
\text { HEINTZE, } \\
\text { Beatrix } \\
\text { (coord.). } \\
\text { Documento 25, } \\
\text { FHA, vol. I, } \\
\text { 1985, pp. 201- } \\
\text { 203. }\end{array}$ \\
\hline
\end{tabular}




\begin{tabular}{|c|c|c|c|c|c|c|}
\hline Nome & Localização & Função & Tarefas & Âmbito & Proveniência & Documentos \\
\hline $\begin{array}{c}\text { João del } \\
\text { Rincon } \\
\text { Salazar }\end{array}$ & Muxima & Capitão & $\begin{array}{c}\text { "Fazer } \\
\text { mucanos", zelar } \\
\text { pela proteção } \\
\text { dos sobas, } \\
\text { segurança dos } \\
\text { baculamentos, } \\
\text { beneficiamentos } \\
\text { das feiras, } \\
\text { defesa da } \\
\text { conquista, } \\
\text { guarnecimento } \\
\text { dos presídios e } \\
\text { conservação da } \\
\text { "paz". }\end{array}$ & $\begin{array}{l}\text { Jurisdicional, } \\
\text { militar, penal } \\
\text { e viagens } \\
\text { para a } \\
\text { descoberta de } \\
\text { minas. }\end{array}$ & $\begin{array}{l}\text { Portuguesa } \\
\text { (bastante } \\
\text { experiente } \\
\text { na terra). }\end{array}$ & $\begin{array}{c}\text { Fernão de } \\
\text { Sousa [escrito } \\
\text { por Luís Correa } \\
\text { Coelho]. } \\
\text { Regimento de } \\
\text { Fernão de } \\
\text { Sousa a João } \\
\text { del Rincon } \\
\text { Salazar, } \\
\text { Constantino } \\
\text { Cadena e } \\
\text { Sebastião Dias } \\
\text { Tição. 25 de } \\
\text { julho de 1624. } \\
\text { BAL, cód. 51- } \\
\text { IX-21, ff. 124- } \\
\text { 24v. IN: } \\
\text { HEINTZE, } \\
\text { Beatrix } \\
\text { (coord.). } \\
\text { Documento } \\
\text { 172, FHA, vol. } \\
\text { II, 1988, pp. } \\
267-268 .\end{array}$ \\
\hline
\end{tabular}

${ }^{960}$ Segundo Beatrix Heintze, no momento em que Fernão de Sousa aportou em Luanda, João del Rincon Salazar já prestava serviço havia 23 anos nessa região da África. Lá ele exerceu diversos postos, como os de sargento, ajudante, capitão de infantaria e sargento-mor. Foi nomeado "capitão de Muxima" em 25 de julho de 1624, onde deveria ficar por um ano. HEINTZE, Beatrix. Breves biografias de alguns europeus em Angola (1620-1630). FHA, vol. I, 1985, p. 105. 


\begin{tabular}{|c|c|c|c|c|c|c|}
\hline Nome & Localização & Função & Tarefas & Âmbito & Proveniência & Documentos \\
\hline $\begin{array}{c}\text { João } \\
\text { Carreiro } \\
\text { Fidalgo }\end{array}$ & Ambaca & Capitão & $\begin{array}{c}\text { "Fazer mucanos", } \\
\text { zelar pela proteção } \\
\text { dos sobas, segurança } \\
\text { dos baculamentos, } \\
\text { beneficiamentos das } \\
\text { feiras, defesa da } \\
\text { conquista, } \\
\text { guarnecimento dos } \\
\text { presídios, } \\
\text { conservação da } \\
\text { "paz" e condução da } \\
\text { eleição de soba } \\
\text { (Andala Catungo). }\end{array}$ & $\begin{array}{l}\text { Jurisdicional, } \\
\text { militar, penal. }\end{array}$ & $\begin{array}{l}\text { Portuguesa } \\
\text { e reinol. }{ }^{961}\end{array}$ & $\begin{array}{c}\text { Fernão de } \\
\text { Sousa. Portaria } \\
\text { de Fernão de } \\
\text { Sousa. } 16 \text { de } \\
\text { março de } 1630 . \\
\text { BAL, cód. } 51- \\
\text { IX-20, ff. } \\
\text { 444v-43. IN: } \\
\text { HEINTZE, } \\
\text { Beatrix } \\
\text { (coord.). } \\
\text { Documento } \\
215, F H A, \text { vol. } \\
\text { II, 1988, pp. } \\
318-319 .\end{array}$ \\
\hline $\begin{array}{c}\text { Manuel } \\
\text { Ferreira } \\
\text { Arco }\end{array}$ & Ambaca & Tendala & $\begin{array}{c}\text { Aceitou a } \\
\text { utilização de sua } \\
\text { casa como } \\
\text { cárcere, onde os } \\
\text { sobas eram } \\
\text { extorquidos a } \\
\text { fornecer peças. }\end{array}$ & $\begin{array}{l}\text { Comparsa de } \\
\text { Henrique de } \\
\text { Magalhães }\end{array}$ & $?$ & $\begin{array}{c}\text { Fernão de } \\
\text { Sousa. Portaria } \\
\text { de Fernão de } \\
\text { Sousa. } 16 \text { de } \\
\text { março de } 1630 . \\
\text { BAL, cód. 51- } \\
\text { IX-20, ff. } \\
444 v-43 \text {. IN: } \\
\text { HEINTZE, } \\
\text { Beatrix } \\
\text { (coord.). } \\
\text { Documento } \\
215, F H A, \text { vol. } \\
\text { II, 1988, pp. } \\
318-319 .\end{array}$ \\
\hline
\end{tabular}

${ }^{961}$ Segundo Beatrix Heintze, João Carreiro Fidalgo era "moço da Câmara do rei" e filho de Bartolomeu Carreiro. Em princípios de 1622, foi nomeado, pelo prazo de três anos, capitão da "fortaleza de Ango que ora se chama da Nossa Senhora de Assunção em Ambaca para onde o governador Luis Mendes de Vasconcelos mudou a dita fortaleza". Deixou a África em janeiro de 1628, rumo à Bahia de Todos os Santos. HEINTZE, Beatrix. Breves biografias de alguns europeus em Angola (1620-1630). FHA, vol. I, 1985, p. 89. 


\begin{tabular}{|c|c|c|c|c|c|c|}
\hline Nome & Localização & Função & Tarefas & Âmbito & Proveniência & Documentos \\
\hline $\begin{array}{c}\text { Manuel } \\
\text { Dias }\end{array}$ & $\begin{array}{c}\text { Quiçá } \\
\text { transitava } \\
\text { pela Angola } \\
\text { portuguesa. }\end{array}$ & $\begin{array}{c}\text { Soldado } \\
\text { (experiente) }\end{array}$ & \begin{tabular}{|c|} 
Junto com \\
Dionísio Faria \\
Barreto, serviu \\
em missão \\
diplomática. \\
enviada a \\
Angola \\
Ambande.
\end{tabular} & $\begin{array}{l}\text { Coercitivo, } \\
\text { militar e } \\
\text { diplomático. }\end{array}$ & Portuguesa & $\begin{array}{c}\text { Fernão de } \\
\text { Sousa. História } \\
\text { das relações } \\
\text { entre a Angola } \\
\text { portuguesa e o } \\
\text { Ndongo 1617- } \\
\text { 1624. S.d., por } \\
\text { volta do outono } \\
\text { de 1624. BAL, } \\
\text { cód. 51- IX- } \\
\text { 20, ff. 414- } \\
\text { 14v. IN: } \\
\text { HEINTZE, } \\
\text { Beatrix } \\
\text { (coord.). } \\
\text { Documento 23, } \\
\text { FHA, vol. I, } \\
\text { 1985, pp. 195- } \\
\text { 197. }\end{array}$ \\
\hline $\begin{array}{c}\text { Marcos } \\
\text { Pires }\end{array}$ & Massangano & $\begin{array}{c}\text { Mani } \\
\text { quitanda }\end{array}$ & $\begin{array}{c}\text { Foi chamado } \\
\text { para ocupar o } \\
\text { cargo de mani } \\
\text { quitanda na feira } \\
\text { de Gunza } \\
\text { Ambande, em } \\
1627 .\end{array}$ & Fiscal & $\begin{array}{l}\text { Africana. Ele } \\
\text { foi descrito } \\
\text { como um } \\
\text { "quimbar } \\
\text { forro". }\end{array}$ & $\begin{array}{c}\text { Fernão de } \\
\text { Sousa. O } \\
\text { extenso } \\
\text { relatório do } \\
\text { governador aos } \\
\text { seus filhos. } \\
\text { S.d., 1625- } \\
\text { 1630. BAL, } \\
\text { cód. 51-IX-20, } \\
\text { ff. 220-74v. } \\
\text { IN: HEINTZE, } \\
\text { Beatrix } \\
\text { (coord.). } \\
\text { Documento 30, } \\
\text { FHA, vol. I, } \\
\text { 1985, pp. 217- } \\
362 .\end{array}$ \\
\hline
\end{tabular}




\begin{tabular}{|c|c|c|c|c|c|c|}
\hline Nome & Localização & Função & Tarefas & Âmbito & Proveniência & Documentos \\
\hline $\begin{array}{l}\text { Paio de } \\
\text { Araújo } \\
\text { de } \\
\text { Azevedo }\end{array}$ & $\begin{array}{c}\text { Atravesso } \\
\text { u o } \\
\text { continente } \\
\text { em busca } \\
\text { de Ginga } \\
\text { Ambande. }\end{array}$ & $\begin{array}{l}\text { Capitão- } \\
\text { mor }^{962}\end{array}$ & $\begin{array}{c}\text { Como capitão-mor } \\
\text { do quilombo que } \\
\text { procurava Ginga } \\
\text { Ambande, o } \\
\text { português foi } \\
\text { responsável por } \\
\text { arregimentar a } \\
\text { "gente de guerra", } \\
\text { traçar operações } \\
\text { bélicas, dirigir as } \\
\text { companhias de } \\
\text { soldados e } \\
\text { esquematizar táticas } \\
\text { de ofensiva militar. } \\
\text { Durante o regresso a } \\
\text { Luanda, foi } \\
\text { responsável pela } \\
\text { dissolução do } \\
\text { quilombo. }\end{array}$ & $\begin{array}{c}\text { Militar, } \\
\text { tributário e } \\
\text { coercitivo. } \\
\text { Foi também } \\
\text { encarregado } \\
\text { de submeter } \\
\text { os sobas. }\end{array}$ & $\begin{array}{c}\text { Portuguesa } \\
\text { e reinol. }\end{array}$ & Vários \\
\hline $\begin{array}{l}\text { Sebastião } \\
\text { Dias Tição }\end{array}$ & $\begin{array}{c}\text { Atravessou o } \\
\text { continente } \\
\text { em busca de } \\
\text { Ginga } \\
\text { Ambande. }\end{array}$ & Capitão & $\begin{array}{c}\text { Foi nomeado capitão } \\
\text { de Massangano em } \\
1624 . \\
\text { Posteriormente, } \\
\text { assumiu uma } \\
\text { companhia de } \\
\text { soldados durante as } \\
\text { campanhas militares } \\
\text { contra Ginga } \\
\text { Ambande. }\end{array}$ & $\begin{array}{c}\text { Jurisdicional, } \\
\text { militar, penal } \\
\text { (durante o } \\
\text { exercício da } \\
\text { direção de } \\
\text { Massangano). }\end{array}$ & $\begin{array}{c}\text { Portuguesa } \\
\text { (natural de } \\
\text { Évora). }\end{array}$ & Vários \\
\hline
\end{tabular}

962 Quando Fernão de Sousa chegou à África, Paio de Araújo de Azevedo já detinha o título "honorífico" de capitão-mor. O capitão chegara e Luanda em 1602, acompanhando o governador João Rodrigues Coutinho. Ocupou desde então diversos ofícios e cargos, entre eles os de capitão lugar-tenente em Cambambe, juiz ordinário da Câmara de Luanda e durante o governo de Fernão de Sousa foi nomeado "ouvidor geral, provedor da fazenda, da comarca, das causas do mar e juiz dos órfãos", em decorrência da morte de Fernão Vogado Sotomaior. Ocupou a função de capitão-mor do quilombo após a morte de Bento Banha Cardoso, recebendo um regimento do governador, datado de 27 de agosto de 1628. HEINTZE, Beatrix. Breves biografias de alguns europeus em Angola (1620-1630). FHA, vol. I, 1985, pp. 73-74. 


\section{ANEXOS}

\section{Alguns títulos ou posições de soberania no Ndongo}

Tabela 3: Genealogia dos reis do Ndongo de acordo com uma tradição pende ${ }^{963}$

\begin{tabular}{|c|c|}
\hline Nome registrado ou posição titular & Breve descrição \\
\hline 1) Ngana Ngombe & "Aquele que iniciou o tráfico de escravos". \\
\hline 2) Ngola Inene Kiluanji & - \\
\hline 3) Ngola Ndambi Inene Ndjenge & "Um rei cruel". \\
\hline 4) Ngola Kiluanji kia Samba & - \\
\hline 5) Ngola Nzinga ia Bandji & - \\
\hline 6) Njinga Pande & "Rainha Nzinga, 1624-1663". \\
\hline
\end{tabular}

Tabela 4: Genealogia dos reis do Ndongo segundo Francesco Maria Gioia ${ }^{964}$

\begin{tabular}{|c|c|}
\hline Nome registrado ou posição titular & Breve descrição \\
\hline 1) Angola Bumbambula & Era um "ferreiro". \\
\hline 2) Zunduria Angola & Filho do primeiro soberano do Ndongo. \\
\hline 3) Chiluangi Chiasamba & $\begin{array}{l}\text { Era um "senhor de Bemba, casado com Hohoria } \\
\text { Angola", filha do primeiro rei acima registrado. }\end{array}$ \\
\hline 4) Angola Chiluangi & Filho do terceiro rei. \\
\hline 5) Dambi Angola & Filho do quarto rei. \\
\hline 6) Chiluangi Chiandambi Angola & Filho do quinto rei (teria morrido em 1557?). \\
\hline
\end{tabular}

${ }^{963}$ Informações extraídas de: BIRMINGHAM, David. Trade and conflict in Angola [...]. Londres: Clarendon Press/ Oxford University Press, 1966, p. 31. Por sua vez, Birmingham conseguiu as informações de: HAVEAUX, G. L. La Tradition historique des Bapende orientaux. Bruxelas: Institut Royal Colonial Belge (IRCB), 1954, pp. 10 e 48.

${ }^{964}$ Informações extraídas de: HEINTZE, Beatrix (coord.). Apêndice: Os reis do Ndongo segundo F. M. Gioia, $F H A$, vol. I, 1985, p. 394 e nota 3. Por sua vez, Heintze retirou a base dessa tabela de: GIOIA, Francesco Maria. La Maravigliosa conversione alla Santa Fede di Cristo della Regina Singa a del svo Regno di Matamba nell'Africa meridionale. Napoli: Biblioteca Nazionale, 1669, pp. 134-172 e 202-209. Heintze ainda aponta várias diferenças entre os escritos de Gioia em comparação com os de João António Cavazzi de Montecúccolo. Aqui optamos por retirar os apontamentos da pesquisadora, por entender que eles seriam redundantes em relação às informações registradas na "tabela 3" que segue abaixo. 


\begin{tabular}{|c|l|}
\hline 7) Angola Chiluangi & $\begin{array}{l}\text { Filho do sexto rei. Era o governante "no tempo das } \\
\text { duas expedições de Paulo Dias de Novais a } \\
\text { Angola". }\end{array}$ \\
\hline 8) Bandi Angola & \multicolumn{1}{|c|}{ Filho do sétimo rei } \\
\hline 9) Angola Bandi & $\begin{array}{l}\text { Trata-se do nosso "Angola Ambande". Era filho } \\
\text { do oitavo rei. Governou de 1617 até a primavera } \\
\text { de 1624, quando morreu. }\end{array}$ \\
\hline 10) Singa & $\begin{array}{l}\text { Trata-se da nossa "Ginga Ambande". Era filha do } \\
\text { oitavo rei. Viveu entre 1582 e 17 de dezembro de } \\
1663 .\end{array}$ \\
\hline 11) Angola Hari D. Filippo & Trata-se do nosso "Angola Aire Filipe I". \\
\hline
\end{tabular}

Tabela 5: Genealogia dos reis do Ndongo segundo João António Cavazzi de Montecúccolo 965

\begin{tabular}{|c|c|}
\hline Nome registrado ou posição titular & Breve descrição \\
\hline 1) Ngola a Kiluanje & - \\
\hline 2) Ndambi a Ngola & - \\
\hline 3) Ngola a Kiluanje & "Um usurpador" \\
\hline 4) Jinga a Ngola a Kilombo kya Kasenda & - \\
\hline 5) Mbande a Ngola & \\
\hline
\end{tabular}

965 Informações extraídas de: MILLER, Joseph C. Poder político e parentesco [...]. [1976]. Luanda: Arquivo Histórico Nacional, 1995, p. 82. Por sua vez, Miller retirou a base dessa tabela de: MONTECÚCCOLO, João António Cavazzi de. Descrição histórica dos três reinos do Congo, Matamba e Angola. [1687]. Lisboa: Junta de Investigação do Ultramar, vol. I, 1965, pp. 256-257. Para mais informações, consultar a figura e o quadro disponibilizados por Miller na p. 85 da primeira obra referenciada. 


\section{Uma cosmologia mbundu}

As duas tabelas que seguem abaixo explicam o funcionamento das visões de mundo na sociedade mbundu, de acordo com etno-historiador Virgílio Coelho. As informações levantadas por Coelho foram reorganizadas a fim de resumir o maior número de conteúdo coletado em campo de uma maneira descomplicada, ficando de fora apenas algumas redundâncias existentes no vários textos consultados.

\section{Tabela 6: Elementos básicos da cosmologia mbundu ${ }^{966}$}

\begin{tabular}{|c|c|c|c|c|}
\hline $\begin{array}{c}\text { Sistemas de } \\
\text { Representação }\end{array}$ & $\begin{array}{c}\text { Espaços } \\
\text { geográficos }\end{array}$ & $\begin{array}{c}\text { Territórios } \\
\text { sobrenaturais }\end{array}$ & $\begin{array}{c}\text { Evocação } \\
\text { Social }\end{array}$ & Materialização \\
\hline Kákùlù & $\begin{array}{c}\text { Mar } \\
\text { [Oceano Atlântico]. }\end{array}$ & $\begin{array}{l}\text { Kàlùngà ou íxì } \\
y \grave{a} \text { Kàlùngà = } \\
\text { Mundo dos } \\
\text { mortos. Além. }\end{array}$ & $\begin{array}{c}\text { Íxì yà } \\
\text { Álùngàngònbè = } \\
\text { Espaço territorial } \\
\text { dos } \\
\text { "Antepassados". }\end{array}$ & $\begin{array}{l}\text { Depósito das } \\
\text { relíquias reais. }\end{array}$ \\
\hline Kábàsà & $\begin{array}{c}\text { Terra } \\
\text { [Inclui a terra } \\
\text { propriamente dita e } \\
\text { o espaço visível } \\
\text { pelo Homem que } \\
\text { constitui o céu]. }\end{array}$ & $\begin{array}{l}\text { Ngòngò ou Kúlù } \\
n i ̀ \text { díwùlù = } \\
\text { Mundo dos } \\
\text { vivos. Universo. }\end{array}$ & $\begin{array}{c}\text { Íxì yà Ngòngò } \\
\text { País dos } \\
\text { Túmúndòngò, } \\
\text { espaço territorial } \\
\text { dos vivos. }\end{array}$ & $\begin{array}{c}\text { Espaço de } \\
\text { convívio com os } \\
\text { súbditos. }\end{array}$ \\
\hline
\end{tabular}

\footnotetext{
${ }^{966}$ Informações reagrupadas a partir de: COELHO, Virgílio. Os Túmúndòngò, os "génios" da natureza e o kílàmbà: Estudos sobre a sociedade e a cultura kímbùndù. Luanda: Kilombelombe, 2010, quadro 7, "As terminologias e as suas correspondências", p. 164; quadro 8, "As terminologias e as suas correspondências", p. 166. Do mesmo autor: "Em busca de Kábàsà!..." Estudos e reflexões sobre o "Reino" do Ndòngò: Contribuições para a História de Angola. Luanda: Kilombelombe, 2010, quadro 1, p. 72; quadro 2, p. 149; quadro 3 p. 160 e quadro 4, p. 218.
} 


\section{Tabela 7: Esboço geral sobre as concepções de kákùlù e kábàsàa 967}

\begin{tabular}{|c|l|}
\hline $\begin{array}{c}\text { Sistemas de } \\
\text { Representação }\end{array}$ & \multicolumn{1}{|c|}{ Considerações e aspectos gerais } \\
\hline Kákùlù & $\begin{array}{l}\text { Mundo dos mortos, dos antepassados dos Túmúndòngò, mundo do além, da } \\
\text { negrura, da imensidão. Mar, Oceano Atlântico, Kálùngà. Entidade do mundo } \\
\text { numinoso. Mundo primordial, mundo dos começos, mundo do criador de tudo } \\
\text { quanto possuímos hoje ou de quem herdamos e que é necessário reverenciar } \\
\text { sempre que possível (e necessário). }\end{array}$ \\
\hline Kábàsà & $\begin{array}{l}\text { Mundo dos seres vivos, do Homem, de todos aqueles que falam a língua do país (o } \\
\text { kímbùndù), factor de unidade e aglutinadora dos seus membros, na partilha de uma } \\
\text { mesma cultura e identidade. Kímbùndù: túzwélè mù kábàsà kwètù, isto é, "falemos } \\
\text { a nossa língua", dizem. }\end{array}$ \\
\hline
\end{tabular}

${ }^{967}$ Listas de informações extraídas e reagrupadas a partir de: COELHO, Virgílio. Os Túmúndòngò [...]. Luanda: Kilombelombe, 2010, quadro 7, “As terminologias e as suas correspondências”, p. 164. Do mesmo autor: “Em busca de Kábàsà!...” [...]. Luanda: Kilombelombe, 2010. pp. 71-72; pp. 148-149 e 219. 


\section{FONTES E BIBLIOGRAFIA}

\section{Fontes}

BLUTEAU, Raphael. Vocabulario portuguez, e latino, aulico, anatomico, architectonico, bellico, botanico... autorizado com exemplos dos melhores escritores portuguezes e latinos e offerecido a El rey de Portugal D. João V. [1712-1728]. Hildesheim: Georg Olms Verlag, 10 vols., 2002.

BRÁSIO, António (col. e anot.). Monumenta Missionaria Africana. África Ocidental. Lisboa: Agência Geral do Ultramar, $1^{\mathrm{a}}$ série, 15 vols., 1952-1985.

BRITO, Domingos de Abreu e. Um inquérito à vida administrativa e económica de Angola $e$ do Brasil em fins do século XVI: segundo o manuscrito inédito existente na Biblioteca Nacional de Lisboa. $1^{a}$ edição. Coimbra: Imprensa da Universidade, 1931, p. 97.

CADORNEGA, António de Oliveira de. História Geral das Guerras Angolanas. [16801681]. Edição de José Matias Delgado (vols. I e II) e Manuel Alves da Cunha (vol. III). Lisboa: Divisão de Publicações e Biblioteca/ Agência Geral das Colónias, 1940-1942.

CORTESÃO, Armando; MOTA, Avelino Teixeira da. Portvgaliae Monvmenta Cartographica. Lisboa: Comissão Executiva das Comemorações do V Centenário da Morte do Infante D. Henrique, 6 vols, 1960.

DAPPER, Olfert. Umbständliche und eigentliche Beschreibung von Afrika, Anno 1668. Amsterdam: Steingrüben, 1670.

FELNER, Alfredo Albuquerque de. Angola. Apontamentos sobre a ocupação e início de estabelecimento dos portugueses no Congo, Angola e Benguela. $1^{\text {a }}$ edição. Coimbra: Imprensa da universidade, 1933, p. 593.

GIOIA, Francesco Maria. La Maravigliosa conversione alla Santa Fede di Cristo della Regina Singa a del svo Regno di Matamba nell'Africa meridionale. Napoli: Biblioteca Nazionale, 1669.

HEINTZE, Beatrix (coord.). Fontes para a história de Angola do século XVII: I. Cartas e documentos oficiais da coletânea de Fernão de Sousa (1622-1635). $1^{\mathrm{a}}$ edição. Stuttgart: Frans Steiner Verlag Wiesbaden GMBH, 1985, p. 419. II. Cartas e documentos oficiais da coletânea de Fernão de Sousa (1624-1635). $1^{\mathrm{a}}$ edição. Stuttgart: Frans Steiner Verlag Wiesbaden GMBH, 1988, p. 431.

IARRIC, Pierre du. Histoires des choses plus memorables advenves tant ez Indes Orientales, que autres païs de la decounerte des Portugais. Bordeaux, 1610. 
MONTECÚCCOLO, João António Cavazzi de. Descrição histórica dos três reinos do Congo, Matamba e Angola. [1687]. Tradução de Graciano Maria de Leguzzano; prefácio de Francisco Leite de Faria. Lisboa: Junta de Investigação do Ultramar, 2 vols., 1965.

\section{Bibliografia citada}

ALENCASTRO, Luiz Felipe de. A economia política dos descobrimentos. IN: NOVAES, Adauto (org.). A descoberta do homem e do mundo. $1^{\mathrm{a}}$ edição. Rio de Janeiro: Minc-FUNARTE/ Companhia das Letras, São Paulo, 1998, p. 592.

O trato dos viventes: A formação do Brasil no Atlântico

Sul. $1^{\text {a }}$ edição, $5^{\text {a }}$ reimpressão utilizada. São Paulo: Companhia das Letras, 2000, p. 525.

. The Economic Network of Portugal's Atlantic World.

Tradução de Marguerite Itamar Harisson. IN: BETHENCOURT, Francisco; CURTO, Diogo Ramada (ed.). Portuguese Oceanic Expansion, 1400-1800. $1^{\text {a }}$ edição. Cambridge: Cambridge University Press, 2007, p. 536.

. The Ethiopic Ocean - History and Historiography, 16001975. IN: ALENCASTRO, Luiz Felipe de (ed.). The South Atlantic, Past and Present. $1^{\text {a }}$ edição. Dartmouth: Tagus Press at UMass Dartmouth, 2014, pp. 1-79.

ANDERSON, Benedict. Imagined Communities. Reflection on the Origin and Spread of Nationalism. $1^{\text {a }}$ edição de 1983, $2^{\text {a }}$ edição. Nova Iorque e Londres: Verso, 1991, p. 224.

ANDERSON, Perry. Linhagens do estado Absolutista. Título original: Lineages of the absolutist state. [1974]. Tradução de João Roberto Martins Filho. $1^{\circ}$ edição brasileira de 1985, $2^{\mathrm{a}}$ reimpressão utilizada. São Paulo. Editora Brasiliense, 2004, p. 548.

Classes e Estados: Problemas de Periodização. [1976]. IN: HESPANHA, António Manuel (ed.). Poder e instituições na Europa do Antigo Regime: coletânea de textos. $1^{\mathrm{a}}$ edição. Lisboa: Fundação Calouste Gulbenkian, 1984, p. 541.

BALANDIER, Georges. A Noção de Situação Colonial. [1955]. Tradução de Nicolás Nyimi Campanário, revisão de Paula Monteiro. Cadernos de Campo. São Paulo: Universidade de São Paulo (USP), n. ${ }^{\circ}$ 3, 1993, pp. 107-131.

. A situação colonial: abordagem teórica. [1951]. Tradução de Bruno Anselmi Matangrano. Cadernos CERU. São Paulo: Universidade de São Paulo (USP), série 2, vol. 25, n. ${ }^{\circ}$, junho de 2014, pp. 33-58.

BATSÎKAMA, Patrício. O poder político entre os Mbûndu. Sankofa: Revista de História da África e de Estudos da Diáspora Africana. São Paulo: Universidade de São Paulo (USP), vol. 9, n. ${ }^{\circ}$ 16, janeiro de 2016. 
BENJAMIN, Walter. Sobre o conceito da História. [1940]. IN: Magia e técnica, arte e política: ensaios sobre literatura e história da cultura. $1^{\mathrm{a}}$ edição de $1985 ; 8^{\mathrm{a}}$ edição revista utilizada. São Paulo: Editora Brasiliense, vol. I, 2012, p. 272.

BETHENCOURT, Francisco. Creolization of the Atlantic World: The Portuguese and the Kongolese. Portuguese Studies. Cambridge: Modern Humanities Research Association, vol. 27, $1^{\circ}$ semestre de 2011, pp. 56-69.

BETHENCOURT, Francisco; CURTO, Diogo Ramada (ed.). Portuguese Oceanic Expansion, 1400-1800. $1^{\text {a }}$ edição. Cambridge: Cambridge University Press, 2007, p. 536.

BHABHA, Homi K. The Location of Culture. $1^{\mathrm{a}}$ edição. Londres e Nova Iorque: Routledge, 1994, p. 408.

BLOCH, Marc Leopold Benjamin. Apologia da história, ou, O Ofício de historiador. Título original: Apologie pour l'histoire ou Métier d'historien. [1949]. Prefácio, Jacques Le Goff; apresentaçaõ à edição brasileira, Lilia Moritz Schwarcz; tradução, André Telles. $1^{\mathrm{a}}$ edição brasileira. Rio de Janeiro: Zahar, 2001.

BICALHO, Maria Fernanda Baptista. As câmaras ultramarinas e o governo do Império. IN: FRAGOSO, João; BICALHO, Maria Fernanda Baptista; GOUVÊA, Maria de Fátima Silva (org.). O Antigo Regime nos trópicos: a dinâmica imperial portuguesa (séculos XVI-XVIII). $1^{\text {a }}$ edição. Rio de Janeiro: Civilização Brasileira, 2001, p. 473. As fronteiras da negociação: as câmaras municipais na América Portuguesa e o poder central. IN: XX SIMPÓSIO NACIONAL DE HISTÓRIA, 1999, Florianópolis. NODARI, Eunice; PEDRO, Joana Maria. LOKOI, Zilda M. Gricoli (org.). História: Fronteiras - Anais do XX Simpósio Nacional de História. São Paulo: Associação Nacional de História (ANPUH), 1999, pp. 467483.

. Conquista, Mercês e Poder Local. A nobreza da terra na América portuguesa e a cultura política do Antigo Regime. Almanack Braziliense. São Paulo: Universidade de São Paulo (USP)/ Instituto de Estudos

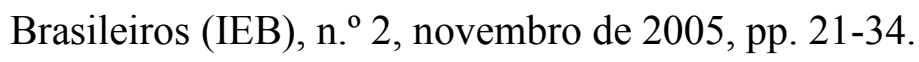

- Entre a teoria e a prática: dinâmicas políticoadministrativas em Portugal e na América portuguesa (séculos XVII e XVIII). Revista de História. São Paulo: Universidade de São Paulo, n. ${ }^{\circ}$ 167, julho/dezembro de 2012 pp. 75-98.

BIRMINGHAM, David. Central Africa to 1870: Zambezia, Zaïre and the South Atlantic. $1^{\text {a }}$ edição de 1981, reimpressão utilizada. Cambridge: Cambridge University Press, 2012, p. 177.

1999, p. 203.

. Portugal and Africa. $1^{\mathrm{a}}$ edição. Athens: Ohio University Press,

. Trade and conflict in Angola: the Mbundu and their neighbours under the influence of the Portuguese 1483-1790. $1^{\mathrm{a}}$ edição. Londres: Clarendon Press/ Oxford University Press, 1966, p. 178. 
. Trade and empire in the Atlantic, 1400-1600. $1^{\mathrm{a}}$ edição. Londres e Nova Iorque: Routledge, 2000, p. 99.

BONCIANI, Rodrigo Faustinoni. Descolonização e Racismo: atualidade e crítica, Diáspora e Colonização. Sankofa: Revista de História da África e de Estudos da Diáspora Africana. São Paulo: Universidade de São Paulo (USP), n. ${ }^{\circ}$ 8, ano IV, dezembro de 2011, pp. 21-28.

- O dominium sobre os indígenas e africanos e a especificidade da soberania régia no Atlântico: Da colonização das ilhas à política ultramarina de Felipe III (1493-1615). Tese de doutorado em História Social, Faculdade de Filosofia, Letras e Ciências Humanas (FFLCH)/ Departamento de História, Universidade de São Paulo (USP), 2010.

BORNHEIN, Gerd. A descoberta do homem e do mundo. IN: A descoberta do homem e do mundo. $1^{\mathrm{a}}$ edição. Rio de Janeiro: Minc-FUNARTE: Companhia das Letras, São Paulo, 1998, p. 592.

BRAUDEL, Fernand. A Dinâmica do Capitalismo. Título original: La Dynamique du Capitalisme. [1985]. Tradução de Carlos da Veiga Ferreira. 1 ${ }^{a}$ edição. Lisboa: Editorial Teorema, 1985, p. 123.

. A Longa Duração. [1958]. IN: História e Ciências Sociais. Tradução de Carlos Braga e Inácia Canelas. 1ª edição. Lisboa: Editorial Presença, 1972, p. 260.

. O Mediterrâneo e o Mundo Mediterrânico na época de Filipe II. [1966]. Tradução a partir da quarta edição francesa de 1979. $1^{a}$ edição. Lisboa: Editora Martins Fontes/ Publicações Dom Quixote, 1983, vol. I, p. 694. 1ª edição. Lisboa: Editora Martins Fontes/ Publicações Dom Quixote, 1984, vol. II, p. 729.

BROOKS, George E. Eurafricans in the Western Africa: Commerce, Social Status, Gender, and Religious Observance from the Sixteenth to the Eighteenth Century. $1^{\text {a }}$ edição. Athens: Ohio University Press/ Oxford: James Currey, 2003, p. 355.

BURKE, Peter. A Escola dos Annales (1929-1989): a Revolução Francesa da historiografia. Título Original: The French Historical Revolution: The Annales School, 1929-1989. [1990]. Tradução de Nilo Odalia. 1ª edição brasileira. São Paulo: Fundação Editora da UNESP, 1997, p. 154.

CANDIDO, Mariana P. Los lazos que unen Centroamérica a un puerto africano del Atlántico Sur. Benguela y la Trata de esclavos, 1617-1800. Boletín AFEHC. Toulouse: Asociación para el Fomento de los Estudios Históricos en Centroamérica, n. ${ }^{\circ}$ 55, 4 de dezembro de 2012, pp. 1-19. Endereço eletrônico: http://afehc-historiacentroamericana.org/index.php? action $=$ fi_aff\&id $=3229$.

. O limite tênue entre liberdade e escravidão em Benguela durante a era do comércio transatlântico. Afro-Ásia. Salvador: Universidade Federal da Bahia (UFBA), n. ${ }^{\circ}$ 47, 2013, pp. 239-268. O mesmo texto foi publicado em: 
Almanack. Guarulhos: Universidade Federal de São Paulo (UNIFESP), n. ${ }^{\circ}$ 6, novembro de 2013, pp. 239-268.

. Os agentes não europeus na comunidade mercantil de Benguela, c. 1760-1820. Sceculum: Revista De História. João Pessoa: Universidade Federal da Paraíba (UFPB), n. ${ }^{\circ}$ 29, julho/dezembro de 2013, pp. 97-124.

. South Atlantic Exchanges: The Role of Brazilian-Born Agents in

Benguela, 1650-1850. Luso-Brazilian Review. Madison: University of Wisconsin Press, vol. 50, n. ${ }^{\circ}$ 1, 2013, pp. 53-82. Endereço eletrônico: http://muse.jhu.edu/journals/lbr/summary/v050/50.1.candido.html.

CABRAL, Iva. Ribeira Grande: vida urbana, gente, mercancia, estagnação. IN: SANTOS, Maria Emília Madeira (coord.). História Geral de Cabo Verde. $1^{\text {a }}$ edição. Lisboa: Instituto de Investigação Científica Tropical, vol. II, 1995, p. 642.

CARVALHO, Flávia Maria de. Os homens do rei em Angola: sobas, governadores e capitães-mores, séculos XVII e XVIII. Tese de doutorado, Instituto de Ciências Humanas e Filosofia, Universidade Federal Fluminense (UFF), 2013.

CERUTTI, Simona. Processo e experiência: indivíduo, grupos e identidades em Turim no século XVII. IN: REVEL, Jacques (org.). Jogos de escalas: a experiência da microanálise. Título original: Jeux d'échelles: la micro-analyse à l'expérience. [1996]. Tradução de Dora Rocha. $1^{\text {a }}$ edição brasileira. Rio de Janeiro: Editora Fundação Getúlio Vargas (FGV), 1998, p. 262.

CHAKRABARTY, Dipesh. Habitations of modernity: essays in the wake of subaltern studies. $1^{\text {a }}$ edição. Chicago: The University of Chicago Press, 2002, p. 173.

. Provincializing Europe: Postcolonial Thought and Historical Difference. $1^{\mathrm{a}}$ edição de $2000,2^{\mathrm{a}}$ edição utilizada. Princeton: Princeton University Press, 2008, p. 305.

CHAMBOULEYRON, Rafael; MELO, Vanice Siqueira de. Governadores e índios, guerras e terras entre o Maranhão e o Piaú (primeira metade do século XVIII). Revista de História. São Paulo: Universidade de São Paulo, n. ${ }^{\circ}$ 168, janeiro/junho 2013, pp. 167-200. Endereço eletrônico: http://revhistoria.usp.br/index.php/br/edicoes/271-rh168.

CHAMBOUlEYRON, Rafael; BONIFÁCIO, Monique da Silva; MELO, Vanice Siqueira de. Pelos sertões "estão todas as utilidades". Trocas e conflitos no sertão amazônico (século XVII). Revista de História (USP). São Paulo: Universidade de São Paulo, n. ${ }^{\circ} 162,1^{\circ}$ semestre de 2010 , pp. 13-49.

COELHO, Virgílio. "Em busca de Kábàsà!..." Estudos e reflexões sobre o "Reino" do Ndòngò: Contribuições para a História de Angola. $1^{\text {a }}$ edição. Luanda: Kilombelombe, 2010, p. 468. . Em busca de Kábàsà: Uma tentativa de explicação da estrutura políticoadministrativa do "Reino de Ndongo". IN: ENCONTRO DE POVOS E CULTURAS EM ANGOLA, 1995, Luanda. Actas do Seminário Encontros de 
povos e culturas em Angola. Luanda: Comissão Nacional para as Comemorações dos Descobrimentos Portugueses, 1995. . Os Túmúndòngò, os "génios" da natureza e o kílàmbà: Estudos sobre a sociedade e a cultura kímbùndù. $1^{a}$ edição. Luanda: Kilombelombe, 2010, p. 418.

CORRÊA, Elias Alexandre da Silva. História de Angola. [1792-1799]. Anotações de Manuel Múrias. Lisboa: Editorial Ática, Colecção dos clássicos da expansão portuguesa no mundo, série E (Império africano), 2 vols., 1937.

CUNHA, Mafalda Soares da. A Casa de Bragança 1560-1640: Práticas senhoriais e redes clientelares. $1^{\mathrm{a}}$ edição. Lisboa: Editorial Estampa, 2000, p. 654. . Governo e governantes do Império português do Atlântico (século XVII). IN: BICALHO, Maria Fernanda Baptista; FERLINI, Vera Lúcia Amaral (org.). Modos de governar: idéias e práticas políticas no Império português, séculos XVI-XIX. $1^{\mathrm{a}}$ edição. São Paulo: Alameda, 2005, p. 448.

CUNHA, Mafalda Soares da; MONTEIRO, Nuno G. Aristocracia, poder e família em Portugal, séculos XV-XVIII. IN: CUNHA, Mafalda Soares da; FRANCO, Juan Hernández (org.). Sociedade, família e poder na Península Ibérica: Elementos para uma História Comparativa. $1^{\text {a }}$ edição. Lisboa: Edições Colibri/ CIDEHUS Universidade de Évora/ Universidad de Murcia, 2010, p. 276.

CURTIN, Philip D. Economic Change in Precolonial Africa: Senegambia in the Era of the Slave Trade. $1^{\text {a }}$ edição. Wisconsin: University of Wisconsin, 1975, vol. I de p. 363, vol. II de p. 150.

49.

.Why People Move. $1^{a}$ edição. Waco: Baylor University Press, 1995, p.

CURTIN, Philip D.; FEIERMAN, Steven; THOMPSON, Leonard; VANSINA, Jan. African History: From Earliest Times to Independence. $1^{\text {a }}$ edição de 1978, $2^{\text {a }}$ edição utilizada. Edimburgo: Longman Pearson Education, 1995, p. 546.

CURTO, José C. Resistência à escravidão na áfrica: o caso dos escravos fugitivos recapturados em Angola, 1846-1876. Afro-Ásia. Salvador: Universidade Federal da Bahia (UFBA), n. ${ }^{\circ}$ 33, 2005, pp. 67-86.

. The Anatomy of a Demographic Explosion: Luanda, 1844-1850. The International Journal of African Historical Studies. Boston: Boston University African Studies, vol. 32, n. ${ }^{\circ}$ 2/3, 1999, pp. 381-405. Endereço eletrônico: http://www.jstor.org/stable/220347.

DIAS, Jill. Caçadores, Artesãos, Comerciantes, Guerreiros: os Cokwe em perspectiva histórica. COLÓQUIO EM HOMENAGEM A MARIE-LOUISE BASTIN, PORTO, 1999. IN: SILVA, Armando Coelho Ferreira da; GONÇALVES, António Custódio (org.). A Antropologia dos Tshokwe e povos aparentados. $1^{\mathrm{a}}$ edição. Porto: Faculdade de Letras da Universidade do Porto, 2003, p. 107. 
_. Famine and Disease in the History of Angola c. 1830-1930. The Journal of African History. Cambridge: Cambridge University Press, vol. 22, n. ${ }^{\circ} 3$, 1981, pp. 349-378. Endereço eletrônico: http://www.jstor.org/stable/181808.

Mudanças nos padrões de poder no «hinterland» de Luanda: o impacto da colonização sobre os Mbundu (c. 1845-1920). Penélope: revista de história e ciências sociais. Lisboa: Cooperativa Penélope, Fazer e Desfazer a História, n. ${ }^{\circ} 14$, 1994, pp. 43-91. Endereço digital: http://dialnet.unirioja.es/servlet/articulo?codigo $=2685347$.

ELTIS, David; BEHRENDT, Stephen D.; RICHARDSON, David. A participação dos paises da Europa e das Américas no tráfico transatlântico de escravos: novas evidências. Afro-Ásia. Salvador: Universidade Federal da Bahia (UFBA), n. ${ }^{\circ}$ 24, 2000, pp. 9-50.

FERREIRA, Roquinaldo. Cross-Cultural Exchange in the Atlantic World: Angola and Brazil During the Era of the Slave Trade. $1^{\mathrm{a}}$ edição. Cambridge: Cambridge University Press, 2012, p. 261.

. "Ilhas crioulas": o significado plural da mestiçagem cultural na África Atlântica. Revista de História (USP). São Paulo: Universidade de São Paulo, n. ${ }^{\circ} 155,2^{\circ}$ semestre de 2006, pp. 17-41.

. The Supply and Deployment of Horses in Angolan Warfare (17th and 18th centuries). IN: HEINTZE, Beatrix; OPPEN, Achim von (ed.). Angola on the Move: Transport Routes, Communications and History. $1^{\mathrm{a}}$ edição. Frankfurt am Main: Verlag Otto Lembeck, 2008, p. 265. Endereço digital: http://www.frobeniusinstitut.de.

FERREIRA, Aurora Fonseca; TAVARES, Ana Paula Ribeiro. A problemática da pesquisa sobre História de Angola. África: Revista do Centro de Estudos Africanos da USP. São Paulo: Universidade de São Paulo, n. ${ }^{0}$ 9, 1986, pp. 80-90.

FONSECA, M.B. Nzinga Mbandi e as guerras de resistência em Angola: século XVII. Dissertação de mestrado em História Social, Faculdade de Filosofia, Letras e Ciências Humanas (FFLCH)/ Departamento de História, Universidade de São Paulo (USP), 2012.

FRAGOSO, João; GOUVÊA, Maria de Fátima Silva; BICALHO, Maria Fernanda Baptista (org.). Uma leitura do Brasil Colonial: Bases da materialidade e da governabilidade no Império. Penélope: revista de história e ciências sociais. Lisboa: Cooperativa Penélope, Fazer e Desfazer a História, n. ${ }^{\circ}$ 23, 2000, pp. 67-88.

FROMONT, Cécile. The Art of Conversion: Christian Visual Culture in the Kingdom of Kongo. $1^{a}$ edição. Chapel Hill: The University of North Carolina Press, 2014, p. 352.

GEERTZ, Clifford. A interpretação das Culturas. $1^{\text {a }}$ edição. Rio de Janeiro: Editora Guanabara Koogan, 1989, p. 321. 
GINZBURG, Carlo. Mitos, emblemas, sinais: morfologia e história. Título original: Mitti emblemi spie: morfologia e storia. [1986]. Tradução de Federico Carotti. $1^{\text {a }}$ edição brasileira de 1989; $5^{\text {a }}$ reimpressão da $2^{\text {a }}$ edição utilizada. São Paulo: Companhia das Letras, 2012.

. O queijo e os vermes: o cotidiano e as ideias de um moleiro perseguido pela Inquisição. Título original: Il formaggio e $i$ vermi: Il cosmo di un mugnaio del '500. [1976]. Tradução de Maria Betânia Amoroso; Tradução dos poemas de José Paulo Paes; revisão téncnica de Hilário Franco Jr. $1^{\mathrm{a}}$ edição brasileira de 2006, $4^{\mathrm{a}}$ reimpressão utilizada. São Paulo: Companhia das Letras, 2010 .

GODINHO, Vitorino Magalhães. O que significa descobrir?. IN: NOVAES, Adauto (Org.). A descoberta do homem e do mundo. $1^{\mathrm{a}}$ edição. Rio de Janeiro: Minc-FUNARTE: Companhia das Letras, São Paulo, 1998, p. 592.

GOMES, Flávio; FERREIRA, Roquinaldo. A miragem da miscigenação. Novos estudos. São Paulo: CEBRAP, n. ${ }^{\circ} 80$, março de 2008, pp. 141-160.

GONÇALVES, Rosana. África Indômita: Missionários capuchinhos no Reino do Congo (século XVII). Dissertação de mestrado em História Social, Faculdade de Filosofia, Letras e Ciências Humanas (FFLCH)/ Departamento de História, Universidade de São Paulo (USP), 2008.

GOUVÊA, Maria de Fátima Silva. Poder político e administração na formação do complexo atlântico português (1645-1808). IN: FRAGOSO, João; BICALHO, Maria Fernanda Baptista; GOUVÊA, Maria de Fátima Silva (org.). O Antigo Regime nos trópicos: a dinâmica imperial portuguesa (séculos XVI-XVIII). $1^{\mathrm{a}}$ edição. Rio de Janeiro: Civilização Brasileira, 2001, p. 473.

GREEN, Tobias. Masters of Difference: Creolization and the Jewish presence in Cabo Verde, 1497-1672. Tese de doutorado, Centre of West African Studies, Universidade de Birmingham, 2007. . Beyond an Imperial Atlantic: trajectories of Africans from Upper Guinea and West-Central Africa in the early Atlantic World. Past and Present. Oxford: Oxford University Press, n. ${ }^{\circ}$ 230, fevereiro de 2016, pp. 91-122.

GRENDI, Edoardo. Microanálise e história social. IN: ALMEIDA, Carla Maria Carvalho de, OLIVEIRA, Mônica Ribeiro de (org.). Exercícios de micro-história. $1^{\text {a }}$ edição. Rio de Janeiro: Editora Fundação Getúlio Vargas (FGV), 2009, p. 300.

. Repensar a micro-história?. IN: REVEL, Jacques (org.). Jogos de escalas: a experiência da micro-análise. Título original: Jeux d'échelles: la microanalyse à l'expérience. [1996]. Tradução de Dora Rocha. $1^{\mathrm{a}}$ edição brasileira. Rio de Janeiro: Editora Fundação Getúlio Vargas (FGV), 1998, p. 262.

HALL, Stuart. A identidade cultural na pós-modernidade. Título original: The question of cultural identity. [1992]. Tradução de Tomaz Tadeu da Silva e Guacira Lopes Louro. $3^{\text {a }}$ edição. Rio de Janeiro: DP\&A, 2006, p. 102. 
HANSEN, João Adolfo. A servidão natural do selvagem e a guerra justa contra o bárbaro. IN: NOVAES, Adauto (Org.). A descoberta do homem e do mundo. $1^{\text {a }}$ edição. Rio de Janeiro: Minc-FUNARTE/ Companhia das Letras, São Paulo, 1998, p. 592.

HAVEAUX, G. L. La Tradition historique des Bapende orientaux. Bruxelas: Institut Royal Colonial Belge (IRCB), Section des Sciences morales et politiques, mémoire in- $8^{\circ}$, tomo XXXVII, fasc. 1, 1954, p. 56.

HAVIK, Philip J.; GREEN, Tobias. Introduction: Brokerage and the Role of Western Africa in the Atlantic World. GREEN, Tobias (ed). Brokers of Change: Atlantic Commerce and Cultures in Precolonial Western Africa. $1^{\text {a }}$ edição. Oxford: The British Academy/ Oxford University Press, 2012, p. 415

HEINTZE, Beatrix. Angola nos séculos XVI e XVII: estudos sobre fontes, métodos e história. $1^{\mathrm{a}}$ edição. Luanda: Kilombelombe, 2007, p. 623.

. A lusofonia no interior da África Central na era pré-colonial: Um contributo para a sua história e compreensão na actualidade. Cadernos de Estudos Africanos. Lisboa: Centro de Estudos Internacionais/ Instituto Universitário de Lisboa (ISCTE-IUL), n. ${ }^{\circ} \quad 7 / 8, \quad 2005, \quad$ pp. 180-207. Endereço digital: http://cea.revues.org/1361.

. References in the Humanities: Strategies of Being Open, Being Obscure and Being Misleading. History in Africa. Nova Jersey: African Studies Association, vol. 27, 2000, pp. 437-442. Endereço digital: http://www.jstor.org/stable/3172124.

. The Extraordinary Journey of the Jaga Through the Centuries: Critical Approaches to Precolonial Angolan Historical Sources. History in Africa. Nova Jersey: African Studies Association, vol. 34, 2007, pp. 67-101. Endereço digital: http://www.jstor.org/stable/25483692.

. Resenha sem título. Journal of the International African Institute. Cambridge: Cambridge University Press/ International African Institute, vol. 48, no. 1, 1978, pp. 85-86. Endereço digital: http://www.jstor.org/stable/1158713.

. Translations as Sources for African History. History in Africa. Nova Jersey: African Studies Association, vol. 11, 1984, pp. 131-161. Endereço digital: http://www.jstor.org/stable/3171632.

. Written Sources and African History: A Plea for the Primary Source. The Angola Manuscript Collection of Fernão de Sousa. History in Africa. Nova Jersey: African Studies Association, vol. 9, 1982, p. 77-103. Endereço digital: http://www.jstor.org/stable/3171600.

HENRIQUES, Isabel Castro. A materialidade do simbólico: marcadores territoriais, marcadores identitários angolanos (1880-1950). Textos De História. Brasília: Universidade de Brasilia (UnB), vol. 12, n.. 1/2, 2004, pp. 9-41. . Reflexões sobre o "escravo" africano. IN: O Pássaro do mel: Estudos de História Africana. $1^{\mathrm{a}}$ edição. Lisboa: Edições Colibri, 2003, p. 248. 
HESPANHA, António Manuel. A constituição do Império português. Revisão de alguns enviesamentos correntes. IN: FRAGOSO, João; BICALHO, Maria Fernanda Baptista; GOUVÊA, Maria de Fátima Silva (org.). O Antigo Regime nos trópicos: a dinâmica imperial portuguesa (séculos XVI-XVIII). $1^{\mathrm{a}}$ edição. Rio de Janeiro: Civilização Brasileira, 2001, p. 473.

. As vésperas do Leviathan: instituições e poder político. Portugal, século XVII. $1^{\text {a }}$ edição. Coimbra: Editora Almedina, 1994, p. 682.

História das Instituições: época medieval e moderna. $1^{\mathrm{a}}$ edição. Coimbra: Livraria Almedina, 1982, p. 569.

- Para uma teoria da história institucional do Antigo Regime. [1982]. IN: HESPANHA, António Manuel (ed.). Poder e instituições na Europa do Antigo Regime: coletânea de textos. $1^{\mathrm{a}}$ edição. Lisboa: Fundação Calouste Gulbenkian, 1984, p. 541.

. Por que é que foi "portuguesa" a expansão portuguesa? ou O revisionismo nos trópicos. IN: SOUZA, Laura de Mello e; FURTADO, Júnia Ferreira; BICALHO, Maria Fernanda (org.). O governo dos povos. 1ª edição. São Paulo: Alameda, 2009.

HEYWOOD, Linda M.; THORNTON, John K. Central Africans, Atlantic Creoles, and the Foundation of the Americas, 1585-1660. $1^{\text {a }}$ edição. Cambridge: Cambridge University Press, 2007, p. 386.

HOBSBAWN, Eric. Sobre história. Título original: On History. [1997]. Tradução de Cid Knipel Moreira. $1^{a}$ edição brasileira de 1998, $4^{a}$ reimpressão utilizada. São Paulo: Companhia das Letras, 2001.

HORTA, José da Silva. A "Guiné do Cabo Verde": produção textual e representações (1578-1648). $1^{\text {a }}$ versão de 2002; $2^{\text {a }}$ versão revisada utilizada. Tese de doutorado em História da Expansão Portuguesa, Faculdade de Letras, Universidade de Lisboa, 2010.

HUTZ, Ana. Homem de Nação e de Negócio: redes comerciais no Mundo Ibérico (15801640). Tese de doutorado em História Econômica, Faculdade de Filosofia, Letras e Ciências Humanas (FFLCH)/ Departamento de História, Universidade de São Paulo (USP), 2014.

LARA, Silvia Hunold. Conectando historiografias: a escravidão africana e o Antigo Regime na América portuguesa. IN: BICALHO, Maria Fernanda Baptista; FERLINI, Vera Lúcia Amaral (org.). Modos de governar: idéias e práticas políticas no Império português, séculos XVI-XIX. $1^{\mathrm{a}}$ edição. São Paulo: Alameda, 2005, p. 448.

. Fragmentos setecentistas: escravidão, cultura e poder na América portuguesa. $1^{a}$ edição. São Paulo: Companhia das Letras, 2007, p. 456.

- Palmares \& Cucaú: o aprendizado da dominação. Tese para concurso de Professor Titular, Área de História do Brasil, Instituto de Filosofia e Ciências Humanas (IFCH)/ Departamento de História, Universidade Estadual de Campinas (UNICAMP), 2008. 
Senhores da régia jurisdição: o particular e o público na vila de São Salvador dos Campos dos Goitacases na segunda metade do século XVIII. IN: LARA, Silvia Hunold; MENDONÇA, Joseli Maria Nunes. Direitos e justiças no Brasil: ensaios de história social. $1^{\text {a }}$ edição. Campinas: Editora da UNICAMP, 2006, p. 543.

LATOUR, Bruno. Jamais fomos modernos: ensaio de antropologia simétrica. Título original: Nous n'avons jamais été modernes. [1991]. Tradução de Carlos Irineu da Costa. $1^{\text {a }}$ edição brasileira de $1994,2^{a}$ edição de $2009,1^{\text {a }}$ reimpressão utilizada. Rio de Janeiro: Editora 34, 2011, p. 151.

LE GOFF, Jacques. Por amor às cidades: conversações com Jean Lebrun. Título original: Pour l'amour des villes. [1997]. Tradução de Reginaldo Carmello Corrêa de Moraes. $1^{a}$ edição. São Paulo: Fundação Editora da UNESP, 1998, p. 160.

LEVI, Giovanni. Microanálise e história social. IN: ALMEIDA, Carla Maria Carvalho de, OLIVEIRA, Mônica Ribeiro de (org.). Exercícios de micro-história. $1^{\mathrm{a}}$ edição. Rio de Janeiro: Editora Fundação Getúlio Vargas (FGV), 2009, p. 300.

LUANSI, Lukonde. Angola: Movimentos migratórios e Estados pré-coloniais - Identidade nacional e autonomia regional. SIMPÓSIO INTERNACIONAL ANGOLA ON THE MOVE: TRANSPORT ROUTES, COMMUNICATION AND HISTORY, Berlim, 24-26 de Setembro de 2003. IN: Angola on the Move: Transport Routes, Communication and History, Berlim, 2003, pp. 1-10.

LOVEJOY, Paul E. A escravidão na África: uma história de suas transformações. Título original: Transformations in Slavery: A History of Slavery in Africa. [1983]. Tradução de Regina A. R. F. Bhering e Luiz Guilherme B. Chaves. 1 a edição brasileira. Rio de Janeiro: Civilização Brasileira, 2002, p. 497.

MACGAFFEY, Wyatt. Complexity, Astonishment and Power: The Visual Vocabulary of Kongo Minkisi. Journal of Southern African Studies. Taylor \& Francis Ltd, vol. 14, n. 2, "Special Issue on Culture and Consciousness in Southern Africa", janeiro de 1988, pp. 188-203. Endereço eletrônico: http://www.jstor.org/stable/2636628.

Crossing the River: Myth and Movement in Central Africa. IN: HEINTZE, Beatrix; OPPEN, Achim von (ed.). Angola on the Move: Transport Routes, Communications and History. $1^{a}$ edição. Frankfurt am Main: Verlag Otto Lembeck, 2008, p. 265.

MAESIMA, Cacilda. Noções de Arquivística e Organizações de Arquivos Históricos. IN: HAHN, Fábio André; MEZZOMO, Frank Antonio (org.). Nas Malhas do Poder: história, cultura e espaço social. $1^{a}$ ediçaõ. Campo Mourão: Editora Fecilcam, 2011, p. 359.

MARK, Peter. "Portuguese" style and Luso-African identity: precolonial Senegambia, sixteenth-nineteenth centuries. $1^{\text {a }}$ edição. Blooming \& Indianápolis: Indiana University Press. 2002, p. 208. 
MARQUES, A. H. de Oliveira. História de Portugal: desde os tempos mais antigos até ao governo do Sr. Pinheiro de Azevedo. $1^{\text {a }}$ edição de 1972; $8^{\text {a }}$ edição utilizada. Lisboa: Palas Editores, 1980, p. 698.

MARQUES, Guida. Do índio gentio ao gentio bárbaro: usos e deslizes da guerra justa na Bahia seiscentista. Revista de História (USP). São Paulo: Universidade de São Paulo, n. ${ }^{\circ}$ 171, julho/dezembro de 2014, pp. 15-48. Endereço digital: http://revhistoria.usp.br/index.php/br/edicoes/292-rh-171.

MARQUESE, Rafael de Bivar. A dinâmica da escravidão no Brasil: resistência, tráfico negreiro e alforrias, séculos XVII a XIX. Novos estudos. São Paulo: CEBRAP, n. ${ }^{\circ}$ 74, março de 2006, pp. 107-123. Endereço eletrônico: http://www.scielo.br/scielo.php?script=sci_arttext\&pid=S010133002006000100007\&lng=en\&nrm=iso. - Feitores do corpo, missionários da mente: Senhores, letrados e o controle dos escravos nas Américas, 1660-1860. $1^{\text {a }}$ edição. São Paulo: Companhia das Letras, pp. 496.

Ideologia imperial, poder patriarcal e o governo dos escravos nas Américas, c. 1660-1720. Afro-Ásia. Salvador: Universidade Federal da Bahia (UFBA), n. ${ }^{\circ} \quad 31, \quad 2004$, pp. 39-82. Endereço eletrônico: http://www.redalyc.org/articulo.oa?id=77003102.

MAURO, Frédéric. Portugal, o Brasil e o Atlântico (1570-1560). Título original: Le Portugal, Le Brésil et l'Atlantique au XVII' siècle (1570-1670). [1960]. Tradução de Manuel Barreto. $1^{\text {a }}$ edição. Lisboa: Editorial Estampa, 1989, vol. I de p. 389, vol. II de p. 388.

MUDIMBE, Valentin-Yves. The Idea of Africa. $1^{\text {a }}$ edição. Bloomington e Indianápolis: Indiana University Press, 1994, p. 234. . The Invention of Africa: Gnosis, Philosophy, and the Order of Knowledge. $1^{\text {a }}$ edição. Bloomington: Indiana University Press, 1988, p. 241.

MENESES, Ulpiano T. Bezerra de. A História, Cativa da Memória? Para um Mapeamento da Memória no Campo das Ciências Sociais. Revista do Instituto de Estudos Brasileiros. São Paulo: Universidade de São Paulo, n. ${ }^{o}$ 34, dez. 1992, pp. 9-24. Endereço eletrônico: http://www.revistas.usp.br/rieb/article/view/70497.

MILLER, Joseph C. Legitimacy and Political Power: Queen Njinga, 1624-1663. The Journal of African History. Cambridge: Cambridge University Press, vol. 32, n. ${ }^{\circ} 1$, 1991, pp. 25-40. Endereço eletrônico: http://www.jstor.org/stable/182577.

. Nzinga of Matamba in a New Perspective. The Journal of African History. Cambridge: Cambridge University Press, vol. 16, n. ${ }^{\circ}$ 2, 1975, pp. 201-216. Endereço eletrônico: http://www.jstor.org/stable/180812.

- O Atlântico escravista: açúcar, escravos e engenhos. Afro-Ásia. Salvador: Universidade Federal da Bahia (UFBA), n. ${ }^{\circ}$ 19/20, 1997, 9-36. 
. Poder político e parentesco: Os antigos estados Mbundu em Angola. Título original: Kings and Kinsmen: Early Mbundu States in Angola. [1976]. Tradução de Maria da Conceição Neto. $1^{\text {a }}$ edição. Luanda: Arquivo Histórico Nacional, 1995, p. 308.

. The Significance of Drought, Disease and Famine in the Agriculturally Marginal Zones of West-Central Africa. The Journal of African History. Cambridge: Cambridge University Press, vol. 23, n. ${ }^{\circ}$ 1, 1982, pp. 17-61. Endereço eletrônico: http://www.jstor.org/stable/181270.

. Way of Death: Merchant Capitalism and the Angolan Slave Trade, 1730-1830. $1^{a}$ edição. Madison: The University of Wisconsin Press, 1988, p. 800.

MONTERO, Paula. Introdução: A Questão Colonial Revisitada. Cadernos de Campo. São Paulo: Universidade de São Paulo (USP), n³, 1993, pp. 103-106.

MONTEIRO, Nuno Gonçalo F. Trajetórias sociais e governo das conquistas: notas preliminares sobre os vice-reis e governadores-gerais do Brasil e da Índia nos séculos XVII e XVIII. IN: FRAGOSO, João; BICALHO, Maria Fernanda Baptista; GOUVÊA, Maria de Fátima Silva (org.). O Antigo Regime nos trópicos: a dinâmica imperial portuguesa (séculos XVI-XVIII). $1^{\text {a }}$ edição. Rio de Janeiro: Civilização Brasileira, 2001, p. 473.

NETO, Maria da Conceição. Nas Malhas da Rede: Aspectos do impacto económico e social do transporte rodoviário na região do Huambo c. 1920 - c. 1960. IN: HEINTZE, Beatrix; OPPEN, Achim von (ed.). Angola on the Move: Transport Routes, Communications and History. $1^{\mathrm{a}}$ edição. Frankfurt am Main: Verlag Otto Lembeck, 2008, p. 265. Endereço digital: http://www.frobenius-institut.de.

- Ideologias, contradições e mistificações da colonização de Angola no século XX. Lusotopie. Bordeux: Centre d'étude d'Áfrique noire/ Centre national de recherche scientifique, 1997, pp. 327-359.

. In Town and Out of Town: A Social History of Huambo (Angola), 1902-1961. Tese de doutorado em História, Departamento de História/ School of Oriental and African Studies (SOAS), Universidade de Londres, 2012.

NOVAIS, Fernando Antonio. Portugal e Brasil na Crise do Antigo Sistema Colonial (1777-1808). $1^{a}$ edição de 1979, sexta edição utilizada. São Paulo: Editora Hucitec, 1995 , p. 420.

OLIVAL, Fernanda. As Ordens Militares e o Estado Moderno: Honra, Mercê e Venalidade em Portugal (1641-1789). 1a edição. Lisboa: Editora Estar, 2001, p. 571.

ORTIZ, Fernando. Contrapunteo cubano del tabaco y el azúcar. $1^{\mathrm{a}}$ edição. Habana: Editorial de Ciencias Sociales, 1983, p. 484.

PARREIRA, Adriano. Economia e sociedade em Angola na época da Rainha Jinga (século XVII). $1^{\text {a }}$ edição. Lisboa: Editora Estampa, 1997, p. 245. 
PRADO JR., Caio. Formação do Brasil Contemporâneo. $1^{\mathrm{a}}$ edição de 1942, $23^{\mathrm{a}}$ edição de 1994 utilizada. São Paulo: Brasiliense, 2007, p. 390.

PRATT, Mary Louise. Globalización, desmodernización y el retorno de los monstruos. Revista de História (USP). São Paulo: Universidade de São Paulo, n. ${ }^{0} 156,1^{\circ}$ semestre de 2007, pp. 13-29.

. Os olhos do Império: os relatos de viagem e transculturação. Título original: Imperial Eyes: Travel Writing and Transculturation. [1992]. Tradução de Jézio Hernani Bonfim Gutierre; Revisão técnica de Maria Helena Machado, Carlos Válero. Bauru, São Paulo: EDUSC, 1999.

PUNTONI, Pedro Luis. O Estado do Brasil: poder e política na Bahia colonial. Tese de livre-docência em História do Brasil Colonial, Faculdade de Filosofia, Letras e Ciências Humanas (FFLCH)/ Departamento de História, Universidade de São Paulo (USP), 2010.

RAMINELLI, Ronald. Nobreza e riqueza no Antigo Regime ibérico setecentista. Revista de História (USP). São Paulo: Universidade de São Paulo, n. ${ }^{\circ} 169$, julho/dezembro de 2013, pp. 83-110.

RESENDE, Maria Leônia Chaves de. Visões da conquista: verso e reverso (As missões jesuiticas nos séculos XVI/XVII). Dissertação de mestrado, Instituto de Filosofia e Ciências Humanas (IFCH)/ Departamento de História, Universidade de Campinas (UNICAMP), 1993.

REVEL, Jacques. Microanálise e construção do social. IN: REVEL, Jacques (org.). Jogos de escalas: a experiência da micro-análise. Título original: Jeux d'échelles: la micro-analyse à l'expérience. [1996]. Tradução de Dora Rocha. $1^{\mathrm{a}}$ edição brasileira. Rio de Janeiro: Editora Fundação Getúlio Vargas (FGV), 1998, p. 262.

RODNEY, Walter. A History of the Upper Guinea Coast, 1545 to 1800. $1^{\text {a }}$ publicação de 1970, reedição utilizada. Nova Iorque: Monthly Review Press, 1989, p. 290. . How Europe Underdeveloped Africa. $1^{\mathrm{a}}$ publicação de 1972, reedição utilizada. Oxford: Pambazuka Press, 2012, p. 312.

SALDANHA, António Vasconcelos. Iustum Imperium. Dos Tratados como Fundamento do Império dos Portugueses no Oriente. Estudo de História do Direito Internacional e do Direito Português. 1ª edição. Lisboa: Fundação Oriente, 1997, p. 751.

SAID, Edward W. Humanismo e crítica democrática. Título original: Humanism and Democratic Criticism. [2004]. Tradução de Rosaura Eichemberg. $1^{\mathrm{a}}$ edição brasileira. São Paulo: Companhia das Letras, 2007, p. 183.

. Orientalismo: O Oriente como invenção do Ocidente. Título original: Orientalism - Western conceptions of the Orient. [1978]. $1^{a}$ edição edição brasileira. São Paulo: Companhia das Letras, 2007, p. 528. 
SANCHES, Manuela Ribeiro (org.). Malhas que os impérios tecem. Textos anticoloniais, contextos pós-coloniais. $1^{\mathrm{a}}$ edição. Lisboa: Edição 70, 2011, p. 382.

SANTOS, Catarina Madeira. Administrative knowledge in a colonial context: Angola in the eighteenth century. The British Journal for the History of Science (BJHS), vol. 43, Assunto especial 4, dezembro de 2010, pp. 539-556.

. De "antigos conquistadores" a "angolenses". Cultura: Revista de História e Teoria das Ideias. Lisboa: Universidade Nova de Lisboa/ Centro da Cultura, vol. 24, 2007, pp. 195-222. Endereço digital: http://cultura.revues.org/898.

. Ecrire le pouvoir en Angola: Les archives Ndembu (XVIIeXXe siècles). Annales. Histoire, Sciences Sociales. Paris: Éditions de l'EHESS, n. ${ }^{\circ}$ 64, 2009/4, pp. 767-795. Endereço eletrônico: http://www.cairn.info/revue-annales2009-4-page-767.htm.

. Entre deux droits : les Lumières en Angola (1750-v. 1800). Annales. Histoire, Sciences Sociales. Paris: Éditions de l'EHESS, n. ${ }^{\circ}$ 60, 2005/4, p. 817-848. Endereço eletrônico: http://www.jstor.org/stable/27587649.

. Entre Velha Goa e Panguim: a capital do Estado da Índia e as reformulações da politica ultramarina, séculos XVI-XIX. $1^{\mathrm{a}}$ edição. Lisboa: Instituto de Investigação Científica Tropical, 2001, p. 40.

. Esclavage africain et traite atlantique confrontés: transactions langagières et juridiques (à propos du tribunal de mucanos dans l'Angola des XVIIe et XVIIIe siècles). Brésil(s). Paris: Éditions de la Maison des Sciences de l'Homme, n. ${ }^{\circ}$ 1, 2012, pp. 127-148. Endereço eletrônico: http://bresils.revues.org/741.

. Escrever o Poder: os Autos de Vassalagem e a Vulgarização da Escrita entre as Elites Africanas Ndembu. IN: HEINTZE, Beatrix; OPPEN, Achim von (ed.). Angola on the Move: Transport Routes, Communications and History. $1^{\mathrm{a}}$ edição. Frankfurt am Main: Verlag Otto Lembeck, 2008, p. 265. Endereço digital: http://www.frobenius-institut.de. O mesmo texto foi publicado em: Revista de História (USP). São Paulo: Universidade de São Paulo, n. ${ }^{\circ} 155,2^{\circ}$ semestre de 2006, pp. 81-95.

- Goa á a chave de toda a Índia: perfil politico da capital do Estado da İndia (1505-1570). Prefácio de Luís Filipe F. R. Thomaz. $1^{a}$ edição. Lisboa: Comissão Nacional para as Comemorações dos Descobrimentos Portugueses, 1999, p. 373.

. Un Monde Excessivement Nouveau - savoirs africains et savoirs missionnaires: fragments, appropriations et porosités dans l'œuvre de cavazzi di montecúccolo. IN: CASTELNAU-L'ESTOILE, Charlotte De; COPETE, Marie-Lucie; MALDAVSKY, Aliocha; ŽUPANOV, Ines G. (ed.). Missions d'évangélisation et circulation des savoirs (XVIe-XVIIIe siècle). $1^{\text {a }}$ edição. Madri: Casa de Velázquez, 2011, p. 522.

. Um governo "polido" para Angola: Reconfigurar dispositivos de domínio. (1750-c.1800). Tese de doutorado em História dos Descobrimentos e da Expansão Portuguesa, Faculdade de Ciências Sociais e Humanas, Universidade Nova de Lisboa, 2005.

. Portugal and the World Shipping Routes. $1^{\mathrm{a}}$ edição. Lisboa:

Comissão Nacional para as Comemorações dos Descobrimentos Portugueses, 1997, p. 60. 
SANTOS, João Marinho dos. A Expansão pela espada e pela cruz. IN: NOVAES, Adauto (org.). A descoberta do homem e do mundo. $1^{\mathrm{a}}$ edição. Rio de Janeiro: MincFUNARTE: Companhia das Letras, São Paulo, 1998, p. 592.

SANTOS, Maria Emília Madeira (coord.). História Geral de Cabo Verde. $1^{a}$ edição. Lisboa: Instituto de Investigação Científica Tropical, vol. II, 1995, p. 642. . Nos caminhos de Africa: serventia e posse (Angola Século XIX). $1^{\text {a }}$ edição. Lisboa: Instituto de Investigação Científica Tropical, 1998, p. 606.

SCHWARTZ, Stuart B. Burocracia e sociedade no Brasil Colonial: o Tribunal Superior da Bahia e seus desembargadores, 1609-1751. Título original: Sovereignty and society in colonial Brazil: The High Court of Bahia and the judges, 1609-1751. [1973]. Tradução de Berilo Vargas. 1ª edição. São Paulo: Companhia das Letras, 2011, p. 414.

SEIBERT, Gerhard. Creolization and Creole Communities in the Portuguese Atlantic: São Tomé, Cape Verde, the Rivers Guinea and Central Africa in Comparison. IN: GREEN, Tobias (ed). Brokers of Change: Atlantic Commerce and Cultures in Precolonial Western Africa. $1^{\text {a }}$ edição. Oxford: The British Academy/ Oxford University Press, 2012, p. 415.

SERRÃO, Joel (dir.). Dicionário de História de Portugal. [1963-1971]. Porto: Figueirinhas, 6 vols., 2002.

SILVA, António Leão Correia e. A sociedade agrária, gentes das águas: senhores, escravos e forros. IN: SANTOS, Maria Emília Madeira (coord.). História Geral de Cabo Verde. $1^{\mathrm{a}}$ edição. Lisboa: Instituto de Investigação Científica Tropical, vol. II, 1995, p. 642 .

SOARES, Francisco Manuel Antunes. Crioulizações internas: processos de transculturação nos Bantu angolanos. Almanack. Guarulhos: Universidade Federal de São Paulo (UNIFESP), n. ${ }^{\circ} 8,2^{\circ}$ semestre de 2014, pp. 84-103.

SOUZA, Laura de Mello e. Política e Administração colonial: problemas e perspectivas. IN: SOUZA, Laura de Mello e; FURTADO, Júnia Ferreira; BICALHO, Maria Fernanda (org.). O governo dos povos. $1^{\text {a }}$ edição. São Paulo: Alameda, 2009, p. 560.

SOUZA, Marina de Mello e. Reis negros no Brasil escravista: história da festa de coroação de Rei Congo. $1^{a}$ edição de 2002; $1^{\text {a }}$ reimpressão. Belo Horizonte: Editora UFMG, 2006, p. 387.

SUBRAHMANYAM, Sanjay. Connected Histories: Notes towards a Reconfiguration of Early Modern Eurasia. Modern Asian Studies. Cambridge: Cambridge University Press, vol. 31, n. ${ }^{\circ}$, julho de 1997, pp. 735-762. 
. Du Tage au Gange au XVIe siècle: une conjoncture millénariste à l'échelle eurasiatique. Annales. Histoire, Sciences Sociales. Paris: Éditions de l'EHESS, n. ${ }^{\circ}$ 56, 2001/1, pp. 51-84. Endereço eletrônico: http://www.cairn.info/revue-annales-2001-1-page-51.htm.

. O Império Asiático Português 1500-1700: Uma História

Política e Econômica. Título original: The Portuguese Empire in Asia 1500-1700. [1993]. Tradução de Paulo Jorge Sousa Pinto. $1^{a}$ edição. Linda-a-velha: Difel, 1995, p. 447.

TEIXEIRA, André. Povoamento: um processo que se prolonga no tempo IN: SERRÃO, Joel; MARQUES, A. H. Oliveira (dir.). Nova História da Expansão Portuguesa: A Colonização Atlântica. Coordenação de Artur Teodoro de Matos. $1^{\text {a }}$ edição. Lisboa: Editorial Estampa, vol. III, tomo 2, 2005, p. 536.

THOMAZ, Luís Felipe F. R. De Ceuta a Timor. $1^{a}$ edição. Linda-a-velha: Difel, 1994, p. 778.

THORNTON, John K. Africa and Africans in the Making of the Atlantic World, 1400-1800. $1^{\mathrm{a}}$ edição de 1992, $2^{\mathrm{a}}$ edição utilizada. Cambridge: Cambridge University Press, 1998, p. 340.

. A Cultural History of the Atlantic World, 1250-1820. $1^{\text {a }}$ edição. Cambridge: Cambridge University Press, 2012, p. 543.

. The Art of War in Angola, 1575-1680. Comparative Studies in

Society and History. Cambridge: Cambridge University Press, vol. 30, n. ${ }^{\circ}$ 2, abr. de 1988, pp. 360-378. Endereço eletrônico: http://www.jstor.org/stable/178839.

. The Kongolese Saint Anthony: Dona Beatriz Kimpa Vita and the Antonian Movement, 1684-1706. $1^{\text {a }}$ edição de 1998, 11ª reimpressão utilizada. Cambridge: Cambridge University Press, 2009, p. 228.

. The Portuguese in Africa. IN: BETHENCOURT, Francisco; CURTO, Diogo Ramada (ed.). Portuguese Oceanic Expansion, 1400-1800. $1^{\text {a }}$ edição. Cambridge: Cambridge University Press, 2007, p. 536.

. Warfare in Atlantic Africa 1500-1800. $1^{\mathrm{a}}$ edição de 1999, $1^{\mathrm{a}}$ reimpressão utilizada. Londres e Nova Iorque: Routledge, 2003, p. 194.

VANSINA, Jan. Communications between Angola and East Central Africa Before c. 1700. IN: HEINTZE, Beatrix; OPPEN, Achim von (ed.). Angola on the Move: Transport Routes, Communications and History. $1^{\mathrm{a}}$ edição. Frankfurt am Main: Verlag Otto Lembeck, 2008, p. 265. Endereço digital: http://www.frobenius-institut.de.

. Ethnohistory in Africa. Ethnohistory. Durham: Duke University Press, vol. 9, n. ${ }^{\circ}$ 2, primavera de 1962, pp. 126-136. Endereço eletrônico: http://www.jstor.org/stable/480672.

. Finding Food and the History of Precolonial Equatorial Africa: A Plea. African Economic History. Madison: University of Wisconsin-Madison/ African Studies Program, n. ${ }^{\circ}$ 7, Contributions to a History of Agriculture and Fishing in Central Africa, primavera de 1979, pp. 9-20. Endereço digital: http://www.jstor.org/stable/3601199. 
. How Societies Are Born: Governance in West Central Africa before 1600.

$1^{\text {a }}$ edição. Charlottesville: University of Virginia Press, 2004, p. 325.

. Kingdoms of the Savanna. $1^{\text {a }}$ edição. Madison: University of Wisconsin

Press, 1966, p. 364.

. Kongo, Angola, and Western Forests, History of (1500 to 1880). IN: MIDDLETON, John; MILLER, Joseph C (ed.). New Encyclopedia of Africa. $1^{\text {a }}$ edição de 2007, $2^{\mathrm{a}}$ edição utilizada. Detroit: Charles Scribner's Sons, vol. 3, 2008, pp. 161-165.

. L'homme, les forêts et le passé en Afrique. Annales. Économies, Sociétés, Civilisations. Paris: Éditions de l'EHESS, ano $40^{\circ}$, n. ${ }^{\circ}$ 6, 1985, pp. 1307-1334. Endereço eletrônico:

http://www.persee.fr/doc/ahess_0395$2649 \_1985$ num $40 \_6283239$.

. More on the Invasions of Kongo and Angola by the Jaga and the Lunda. The Journal of African History. Cambridge: Cambridge University Press, vol. 7, n. ${ }^{\circ}$ 3, 1966, pp. 421-429. Endereço eletrônico: http://www.jstor.org/stable/180111.

. On Ravenstein's Edition of Battell's Adventures in Angola and Loango.

History in Africa. Nova Jersey: African Studies Association, vol. 34, 2007, pp. 321347. Endereço eletrônico: http://www.jstor.org/stable/25483702.

. Paths in the Rainforests: Toward a History of Political Tradition in Equatorial Africa. $1^{\text {a }}$ edição. Madison-Wisconsin: University of Wisconsin Press, 1990, p. 448.

. The Ambaca Society and the Slave Trade c. 1760-1845. The Journal of African History. Cambridge: Cambridge University Press, vol. 46, n. ${ }^{\circ} 1,2005$, pp. 1-27. Endereço eletrônico: http://www.jstor.org/stable/4100827.

. The Foundation of the Kingdom of Kasanje. The Journal of African History. The Journal of African History. Cambridge: Cambridge University Press, vol. 4, n. ${ }^{\circ}$ 3, 1963, pp. 355-374. Endereço eletrônico: http://www.jstor.org/stable/180028.

VENÂNCIO, José Carlos. Mestiços em África: Mediadores Culturais Naturais. II COLÓQUIO INTERNACIONAL SOBRE MEDIADORES CULTURAIS, SÉCULOS XV A XVIII, Lagos, outubro de 1997. IN: LOUREIRO, Rui Manuel; GRUZINSKI, Serge (coord.). Passar as Fronteiras: Actas do II Colóquio Internacional sobre Mediadores Culturais, Séculos XV a XVIII. Braga: Centro de estudos Gil Eanes, 1999, p. 408.

VIVES, Jaime Vicens. A estrutura administrativa estadual nos séculos XVI e XVII. [1960]. IN: HESPANHA, António Manuel (ed.). Poder e instituições na Europa do Antigo Regime: coletânea de textos. $1^{a}$ edição. Lisboa: Fundação Calouste Gulbenkian, 1984, p. 541.

WISSENBACH, Maria Cristina Cortez. Dinâmicas históricas de um porto centro-africano: Ambriz e o Baixo Congo nos finais do tráfico atlântico de escravos (1840-1870). Revista de História (USP). São Paulo: Universidade de São Paulo, n. ${ }^{\circ} 172$, janeiro/junho, 2015, pp. 163-195. Endereço eletrônico: http://dx.doi.org/10.11606/issn.2316-9141.rh.2015.89698. 
XAVIER, Ângela Barreto; SANTOS, Catarina Madeira. Cultura intelectual das elites coloniais. Cultura: Revista de História e Teoria das Ideias. Lisboa: Universidade Nova de Lisboa/ Centro da Cultura, vol. 24, 2007, pp. 9-33. Endereço eletrônico: http: // cultura.revues.org/777.

ZERON, Carlos Alberto de Moura Ribeiro. A construção de uma ordem colonial nas margens americanas do Império português: discussões sobre o "bem comum" na disputa de moradores e jesuitas pela administração dos índios (XVI-XVII). Tese de livre-docência, Faculdade de Filosofia, Letras e Ciências Humanas (FFLCH)/ Departamento de História, Universidade de São Paulo (USP), 2009.

. A ocidente do ocidente: linhas e perspectivas em confronto. Revista de História (USP). São Paulo: Universidade de São Paulo, n. ${ }^{\text {o }}$ 170, janeiro/junho, 2014, p. 77-106. Endereço eletrônico: http://dx.doi.org/10.11606/issn.2316-9141.v0i170p77-106.

- Interpretações das relações entre cura animarum e potestas indirecta no mundo luso-americano. Clio: Revista de Pesquisa Histórica. Recife: Universidade Federal de Pernambuco (UFPE), n. ${ }^{\circ}$ 27-1, 2009, pp. 140-177.

Les Jésuites et le commerce d'esclaves entre le Brésil et l'Angola à la fin du XVIe siècle: contribution à un débat. Traverse: Zeitschrift für Geschichte. Zurique: Éditions Chronos, n. ${ }^{\circ}$ 1, 1996, pp. 34-50. Endereço eletrônico: http://dx.doi.org/10.5169/seals-9813.

- Linha de fé: a Companhia de Jesus e a Escravidão no Processo de Formação da Sociedade Colonial (Brasil, Séculos XVI e XVII). Título original: La compagnie de Jésus et l'institution de l'esclave au Brésil: les justification d'ordre historique, théologique et juridique, et leur intégration par une mémoire historique. [1998]. Tradução Antonio de Padua Danesi. 1a edição brasileira. São Paulo: Editora da Universidade de São Paulo, 2011, p. 611.

. Pombeiros e tangomaus, intermediários do tráfico de escravos na África. II COLÓQUIO INTERNACIONAL SOBRE MEDIADORES CULTURAIS, SÉCULOS XV A XVIII, Lagos, outubro de 1997. IN: LOUREIRO, Rui Manuel; GRUZINSKI, Serge (coord.). Passar as Fronteiras: Actas do II Colóquio Internacional sobre Mediadores Culturais, Séculos XV a XVIII. Braga: Centro de estudos Gil Eanes, 1999, p. 408. 